

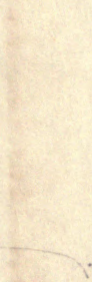




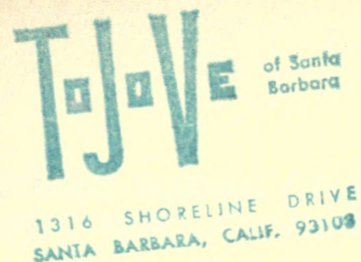





\section{THE PHILIPPINE BUREAU OF SCIENCE MONOGRAPHIC PUBLICATIONS ON FISHES}

No. 1. A CHECK-LIST OF PHILIPPINE FISHES, by David Starr Jordan and Robert Earl Richardson, 1909. No. 23. GOBIES OF THE PHILIPPINES AND THE CHINA SEA, by Albert W. Herre, 1927.

No. 24. POMACENTRIDAE OF THE PHILIPPINE ISLANDS, by Heraclio R. Montalban, 1927.

Reprinted 1965, for the Smithsonian Institution by T.F.H. Publications, Inc., Jersey City 2, New Jersey, U.S.A.

For sale by the Smithsonian Institution, Washington, D.C. 20560 Price per volume, cloth bound, $\$ \mathbf{5 . 5 0}$ 
This reprint is the third in a publication program inaugurated pursuant to an agreement between the Smithsonian Institution and T.F.H. Publications, Inc. The proceeds derived from the sale of this and other such reprints will be used to increase, at the Smithsonian Institution, the T.F.H. Fund "for research, collection or purchase of fish specimens, exploration and publication of scientific reports related to aquarium fishes."

This edition is reprinted from the original without change except that the color plates have been grouped together, and the text has been reduced in size to enable this volume to match the format of the previous T.F.H. reprints.

Errata for reprint of "The Philippine Bureau of Science, Monographic Publications on Fishes"

The color plates do not represent an exact reproduction of the originals because the inks used resulted in much greater intensity of colors. In addition, color plates 27,29 , and 8 are slightly too green; color plates $30,3,8,17$, and 19 a little too blue; and color plates 28, 30, 3, 5, and 17 slightly too yellow. The frontispiece is upside down and reversed. Figure 2 on color plate 27 is too dark, obscuring the color pattern. 


\title{
CHECK-LIST OF THE SPECIES OF FISHES KNOWN FROM THE PHILIPPINE ARCHIPELAGO
}

\author{
BY \\ DAVID STARR JORDAN \\ AND \\ ROBERT EARL RICHARDSON
}

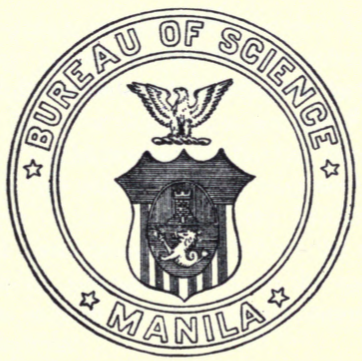


Department of the Interiok, Bureau of Science, Manila.

Publication No. 1 .

(Actual date of publication January 20, 1910.) 2 


\section{CHECK-LIST OF THE SPECIES OF FISHES KNOWN FROM THE PHILIPPINE ARCHIPELAGO.}

By Datid Stark Jordan and Robert Earl Richardsox.

In the present paper is giren a list of all species of fishes positively known at the date of January 1, 1909, as inhabiting the waters of the Philippine Archipelago. A complete bibliography of the ichthyology of the Philippines is given in the Appendix.

The writers are indebted to Mr. Alvin Seale and to Mr. Richard Crittenden McGregor for important aid on the preliminary work of the preparation of this catalogue; 830 species are included, a large number, which probably represents less than half of the actual fish fauna of these Islands.

\section{INTRODUCTION.}

The list has been drawn up without reference to the lists of Elera, Gogorza, and Palacky (noted in the bibliography). A list of those species of Palacky's catalogue which are known on no other authority than that of Palacky, Elera, or Gogorza, is appended at the conclusion of the present check-list. In the present list the full reference to the original description is given in case only of those species not noticed or describer in Günther's Catalogue of the Fishes of the British Muscum. In the record of geographical distribution which follows the name of each spccies admitted to the check-list, the name by which the species was designated by an author is given only in case the specific name used was different from the one here employed. 



\section{Class SELACHII.}

Family ORECTOLOBIDA.

CHILOSCYLLIUM Müller \& Henle.

1. Chiloscyllium indicum (Gmelin). Manila (Günther, A).

Family CARCHARIID $\mathrm{E}$.

SCOLIODON Müller \& Henle.

2. Scoliodon walbeehmii (Bleeker). Manila (Jordan \& Richardson).

3. Scoliodon acutus (Rüppell). Manila (Jordan \& Seale, A).

Family SPHYRNIDÆE.

SPHYRNA Rafinesque.

4. Sphyrna zygæna (Linnæus). Cavite (Jordan \& Seale, A).

Family RHINOBATIDÆ.

RHYNCHOBATUS Müller \& Henle.

5. Rhynchobatus djiddensis (Forskål). Cavite (Jordan \& Seale, A).

Family DASYATID无.

DASYATIS Rafinesque.

6. Dasyatis kuhli (Müller \& Henle). Philippine Islands (Jordan \& Seale, A); Zamboanga (Seale \& Bean).

HIMANTURA Duméril.

7. Himantura uarnak (Forskål). Manila (Jordan \& Richardson).

TFENIURA Müller \& Henle.

8. Tæniura lymma (Forskål). Zamboanga (Seale \& Bean).

Family Ä̈TOBATIDÆ.

STOASODON Cantor.

9. Stoasodon narinari (Euphrasen). Cavite (Jordan \& Seale, A).

\section{Class PISCES.}

Family ELOPID $Æ$.

ELOPS Linnæus.

10. Elops hawaiiensis Regan. Manila (Jordan \& Richardson); Bulan (Evermann \& Seale, A) (as E. saurus). 


\section{Family MEGALOPIDA.}

MEGALOPS Lacépède.

11. Megalops cyprinoides (Broussonet). Luzon (Peters, c); Negros (Jordan \& Seale, B); Bulan (Evermann \& Seale, A).

\section{Family CHIROCENTRIDAE.}

CHIROCENTRUS Cuvier.

12. Chirocentrus dorab (Forskål). Cavite (Jordan \& Seale, A); Manila (Jordan \& Richardson); Mindanao (Smith \& Seale); Bacon (Evermann \& Seale, A).

\section{Family CHANID E.}

\section{CHANOS Cuvier.}

13. Chanos chanos (Forskål). Cavite (Jordan \& Seale, A); Manila (Jordan \& Richardson); Manila (Evermann \& Seale, B). Zamboanga, Seale \& Bean.

\section{Family CLUPEID无.}

\section{STOLEPHORUS Lacépède. (Spratelloides Bleeker.)}

14. Stolephorus gracilis (Temminck \& Schlegel). Bacon (Evermann \& Seale, A) ; (?) Negros (Jordan \& Seale, B, Stolephorus japonicus; see note in Evermann \& Seale, A).

15. Stolephorus delicatulus (Bennett). Bulan (Evermann \& Seale, A).

DUSSUMIERIA Cuvier \& Valenciennes.

16. Dussumieria acuta Cuvier \& Valenciennes. Manila (Kner).

17. Dussumieria elopsoides Bleeker. Cavite (Jordan \& Seale, A) ; Iloilo (Jordan \& Richardson).

18. Dussumieria hasseltii Bleeker. Manila (Jordan \& Richardson).

\section{AMBLYGASTER Bleeker. (Sardinia Poey.)}

19. Amblygaster sirm (Rüppell). Negros (Jordan \& Seale, B).

20. Amblygaster clupeoides (Bleeker). Negros (Jordan \& Seale, B); Bulan (Evermann \& Seale, A).

21. Amblygaster perforatum (Cantor). Bacon (Evermann \& Seale, A).

SARDINELLA Cuvier \& Valenciennes. (Harengula Cuv. \& Val).

22. Sardinella moluccensis (Bleeker). Cavite (Jordan \& Seale, A); Negros (Jordan \& Seale, B) ; Manila (Jordan \& Richardson); Bacon; Bulan (Evermann \& Seale, A); Zamboanga, Seale \& Bean.

23. Sardinella gibbosa (Bleeker). Philippine Islands (Jordan \& Seale, A); Manila (Jordan \& Richardson).

24. Sardinella sundaica (Bleeker). Negros (Jordan \& Seale, B); Manila; Aparri; Iloilo (Jordan \& Richardson).

25. Sardinella vanicoris Jordan \& Seale. Zamboanga (Seale \& Bean) as Clupea melanura, not of Cuvier. 
ILISHA Gray.

26. Ilisha nœvenii (Bleeker). Cavite (Jordan \& Seale, A); Manila (Jordan \& Richardson); San Fabian (Evermann \& Seale, A).

Family DOROSOMATIDE.

ANODONTOSTOMA Blecker.

27. Anodontostoma chacunda (Hamilton-Buchanan). Cavite (Jordan \& Scalle, A, var. selangkat); Negros (.Jordan \& Seale, B); Manila; Iloilo (Jorlan \& Richardson); Mindanao (Smith \& Sieale); Bacon (Evermann \& Seale, A).

KONOSIRUS Jordan \& Snyiler.

28. Konosirus thrissa (Osbeck). Philippine Islands ((iiintlier, Evermaun \& Seale, A); Zamboangn (Seale \& Bean). (Dorosoma nasvs (Bloch).)

Family ENGRAULID必.

ANCHOVIA Jordan \& Evermann.

29. Anchovia commersoniana (Lacepede). Manila (Jordan \& Seale, A); Negros (Jordan \& Seale, B).

30. Anchovia hamiltoni (Gray). Cavite (Jordan \& Seale, A); Manila; lloilo (Jordan \& Richardson).

31. Anchovia bœlama (Forskål). Cagayancillo; Iloilo (Jordan \& Richardson); Mindanao (Smith \& Seale). Zamboanga (Seale \& Bean).

32. Anchovia indica (Van Hasselt). Cavite (Jordan \& Seale, A); Bulan (Evermann \& Seale, A).

33. Anchovia setlrostris (Broussonet). Aparri (Jordan \& Richardson).

Family SYNODONTIDE.

TRACHINOCEPHALUS Gill.

34. Trachinocephalus myops (Forster). Bulan (Evermann \& Seale, A).

SYNODUS Gronow.

35. Synodus japonicus (Houttuyn). ('uyo (Jordan \& Richardson); Bulan; Bincon (Evermann \& Seale, A, Synodus varius).

SAURIDA Cuvier \& Valenciennes.

36. Saurida gracilis (Quoy \& Gaimard). Manila (Jordan \& Seale, A); Cuyo (Jordan \& Richardson); Bacon (Evermann \& Seale, A).

37. Saurida argyrophanes Richardson. Cavite (Jordan \& Seale, A, Saurida japonica); Miıniliı (Jordan \& Richardson); San Fabian (Evermann \& Seale, A).

38. Saurida badi (Cuvier). Negros (Jordan \& Seale, B).

Family ALEPOCEPHALID $A$.

BATHYTROCTES Günther.

39. Bathytroctes macrolep is Gïnther. Sta. 198, north of Celebes (Günther, B). (Bathytroctes macrolepis Gïnther, Deep Sea Fishes Challenger, p. 225, pl. LVII, fig. B; Sta. 198, north of Celebes.) 


\section{Family MALACOSTEID $Æ$.}

MALACOSTEUS Ayres.

40. Malacosteus indicus Günther. Sta. 214, near Philippine Islands (Günther, B). Malacosteus indicus Günther, Ann. Mag. N. H., II, 1878, 181.

Family MYCTOPHID

MYCTOPHUM Rafinesque.

41. Myctophum gilberti Evermann \& Seale. Bulan (Evermann \& Seale, A). Myctophum gilbcrti Evermann \& Seale, Bull. U. S. Fish Comm., XXVI, 1906, 55, fig. 1 ; Bulan, P. I.

LAMPADENA Goode \& Bean.

42. Lampadena engraulis (Ginther). Sta. 200, Philippine Islands (Günther, B).

Scopelus cngraulis Günther, Deep Sea Fishes Challenger, p. 197, pl. LI, fig. C; Sta. 200, Philippine Islands.

NANNOBRACHIUM Günther.

43. Nannobrachium nigrum Giinther. Sta. 214, 8outh of Philippines. (Günther, B).

Nannobrachium nigrum Günther, Deep Sea Fishes Challenger, p. 199, pl. LIl, fig. B; Sta. 214, south of Philippines.

\section{Family STERNOPTYCHID}

\section{POLYIPNUS rïunther.}

44. Polyipnus spinosus Günther. Sta. 200, between Philippine Islands and Borneo (Günther, B).

Polyipnus spinosus Günther. Deep Sea Fishes Challenger, p. 170; Sta. 200, between Philippine Islands and Borneo.

\section{STERNOPTYX Hermann.}

45. Sternoptyx diaphana Hermann. Sta. 214, Plıilippine Islands (Günther, B). Family EVERMANEILIDAE.

OMOSUDIS Günther.

46. Omosudis lowii Gtinther. Sta. 214, south of Philippine Islands (Güther, B). Omosudis lowii Günther, Deep Sea Fishes Challenger, p. 201, pl. LII, fig. C. C'; Sta. 214, south of Philippine Islands.

\section{Family HALOSAURID瓜.}

\section{HALOSAURUS Jolınson.}

47. Halosaurus medirostris Günther. Sta. 207, west of Philippine Islands (Günther, B).

Halosaurus medirostris Guinther, Deep Sea Fishes Challenger, p. 239, pl. LIX, fig. C; Sta. 207, west of Philippines. 


\section{Family SYMBRANCHIDE.}

SYMBRANCHUS Bloch.

Symbranchus bengalensis (McClelland). Philippine Islands (Giinther); Lw\%on (Peters, C).

\section{Family ANGUILLIDAE.}

ANGUILLA Thumberg.

49. Anguilla mauritiana Bennett. Plilippine Islands (Güntler) ; 'Tarlac (Evermaun \& Seale, A); Calayan; Mindoro (Jordan \& Richardson); Manila (Bleeker, as Murana maculata); Zamboanga (Seale \& Bean).

50.Angullia manillensis (Bleeker). Manila (Bleeker). May not be different from Anguilla mauritiana.

\section{Family LEPTOCEPHALIDA.}

\section{LEPTOCEPHALUS Gmelin.}

51. Leptocephalus brevicaudus Peters.

A species of uncertain standing, Leptocephalus (Diaphanichthys) brevicaudus Peters, Monatsber. Akad. Wiss. Berl., 1868, 275; Maslate, Luzon; a larva form of some conger eel.

UROCONGER Kaup.

52. Uroconger lepturus Richardson. Manila (Jordan \& Seale, A).

\section{Family MURANESOCID}

\section{MURAENESOX McClelland.}

53. Muræenesox clnereus (Forskal). Philippine Islands (Günther; Richardson, A, (Congrus hamo); = Muranesox bagio fide Bleeker=cinercus) Manila (Jordan \& Seale, A; Jordan \& Richardson).

\section{Family MYRID压.}

MURENICHTHYS Bleeker.

54. Murænichthys gymnopterus (Bleeker). Cavite (Jordan \& Seale, A).

55. Muranichthys macropterus Bleeker. Negros (Jordan \& Seale, B).

56. Murzenichthys thompsoni Jordan \& Richardson. Manila Bay (Jordan \& Richardson).

Muranichthys thompsoni Jordan \& Richardson, Bull. U. S. Bur. Fislı., XXVII, 237, 1908. Manila Bay.

\section{Family OPHICH'THYIDAE.}

\section{OPHICHTHUS Ahl.}

57. Ophichthus cephalozonus Bleeker. Philippine Islands (Günther).

58. Ophichthus grandoculis (Cantor). Manila (Jordan \& Richardson) 


\section{CIRRHIMURAENA Kaup.}

'This genus may be provisionally recognized for those ophichthyid eels which have the maxillary teeth in bands, the lips fringed, and the dorsal inserted over or behind the gill-opening.

59. Cirrhimuræena tapeinoptera (Bleeker). Cavite (Jordan \& Seale, A); Manila (Jordan \& Richardson).

60. Cirrhimuræna nectura (Jordan \& Seale) Cavite (Jordan \& Seale, A) . Jenkinsiella ${ }^{1}$ nectura Jordan \& Seale, Bull. U. S. Fish. Comm., XXVI, 1906, 6, fig. 1; Cavite, P. I.

\section{PISOODONOPHIS Kaup.}

61. Pisoodonophls cancrivorus (Richardson). Philippine Islands (Günther; Richardson, A) ; Manila ; Cuyo (Jordan \& Richardson).

62. Pisoodonophis macgregori Jordan \& Richardson. Manila (Jordan \& Richardson).

Pisoodonophis macgregori Jordan \& Richardson, Bull. U. S. Bur. Fish., XXVII, 238, 1908. Manila, P. I.

\section{LEIURANUS Bleeker.}

63. Leiuranus IIthinus Jordan \& Richardson. Cuyo (Jordan \& Richardson). Leiuranus lithinus Jordan \& Richardson, Bull. U. S. Bur. Fish., XXVII, 239, 1908. Cuyo, P. I.

CCECULA Vahl. (Dalophis Rafinesque.)

64. Cœcuia mindora Jordan \& Richardson. Mindoro (Jordan \& Richardson). Caccula mindora Jordan \& Richardson, Bull. U. S. Bur. Fish., XXVII, 239. 1908. Mindoro, P. I.

\section{Family MORINGUIDÆ.}

MORINGUA Gray: (Aphthalmichthys Kaup.)

65. Moringua abbreviata (Bleeker). Negros (Jordan \& Seale, B); Ticao (Jordan \& Richardson).

66. Moringua lumbricoidea Richardson. Negros (Jordan \& Seale, B).

67. Moringua macrocephala (Bleeker). Luzon (Peters, C).

${ }^{1}$ Microdonophis macgregori Jenkins (Bull. U. S. Fish. Comm. XXII, 1902, p. 422), the type of Jenkinsiella Jordan \& Evermann, with lips fringed, maxillary teeth uniserial (fide Jenkins), and dorsal inserted far in advance of gill-openings seems to be congeneric with Ophichthys (Cirrhimurana) calamus Günther, from Australia. The orignal description of Cirrhimurana (Jenkinsiella) nectura (Jordan \& Seale) erroneously states that the maxillary teeth are in a single series. A reexxamination of the type proves that they are in broad bands. Of the four species included by Dr. Gunther in the subdivision Cirrhimurana, one, ophichthys playfairii Ginther, from Zanzibar, with the teeth in bands, the lips fringed, and dorsal commencing "a short distance behind angle of mouth," appears to be intermediate between Jenkinsiella (macgregori) and Cirrhimurana as above defined. 


\section{Family MURÆNIDÆ.}

\section{GYMNOTHORAX Bloch.}

68. Gymnothorax punctatofasclatus Bleeker. Negros (Jordan \& Seale, B).

69. Gymnothorax polyuranodon Bleeker. Palawan (Boulenger, A.).

70. Gymnothorax petelli (Bleeker). Calayan (Jordan \& Richardson).

Murana petelli Bleeker, Nat. Tijds., XI, 84, Java.-Günther, Cat. V'III, $1870,105$.

Gymnothorax petelli Bleeker, Atlas, Muræn., 99, tab. XXXII, fig. 1.Jordan \& Seale, Bull. U. S. Fish Comm., XXV, 1905, 197 ; Samoa.

Murama interrupta Kaup, Apodes, 67, fig. 51, 1854; Red Sea.

Gymnothorax leucacme Jenkins, Bull. U. S. Fish Comm., XXII, 1902, 427.

fig. 7. Honolulu.

Gymnothorax waialux snyder, Bull. U. S. Fish Comnı., XXII, 1902, 520, pl. 6; Waialua, near Honolulu.

71. Gymnothorax richardsoni (Bleeker). Reefs near Cebu (Gïnther, A); San

Fabian (Evermann \& Seale, A); Sibuyan (Jordan \& Richardson).

Muræna richardsoni Bleeker, Nat. Tijds., III, 1852, 296 ; Wahai, Ceram, Padang, Sumatra.

Gymnothorax richardsoni Bleeker, Atlas Muræn. 100, pl. XLII, fig. 2.

Gymnothorax scoliodon Bleeker, 1. c., 101, pl. XL, fig. 2.

Gymnothorax ceramensis Bleeker, Ned. Tijds. Dierk., I, 261 Ceram.-Atlas.

Muræn., 101, pl. XXXIII, fig. 3.

(?) Muranophis lineatus Lesson, Voy. Coquille, 1830, 127, pl. II, fig. I;

Oualan. (Figure very poor; probably not the same species.)

72. Gymnothorax flavomarginatus (Riippell). Calayan (Jordan \& Richardson).

73. Gymnothorax philippinus Jordan \& Seale. Cavite (Jordan \& Seale, A).

Gymnothorax philippinus Jordan \& Seale, Bull. U. S. Fish Comm., XXVI, 1906, 7, fig. 2; Cavite, P. I.

74. Gymnothorax afer Bloch. Bacon (Evermann \& Seale, A).

75. Gymnothorax litus (Richardson). Cuyo; Cagayancillo (Jordan \& Richardson).

76. Gymnothorax plctus (Ahl). Samar (Peters, C); Negros (Jordan \& Seale, B) ; Cagayancillo; Ticao (Jordan \& Richardson).

77. Gymnothorax undulatus (Lacépède). Manila (Kner, Gymnothorax cancellatus).

78. Gymnothorax tile (Hamilton-Buchanan). Luzon (Peters, C).

79. Gymnothorax fimbriatus (Bennett) (G. isingleenoides Bleeker) Zamboanga (Seale \& Bean).

\section{ECHIDNA Forster.}

80. Echldna nebulosa (Ahl). Reefs of Cebu (Günther, A); Negros (Jordan \& Seale, B); Calayan ( Jordan \& Richardson).

81. Echidna delicatula (Kaup). Negros (Jordan \& Seale, B).

82. Echidna polyzona (Richardson). Calayan (Jordan \& Richardson).

Murana polyzona Richardson, Voy. Sulphur, Ichth., III, 1845, 112, pl. 55, fig. 11-14; no loc.

Echidna zonophaa Jordan \& Evermann, Bull. U. S. Fish Comm., XXII, 1902,167 ; 1. c. XXIII, pt. I, 1903, 109, pl. 21 ; Hawaii.

Echidna vincta Jenkins, Bull. U. S. Fish Comm., XXII, 1902, 429; Hawaii.

Echidna obscura Jenkins, Bull. U. S. Fish Comm., XXII, 1902, 430, fig.

11; Honolulu. 
Echidna psalion Jenkins, Bull. U. S. Fish Comm., XXII, 1902, 431, fig. 12; IIonolulu.

(?) Echilna lcihala Jenkins, Bull. U. S. Fish Comm., XXII, 1902, 428, fig. 9. Honolulu.

(?) Pocilophis tritor Vaillant \& Sauvage, Rev. et Mag. Zool. (3). 111287. 1875 ; Hawaii.

UROPTERYGIUS Rïppell.

83. Uropterygius concolor Riippell. Negros (Jordan \& Seale, B).

\section{Family CYPRINIDA.}

BARBODES Bleeker.

83. (84). Barbodes quinquemaculatus (Seale \& Bean). Zambonna (Günther,) Mount Malindang, Zamboanga (Seale \& Bean). (Barbodes maculatus var. A. Giinther.)

85. Barbodes palawanensis Boulenger. Palawan (Boulenger, A).

Barbus palaranensis Boulenger, Ann. Mag. N. H. (6) XV, 1895, 186; Palawan, P. I.

86. Barbodes hemictenus Jordan \& Richardson. Mindoro (Jordan \& Richardson).

Barbodes hemictenus Jordan \& Ricliardson, Bull. U. S. Bur. Fisl. XXVII, 2+2, 1908. Mindoro, P. I.

RASBORA Bleeker.

87. Rasbora phlllppina Günther. Pasananca, near Zamboanga (Giintlier, A). Rasbora philippina Güntler, Shore Fishes Challenger, p. 54; River at Pasananca, near Zamboanga, P. I.

88. Rasbora punctulata Seale \& Bean, Zamboanga. (Seale \& Bean).

89. Rasbora everetti Boulenger. Palawan (Boulenger, A).

Rasbora evcretti Boulenger, Ann. Mag. N. H. (6) XV, 1895, 187; Palawan, P. I.

\section{NEMATABRAMIS Bonlenger.}

90. Nematabramis everetti Boulenger. Paląwan (Boulenger, A).

Nematabramis everetti Boulenger, Ann. Mag. N. H. (6) XV, 1805, 187; Palawan, $P$. I.

01. Nematabramis alestes (Seale \& Bean). Mearnsiella alestes ${ }^{1}$ (Seale \& Bean). Zamboanga (Seale \& Bean).

DANGILA Cuvier \& Valenciennes.

92. Dangila philippinia Heckel. Plilippine Islands (Heckel, A).

Cyrene philippinia Heckel, Russegger's Reisen, I, 1025; Philippine Islands.

93. Dangila cyanopareia Heckel. Philippine Islands (Heckel, A).

Cyrene eyanojareia Heckel, Russegger's Reisen, I, 1025; Philippine Islands.

\footnotetext{
${ }^{1}$ According to Mr. Seale, Mearnsiella alestes is probably a species of Nematabramis.
} 
Family SILURIDÆ.

NETUMA Bleeker.

94. Netuma nasuta (Bleeker). Cavite (Jordan \& Seale, A).

95. Netuma thalassina (Rüppell). Philippines (Jordan \& Richardson); San Fabian; Bulan (Evermann \& Seale, A).

TACHYSURUS Lacépède. (Arius Cuv. \& Val.)"

90. Tachysurus venosus (Cuvier \& Valenciennes). Manila (Cuvier \& Valenciennes, after figure of Mertens).

RITA Bleeker.

97. Rita manillensis (Cuvier \& Valenciennes). Manila (Cuvier \& Valenciennes, $\mathrm{XV}, \mathbf{9 3}$ ).

HEMIPIMELODUS Bleeker.

98. Hemipimelodus manillensis (Cuvier \& Valenciennes). Manila (Cuvier \& Valenciennes, XV, 192).

\section{Family CLARIID无.}

\section{CLARIAS Gronow.}

99. Clarias magur (Hamilton-Buchanan). Philippines, Jordan \& Seale, A).

100. Clarlas batrachus (Bloch). Luzon; Samar (Peters, C). (Clarias fuscus Auct.)

101. Clarias nieuhofil Cuvier \& Valenciennes. Philippine Islands (Günther); Luzon (Peters, C).

102. Clarias gilli Smith \& Seale. Mindanao (Smith \& Seale).

Clarias gilli Smith \& Seale, Proc. Biol. Soc. Wash., XIX, 1906, 74, fig. a, b; Rio Grande, Mindanao, P. I.

Family PLOTOSIDÆ.

PLotosus Lacépede.

103. Plotosus anguillaris (Bloch). Philippine Islands (Güther); Manila (Jordan \& Seale, A); Cuyo (Jordan \& Richardson); Jolo; Bacon (Evermann \& Seale, A). Zamboanga (Seale and Bean).

Family BELONID必.

TYLOSURUS Cocco.

104. Tylosurus giganteus (Temminck \& Schlegel). Cavite (Jordan \& Seale, A) ; Negros (Jordan \& Seale, B) ; Manila; Iloilo (Jordan \& Richardson); Bacon (Evermann \& Seale, A).

105. Tylosurus lelurus (Bleeker). Cavite (Jordan \& Seale, A); Aparri (Jordan \& Richardson). Zamboanga (Seale \& Bean).

${ }^{1}$ It is perhaps not certain that Tachysurus chinensis is a species of this genus, as the description of Lacépede, based on a Chinese painting, is not surely identifiable. 
106. Tylosurus leluroides (Bleeker). Bacon (Evermann \& Seale, A). Zamboanga (Seale \& Bean).

107. Tylosurus caudlmaculatus (Cuvier). Iloilo (Jordan \& Richardson).

\section{Family EXOCCETID乎.}

\section{HEMIRAMPHUS Cuvier.}

108. Hemiramphus quoyi (Cuvier \& Valenciennes). Cavite (Jordan \& Seale, A); Bacon (Evermann \& Seale, A); Manila (Evermann \& Seale, B).

109. Hemiramphus limbatus Cuvier \& Valenciennes. Cuyo (Jordan \& Riclı. ardson).

110. Hemiramphus dussumieri (Cuvier \& Valenciennes). Bacon; Bulan (Evermann \& Seale, A).

111. Hemiramphus neglectus Bleeker. Aparri (Jordan \& Richardson).

112. Hemiramphus marginatus (Forskal). Bacon (Evermann \& Seale. A): Manila (Jordan \& Richardson).

113. Hemiramphus lutkei Cuvier \& Valenciennes. Manila (Cuvier \& Valenciennes, record based on figure of Mertens). Made a synonym of Hemiramphus marginatus by Dr. Günther.

114. Hemiramphus cantoris Bleeker. Cavite (Jordan \& Seale).

115. Hemiramphus cotnog Smith. Luzon (Smith). Hemiramplus cotnog, Smith, Bull. U. S. Fish Comm., XXI, 1902, 170, fig.; L. Buhi, lızon. P. $I$.

\section{ZENARCHOPTERUS (iill.}

116. Zenarchopterus philippinus Peters. Lw\%on; Samar (Peters, C); Bacon (Evermann \& Seale, A). Zamboanga (Seale \& Bean).

Hemirhamphus (Zenarchopterus) philippinus Peters, Monatsber. Akad. Wiss. Berl., 1868, 273; Luzon and Samar.

117. Zenarchopterus dispar (Cuvier \& Valenciennes). Cavite (Jordan \& Seale, A); Bacon (Evermann \& Seale, A). Zamboanga (Seale \& Bean).

DERMATOGENYS Van Hasselt.

118. Dermatogenys viviparus Peters. Luzon; Samar (Peters, A).

Hemirhamphus (Dermatogenys) viviparus Peters, Monatsber. Akad. Wiss. Berl., 1865, 132; Namar, P. I.

\section{PAREXOCCETUS Bleeker.}

119. Parexocœtus mento (Cuvier \& Valenciennes). Manila (Jordan \& Rich ardson); Cavite (Jordan \& Seale, A).

CYPSELURUS ${ }^{2}$ Swainson.

120. Cypselurus slmus (Cuvier \& Valenciennes). Bacon; Bulan (Evermann \& Seale, A).

121. Cypselurus spilonotopterus (Bleeker). Negros (Jordan \& Richardson) (Exocatus bahiensis Bleeker, probably not of Ranzani).

122. Cypselurus brachysomus (Bleeker). Cavite (Jordan \& Seale, A). 123. Cypselurus altipinnis (Cuv. \& Val.) Zamboanga (Seale \& Bean).

${ }^{1}$ Cypsilurus Swainson is plainly an error of transcription. 


\section{Family ATHERINID $Æ$.}

ATHERINA Linnæus.

124. Atherina lacunosa Forster. Iloilo (Jordan \& Richardson); Bacon (Jordan \& Seale, A). Zamboanga (Seale \& Bean) (dark lateral band; no dark on pectoral). (It is not certain what the original of Atherina lacunosa really is.)

125. Atherina temmincki (Bleeker). Negros (Jordan \& Seale, B); Bulan; Bacon (Evermann \& Seale, A).

126. AtherIna forskalii Rüppell. Bulan; Bacon (Evermann \& Seale, A).

127. Atherina lineata Günther. Cebu (Günther, C).

Atherina lineata Günther, Ann. Mag. Nat. Hist., 1872, 398; Cebu, P. I.

128. Atherina panatela Jordan \& Richardson. Calayan (Jordan \& Richardson). Atherina panatela Jordan \& Richardson, Bull U. S. Bur. Fish., XXVII, 244, 1908. Calayan, P. 1 .

\section{Family MUGILID $Æ$.}

\section{MUGIL Linnæus.}

129. Mugil cephalus Linnæus. Calayan (Jordan \& Richardson). Manila, Kner (Mugil cephalotus).

130. Mugil planiceps Cuvier \& Valenciennes. Bulan (Evermann \& Seale, A).

131. Mugil sundanensis Bleeker. Cavite (Jordan \& Seale, A); Bacon (Evermann \& Seale, A); Manila (Evermann \& Seale, B).

132. Mugil kelaartii Günther. Philippine Islands (Günther); Luzon (Peters, C) .

133. Mugll longimanus Günther. Cavite (Jordan \& Seale, A).

\section{LIZA Jordan \& Swain.}

134. Liza amarula (Cuvier \& Valenciennes). Cavite (Jordan \& Seale, A). Zamboanga. (Seale \& Bean).

135. Liza waigiensis (Quoy \& Gaimard). Cavite (Jordan \& Seale, A). Zamboanga (Seale \& Bean).

136. Liza oligolepis (Bleeker). Iloilo (Jordan \& Richardson).

137. Liza troscheli (Bleeker). Cavite (Jordan \& Seale, A); Iloilo (Jordan \& Richardson); Manila (Evermann \& Seale, A); Mindanao (Smith \& Seale). Zamboanga (Seale \& Bean).

\section{ESCHRICHTHYS Macleay.}

138. Eschrichthys goldiei Macleay. Mindoro (Jordan \& Richardson).

Eschrichthys goldiei Macleay,, Proc. Linn. Soc. N. S. Wales, 1883, 5, fig. I \& 2; Goldie R,, New Guinea.

\section{Family SPHYRÆNIDA.}

\section{SPHYRENA Linnæus.}

139. Sphyræna obtusata Cuvier \& Valenciennes. Cavite (Jordan \& Seale, A); Bulan (Evermann.\& Seale, A); Mindanao (Smith \& Seale). Zam. boanga (Seale \& Bean).

140. Sphyrzna jello Cuvier \& Valenciennes. Manila (Jordan \& Seale, A); Negros (Jordan \& Seale, B) Iloilo (Jordan \& Richardson); Bacon; Bulan (Evermann \& Seale, A). 
141. Sphyrzena langsar Bleeker. Bulan; Bacon; San Fabian (Evermann \& Seale, A).

142. Sphyrzena snodgrassi Jenkins. Aparri (Jordan \& Richardson). (Identification doubtful, probably Sphyrana commersoni.)

Sphyrana snodgrassi Jenkins, Bull. U. S. Fish Comm., XIX, 1899, 388, fig. 2; Honolulu, H. I.

\section{Family POLYNEMIDAॄ.}

POLYDACTYLUS Lacepede.

143. Polydactylus piebeius (Broussonet). Zamboanga (Seale \& Bean).

144. Polydactylus zophomus Jordan \& Seale. Cavite (Jordan \& Seale, A); Manila; Iloilo (Jordan \& Richardson).

Polydactylus zophomus Jordan \& Seale, Bull. U. S. Fish Comm., XXVI, 1906, 11, fig. 4 ; Cavite, Luzon, P. I.

145. Polydactylus sealel Jordan \& Richardson, new specific name. (Polydactylus opercularis Seale \& Bean, Proc. U. S. N. M., 1907, 234, not of Gill.) Zamboanga (Seale \& Bean).

ELEUTHERONEMA Bleeker.

146. Eleutheronema tetradactylum (Shaw). Manila (Jordan \& Richardson).

\section{Family AULOSTOMID压.}

AULOSTOMUS Cuvier.

147. Aulostomus chinensis (Linnæus). Philippine Islands (Lacêpede, fide Con. merson).

(Aulostoma valentini Bleeker.)

Family FISTULARIID无.

FISTULARIA Linnæus.

148. Fistuiarla petimba Lacepede. Cuyo; Lubang (Jordan \& Ríchardson); San Fabian; Bacon (Evermann \& Seale, A); Cavite (Jordan \& Seale, A).

149. Fistuiaria serrata Cuvier. Cavite (Jordan \& Seale, A); Manila (Jordan \& Richardson); Bacon (Evermann \& Seale, A).

Family CENTRISCID $Æ$.

CENTRISCUS Linnæus.

150. Centriscus scutatus Linnæus. Philippine Islands (Günther); Station 203, Philippines (Günther, A); Manila (Jordan \& Seale, A).

EOLISCUS Jordan \& Starks.

151. Eol iscus strigatus (Günther). Cagayancillo (Jordan \& Richardson); Bacon (Evermann \& Seale, A).

\section{Family SYNGNATHID无.}

\section{SIPHOSTOMA Rafinesque.}

152. Siphostoma schlegeli (Kaup). Zamboanga (Seale \& Bean). (A Japanese species, not to be expected to occur so far south.) 


\section{CORYTHROICHTHYS Kaup.}

153. Corythroichthys spiclfer (Kaup). Manila; Cavite (Jordan \& Seale, A); Aparri (Jordan \& Richardson); Luzon (Peters, C) ; Samar; Leyte (Peters, C, var. rivalis).

154. Corythroichthys pullus Smith \& Seale. Rio Grande, Mindanao (Smith \& Seale).

Corythroichthys pullus Smith \& Seale, Proc. Biol. Soc. Wash., XIX, 1906, 75, fig; Rio Grande, Mindanao, P. I.

155. Corythroichthys eierz Evermann \& Seale. Bacon (Evermann \& Seale, A). Corythroichthys elerce Evermann \& Seale, Bull. U. S. Bur. Fish., XXVI, 1906, 57, fig. 2; Bacon, P. I.

156. Corythroichthys bleekeri Day. Zamboanga (Seale \& Bean).

\section{DORYRHAMPHUS Kaup.}

157. Doryrhamphus macgregori Jordan \& Richardson. Calayan (Jordan \& Richardson).

Doryrhamphus macgregori Jordan \& Richardson, Bull. U. S. Bur. Fish., XXVII, 246, 1908. Calayan, P. I.

\section{CCELONOTUS Peters.}

158. Cœlonotus leiaspis (Bleeker). Mindoro; Sibuyan (Jordan \& Richardson).

\section{DORYICHTHYS Kaup.}

159. Dorylchthys spanlaspis Jordan \& Seale. Cavite (Jordan \& Seale, A).

Doryichthys spaniaspis Jordan \& Seale, Bull. U. S. Bur. Fish., XXVI, 1906, 10, fig. 3 ; Cavite, P. I.

\section{MICROPHIS Kaup.}

160. Microphis pleurostictus Peters. Luzon (Peters, C; Günther); Palawan (Boulenger, A).

161. Microphis caudatus Peters. Samar (Peters, C).

162. Microphis jagoril Peters. Samar (Peters, C).

\section{GASTEROTOKEUS Heekel.}

163. Gasterotokeus biaculeatus (Bloch). Philippine Islands (Gunther; Richardson, B) ; Leyte (Peters, C) ; Panay (Jordan \& Seale, A); Negros (Jordan \& Seale, B) ; Cuyo; (Jordan \& Richardson); Bacon (Evermann \& Seale, A). Zamboanga (Seale \& Bean).

\section{HIPPOCAMPUS Linnæus.}

164. Hippocampus kuda Bleeker. Cavite (Jordan \& Seale, A); Mindoro (Jordan \& Richardson); Zamboanga (Seale \& Bean).

165. Hippocampus aterrimus Jordan \& Snyder. Cavite (Jordan \& Seale, A); Negros (Jordan \& Seale, B, Hippocampus kuda, not of Bleeker).

Hixpocampus aterrimus Jordan \& Snyder, Proc. U. S. Nat. Mus., XXIV, 1901, 14, pl. IX; Ishigaki, Riukiu.

166. Hippocampus barbouri Jordan \& Richardson. Cuyo; (Jordan \& Richardson).

Hippocampus barbouri Jordan \& Richardson, Bull. U. S. Bur. Fish., XXVII, 247, 1908. Cuyo, P.I. 


\section{Family PEGASID \\ PARAPEGASUS Duméril.}

167. Parapegasus natans (Linnæus). Cavite (Jordan \& Seale, A).

PEGASUS Linnæus.

168. Pegasus volitans Linnæus. (Pegasus draconis Linnæus (1768). Zamboanga (Seale \& Bean).

\section{Family HOLOCENTRID $A$.}

\section{MYRIPRISTIS Cuvier.}

169. Myripristis murdjan (Forskål). Cagayancillo (Jordan \& Richardson); Bacon (Evermann \& Seale, A); Zamboanga (Seale \& Bean).

170. Myripristis microphthalmus Bleeker. Bacon; Bulan (Evermann A Seale, A).

171. Myripristis pralinius Cuvier \& Valenciennes. Bacon (Evermann \& Seale, A).

172. Myripristis macrolepis Bleeker. Zamboanga (Evermann \& Seale, A). Zamboanga (Seale \& Bean).

\section{HOLOCENTRUS (Artedi) Gronow.}

173. Holocentrus ruber Lacépède. Cagayancillo; Cuyo; Calayan (Jordan \& Richardson); Philippines (Günther, Holocentrus rubrum); Panay (Jordan \& Seale, A, Holocentrus ruber); Manila (Kner, Holocentrus rubrum). (Including the ontogenetic subspecies praslin found on coral reefs.)

174. Holocentrus caudimaculatus Rüppell. Zamboanga (Seale \& Bean).

175. Holocentrus lacteoguttatus Cuvier \& Valenciennes. Calayan (Jordan \& Richardson).

(Holocentrus lacteoguttatum, punctatissimum, and argenteum, Cuvier \& Valenciennes; diploxiphus Günther; gracilospinis and gladispinis Fowler).

176. Holocentrus microstomus Güntber. Cagayancillo (Jordan \& Richardson). 177. Holocentrus cornutus Bleeker. Bacon; Bulan (Evermann \& Seale, A); Zamboanga (Seale \& Bean).

178. Holocentrus sammara (Forskål). Cagayancillo (Jordan \& Richardson).

\section{Family SCOMBRID $ઋ$.}

\section{SCOMBER Linnæus.}

179. Scomber microlepidotus Rüppell. Cavite (Jordan \& Seale, A); Manila; (Jordan \& Richardson); Bacon (Evermann \& Seale, A); Zamboanga, (Seale \& Bean) .

180. Scomber japonicus Houttuyn. Bulan (Evermann \& Seale, A).

\section{RASTRELLIGER Jordan \& Piction.}

181. Rastrelliger brachysomus Bleeker. San Fabian (Evermann \& Seale, A). 182. Rastrelliger loo Cuvier \& Valenciennes. Manila (Kner). 
EUTHYNNUS ${ }^{1}$ Lüken.

183. Euthynnus pelamis (Linnæus). Bulan (Evermann \& Seale, A).

NESOGRAMMUS Evermann \& Seale.

184. Nesogrammus piersoni Evermann \& Seale. Bulan (Evermann \& Seale, A). Nesogrammus piersoni Evermann \& Seale, Bull. U. S. Bur. Fish., XXVI, 1906, 61, fig. 3; Bulan, P. I.

SCOMBEROMORUS Lacépède.

185. Scomberomorus commersoni Lacépède. Cavite (Jordan \& Seale, A).

186. Scomberomorus konam (Bleeker). Manila (Kner).

$$
\text { Family CARANGID有. }
$$

SCOMBEROIDES Lacépède.

187. Scomberoldes tol (Cuvier \& Valenciennes). Manila (Jordan \& Richardson); Cavite (Jordan \& Seale, A, Scomberoides toloo-parah, not of Rüppell). (Chorinemus moadetta Day, not of C. \& V.)

188. Scomberoides toloo-parah (Rüppell). Cavite (Jordan \& Richardson); San Fabian (Evermann \& Seale, A); Mindanao (Smith \& Seale); Zamboanga, (Seale \& Bean).

\section{ELERIA Jordan \& Seale.}

189. Eleria philippina Jordan \& Seale. Negros (Jordan \& Seale, B).

Eleria philippina Jordan \& Seale, Proc. U. S. Nat. Mus., XXVIII, 1905, 774, fig. 1; Negros, P. I.

(=Chorinemus tala Day, probably not C. \& V.)

190. Eleria tala (Cuvier \& Valenciennes). Cavite (Jordan \& Seale, A); Manila;

Iloilo (Jordan \& Richardson); Mindanao (Smith \& Seale). (Chorinemus tala \& toloo C. \& V.; (?) Scomber aculeatus Bloch). Zamboanga (Seale \& Bean).

\section{SERIOLA Cuvier.}

191. Seriola nigrofasciata (Rüppell). Bulan (Evermann \& Seale, A).

192. Seriola dumerilii (Risso). Manila (Kner).

LACTARIUS Cuvier \& Valenciennes.

193. Lactarius lactarius (Bloch \& Schneider). San Fabian (Evermann \& Seale, A).

\section{MEGALASPIS Bleeker.}

194. Megalaspis cordyla (Linnæus). Bulan; Jolo (Evermann \& Seale, A); Manila (Jordan \& Richardson); Zamboanga (Seale \& Bean).

\section{DECAPTERUS Bleeker.}

195. Decapterus macrosomus Bleeker. Bulan; Bacon (Evermann \& Seale, A). 196. Decapterus kurra Bleeker. Bulan (Evermann \& Seale, A).

${ }^{1}$ The genus Gymnosarda (nuda) with scaleless corselet is apparently distinct from Euthynnus. 


\section{TRACHUROPS Gill.}

197. Trachurops crumenophthalma (Bloch). Cavite (Jordan \& Seale, A); Manila; Lubang (Jordan \& Richardson).

CARANX Lacépède.

198. Caranx forsterl (Cuvier \& Valenciennes). Negros (Jordan \& Seale, B); Manila; Lubang; Iloilo; Cagayancillo (Jordan \& Richardson).

199. Caranx Ignobilis (Forskål). Cavite (Jordan \& Seale, A); Iloilo; Lubang (Jordan \& Richardson); Mindanao (Smith \& Seale, Caranx carangus, specimens said to have breast naked); Zamboanga (Seale \& Bean) as Caranx carangus.

200. Caranx sexfasclatus Quoy \& Gaimard. Cavite (Jordan \& Seale, A); San Fabian (Evermann \& Seale, A); Zamboanga (Seale \& Bean).

201. Caranx boops Cuvier \& Valenciennes. Bacon (Evermann \& Seale, A).

202. Caranx affinis Ruppell. Cavite (Jordan \& Richardson; Jordan \& Seale, A, Caranx hasselti, not of Bleeker).

203. Caranx hasselti Bleeker. Negros (Jordan \& Seale, B).

204. Caranx cynodon Bleeker. Bacon (?) (Evermann \& Seale, A).

205. Caranx brevis (Bleeker). Philippines (Evermann \& Seale, A).

206. Caranx freerl Evermann \& Seale. San Fabian (Evermann \& Seale, A).

Caranx freeri Evermann \& Seale, Bull. U. S. Fish Comm., XXVI, 1906, 63, fig. 4; San Fabian, P. I.

207. Caranx ophthaimotænia (Bleeker). Bulan (Evermann \& Seale, A).

208. Caranx ire Cuvier \& Valenciennes. Negros (Jordan \& Seale, B); Manila; Iloilo (Jordan \& Richardson).

209. Caranx leptolepls Cuvier \& Valenciennes. Manila (Cuvier \& Valenciennes, Caranx mertensi; based on figure of Mertens); Cavite (Jordan \& Richardson).

210. Caranx calla Cuvier \& Valenciennes. Cavite (Jordan \& Seale, A, Caranx nigripinnis, not of Day); Manila ; Iloilo (Jordan \& Richardson); Bulan (Evermann \& Seale, A).

211. Caranx djeddaba (Forskål). Manila (Jordan \& Richardson); Philippines (Evermann \& Seale, A).

212. Caranx deani Jordan \& Seale. Negros (Jordan \& Seale, B) ; Cavite (Jordan \& Richardson).

Caranx deani Jordan \& Seale, Proc. U. S. Nat. Mus., XXVIII, 1905, 776, fig. 2; Negros P. I.

213. Caranx rastrosus Jordan \& Snyder.

(Caranx rastrosus Jordan \& Snyder, Bull. Carnegie Museum, 1908, IV, p. 37, pl. 61, Formosa, Cavite).

214. Caranx armatus (Forskål). Cavite (Jordan \& Seale, A); Manila (Jordan \& Richardson); San Fabian (Evermann \& Seale, A).

215. Caranx altissimus Jordan \& Seale. Manila (Jordan \& Richardson).

Caranx altissimus Jordan \& Seale, Proc. Davenport Acad., X, 1905, 7, pl. 3; Hong Kong.

216. Caranx halli (Evermann \& Seale.) San Fabian (Evermann \& Seale, A).

Citula halli Evermann \& Seale, Bull. U. S. Fish Comm., XXVI, 1906, 65, fig. 5, San Fabian, P. I. 


\section{ULUA Jordan \& Snyder.}

217. Ulua richardson I Jordan \& Snyder. Cavite (Lung Coll. recorded as Carano plumbeus).

(Ulua richardsoni Jordan \& Snyder, Bull. Carnegie Museum, I908, IV, p. 39, pl. I.III : Formosa; Cavite.)

\section{GNATHANODON Bleeker.}

218. Gnathanodon speciosus (Forskal). Philippine Islands (Gunther); Cavite (Jordan \& Seale, A) Bulan (Evermann \& Seale, A); Zamboanga (Seale \& Bean).

\section{ALECTIS Rafinesque.}

219. Alectis major (Cuvier \& Valenciennes). Manila (Jordan \& Richardson); Cavite (Jordan \& Seale, A, Alectis ciliaris, not of Bloch). Zamboanga (Seale \& Bean) as Alectis ciliaris.

Zeus gallus Bloch, not of Linnæus; (?) Zeus virescens Lacepede; Gallichthys major Cuvier \& Valenciennes; Scyris indica Ruppell.

TRACHINOTUS Lacépede.

220. Trachinotus bailloni (Lacépède). Zamboanga (Evermann \& Seale, A).

APOLECTUS Cuvier \& Valenciennes.

221. Apolectus niger (Bloch). Cavite (Jordan \& Seale, A); Manila (Jordan \& Richardson).

\section{Family RACHYCENTRID Æ.}

\section{RACHYCENTRON Kaup.}

222. Rachycentron canadum (Linnæus). Manila; Panay (Jordan \& Seale, A, Rachycentron pondicerianum) ; Manila (Jordan \& Richardson); Bulan (Evermann \& Seale, A).

\section{Family TRICHIURID无.}

\section{TRICHIURUS Linnæus.}

223. Trichiurus haumela (Forskål). Manila (Jordan \& Richardson); San Fabian (Evermann \& Seale, A) ; Cavite (Jordan \& Seale, A, Trichiurus savala, not of Bleeker).

224. Trichiurus lajor Bleeker. Manila (Kner).

$$
\text { Family EQUULID }
$$

\section{LEIOGNATHUS Lacépède.}

225. Lelognathus caballus (Cuvier \& Valenciennes). Manila; Iloilo; Aparri (Jordan \& Richardson); Cavite (Jordan \& Seale, A, Leiognathus dussumieri, not of C. \& V.); San Fabian (Evermann \& Seale, A, Leiognathus edentula). (=Totah-Karah Russell; (?) Bcomber equula Forskål). Zamboanga (Seale \& Bean) as $L$. edentula. 
226. Leiognathus ensiferus (Cuvier \& Valenciennes). Manila (Jordan \& Richardson); Philippine Islands (Guinther, A, Equula dussumieri; (?) Mindanao (Smith \& Seale, ${ }^{1}$ Leiognathus dussumieri).

(=Equula ensifera \& dussumieri Cuvier \& Valenciennes; Equula dussumieri, Günther; Equula edentula, Günther, part). Zamboanga (Seale \& Bean) (as L. dussumieri).

227. Leiognathus coma (Cuvier \& Valenciennes). Iloilo; Manila (Jordan \& Richardson); San Fabian (Evermann \& Seale, A, Leiognathus dussumieri, not of C. \& V.).

(Equula coma Cuvier \& Valenciennes, after Komah-Karah of Russell.)

228. Leiognathus spiendens (Cuvier). Negros (Jordan \& Seale, B); Manila, Aparri (Jordan \& Richardson); San Fabian; Bacon (Evermann \& Seale, A); Mindanao (Smith \& Seale).

229. Lelognathus fasciatus (Lacépede). Philippine Islands (Günther; also A); Manila (Cuvier \& Valenciennes, Equula longispinis, after drawing made by Russian Expedition); Cavice (Jordan \& Seale, A); San Fabian (Evermann \& Seale, A).

230. Leiognathus leuciscus (Günther). Negros (Jordan \& Seale, B).

231. Leiognathus virgatus Fowler. Bulan (Evermann \& Seale, A).

Leiognathus virgatus Fowler, Journ. Ac. Nat. Sci. Phila., (2) XII, 1904, 515, pl. XV, fig. 4 ; Padang, Sumatra.

232. Leiognathus stercorarius Evermann \& Seale. Bulan (Evermann \& Seale, A).

Leiognathus stercorarius Evermann \& Seale, Bull. U. S. Fish Comm., XXVI, 1906, 67, fig. 6; Bulan, P. I.

233. Leiognathus edwardsi Evermann \& Seale. San Fabian (Evermann \& Seale, A).

Leiognathus edwardsi Evermann \& Seale, Bull. U. S. Fish Comm., XXVI, 1906, 68, fig. 7; San Fabian, P. I.

\section{EQUULA Cuvier. (Deveximentum Fowler.)}

234. Equula Insidiator (Bloch). Manila (Kner); Cavite (Jordan \& Seale, A); Negros (Jordan \& Seale, B); Manila (Jordan \& Richardson).

235. Equula ruconia (Hamilton-Buchanan). Cavite (Jordan \& Seale, A).

GAZZA Rlippell.

236. Gazza minuta (Bloch). Cavite (Jordan \& Seale, A); Negros (Jordan \& Seale, B); Iloilo; Manila; Lubang (Jordan \& Richardson); San Fabian (Evermann \& Seale, A); Mindanao (Smith \& Seale).

237. Gazza tapelnosoma Bleeker. Bulan (Evermann \& Seale, A).

Family MENID无.

MENE Lacépède.

238. Mene maculata (Bloch). Panay (Jordan \& Seale, A); Manila (Jordan \& Richardson).

${ }^{1}$ Description by Smith \& Seale not sufficient for determination. These writers probably followed Guinther, in which case references fall in present synonymy. 


\section{Family PEMPHERID开.}

\section{PEMPHERIS Cuvier.}

239. Pempheris oualensis Cuvier \& Valenciennes. Calayan (Jordan \& Richardson).

240. Pempheris vanlcolensis Cuvier \& Valenciennes. Bacon; Bulan (Evermann \& Seale, A).

\section{Family APOGONICHTHYIDE.}

\section{AMIA Gronow. (Apogon Lacépedè.)}

241. Amla hyalosoma (Bleeker). Luzon (Peters, C); Calayan; Mindoro (Jordan \& Richardson).

242. Amla koilomatodon(Bleeker). Bacon (Evermann \& Seale, A).

243. Amia margaritophora (Bleeker). Bacon (Evermann \& Seale, A).

244. Amla sangiensis (Bleeker). Bulan (Evermann \& Seale, A).

245. Amia monochroa (Bleeker). Bulan (Evermann \& Seale, A).

246. Amla novæe-guineæ (Valenciennes). Philippines (Jordan \& Seale, A); Negros (Jordan \& Seale, B); Iloilo (Jordan \& Richardson).

247. Amla bifasciata (Rüppell). Philippine Islands (Günther). (?Amia elizabetha Jordan \& Seale).

248. Amia quadrifasciata (Cuvier \& Valenciennes). Cavite (Jordan \& Seale, A) ; Manila (Jordan \& Richardson); Jolo (Evermann \& Seale, A).

249. Amia endekatzenla (Bleeker). Bacon (Evermann \& Seale, A).

250. Amia novemfasciata (Cuvier \& Valenciennes). Negros (Jordan \& Seale, B) ; Calayan; Cuyo; Ticao (Jordan \& Richardson); Bacon (Evermann \& Beale, A, Amia fasciata, ${ }^{1}$ not of White). Apogon fasciatus Peters, C., Luzon, Samar, is doubtless A. novemfasciata. Zamboanga, as Amia fasciata (Seale \& Bean).

250a. Amla frænata (Valenciennes). Bacon (Evermann \& Seale, A).

251. Amla savayensis (Günther). Bacon (Evermann \& Seale, A).

252. Amia chrysopoma (Bleeker). Bacon (Evermann \& Seale, A).

253. Amia hartzfeldi (Bleeker). Bacon (Evermann \& Seale, A).

254. Amia kalloptera (Bleeker). Fuga (Jordan \& Richardson),

255. Amia lateralis (Valenciennes). Cuyo (Jordan \& Richardson).

256. Amia bleekerl (Günther). Bacon; San Fabian (Evermann \& Seale, A).

257. Amia gilberti Jordan \& Seale. Negros (Jordan \& Seale, B).

A mia gilberti Jordan \& Seale, Proc. U. S. Nat. Mus., XXVIII, 1905, 777, fig. 3 ; Negros, P. I.

258. Amia cavitensis Jordan \& Seale. Cavite (Jordan \& Seale, A). A mia cavitensis Jordan \& Seale, Bull. U. S. Fish Comm., XXVI, 1906, 16, fig. 5 ; Cavite, P. I.

259. Amia jenkinsi (Evermann \& Seale). Bulan (Evermann \& Seale, A). A mia jenkinsi Evermann \& Seale, Bull. U. S. Fish Comm., XXVI, 196, 73, fig. 9 ; Bulan, P. I.

260. Amla orblcularis (Cuvier \& Valenciennes). Palawan (Vaillant); Zamboanga (Seale \& Bean).

${ }^{1}$ If Mullus fasciatus White from Sydney is a species distinct from Apogon fasciata Quoy \& Gaimard, as it seems to be, the name novemfasciata of C. \& V., although published later must supersede fasciata of $Q$. \& G. 
MIONORUS Krefft.

261. Mionorus glaga (Bleeker). Cavite (Jordan \& Seale, A); Manila (Jordan \& Richardson).

262. Mionorus mydrus (Jordan \& Seale). Negros (Jordan \& Seale, B). Mionorus mydrus Jordan \& Seale, Proc. U. S. Nat. Mus., XXVIII, 1905, 778, fig. 4 ; Negros, P. I.

APOGONICHTHYS Bleeker. (Foa Jordan \& Evermann.)

263. Apogonichthys fo Jordan \& Seale. Negros (Jordan \& Seale, B); Cavite (Jordan \& Seale, A); Iloilo (Jordan \& Richardson).

Foa fo Jordan \& Seale, Proc. U. S. Nat. Mus., XXVIII, 1905, 779, fig. 5 ; Negros, P. I. (with figure of Fovleria brachygramma).

\section{ARCHAMIA Gill.}

264. Archamia lineolata (Ehrenberg). Cavite (Jordan \& Seale, A); Zamboanga (Smith \& Seale).

265. Archamia macropteroides (Bleeker). Bacon (Evermann \& Seale, A).

266. Archamia bleekeri (Günther). Bacon; San Fabian (Evermann \& Seale, A).

PSEUDAMIA Bleeker.

267. Preudamia polystigma (Bleeker). Cavite (Jordan \& Seale, A).

FOWLERIA Jordan \& Evermann.

268. Fowleria mentalis (Evermann \& Seale). Bacon (Evermann \& Seale, A). A pogonichthys mentalis Evermann \& Seale, Bull. U. S. Fish Comm., XXVI, 1906, 74, fig. 10; Bacon, P. I. This species may not belong to this genus.

\section{Family AMBASSIDAE.}

AMBASSIS Lacépède.

269. Ambassis urotzenla Bleeker. Calayan; lloilo (Jordan \& Richardson); Bacon (Evermann \& Seale, A); Mindanao (Smith \& Seale).

270. Ambassis lungi ${ }^{2}$ (Jordan \& Seale). Cavite (Jordan \& Seale, A); Bacon (Evermann \& Seale, A). Zamboanga (Seale \& Bean).

Priopis lungi Jordan \& Seale, Bull. U. S. Fish Comm., XXVI, 1906, 18, fig. 6; Cavite.

271. Ambassis kopsi (Bleeker). Cavite (Jordan \& Seale, A); Iloilo (Jordan \& Richardson).

272. Ambassis commersonii Cuvier \& Valenciennes.

(Centropomus ambassis Lacépede) Philippines (Günther).

PRIOPIS Kuhl \& Van Hasselt. (Lateral line interrupted.)

273. Prlopis interruptus (Bleeker). Luzon; Samar (Peters, C); Cavite (Jordan \& Seale, A); Mindoro; Cuyo (Jordan \& Richardson).

274. Priopis buruensia (Bleeker). Cavite (Jordan \& Seale, A); Aparri (Jordan \& Richardson).

275. Priopls gymnocephalus (Lacépède). Negros (Jordan \& Seale, B).

276. Priopis urotzenia (Bleeker). Zamboanga (Seale \& Bean).

${ }^{1}$ The lateral line in this species is really complete. It is therefore an Ambassis not a Priopis. 


\section{Family ACROPOMATIDÆ.}

ACROPOMA Temminck \& Schlegel.

277. Acropoma phillpplnense Günther. Sta. 201, Philippine Islands (Günther, A).

Acropoma philippinense Günther, Shore Fishes Challenger, p. 51 ; Sta. 201, Philippine Islands.

\section{Family KUHLIID $Æ$.}

KUHLIA Gill.

278. Kuhlia marginata (Cuvier \& Valenciennes). Rio Baco, Mindoro; Aparri (Jordan \& Richardson).

279. Kuhlia rupestris (Lacépede). Samar; Leyte (Peters, C) ; Mindoro (Jordan \& Richardson). Zamboanga (Seale \& Bean).

280. Kuhlia malo (Cuv. \& Val.). Zamboanga (Seale \& Bean.)

\section{Family SERRANID压.}

\section{LATES Cuvier.}

281. Lates calcarifer (Bloch). Cavite (Jordan \& Seale, A); Zamboanga (Evermann \& Seate, A).

NIPHON Cuvier \& Valenciennes.

282. Niphon spinosus Cuvier \& Valenciennes. Cuyo (Jordan \& Richardson).

VARIOLA Swainson.

283. Variola louti (Forskål). Calayan (Jordan \& Richardson).

CEPHALOPHOLIS Bloch \& Schneider.

284. Cephalopholis stigmatopomus (Richardson). Manila (Jordan \& Seale, A). 285. Cephalopholis minlatus (Forskal). Calayan (Jordan \& Richardson). 286. Cephalopholis argus (Bloch). Cagayaucillo (Jordan \& Richardson). 287. Cephalopholis maculatus Seale \& Bean). Zamboanga (Seale \& Bean). 288. Cephalopholis leopardus (Lacépede). Calayan (Jordan \& Richardson). 289. Cephalopholls urodelus (Forster). Zamboanga (Seale \& Bean). 290. Cephalopholis boenack (Bloch). Bacon (Evermann \& Seale, A). 291. Cephalopholls sonnerati (Cuv. \& Val.). Zamboanga (Seale \& Bean). 292. Cephalopholis pachycentron (Cuvier \& Valenciennes). Bacon (Evermann \& Seale, A).

293. Cephalopholls kendalli Evermann \& Seale. Bacon (Evermann \& Seale, A). Cephalopholis kendalli Evermann \& Seale, Bull. U. S. Bur. Fish, XXVI, 1906, 76, fig. 11; Bacon, P. I.

294. Cephalopholis obtusauris Evermann \& Seale. Bacon (Evermann \& Seale, A).

Cephalopholis obtusauris Evermann \& Seale, Bull. U. S. Bur. Fish, XXVI, 1906, 77, fig. 12; Bacon, P. I. Zamboanga (Seale \& Bean).

EPINEPHELUS Bloch.

295. Eplnephelus merra Bloch. Philippine Islands (Günther; Boulenger, B); Bacon (Evermann \& Seale, A) (prob, not $\mathbf{S}$. merra of Day, which prob. $=$ Epinephelus megachir); Zamboanga (Seale \& Bean). 
296. Epinephelus hexagonatus (Bloch \& Schneider). Philippine Islands (Günther). (Regarded as a synonym of Epinephelus merra by Boulenger, Cat. I, 241.)

297. Epinephelus tauvina (Forskål). Cavite (Jordan \& Seale, A); Negros (Jordan \& Seale, B); Bacon (Evermann \& Seale, A); Zamboanga (Seale \& Bean).

298. Epinephelus malabaricus (Bloch). Cavite (Jordan \& Seale, A); Philippine Islands (Günther, Serranus suillus). (Regarded as synonym of Epinephelus tauvina by Boulenger.)

299. Epinephelus megachir (Richardson). Philippine Islands (Boulenger, B); Cavite (Jordan \& Seale, A); Calayan (Jordan \& Riclıardson).

300. Epinephelus dlacanthus (Cuvier \& Valenciennes). Philippine Islands (Günther, A) ; Cavite (Jordan \& Seale, A) ; Cuyo; Cagayancillo (Jordan \& Richardson).

301. Epinephelus bontoides (Bleeker). Mindanao (Smith \& Seale).

302. Epinephelus fasciatus (Forskål). Cebu (Boulenger, B); Bacon (Evermann \& Seale, A) ; Zamboanga (Seale \& Bean).

303. Epinephelus maculatus (Bloch). San Fabian (Evermann \& Seale, A).

(=Serranus albofuscus of Günther).

304. Epinephelus nebulosus (Cuvier \& Valenciennes). Aparrî (Jordan \& Richardson).

305. Epinephelus cæruleopunctatus (Bloch). Philippine Islands (Boulenger, B).

306. Epinephelus fuscoguttatus (Forskål). Philippine Islands (Boulenger, B). 307. Epinephelus undulosus (Quoy \& Gaimard). Zamboanga (Seale \& Bean).

CROMILEPTES Swainson.

308. Cromlleptes altivelis (Cuvier \& Valenciennes). Cebu (Boulenger, B); Manila (Jordan \& Seale, A); Negros (Jordan \& Seale, B); Bacon Evermann \& Seale, A).

PSAMMOPERCA Richardson.

309. Psammoperca waigiensis (Cuvier \& Valenciennes). Bulan (Evermann \& Seale, A); Manila (Müller \& Troschel, Cnidon chinensis; Günther, after M. \& T; Kner); Cebu (Boulenger, B).

GRAMMISTES Bloch \& Schneider.

310. Grammistes sexlineatus (Thunberg). Philippine Islands (Günther, Grammistes orientalis, Boulenger, B); Bacon (Evermann \& Seale, A); Palawan (Vaillant, Grammistes orientalis).

CENTROGENYS Richardson. (Myriodon Brisout de Barneville; Gennadius Jordan \& Seale.)

311. Centrogenys vaigiensis (Quoy \& Gaimard). Panay (Jordan \& Seale, A, Gennadius stolicza); Cuyo (Jordan \& Richardson); Cebu (Boulenger, B).

The serranoid rather than scorpænoid affinities of the Scorpene de Vaigiou of Quoy \& Gaimard (erroneously figured with lower pectoral rays unbranched) seems to be beyond question. There also seems to be no doubt that the Sebastes stolicza of Day (=Gennadius stolicza, Jordan \& Seale) is identical with the present species of Quoy \& Gaimard, as subsequently admitted by Dr. Day and more recently formally stated by Boulenger. 
PHAROPTERYX Rüppell.

312. Pharopteryx nigricans (Rüppell). Luzon (Peters, C), Plesiops caruleolineatus); Bacon (Evermann \& Seale, A); Calayan (Jordan \& Richardson); Palawan (Vaillant, Plesiops corallicola).

313. Pharopteryx melas (Bleeker). Negros (Jordan \& Seale, B); Calayan (Jordan \& Richardson).

\section{Family PRIACANTHIDÆ.}

\section{PRIACANTHUS Cuvier. (Plesiops Cuvier.)}

314. Priacanthus cruentatus (Lacépede). Cavite (Jordan \& Seale, A). 315. Priacanthus hamrur (Forskål). Bulan (Evermann \& Seale, A); Calayan (Jordan \& Richardson).

\section{Family LUTIANIDÆ.}

\section{LUTIANUS Bloch.}

316. Lutianus sebæ (Cuvier \& Valenciennes). Bulan (Evermann \& Seale, A); Zamboanga (Seale \& Bean).

317. Lutianus decussatus (Cuvier \& Valenciennes). Philippine Islands (Günther) ; Manila (Jordan \& Seale, A); Negros (Jordan \& Seale, B); Bacon (Evermann \& Seale, A).

318. Lutianus gibbus (Forskål). Cavite (Jordan \& Seale, A); Bacon (Evermann \& Seale, A) ; Zamboanga (Seale \& Bean).

319. Lutianus fulvifiamma (Forskål). Bacon; Zamboanga (Evermann \& Seale, A); Zamboanga (Seale \& Bean).

320. Lutlanus russelli (Bleeker). Cavite (Jordan \& Seale, A); Cuyo; Iloilo (Jordan \& Richardson). Perhaps not distinct from Lutianus fulviflamma.

321. Lutianus Iuzonius Evermann \& Seale. Bacon (Evermann \& Seale, A).

Lutianus luzonius Evermann \& Seale, Bull. U. S. Bur. Fish, XXVI, 1906, 80, fig. 13 ; Bacon, P. I.

322. Lutianus rivulatus (Cuv. \& Val.). Zamboanga (Seale \& Bean).

323. Lutlanus monostigma (Cuvier \& Valenciennes). Bacon (Evermann \& Seale, A); Zamboanga (Seale \& Bean).

324. Lutlanus amboinensis (Bleeker). Bulan (Evermann \& Seale, A).

325. Lutlanus Johni (Bloch). Philippine (Kner); Negros (Jordan \& Seale, B); Bacon; Bulan; Jolo (Evermann \& Seale, A).

326. Lutianus dodecacanthoides (Bleeker). Manila (Jordan \& Seale, A).

327. Lutianus quinquelineatus (Bloch). Bulan (Evermann \& Seale, A); Manila; Aparri (Jordan \& Richardson).

328. Lutianus vitta (Quoy \& Gaimard). Cavite (Jordan \& Seale, A); Bacon; Bulan; Zamboanga (Evermann \& Seale, A); Zamboanga (Seale \& Bean).

329. Lutianus lineatus (Quoy \& Gaimard). San Fabian (Evermann \& Seale, A); Mindanao (Smith \& Seale); Aparri; Lubang (Jordan \& Richardson).

330. Lutlanus marginatus (Cuv. \& Val.). Zamboanga (Seale \& Bean).

331. Lutlanus chrysotzenla Bleeker. Zamboanga (Seale \& Bean).

332. Lutianus malabaricus (Bloch \& Schneider). Bulan (Evermann \& Seale, A); Mindanao (Smith \& Seale). 
333. Lutianus furvicaudatus Fowler. Bacon (Evermann \& Scale, A).

Lutianus furvicaudatus Fowler, Journ. Ac. Nat. Sci. Phila., (2) XII, 1904, 525, pl. XVIII, lower fig.; Padang.

334. Lutianus lunulatus (Mungo Park). Bacon; Bulan (Evermann \& Seale, A).

335. Lutlanus erythropterus Bloch. (Not of Bleeker, which=Lutianus lineolata Rippell). San Fabian (Evermann \& Seale, A).

The identity of Bloch's Lutianus erythroptcrus with the Mesoprion annularis of Cuvier \& Valenciennes seems to rest on the authority of Dr. Day, who examined the types and found one of them "with the distinct colors of the annularis." The description and figure of Bloch give a far from adequate idea of what species was meant.

336. Lutlanus lineolatus (Rüppell). Bacon; Bulan (Evermann \& Seale, A).

(=Lutianus lineolatus of Day=Lutianus erythropterus of Bleeker; probably not Lutianus erythropterus of Bloch, as stated by Jordan \& Seale, Fishes Sanoa, p. 264 ; see note on preceding species.)

337. Lutianus kasmira Forskål). Fuga Island (Jordan \& Richardson); Zamboanga (Seale \& Bean).

338. Lutianus argentlmaculatus (Forskål). Calayan; Rio Baco, Mindoro; Iloilo (Jordan \& Richardson).

\section{NEMIPTERUS Swainson (Synagris Giintlier).}

339. Nemipterus japonicus (Bloch). Cavite (Jordan \& Seale, A); San Fabian (Evcrmann \& Seale, A); Manila (Jordan \& Richardson).

340. Nemipterus ovenii (Bleeker). Cavite (Jordan \& Seal, A); Bulan (Evermann \& Seale, A).

341. Nemipterus tæniopterus (Cuvier \& Valenciennes). Manila (Jordan \& Seale, A); San Fabian (Evermann \& Seale, A).

(Synagris notatus Day.)

342. Nemlpterus isacanthus (Bleeker). Negros (Jordan \& Seale, A).

343. Nemlpterus metopias (Bleeker). Cavite (Jordan \& Seale, A).

344. Nemlpterus luteus (Bloch). Cavite (Jordan \& Seale, A).

345. Nemipterus tolu (Cuvier \& Valenciennes). Cavite (Jordan \& Seale, A).

346. Nemipterus nemurus (Bleeker). Jolo (Evermann \& Seale, A).

347. Nemlpterus worcesterl Evermann \& Seale, A. Bacon (Evermann \& Seale, A).

Nemipterus worcesteri Evermann \& Seale, Bull. U. S. Bur. Fish, XXVI, 1906, 81, fig. 14; Bacon, P. I.

\section{GYMNOCRANIUS Klunzinger.}

348. Gymnocranius lethrinoides (Bleeker). Bulan (Evermann \& Seale, A); Zamboanga (Seale \& Bean).

PINJALO Bleeker.

349. Pinjalo pinjalo (Bleeker). San Fabian; (Pinjalo typus Bleeker) Bulan (Evermann \& Seale, A); Cavite (Jordan \& Seale, A).

It is not certain whether the name Casio pinjalo Bleeker 1850 is older than the name Pinjalo typus, given by the same author at about the same time.

CAESIO Cuvier.

250. Caslo erythrogaster (Kuhl \& Van Hasselt). Zamboanga (Seale \& Bean). 351. Casio chrysozona Kuhl \& Van Hasselt. Bacon (Evermann \& Seale, A). 
352. Caeslo carulaureus (Lacépede). Bacon; Zamboanga; San Fabian (Evermann \& Seale, $A$ )

353. Caslo cuning (Bloch). Bacon; Zamboanga (Evermann \& Seale, $\Delta$ ).

354. Creslo lunarie (Ebrenberg). Zamboanga (Seale \& Bean).

\section{Family THERAPONID无.}

THERAPON ${ }^{2}$ Cuvier.

355. Therapon cancellatus (Cuvier \& Valenciennes). Samar; Leyte (Peters, C) ; Mindoro (Jordan \& Richardson).

356. Therapon quadrlilneatus (Bloch). Manila (Kner; Jordan \& Seale, A); Bulan; San Fabian (Evermann \& Seale, A); Cuyo; Lubang; Iloilo; Aparri (Jordan \& Richardson).

357. Therapon theraps (Cuvier \& Valenciennes). Philippine Islands (Günther); Philippincs, Sta. 203 (Günther, A) ; Panay (Jordan \& Seale, A); Bulan; Bacon (Evermann \& Seale, A); Zamboanga (Seale \& Bean).

358. Therapon jarbua (Forskål). Cavite (Jordan \& Seale, A) : Negros (Jordan \& Seale, B) ; Bulan; San Fabian (Evermann \& Seale, A); Manila (Evermann \& Seale, B); Mindanao (Smith \& Seale); Manila; Calayan; Ticao (Jordan \& Richardson); Zamboanga (Seale \& Bean).

359. Therapon puta (Cuvier \& Valenciennes). Cavite (Jordan \& Seale, A); Bulan; Bacon; San Fabian (Evermann \& Seale, A) ; Iloilo; Manila (Jordan \& Richardson).

360. Therapon brachycentrus (Peters). Luzon (Peters, C and D).

Therapon brevispinis Peters, Monatsber. Akad. Wiss. Berl., 1868, 256 Luzon, P. I.

Therapon brachycentrus Peters, Monatsber. Akad. Wiss. Berl., 1869, 705 (substitute for Therapon brevispinis, preoccupied).

\section{HELOTES Cuvier.}

361. Helotes sexlineatus (Quoy \& Gaimard). Manila (Kner; Jordan \& Richardson).

\section{POMADASIS Lacépede.}

362. Pomadasis hasta (Bloch). Philippine Islands (Günther); Mindanao (Smith \& Seale); Zamboanga (Seale \& Bean).

363. Pomadasis maculatus (Bloch). Cavite (Jordan \& Seale, A); San Fabian (Evermann \& Seale, A); Manila (Jordan \& Richardson).

364. Pomadasls argenteus (Lacépede). Cavite (Jordan \& Seale, A); Manil (Evermann \& Seale, B; Jordan \& Richardson).

365. Pomadasis argyreus (Cuvier \& Valenciennes). Manila (Jordan \& Richardson).

(=Pomadasis guoraka of Dav, not of Bleeker).

366. Pomadasis niger (Cuvier \& Valenciennes). Manila (Cuvier \& Valenciennes; Günther).

SCOLOPSIS Cuvier.

367. Scolopsis vosmeri Bleeker. Manila (Jordan \& Seale, A).

368. Scolopsis cillata (Lacépède). Manila (Jordan \& Seale, A) ; Negros (Jordan \& Seale, B).

'Originally printed Terapon; an "error of transcription," later corrected to Therapon. 
369. Scolopsis bimaculatus (Riippell). Zamboanga (Seale \& Bean).

370. Scolopsis monogramma (Kull \& Van Hasselt). Philippines, Sta. 203 (Gïnther, A); Bulan (Evermann \& Seale, A).

371. Scolopsis cancellata (Cuvier \& Valenciennes). Bacon; Bulan (Evermann \& Seale, A); Cuỵo (Jordan \& Richardson); Zamboanga (Seale \& Bean).

372. Scolopsis margaritifera (Cuvier \& Velencienues). Bacon; Bulan (Evermann \& Seale, A).

373. Scolopsis bilineata (Bloch). Bulan (Evermann \& Seale, A).

374. Scolopsis Iuzonia Jordan \& Seale. Cavite (Jordan \& Seale, A); Bacon; San Fabian (Evermann \& Seale, A).

Scolopsis luzonia Jordan \& Seale, Bull. U. S. Bur. Fish, XXVI, 1906, 23, fig. 8; Cavite, P. I.

375. Scolopsis bulanensis Evermann \& Seale. Bulan (Evermann \& Seale, A). Scolopsis bulanensis Evermann \& Seale, Bull. U. S. Bur. Fish, XXVI, 1906, 85, fig. 15; Bulan, P. I.

PENTAPUS Cuvier \& Valenciennes.

376. Pentapus vittatus (Bloch). Philippines (Jordan \& Seale, A).

377. Pentapus setosus Cuvier \& Valenciennes. Bulan; Jolo (Evermann \& Seale A).

378. Pentapus caninus (Cuvier \& Valenciennes). Bacon (Evermann \& Seale, A) ; Cuyo; Cuyu (Jordan \& Richardson).

379. Pentapus nemurus (Bleeker). Zamboanga (Seale \& Bean).

\section{PLECTORHYNCHUS Lacépède.}

380. Plectorhynchus orientalis (Bloch). Calayan (Jordan \& Richardson). 381. Plectorhynchus lineatus (Linnæus) Aparri (Jordan \& Richardson).

382. Plectorhynchus goldmanni (Bleeker). Jolo; San Fabian (Evermann \& Seale, A).

383. Plectorhynchus celebicus Bleeker. Jolo (Evermann \& Seale, A). 384. Plectorhynchus chrysotzenia (Bleeker). Bulan (Evermann \& Seale, A). 385. Plectorhynchus hæmatochir (Bleeker). Zamboanga (Seale \& Bean).

SPILOTICHTHYS Fowler.

386. Spllotichthys pictus (Thunberg). Cavite (Jordan \& Seale, A); Bulan; Jolo (Evermann \& Seale, A).

EUELATICHTHYS Fowler.

387. Euelatichthys crassispinus (Rüppell). Cavite (Jordan \& Seale, A); Manila (Evermann \& Seale, A); Zamboanga (Seale \& Brown).

HAPALOGENYS Richardson.

388. Hapalogenys meyeni Peters. Manila (Peters, B).

Hapalogenys meyeni Peters, Monatsber. Akad. Wiss. Berl., 1866, 96; Manila, P. I.

Family SPARID丑.

LETHRINELLA Fowler.

389. Lethrinella miniata (Forster) Zamboanga, (Seale \& Bean). 


\section{LETHRINUS Cuvier.}

390. Lethrinus harak (Forskål). Bacon; San Fabian; Jolo (Evermann \& Seale, A); Zamboanga, (Seale \& Bean).

391. Lethrinus bonhamensis (Günther). Negros (Jordan \& Seale, B).

392. Lethrinus amboinensis Bleeker. Cavite (Jordan \& Seale, A).

393. Lethrinus mahsena (Forskål). Philippine Islands (Günther, D; Evermann \& Seale, A, Lethrinus hypselopterus).

394. Lethrinus mahsenoides Ehrenberg. Philippine Islands (Gïnther); Plilippines (Jordan \& Seale, A) ; Evermann \& Seale, A) ; Jolo (Evermann \& Seale, B); Cuyo (Jordan \& Richardson); Zamboanga, (Seale \& Bean).

395. Lethrinus moensii Bleeker. Bacon (Evermann \& Seale, A); Jolo (Evermann \& Seale, B) ; Calayan (Jordan \& Richardson).

396. Lethrinus ornatus Cuvier \& Valenciennes. Bulan (Evermann \& Seale, A). 397. Lethrinus variegatus Ehrenberg. San Fabian (Evermann \& Seale, A).

398. Lethrinus nematacanthus Bleeker. Bulan (Evermann \& Seale, A).

399. Lethrinus jagorii Peters. Luzon (Peters, C). Lethrinus jagorii Peters, Monatsber. Akad. Wiss. Verl., 1868, 257; Luzon, P. I.

400. Lethrinus richardsoni Gïnther. Bacon (Evermann \& Seale, A); Manila (Kner, Lethrinus hamatopterus).

(Not Lethrinus hamatopterus of Temminck \& Schlegel). Zamboanga (Seale \& Bean).

401. Lethrinus xanthotænia (Bleeker). Zamboanga (Seale \& Bean).

SPARUS Linnæus. (Chrysophrys Cuvier \& Valenciennes).

402. Sparus calamara Russell. Bulan (Evermann \& Seale, A).

403. Sparus berda Forskål. Manila (Kner, Chrysophrys hasta).

Family KYPHOSID $Æ$.

KYPHOSUS Lacépède.

404. Kyphosus cinerascens (Forskål). Philippine Islands (Günther, Pimelepterus tahmel); Calayan (Jordan \& Rlchardson).

Family M ENID $A$.

EMMELICHTHYS Richardson.

405. Emmelichthys leucogrammicus (Bleeker). Bulan; Bacon (Evermann \& Seale, A).

Family GERRID AE.

XYSTAEMA Jordan \& Evermann.

406. Xystæma punctatum (Cuvier \& Valenciennes). Philippine Islands (Günther); Cavite (Jordan \& Seale, A); Negros, (Jordan \& Seale, B) ; Calayan; Aparri; Iloilo; Zamboanga (Seale \& Bean); (Jordan \& Richardson); Bulan (Evermann \& Seale, A); Samar (Peters, C, Gerres filamentosus).

407. Xyxtæma kapas (Bleeker). Cuyo (Jordan \& Richardson); Bacon; Bulan; Jolo (Evermann \& Seale, A); Zamboanga, (Seale \& Bean). 
408. Xystama phillppinum (Günther). Philippine Islands (Günther).

409. Xystzema baconensis Evermann \& Seale. Bacon; Jolo (Evermann \& Seale, A).

Xystcema baconensis Evermann \& Seale, Bull. U. S. Bur. Fish, XXVI, 1906, 69 , fig. 8; Bacon and Jolo, P. I.

410. Xystæema oyena (Forskål). Zamboanga (Seale \& Bean).

PENTAPRION Bleeker.

411. Pentaprion longimanus (Cantor). Cavite (Jordan \& Seale, A).

\section{Family MULLID Æ.}

\section{UPENEUS ${ }^{1}$ Cuvier.}

412. Upeneus barberinus (Lacépède). Iloilo (Jordan \& Seale, A); Negros (Jordan \& Seale, B); Cuyo (Jordan \& Richardson); San Fabian; Bacon (Evermann \& Seale, A).

413. Upeneus indicus (Shaw). Hoilo (Jordan \& Seale, A); Bacon; Bulan (Evermann \& Seale, A).

414. Upeneus malabarlcus (Cuvier \& Valenciennes). Philippine Islands (Günther).

415. Upeneus chryseredros (Lacépede). Cagayancillo (Jordan \& Richardson). 416. Upeneus bifasciatus (Lacépède). Bacon (Evermann \& Seale, A).

417. Upeneus Iuteus (Cuvier \& Valenciennes). Jolo (Evermann \& Seale, A).

418. Upeneus spilurus (Bleeker). Bulan (Evermann \& Seale, A).

419. Upeneus moana (Jordan \& Seale). Bacon (Evermann \& Seale, A); Zamboanga, (Seale \& Bean).

Pseudupeneus moana Jordan \& Sealc, Bull. U. S. Bur. Fish XXV, 1005, 274; Samoa.

MULLOIDES Bleeker.

420. Mulloides auriflamma (Forskål). Negros (Jordan \& Seale, B).

421. Muiloides vanicolensis (Cuvier \& Valenciennes). Zamboanga (Evermann \& Seale, A).

422. Mulloides japonlcus (Houttuyn). Bulan (Evermann \& Seale, A).

423. Mulioides samoensis Günther. San Fabian; Bacon (Evermann \& Seale, A). Mulloides samoensis Günther, Südsee, 57, pl. 43 fig. B; Apia, Samoa.

UPENOIDES Bleeker.

424. Upeneoides vittatus (Forskål). Philippine Islands (Günther); Lubang; Iloilo (Jordan \& Richardson); Mindanao (Smith \& Seale); Zam. boanga (Seale \& Bean).

425. Upeneoides traguia (Richardson). Philippine Islands (Günther); Iloilo (Jordan \& Seale, A); Negros (Jordan \& Seale, A); Cuyu; Cuyo (Jordan \& Richardson); Bacon (Evermann \& Seale, A).

426. Upeneoides Iuzonius (Jordan \& Seale). Cavite (Jordan \& Seale, A); Manila (Jordan \& Richardson).

Upeneus luzonius Jordan \& Seale. Bull. U. S. Bur. Fish, XXVI, 1906, 26 fig. 9 ; Cavite, P. I.

'Under the rules of the International Code of Zöological Nomenclature Mullus bifasciatus Lacepede is the type of Upeneus. 
427. Upenoldes sulphureus (Cuvier \& Valenciennes). Cavite (Jordan \& Seale, A) ; Manila (Jordan \& Richardson) ; San Fabian (Evermann \& Seale, A).

428. Upeneoldes sundalcus (Bleeker). Bacon (Evermann \& Seale, A).

Family SCI无NID无.

UMBRINA Cuvier.

429. Umbrina dussumleri Cuvier \& Valenciennes. Cavite (Jordan \& Seale, A); Manila (Jordan \& Richardson); San Fabian (Evermann \& Seale, A). 430. Umbrina russelll Cuvier \& Valenciennes Cavite (Jordan \& Seale, A); San Fabian (Evermann \& Seale, A).

\section{PSEUDOSCIFENA Bleeker.}

431. Pseudoscizena anea (Bloch). Cavite (Jordan \& Seale, A); Manila (Jordan \& Richairdson).

JOHNIUS Bloch \& Schneider.

432. Johnius belengerl (Cuvier \& Valenciennes). Manila (Kner); San Fabian (Evermann \& Seale, A).

OTOLITHES ${ }^{1}$ (Cuvier) Oken.

433. Otolithes argenteus Kuhl \& Van Hasselt. Bacon (Evermann \& Seale, A). 434. Otolithes leuciscus Günther. Manila (Günther, C).

Otolithus leuciscus Günther, An. Mag. N. H., 1872, 398; Manila, P. I.

Family SILLAGINID无.

SILLAGO Cuvier.

435. Slllago sihama (Forskål). Philippine Islands (Günther); Cavite (Jordan

\& Seale, A); Negros (Jordan \& Seale, B); Manila; Aparri (Jordan \& Richardson).

436. Sillago macrolepis Bleeker. Bulan (Evermann \& Seale, A).

437. Sillago maculata Quoy \& Gaimard. Manila (Kner).

\section{Family PSEUDOCHROMID无.}

PSEUDOCHROMIS Rüppell.

438. Pseudochromis adustus Müller \& Troschel. Philippine Islands (Müller \& Troschel, Günther).

439. Pseudochromis tapeinosomus (Bleeker) Negros (Jordan Seale, B).

DAMPIERIA \& Castelnau (1875). (Cichlops Miller \& Troschel, preoccupied; Labracinus Schlegel, Gill.)

440. Dampieria spiloptera (Bleeker). Calayan; Fuga (Jordan \& Richardson). 441. Dampieria melanotzenia (Bleeker). Cuyo (Jordan \& Richardson); Bulan (Evermann \& Seale, A).

442. Dampleria trispilos (Bleeker). Bacon (Evermann \& Seale, A).

${ }^{1}$ This name first appeared in systematic zoölogy as Otolithes, not as Otolithus.

${ }^{2}$ See Ogilby, Ann. Queensland Mus. 1908, p. 35. 


\section{Family OPISTHOGNATHIDÆ.}

GNATHYPOPS Gill.

443. Gnathypops macrolep is (Peters). Philippine Islands, Sta. 201, 82 fathoms (Günther, A).

Opisthognathus macrolepis Peters, Monatsber, Ak. Wiss. Berl., 1866, 520; Bangkok.

444. Gnathypops dendritica Jordan \& Richardson. Cuyo (Jordan \& Richardson).

Gnathypops dendritica Jordan \& Richardson, Bull. U. S. Bur. Fish, XXVII, 262, 1908. Cuyo, P. I.

\section{Family CHAMPSODONTID}

CHAMPSODON Günther.

445. Champsodon vorax Günther. Philippine Islands, Sta. 204, 115 fathoms (Günther).

Champsodon vorax Günther, Proc. Zool. Soc. Lond., 1867, 102; no loc.

Family CEPOLID $Æ$.

ACANTHOCEPOLA Bleeker.

446. Acanthocepola abbreviata (Cuvier \& Valenciennes). Cavite (Jordan \& Seale, A).

\section{Family OPHICEPHALID $\approx$.}

OPHICEPHALUS Bloch.

447. Ophicephalus striatus Bloch. Manila (Cuvier \& Valenciennes, Coll M. Mertens) ; Philippine Islands (Günther) Cavite (Jordan \& Seale, A) ;

Negros (Jordan \& Seale, B); Philippines (Evermann \& Seale, A);

Siassi Island (Evermann \& Seale, B); Lake Buhi, Luzon (Smith).

448. Ophicephalus melanosomus Bleeker. Balabac (Boulenger, A).

449. Ophicephalus melanopterus Bleeker. Mindanao (Smith \& Seale).

450. Ophicephalus vagus Peters. Luzon; Samar; Leyte (Peters, C); Manila (Günther, A).

Ophicephalus vagus Peters, Monatsber, Ak. Wiss. Berl., 1868, 260; Luzon; Samar; Leyte, P. I.

451. Ophicephalus maculatus Cuvier \& Valenciennes. Manila P. I. (Kner).

Family ANABANTID五.

ANABAS Cuvier.

452. Anabas testudineus (Bloch, 1792) Manila (Cuvier \& Valenciennes, $A$. scandens, after a drawing made by Russian Expedition); Philippine Islands (Günther, A. scandens); Luzon; Ieyte (Peters, C) ; Negros (Jordan \& Seale, B) ; Sibuyan (Jordan \& Richardson); Lake Buhi, Luzon (Smith, A. scandens); Mindanao (Smith \& Seale, A. scandens.) This name is earlier than that of Perca scandens Daldorff, 1797.

\section{Family POMACENTRIDA.}

PREMNAS Cuvier.

453. Premnas biaculeatus (Bloch). Philippine Islands (Gunther). 
AMPHIPRION Bloch \& Schneider.

454. Amphiprion boholensis Cartier. Bohol (Cartier).

Amphiprion boholensis Cartier, Verh. Ges. Würzburg, 1873, 102; Bohol, P. $I$.

POMACENTRUS Lacépède.

455. Pomacentrus tripunctatus Cuvier \& Valenciennes. Cavite (Jordan \& Seale, A) ; Bacon (Evermann \& Seale, A); (?) Palawan (Vaillant P. trillineatus).

456. Pomacentrus trimaculatus Cuvier \& Valenciennes. Bacon; San Fabian (Evermann \& Seale, A).

457. Pomacentrus nigricans Lacépède. Calayan; Cagayancillo (Jordan \& Richardson).

458. Pomacentrus albofasciatus Schlegel. Calayan. (Jordan \& Richardson). 459. Pomacentrus lividus (Forster); Negros (Jordan \& Seale, B).

460. Pomacentrus chrysopœcilus Kulli \& Van Hasselt. Cuyo (Jordan \& Richardson; as Pomacentrus pristiger Cuv. \& Val.).

461. Pomacentrus littorai is Kuhl \& Van Flasselt. Cavite (Jordan \& Richardson; Bacon (Evermann \& Seale, A).

462. Pomacentrus emarginatus Cuvier \& Valenciennes; Negros (Jordan \& Seale, B., I. delurus) ; Ticao; Cuyo (Jordan \& Richardson).

Pomacentrus delurus Jordan \& Seale, Proc. U. S. Nat. Mus., XXVIII, 1905, 783, fig. 6; Negros, P. 1.

463. Pomacentrus moluccensis Bleeker. Bacon (Evermann \& Seale, A).

464. Pomacentrus alexandræ Evermann \& Seale. Bacon (Evermann \& Seale, A).

Pomacentrus alexandra. Evermann \& Seale, Bull. U. S. Fish Comm., XXVI, 1906, 91, fig. 17; Bacon, P. I.

165. Pomacentrus popei Evermann \& Seale. Bacon (Evermann \& Seale, A),

Pomacentrus popei Evermann \& Seale, Bull. U. S. Fish Comm., XXVI, 1906, 90, fig. 16; Bacon, P. 1 .

466. Pomacentrus philippinus Evermann \& Seale. Bacon (Evermann \& Seale, A).

Pomacentrus philippinıs Evermann \& Seale, Bull. U. S. Bur. Fish, XXVI, 1906, 92, fig. 18 ; Bacon, P. $I$.

46i. Pomacentrus punctatolineatus Cartier. Bohol (Cartier).

Pomacentrus punctatolineatus Cartier, Verh. Ges. Würzburg, 1873, 98; Bohol, P. I.

468. Pomacentrus ovoides Cartier. Bohol; Cavite (Cartier).

Pomacentrus ovoides Cartier, Verh. Ges. Würzburg, 1873, 98; Bohol; Cavite, I'. 1.

469. Pomacentrus jerdoni Day. Bulan (Evermann \& Seale, A).

470. Pomacentrus fasciatus Cuvier \& Valenciennes. Plilippine Islands (Giinther); Ticao (Jordan \& Richardson).

471. Pomacentrus tæeniurus Bleeker. Bohol (Cartier, var.); Philippines (Evermann \& Seale, A).

472. Pomacentrus pavo Bloch. Cebu (Cartier, var?).

ABUDEFDUF Forskål. (=Glyphisodon Jacépède.)

473. Abudefduf septemfasciatus (Cuvier \& Valenciennes). Philippine Islands (Günther); Bulan (Evermann \& Seale, A); Zamboanga (Seale \& Bean).

474. Abudefduf curacao (Bloch). Bacon (Evermann \& Seale, A). 
475. Abudefduf saxatilis (Linnaeus). Manila (Jordan \& Seale, A); Manila; Calayan (Jordan \& Richardson).

476. Abudefduf sexfasciatus (Lacépede). ${ }^{2}$ Luzon (Peters, C).

(Glyphisodon coelestinus Cuv. \& Val.)

477. Abudefduf dicki (Lienard). Cagayancillo (Jordan \& Richardson).

478. Abudefduf glaucus (Cuvier \& Valenciennes). Cagayancillo; Ticao (Jordan

\& Richardson); Bacon (Evermann \& Seale, A).

479. Abudefduf amabilis (De Vis). Calayan (Jordan \& Richardson).

480. Abudefduf unimaculatus (Cuvier \& Valenciennes). Negros (Jordan \&

Seale, B); Calayan; Cagayancillo (Jordan \& Richardson); Bacon

(Evermann \& Seale, A).

481. Abudefduf turchesius Jordan \& Seale. Cavite (Jordan \& Seale, A).

482. Abudefduf bankieri (Richardson). Bacon (Evermann \& Seale, A).

483. Abudefduf cyaneus (Quoy \& Gaimard). Bacon (Evermann Seale, A). (Identification perhaps questionable.)

484 (485). Abudefduf xanthurus (Bleeker). Bacon (Evermann \& Seale, A). 486. Abudefduf mutabilis (Cartier). Cebu (Cartier).

Glyphidon mutabilis Cartier, Verh. Ges. Würzburg, 1873, 100; Cebu, P. I. 487. Abudefduf tænioruptus Cartier. Bohol (Cartier).

Glyphidon tanioruptus Cartier, Verh. Ges. Würzburg, 1873, 101; Bohol, P. $I$.

488. Abudefduf cingulatus (Kner). Bohol (Cartier).

Glyphidodon cingulatus Kner, Sitsungsber. Ak. Wiss. Wien., Bd. 56, 725.

489. Abudefduf un locellatus (Quoy \& Gaimard). Philippine Islands (Gunther, as Glyphidodon assimilis); Luzon (Peters, C, Glyphidodon assimilis, var.)

490. Abudefduf brownrlggl (Bennett). Ticao (Jordan \& Richardson).

491. Abudefduf antjerius (Kuhl \& Van Hassett). Samar (Peters, C); Ticao; Calayan (Jordan \& Richardson); Bacon (Evermann \& Seale, A); Zamboanga (Seale \& Bean).

492. Abudefduf zonatus (Cuvier \& Valenciennes). Cagayancillo (Jordan \& Richardson) ; Bacon (Evermann \& Seale, A).

493. Abudefduf sapphirus Jordan \& Richardson. Ticao (Jordan \& Richardson).

(Abudefduf sapphirus Jordan \& Richardson Bull. U. S. Bur. Fish., XXVII, 264, 1908, Ticao, P. I.)

\section{DASCYLLUS Cuvier.}

494. Dascyilus melanurus Bleeker. Cagayancillo (Jordan \& Richardson).

495. Dascyllus aruanus (Linnaeus). Cavite (Jordan \& Seale, A).

496. Dascyilus trimaculatus (Rüppell). Manila (Jordan \& Richardson).

497. Dascyllus retlculatus Richardson. Bohol. (Cartier).

\section{Family LABRIDÆ.}

\section{CHCERODON Bleeker.}

498. Chœrodon anchorago (Bloch). Manila (Jordan \& Seale, A); Bacon; Jolo (Evermann \& Seale, A); Cuyo (Jordan \& Richardson).

499. Chcrodon meander (Cartier). Cebu (Cartier).

Chorops meander Cartier, Verh. Ges. Würzburg, 1873, 102; Cebu, P. I.

Probably the young of Charodon anchorago.

${ }^{1}$ The identity of Labrus sexfasciatus Lacepede with Abudefduf colestinus noted by Cuv. \& Val., is recalled by Dr. Evermann. 
500. Chœrodon macrodon Bleeker. Zamboanga (Seale \& Bean).

501. Chœrodon ollgacanthus (Bleeker). lloilo (Jordan \& Richardson).

502. Chœrops schœnleini (Agassiz). Negros (Jordan \& Seale, B).

503. Chœrodon unimaculatus (Cartier). Cavite (Cartier).

Chorops unimaculatus Cartier, Verh. Ges. Wurzburg, 1873, 102; Cavite, P. I. (Probably equals $C$. schoenleini of Bleeker; not of Agassiz.)

504. Chcerodon zamboanga (Seale \& Bean). Zamboanga (Seale \& Bean).

\section{LEPIDAPLOIS Gill.}

505. Lepidaplois mesothorax (Bloch \& Schneider). Bacon (Evermann \& Seale, A).

506. Lepidaplois macrurus (Lacépède). Manila (Jordan \& Seale, A).

507. Lepidaplois bilunulatus (Lacépede). Zamboanga (Seale \& Bean).

LABROIDES Bleeker.

508. Labroides paradiseus Bleeker. Bacon (Evermann \& Seale, A).

DUYMFRIA Bleeker.

509. Duymaria fiagellifera Cuvier \& Valenciennes. Samboangan (Günther, A).

AMPHECES Jordan \& Evermann.

510. Ampheces pterophthalmus (Bleeker). Cuyo (Jordan \& Richardson).

STETHOJULIS Günther.

511. Stethojulis phekadopleura Bleeker. Cavite (Jordan \& Seale, A); Negros (Jordan \& Seale, B) ; Cuyo; Calayan (Jordan \& Richardson); Bacon (Evermann \& Seale).

512. Stethojulis bandanensls (Bleeker). Cavite (Jordan \& Seale); Negros (Jordan \& Seale, B); Cuyo; Cagayancillo (Jordan \& Richardson).

513. Stethojulis strigiventer (Bennett) Cuyo; Cuyu (Jordan \& Richardson); Palawan (Vaillant).

514. Stethojulis kalosoma Bleeker. Cavite (Jordan \& Seale, A); Negros (Jordan \& Seale, B).

515. Stethojulis zatima Jordan \& Seale. Negros (Jordan \& Seale, B); Cuyo; Calayan (Jordan \& Richardson); Bacon (Evermann \& Seale, A).

Stethojulis zatima Jordan \& Seale, Proc. U. S. Nat. Mus., XXVIII, 1905, 788, fig. 9 ; Negros, P.I.

PLATYGLOSSUS (Klein) Bleeker.

516. Platyglossus notopsis (Kuhl \& Van Hasselt). Calayan (Jordan \& Richardson).

HALICHCERES Riippell.

517. Halichœres scapularis (Bennett). Manila (Jordan \& Seale, A); Bacon (Evermann \& Seale); Negros (Jordan \& Seale, B, H. cymatogrammus); Palawan (Vaillant).

Halichoeres cymatogrammus Jordan \& Seale, Proc. U. S. Nat. Mus., XXVIII, 1905, 786, fig. 8; Negros, P. I.

518. Halichœres centlquadrus (Bleeker). Cagayancillo (Jordan \& Richardson).

519. Halichœeres trimaculatus (Quoy \& Gaimard). Cagayancillo (Jordan \& Richardson). 
i20. Halichœres nigrescens (Bloch \& Schneider). Manila (Jordan \& Seale, A); Bulan (Evermann \& Seale, A).

521. Halichœres purpurascens (Bloch \& Sclineider) Bacon (Evermann \& Seale, A).

522. Halichœres polyophthalmus (Bleeker). Bacon (Evermann \& Seale, A as H. guttatus); Cavite (Jordan \& Seale, A, H. argus); Negros (Jordan \& Seale, B, H. argus). (The early names for this species, guttatus and argus were both preoccupied.)

523. Halichœres leparensis (Bleeker). Bacon (Evermann \& Seale, A).

524. Haliohores gymnocephalus (Bloch \& Schneider). Philippine Islands (Bleeker, H. modestus, specimens in Berlin Museum); Cuyo; (Jordan \& Richardson).

(H. modestus Bleeker; Platyglossus modestus Günther.)

525. Hallchœres binotopsis Bleeker. Cavite (Jordan \& Seale, A); Negros (Jordan \& Seale, B).

526. Halichœres pœcilus (Lay \& Bennett). Luzon (Peters, C); Cavite (Jordan \& Seale, A) ; Negros (Jordan \& Seale, B) ; Bacon (Evermann \& Seale, A); Calayan (Jordan \& Richardson).

527. Halichœeres opercularis (Günther). Calayan (Jordan \& Richardson).

528. Hallchœres nebulosus (Cuvier \& Valenciennes). Cuyo; Cuyu (Jordan \& Richardson).

529. Halichœres miniatus (Kuhl \& Van Hasselt). Luzon (Peters, C) ; Negros (Jordan \& Seale, B); Cavite (Jordan \& Seale, A); Calayan (Jordan \& Richardson; Bacon (Evermann \& Seale, A).

530. Halichœres pseudominiatus (Bleeker). Cavite (Jordan \& Seale, A); Negros (Jordan \& Seale, A).

531. Halichœres hyrtli Bleeker. Manila (Jordan \& Seale, A).

532. Halichœres alternans (Cartier). Cebu; Panglao (Cartier).

Platyglossus alternans Cartier, Verh. Ges. Würzburg, 1873, 104; Cebu \& Panglao, P. $I$.

533. Halichœres ubayensis (Cartier). Bolo (Cartier).

(Platyglossus ubayensis Cartier, Verh. Ges. Würzburg, 1873, 104; Bohol, P. I.)

534. Halichœres pseudogramma (Cartier). Bohol (Cartier).

(Platyglossus pseudogramma Cartier, Verl. Ges. Würzburg, 1873, 103; Bohol, P. I. (Name changed to P. pseudogrammicus by Palacky.)

535. Hallchœres reticulatus (Cartier). Cebu (Cartier).

Platyglossus reticulatus Cartier, Verh. Ges. Würzburg, 1873, 104, Cebu, P. $I$.

\section{CHEILIO Lacépede.}

536. Chelllo inermis (Forskål). Philippine Islands (Günther). Negros (Jordan \& Seale, B) ; Bacon (Evermann \& Seale, A); Cuyo (Jordan \& Richardson); Zamboanga (Seale \& Bean).

THALASSOMA Swainson. (Julis Günther; not of Cuvier.)

537. Thalassoma dorsale (Quoy \& Gaimard). Philippine Islands (Günther); Manila (Jordan \& Seale, A); Cagayancillo (Jordan \& Richardson).

538. Thalassoma güntheri (Bleeker). Calayan (Jordan \& Richardson).

539. Thalassoma umbrostigma (Rüppell). Calayan (Jordan \& Richardson).

540. Thalassoma lunare (Linnæus). Cavite (Jordan \& Seale, A); Bacon (Evermann \& Seale, A).

541. Thalassoma truncatum Cartier. Cebu (Cartier).

(Julis truncatus Cartier, Verh. Ges. Würzburg, 1873, 104; Cebu, P. I.) 
CHEILINUS Lacépède.

542. Cheilinus digrammus (Lacépèrle). Ronıblon (Jordan \& Richardson).

543. Cheilinus oxycephalus Bleeker. Cuyo (Jordan \& Richardson).

544. Cheillnus trilobatus (Lacépède). Manila (Jordan \& Seale, A); Zanhoanga (Seale \& Bean).

545. Cheilinus rostratus Cartier. Cebu (Cartier); Panay (Jordan \& Seale, A). (Cheilinus rostratus Cartier, Verh. Ges. Würzburg, 1873, 103; Cebu, P. I.)

546. Cheilinus fasciatus (Bloch). Bacon (Evermann \& Seale, A).

THALLIURUS Swainson.

547. Thalliurus chlorurus (Bloch). Bacon (Evermann \& Seale, A); Zamboanga (Seale \& Bean).

NOVACULICHTHYS Bleeker.

54\$. Novaculichthys macrolepidotus (Bloch). Negros (Jordan \& Seale, B); Bacon (Evermaun \& Seale, A).

549. Novaculichthys kallosomus (Bleeker). Negros (Jordan \& Seale, B).

550. Novaculichthys tæniurus (Lacépède). Cagayancillo (Jordan \& Richardson).

HEMIPTERONOTUS Lacépède.

551. Hemipteronotus pentadactylus (Lacépede). Manila (Jordan \& Seale, A).

Family ODACIDAE.

PSEUDODAX Bleeker.

552. Pseudodax moluccanus (C'uvier \& Valenciennes). Bolıol (C'articr, spelled moluccensis).

\section{Family SCARICH'THYID)E.}

SCARICHTHYS 13leeker.

553. Scarichthys auritus (Kuhl \& Van Hasselt). Cagayancillo (Jordan \& Richardsou); Bacon (Evermann \& Seale, A); Zamloanga (Seale \& Bean).

554. Scarichthys cœruleopunctatus (Rüppell). Bacon; Bulan; Jolo (Evermann \& Seale, A) ; Zamboanga (Seale \& Bean).

CALOTOMUS Gilbert.

555. Calotomus gen istriatus (Cuvier \& Valenciennes). Zamboanga; Jolo (Evermann \& Seale, A).

556. Calotomus vaigiensis (Quoy \& Gaimard). Negros (Jordan \& Seale, B).

557. Calotomus moluccensis (Bleeker). Negros (Jordan \& Seale, B); Cuyo (Jordan \& Richardson).

CALLYODON Gronow. (Scarus l'orskål; not of Gronow.)

558. Callyondon ballinensis (Bleeker). Bacon (Evermann \& Seale A).

559. Callyodon oktodon (Bleeker). Zamboanga (Evermann \& Seale, A).

560. Collyodon lacerta (Cuvier \& Valenciennes). Bulan; Bacon (Evermann \& Seale, A) ; Panay (Jordan \& Seale, A).

561. Callyodon quoyi (Cuvier \& Valenciennes). Bacon (Evermann \& Seale, A). 
562. Callyondon muricatus (Cuvier \& Valenciennes). Negros (Jordan \& Seale, B).

563. Callyodon margaritus (Cartier). Cebu (Cartier).

Pseudoscarus margaritus Cartier, Verh. Ges. Wurzburg, 1873, 105; Cebu, P. $I$.

564. Callyodon aruginoaus (Cuvier \& Valenciennes). Manilá (Kner).

565. Callyodon elerz Jordun \& Seale. Cavite (Jordan \& Seale, A).

Callyodon elerae Jordan \& Seale, Bull. U. S. Fish Comm., XXVI, 1906, 31, fig. 11 ; Cavite, $P$. $I$.

566. Callyodon capistratoldes (Bleeker). Cagayancillo (Jordan \& Richardson).

(Pseudoscarus dussumieri Bleeker. Not Scarus dussumieri (Cuvier \& Valenciennes).)

567. Callyodon latifasclatus Seale \& Bean. Zamboanga (Seale \& Bean).

568. Callyodon niger (Rüppell). Zamboanga (Seale \& Bean).

569. Callyodon macrorhinus (Bleeker). Zamboanga (Seale \& Bean).

570. Callyodon rivulatus (Cuvier \& Valenciennes). Zamboanga (Seale \& Bean). 571. Callyodon zonularis Jordan \& Seale. Zamboanga (Seale \& Bean).

\section{Family TOXOTID在.}

\section{TOXOTES Cuvier.}

572. Toxotes Jaculatrix (Pallas). Samar (Peters, C, Toxotes jaculator); Mindoro (Jordan \& Richardson); Palawan (Vaillant); Zamboanga (Seale \& Bean).

Family SCATOPHAGIDAE.

SCATOPHAGUS Cuvier \& Valenciennes.

573. Scatophagus argus (Gmelin). Luzon (Peters, C); Cavite (Jordan \& Seale, E) ; Negros (Jordan \& Seale, B); Manila; Iloilo (Jordan \& Richardson); Bacon, San Fabian (Evermann \& Seale, A); Mindanao (Smith \& Seale); Zamboanga (Seale \& Bean).

Family DREPANID死.

DREPANE Cuvier \& Valenciennes.

574. Drepane punctata (Gmelin). Philippine Islands (Günther); Cavite (Jordan \& Seale, A) ; Manila; Lubang (Jordan \& Richardson).

Family PLATACID正.

PLATAX Cuvier.

575. Platax orblcularis (Forskål). Philippine Islands (Günther, as Platax vespertilio); Panay (Jordan \& Seale, A) ; Ticao; Cagayancillo (Jordan \& Richardson); Jolo (Evermann \& Seale, A); Zamboanga (Seale \& Bean).

Family SCORPID无.

MONODACTYLUS Lacépede.

576. Monodactylus argenteus (Linnæus). Cavite (Jordan \& Seale, A); Aparri; Iloilo; Calayan (Jordan \& Richardson); Bulan (Evermann \& Seale, A). 


\section{Family CHATODONTIDAE.}

\section{PARACHETODON Bleeker.}

577. Parachatodon ocellatus (Cuvicr \& Valenciennes). Philippine Islands (Günther, Chatodon oligacanthus); Negros (Jordan \& Seale, B) .

(Chatodon oligacanthus Bleeker.)

578. Parachatodon blocellatus (Cuvier \& Valenciennes). Cavite (Jordan \& Seale, A).

- GONOCHETODON Bleeker.

579. Gonochatodon triangulum (Cuvier \& Valenciennes). Philippines (Jordan \& Seale, A); Cagayancillo (Jordan \& Richardson).

\section{CHETODON Linnaeus.}

580. Chætodon setifer Forskil. Cagayancillo (Jordan \& Richardson); Palawan (Villant).

581. Chztodon auriga Furskả. Bacon (Evermann \& Seale, A).

582. Chatodon unimaculatus Bloch. Bacon (Evermann \& Seale, A).

583. Chztodon kleini Bloch. Manila (Jordan \& Seale, A); Cagayancillo (Jordan \& Richardson).

584. Chatodon ephippium Cuvier \& Valenciennes. Cagayancillo (Jordan \& Richardson).

585. Chætodon punctatofasciatus Cuvier \& Valenciennes. Manila (Jordan \& Seale, A).

586. Chætodon citrinellus (Broussonet). Cagayancillo (Jordan \& Richardson).

587. Chætodon trifasclatus Park. Cavite (Jordan \& Seale, A); Cagayancillo (Jordan \& Richardson).

588. Chatodon ornatissimus (Cuvier \& Valenciennes). Manila (Jordan \& Seale, A).

589. Chatodon vagabundus Linnæus. Bacon (Evernann \& Seale, A).

590. Chatodon octofasciatus Bloch. Bacon (Evermann \& Seale, A).

591. Chætodon selene Bleeker. Bulan (Evermann \& Seale, A).

592. Chatodon falcula Bloch. Bacon (Evermann \& Seale, A).

\section{CHELMON Cuvier.}

593. Chelmon rostratus (Linnæus). Luzon (Peters, C); Cavite (Jordan \& Seale, A).

\section{HENIOCHUS Cuvier \& Valenciennes.}

594. Heniochus acuminatus (Linnæus). Manila (Cuvier \& Valenciennes), fide Dussumier, as Heniochus macrolepidotus); Bacon; San Fabian (Evermann \& Seale, A).

(Chatodon macrolepidotus Linnæus.)

595. Heniochus varius (Cuvier \& Valenciennes). Bacon (Evermann \& Seale, A).

HOLACANTHUS Lacépède.

596. Holacanthus bicolor (Bloch). Manila (Jordan \& Seale, A); Cagayancillo (Jordan \& Richardson).

597. Holacanthus diacanthus (Boddært). Manila (Jordan \& Seale, A).

598. Holacanthus nicobarlensis (Bloch \& Schneider). Palawan (Vaillant). 


\section{Family ZANCLID王.}

\section{ZANCLUS Comınierson) Lacépède.}

599. Zanclus cornutus (Linneus). Cagavancillo; Fuga (Jordan \& Richarsoni).

$$
\text { Family HEPATID正. }
$$

HEPATUS Gronow 1765. (Teuthis Linnæus 1766; Theutis Cnvier; Acanthurus Forskal, as restricted by Cuvier; Harpurus Forster; Acronurus Gronow.)

600. Hepatus celebicus (Bleeker). Manila (Jordan \& Seale, A); Bulan (Evermann \& Seale, A) ; Zamboanga (Seale \& Bean).

601. Hepatus ollvaceus (Bloch \& Schneider). ('agayancillo (Jordan \& Richardson).

602. Hepatus lineatus (Gmelin). Philippine Islands (Günther); Cagayancillo (Jordan \& Richardson).

603. Hepatus dussumieri (Cuv. \& Val.). Zamboanga (Seale \& Bean).

604. Hepatus triostegus (Iinnæus). Cagayancillo (Jordan \& Richardson).

605. Hepatus matoides (Cuvier \& Valenciennes). Calayan; Aparri (Jordan \& Richardson); Zamboanga; Jolo (Evermann \& Seale, A).

606. Hepatus elongatus (Cuvier \& Valenciennes). Cagayancillo (Jordan \& Richardson).

\section{CTENOCHETUS Gill.}

607. Ctenochetus striatus (Quoy \& Gaimard). Zamboanga (Evermann \& Seale, A).

\section{COLOCOPUS Gill.}

608. Colocopus lambdurus Gill. Zamboanga (Gïnther, A) ; Acuthurus hepatus Giinther, Sildsee, 115, taf. 75; not Teuthis hepatus Linnæus= a West Indian species) Colocopus lambdurus Gill, Proc. U. S. Nat. Mus., 1884, 279 (after Gïnther); Kingsmill I., Mauritius.

\section{ZEBRASOMA Swainson.}

609. Zebrasoma rhombeum (Kittlitz). Cagayancillo (Jordan \& Richardson).

MONOCEROS Bloch \& Schneider.

(Naso Lacépède; Naseus Cuvier \& Valenciennes. Acanthurus Forskål in part, not as restricted by Cuvier.)

610. Monoceros annulatus (Quoy \& Gaimard). Zamboanga (Seale \& Bean).

611. Molloceros tuberosus (Cuv. \& Val). Zamboanga (Seale \& Bean).

612. Monoceros lituratus (Forskål). Zamboanga (Seale \& Bean).

613. Monoceros marginatus (Cuv. \& Val). Zamboanga (Seale \& Bean).

614. Monoceros unicornis (Forskål). San Fabian (Evermann \& Seale, A).

615. Monoceros olivaceus Solander. Philippine Islands (Günther).

\section{Family SIGANID $\not$ E.}

SIGANUS Forskål. (Teuthis Günther, not of Linnæus, as restricted by Cuvier, or Gill.)

616. Siganus Javus (Linnæus). Cavite (Jordan \& Seale, A); Manila; Iloilo (Jordan \& Richardson); Bulan (Evermann \& Seale, A).

617. Siganus virgatus (Cuvier \& Valenciennes). Philippine Islands (Günther); Panay (Jordan \& Seale, A); Cuyo (Jordan \& Richardson); Bacon (Evermann \& Seale, A); Zamboanga (Seale \& Bean). 
618. Slganus lineatus (Cuvier \& Valenciennes). Manila (Jordan \& Seale, A); Cuyo; Aparri (Jordan \& Richardson); Bulan; Bacon (Evermann \& Seale, A).

619. Siganus oram In (Bloch \& Schneider). Cavite (Jordan \& Seale, A) ; Negros Jordan \& Seale, B) ; Aparri; Cavite (Jordan \& Richardson).

620. Siganus marmoratus (Quoy \& Gaimard). Manila (Jordan \& Seale, A) ; Calayan (Jordan \& Richardson).

621. Siganus vermiculatus (Kuhl \& Van Hasselt). Philippine Islands (Günther) ; Zamboanga; Bacon; San Fabian (Evermann \& Seale, A) ; Zamboanga; (Seale \& Bean).

622. Siganus tetrazonus (Bleeker). Manila (Jordan \& Seale, A).

623. Siganus concatenatus (Cuvier \& Valenciennes). Negros (Jordan \& Seale, B).

624. Siganus corallinus (Cuvier \& Valenciennes). Cagayancillo (Jordan \& Richardson).

625. Siganus rostratus (Cuvier \& Valenciennes). Fuga (Jordan \& Richardson). 626. SIganus fuscescens (Houttuyn). Bacon; Jolo; San Fabian (Evermann \& Seale, A); Zamboanga (Seale \& Bean).

627. Siganus albopunctatus (Temminck \& Schlegel). Philippine Islands (Günther); Manila (Kner).

LO Seale. (Lo Seale, Bull. U. S. Bur. Fish., XXV, 1905,360 (vulpinus).)

628. Lo unImaculatus Evermann \& Seale. Bacon (Evermann \& Seale, A).

Lo unimaculatus Evermann \& Seale, Bull. U. S. Bur. Fish., XXVI, 1906, 99, fig. 19 ; Bacon, P. I.

\section{Family TRIACANTHID $\not$.}

\section{TRIACANTHUS Cuvier.}

629. Triacanthus strigilifer Cantor. Philippine Islands (Günther); Negros (Jordan \& Seale, B).

630. Triacanthus oxycephalus Bleeker. Samar (Peters, C).

631. Trlacanthus blochi Bleeker. Iloilo; Manila (Jordan \& Richardson).

Family BALISTID无.

BALISTES (Artedi) Linnæus.

632. Balistes flavimarginatus Rüppell. Cuyo (Jordan \& Richardson); Bacon (Evermann \& Seale, A).

633. Balistes niger Park. Bacon (Evermann \& Seale, A).

634. Ballstes chrysopterus Bloch \& Schneider. Fuga (Jordan \& Richardson).

BALISTAPUS Tilesius.

635. Ballstapus verrucosus (Linnæus). Philippine Islands (Günther); Zebu (Günther, A); Cagayancillo (Jordan \& Richardson). Zamboanga (Seale \& Bean).

636. Balistapus undulatus (Park). Philippine Islands (Günther, A); Cavite (Jordan \& Seale, A); Cagayancillo (Jordan \& Richardson); Bacon (Evermann \& Seale, A); (=Balistes lineatus Bleeker).

637. Ballstapus aculeatus (Linnæus). Cuyo (Jordan \& Richardson); Bacon; Zamboanga (Evermann \& Seale, A).

638. Ballistapus rectangulus (Bloch \& Schneider). Calayan (Jordan \& Richardson). 


\section{Family MONACANTHIDÆ.}

CANTHERINES Swainson.

639. Cantherines sandwichiensis (Quoy \& Gaimard). Romblon (Jordan \& Richardson); Cebu (Günther, A, Monacanthus pardalis.)

640. Cantherines macrurus (Bleeker). Negros (Jordan \& Seales, B); Bacon; Jolo (Evermann \& Seale, A).

641. Cantherines tessellatus (Günther). Philippine Islands, Sta. 204, 115 fatl. (Guinther, A).

\section{MONACANTHUS Cuvier.}

642. Monacanthus tomentosus (Linnæus). Cuyo; Lubang (Jordan \& Richardson); Panay; Manila (Jordan \& Seale, A, M. nemurus, not of Linnæus); Palawan (Vaillant).

643. Monacanthus chinensis (Bloch). Manila (Jordan \&.Seale, A); Negros (Jordan \& Seale, B) ; Iloilo (Jordan \& Richardson) ; Bulan (Evermann \& Seale, A).

644. Monacanthus surothura Van Hasselt. Negros (Jordan \& Seale, B); (perhaps equals Monacanthus hajam Bleeker).

\section{OSBECKIA Jordan \& Evermann.}

645. Osbeckia scripta (Osbeck). Jolo (Evermann \& Seale, A).

ALUTERA (Cuvier) Oken.

646. Alutera monoceros (Osbeck). Manila (Jordan \& Seale, A).

Family TETRAODONTID $Æ$.

\section{SPHEROIDES (Lacépède) Duméril.}

647. Spheroides lunaris (Bloch). Philippine Islands (Günther, var. spadiceus);

Cavite (Jordan \& Seale, A); Negros (Jordan \& Seale, B) Manila; Iloilo (Jordan \& Richardson); San Fabian (Evermann \& Seale, B); Zamboanga (Seale \& Bean).

648. Spheroides ocellatus (Osbeck). Manila (Jordan \& Seale, A); Negros (Jordan \& Seale, B).

649. Spheroides hypselogenion (Bleeker). Bulan (Evermann \& Seale, A). 650. Spheroides sceleratus (Forster). Philippine Islands (Günther).

\section{TETRAODON Linnæus.}

651. Tetraodon hlapidus Linnxus. Manila; Panay (Jordan \& Seale, A); Cuyo (Jordan \& Richardson).

652. Tetraodon reticularis Bloch \& Schneider. Cavite (Jordan \& Seale, A); Negros (Jordan \& Seale, B); Lubang (Jordan \& Richardson) ; Zamboanga (Seale \& Bean).

653. Tetraodon nigropunctatus Bloch \& Schneider. Bacon (Evermann \& Seale, A).

654. Tetraodon immaculatus Bloch \& Schneider. Philippine Islands (Günther, var. virgata; Günther, A) ; Manila (Proce) ; Cavite (Jordan \& Seale, A) ; Negros (Jordan \& Seale, B) ; Lubang; Iloilo; Cuyu; Ticao (Jordan \& Richardson); Manila (Evermann \& Seale, A); Zamboanga (Seale \& Bean). 
655. Tetraodon fluviatilie Hamilton-Buchanan. Philippine Islands (Gïnther); Manila (Procé), T. nigroviridis=fluviatilis fide Bleeker, Atlas).

CHELONODON Mäller.

656. Chelonodon patoca (Hamilton-Buchanan). Philippine Islands, Sta: 203, (Günther, A); Manila (Jordan \& Richardson); Mindanao (Smith \& Seale); Zamboanga (Seale \& Bean).

\section{CANTHIGASTER Swainson.}

657. Canthlgaster compressus (Procé). Manila (Procé); Philippine Islands (Gunther, Tetrodon striolatus); Cavite (Jordan \& Seale, A); Negros (Jordan \& Seale, B) ; Philippines (Evermann \& Seale, A); Zamboanga (Evermann \& Sealc, B); Zamboanga (Seale \& Bean).

658. Canthlgaster bennetti (Bleeker). Bacon (Evermann \& Seale, A).

\section{Family DIODONTID瓜.}

DIODON Linnæus.

659. Dlodon holacanthus Linnæus. Sulu Sea (Günther, Diodon maculatus, var.).

660. Diodon hystrix Linnæus. Luzon (Peters, C) Diodon punctatus.

CHILOMYCTERUS Bibron.

661. Chllomycterus orbicularis (Bloch). Straits near Cebu (Günther, A).

Family OSTRACIIDA.

OSTRACION Linnæus.

662. Ostracion tubercuiatum Linnxus. Cavite (Jordan \& Seale, A); Jolo (Evermann \& Seale, A).

663. Ostracion glbbosum Linnæus. Cavite (Jordan \& Seale, A); Jolo (Evermann \& Seale, A).

664. Ostracion cornutum Linnæuus. Cavite (Jordan \& Seale, A); Negros (Jordan \& Seale, B).

\section{Family GOBIID压.}

BOSTRYCHUS Lacépede.

665. Bostrychus sinensis (Lacépède). Manila (Kner).

\section{VALENCIENNEA Bleeker.}

666. Valenciennea muralis (Quoy \& Gaimard). Cuvier \& Valenciennes. Philippine Islands (Günther).

667. Valenciennea strigata (Broussonet). Bacon (Evermann \& Seale, A).

668. Valenciennea violifera Jordan \& Seale. Negros (Jordan \& Seale, B).

Valenciennea violifera Jordan \& Seale, Bull. U. S. Bur. Fish. XXV, 1905, 383 ; Samoa.

Valenciennea species, Jordan \& Seale, Proc. U. S. Nat. Mus., XXVIII, 1005, 794; Negros.

ELEOTRIS Gronow.

669. Eleotrls fusca (Bloch \& Schneider). Luzon, Samar (Peters, C); Palawan

(Boulenger, A) ; Sibuyan; Aparri (Jordan \& Richardson). 
OPHIOCARA Gill.

670. Ophlocara aporos (Bleeker). Samar (Peters, C); Palawan; Balalalc (Boulenger, A); Mindoro; Sibuyan (Jordan \& Richardson).

671. Ophlocara porocephala (Cuvier \& Valenciennes). Philippine Islands (Giinther, Eleotris ophiocephalus); Luzon (Peters, C, E. ophiocephalus); Calayan; Mindoro (Jordan \& Richardson); Zamboanga (Seale \& Bean). (Not Eleotris ophiocephalus of Day.)

672. Ophiocara laglaizi (Sauvage). Manila (Sauvage, B).

Eleotris laglaizi Sauvage, Bull. Soc. PJilomath., 1880, 54; Manila, P. I.

\section{BUTIS Bleeker.}

673. Butis butis (Hainilton-Buchanan). Plilippine Islands (Günther, in part); ?Palawan (Boulenger, A); Manila; Iloilo (Jordan \& Richardson); Negros (Jordan \& Seale A, Butis leucurus); Cavite (Jordan \& Seale, A, Butis leucurus); Bacon (Evermann \& Serle, A, Butis lcucurus); Palawan (Vaillant).

Butis leucurus Jordan \& Seale, Proc. U. S. Nat. Mus., XXVIII. 1905, 794, fig. 13; Negros.

674. Butis koilomatodon (Bleeker). Iloilo (Jordan \& Riclırdson); Cavite (Jordan \& Seale, A, Butis serrifrons).

(Eleotris caperatus Cantor, Cat. Mal. Fishes, 1850, 1179; Sea of Pinang.)

(Prionobutis serrifrons Rutter, Proc. Ac. Nat. Sci. Phila., 1897, 84; Swatow, China.)

675. Butis ambolnensis, Bleeker. Mindoro (Jordan \& Richardson). (Probably not Eleotris amboinensis of Day.)

676. Butis prismaticus (Bleeker). Cuyo; Manila (Jordan \& Richardson).

ODONTOBUTIS Bleeker.

677. Odontobutis obscurus (Peters). Zamboanga (Seale \& Bean).

ASTER-ROPTERIX Rïppell. (Brochyeleotris Beeker.)

678. Asterropterix everettl Boulenger. Palawan (Boulenger, A).

(Asterropteryx everetti Boulenger, Ann. Mag. Nat. Hist. (6) XV, 186; Palawan, P. I.)

HYPSELEOTRIS Gill.

679. Hypseleotris cyprinoides (Cuvier \& Valenciennes). Negros (Jordan \& Seale, B).

(Not Eleotris cyprinoides of Günther=Asterropteryx güntheri Bleeker.)

680. Hypseleotris modestus (Bleeker). Mindoro (Jordan \& Richardson).

PERIOPHTHALMUS Bloch \& Schneider.

681. Perlophthalmus barbarus (Linnæus). Negros (Jordan \& Seale, B); Ticao; Aparri (Jordan \& Richardson); Panay (Jordan \& Seale, A, $P$. chrysospilus).

[We are unable to separate the nominal species of this genus and think it doubtful if more than one can be defined.] 
PERIOPHTHALMODON Gill.

682. Periophthaimodon schlosserl Bloch. Cavite (Jordan \& Seale, A).

SCARTELAOS Swainson.

(Boleops Gill).

683. Scartelaos viridis (Hamilton-Buchanan). Negros (Jordan \& Seale, B, fig.).

GNATHOLEPIS Bleeker.

684. Gnatholepis calliurus Jordan \& Seale. Negros (Jordan \& Seale, B).

Gnatholepis calliurus Jordan \& Seale, Proc., U. S. Nat. Mus., XXVIII, 1905, 796, fig. 14; Negros.

685. Gnatholepis deltoldes (Seale). Negros (Jordan \& Seale, B).

Gobius deltoides Seale, Occ. Papers Bishop Mus., I, 1901, No. 3, 125; Guam.

686. Gnatholepis (?) sternbergl ${ }^{1}$ (Smith). Lake Buhi, P. I. (Smith); Zamboanga (Seale \& Bean).

OPLOPOMUS Steindachner. (Centrogobius Bleeker; not oplopoma Girard.)

687. Oplopomus vergens Jordan \& Seale. Cavite (Jordan \& Seale, A).

Oplopomus vergens Jordan \& Seale, Bull. U. S. Bur. Fish., XXVI, 1906, 44, fig. 17; Cavite.

RUPPELlIA Swainson. (Paragobiodon Bleeker.) (Printed Ruppelia and Rupellia by Swainson by an "error in transcription.")

688. Ruppellia echinocephala (Rüppell). Cebu (Günther, C).

689. Ruppellia melanosoma (Bleeker). Luzon (Peters, C); Manila (Jordan \& Seale, A, Paragobiodon).

DROM BUS Jordan \& Seale. (Drombus Jordan \& Seale, Proc. U. S. Nat. Mus., XXVIII, 1905, 797 (palackyi).)

690. Drombus palackyl Jordan \& Seale. Negros (Jordan \& Seale, B); Zamboanga (Seale \& Bean).

Drombus palackyi Jordan \& Seale, Proc. U. S. Nat. Mus., XXVIII, 1905, 797, fig. 15; Negros.

RHINOGOBIUS Gill. (Ctenogobius Jordan \& Snyder, not of Gill; Coryphopterus Gill; Porogobius and Acentrogobius Bleeker.)

691. Rhinogobius nebulosus (Forskål). Panay; Cavite (Jordan \& Seale, A, R. nebulosus and lungi); Manila; Aparri (Jordan \& Richardson).

Gobius criniger Cuvier \& Valenciennes, and of Gtinther and Day.

Rhinogobius lungi Jordan \& Seale,.Bull. U. S. Bur. Fish., XXVI, 1906, 41, fig. 13; Cavite, P. I.

692. Rhinogobius caninus (Cuvier \& Valenciennes). Negros (Jordan \& Seale, B). Iloilo; Lubang (Jordan \& Richardson).

${ }^{1}$ Dorsal V-8; Anal 8; scales 25-26; cheeks and opercles covered with large scales; teeth in upper jaw in three irregular rows; in lower jaw in a band, some canine-like; caudal bluntly rounded, not elongated; tongue not described; pectoral rays not silk-like. (Smith.) 
693. Rhinogobius baliuroides (Bleeker). Aparri (Jordan \& Richardson).

694. Rhinogobius calderze (Evermann \& Seale). Mindanao (Evermann \& Seale, B).

Gobius calderce Evermann \& Seale, Proc. U. S. Nat. Mus., XXXI, 1906, 511, fig. 3; Caldera Bay, Mindanao. Since the publication of the original description, Dr. Evermann has written us that the upper pectoral rays of this species are not silk-like. It is evidently a Rhinogobius.

ZONOGOBIUS Bleeker.

695. Zonogobius semidoliatus (Cuvier \& Valenciennes). Negros (Jordan \& Seale, B).

CREISSON Jordan \& Seale. (Creisson Jordan \& Seale, Bull. U. S.

Bur. Fish. XXVI, 1906, 43 (validus).)

696. Creisson validus Jordan \& Seale. Cavite (Jordan \& Seale, A).

Creisson validus Jordan \& Seale, Bull. U. S. Bur. Fish., XXVI, 1906, 43, fig. 16 ; Cavite, P. I.

MISTICHTHYS Smith. (Mistichthys Smith, Bull. U. S. Bur. Fish., $\mathrm{XXI}, 1901,167$ (luzonensis).)

This genus seems to be chiefly distinguished by its very short and low spinous dorsal. The teeth are curved and uniserial.

697. Mistichthys luzonensis Smith. Lake Buhi (Smith).

Mistichthys luzonensis Smith, Bull. U. S. Bur. Fish., XXI, 1901, 167, fig.; Lake Buhi, P. I.

\section{GOBIUS (Artedi) Linnæus.}

698. Gobius ornatus Rüppell. Philippine Islands (Günther); Luzon (Peters, C.) ; Ticao (Jordan \& Richardson); Palawan (Vaillant).

699. Goblus oligolep is Bleeker. Luzon (Peters, C).

700. Goblus ophthalmotzenia Richardson; Panay (Jordan \& Seale, A).

MAPO Smitt. (Mapo Smitt, Afh. Vet. Kong. Ak. Stockholm, 1899, 543 (soporator).)

701. Mapo fuscus (Rüppell). Cavite (Jordan \& Seale, A.); Zamboanga (Seale \& Bean).

Gobius albopunctatus Cuvier \& Valenciennes, Hist. Nat. Poiss., XII, 57, 1837; Ile de France.

Gobius soporator Cuv. \& Val.

702. Mapo mearnsi Evermann \& Seale. Mindanao (Evermann \& Seale, B).

Mapo mearnsi Evermann \& Seale. Proc. U. S. Nat. Mus., XXXI, 1906, 510, fig. 2; Zamboanga, Mindanao, P. I.

\section{GLOSSOGOBIUS Gill.}

703. Glossogobius giuris (Hamilton-Buchanan). Philippine Islands (Günther); Luzon; Leyte (Peters, C); Palawan (Boulenger, A) Bacon; San Fabian; Bulan (Evermann \& Seale, A); Mindanao (Smith \& Seale); Mindoro; Aparri; Iloilo (Jordan \& Richardson).

Gobius giuris (Günther), Cat. Fishes, III, 1861, 21 (in part only, Gobius fasciato-punctatus (Richardson) being identical with Glossogobius brunneus (Temminck \& Schlegel)) ; not Gobius giuris of Rutter, which equals Glossogobius brunneus (Temminck \& Schlegel); nor of Abbott, which equals Rhinogobius giurinus (Rutter).) 
704. Glossogobius biocellatus (Cuvier \& Valenciennes). Bacon (Evermann \& Seale, A) ; Mindanao (Smith \& Seale).

705. Glossogobius obscuripinnis (Peters). Luzon (Peters, C).

Gobius obscuripinnis Peters, Monatsber. Akad. Wiss. Berl., 1868, 263; Bicol R., Province of Albay, and creeks in Luzon.

706. Glossogoblus aglestes Jordan \& Seale. Negros (Jordan \& Seale, B).

Glossogobius aglestes, Jordan \& Seale, Proc, U. S. Nat. Mus., XXVIII, 1905, 798, fig. 16; Negros. This species has the short snout and coloration (for the most part) of Glossogobius obscuripinnis Peters, and may not be different.

707. Glossogoblus pavo (Steindachner). Philippine Islands (Steindachner, B). Gobius pavo (Glossogobius?) Steindachner S. B. Ak. Wien., 1867, 715, Philippine Islands.

Dorsal VI-1, 8, scales 31; head broad, depressed; lower jaw projecting; teeth in outer row in both jaws enlarged; pectoral without silky rays; ventrals ("ventral-scheibe") half length of head; (This apparently means that the ventrals are united.) Scales increasing in size backward; upper part of head, behind eyes, scaled, as well as upper part of opercle; rest of head naked, crossed lengthwise and crosswise by (rows of) sensory pores; color gold brown, each side with four large black spots. (Steindachner 1. c.)

ILLANA Smith \& Seale. (Illana Smith \& Seale, Proc. Biol. Soc. Wash., XIX, 1906, 79, (cacabet).)

708. Illana cacabet Smith \& Seale. Mindanao (Smith \& Seale).

Illana cacabet Smith \& Seale, Proc. Biol. Soc. Wash., XIX, 1906, 79, fig; Rio Grande in Mindanao.

AWAOUS Steindachner.

709. Awaous ocellaris (Broussonet). Mindoro (Jordan \& Richardson).

710. Awaous grammepomus (Bleeker). Palawan (Boulenger, A).

711. Awaous lacrymosus ${ }^{1}$ (Peters). Quingoa R., in Luzon (Peters, C).

AMBLYGOBIUS Bleeker. (Amblygobius Bleeker, Arch. Neerl., 1875, 322 (sphinx). Odontogobius Bleeker, Arch. Neerl., 1875, 323 (bynoensis).)

712. Amblygoblus bynoensis (Richardson). Luzon (Peters, C); Negros, (Jordan \& Seale, B).

713. Amblygobius phalzena (Cuvier \& Valenciennes). Cagayancillo (Jordan \& Richardson).

714. Amblygoblus sphinx (Cuvier \& Valenciennes). Negros (Jordan \& Seale, B).

EXYRIAS Jordan \& Seale.

715. Exyrias puntang (Bleeker). Palawan (Vaillant).

We do not know whether this is the Gobius puntang of Bleeker, Natuurk. Tydschr, Nederl Ind. III, page 692 , or the G. puntang of Bleeker, Riouw, page 486, said to be different species by Dr. Günther. Gobius puntang of Bleeker is said by Dr. Günther to equal G. puntang. oides Bleeker, Ceram. III, page 242 (=Exyrias puntangoides of Jordan \& Seale, Samoa, p. 405).

${ }^{1}$ Dorsal VI-1, 10; anal I, 10; Scales 52-55; eyes one eye apart; maxillary to middle of eye; no canines; outer row of teeth enlarged; head naked behind eyes except for a few scales on upper part of opercle and preopercle; scales on nape smaller; pectoral without silk-like rays. (Peters.) 
WAITEA Jordan \& Seale. (Waitea Jordan \& Seale, Bull. U. S. Bur. Fish., XXV, 1905, 407 (mystacina).)

716. Waitea mystacina (Cuvier \& Valenciennes). Aparri (Jordan \& Richardson).

APARRIUS Jordan \& Richardson. (Aparrius Jordan \& Richardson, Bull. U. S. Bur. Fish., XXVI, 1908, p. 278, (acutipinnis).)

717. Aparrius acutipinnis (Cuvier \& Valenciennes). Mindanao (Smith \& Seale); Cavite (Jordan \& Seale, A, Rhinogobius ocyurus); Aparri (Jordan \& Richardson).

Rhinogobius ocyurus Jordan \& Seale, Bull. U. S. Fish Comm., XXVI, 1906, 42, fig. 14, Cavite, P. I.

Acentrogobius acutipinnis Smith \& Seale, Proc. Bio, Soc. Wash., XIX, 1906, fig. 81 ; Mindanao, P. I.

A parrius acutipinnis Jordan \& Richardson, Bull. U. S. Bur. Fish, XXVI, 1908, p. 278 ; Aparri, P. 1 .

Gobius (Acentrogobius) acutipinnis Day, Fishes, India, 1878-1888, 292, pl. LXI, fig. 2; seas of India to Andamans.

GOBIICHTHYS Klunzinger. (Pselaphias Jordan \& Seale.) Gobiichthys Klunzinger, Fische des Rothen Meeres, 1871, 479 (petersii).

- Except in the presence of a tentacle over the eye this genus does not differ from Oxyurichthus Bleeker.

718. Goblichthys tentacularis (Cuvier \& Valenciennes). Cavite (Jordan \& Seale, A, Oxyurichthys tentacularis); Iloilo; Aparri (Jordan \& Richardson).

OXYURICHTHUS Bleeker.

The genus Oxyurichthus (belosso) differs from Gobiichthys Klunzinger (Pselaphias, Jordan \& Seale) in lacking a tentacle over the eye and from Gobiichthys Girard, in having the upper teeth in a single series and the tongue convex.

719. Oxyurichthus cristatus (Day). Iloilo (Jordan \& Seale, A); San Fabian (Evermann \& Seale, A); Cagayancillo (Jordan \& Richardson).

720. Oxyurichthus papuensis (Cuvier \& Valenciennes). Negros (Jordan \& Seale, B).

721. Oxyurichthus arguius ${ }^{1}$ (Peters). Luzon (Peters, C).

Gobius argulus Peters, Monatsber. Akad. Wiss. Berl., 1868, 263; Luzon, P. $I$.

721a. Oxyurichthus (?) filifer Cuvier \& Valenciennes. Palawan (Vaillant).

GoBIosomA Girard.

722. Gobiosoma marmoratum (Peters). Samar (Peters, C).

Gobiosoma marmoratum Peters, Monatsber. Akad. Wiss. Berl., 1868, 267; Samar, $P$. $I$. The generic relations of this scantily described species are uncertain. It is doubtless not a Gobiosoma.

${ }^{1}$ Dorsal VI-I, 12; anal 7; scales very small; canines in upper and lower jaws; caudal pointed; near Gobius arabicus. (Peters.) 
SICYOPTERUS Gill.

723. Slcyopterus tæeniurus (Günther). Mindoro (Jordan \& Richardson).

724. Slcyopterus cynocephalus (Cuvier \& Valenciennes). Palawan (Boulenger, A).

TRYPAUCHENICHTHYS Bleeker.

725. Trypauchenichthys typus (Bleeker). Cagayancillo (Jordan \& Richardson).

CARAGobIUS Smith \& Seale. (Caragobius Smith \& Seale, Proc. Biol. Soc. Wash., XIX, 1906, 81, (typhlops).)

726. Caragobius typhlops Smith \& Seale. Mindanao (Smith \& Seale.)

Caragobius typhlops Smith \& Seale, Proc. Biol. Soc. Wash., XIX, 1906, 81, fig.; Rio Grande, Mindanao, P. I.

GOBIOIDES Lacépède.

727. Gobloides brachygaster (Günther). Aparri (Jordan \& Richardson).

Goblidæ: Species incertæ sedis:

728. (Goblus) dispar Peters, Monatsber, Akad. Wiss. Berl., 1868, 263; Luzon. Dorsal VI-I, 7; anal I, 7; scales 23-30; in form like an Apogon; eyes an eye apart; mouth large, maxillary to back of preopercle in males; no canines; outer row of teeth enlarged. Habitat, lakes and rivers of Luzon. (Peters.) Perhaps a Glossogobius.

729. (Gobius) viganensis, Steindachner, S. B. Ak. Wien, CII, 1893, 230; Philippine Islands. Description not seen by us.

\section{Family ECHENEID必.}

ECHENEIS Linnæus.

730. Echeneis naucrates (Linnæus). Manila (Jordan \& Seale, A); Bulan (Evermann \& Seale, A).

\section{Family SCORPAENID $A$.}

\section{MERINTHE ${ }^{1}$ Snyder.}

731. Merinthe nematophthalma (Günther). Philippine Islands, Sta. 201 (Günther, A).

\section{LIOSCORPIUS Günther.}

732. Lloscorplus longiceps Günther. Philippine Islands (Günther, A).

Lioscorpius longiceps Günther, Shore Fishes Challenger, p. 40, pt. XVII, fig. C.; Ki. Islands.

\section{SEBASTOPSIS Gill.}

733. Sebastops ls marmorata (Cuvier \& Valenciennes). Manila (Kner).

734. Sebastopsis guamensis (Quoy \& Gaimard). Calayan (Jordan \& Richardson).

(=Sebastes polylepis Bleeker.)

735. Sebastopsis scabra (Ramsay \& Ogilby). Cavite (Jordan \& Seale, A); Negros (Jordan \& Seale, B); Bacon (Evermann \&.Seale, A).

${ }^{1}$ Listed as Merinthe Jordan \& Evermann in Samoan Report. The name was a MS. name of Jordan \& Evermann, adopted by Snyder. 
HYPOMACRUS Evermann \& Seale.

736. Hypomacrus albaiensis Evermann \& Seale. Bacon (Evermann \& Seale, A). Hypomacrus albaiensis Evermann \& Seale, Bull. U. S. Fish Comm., XXVI, 1906, p. 102, fig. 20. Bacon, Philippine Islands.

SCORPAENOPSIS Bleeker.

737. Scorpæenopsis novæ-guinez (Cuvier \& Valenciennes). Cavite (Jordan \& Seale, A); Negros (Jordan \& Seale, B).

738. Scorpzenopsis cirrhosa (Thunberg). Panay (Jordan \& Seale, A).

\section{SEBASTAPISTES Gill.}

739. Sebastapistes trist is (Kklunzinger). Panay (Jordan \& Seale, A); Bacon (Evermann \& Seale, A).

740. Sebastapistes nuchalis (Günther). Calayan (Jordan \& Richardson). Scorpana nuchalis Günther, Sudsee, I, 76 ; Rarotonga.

741 (742). Sebastapistes nivifer Jordan \& Seale. Negros (Jordan \& Seale, B). Sebastapistes nivifer Jordan \& Seale, Proc. U. S. Nat. Mus., XXVIII, 1905, 791, fig. 10; Negros, P. 1 .

SYNANCEIA Bloch \& Schneider.

743. Synanceia horrida (Linnæus). Kamboanga (Seale \& Bean).

PTEROIS Cuvier.

744. Pterois zebra (Cuvier \& Valenciennes). Bacon (Evermann \& Seale, A). 745. Pterois volitans (Linnæus). Bacon (Evermann \& Seale, A).

DECTERIAS Jordan \& Starks.

746. Decterias puslllus (Temminck \& Schlegel). Panay (Jordan \& Seale, A).

PARACENTROPOGON Bleeker:

747. Paracentropogon longispinis (Cuvier \& Valenciennes). Philippine Islands, Sta. 203 (Günther, A); Cuyo (Jordan \& Richardson).

748. Paracentropogon indicus (Day). Cuyo (Jordan \& Richardson).

AMBLYAPISTUS Bleeker.

749. Amblyapistus crista-galli (Günther). Philippine Islands (Günther). [Said by Bleeker (Mem. Spec. Insul. Scorpæn.) to be a synonym of $\boldsymbol{A}$. toenionotus (C. V.)]

VESPICULA Jordan \& Richardson, new genus, type Prosopodasys gogorza (Jordan \& Seale). (Prosopopasys of Günther, not of Cantor, who gives the name Prosopodasys, as a substitute for Apistus, changed on account of the prior Apistis.)

750. Vesplcula gogorzæ (Jordan \& Seale). Negros (Jordan \& Seale, B).

Prosopodasys gogorza Jordan \& Seale, Proc. U. S. Nat. Mus., XXVIII, 1906, 792, fig. 11; Negros, P. I.

\section{TETRAROGE Günther.}

751. Tetraroge barbata (Cuvier \& Valenciennes). Aparri (Jördan \& Richardson). 


\section{Family PLATYCEPHALID无.}

PLATYCEPHALUS Bloch.

752. Platycephalus indicus (Linnæus). Cavite (Jordan \& Seale, A, P. insidiator); Negros (Jordan \& Seale, B, P. insidiator); Manila (Jordan \& Richardson); San Fabian (Evermann \& Seale, A, P. insidiator); Manila (Evermann \& Seale, B, $P$. insidiator); (equals Cottus insidiator Forskål).

THYSANOPHRYS Ogilby. (Insidiator Jordan \& Snyder.)

753. Thysanophrys Isacanthus (Cuvier \& Valenciennes). Cavite (Jordan \& Seale, A).

754. Thysanophrys crocodilus (Tilesius). Cavite (Jordan \& Seale, A, Platycephalus punctatus).

755. Thysanophrys bataviensis (Bleeker). Jolo (Evermann \& Seale, A).

756. Thysanophrys macracanthus (Bleeker). Manila (Jordan \& Seale, A); San Fabian (Evermann \& Seale, A).

757. Thysanophrys tentaculatus (Rüppell). Cuyo (Jordan \& Richardson).

ELATES Jordan \& Seale.

758. Elates thompsoni Jordan \& Seale. Manila (Jordan \& Seale, A).

Elates thompsoni Jordan \& Seale, Bull. U. S. Fish Comm., XXVI, 1906, 39, fig. 12; Manila, P. I.

\section{Family COTTIDA.}

TRACHYDERMUS Heckel. (Centridermichthys Richardson).

759. Trachydermus fasciatus ${ }^{1}$ Heckel. Philippine Islands (Heckel, B); Manila (Günther, $\mathrm{C}) . \quad(=T$. ansatus Richardson from China.)

Trachidermus fasciatus Heckel, Ann. Wiener, Mus., II, 1840, 160, pl. IX, fig. 1, 2; Philippines.

\section{Family TRIGLID压,}

\section{LEPIDOTRIGLA Günther.}

760. Lepidotrigla eydouxl Sauvage. Manila (Sauvage).

Lepidotrigla eydouxi Sauvage, Nouv. Arch. Mus., 1878, 156; Manila, P. I.

$$
\text { Family DACTYLOPTERID } Æ .
$$

$$
\text { EBISINUS Jordan \& Richardson. }
$$

761. Ebisinus cheirophthalmus (Bleeker). Manila; Cavite (Jordan \& Seale, A).

\section{Family PLEURONECTID底.}

\section{PSETTODES Bennett.}

762. Psettodes erumel (Bloch). Cavite (Jordan \& Seale, A); San Fabian (Evermann \& Seale, A).

${ }^{1}$ It is extremely improbable that this species, native in the mountain springs of Kiusiu, Japan, and in China, is found in the Philippines. 


\section{PSEUDORHOMBUS Bleeker. (Ancylopsetta Gill).}

763. Pseudorhombus Javanicus (Bleeker). Cavite (Jordan \& Seale, A, P. polyspilos, not of Bleeker); Bulan (Evermann \& Seale, A).

764. Pseudorhombus arsius (Hamilton-Buchanan). Cavite (Jordan \& Seale, A); Philippines (Günther, A, P. russelli); Bulan (Evermann \& Seale, A, $P$. russellii), (=Platessa russelli Gray).

765. Pseudorhombus polyspllus (Bleeker). Cavite (Jordan \& Seale, A); Iloilo; Manila (Jordan \& Richardson).

766. Pseudorhombus neglectus (Bleeker). San Fabian (Evermann \& Seale, A). 767. Pseudorhombus malayanus Bleeker. Manila (Jordan \& Richardson).

768. Pseudorhombus palad Evermann \& Seale. Bulan (Evermann \& Seale, A).

Pseudorhombus palad Evermann \& Seale, Bull. U. S. Bur. Fish., XXVI, 1906, 105, fig. 21, Bulan, P. I.

\section{PLATOPHRYS Swainson.}

769. Platophrys pantherinus (Rüppell). Aparri (Jordan \& Richardson); Bacon (Evermann \& Seale, A).

770. Platophrys mancus (Broussonet). Malanipa, near Zamboanga (Günther, A, Rhomboidichthys pavo).

\section{SCAEOPS Jordan \& Starks.}

771. Scæops pœcilura (Bleeker). Negros (Jordan \& Seale, B).

772. Sczops orbicularis (Bleeker). Cavite (Jordan \& Seale, A).

773. Scæops spilura (Günther). Straits of Cebu (Günther, A). Rhomboidichthys spilurus Günther, Shore Fishes Challenger, p. 53, pl. XXI, fig. A.; Straits of Cebu, P.I.

\section{Family SOLEID瓜.}

AMATE Jordan \& Starks.

774. Amate hartzfeldi (Bleeker). Philippines (Evermann \& Seale, A).

775. Amate thepassil (Bleeker). Mindanao (Smith \& Seale).

PARDACHIRUS Günther.

776. Pardachirus pavoninus (Lacépède). Bacon (Evermann \& Seale, A).

SOLEICHTHYS ${ }^{1}$ Bleeker.

777. Soleichthys heterorhinos (Bleeker). Bacon (Evermann \& Seale, A).

MICROBUGLOSSUS Günther.

778. Microbuglosus humilis (Cantor). Cavite (Jordan \& Seale, A); Manila (Jordan \& Richardson).

779. Microbuglossus ovatus (Richardson). Philippines, Sta. 203 (Günther, A).

${ }^{1}$ Blkr., Enum. Spec. p. 183; for figure of the type (heterorhinos) see Day, Fish. India, pl. XCII, fig. 5. 
SYNAPTURA ${ }^{1}$ Cantor.

780 (781). Synaptura sorcogonensis Evermann \& Seale. Bacon (Evermann \& Seale, A); Manila; Lubang (Jordan \& Richardson).

Synaptura sorsogonensis Evernann \& Seale, Proc. U. S. Fish Comm., XXVI, 1906, 106, fig. 22; Bacon, P. $I$.

CYNOGLOSSUS Hamilton-Buchanan.

782. Cynoglossus sumatrensis (Bleeker). Ticao (Jordan \& Richardson).

783. Cynoglossus sindensis Day. Manila (Jordan \& Richardson).

784. Cynoglossus puncticeps (Richardson). Philippines, Sta. 203 (Günther, A) Manila (Jordan \& Seale, A).

785. Cynoglossus macrolepidotus (Bleeker). Manila (Kner).

Family PTEROPSARID $A$.

PARAPERCIS Bleeker.

786. Parapercis hexophthalma (Ehrenberg). Philippines (Jordan \& Seale, A);

Bacon (Evermann \& Seale, A).

787. Parapercis tetracantha (Lacépède). Calayan (Jordan \& Richardson).

788. Parapercis cylindrica (Bloch). Philippine Islands (Günther) Cuyo (Jordan \& Richardson); Zamboanga (Seale \& Bean).

\section{Family BATRACHOIDIDE.}

CORYZICHTHYS Ogilby.

789. Coryzichthys diemensis (Le Sueur). Cuyo (Jordan \& Richardson).

Family CALLIONYMIDAE.

CALLIONYMUS Linnæus.

790. Calllonymus sagitta Pallas. Manila (Jordan \& Richardson).

791. Callionymus curvicornis Cuvier \& Valenciennes. Philippine Islands, Sta. 201 (Günther, A).

792. Callionymus calauropomus Richardson. Plilippines, Sta. 204 (Giinther, A).

CALLIURICHTHYS Jordan \& Fowler.

793. Calliurichthys reevesil (Richardson). Bulan (Evermann \& Seale, A).

SYNCHIROPUS Gill.

794. Synchiropus ocellatus (Pallas). Calayan (Jordan \& Richardson).

DACTYLOPUS Gill.

795. Dactylopus dactylopus (Bennett). Cavite, (Jordan \& Seale, A).

${ }^{1}$ The name Brachirus of Seranison belongs to the closely allied genus Euryglossa, as restricted by Swain. 
Family RHYACICHTHYIDÆ.

RHYACICHTHYS Boulenger. (l'latyptera Kuhl \& Van Hasselt, preoccupied).

796. Rhyacichthys aspro (Kuhl \& Vau Hasselt). Samar; Leyte (Peters, C).

Family BLENNIID丑.

\section{ENNEAPTERYGIUS Rlippell.}

797. Enneapterygius philipplnua (Peters). Luzon (Peters, C); Calayan (Jordan \& Richardson).

Tripterygium philippinum Peters, Monatsber, Ak. Wiss. Berl., 1868, 269; Luzon, P. 1.

CRISTICEPS Cuvier \& Valenciennes.

798. Cristlceps filifer Steindachner. Philippine Islands (Steindachner, A).

Cristiceps filifer Steindachner, Archiv. per la Zoologia, vol. III, fasc 1, 1867, 199-200; Philippine Islands.

BLENNIUS Linnæus.

799. Blennius thysanius Jordan \& Seale. ('avite, (Jordan \& Seale, A).

Blennius thysanius Jordan \& Seale, Bull. U. S. Bur. Fish., XXVI, 1906, 47, fig. 19; Cavite, 1 . 1.

\section{HYPLEUROCHILUS Gill.}

800. Hypleurochilus loxias Jordan \& Seale. Negros (Jordan \& Seale, B).

Hypleurochilus loxias Jordan \& Seale, Proc. U. S. Nat. Mus., XXVIII, 1905, 802, fig. 20; Negros, P. I.

ALTICUS (Conımerson) Lacépede.

801. Alticus periophthalmus (C'uvier \& Valenciennes). Samar (Peters, C).

SALARIAS Cuvier.

802. Salarias edentulus (Bloch \& Schneider). Negros (Jordan \& Seale, B); Calayan (Jordan \& Richardson).

803. Salarias rivulatus Rüppell. Calayan (Jordan \& Richardson).

804. Salarlas fasciatus (Bloch). Philippine Islands (Günther); Luzon (Peters, C) ; Negros (Jordan \& Seale. B); Cagayancillo (Jordan \& Richardson); Bacon (Evermann \& Seale, A).

805. Salarias bilineatus Peters. Samar (Peters, C).

Salarias bilineatus Peters, Monatsber. Ak. Wiss. Berl., 1868, 269; Samar, P. $I$.

806. Salarias deani Jordan \& Seale. Negros (Jordan \& Seale, B ) ; Calayan (Jordan \& Richardson, determination questionable).

Salarias deani Jordan \& Seale, Proc. U. S. Nat. Mus., XXVIII, 1905, 799, fig. 17 ; Negros, P. I.

807. Salarias undecimalis Jordan \& Seale. Negros (Jordan \& Seale, B).

Salarias undecimalis Jordan \& Seale, Proc. U. S. Nat. Mus., XXVIII, 1905, 800, fig. 18, Negros, P. I.

808. Salarias zamboangz Evermann \& Seale. Mindanao (Evermann \& Seale, B).

Salaries zamboanga Evermann \& Seale, Proc. U. S. Nat. Mus., XXXI, 512, fig. 4; Mindanao, P.I. 
800. Salarias holomelas Gilnther. Cebu (Günther, C).

Salarias holomelas Giinther, Ann. Mag. N. H., 1872, 399; Cebu, P. I.

810. Salarias reyi Sauvage. Luzon (Sauvage, B).

Salarias reyi Sauvage, Bull. Soc. Philom. (7) IV, 1880, 219; Luzon, P. I. [No canines.]

811. Salarias montanoi Sauvage. Luzon (Sauvage, B).

Salarius montanoi Sauvage, Bull. Soc. Philom. (7) IV, 1880, 219; Luzon, I. I. [No canines.]

PETROSCIRTES Riippell.

812. Petroscirtes grammistes (uvier \& Valenciennes. Bacon (Evernann \& Seale, A).

813. Petroscirtes eretes Jordan \& Seale. Panay (Jordan \& Seale, A) ; Manila

(Jordan \& Seale A, P'. vulsus) ; Negros (Jordan \& Seale, B) ; Cuyo (Jordan \& Richardson).

Pctroscirtes eretes Jordan \& Seale, Proc. U. S. Nat. Mus.. XXVIII, 1905, 801, fig. 19; Negros, P. I.

l'etroscirtes vulsus Jordan \& Seale, Bull. I. S. Fish ('omm.. XXVI, 1006, 48, fig. 20 ; Manila, P. I.

\section{Family CONGROGADIDÆ.}

CONGROGADUS Güntler. (Macharium Richardson, Hierichthys Jordan \& Fowler.)

814. Congrogadus subducens (Richardson). Cuyo (Jordan \& Richardson).

815. Congrogadus hierichthys Jordan \& Richardson. Cuyo (Jordan \& Richardson).

Congrogadus hierichthys Jordan \& Richardson, Bull. U. S. Bur. Fish., XXVII, 1908, 285; Cuyo, P. I.

\section{Family FIERASFERID $A$.}

FIERASFER Cuvier.

816. Fierasfer homel Richardson. Cavite (Jordan \& Senle A).

\section{ENCHELIOPHIS Müller.}

817. Encheilophis vermicularle (Müller). Philippine Islands (Miiller, Günther). This fish is stated by Dr. Boulenger (Cambridge Nat. Hist., Vol. VII, 625) to be a larval Fierasfer.

Family BROTULID丑.

DINEMATICHTHYS Bleeker.

818. Dinematichthys iluocœteoides Bleeker. Ticao (Jordan \& Richardson).

BROTULOPHIS Kaup.

819. Brotulophis argentistriatus Kaup. Sulu? (Kaup; Gitinther, after Kaup).

NEOBYTHITES Goode \& Bean.

820. Neobythites macrops Günther. Sta. 210 off Philippines (Giintlier, B). Neobythites macrops Günther, Deep Sea Fishes (lıallenger, p. 102, pl. XX, fig. A; Sta. 210 off Philippines. 
BATHYONUS Günther.

821. Bathyonus compressus Günther. Sta. 205, Philippine Islands (Guinther, B).

Bathyonus compręssus Günther, Ann. Mag. N. H., II, 1878, 20.

ACANTHONUS Günther.

822. Acanthonus armatus Günther. Sta. 205, Philippine lslands (Guinther, B). Acanthonus armatus Günther, Ann. Mag. N. H., 11 1878, 22.

Family BREGMACEROTID㘴.

BREGMACEROS Thompson.

823. Bregmaceros maccleliandli Thompson. Philippine Islands (Günther).

Family MACROURID

TRACHONURUS Günther.

824. Trachonurus villosus (Günther). Sta. 214, South of Philippines (Gïnther, B).

Macrurus villosus Günther, Ann. Mag. N. H., XX, 1877, 441.

BATHYGADUS Günther.

825. Bathygadus multifilis Günther. Sta. 214, South of Philippines (Günther, B).

Bathygadus multifilis Günther, Deep Sea Fishes Challenger, p. 155, pl. XLII, fig. B.; Sta. 214, South of Philippines.

Family LOPHIID无.

CHIROLOPHIUS Regan.

826. Chirolophius nareai (Günther). Sta. 204, Philippine Islands (Günther, A) ; Philippines (Regan).

Lophius naresi Günther, Shore Fishes Challenger, p. 56, pl. XXV; Sta. 204, Philippine Islands.

Family ANTENNARIID无.

ANTENNARIUS (Commerson) Lacépede.

827. Antennarius hispidus (Bloch). Manila; Cavite; Panay (Jordan \& Seale, A).

828. Antennarius chironectes (Lacépède). Cagayancillo (Jordan \& Richardson).

829. Antennarius lithinostomus Jordan \& Richardson. Cuyo (Jordan \& Richardson).

Antennarius lithinostomus Jordan \& Richardson, Bull. U. S. Bur. Fish, XXVII, 1908, 286; Cuyo, P. I.

\section{PTEROPHRYNE Gill.}

830. Pterophyne histrio (Linnæus). Manila (Jordan \& Seale, A). 


\section{SPECIES ATTRIBUTED TO PHILIPPINE ISLANDS.'}

[These names are given on the authority of Palacky, Elera, or Gogorza; see below.]

\section{CARCHARIIDEE.}

Hypoprionodon hemiodon (Müller \& Henle).

\section{PRISTDE.}

Pristis perotteti (Müller \& Henle).

\section{CLUPEIDFE.}

Sardinella fimbriata (Cuvier \& Valenciennes).

Sardinella zunasi (Bleeker).

$$
\text { ENGRAULIDF. }
$$

Anchovia tri (Bleeker).

Anchovia rhinorhyncha (Bleeker).

ANGUiLLIDE.

Anguilla amboinensis Peters.

\section{LEPTOCEPHALIDFE.}

Leptocephalus conger (Linnæus).

\section{OPHICHTHYIDEE.}

Ophichthus apicalis (Bennett).

Pisoodonophis boro (Hamilton-Buchanan).

Chlevastes colubrinus (Bleeker).

Cirrhimuræna chinensis (Hamilton-Buchanan).

\section{MURENIDE.}

Uropterygius marmoratus (Lacépède).

SILURIDF.

Pseudarius falcarius (Richardson).

Pseudarius pidada (Bleeker).

Ariodes tonggol (Bleeker).

\section{CLARIIDE.}

Clarias melanodermus Bleeker.

Clarias macrocephalus Günther.

\section{BELONIDFE.}

Tylosurus melanotus (Bleeker).

Tylosurus schismatorhynchus (Bleeker).

${ }^{1}$ In this list generic names have, when nècessary, been changed to make them conform with the nomenclature of the preceding check-list. 


\section{EXOCCETIDE.}

Hemiramphus commersoni Cuvier \& Valenciennes.

Hemiramphus georgii (Bleeker).

Cypselurus oligolepis (Bleeker).

\section{MUGILIDE.}

Mugil subviridis Cuvier \& Valenciennes.

Liza melinoptera (Cuvier \& Valenciennes).

\section{SPHYRENIDE.}

Sphyræna commersonii Cuvier \& Valenciennes.

\section{SYNGNATHIDEE.}

Corythroichthys cyanospilus (Bleeker).

Corythroichthys conspicillatus (Jenyns).

\section{CARANGIDE.}

Scomberoides sanctipetri (C'uvier \& Valenciennes).

Decapterus muroadsi (Temminck \& Schlegel).

\section{TRICHIURIDE.}

Trichiurus savala Bleeker.

\section{EQUULIDE.}

Leiognathus nuchalis (Temminck \& Schlegel).

\section{APOGONICHTHYIDE.}

Amia orbicularis (Kuhl \& Van Hasselt).

Chéilodipterus quinquelineatus (Cuvier \& Valenciennes).

AMBASSIDEE.

Ambassis batjanensis Bleeker.

SERRANIDE.

Epinephelus celebicus (Bleeker).

\section{LUTIANDE.}

Nemipterus nematophorus (Bleeker).

Cæsio maculatus Cuvier \& Valenciennes.

\section{THERAPONIDE.}

Therapon argenteus (Cuvier \& Valenciennes).

Therapon ellipticus ${ }^{1}$ (Richardson).

Scolopsis bleekeri Günther.

Pentapus nemurus (Bleeker).

Plectorhynchus chætodonoides (Lacépède).

\section{SPARIDEE.}

Lethrinus ramak (Forskål).

Monotaxis heterodon (Bleeker).

\section{MULLIDE.}

Upeneus pleurospilos (Bleeker).

Upeneoides moluccensis (Bleeker).

${ }^{1}$ Originally described from rivers of West Australia. Richardson, Erebus and Terror, p. 118. 
SCIENIDE.

Pseudosciæna sina (Belanger).

POMACENTRIDE.

Pomacentrus chrysopcellus Kuhl \& Van Hasselt.

\section{LABRIDAE.}

Chœrodon macrodonta (Lacépède).

Chcerodon leucozonus (Bleeker).

Anampses godeffroyi Günther.

Halichœres schwartzii (Bleeker).

\section{SCARICHTHYIDEE.}

Callyodon chrysopomus (Bleeker).

SIGANIDE.

Siganus Iuridus (Rüppell).

TRIACANTHIDE.

Triacanthus strigilifer Cantor.

TETRAODONTIDAE.

Sphaeroides oblongus (Bloch).

Tetraodon mappa Lesson.

Canthigaster papua (Bleeker).

BALISTIDE.

Balistes bursa Bloch \& Schneider.

\section{OSTRACIIDEE.}

Ostracion diaphanum Bloch \& Schneider.

\section{GOBIIDE.}

Belobranchus belobranchus (Cuvier \& Valenciennes).

Oxyeleotri marmorata (Bleeker).

Odontobutis obscura (Temminck \& Schlegel).

Exyrias puntangoides (Bleeker).

Oplopomus oplopomus (Cuvier \& Valenciennes).

(? Drombus) baliurus (Cuvier \& Valenciennes).

Rhinogobius cyanoclavis (Cantor).

Rhinogobius chlorostigmatoides (Bleeker).

(? Glossogobius) spectabilis (Günther).

Parapocryptes nexipinnis (Cantor).

Pseudapocryptes borneens is (Bleeker).

Apocryptodon madurensis (Bleeker).

\section{SCARPAENIDFE.}

Merinthe bandanensis (Bleeker) .

Scarpænopsis diabolus (Cuvier \& Valenciennes).

Sebastapistes strongius (Cuvier \& Valenciennes).

Centropogon robustus Günther.

Centropogon fuscovirens (Quoy \& Gaimard).

Amblyapistus tæn ionotus (Cuvier \& Valenciennes). 
SOLEIDFE.

Cynoglossus quadrilineatus (Bleeker).

Cynoglossus brachyrhynchus (Bleeker).

TRIGHONOTIDEE.

Trichonotus setigerus (Bloch \& Schneider).

$$
\text { LOPHIIDE. }
$$

Lophiomus setigerus (Vahl). 


\section{LIST OF PAPERS CONTAINING ORIGINAL RECORDS OR DESCRIPTIONS OF PHILIPPINE FISHES.}

Bleeker, Pieter. Atlas ichthyologique des Indes Orientales néerlandaises, t. I-IX, pp. 1246, pl. I-cccoxx. Amsterdam, 1862-1877.

Philippine species recorded or described:

Anguillidæ 1

Labridæ 1

Localities represented:

Philippine Islands.

Manila.

Boulenger, George Albert (A). List of the Freshwater Fishes collected by Mr. A. Everett on Palawan and Balabac. Annals and Magazine of Natural History, ser. 6, XVं, 1895, pp. 185-187.

Species recorded or described:

Murænidæ 1

Cyprinidæ 3

Syngnathidæ 1

Ophicephalidæ 1

Gobiidæ 7

Localities represented:

Palawan.

Balabac.

Boulenger, George Albert (B). Catalogue of the Fishes of the British Museum. Second edition. Vol. I. London, 1895.

Philippine species recorded or described:

Serranidæ

9

Localities represented:

Philippine Islands.

Cebu.

Cartier, Oscar. Ein Beitrag zur Kenntniss der Fische des philippinischen Archipels. Verhandlungen der physikalisch-medicinischen Gesellschaft in Würzburg, 1873, pp. 96-106. Würzburg, 1873.

Species recorded or described:

Pomacentridæ $\quad 9$

Labridæ 9

Scarichthyidæ $\quad 2$

Localities represented:

Cavite, Luzon.

Bohol.

Cebu.

Panglao. 
Cuvier, Georges et Valenclennes, Achille. Histoire naturelle des poissons, t. 1-22, pp. 8337, pl. I-viII+9-650. Paris, 1828-1846.

Philippine species recorded or described:

Siluridæ 3

Exocœtidæ 1

Carangidæ !

Equulidæ 1

Hæmulidæ 1

Ophicephalidxe 1

Anabantidæ $\quad 1$

Chætodontidæ 1

Locality represented:

Manila.

NotE.-A majority of the above species are recorded on faith of notes or drawings of Commerson, Dussumier, or Mertens, or of "members of the Russian Expedition."

Elera, Castro de. Catálogo sistemático de toda la fauna de Filipinas. I, Vertebrados, pp. 1-701 (Pisces, pp. 454-621). Manila, 1895.

A check-list of many species, based (chiefly) on specimens preserved in the Museo de Santo Tomás de Manila; the identifications not always trustworthy.

Evermann, Barton Warren, and Seale, Alvin (A). Fishes of the Philippine Islands. Bulletin, U. S. Bureau of Fisheries, XXVI, 1906, pp. 49-110, figs. 1-22. Washington, 1907.

Species recorded or described, 296, representing 89 families and 139 genera.

Localities represented :

Luzon-

San Fabian, Province of Pangasinan.

Bacon, Province of Sorsogon.

Bulan, Province of Sorsogon.

Tarlac.

Mindanao, Zamboanga.

Sulu Archipelago, Jolo.

Evermann, Barton Warren, and Seale, Alvin (B). Fishes collected in the Philippine Islands by Maj. Edgar A. Mearns, surgeon, U. S. Army. Proceedings U. S. National Museum, XXXI, 1906, pp. 505-512, figs. 1-4. Washington, 1906.

Species recorded or described:

$\begin{array}{ll}\text { Chanidæ } & 1 \\ \text { Mugilidæ } & 2 \\ \text { Exocœtidæ } & 1 \\ \text { Ophicephalidæ } & 1 \\ \text { Lutianidæ } & 1 \\ \text { Hæmulidæ } & 2 \\ \text { Sparidæ } & 2 \\ \text { Acanthuridæ } & 1 \\ \text { Platycephalidæ } & 1 \\ \text { Tetraodontidæ } & 2 \\ \text { Gobiidæ } & 2 \\ \text { Blenniidæ } & 1\end{array}$


Localities represented:

Luzon, Manila.

Mindanao, Caldera Bay at Zamboanga.

Siassi.

Sulu Archipelago, Jolo.

Gogorza y Gonzalez, José. Peces de las Islas Filipinas. Atlas de la Sociedad Española de Historia Natural, XIV, pp. 72-74. Madrid, 1885. ${ }^{1}$

A check-list of many species, evidently largely a compilation; the identifications not always trustworthy.

Gogorza y Gonzalez, José. Datos para la Fauna Filipina. Anales de la Sociedad Española de Historia Natural, XVII, pp. 247-303 (pisces, pp. 281-303). Madrid, 1887.

A check-list of many species. Introduction contains a historical sketch of collecting done up to year 1887 .

Günther, Albert. Catalogue of the fishes in the collections of the British Museum, Vol. I-VIII. London, 1859-1870.

Philippine species recorded or described (with the exception of about a half dozen species, ${ }^{2}$ on authority of Heckel, Kaup, or Muller \& Troschel; the following records based on specimens in the British Museum):

$\begin{array}{ll}\text { Dorosomatidæ } & 1 \\ \text { Symbranchidæ } & 1 \\ \text { Anguillidæ } & 1 \\ \text { Murænesocidæ } & 1 \\ \text { Ophichthyiidæ } & 2 \\ \text { Clariidæ } & 1 \\ \text { Plotosidæ } & 1 \\ \text { Mugilidæ } & 1 \\ \text { Centriscidæ } & 1 \\ \text { Syngnathidæ } & 1 \\ \text { Holocentridæ } & 1 \\ \text { Carangidæ } & 1 \\ \text { Equulidæ } & 1 \\ \text { Apogonichthyidæ } & 1 \\ \text { Ambassidæ } & 1 \\ \text { Serranidæ } & 5 \\ \text { Lutianidæ } & 1 \\ \text { Hæmulidæ } & 3 \\ \text { Sparidæ } & 2 \\ \text { Gerridæ } & 2 \\ \text { Mullidæ } & 3 \\ \text { Sillaginidæ } & 1 \\ \text { Pseudochromidæ } & 1 \\ \text { Ophicephalidæ } & 1 \\ \text { Anabantidæ } & 1 \\ \text { Pomacentridæ } & 4 \\ \text { Labridæ } & 2 \\ \text { Drepanidæ } & 1 \\ \text { Platacidæ } & 1\end{array}$

Zool. Record, 1885, Pisc. p. 15.

2 These species are credited to their original recorders in the present check-list. (J. \& R.) 


$\begin{array}{ll}\text { Chætodontidæ } & 1 \\ \text { Acanthuridæ } & 2 \\ \text { Siganidæ } & 2 \\ \text { Triacanthidæ } & 1 \\ \text { Tetraodontidæ } & 5 \\ \text { Balistidæ } & 1 \\ \text { Diodontidæ } & 1 \\ \text { Gobiidæ } & 5 \\ \text { Scorpænidæ } & 1 \\ \text { Pteropsaridæ } & 1 \\ \text { Blenniidæ } & 1 \\ \text { Fierasferidæ } & 1 \\ \text { Brotulidæ } & 1 \\ \text { Bregmacerotidæ } & 1\end{array}$

Localities represented:

Philippine Islands.

Soolo (after Kaup;=Sulu).

Günther, Albert (A). Report on the Shore Fishes procured during the voyage of H. M. S. "Challenger" in the years 1873-1876. Voyage of H. M. S. "Challenger," Zoölogy, I, pt. VI, 82 pp., 32 pl. London, 1880.

Philippine species recorded and described:

$\begin{array}{ll}\text { Hemiscylliidæ } & 1 \\ \text { Murænidæ } & 3 \\ \text { Cyprinidæ } & 2 \\ \text { Equulidæ } & 2 \\ \text { Centriscidæ } & 1 \\ \text { Acropomidæ } & 1 \\ \text { Serranidæ } & 1 \\ \text { Hæmulidæ } & 2 \\ \text { Ophicephalidæ } & 1 \\ \text { Champsodontidæ } & 1 \\ \text { Ophicephalidæ } & 1 \\ \text { Labridæ } & 1 \\ \text { Monacanthidæ } & 2 \\ \text { Tetraodontidæ } & 2 \\ \text { Balistidæ } & 2 \\ \text { Diodontidæ } & 1 \\ \text { Scorpænidæ } & 3 \\ \text { Platycephalidæ } & 1 \\ \text { Pleuronectidæ } & 3 \\ \text { Soleidæ } & 2 \\ \text { Callionymidæ } & 2 \\ \text { Lophiidæ } & 1\end{array}$

Localities represented:

Luzon, Manila.

Reefs near Zebu (Cebu).

Samboangan (=Zamboanga, Mindanao).

Pasananca, near Samboangan.

Malanipa, near Samboangan.

Stations 201, 203, and 204. 
Günther, Albert (B). Voyage of H. M. S. "Challenger," Zoölogy, XXII, pp. I-LXV + 335, $73 \mathrm{pl}$. London, 1887.

Plilippine species recorded or described:

Alepocephalidæ $\quad 1$

Malacosteidæ 1

Myctophidæ 2

Sternoptychidæ 2

Evermannellidæ 1

Halosauridæ 1

Brotulidæ 3

Macrouridæ 2

Localities represented:

Station 198, north of Celebes.

Station 200, between Philippine Islands and Borneo.

Station 205, off Philippines.

Station 207, west of Philippines.

Station 210, off Philippines.

Station 214, south of Philippines.

Günther, Albert (C). Report on the Deep Sea Fishes collected by H. M. S. "Challenger" during the years 1873-76. Annals and Magazine of Natural History, 1872, pp. 397-399. London, 1872.

Philippine species recorded or described:

Atherinidæ $\quad 1$

Sciænidæ 1

Gobiidæ 1

Cottidæ 1

Blenniidæ 1

Localities represented:

Luzon, Manila.

Cebu.

Günther, Albert (D). Fische der Südsee. Bd. I, pp. 1-128, taf. 1-83. Journal des Museums Godeffroy, Bd. II, Hft. III. Hamburg, 1873.

Philippine species recorded or described:

Sparidæ, 1.

Locality represented:

Philippine Islands.

Heckel, Jacob. (A). Russegger's Reisen, I, 1025, 1840.

Philippine species recorded or described:

Cottidæ, 2.

Locality represented:

Philippine Islands.

Heckel, Jacob. (B). Ann. Wiener Mus. II, 160, 1840 (Günther, Cat. II, 169) or 1837 (Agassiz, Nomenclator Zoolog., Trachidermus; Pisc.).

Philippine species recorded or described:

Cottidæ, 1.

Locality represented:

Philippine Islands. 
Jordan, David Starr, and Richardson, Robert Earl. List of Fishes Collected in the Philippines by Richard Crittenden McGregor. Bulletin U. S. Bureau of Fisheries, XXVII, pp. 233-287, figs. 1-12. Washington, 1908.

Localities represented:

Calayan.

Fuga.

Luzon-

Aparri.

Manila.

Ticao.

Lubang.

Mindoro.

Sibuyan.

Romblon.

Cuyo.

Jordan, David Starr, and Seale, Alvin (A). Fishes of the Islands of Luzon and Panay. Bulletin U. S. Bureau of Fisheries, XXVI, 1906, pp. 1-48, figs. 1-20. Washington, 1907.

Descriptive list of 239 species.

Localities represented:

Luzon-

Manila.

Cavite.

Panay, Mloilo.

Jordan, David Starr, and Seale, Alvin (B). List of Fishes collected by Dr.

Bashford Dean on the Island of Negros, Philippines. Proceedings U. S. National Museum, XXVIII, pp. 769-803, figs. 1-20. Washington, 1905.

Contains records or descriptions of 114 species.

Locality represented:

Negros.

Jordan, David Starr, and snyder, John Otterbein. Description of three new species of fishes from Formosa, Bulletin Carnegie Museum, 1908, IV, No. 2. (Two of these species recorded from Cavite.

Kaup, J. J. Wiegmann's Archiv. 1858, p. 93. ${ }^{1}$

Philippine species recorded or described:

Brotulidæ, 1 .

Locality represented:

Island of Soolo (=Sulu).

Kner, Rndolf. Reise der österreichischen Fregette Novara um die Erde in den Jahren 1857, 1858, 1859. Zoologischer Theil, Bd. I, Fische, 1, 2, und 3 Abtheilung, pp. 1-433, taf. I-xvi. Wien, 1865-1867.

Philippine species recorded or described:

Clupeidæ 1

Murænidæ 1

Mugilidæ 1

Holocentridæ 1

Scombridæ 2

Carangidæ 1

Trichiuridæ 1

${ }^{1}$ Fide Gunther, Cat. IV, 376. 


$\begin{array}{ll}\text { Equulidæ } & 1 \\ \text { Serranidæ } & 1 \\ \text { Lutianidæ } & 1 \\ \text { Hæmulidæ } & 2 \\ \text { Sparidæ } & 2 \\ \text { Sciænidæ } & 1 \\ \text { Sillaginidæ } & 1 \\ \text { Ophiocephalidæ } & 1 \\ \text { Scarichthyidæ } & 1 \\ \text { Siganidæ } & 1 \\ \text { Gobiidæ } & 1 \\ \text { Scorpænidæ } & 1 \\ \text { Soleidæ } & 1\end{array}$

Locality represented:

Manila.

Lacépède, Bernhard Germain Etienne. Histoire naturelle des poissons. Tomes 5 Paris, 1798-1803.

Philippine species recorded or described:

Aulostomidæ, 1.

Locality represented:

Philippine Islands.

Mäller, Johannes. Abhandl. Berl. Akad., 1843, 153, 154."

Philippine species recorded or described:

Fierasferidæ, 1.

Locality represented:

Philippine Islands.

Müller, Johannes und Troschel, F. H. Horae Ichthyologicæ. Berlin, 1845-1849.

Philippine species recorded or described:

Serranidæ 1

Pseudochromidæ 1

Localities represented:

Philippine Islands.

Manila.

Palacky, J. Die Verbeitung der Fische. Zweite Auflage, pp. 1-239, Prag, 1895. Contains (pp. 228-23.0) a list of many species, apparently compiled from authors for the most part, and not wholly trustworthy.

Peters, Wilhelm (A). Uber lebendig gebărende Arten der Fischgattung Hemiramphus. Monatsberichte der Königlichen Akademie der Wissenschaften zu Berlin, 1865, pp. 132 and 133.

Philippine species recorded or described:

Exocœtidæ, 1.

Locality represented:

Samar.

Peters, Wilhelm (B). Monatsberichte der Königl. Akademic der Wissenschaften zu Berlin, 1866, p. 96.

Philippine species recorded or described:

Hæmulidæ, 1

Locality represented:

Manila. 
Peters, Wilhelm (C). Über die von Hrn. Dr. F. Jagor in dem ostindischen Archipel gesammelten und dem Königlischen Zoologischen Museum iibergegebenen Fische. Monatsberichte der Königl. Akademie der Wissenschaften zu Berlin, 1868, pp. 254-281.

Philippine species recorded or described:

$\begin{array}{lr}\text { Elopidæ } & 1 \\ \text { Symbranchidæ } & 1 \\ \text { Anguillidæ } & 1 \\ \text { Leptocephalidæ } & 1 \\ \text { Moringuidæ } & 1 \\ \text { Murænidæ } & 3 \\ \text { Clariidæ } & 2 \\ \text { Exocœtidæ } & 1 \\ \text { Mugilidæ } & 1 \\ \text { Syngnathidæ } & 5 \\ \text { Apegonichthyidæ } & 2 \\ \text { Ambassidæ } & 1 \\ \text { Kuhliidæ } & 1 \\ \text { Serranidæ } & 1 \\ \text { Hæmulidæ } & 2 \\ \text { Sparidæ } & 1 \\ \text { Gerridæ } & 1 \\ \text { Ophiocephalidæ } & 1 \\ \text { Anabantidæ } & 1 \\ \text { Pomacentridæ } & 3 \\ \text { Labridæ } & 2 \\ \text { Toxotidæ } & 1 \\ \text { Ephippidæ } & 1 \\ \text { Chætodontidæ } & 1 \\ \text { Triacanthidæ } & 1 \\ \text { Diodontidæ } & 1 \\ \text { Gobiidæ } & 13 \\ \text { Callionymidæ } & 1 \\ \text { Blenniidæ } & 4\end{array}$

Localities represented:

Luzon.

Masbate.

Samar.

Leyte.

Peters, Wilhelm (D). Monatsberichte der Königl. Akademie der Wissenschaften zu Berlin, 1869, p. 705.

In this paper a new name is proposed for Therapon brevispinus Peters, 1868, from Luzon, preoccupied. (See Peters, C.)

Procé, Marion de. Sur plusieurs espéces nouvelles des poissions et des crustacés observées par M. Marion de Procé. Bulletin des Sciences par la Societe Philomathique de Paris, 1822, pp. 129-134.

Philippine species recorded or described:

Tetraodontidæ, 3.

Locality represented :

Manila.

Regan, C. Tate. A Revision of the Fishes of the Family Lophiidce. Annals and Magazine of Natural History. Ser. 7, XI, 1903, pp. 277-285.

Philippine species recorded or described:

Lophiidæ, 1. 
Locality represented:

Philippine Islands.

Richardson, Sir John (A). The Zoölogy of the Voyage of H. M. S. Erebus and Terror. Fishes, pp. 1-139, pls. 60. London, 1844-1848.

Philippine species recorded or described:

Murænesocidæ 1

Ophichthyidæ 1

Locality represented:

Philippine Islands.

Richardson, Sir John (B). Report on the Ichthyology of the Seas of China and Japan. Report of British Association for the Advancement of Science for 1845, pp. 187-326. London, 1846 .

Philippine species recorded or described:

Syngnathidæ, 1.

Locality represented:

Plilippine Islands.

Sauvage, H. E. (A). Nouvelles Archives du Museum d' Histoire Naturelle (2me serie), I, 1878, p. 156.

Philippine species recorded or described:

Triglidæ, 1.

Locality represented:

Manila.

Sauvage, H. E. (B). Bulletin de la Societe Philomathique de Paris, (7) IV, 1880 pp. 54 and 219.

Philippine species recorded or described:

Gobiidæ 1

Blenniidæ 2

Locality represented:

Luzon.

Manila.

Seale, Alvin, and Bean, Barton $\Delta$. On a collection of fishes from the Philippine Islands, made by Maj. Edgar A. Mearns, surgeon, U. S. Army, with descriptions of seven new species. Proc. U. S. N. M., XXXIII 1907, pp. 229-248. 131 species from Zamboanga in Mindanao, 7 of them new.

Smith, Hngh M. Notes on five food fishes of Lake Buhi, Luzon, Philippine Islands.

Bulletin U. S. Fish Commission. XXI, 1901, pp. 167-171, 3 figs.

Species recorded or described:

Exocœetidæ 1

Anabantidæ $\quad 1$

Ophiocephalidæ 1

Gobiidæ 2

Locality represented:

Lake Buhi, Province Camarines Sur, Luzon.

Smith, Hngh M., and Seale, Alvin. Notes on a collection of fishes from the Island of Mindanao, Philippine Archipelago, with descriptions of new genera and species. Proceedings Biological Society of Washington, XIX, 1906, pp. 73-82, 5 figs.

Species recorded or described:

Chirocentridæ $\quad 1$

Dorosomatidæ 1

Engraulidæ $\quad 1$

Clariidæ 1

Syngnathidæ $\quad 1$

Mugilidæ ] 


$\begin{array}{ll}\text { Sphyrænidæ } & 1 \\ \text { Carangidæ } & 4 \\ \text { Equulidæ } & 3 \\ \text { Ambassidæ } & 1 \\ \text { Serranidæ } & 1 \\ \text { Lutianidæ } & 2 \\ \text { Hæmulidæ } & 2 \\ \text { Mullidæ } & 1 \\ \text { Ephippidæ } & 1 \\ \text { Tetraodontidæ } & 1 \\ \text { Anabantidæ } & 1 \\ \text { Ophiocephalidæ } & 1 \\ \text { Gobiidæ } & 5 \\ \text { Soleidæ } & 1 \\ \text { Rio Grande, Mindanao. }\end{array}$

Steindachner, Franz (A). Ueber eine neue Cristiceps Art, von den Philippinen, Archivio per la Zoologia, Vol. III, fasc. I, 1864, pp. 199-200.

Species recorded or described:

Blenniidæ, 1.

Locality represented:

Philippines Islands.

Steindachner, Franz (B). Ueber eine neue Gobius-Art von den Philippinen Ichthyologische Notizen (V), Sitzungsberichte der Mathematischnaturwissenschaftlichen Classe der Kaiserlichen Akademie der Wissenschaften. Wien, 1867, I Abth., p. 715.

Species recorded or described:

Gobiidæ, 1.

Locality represented:

Philippine Islands.

Steindachner, Franz (C). Ichthyologische Beiträge, XVI. Sitzungsberichte der mathematisch-naturwissenschaftlichen Classe der Kaiserlichen Akademie der Wissenschaften. CII, 1893, p. 230. Wien.

Philippine species recorded or described:

Gobiidæ, 1.

Locality represented:

Philippine Islands.

Vaillant, Léon. Nouvelles Archives du Muséum d'histoire naturelle. (3 serie) V, 1893, p. 57.

Philippine species recorded:

Apogonichthyidæ 1

Serranidæ 1

Pomacentridæ 1

Labridæ 2

Toxotidæ 1

Chætodontidæ 2

Monacanthidæ 2

Labridæ 1

Locality represented:

Palawan. 


\section{LIST OF LOCALITIES IN PHILIPPINE ARCHIPELAGO.}

Fishes have been recorded from the following localities by the authors named in the preceding bibliography (omitting Elera, Gogorza, and Palacky). The arrangement of the islands and provinces is from north to south, as far as possible.

PhilipPine Islands (Bleeker; Boulenger, B; Günther; Günther, D; Heckel, A \& B; Lacépède; Müller; Müller \& Troschel; Regan; Richardson, A \& B; Steindachner, A ? B ? \& C).

1. Calayan (Jordan \& Richardson; McGregor Collection).

2. Fuga (Jordan \& Richardson).

3. Luzon (Peters, A \& C; Sauvage, B).

Province of Cagayan:

Aparri (Jordan \& Richardson).

Province of Pangasinan:

San Fabian (Evermann \& Seale, A).

Province of Tarlac:

Tarlac (Evermann \& Seale, A).

Province of Bulacan:

Calumpit (Peters, C).

Province of Cavite:

Manila (Bleeker; Cuvier \& Valenciennes; Evermann \& Seale, B; Günther; Günther, A \& C; Jordan \& Seale, A; Jordan \& Richardson; Kner; Muller \& Troschel ; Peters, B; Procé; Sauvage, A \& B) .

Cavite (Cartier; Jordan \& Seale, A).

Province of Camarines Norte:

Lake Batu (Peters, C).

Province of Camarines Sur:

Lake Batu (Peters, C).

Lake Buhi (Smith).

Lebmann River (Peters, C).

Coral reef at Mambulao ${ }^{1}$ (Peters, C).

Province of Albay:

Legaspi (Peters, C).

Tibi (Peters, C).

Yassot River (Peters, C).

Province of Sorsogon:

Bacon (Evermann \& Seale, $\mathbf{A}$ ).

Bulan (Evermann \& Seale, A).

${ }^{1}$ On map, Century Atlas, Mambulao appears to be in Camarines Norte, but is not so stated by Peters. 

4. Ticao (Jordan \& Richardson).
5. Lubang (Jordan \& Richardson).
6. Mindoro (Jordan \& Richardson).
7. Sibuyan (Jordan \& Richardson).
8. Romblon (Jordan \& Richardson).
9. Panay:
Iloilo (Jordan \& Seale, A).

10. Cuyo (Jordan \& Richardson).

11. Negros (Jordan \& Seale, B).

12. Cagayancillo (Jordan \& Richardson).

13. Bohol (Cartier).

13 (b). Panglao (Cartier).

14. Cebu ${ }^{1}$ (Boulenger, B; Cartier; Günther; Günther, A \& C).

15. Masbate (Peters, C) :

Between Masbate and Luzon (Peters, C).

16. Samar (Peters, A \& C) :

Loquilocum (Peters, C).

Lauang (Peters, C).

Coral reef east of Lauang (Peters, C).

Catbalogan (Peters, C) .

Basey River at Calbigan (Peters, C) .

Calbigan River (Peters, C).

17. Leyte (Peters, C) :

Tacloban (Peters, C).

Barauen River (Peters, C).

Lake Bito (Peters, C).

18. Mindanao:

Zamboanga $^{2}$ (Günther, A; Evermann \& Seale).

Zamboanga (Seale and Bean).

Caldera Bay at Zamboanga (Evermann \& Seale, A).

Pasananca, near Zamboanga (Günther, A).

Malanipa, near Zamboanga (Günther, A).

Rio Grande at Cotabato (Smith \& Seale).

19. Palawan (Boulenger, A; Vaillant).

20. Balabac (Boulenger, A).

21. Sulu Archipelago:

Jolo (Evermann \& Seale, A \& B).

Siassi (Evermann \& Seale, B).

Sulu $^{3}$ (Kaup).

Sulu Sea (Günther, after Kaup).

\footnotetext{
${ }^{1}$ Spelled Zebu.

${ }^{2}$ Spelled Samboangan.

${ }^{3}$ Spelled Soolo.
} 


\section{INDEX TO ESTABLISHED GENERA.}

\begin{tabular}{|c|c|c|c|}
\hline Abudefduf & Page. & ('alotomus & Page \\
\hline Acanthour & 58 & Cantherines ... & \\
\hline Acanthocepola & 34 & Cantligaster & \\
\hline cropoma & 25 & Caragobius ... & \\
\hline Aoliscus .............. & 16 & Caranx & \\
\hline Eschrichtlyys. & 15 & Centriscus ..... & \\
\hline Alectis ............... & 21 & Centrogenys ... & \\
\hline Alticus & $5 i$ & Cephalopholis ... & \\
\hline Alutera ...................... & 44 & Chætodon ............. & \\
\hline Amate ............... & 54 & Champsodon ... & \\
\hline Ambassis .............. & 24 & Chanos ......... & \\
\hline Amblyapistus ........ & 52 & Cheilinus ......... & \\
\hline Amblygaster . & i] & Cheilio .......... & \\
\hline Anblygobius ............. & 4!) & Chelmon ..... & \\
\hline mia. & 23 & Chelonodon .... & \\
\hline ion ….......... & 35 & Chilose & \\
\hline 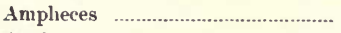 & 37 & Chilor & \\
\hline 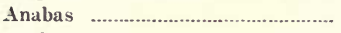 & 34 & Chi & \\
\hline ia & 7 & Chi & \\
\hline 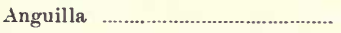 & 9 & & \\
\hline ostoma . & 7 & ræna $\ldots$ & \\
\hline ius & 58 & Cla & \\
\hline.. & 50 & $\mathrm{Coes}$ & \\
\hline$\ldots$ & 21 & otus ....... & \\
\hline hthys ........ & 24 & Colo & \\
\hline reh & 24 & Cong & \\
\hline ina .... & 15 & ichthys & \\
\hline is ................. & 49 & hthys ....... & \\
\hline alistes ............ & 43 & Creis & \\
\hline Balistapus .......... & 43 & Crist & \\
\hline Barb & 12 & eptes & \\
\hline athygadus ........ & 58 & Ctenochætus .. & \\
\hline 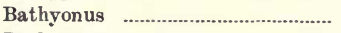 & 58 & Cynoglossus ........ & \\
\hline Bathytroctes & 7 & Cypselurus .............. & \\
\hline Blen & 56 & Dactylopus .... & \\
\hline chus & 45 & Damp & \\
\hline haceros. & 58 & Dang & \\
\hline 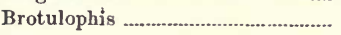 & 57 & Dasy & \\
\hline Butis . & 46 & Dase & \\
\hline Cæsio ... & 28 & Decapterus. & \\
\hline Callionyn & 55 & 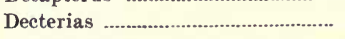 & \\
\hline 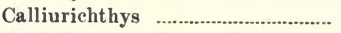 & 55 & Dermatogenys ............ & \\
\hline Callyodon & 39 & Dinematichthys .......................... & \\
\hline
\end{tabular}


Diodon

Doryichthys

Doryrhamphus

Drepane

Drombus .

Dussumieria

Duymæria

Ebisinus

Echidna

Echeneis

Elates

Eleotrix

Eleria

Eleutheronenta

Elops

Emmelichtliys

Encyeliophis

Enneapterygius

Epinephelus

Equula

Euelatichthys

Euthynnus

Exyrias

Fierasfer

Fistularia

Fowleria

Gasterotokeus

Gazza

Glossogobius

Gilatlianodon

Gnatholepis

Gnathypops

Gobiichthys

Gobioides

Gobiosoma

Gobius

Gonochætodon

Grammistes

Gymnocranius

Gymnothorax

Halichœres

Halosaurus

Hapalogenys

Helotes

Hemipimelodus

Hemipteronotus

Hemiramphus

Heniochus

Hepatus

Himantura

Hippocampus

Holacanthus
Page.

45

17

17

40

47

(5)

$3 i$

53

11

5l

53

45

19

16

.
Holocentrus

Page.

Holoutrous

Hpleurochilus

Hypomacrus ................................... 52

Hypseleotris .................................... 46

Illana ................................................ 49

nisha ...................................... 7

Johnius ......................................... 33

Konosirus …................................. 7

Kuhlia ............................................... 25

Kyphosus ......................................... 31

Labroides ….......................................

Lactarius ....................................... 19

Lampadena ....................................... 8

Lates .............................................. 25

Leiognathus ..................................... 21

Jeiuranus ....................................... 10

Lepidaplois ...................................... 37

| Lepidotrigla .................................... 53

Leptocephalus ............................... 9

Lethrinella ...................................... 30

Lethrinus ......................................... 31

Lioscorpius .................................... 51

Liza ............................................ 15

Lo .................................................. 43

Lutianus ...................................... 27

Malacosteus .................................... 8

Mapo ............................................. 48

Megalaspis .................................... 19

Megalops ........................................ 6

Mene ............................................ 22

Merinthe ..........................................

Microbuglosus ................................ 54

Microphis ....................................... 17

Mionorus ........................................ 24

Mistichthys ..................................... 48

Monacanthus .................................. 44

Monoceros ....................................... 42

6 Monodactylus ................................ 40

Moringua .......................................... 10

Mugil ............................................. 15

Mulloides ....................................... 32

Murænesox ......................................... 9

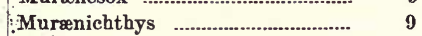

Mytophum ....................................... 8

Myriprigtis ................................. 18

Nannobrachium ............................ 8

Nematabramis .............................. 12

Nemipterus .................................... 28

Neobythites ...................................... 57

Nesogrammus ................................ 19

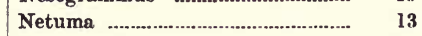

Niphon ..................................................... 
Novaculichthys

Odontobutis

Omosudis

Oplopomus

Ophicephalus

Ophichthus

Ophiocara

Osbeckia

Ostracion

Otolithes

Oxyurichthus.

Paracentropogon

Parachætodon

Parapegasus

Parapercis

Pardachirus

Parexoceetus

Pegasus

Pempheris

Pentaprion

Pentapus

Periophthalmus

Periophthalmodon

Petroscirtes

Pharopteryx

Pinjalo

Pisoodonophis

Platax

Platophrys

Platycephalus

Platyglossus

Plectorhynchus

Plotosus

Polydactylus

Polyipnus

Pomacentrus

Pomadasis

Premnas

Priacantlius

Priopis

Psammoperca

Psettodes

Pseudamia

Pseudochromis

Pseudodax

Pseudosciæna

Pseudorhombus

Pterois

Pterophryne

Rachycentron

Rasbora

Rsstrelliger
Page.

3y

46
Rita

Page.

Rhinogobius ...................................... 47

Rhyacichthys .................................. 56

Rhyuchobatus ................................... 5

Ruppellia .......................................... 47

Salarias ............................................ 56

Sardinella ........................................ 8

Saurida ............................................ 7

Scæops .......................................... 54

Scarichthys …................................ 39

Scartelaos ......................................... 47

Scatophagus ................................... 40

Sooliodon .......................................... j

Scolopsis ...................................... 29

Seomber ............................................. 18

Scomberoides .................................. 19

Scomberomorus ............................. 19

Scorpænopsis …….......................... 52

Sebastapistes ….............................. 52

Sebastopsis ...................................... 51

Seriola ........................................... 19

Sicyopterus ................................... 5]

Siganus ......................................... 42

Sllago ............................................... 33

Siphostoma ....................................... 16

Soleichthys ......................................... 54

Sparus ................................................ 31

Spheroidte ....................................... 44

Sphyræna ....................................... 15

Sphyrna .......................................... 5

Spilotichthys ................................. 30

Sternoptyx …................................ 8

Stethojulis ….................................. 37

Stoasodon ....................................... 5

Stolephorus ...................................... 6

Symbranchus .................................. y

Synancera ........................................ 52

Synaptura ....................................... 55

Synchiropus …............................... 55

Synodus .......................................... 7

Tachysurus ....................................... 13

Tæniura .......................................... 5

Tetraodon ...................................... 44

Tetraroge ......................................... 52

Thalassoma ..................................... 38

Thalliurus ...................................... 39

Therapon ....................................... 29

Thysanophrys ................................. 53

Toxotes ........................................ 40

Trachinocephalus ............................ 7

Trachinotus .................................. 21

Trachonurus .................................. 58 
INDEX.

Trachurops

Page.

Trachydermus

20 Uroconger

Page.

53 Uropterygius .................................. 12

Triacanthus

43 Valenciennea

45

Trichiurus

21 Variola …………............................. 25

Trypauchenichthys

51 Vespicula

52

Tylosurus

13 Xystæma

Ulua

21 Zanclus

42

Umbrina

33 Zebrasoma

32 Zenarchopterus 42

Upeneus

32 Zonogobius 14

Upenoides

48 


\title{
GOBIES OF THE PHILIPPINES AND THE CHINA SEA
}

BY

\author{
ALBERT W. HERRE
}

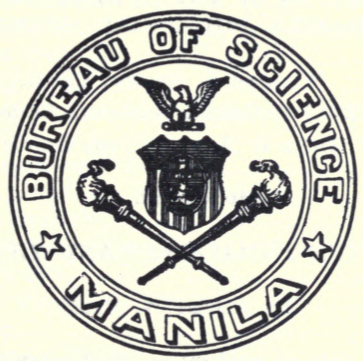

MANILA

BUREAU OF PRINTING 
MONOGRAPHS OF THE BUREAU OF SCIENCE MANILA, PHILIPPINE ISLANDS

WILLIAM H. BROWN, Editor

R. C. MCGREGOR, Associate Editor

ANNA B. BANYEA, Copy Editor

Monograph 23

GOBIES OF THE PHILIPPINES AND THE CHINA SEA

By ALBert W. HerRe

(Actual date of publication, September 15, 1927.)

2 


\section{CONTENTS}

ILLUSTRATIONS

INTRODUCTION

ORDER GOBIOIDEA

FAMILY RHYACICHTHYIDE

Genus 1. Rhyacichthys Boulenger.............................................................. 22

1. Rhyacichthys aspro (Kuhl and Van Hasselt) ....................... 22

Family Eleotridæ ...................................................................................... 25

Genus 2. Asterropteryx Rüppell ........................................................... 27

2. Asterropteryx everetti Boulenger .............................................. 28

3. Asterropteryx semipunctatus Rüppell ........................................... 28

Genus 3. Eleotris (Gronow) Bloch and Schneider.................................. 29

4. Eleotris fusca (Bloch and Schneider) ...................................... $\quad 30$

5. Eleotris melanosoma Bleeker ........................................................ 33

Genus 4. Belobranchus Bleeker ............................................................... $\quad 35$

6. Belobranchus belobrancha (Cuvier and Valenciennes)............. 35

Genus 5. Hypseleotris Gill .................................................................. 37

7. Hypseleotris agilis sp. nov........................................................ 38

8. Hypseleotris cyprinoides (Cuvier and Valenciennes) ................ $\quad 38$

9. Hypseleotris bipartita sp. nov...................................................... $\quad 39$

10. Hypseleotris modestus (Bleeker) .................................................. 41

11. Hypseleotris pangel sp. nov................................................... 42

Genus 6. Bostrichthys Duméril................................................................... 43

12. Bostrichthys sinensis (Lacépède) ................................................... 43

Genus 7. Gobiomorphus Gill......................................................................... $\quad 45$

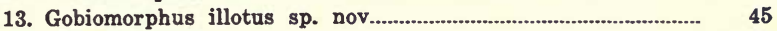

Genus 8. Butis Bleeker.......................................................................... 46

14. Butis amboinensis Bleeker....................................................... 46

15. Butis butis (Buchanan Hamilton) ....................................... 48

16. Butis gymnopomus Bleeker ...................................................... 51

Genus 9. Prionobutis Bleeker ................................................................ $\quad 52$

17. Prionobutis koilomatodon Bleeker............................................... 52

Genus 10. Odontobutis Bleeker ............................................................ 54

18. Odontobutis obscura (Schlegel) ............................................. 55

Genus 11. Paloa g. nov................................................................................ 56

19. Paloa polylepis sp. nov.............................................................. 56

Genus 12. Boroda g. nov................................................................. 58

20. Boroda albo-oculata sp. nov................................................ 58

21. Boroda expatria sp. nov ........................................................ 59

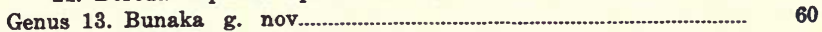

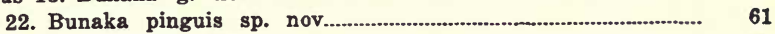

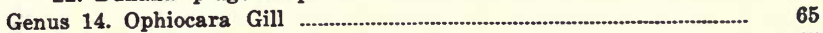

23. Ophiocara aporos Bleeker ..................................................... 65

24. Ophiocara porocephala (Cuvier and Valenciennes) ................ 69 
Genus 15. Eviota Jenkins

25. Eviota gymnocephalus Weber.................................................... 72

26. Eviota sealei sp. nov.............................................................. 73

Genus 16. Oxyeleotris Bleeker ................................................................ 74

27. Oxyeleotris marmorata Bleeker ........................................... 74

Genus 17. Valenciennea Bleeker ...................................................... 75

28. Valenciennea longipinnis (Bennett) ......................................... 76

29. Valenciennea strigata (Broussonet) ........................................... 78

30. Valenciennea muralis (Quoy and Gaimard).......................... $\quad 79$

31. Valenciennea violifera Jordan and Seale............................. 80

Genus 18. Parviparma g. nov................................................................. 81

32. Parviparma straminea sp. nov............................................... 82

Genus 19. Ptereleotris Gill ...................................................................... 83

33. Ptereleotris dispersus sp. nov............................................. 83

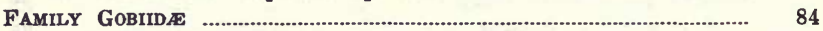

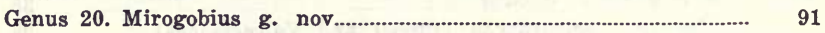

34. Mirogobius stellatus sp. nov.................................................... 92

35. Mirogobius lacustris sp. nov .......................................................... 93

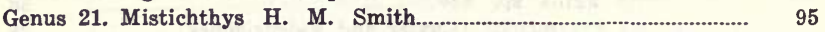

36. Mistichthys luzonensis H. M. Smith $\ldots 5$

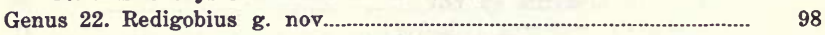

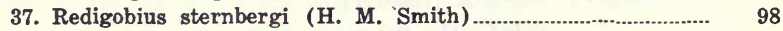

Genus 23. Macgregorella Seale .............................................................. 100

38. Macgregorella intonsa sp. nov.............................................. 100

39. Macgregorella moroana Seale ...................................................... 102

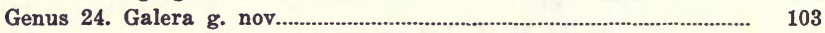

40. Galera producta sp. nov............................................................ 104

Genus 25. Gobius (Artedi) Linnæus.................................................... 105

41. Gobius panayensis Jordan and Seale.......................................... 106

42. Gobius cauerensis Bleeker ....................................................... 107

43. Gobius ornatus Rüppell ....................................................... 108

44. Gobius oligolepis Bleeker.............................................................. 110

Genus 26. Bathygobius Bleeker ............................................................ 111

45. Bathygobius bravoi sp. nov............................................................ 112

46. Bathygobius fuscus (Rüppell) ....................................................... 113

47. Bathygobius mearnsi (Evermann and Seale) ....................... 116

48. Bathygobius nox Bleeker ........................................................ 116

Genus 27. Chlamydes Jenkins ................................................................. 118

49. Chlamydes leytensis sp. nov.................................................. 118

Genus 28. Tukugobius g. nov......................................................... 119

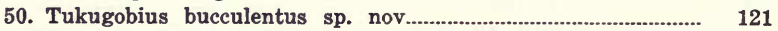

51. Tukugobius carpenteri (Seale) .................................................... 122

52. Tukugobius philippinus sp. nov........................................... 124

Genus 29. Gnatholepis Bleeker............................................................... 126

53. Gnatholepis puntangoides (Bleeker) ....................................... 127

54. Gnatholepis calliurus Jordan and Seale................................ 130

55. Gnatholepis volcanus sp. nov.................................................... 131

56. Gnatholepis deltoides (Seale) ..................................................... 133

57. Gnatholepis davaoensis Seale ............................................... 134 
Genus 29. Gnatholepis Bleeker-Continued.

Page.

58. Gnatholepis gemmeus sp. nov.................................................. 135

59. Gnatholepis knighti Jordan and Evermann........................... 137

Genus 30. Creisson Jordan and Seale................................................... 139

60. Creisson validus Jordan and Seale......................................... 139

Genus 31. Vaimosa Jordan and Seale.................................................. 141

61. Vaimosa dispar (Peters) ......................................................... 142

62. Vaimosa macrognathos sp. nov................................................. 145

63. Vaimosa microstomia Seale .......................................................... 146

64. Vaimosa piapensis sp. nov......................................................... 147

65. Vaimosa rivalis sp. nov........................................................ 149

66. Vaimosa bikolana sp. nov.................................................... 151

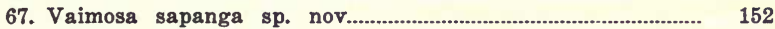

68. Vaimosa tessellata sp. nov........................................................... 153

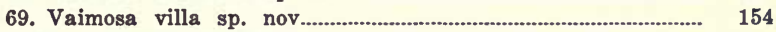

Genus 32. Glossogobius Gill .............................................................. 156

70. Glossobobius biocellatus (Cuvier and Valenciennes)............... 156

71. Glossogobius celebius (Cuvier and Valenciennes)................ 158

72. Glossogobius giurus (Buchanan Hamilton) ............................ 161

72a. Glossogobius giurus obscuripennis (Peters)............................ 164

Genus 33. Oplopomus (Ehrenberg) Steindachner........................................ 166

73. Oplopomus oplopomus (Cuvier and Valenciennes) ................ 166

74. Oplopomus vergens Jordan and Seale....................................... 168

Genus 34. Cristatogobius g. nov.............................................................. $\quad 170$

75. Cristatogobius lophius sp. nov............................................ 170

Genus 35. Paragobiodon Bleeker.................................................................. 172

76. Paragobiodon echinocephalus (Rüppell) ............................... 172

77. Paragobiodon melanosomus (Bleeker) ......................................... 174

78. Paragobiodon xanthosomus (Bleeker) ....................................... 175

Genus 36. Rhinogobius Gill ...................................................................... 176

79. Rhinogobius palackyi (Jordan and Seale) ................................. 178

80. Rhinogobius viridi-punctatus (Cuvier and Valenciennes).... 179

81. Rhinogobius decoratus sp. nov................................................ 181

82. Rhinogobius calderae (Evermann and Seale)....................... 182

83. Rhinogobius hongkongensis Seale ........................................... 184

84. Rhinogobius schultzei sp. nov..................................................... 185

85. Rhinogobius caninus (Cuvier and Valenciennes) ...................... 186

86. Rhinogobius baliuroides (Bleeker) ............................................ 188

87. Rhinogobius multifasciatus sp. nov........................................ 190

88. Rhinogobius criniger (Cuvier and Valenciennes) ................ 191

89. Rhinogobius suluensis sp. nov................................................. 193

90. Rhinogobius neophytus (Günther) ........................................ 195

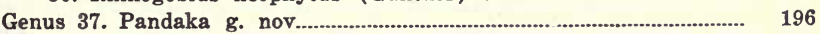

91. Pandaka pusilla sp. nov........................................................ 197

92. Pandaka pygmaea sp. nov......................................................... 198

Genus 38. Zonogobius Bleeker ................................................................. 199

93. Zonogobius semidoliatus (Cuvier and Valenciennes) ............... 200

Genus 39. Cingulogobius g. nov...................................................... 201

94. Cingulogobius boulengeri (Seale) .............................................. 201 
Genus 40. Aboma Jordan and Starks

95. Aboma viganensis (Steindachner)

202

Genus 41. Aparrius Jordan and Richardson

203

96. Aparrius acutipinnis (Cuvier and Valenciennes).

204

97. Aparrius moloanus sp. nov

204

207

Genus 42. Waitea Jordan and Seale

98. Waitea mystacina (Cuvier and Valenciennes).

208

208

Genus 43. Chonophorus Poey

99. Chonophorus genivittatus (Cuvier and Valenciennes)........

210

100. Chonophorus lachrymosus (Peters)

211

101. Chonophorus melanocephalus (Bleeker).

212

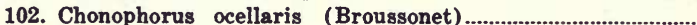

216

218

Genus 44. Tamanka g. nov.

220

103. Tamanka siitensis sp. nov.

220

104. Tamanka tagala sp. nov

222

105. Tamanka umbra sp. nov..

223

106. Tamanka bivittata sp. nov.

224

Genus 45. Amoya g. nov.

107. Amoya brevirostris (Günther)

225

226

Genus 46. Amblygobius Bleeker

227

108. Amblygobius inornatus sp. nov

228

109. Amblygobius perpusillus (Seale) ............................................. 229

109a. Amblygobius perpusillus buanensis var. nov........................ 230

110. Amblygobius linki sp. nov..

231

111. Amblygobius bynoensis (Richardson)

232

112. Amblygobius insignis Seale................................................... 234

113. Amblygobius phalaena (Cuvier and Valenciennes)............ 235

114. Amblygobius sphynx (Cuvier and Valenciennes) .................... 237

Genus 47. Cryptocentrus (Ehrenberg) Bleeker.................................... 239

115. Cryptocentrus cebuanus sp. nov........................................... 240

116. Cryptocentrus filifer (Cuvier and Valenciennes) ................. 241

117. Cryptocentrus fontanesii (Bleeker) ............................................ 242

118. Cryptocentrus vagus 8p. nov................................................ 243

119. Cryptocentrus venustus Seale ............................................ 244

Genus 48. Biat Seale ................................................................................. 245

120. Biat luzonicus Seale..................................................................... 246

Genus 49. Oxyurichthys Bleeker............................................................... 247

121. Oxyurichthys argulus (Peters) .............................................. 249

122. Oxyurichthys amabilis Seale...................................................... 250

123. Oxyurichthys microlepis Bleeker............................................. 251

124. Oxyurichthys papuensis (Cuvier and Valenciennes)........ 253

125. Oxyurichthys visayanus sp. nov............................................... 254

126. Oxyurichthys oculo-mirus sp. nov........................................... 256

127. Oxyurichthys ophthalmonema Bleeker...................................... 257

128. Oxyurichthys viridis sp. nov.................................................... 260

Genus 50. Parapocryptes Bleeker ....................................................... 261

129. Parapocryptes (Paeneapocryptes) mindanensis sp. nov..... 262

130. Parapocryptes serperaster (Richardson) ............................. 262

Genus 51. Apocryptichthys Day ............................................................ 263

131. Apocryptichthys sericus sp. nov............................................. 264 
Genus 52. Acanthogobius Gill.

132. Acanthogobius ommaturus (Richardson) ................................ 266

Genus 53. Synechogobius Gill .............................................................. 267

133. Synechogobius hasta (Schlegel) ................................................. 267

Genus 54. Illana Smith and Seale............................................................... 268

134. Illana cacabet Smith and Seale................................................... 269

Genus 55. Parachaeturichthys Bleeker ................................................ 270

135. Parachaeturichthys polynema (Bleeker) .................................... 270

Genus 56. Lophiogobius Günther................................................................. 272

136. Lophiogobius ocellicauda Günther............................................... 272

Genus 57. Amblychaeturichthys Bleeker ............................................ 274

137. Amblychaeturichthys hexanema Bleeker................................. 274

Genus 58. Chaeturichthys Richardson .................................................. 275

138. Chaeturichthys stigmatias Richardson.................................... 276

Genus 59. Apocryptodon Bleeker .......................................................... 277

139. Apocryptodon montalbani sp. nov............................................ 277

140. Apocryptodon sealei sp. nov................................................ 278

141. Apocryptodon taylori sp. nov..................................................... 279

Genus 60. Triaenopogon Bleeker ..................................................... 280

142. Triaenopogon barbatus (Günther) ......................................... 281

Genus 61. Tridentiger Gill ........................................................... 283

143. Tridentiger bifasciatus Steindachner.................................... 283

144. Tridentiger trigonocephalus (Gill) .............................................. 285

Genus 62. Caragobius Smith and Seale................................................. 286

145. Caragobius typhlops Smith and Seale................................... 287

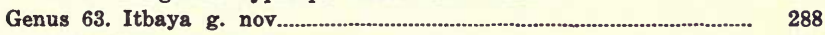

146. Itbaya nuda sp. nov................................................................. 288

Genus 64. Gobiosoma Girard ......................................................... 289

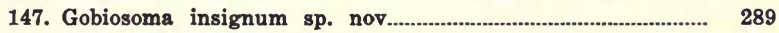

148. Gobiosoma marmoratum Peters................................................. 291

Genus 65. Gobiodon (Kuhl and Van Hasselt) Bleeker........................ 291

149. Gobiodon fulvus sp. nov..................................................... 292

150. Gobiodon hypselopterus Bleeker................................................... 293

151. Gobiodon quinquestrigatus (Cuvier and Valenciennes).... 294

Genus 66. Microsycidium Bleeker ............................................................ 295

152. Microsycidium atro-purpureum sp. nov.................................... 296

153. Microsycidium formosum sp. nov............................................. 297

154. Microsycidium pulchellum sp. nov ....................................... 299

Genus 67. Sicyopterus Gill .......................................................... 300

155. Sicyopterus lacrymosus sp. nov............................................... 303

156. Sicyopterus cynocephalus (Cuvier and Valenciennes)....... 306

157. Sicyopterus crassus sp. nov...................................................... 307

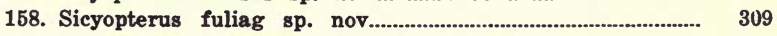

159. Sicyopterus extraneus sp. nov..................................................... 311

160. Sicyopterus panayensis sp. nov.................................................. 313

FAMILY PERIOPHTHALMIDEE ........................................................................ 315

Genus 68. Periophthalmus Bloch and Schneider.................................... 316

161. Periophthalmus barbarus (Linnæus) ......................................... 316

Genus 69. Periophthalmodon Bleeker .................................................... 320

162. Periophthalmodon schlosseri (Pallas) .................................. 320 
Genus 70. Boleophthalmus Valenciennes.

Genus 71. Scartelaos Swainson ……................................................... 324

164. Scartelaos viridis (Buchanan Hamilton) ................................ 325

FAMILY GOBIOIDIDAE _........................................................................... 327

Genus 72. Brachyamblyopus Bleeker .................................................. 328

165. Brachyamblyopus olivaceus sp. nov..................................... 329

Genus 73. Taenioides Lacépède ........................................................ $\quad 330$

166. Taenioides caeculus (Bloch and Schneider) ............................ 331

167. Taenioides cirratus (Blyth) ...................................................... 333

168. Taenioides gracilis (Cuvier and Valenciennes) .......................... 334

Genus 74. Sericagobioides $g$. nov.......................................................... 335

169. Sericagobioides lighti sp. nov............................................... 336

FAMILY TRYPAUCHENIDEE _................................................................... 337

Genus 75. Trypauchen Cuvier and Valenciennes.................................... 338

170. Trypauchen vagina Bloch and Schneider............................... 338

Genus 76. Trypauchenichthys Bleeker .................................................. 339

171. Trypauchenichthys typus Bleeker.......................................... $\quad 340$

Genus 77. Ctenotrypauchen Steindachner ……….................................. 341

172. Ctenotrypauchen microcephalus (Bleeker) ............................ 341

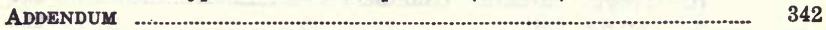

Rhinogobius maculipinnis (Fowler) .................................................. 342

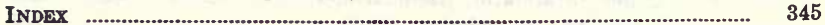




\section{ILLUSTRATIONS}

\section{FRONTISPIDCE}

Chonophorus lachrymosus (Peters). (Drawing by A. L. Canlas.)

\section{Plate 1}

FIG. 1. Rhyacichthys aspro (Kubl and Van Hasselt). (Drawing by M. L. Nievera.).

2. Asterropteryx semipunctatus Rüppell. (Drawing by P. Bravo.)

Plate 2

Fig. 1. Eleotris fusca (Bloch and Schneider). (Drawing by P. Bravo.)

2. Belobranchus belobrancha (Cuvier and Valenciennes). (Drawing by P. Bravo.)

3. Hypseleotris agilis sp. nov. (Drawing by P. Bravo.)

\section{Plate 3}

Fig. 1. Hypseleotris bipartita sp. nov. (Drawing by P. Bravo.)

2. Hypseleotris pangel sp. nov. (Drawing by M. L. Nievera.)

3. Bostrichthys sinensis (Lacépède). (Drawing by P. Bravo.)

4. Gobiomorphus illotus sp. nov. (Drawing by P. Bravo.)

\section{Plate 4}

FIG. 1. Butis butis (Buchanan Hamilton). (Drawing by M. L. Nievera.)

2. Prionobutis koilomatodon Bleeker. (Drawing by M. L. Nievera.)

3. Paloa polylepis sp. nov. (Drawing by M. L. Nievera.)

\section{Plate 5}

FIG. 1. Boroda expatria sp. nov. (Drawing by P. Bravo.)

2. Ophiocara aporos Bleeker. (Drawing by M. L. Nievera.)

3. Ophiocara porocephala (Cuvier and Valenciennes). (Drawing by P. Bravo.)

Plate 6

Fig. 1. Valenciennea longipinnis (Bennett). (Drawing by A. B. Estanislao.)

2. Parviparma straminea sp. nov. (Drawing by P. Bravo.)

3. Ptereleotris dispersus sp. nov. (Drawing by M. L. Nievera.)

4. Mirogobius stellatus sp. nov. (Drawing by P. Bravo.)

\section{Plate 7}

FIG. 1. Mistichthys luzonensis H. M. Smith. (Drawing by P. Bravo.)

2. Macgregorella intonsa sp. nov. (Drawing by P. Bravo.)

3. Galera producta sp. nov. (Drawing by M. L. Nievera.)

4. Gobius ornatus Rüppell. (Drawing by P. Bravo.) 
Plate 8

Fig. 1. Bathygobius bravoi sp. nov. (Drawing by J. L. Nievera.)

2. Bathygobius fuscus (Rüppell). (Drawing by P. Bravo.)

3. Chlamydes leytensis sp. nov. (Drawing by J. L. Nievera.)

4. Tukugobius bucculentus sp. nov. (Drawing by M. L. Nievera.)

\section{Plate 9}

Fig. 1. Gnatholepis puntangoides (Bleeker). (Drawing by A. L. Canlas.)

2. Gnatholepis calliurus Jordan and Seale. (Drawing by A. L. Canlas.)

3. Gnatholepis gemmeus sp. nov. (Drawing by A. L. Canlas.)

\section{Plate 10}

Fig. 1. Creisson validus Jordan and Seale. (Drawing by P. Bravo.)

2. Vaimosa macrognathos sp. nov. (Drawing by A. L. Canlas.)

3. Vaimosa piapensis sp. nov. (Drawing by P. Bravo.)

Plate 11

Fig. 1. Vaimosa rivalis sp. nov. (Drawing by P. Bravo.)

2. Vaimosa bikolana sp. nov. (Drawing by P. Bravo.)

3. Vaimosa sapanga sp. nov. (Drawing by P. Bravo.)

\section{Plate 12}

Fig. 1. Vaimosa tessellata sp. nov. (Drawing by P. Bravo.)

2. Vaimosa villa sp. nov. (Drawing by P. Bravo.)

3. Glossogobius biocellatus (Cuvier and Valenciennes). (Drawing by P. Bravo.)

4. Glossogobius celebius (Cuvier and Valenciennes). (Drawing by P. Bravo.)

\section{Plate 13}

Fig. 1. Cristatogobius lophius sp. nov. (Drawing by A. L. Canlas.)

2. Paragobiodon echinocephalus (Rüppell). (Drawing by A. L. Canlas.)

3. Rhinogobius decoratus sp. nov. (Drawing by J. L. Nievera.)

4. Rhinogobius caninus (Cuvier and Valenciennes). (Drawing by $\mathbf{P}$. Bravo.)

\section{Plate 14}

FIG. 1. Rhinogobius multifasciatus sp. nov. (Drawing by P. Bravo.)

2. Rhinogobius criniger (Cuvier and Valenciennes). (Drawing by $\mathbf{P}$. Bravo.)

3. Rhinogobius suluensis sp. nov. (Drawing by J. L. Nievera.)

4. Rhinogobius neophytus (Günther). (Drawing by A. L. Canlas.)

Plate 15

Fig. 1. Pandaka pusilla sp. nov., female. (Drawing by P. Bravo.)

2. Pandaka pusilla sp. nov., male. (Drawing by P. Bravo.)

3. Pandaka pygmaea sp. nov. - (Drawing by P. Bravo.) 
Plate 16

Fig. 1. Cingulogobius boulengeri (Seale). (Drawing by J. L. Nievera.)

2. Aparrius acutipinnis (Cuvier and Valenciennes). (Drawing by P. Bravo.)

3. Aparrius moloanus sp. nov. (Drawing by M. L. Nievera.)

4. Chonophorus genivittatus (Cuvier and Valenciennes). (Drawing by P. Bravo.)

Plate 17

Fig. 1. Chonophorus melanocephalus (Bleeker). (Drawing by P. Bravo.)

2. Chonophorus ocellaris (Broussonet). (Drawing by P. Bravo.)

3. Tamanka siitensis sp. nov. (Drawing by A. L. Canlas.)

4. Tamanka bivittata sp. nov. (Drawing by A. L. Canlas.)

Pzate 18

Fig. 1. Amoya brevirostris (Günther). (Drawing by A. L. Canlas.)

2. Amblygobius perpusillus buanensis var. nov. (Drawing by A. L. Canlas.)

3. Amblygobius insignis Seale. (After Seale.)

4. Amblygobius linki sp. nov. (Drawing by P. Bravo.)

Plate 19

Fig. 1. Amblygobius bynoensis (Richardson). (Drawing by P. Bravo.)

2. Cryptocentrus cebuanus sp. nov. (Drawing by J. L. Nievera.)

3. Cryptocentrus vagus sp. nov. (Drawing by A. L. Canlas.)

Plate 20

F1G. 1. Biat luzonicus (Seale). (Drawing by P. Bravo.)

2. Oxyurichthys microlepis Bleeker. (Drawing by A. L. Canlas.)

3. Oxyurichthys ophthalmonema Bleeker. (Drawing by P. Bravo.)

4. Parapocryptes mindanensis sp. nov. (Drawing by J. L. Nievera.)

Plate 21

Fic. 1. Apocryptichthys sericus sp. nov. (Drawing by A. L. Canlas.)

2. Synechogobius hasta (Schlegel). (Drawing by A. L. Canlas.)

3. Illana cacabet Smith and Seale. (Drawing by P. Bravo.)

4. Parachaeturichthys polynema (Bleeker). (Drawing by J. L. Nievera.)

Plate 22

Fig. 1. Lophiogobius ocellicauda Günther. (Drawing by A. L. Canlas.)

2. Apocryptodon montalbani sp. nov. (Drawing by A. L. Canlas.)

3. A pocryptodon taylori sp. nov. (Drawing by P. Bravo.)

4. Triaenopogon barbatus (Günther). (Drawing by A. L. Canlas.)

Plate 23

Fig. 1. Caragobius typhlops Smith and Seale. (Drawing by P. Bravo.)

2. Itbaya nuda sp. nov. (Drawing by P. Bravo.)

3. Microsycidium formosum sp. nov. (Drawing by A. L. Canlas.)

4. Microsycidium pulchellum sp. nov. (Drawing by J. L. Nievera.) 
Plate 24

Fig. 1. Sicyopterus lacrymosus sp. nov. (Drawing by P. Bravo.)

2. Sicyopterus crassus sp. nov. (Drawing by P. Bravo.)

3. Periophthalmus barbarus (Linnæus). (Drawing by P. Bravo.)

Plate 25

FrG. 1. Boleophthalmus chinensis (Osbeck). (Drawing by A. L. Canlas.)

2. Scartelaos viridis (Buchanan Hamilton). (Drawing by P. Bravo.)

3. Brachyamblyopus olivaceus sp. nov. (Drawing by P. Bravo.)

\section{Plate 26}

FrG. 1. Taenioides gracilis (Cuvier and Valenciennes). (Drawing by J. L. Nievera.)

2. Sericagobioides lighti sp. nov. (Drawing by J. L. Nievera.)

3. Trypauchen vagina Bloch and Schneider. (Drawing by J. L. Nievera.)

\section{Plate 27}

FrG. 1. Glossogobius giurus (Buchanan Hamilton). (Drawing by M. L. Nievera.)

2. Bunaka pinguis sp. nov. (Drawing by M. L. Nievera.)

3. Gobiosoma insignum sp. nov. (Drawing by A. L. Canlas.)

\section{Plate 28}

FIG. 1. Macgregorella moroana Seale. (Drawing by J. L. Nievera.)

2. Gobiodon hypselopterus Bleeker. (Drawing by A. L. Canlas.)

3. Ophiocara aporos Bleeker. (Drawing by T. S. Espinosa.)

\section{Plate 29}

FIG. 1. Gnatholepis knighti Jordan and Evermann. (Drawing by J. L. Nievera.)

2. Tukugobius carpenteri (Seale). (Drawing by A. L. Canlas.)

3. Oplopomus opbopomus (Cuvier and Valenciennes). (Drawing by P. Bravo.)

Plate 30

FIG. 1. Rhinogobius viridi-punctatus (Cuvier and Valenciennes). (Drawing by M. L. Nievera.)

2. Zonogobius semidoliatus (Cuvier and Valenciennes). (Drawing by A. L. Canlas.)

3. Amblygobius phalaena (Cuvier and Valenciennes). (Drawing by P. Bravo, from a color sketch by T. S. Espinosa.)

\section{TEXT FIGURES}

Fig. 1. Sicyopterus lacrymosus sp. nov.; $a$, right side of a tooth; $b$, Page. right side of a broken tooth, showing the relation of the three cusps; $c$, reconstructed drawing, showing the dorsal aspect of the tooth. 
Fig. 2. Sicyopterus crassus sp. nov.; left side of a tooth

Page.

3. Sicyopterus fuliag sp. nov.; $a$, base of a tooth; $b$, muscles of attachment; $c$, broken cusps.

4. Sicyopterus extraneus sp. nov.; left side of two teeth.

5. Sicyopterus panayensis sp. nov.; upper lip

6. Ventral fins of Trypauchenidæ; a, Trypauchen vagina Bloch 314 and Schneider, $\times 1.5 ; b$, Ctenotrypauchen microcephalus (Bleeker), $\times 2$; c, Trypauchenichthys typus Bleeker, $\times 2 \ldots$. 



\section{GOBIES OF THE PHILIPPINES AND THE CHINA SEA}

By Albert W. HBRre

INTRODUCTION

This great group of fishes is of the first economic importance in the northern end of Luzon, although in most parts of the earth it is of no commercial value.

The gobies are small fishes, mostly carnivorous bottom dwellers, living along or near the shore in shallow bays and estuaries, and also in fresh-water swamps, streams, and lakes. Some species seem to be confined to coral reefs, others to the tide pools of "stern and rock-bound" coasts; many kinds lie on the sand, and some burrow in the mud between or below tide levels. A few species spend much of their time out of the water, chasing insects on the strand, on mud flats, or in the mangrove swamps. Some cling to the rocks or gravelly bottom in swift mountain streams, where few fishes are able to withstand the rush of water. While the habitat of the group is mostly marine, several species live only in fresh water. Many other species spend most of their life in fresh-water streams, returning to the sea to spawn. The ascent of the streams by innumerable hosts of the fry of these catadromous species gives rise to a very important industry in the Philippines, and it is through the study of and the attempt to conserve this fishery that this monograph has been prepared.

During the months from October to March the ipon fisheries are of great importance to the inhabitants of the coasts of the Ilocano provinces and the northern coast of Luzon, especially at the mouths of Abra, Abulug, and Cagayan Rivers. Ipon is an Ilocano name for the fry of the various species of gobies that spawn in the sea, but which spend most of their life in the fresh-water streams of the interior. Ipon, or the fry of gobies, occur also in noticeable quantity along the coast of Zambales, at the mouths of the Agusan, the Cagayan de Misamis, and the Rio Grande de Mindanao, and perhaps other places in the Philippines, but it is only along the north and northwest coasts of Luzon that they occur in such enormous quantities that 
their capture and preservation form one of the chief resources of the region and one of the most valuable sources of income.

Only a few species of gobies occur in sufficient quantity and at the same time have a life history so modified and arranged as to bring about the production of enormous quantities of ipon. As far as is known at present, the chief but by no means the only sources of ipon are the following species (their ordinary Ilocano names are also given): Chonophorus melanocephalus, bukto and bunog; Eleotris melanosoma, virot; Glossogobius giurus and Glossogobius celebius, bal-la; Ophiocara aporos; and Sicyopterus lacrymosus, paliling. Two of these are eleotrids, and three are gobies in the strictest sense.

During the months from August to February these species, and many others, successively make their way down to the sea and there lay their eggs.

From about the middle of September to the middle of March vast shoals of tiny, more or less colorless or whitish, scaleless gobies make their appearance at the mouths of Philippine rivers, especially in northern Luzon. They are most abundant for about three days after the full moon each month, when the tides are highest.

Careful watch is kept, and when the first ipon are seen every banca is launched and every effort is made to capture the tiny fish. Huge nets with very fine mesh are used, and vast quantities of ipon are taken. The fish at this stage have a very delicate flavor and great numbers are eaten, either fried in oil or cooked in various other ways.

People dwelling in the coast towns endeavor to capture as much ipon as possible while the fish are still in the salt water along the coast and at the mouths of the rivers. Cagayan River is so large (about 6.5 kilometers broad and comparatively deep at its mouth) that, in spite of the great toll of ipon taken, many millions are able to escape capture and ascend the river. In Abra River conditions are different. It is a broad, swift but shallow, brawling stream, full of rock and gravel carried down from the mountains that extend toward the sea within 6 to 8 kilometers of its mouth.

In this and similar streams the Ilocanos use several deadly devices which will exterminate the ipon before many years. Barricades and dams of loose stones, banana stems, and bamboo are constructed in such a way that the ascending ipon are forced to follow them to an opening leading into a bobo, or bamboo fish trap. The paed is a similar but less permanent 
deadly device; it is merely a cloth fence strung across the river, with bamboo fish traps placed in openings at intervals of 4 or 5 meters. No matter what the form of barricade, the luckless ipon must enter the trap, since no other passage is available. Were it not for occasional heavy rains in the mountains, which cause floods, send floating logs and snags that knock holes in the paed, or shift rock and gravel and alter channels, not a single ipon could pass these barriers.

It cannot be too strongly emphasized nor stated too often that the ipon industry is doomed to perish unless a sufficient number of young are allowed to go in safety to the headwaters of the rivers and reach maturity. If all calves were killed after a while there would be no carabaos. The only way to maintain a large and steady supply of ipon is to see that a sufficient number escape to keep up the breeding stock.

Ipon move upstream very slowly and, if storms or other unfavorable conditions arise, scarcely progress at all. Since ipon are the young of several different kinds of gobies, and their migrations spread over a long time, it would do no good to establish a closed season for a month, as has been proposed. The best plan is to fix a closed season of forty-eight consecutive hours each week, during which time all ipon fishing should be prohibited; all dams, barricades, and paed should have open places for the free passage of fish, and all bobos should be taken from the water during this intermission. If such a regulation were strictly enforced the coast dwellers would be assured of a permanent supply of ipon and the people of the interior would have a much better supply of food fish in their streams than they now have.

There is opposition on the part of some coast dwellers to any sort of restriction or regulation of ipon fishing. To support their unreasonable attitude they have invented a fantastic theory to account for the appearance of the vast swarms of minute fish. They say that a mass of foam forms in the sea and swells until it is like a great bubble. Within this the ipon are formed, and when it rises to the top it bursts and releases them. Of course, the fishermen along the rivers know better, and many of them know, from a lifetime of keen observation, the times of migration for the various species of ipon gobies, and can recognize at a very early stage the tiny young of the more-important adult forms; but, as long as this wild tale of spontaneous generation receives credence, a campaign of education must be carried on among the Ilocano people until all realize the truth 
about the origin of ipon and see the necessity for regulation of the industry.

The ipon industry, properly regulated, could be as permanent as the production of carabaos, hogs, chickens, or any other livestock industry, and would be a permanent asset of vast benefit to future generations. Without such regulation, the increase in population and the increased amount of fishing incident thereto will soon see the extermination of ipon. When the ipon enter fresh water they grow darker in color and their flavor changes, until in some species the flesh is actually bitter. Meanwhile the people capture as many as possible, using all sorts of nets, and even dip them up with buckets as they crowd along the river shores. The enormous surplus has been handled since remote times by converting it into bagoo $\tilde{n g}$.

Bagoong is a sort of fish sauerkraut or fish silage, and was invented by the Malays in remote antiquity. It is a cheap and convenient method of preserving fish in the hot moist climate of the rainy Tropics. Under various names it is known from the Malay Peninsula throughout the East Indies. In the Philippines it is called guinamos by the Visayans, but is more widely known by the name bagoong than by any other.

To make bagoong a layer of salt is placed in a clean tight vessel, then a layer of fish, then another layer of salt, and so on until the vessel is filled. It is then covered tightly and set away. Fermentation goes on just as in sauerkraut, until arrested by the acids excreted by the fermentative bacteria. At the end of a month the bagoong is ripe and ready to use. By that time it possesses a powerful, penetrating, and characteristic odor all its own; if clean and well made it is a wholesome article of food which supplies the necessary protein as well as flavor and pungency to the monotonous rice diet of the people.

Various kinds of small fishes and shrimps are used in making bagoong, but by far the greatest amount is made from ipon. In making bagoong huge, small-mouthed crockery jars are used, holding from 37.5 to $\mathbf{7 5}$ liters each. In some Ilocano towns the making of bagoong is conducted much like an old-time husking or quilting bee, all the housewives gathering at the community house to help one another in this important and very necessary operation. When the jars are all filled and closed they are stored beneath the community house for the bagoong to ripen.

A common method of closing the jar is binding the top with banana leaves. If this is not well done, the splitting of the dried leaves may allow flies to enter, or careless people may not. 
close the top properly after taking out bagoong. The odor attracts flesh flies which deposit eggs or maggots about the top, and the maggots soon make an entrance through even very small crevices. Bagoong is accordingly, in some hands, a nauseous, wormy, semiputrid mass, unfit for human consumption. There is no excuse for such conditions; a little supervision by the local health authorities and education of the ignorant would soon eradicate such evils.

The importance of the ipon fisheries may be gauged by the fact that about half a million pesos worth of bagoong is produced annually in northern Luzon.

Gobies are exceedingly numerous in the tropical and temperate zones, both in species and in individuals. In temperate regions they are not of economic importance and, so far as I am aware, there are no vast runs of young up the rivers of countries with cool climates. Dr. B. W. Evermann informs me that the run of young gobies is very noticeable in the streams of Porto Rico, and they seem to occur more or less markedly throughout the Tropics.

A few kinds of gobies attain a length of from 30 to 60 centimeters and are rather bulky for their length; but most of them are slender little fellows with a maximum length of about 10 centimeters, while many species never exceed 2.5 centimeters when adult. One species found only in Lake Buhi, in southeastern Luzon, is but $\mathbf{1 2 . 5}$ millimeters long when mature; another, from the vicinity of Manila, is mature when 7.5 to 9.5 millimeters long and is the smallest known fish. The Philippine gobies thus include the smallest living vertebrates.

\section{GOBIOIDEA}

The chief characteristics of the order Gobioidea are the following:

The ventral fins are always present, thoracic in position, each having one spine and five, rarely four, soft rays. The ventrals are very close together, the inner rays the longer, and in by far the greater number the two fins are completely joined to form a single fin, which may vary from very short and rounded to rather elongate; but, whether separated or fused into a functional unit, the ventrals are used as a sucking disk, or organ, for clinging to rocks or other objects. The spinous dorsal is nearly always present, short, and is made up of feeble spines, or is much less developed than the soft dorsal. There is no lateral line, the gill openings are confined to the sides, and there is an 
anal papilla. The papilla varies greatly in size and shape; in many species it is long, slender, and pointed in the males, and short, thick, and cylindrical or subglobose in the females. In other species it is alike in both sexes. The preopercle is without a bony stay; there are four gills. The gill membranes are attached to the isthmus, the gill openings thus restricted to the sides and sometimes very narrow. Pseudobranchiæ are present, sometimes only in a rudimentary condition. Usually both air bladder and pyloric cæcæ are wanting.

In the preparation of this monograph, I have carried on field studies in practically every part of the Philippines, kept considerable numbers of living specimens for several years in some cases, and have examined thousands of individuals of each of the species of economic importance. In addition, I have examined the entire collection of gobies at Leland Stanford Junior University and in the United States National Museum.

Bleeker's Esquisse d'un systéme naturel des Gobioides and Révision des espéces insulindiennes de la sousfamille des Eleotriformes are invaluable to any student of the gobies, and especially of the Indo-Pacific forms. While investigating gobies in the United States I was under great obligations to my teacher and friend, David Starr Jordan, to J. O. Snyder, of Stanford University, and to Barton A. Bean, of the United States National Museum.

Jordan's arrangement has been followed, according to which six families and sixty-six genera of the gobioid fishes are known to occur in the Philippines.

$I$ have included in this monograph descriptions of most of the gobies known to occur along the coasts of the China Sea and, when not represented by Philippine material, have described them as far as possible from material sent me by S. F. Light, formerly of Amoy University, Amoy, China. I believe that most of these species will ultimately be found to occur in Philippine waters, when the Batan and Babuyan Islands, the northern and northwestern coast of Luzon, and the west coasts of Palawan and Balabac have been explored. I believe that at least two hundred species of gobioid fishes will be found eventually in the Philippines. I have excluded those gobies known as yet only from the maritime waters of Borneo, Celebes, and the Moluccas, though I fully believe all of them will eventually be collected in Philippine waters. Such islands as Cagayan Sulu, Sibutu, and the maze of reefs and islets about Sitankai are physically a part of Borneo, while the Sarangani Islands and the southern and 
eastern coasts of Mindanao are laved by currents which travel but a short distance from Celebes and Halmahera, with the Sangir Islands and a multitude of reefs between to make still easier the northward extension of their fish fauna.

This paper contains descriptions of seventy-seven genera, one hundred seventy-three species, and two varieties, of which eleven genera and eleven species are from the China Sea, with no specimens as yet known from the Philippines. My assistants, $\mathrm{H}$. R. Montalban, ichthyologist of the Bureau of Science, and Jose Montilla, have given me valuable aid in checking my own field observations in the Ilocano provinces; and Mr. Montalban and G. A. Lopez, collector of the bureau, have obtained large quantities of material for study and comparison. I am also under obligations to the provincial authorities of Ilocos Norte, Ilocos Sur, and Abra for courtesies extended, and to many friends in various parts of the Islands for both material and information.

The illustrations are the work of Pablo Bravo, Marcelino Nievera, Antonino Canlas, and Jose Nievera, young Filipinos who began work under great difficulties and who deserve much credit for their perseverance in working upon such difficult material.

The given length of specimens does not include the caudal fin unless specifically so stated. The scales in transverse series are counted from the origin of the second dorsal to that of the anal, unless otherwise stated.

Key to the Philippine families of Gobioidea.

$a^{2}$. Two separate dorsal fins.

$b^{2}$. Ventrals widely separated.

Rhyacichthyidæ.

$b^{2}$. Ventrals not widely separated.

$c^{2}$. Eyes not stalked; base of pectorals not very muscular.

$d^{2}$. Ventrals close together, but not united

Eleotrida.

$d^{2}$. Ventrals united to form a disk Gobiidæ.

$c^{2}$. Eyes very prominent and close together on short stalks; base of pectorals very muscular. Periophthalmidæ.

$a^{2}$. Dorsals united more or less to form one fin; ventrals united.

$e^{2}$. No cavity above the opercle. Gobioididæ.

$e^{2}$. A cavity above the opercle

Rly acichthyidaz

\section{RHYACICHTHYIDÆ}

This group of fresh-water fishes apparently includes but a single genus, with only one definitely known species.

It is well characterized by the short, broad, depressed head which, with the long, wide pectorals, forms a well-marked 
triangle, and by the flat ventral surface of the head and anterior part of the body. The ventrals are widely separated, and the undersurface of the breast forms a broad, flat, smooth expanse which is used as a sucking disk to attach the fish to rocks.

The trunk is subcylindrical anteriorly, becoming laterally compressed toward the rear and strongly flattened on the caudal peduncle; the scales are ctenoid and of medium size or larger. The two dorsals are rather far apart. The eyes are of moderate size and directed upward. The small mouth is on the underside of the head behind the pointed snout, with a protractile upper jaw; the preopercle is without spines. There are six branchiostegals with gill openings of medium width and four gills; pseudobranchiæ of medium size are present; there is no air bladder.

The Rhyacichthyidæ have been grouped by various authors with the gobies, the blennies, and the Callionymidæ, or dragonets, but it is now definitely decided that they belong with the gobies. Long ago Cuvier and Valenciennes saw that their affinities were essentially with the eleotrids, in spite of the fact that the position of their dorsals and ventrals is similar to that in the Platycephalidæ and in the European genus formerly known as Aspro.

\section{Genus 1. RHYACICHTHYS Boulenger}

Rhyacichthys Boulengr, Ann. \& Mag. Nat. Hist. VII 7 (1901) 267. Platyptera (Kuhl and Van Hasselt) CuvibR and VALENCIENNES, Hist. Nat. Poiss. 12 (1836) 239 (name preoccupied by Meigen, 1803, for a genus of flies).

In addition to the characters given in the family diagnosis, the genus is further distinguished by the very small teeth and the smooth palate.

In 1873 Pieter van Bleeker based his Memoire sur la Faune Ichthyologique de China upon a collection of Chinese paintings. In this paper he described twenty-five new species, among them Platyptera sinensis. So far as I am aware, it has not been actually collected, and the characters given in Bleeker's diagnosis are scarcely sufficient to separate it from Rhyacichthys aspro.

\section{RHYACICHTHYS ASPRO (Kuhl and Van Hasselt)}

Plate 1, Fig. 1

Platyptera aspro (Kuhl and Van Hasselt) Cuvigr and VALENCIENNES, Hist. Nat. Poiss. 12 (1836) 240, pl. 360; GüNTHER, Cat. Fishes Brit. Mus. 3 (1861) 138; Peters, Monatsber. Akad. Wiss. Berlin (1868) 268; GüNTHER, Fishe der Südsee 2 (1876) 191; A. B. MEYæR, Ann., Soc. España Hist. Nat. 14 (1885) 31. 
Local names, pilingan, at Casiguran; delaposcan, at Gingog, Misamis Province, Mindoro; Ilocano name, kampa.

Dorsal VII, I-8; anal I, 8; tubules in the lateral line about 36; scales in transverse series 11 .

Depth from $4 \frac{2}{8}$ to $5 \frac{8}{4}$ times in the length; length of head equals or slightly exceeds depth; the eye contained 2.2 to 2.4 times in snout, which is contained twice or a little less than twice in head. The flat interorbital space a fifth broader than eye.

The forward part of head from tip of snout to preorbitals forms an equilateral triangle; a very low crenulated ridge partially encircles each eye, lying above and behind like a sort of eyebrow, in the words of Cuvier and Valenciennes; the snout, interorbital space and a broad triangle on nape, and the large preopercles naked; a few small scales immediately behind eye; the small opercle partially scaled, those on upper half very small; the upper two-thirds of the muscular pectoral base covered with small scales; the upper half of pectoral covered for three-eighths its length with small but conspicuous scales; the basal half of caudal covered with small scales.

The very large pectorals extend beyond the posterior end of the ventral and resemble those of the Scorpaenidæ and the Cottidæ; the dorsals about equal in height and length of base. The caudal contained about 4.4 times in head and trunk and very slightly lunate. The lateral line begins behind eye, and passes back in a loop over the pectoral, then descends below first dorsal to the lower fourth of the height; between the two dorsals it makes a downward loop and under the beginning of the second dorsal rises to the center of the side and continues on to caudal fin.

The color in alcohol brown to yellowish, darkest on top of head; the first dorsal has a black band near base and another near margin, above which the free tips of the spines project; the figure by Cuvier and Valenciennes shows the second dorsal to have three transverse black bands, but in my specimens these have disappeared; the caudal is marked by transverse bars and blotches of brown.

Here described from two specimens, 104 and 106 millimeters in length, collected in a tributary of Agno River, Luzon. I have also received a specimen, 88 millimeters long, obtained from a mountain stream near Bugasong, Antique Province, Panay.

Since writing the above I have received three specimens, 103 to $\mathbf{1 1 0}$ millimeters in length, from Mamator River near Casiguran, on the eastern coast of northern Luzon. There is a large 
transverse blackish blotch in front of first dorsal; a broad blackish crossband passes from base of first dorsal down side, and a like one goes from second dorsal, while a third crosses caudal peduncle; a black blotch is at the end of the caudal peduncle just in front of base of caudal; a series of five blackish blotches extends along middle of side, the last forming a black spot on base of caudal; below them is a series of blackish spots on each scale forming a series of longitudinal lines, leaving only the pale or white belly, throat, and underside of head unmarked; snout and top of head marked with irregular spots and longitudinal blackish stripes; the first dorsal has a basal black band and another broad one very close to the margin; second dorsal, pectorals, and caudal beautifully crossbarred by irregular blackish bands or rows of spots; upper surface of ventrals dusky. I have fifty-four handsome specimens marked like the preceding, collected by Mr. F. Reveche, of San Jose, Antique Province, Panay; they are from 48 to 86 millimeters long. A large specimen, 133 millimeters long, was collected in a creek at Bangui, Ilocos Norte Province, in August, 1926. The species is said to be common there in the hills. I also have two fine specimens from barrio Cajulogan, Gingog, Misamis Province, Mindanao, the larger 147 millimeters long.

This species was collected by Jagor at Loquilocon, Samar, and in Burauen River, Leyte. Meyer collected it in Luzon, probably at Santa Cruz, a town at the upper end of Laguna de Bay, where he spent some time. In the reference cited the locality is given as "Bahia de Manila," but this is undoubtedly an error, since on page 7 he includes it in a list of ten species obtained only in fresh water, while Manila Bay is salt water.

The species was originally described from Bantam, the westernmost district of Java, and was collected afterward in Celebes and the Solomon Islands. This is such a peculiar, discontinuous distribution that it must also occur in many of the intervening islands, and is certainly to be expected in Borneo. I am certain that it must occur in all the large islands of the Philippines, from Mindanao northward. I have seen what I believe to be this species in the mountain streams near Malaybalay, Bukidnon, but was unable to secure specimens. It lives in swift mountain streams, clinging to the rocks and slipping around and under them when disturbed, and is very difficult to dislodge or collect. It seems to congregate particularly on large bowlders which give it absolutely safe hiding places. 


\section{ELEOTRIDÆ}

In this group are included those gobies with the ventral fins placed very near together but more or less disconnected, and never united to form a single disklike or sucking organ for attaching the fish to objects; the dorsal fins are separate or united only at the base; the eyes are not stalked or unusually prominent; the body is more or less elongate, cylindrical or compressed; branchiostegals four to six, one or more of them ending in an anterior spine in some genera; the body may be scaled or naked. An air bladder is present in most of the genera; ventrals I-5 in our genera.

The eleotrids are abundant in East Indian waters, especially in shallow bays and the mouths of rivers. Some of them are exclusively marine reef dwellers, but the largest and economically most important ascend rivers and enter lakes far beyond the influence of the tides. While it is possible that some eleotrids are exclusively fresh-water, I have no evidence to that effect. J. believe that those found in fresh water spend at least part of their lives in salt water, going down to the sea to spawn, no matter how far in the interior they may dwell most of the time. To this statement the genus Hypseleotris is probably an exception.

In this paper are described eighteen genera of eleotrids, four of them new, and thirty-two species, of which eleven are new. There is little doubt that a more extended search of the coral reefs and the streams of Mindanao and Palawan will reveal at least a third more species than the number here given.

Most eleotrids are plainly colored and inconspicuous, but a few species, especially coral-reef inhabitants, are very brilliantly colored. One is our most beautifully colored fresh-water fish. Many of them are able to change their color to a remarkable degree, according to the character of the substratum and the amount of light present. Such fishes as Eleotris fusca, Bunaka pinguis, and species of Butis can alter their dorsal color from blackish brown to clay gray or putty color; in moderately strong light the gray is confined to a broad band running lengthwise on each side of the back from the snout to the tail, but with stronger light the entire back becomes uniformly pale. With other light conditions the whole back and sides may be marked by longitudinal gray and blackish lines. By these means the 
fishes become practically invisible from above, as they are thus successfully hidden without having changed position.

Philippine Eleotridx.

[New generic names are printed in bold-faced type.]

\begin{tabular}{lcclrr}
\multicolumn{1}{c}{ Genus. } & Species. & $\begin{array}{c}\text { New spe- } \\
\text { cies. }\end{array}$ & \multicolumn{1}{c}{$\begin{array}{c}\text { Genus. } \\
\text { Species. }\end{array}$} & $\begin{array}{c}\text { New spe- } \\
\text { cies. }\end{array}$ \\
Asterropteryx & 2 & 0 & Odontobutis & 1 & 0 \\
Boroda & 2 & 2 & Ophiocara & 2 & 0 \\
Belobranchus & 1 & 0 & Oxyeleotris & 1 & 0 \\
Bostrichthys & 1 & 0 & Paloa & 1 & 1 \\
Bunaka & 1 & 1 & Parviparma & 1 & 1 \\
Butis & 3 & 0 & Prionobutis & 1 & 0 \\
Eleotris & 2 & 0 & Ptereleotris & 1 & 1 \\
Eviota & 2 & 1 & Valenciennea & 4 & 0 \\
Gobiomorphus & 1 & 1 & & - & -11 \\
Hypseleotris & 5 & 3 & & 32 & 1
\end{tabular}

Key to the Philippine genera of Eleotrida.

$a^{2}$. Head armed with one or more spines.

$b^{1}$. Angle of preopercle armed.

$c^{3}$. With two to six stout teeth or spines.

Asterropteryx.

$c^{2}$. With a single downward-curved sharp spine, more or less hidden.

Eleotris.

$b^{2}$. Angle of preopercle not armed; one or two branchiostegals ending anteriorly in a strong spine pointing forward and upward; upper rays of pectoral silklike.

Belobranchus.

$a^{2}$. Head unarmed.

$d^{1}$. Species resembling cyprinid fishes, with head and body laterally compressed

Hypseleotris.

$d^{2}$. Species gobiiform, not cyprinidlike.

$e^{1}$. Teeth on vomer; a large ocellus on base of caudal fin.. Bostrichthys.

$e^{2}$. No teeth on vomer.

$f^{1}$. Head large; snout and cheeks with rows of skinny ridges, bearing papillæ or fibrils

Gobiomorphus.

$f^{2}$. Head without skinny ridges and fibrils on snout and sides.

$g^{2}$. Smooth to serrated bony crests on head.

$h^{2}$. Scales 26 to 30 ; first dorsal with six spines.

$i$. Head very long, pointed, prismatic, its height equal to its breadth; lower jaw very prominent

Butis.

$i^{2}$. Head short, obtuse, broader than deep; lower jaw hardly projecting

Prionobutis.

$h^{2}$. Scales 36 to 46 ; first dorsal with six to eight, usually with seven spines

Odontobutis.

$g^{2}$. No bony crests on head.

$j^{7}$. Head large, broad, depressed; lower jaw prominent.

$k^{2}$. First dorsal with five spines; four to six rows of teeth in each jaw, outer row enlarged; 88 scales in longitudinal series, 58 before first dorsal

$k^{2}$. First dorsal with six spines; 30 to 60 scales in longitudinal series, 13 to 42 before first dorsal. 
$l$. Four rows of teeth in each jaw, outer and inner rows enlarged; 50 to 60 scales in longitudinal series, 32 to 42 before first dorsal. Boroda.

$l$. Six to ten rows of small or minute teeth in each jaw, no canines.

$m^{2}$. Scales 56 to 58 in lateral series, 42 before first dorsal; a broad naked furrow above eye, separated from it by a single row of small scales. Bunaka. $m^{2}$. Scales 30 to 40 in lateral series, 13 to 26 before first dorsal Ophiocara.

$j^{2}$. Head not noticeably large, broad, and depressed.

$n^{1}$. Very small fishes; ventrals long, narrow, with fringed rays; lateral scales 20 to 30 . Eviota.

$n^{2}$. Fishes not excessively small when adult; ventrals of ordinary shape; scales 60 to 170 .

$o^{1}$. No canines; scales ctenoid, 60 to 90 in lateral series, about 70 before first dorsal; soft dorsal and anal rays eight to ten. Oxyeleotris.

$0^{2}$. Canines present.

$p^{1}$. Scales ctenoid, 70 to 110 in lateral series; head naked, few or no scales before first dorsal; one to several pairs of lateral posterior canines in lower jaw; trunk, head, or both, spotted or banded.......... Valenciennea,

$p^{2}$. Scales cycloid, 150 to 170 in lateral series; head mostly naked; one or two pairs of canines present.

$q^{1}$. Soft dorsal and anal of about ten rays; mouth nearly vertical; eyes small; upper jaw with a pair of median canines behind the other teeth.

Parviparma.

$q^{2}$. Soft dorsal and anal of twenty or more rays; mouth curved, oblique; eyes large; lower jaw with one or two pairs of canines behind symphysis.

Ptereleotris.

\section{Genus 2. ASTERROPTERYX Rüppell}

Asterropterix RüPPELL, Atlas Reise nörd. Afrika, Fische (1828) 138 (Asterropteryx on the plate that precedes the text).

The body rather short and deep, laterally compressed, and covered with large ctenoid scales which extend to interorbital space and cover the sides of the convex, pointed head; three to six stout teeth or spines at angle of preopercle; the lower jaw prominent, the mouth oblique, with several rows of teeth in each jaw; teeth all small except those of the outer row which are conspicuously longer and curved, the lateral ones often like canines; no teeth on vomer or palatines; the gill openings of moderate width, the isthmus broad; first dorsal with six spines, the third one excessively long and threadlike; the second dorsal and anal about equal in length and height; caudal fin of mod- 
erate length, its tip obtusely rounded; anal papilla well developed (not absent, as erroneously stated by Rüppell).

\section{Key to the Philippine species of Asterropteryx.}

$a^{1}$. Scales in lateral series, 27 or 28 ; pale olive brown. A. everetti. $a^{2}$. Scales in lateral series, 24; body with blackish brown crossbands or blotches; each scale with a brilliant blue spot. A. semipunctatus.

\section{ASTERROPTERYX EVERETTI Boulenger}

Asterropteryx everetti Boulenger, Ann. \& Mag. Nat. Hist. VI 15 (1895) 186.

Depth of body equal to length of head, $3 \frac{1}{2}$ to $3 \frac{3}{3}$ times in total length. Head longer than deep; diameter of eye equal to length of snout, length of head; interorbital width $2 / 7$ to $\frac{1}{3}$ length of head; maxillary extending to below anterior border of eye. Dorsal VI, I, 9; longest rays of first dorsal $B$ to 3 length of head, of second dorsal 3 to . Anal I, 11; longest rays 8 to 3 length of head. Pectoral 8 length of head. 27 or 28 scales in a longitudinal series, 8 or 9 between origin of dorsal and origin of anal. Pale olive-brown; a small black humeral spot; caudal faintly barred; dorsals black in the male, with round white spots, greyish in the female.

Total length 65 millim.

Six specimens from Palawan.

This species is nearest allied to $A$. compressus, Krefft, from Queensland. [Boulenger.]

This dull-colored little fish was collected by A. Everett during his trip to Balabac and Palawan in 1889, and has not been obtained since that time.

\section{ASTERROPTERYX SEMIPUNCTATUS Rüppell}

Plate 1, Fig. 2

Asterropteryx semipunctatus RüPPELL, Atlas Reise nörd. Afrika, Fische (1838) 138, pl. 34, fig. 4; Günther, Cat. Fishes Brit. Mus. 3 (1861) 132; Jenkins, Bull. U. S. Fish Comm. 22 (1902) 500; Jordan and EvermanN, Bull. U. S. Fish Comm. 23 (1903) 480; JoRDAN and SEALE, Bull. Bur. Fisheries 25 (1906) 385, pl. 36, fig. 1.

Eleotris cyanostigma BLEBKER, Nat. Tijd. Ned. Ind. 8 (1855) 452.

Eleotriodes cyanostigma BLEEKER, Nat. Tijd. Ned. Ind. 15 (1858) 460.

Brachyeleotris cyanostigma BLEEKER, Arch. Neerl. Sci. Nat. 9 (1874) 306; Versl. Akad. Amsterdam 11 (1877) 84.

Eleotris semipunctata GüNTHER, Fische der Südsee 2 (1876) 187, pl. 111, fig. D.

Samal name, kusung.

Dorsal VI, I-10 to 11 ; anal I, 8 to 10 ; scales in lateral line 24 ; in transverse series from origin of second dorsal to anus 8. 
The body compressed, rather stout, the depth 2.9 to 3.2 in the length; the head elongate, with convex upper and lower profiles, and contained 3.5 times in length; the eyes of moderate size, 10 times in the length or $2 \frac{6}{7}$ times in head, and close together, interorbital space 1.75 times in eye; the snout blunt, shorter than eye, $3 \frac{1}{8}$ times in head; the caudal peduncle broad, its least depth $5 \frac{5}{6}$ to $6 \frac{1}{3}$ times in the length; the third dorsal spine threadlike and excessively elongated, from $\frac{1}{2}$ to more than $\frac{8}{4}$ as long as head and body together, and in one specimen extending to posterior margin of caudal; the other spines all flexible, not elongated, second and fourth about the same length, the others. much shorter; the second dorsal and anal approximately equal in length and height, the last ray longest, those of anal reaching well on to caudal, which is shorter than head.

This beautiful little eleotrid, which never reaches a length of more than 50 millimeters, is highly ornamented in life. The body is marked by large, irregular, blackish brown crossbands or blotches, or lengthwise rows, while each scale is marked by a small, circular, purplish blue spot of diamondlike brilliancy; the dorsals, anal, and caudal are pale brown with fine blue dots; sometimes the region between the pectorals and the first dorsal is thickly sprinkled with small blue dots.

Alcoholic specimens are pale brown with darker mottlings and crossbars, and blackish to pale fins; the blue dots on the scales are more or less visible.

Here described from sixteen specimens, ranging in length from 25 to 35 millimeters, or about 42 millimeters over all for the largest one. They were obtained at Sitankai ; Caldera Bay near Zamboanga; and Samal Island in the Gulf of Davao.

Originally described from the Red Sea, this species occurs throughout the tropical parts of the Indian and Pacific Oceans; it has been obtained at the Seychelles, the Cocos Islands, Port Rowen in North Australia, and the Samoan, Society, Pelew, and Hawaiian Islands.

Genus 3. ELEOTRIS (Gronow) Bloch and Schneider

Eleotris GroNow, Zooph. (1763) 83.

Eleotris BLOCH and SchNaIDer, Syst. Ichthy. (1801) 65.

Culius Blbrker, Esq. Syst. Nat. Gobioides, Arch. Neerl. 9 (1874) 303.

The body thick, robust, little elevated, cylindrical anteriorly, compressed behind; head flattened above, smooth, almost everywhere scaly; at lower angle of preopercle is a small, down- 
ward-curved, more or less concealed spine; eyes small, placed high up; mouth large, oblique, with projecting lower jaw, and broad, rounded tongue; the minute teeth are in bands of several rows in each jaw, without canines; those of outer row in upper jaw larger; scales on sides ctenoid, 42 to 73 ; those before first dorsal cycloid; 37 to 50 scales before first dorsal; the isthmus broad. Dorsal VI, I-8 or 9; anal I, 8 or 9 .

The species of this genus are usually small, one attaining a length of about 260 millimeters. They are economically important from their seasonal abundance in the lower reaches of rivers, at river mouths, and in shallow bays and inlets. They range from Madagascar and the east coast of Africa throughout the East Indies, north to the Riu Kiu Islands, and eastward in Polynesia to the Society and the Hawaiian Islands.

\section{Key to the Philippine species of Eleotris.}

$a^{1}$. Lateral scales 58 to 65 ; scales before first dorsal 48 to 50 .... E. fusca. $a^{2}$. Lateral scales 48 to 52 ; scales before first dorsal 37 to 42 E. melanosoma.

4. ELEOTRIS FUSCA (Bloch and Schneider)

Plate 2, Fig. 1

Peocilia fusca BLoch and Sch NBIDER, Syst. Ichthy. (1801) 453 (after Cobitis pacifica Forster, MS.).

Eleotris fusca GüNtHer, Cat. Fishes Brit. Mus. 3 (1861) 125; Petrers, Monatsber. Akad. Wiss. Berlin (1868) 268; Günther, Fische der Südsee 2 (1876) 188; DAY, Fishes of India (1878) 313, pl. 65, fig. 7; Boulenger, Ann. \& Mag. Nat. Hist. VI 15 (1895) 186; JordaN and Richardson, Bull. Bur. Fisheries 27 (1908) 274.

Eleotris nigra QUOY and GAIMARD, Voy. Uranie et Physicienne, Zool. (1824) 259, pl. 60, fig. 2 (scales in figure incorrect).

Culius fuscus BLEEKBR, Rev. Espèces Eleotriformes, Versl. Akad. Amsterdam 11 (1877) 40.

Bicol name, mulug.

Dorsal VI, I-8 or 9 ; anal I, 8 or 9 ; there are from 58 to 65 scales (usually 60 or 62) from the gill opening to the caudal fin, and from 16 to 19 between the origins of the second dorsal and anal fins; there are 12 to 14 scales in a transverse row at the base of the caudal; between the snout and the origin of the first dorsal are from 49 to 50 rows of scales.

The thick, robust, wedge-shaped body is nearly cylindrical immediately behind the broad low head, but the sides taper rapidly posteriorly to caudal peduncle which is strongly compressed; the dorsal profile low and gently convex; the depth contained from a trifle more than 4 to 4.7 times in length; the head large, its 
length 2.85 to 3 times in length, its breadth three-fourths of or equal to its own length; the snout short and blunt, its length 4 to 4.4 times in head; the eyes small but conspicuous, lateral but very high up, 6 to 6.8 times in head, 1.4 to 1.6 in snout, and 1.8 to 2 times in the depressed interorbital space; the mouth rather large, very oblique, with a strongly projecting lower jaw which extends to upper profile; the maxillary usually extends nearly or quite to front margin of eye, but sometimes may reach to below middle of pupil. The minute, sharp-pointed teeth in bands of several rows; those in outer row in upper jaw widely spaced and twice as large as those behind them; in lower jaw usually a few enlarged ones at front of outer row and farther back a few scattered larger pointed teeth. There is a furrow behind interorbital space which is continued backward from behind eye above opercle to pectoral fin base. The scales on sides of body ctenoid; from second dorsal forward to snout the scales are cycloid, becoming smaller anteriorly; on many specimens there are no scales forward of the rear fourth of interorbital space; cycloid scales on breast and throat, pectoral bases, opercles, and more or less scattered over the preopercles, their arrangement beneath the eyes varying greatly, but this space largely naked on most of our specimens. On sides of snout and below eyes are numerous raised lines of minute warts, mostly radiating from the eyes, but with a few cross lines; at lower angle of preopercle is a sharp downwardcurved spine, more or less concealed and less evident in the larger specimens.

Two living specimens from Pasig River, Manila, each with a length of 130 millimeters, or 165 millimeters over all, were, like many gobies, variable in color, changing according to environment or when much disturbed. Usually of a velvety blackish brown, when exposed to direct light they would change the dorsal surface to light gray, slightly mottled with longitudinal blackish streaks; if exposed to strong light the back and sides would become dull gray all over, the longitudinal dark rows along the sides more or less evident, according to the intensity of the light.

The color in alcohol varies from yellowish or pale brown to blackish, each scale along the sides with a dark spot, the spots forming longitudinal rows; all fins crossbarred with alternate rows of dark and pale spots or irregular bars, though the markings usually disappear from the ventrals. 
In addition to a large number of living specimens from Pasig River, I have examined numerous alcoholic specimens, ranging in length from 22 to 132 millimeters, from the following localities :

Agno River, Dagupan, Pangasinan Province, Luzon, 1.

Baliuag, Bulacan Province, Luzon, 1.

Cabatohan River, Zambales Province, Luzon, 21.

Bataan Province, Luzon, 1.

Pasig River, Manila, Luzon, 6.

Rawis River, Legaspi, Albay Province, Luzon, 2.

Yawa River, Legaspi, Albay Province, Luzon, 3.

Aringay River, Legaspi, Albay Province, Luzon, 3.

Arimbay River, Legaspi, Albay Province, Luzon, 9.

Bacon, Sorsogon Province, Luzon, 1.

Polillo, 1.

Tambo River, Ambil Island, 20.

Puerto Galera, Mindoro, 3.

Sibuyan, 3.

Mambugan swamp, San Jose de Buenavista, Antique Province, 39.

Mariri River, Antique Province, 237.
San Jose, Antique Province, 10. Villa, Iloilo Province, 8.

Jordan River, Guimaras, 1.

Dumaguete River, Dumaguete, Oriental Negros, 82.

Lasay, Siquijor, 2.

Anahawan and Cabalian, Leyte, 10.

Cagayan, Misamis Province, 1. Titunod River, Kolambugan, Lanao Province, 3.

Caldera Bay and George River, Zamboanga Province, 3.

Rio Grande de Mindanao, near Dulauan, Cotabato Province, 2.

Saub River, Cotabato Province, 3.

Balabac, 1.

Bancolid River, Jolo, 6.

Martin Ranch, Siasi, 2.

Buan Island, Sulu Province, 2.

Lapid Lapid and Lambog Rivers, Tawitawi, 10.

Sitankai, 1.

The Bureau of Science collection contains a specimen from Calcutta, India, determined by the celebrated student of Indian fishes, Dr. Francis Day. I also place here two specimens from Guam.

Jagor was the first to collect this fish in the Philippines, his specimens coming from Lebmanan River, Luzon, and from Loquilocon and Borongan, Samar. It was also obtained in Palawan, by Everett, as recorded by Boulenger, and Jordan and Richardson list it from Aparri, Luzon, and from Sibuyan, in their study of R. C. McGregor's collection. The Aparri record is a doubtful one, and probably belongs under Eleotris melanosoma.

The Agno River specimen probably came from some other locality and this record is in my opinion also a doubtful one. 
Eleotris fusca reaches maturity while still small. Collections made on August 19, 1925, in Mambugan swamp, San Jose de Buenavista, Antique Province, and from Miriri River in the same province contained spawning females from 36 to 60 millimeters long.

This retiring eleotrid is usually very dark colored in life and lies among stones or on the bottom where it can be detected only with difficulty. It is evidently a voracious and indiscriminate feeder, specimens often being found with the stomach filled with vegetable tissues as well as with mollusca, crustacea, and other fishes. Young specimens are slenderer, while a spawning female collected from Dumaguete River on March 11, 1922 , is much stouter than the proportionate measurements given for the species would indicate. According to Günther, it reaches a length of "ten inches," about 255 millimeters, but I have seen no large Philippine specimens.

This fish is common in rivers near the sea throughout the Philippines, south of and including the Manila Bay region. It is of wide range, occurring from Madagascar and the rivers of the east coast of Africa to Guam, and the Society Islands.

\section{ELEOTRIS MELANOSOMA Bleeker}

Eleotris melanosoma BLввкв , Nat. Tijd. Ned. Ind. 3 (1852) 705; GüNTHER, Cat. Fishes Brit. Mus. 3 (1861) 126.

Culius melanosoma. BLEsKRR, Rev. Espèces Eleotriformes, Versl. Akad. Amsterdam 11 (1875) 43.

Ilocano name, virot.

Dorsal VI, I-8 or 9 ; anal I, 8 or 9 ; there are from 48 to 52 scales from the gill opening to the caudal fin and 14 or 15 in a transverse series from the origin of the second dorsal to that of the anal; there are 10 or 12 scales in a transverse series across the caudal peduncle and from 37 to 42 rows of scales between the first dorsal and the interorbital space.

The shape of body and head like that of $E$. fusca but the snout more elevated; the depth rather variable, 3.9 to 5 times in the length; the long, broad, low head contained from 3 to 3.2 times in the length, its breadth about 0.75 of its own length; the snout short and bluntly rounded, $4 \frac{1}{6}$ to 4.8 times in head; the small conspicuous eyes very high up, lateral but almost looking upward, 4.8 to 5.4 times in head, equal to or $\frac{5}{6}$ of snout, and 1.5 to 1.8 times in the broad interorbital space, which is 2.9 to 3.4 times in head. The mouth large, oblique, the upper maxillary usually extending to a point below the middle of eye but varying 228398_-8 
from the first to the last third; the very small sharp teeth nearly uniform in size, only those of outer row in upper jaw larger and more widely spaced than the others.

The whole body except snout, lips, chin, and subopercles covered with scales, as in $E$. fusca; on lower half of preopercles the scales are minute or sometimes partially absent. The interorbital furrow absent or inconspicuous but the furrow from eye to pectoral is broad; the lines of warts below eye mostly absent and those on cheeks and snout usually less developed than in $E$. fusca, though they are prominent in the specimens from Casiguran. There is a sharp spine, curving downward and forward, at lower angle of preopercle.

In life the color is very dark, blackish or greenish black. In alcohol it varies from yellowish brown to blackish, the abdomen paler. The top of head and back in front of dorsal darkest, the sides of trunk much paler. Usually a small pale spot on each scale along the side gives narrow longitudinal stripes of dark and light, especially behind the pectorals and toward the back. All the fins more or less regularly crossbarred with alternate rows of dark and pale spots or lines, the markings mostly disappearing in preserved specimens.

I have examined one hundred thirty-five specimens, ranging in length from 21 to 86 millimeters, from Laoag River in Ilocos Norte Province, and from Abra River in Ilocos Sur and Abra Provinces; one from Agno River, Dagupan, Pangasinan Province; one from Buguey, Cagayan Province; three from Kabulig River, Casiguran, on the east coast of northern Luzon; one from Malabon, Rizal Province; eight from Puerto Galera, Mindoro; ten from Naganahan River, near Puerto Galera, Mindoro; one from Iloilo, Panay; one from Navalas, Guimaras Island ; and one from Hongkong.

I also have a large number of specimens, from 18 to 36 millimeters in length, part of a lot of ipon caught at Bangar, La Union Province.

The Eleotris fusca recorded from Aparri by Jordan and Richardson probably belongs to this species.

This little eleotrid is an important fish in the Ilocano streams and furnishes a considerable quantity of ipon. Those from Laoag River seem to feed almost exclusively on river snails and frequently it is found that their stomachs contain several shells or a shell of astonishingly disproportionate size. Apparently the shells ultimately disintegrate or are greatly reduced in size 
by the corrosive action of the gastric juice, so that the fish can rid itself of them eventually.

Elsewhere this fish is known from Sumatra eastward to Borneo, Celebes, Batjan, Amboina, Ceram, Buro, and Timor.

\section{Genus 4. BELOBRANCHUS Bleeker}

Belobranchus BLwFkm, Nat. Tijd. Ned. Ind. 13 (1856) 300.

The elongate body cylindrical anteriorly, with a pointed to obtuse flattened and scaleless head; one or two of the upper branchiostegals terminate anteriorly in a sharp spine directed upward and forward; there are 58 to 70 scales in a longitudinal series; the lower jaw prominent, the mouth oblique; the teeth in several rows in each jaw, the outer row a little larger than the others; no canines present; the gill openings separated by a broad isthmus. Dorsal VI, I-7 or 8; anal I, 7 or 8 .

This remarkable genus is completely separated from related eleotrids by the strong spine at the forward end of the first or first and second branchiostegals, and by the completely naked head. Only one species is definitely known, confined to the rivers and estuaries of the East Indies.

\section{BELOBRANCHUS BELOBRANCHA (Cuvier and Valenciennes)}

Plate 2, Fig. 2

Eleotris belobrancha Cuvibr and VALenciennes, Hist. Nat. Poiss. 12 (1836) 183; GüNtHBR, Cat. Fishes Brit. Mus. 3 (1861) 127; A. B. MEYrR, Ann., Soc. España Hist. Nat. 14 (1885) 30.

Belobranchus taeniopterus BLFEKER, Nat. Tijd. Ned. Ind. 12 III 2 (1856-1857) 301.

Eleotris taenioptera GüNTHER, Cat. Fishes Brit. Mus. 3 (1861) 127. Belobranchus.quoyi BLझझKBR, Nat. Tijd. Ned. Ind. 12 III 2 (1856-1857) 300, nomen nudum; BLझßKKR, Rév. Espèces Eleotriformes, Versl. Akad. Amsterdam 11 (1877) 53.

Dorsal VI, I-7 or 8 ; anal I, 7 or 8 ; there are from 58 to 65 scales in a longitudinal series and 20 in a transverse series.

The elongate body cylindrical anteriorly and compressed posteriorly, its depth 6 to 7 times in the length; the length of the depressed head 3.3 to 3.4 times in the total length; the eye 3.5 to 6.5 times in head, according to age; the interorbital space varies from half an eye diameter to $1 \frac{1}{3}$ times eye; the convex snout twice as long as eye, or in the young but little longer; the maxilla is shorter than the mandible and in young specimens reaches to below the middle of eye or even farther; in older specimens it is carried back to the posterior margin of eye or 
a little beyond; a conspicuous groove extends from eye backward above operculum; two longitudinal grooves on cheek, the upper with an ascending branch, the lower one branching forward on snout and above eye and continuous with the groove from eye above operculum; the first or first and second branchiostegals with a strong sharp conical spine at the forward end beneath preopercle, and directed forward and upward; the branchial aperture vertical beneath, not produced upward and forward; throat naked; scales of nape, base of pectorals, and belly cycloid, those of the sides toward tail ctenoid; first dorsal obtuse; the depth of body twice or more than twice the lowest spine, second, third, and fourth longer than the others; the obtusely rounded soft dorsal much higher than spinous dorsal but lower than body; anal subequal to the soft dorsal in form and height; the obtusely rounded pectoral not or scarcely longer than the postocular part of head, its upper rays short and silklike; the ventrals shorter than the postocular part of head; caudal' obtusely rounded.

The color above dark yellowish to violet golden or deep olive, beneath dark brown, golden, or yellow; numerous bands or narrow stripes of dark brown along the series of scales from head to tail; several brown streaks run from eye across opercle; membrane of fins clear violaceous to dusky, with golden rays; the young and half-grown have several golden crossbars or few to many golden ocelli or spots; fins more or less golden and, except the ventrals, variegated with brown, the dorsals and anal with longitudinal stripes, and the pectorals and caudal marked with irregular transverse bars; above base of pectoral commonly a large dark or red spot; older specimens and adults have the body much clouded with brown; the fins much or not at all variegated, the spinous dorsal commonly dusky below apex.

I have examined four specimens, 50 to 59 millimeters in length, collected from Kabatohan River in the mountains east of Iba, Zambales. They are fine types of what Bleeker originally described as Belobranchus taenioptera, but which later proved to be $B$. belobrancha in a young stage. This species reaches a length of 180 millimeters and occurs in the rivers of Borneo, Bali, Celebes, Batjan, and Ceram. According to the citation from A. B. Meyer he obtained it from Manila Bay, but on page 7 he gives it in a list of ten species of fishes obtained only in fresh water, with Luzon as the locality. As Manila Bay is salt, water, it is evident that there is an error somewhere, as in the 
case of Rhyacichthys aspro, already mentioned. His specimens probably came from the hills east of Santa Cruz, at the upper end of Laguna de Bay.

I received a fine specimen, 71 millimeters long, from Alabat Island, and another, 118 millimeters long, from Cajulogan barrio, Gingog, Misamis Province, Mindanao.

\section{Genus 5. HYPSELEOTRIS Gill}

Hypseleotris GILL, Proc. Acad. Nat. Sci. Phila. 15 (1863) 270.

These are fresh-water eleotrids, with the appearance and habits of some cyprinid fishes, as Fundulus. They do not lie on the bottom or attach themselves to objects as do most gobies and eleotrids, but swim freely in the water.

The body oblong, rather short, laterally very much compressed; the head likewise laterally compressed, pointed, higher than wide, its sides scaled, and without bony crests above; the mouth oblique, with short jaws, the lower one prominent; the slender awl-shaped teeth in several rows in each jaw, subequal, without canines; the scales large, 23 to 32 in a lateral series; the dorsals well separated, rather low; the caudal obtuse. Dorsal VI, I-8 to 11 ; anal I, 9 to 11 .

The anal papilla is characteristic of the genus, more or less oblong or square, with notched or bilobed tip, often very large, and in some species with revolute edges.

The genus occurs from the East Indies to Australia and the tropical islands of the South Pacific.

Key to the Philippine species of Hypseleotris.

$a^{1}$. Two brown stripes crossing cheek from eye to operculum; anal papilla small H. agilis.

$a^{2}$. No brown stripes on cheek.

$b^{1}$. Color uniform tawny; a blackish spot on upper pectoral base; anal papilla large, notched. H. cyprinoides.

$b^{2}$. Color brown to gray; a dark crossbar on base of pectoral.

$c^{1}$. No black median lateral line.

$d^{1}$. Caudal clear to golden; dorsals clear in females; males with first dorsal spotted with black; second dorsal deep black with circular white spots; anal papilla with a lunate bilobed tip.

H. bipartita.

$d^{2}$. Caudal crossbarred with brown or black; a large black spot on lower half of caudal base; both dorsals crossbarred by rows of pale and dusky spots; anal papilla small, slender, minutely notched

H. modestus.

$c^{2}$. A blackish median lateral line; anal papilla very broad, long, notched; first dorsal pale basally, remainder black; second dorsal crossbarred pale and black.

H. pangel. 


\section{HYPSELEOTRIS AGILIS sp. nov.}

\section{Plate 2, FIG. 3}

Dorsal VI, I-8 or 9 ; anal I, 9 or 10 ; there are 25 scales in a longitudinal series, 10 in a transverse series, and 15 between the tip of the snout and the first dorsal fin.

The body laterally compressed, its depth 3.5 to 4 times in the length; the dorsal profile descends to snout in an almost straight line; the head depressed, its length a little more than 3 to $3 \frac{1}{8}$ times in the length; the eye from 4.4 to 4.8 times in the head and as long as or a little less than the bluntly round snout, which is sharply elevated above; the rounded interorbital space equals eye; the least depth of caudal peduncle twice in its own length (in one specimen $\frac{7}{1}^{\frac{7}{2}}$ of its length); the caudal much shorter than head, 4.5 to 5 times in the length; the anal papilla small and inconspicuous.

The entire body covered with rather large scales; those on head and predorsal and preventral regions cycloid, the remainder ctenoid; s.nall cycloid scales on base of caudal; the scales on top of head extend forward to base of hump on snout.

The color in alcohol yellowish, crossbarred with darker bands, which form eight dark spots along middle of each side; two narrow diagonal dark brown stripes run from eye backward across preopercle and on to operculum; a faint longitudinal stripe on operculum and one from eye backward above preopercle and opercle; the second dorsal irregularly crossbarred with dark brown; the other fins more or less faintly dotted with darker; an indistinct dark crossbar on base of pectoral.

Here described from the type, No. 10143 Bureau of Science collection, and thirteen cotypes, which I obtained from a creek flowing into Lake Mainit, near the barrio of Mainit, Surigao Province, Mindanao.

This little fish is like no other mentioned in the available literature. The diagonal stripes on the side of the head give it a great resemblance to the young of Ophiocara aporos. The specimens seen were playing about in the current of a small creek, after the manner of Cyprinidæ, very unlike the habit of gobioid fishes.

Agilis, nimble.

8. HYPSELEOTRIS CYPRINOIDES (Cuvier and Valenciennes)

Eleotris cyprinoides Cuvier and VALenclennes, Hist. Nat. Poiss. 12 (1836) 187.

Hypseleotris cyprinoides JoRdaN and SeALE, Proc. U. S. Nat. Mus. 28 (1905) 794. 
Dorsal VI, I-9; anal I, 9.

The body is compressed, its belly convex, its snout pointed, and its mouth very small.

The greatest height, which is at the anus, is five times in the length; this is also the measure of the head and the caudal. The thickness is not more than half the height. The upper and lower lines of the profile are almost straight and meet at an acute angle to form the snout. The eye is more than a fourth of the length of the head; it is less than an eye in diameter from tip of the snout, and the mouth is not even that long. The teeth are as fine as velvet. The dorsals are but little more than half the height of the body.

The genital lobule is large, square, and notched. The scales are large; one cannot count more than twenty-six or twenty-eight between the gill and the caudal, and nine or ten from the back to the belly, wider than long, finely ciliate, with fifteen fanlike rays which are visible at the margin.

In alcohol this little fish is uniform tawny, with a blackish spot at the top of the pectoral base, upon the dorsals traces of brown leave round transparent spots. There are also traces of brown upon the caudal. [Cuvier and Valenciennes]

I have seen no specimens of this species, but Jordan and Seale placed here "seven specimens in good condition," collected by Dr. Bashford Dean on the southern coast of Negros. It is known positively only from the Island of Bourbon, or Réunion, in the Indian Ocean and, in the absence of authentic material with which to make comparison, I doubt its occurrence in the Philippines.

\section{HYPSELEOTRIS BIPARTITA sp. nov.}

Plate 3, Fig. 1

Bicol name, maringyan.

Dorsal VI, I-8 or 9 ; anal I, 10; there are 27 scales in a longitudinal series, 8 in a transverse series, and 15 before the first dorsal.

The body much compressed, pointed anteriorly, the dorsal and ventral profiles much arched, the depth 3.36 to 3.64 times, the head 3.42 to 3.67 times in the length; the short truncate snout $\frac{2}{3}$ the length of eye, 4.4 to 4.75 in head; the eyes large, circular, lateral, 2.7 to 3.5 times in head, the interorbital equal to snout; the mouth strongly oblique, the chin projecting boldly, the posterior angle of maxillary considerably in advance of eye; the least depth of caudal peduncle a trifle more than twice in its own length and 2.2 times in the length of head; fourth spine of first dorsal highest, 1.46 to 1.9 times in head; second dorsal usually higher, the middle rays longest, or sometimes the posterior rays as long, but not reaching caudal when depressed, 
1.18 to 1.75 times in head; the anal is like the second dorsal, both sharply angulate posteriorly, but is lower, its posterior rays 1.5 to 1.8 times in head; caudal a little longer than head, subtruncate, 3.27 to 3.9 in the length; the pointed pectoral 1.16 to 1.5 times in head; ventrals very narrow, elongate, with hairlike tips, 1.16 to 1.4 times in head and often reaching the elongate anal papilla, which is flattened or subcylindrical, with a lunate, bilobed, and often expanded tip.

The color in alcohol uniform blackish or brownish gray, the pale grayish $\cdot$ ground color everywhere minutely punctate with exceedingly minute blackish dots, thus giving the general effect stated; there is a conspicuous black spot or very short vertical bar at base of caudal, rather below its middle; a black band of coarse dots more or less evident, extending from the shoulder down across base of pectoral; on many female specimens there is a broad, vaguely defined, dark lateral band from axil of pectoral to caudal; females have the fins nearly unmarked, the dorsals and anal clear, the membranes lightly specked with minute dark dots, the anal often clear with a dusky border; caudal clear or yellowish, the posterior part blackish or with dusky crossbars; pectoral clear, ventrals clear or golden.

Males have a very different color scheme; the upper half of body, especially anteriorly, is often suffused with dark orange red; the first dorsal deep black, with a clear or white basal spot between first and third spines and fifth and sixth spines, and a broad white crossband near top from first to third or fourth spines, the tip above black; sometimes there is a narrow clear basal band instead of two spots; second dorsal intense black with two to several circular white spots along base and three to five circular white spots across upper part; sometimes the spots coalesce to form bands; more rarely the fin is paler and the spots or bands change position up or down or become diagonal; the anal more or less golden or orange to clear, the margin dusky to blackish; or the anal may be golden anteriorly, changing to white or clear posteriorly, the upper third blackish; caudal clear or golden, the posterior part blackish; the pectoral clear to lemon yellow, the ventrals yellow; anal papilla clear yellow.

I have studied one male specimen, the type, 33.5 millimeters long, from the creek at barrio Puru, Legaspi, Albay Province, and a large series of males and females from Rawis River, Legaspi, Albay Province. The twenty-seven males vary from 24 to 33 millimeters in length; the eighty females, from 22 to 
37, many of them ready to spawn, specimens 22.5 millimeters long being full of eggs; they were collected February 3, 1926.

Bipartita, in two parts, in reference to the strongly differentiated color patterns of the sexes.

\section{HYPSELEOTRIS MODESTUS (Bleeker)}

Eleotris cyprinoides BLEEKGR, Nat. Tijd. Ned. Ind. 4 (1853) 277 (not of Cuvier and Valenciennes or of Günther).

Asterropteryx modestus BLFrkgR, Arch. Néerl. Sci. Nat. 10 (1875) 111; Rév. Espèces Eleotriformes, Versl. Akad. Amsterdam 11 (1877) 81.

Hypseleotris modestus JORDAN and RICHARDSON, Bull. Bar. Fisheries 27 (1908) 276.

Tagalog name, lomog.

Dorsal VI, I-9 or 10 ; anal I, 10 or 11 .

There are 27 to 29 scales in a longitudinal series, 8 in a transverse series from the second dorsal to the anal, and 5 in a transverse series on the caudal peduncle.

The depth of the oblong compressed body contained 3.9 times in the length, the head about 3.5 times; the dorsal and ventral profiles both gently convex, with pointed head and small snout, its tip slightly elevated so that the profile behind it is a little concave; the snout very short, and contained 4.4 times in the head; the eye prominent and larger, its diameter $3 \frac{2}{3}$ times in the head and $1 \frac{1}{6}$ times in the interorbital space; the least depth of caudal peduncle contained twice in its own length; the ventrals as long as or longer than the pectorals, extending beyond anus; the caudal fin broad, rather truncate, its length 3.8 times in the length; the anal papilla small, oblong, its tip minutely notched.

The color in alcohol uniform brown, belly paler; a faint dark crossbar on base of pectoral, and a small dark brown circular spot on lower half of base of caudal fin; the second dorsal and caudal fins obscurely barred with pale brown, the other fins colorless.

I have placed here a single specimen, 38 millimeters long, collected in a brook near Taytay, Palawan. The species was recorded also from Mindoro, by Jordan and Richardson. These specimens do not agree exactly with Bleeker's account. His three specimens from Singapore and Sumatra had 28 scales, the Mindoro specimen, 29.

Since the above was written I have obtained three more specimens, 28, 26, and 23 millimeters long, from Daguitan River, Dulag, Leyte. 
Later, fifty-seven specimens, 19 to 55 millimeters in length, were secured from Pansipit River just below its source at Taal Lake. When fresh they were silvery gray, or the upper half with a golden brownish sheen, the scales of the upper half or two-thirds densely sprinkled with fine blackish specks; a conspicuous vertical black bar, starting on the shoulder, continued down over the base of the pectoral; a large black spot on the lower half of the caudal base; opercle with a large black or violet-black spot; both dorsals and the caudal were crossbarred by numerous alternate whitish or pale and black or dusky spots; the ventrals lemon yellow; the other fins yellowish clear, or partly dusky.

Still later, Mr. F. Reveche sent me from San Jose, Antique Province, Panay, two fine specimens, 41 and 50 millimeters in length; in the larger one the anal papilla is wide with a lunate tip. Also, Dr. P. B. Sivickis, of the University of the Philippines, has given me a specimen, 27 millimeters long, from Puerto Galera, Mindoro.

\section{HYPSELEOTRIS PANGEL sp. nov.}

\section{Plate 3, Fig. 2}

Local name, pañgel.

Dorsal VI, I-8 or 9 ; anal I, 10 ; there are from 27 to 29 scales (usually 28) in a longitudinal series, 8 in a transverse series, and 15 scales between the first dorsal and the tip of the snout.

The depth of the oblong, strongly compressed body about $3 \frac{2}{8}$ times in the length, its thickness about twice in the depth; head laterally compressed and pointed, the dorsal profile descending steeply in a nearly straight line from nape to snout, its length $3 \frac{1}{8}$ to $3 \frac{2}{8}$ in head and body together; the rounded snout wider than its length, which is 3.5 to 4 times in head and equal to or slightly more than an eye diameter; the interorbital space is about the same or slightly exceeds the snout; the mouth small, nearly vertical, with a prominent lower jaw; the maxillary does not extend back as far as front margin of eye; the entire body, except lips and chin, covered with scales; those below eyes and on top of head cycloid, the rest all ctenoid; the conspicuous. anal papilla very broad and long with revolute edges and a bilobed or notched tip. The dorsal spines low, the rays half again or twice as long; the pectorals are long, reaching to anal papilla, as do the pointed ventrals which are little if any shorter; the caudal obtusely rounded, and contained 4 to 4.5 times in the length. 
The color in alcohol very pale grayish brown, the scales punctulated with minute dark specks, especially dorsally; on base of pectoral the dots are larger and thicker, forming a crossbar; a blackish thin line is evident in some specimens, from upper end of pectoral base along side to caudal; the spinous dorsal pale basally, but the greater part of the fin black; the soft dorsal crossbarred alternately with pale and dark, the posterior free portion partly or entirely black; the anal and caudal more or less darkened by transverse rows of pale and dark spots or specks.

I place here twenty specimens, from 32 to 47 millimeters in length, believed to have been collected in Cavite Province. No data were with them when found by me in the collection, except a typewritten slip giving the native name.

From the Eleotris cyprinoides of Cuvier and Valenciennes and "Asterropteryx" modestus of Bleeker this species seems to differ in the presence of a dark lateral line, the black on the dorsals, and in the proportions.

\section{Genus 6. BOSTRICHTHYS Duméril}

Bostrichthys DUMÉRI, Zool. Analyt. (1806) 120, 332.

Bostrychus LACÉPÈDE, Hist. Nat. Poiss. 3 (1802) 144 (preoccupied by Bostrichus Geoffroy, 1762, for a genus of insects).

The body elongate, somewhat cylindrical forward, with compressed sides posteriorly and broad, somewhat flattened head; the eyes lateral, not prominent, of medium size; teeth very small, in many rows on both jaws, without canines; a patch of similar teeth on vomer; the dorsal fins far apart; the base of pectorals slightly muscular; gill openings rather large, with a broad isthmus; the whole body, including head, covered with small cycloid scales.

This genus apparently has but a single species, of wide distribution among the Indo-Australian islands.

\section{BOSTRICHTHYS SINENSIS (Lacépède)}

Plate 3, Fig. 3

Bostrichthys sinensis GIL, Proc. Acad. Nat. Sci. Phila. (1860) 125; DAY, Fishes of India (1878) 309, pl. 65, fig. 4.

Bostrychus sinensis (LACEPEेDE), Hist. Nat. Poiss. 3 (1802) 141, pl. 14, fig. 2; KNer, Reise Novara, Fische (1865) 186; BLFआKER, Versl. Akad. Amsterdam 11 (1877) 16; Jordan and Sealm, Proc. U. S. Nat. Mus. 29 (1905) 526; Bull. Bur. Fisheries 25 (1906) 382; Staue, Philip. Journ. Sci. \& D 9 (1914) 74.

Philypnus ocellicauda RICHARDSON, Zool. Voy. Sulphur, Ichthy. (1844) 59. 
Philypmus sinensis RICHARDSON, Zool. Voy. Sulphur, Ichthy. (1845) 149 , pl. 56, figs. 15 and 16.

Eleotris sinensis GüNTHER, Cat. Fishes Brit. Mus. 3 (1861) 127; Fische der Südsee 2 (1876) 189.

Dorsal VI, I-12 or 11 ; anal I, 8 or 9 ; scales in longitudinal row 130 to 135 (140, according to Günther).

The body elongate, the posterior half strongly compressed laterally; the depth from 5.25 to 5.7 in the length, and a little more or less than $\frac{2}{3}$ of the length of the broad, low head; the greatest width of head equals its length from the forward margin or middle of eye; the snout broad, blunt, rounded, its length 3.5 to 4 times in head; the eyes lateral, 5.1 to 5.8 in head; interorbital space broad, flat or gently rounded, twice or nearly twice eye; mouth wide, with thick lips and protruding lower jaw; the maxillary reaches beyond middle or even beyond posterior margin of eye; tube of anterior nostril $\frac{1}{2}$ to $\frac{3}{4}$ of eye; the teeth vary in size in different individuals, from velvety to needlelike, but are always small and uniform; the vomerine patch also varies in size, but is never very large; the wide caudal peduncle equals $\frac{3}{4}$ to $\frac{7}{9}$ of the depth.

The first dorsal low, second dorsal 1.5 times as high or more, the posterior rays longest; anal shorter and a trifle lower than second dorsal; the pectorals large, reaching well beyond the ventrals, which scarcely extend halfway to anus; caudal broad, rounded to wedge-shaped, 4 to 4.6 in the length.

The entire body covered with small cycloid scales, more or less rudimentary on snout and top of head, small on cheeks, larger on opercles, more or less irregularly arranged on trunk, and becoming largest on caudal peduncle; scales extend upon the caudal fin for half its length.

The color in alcohol brown, mottled, or streaked with fine lines of darker brown or blackish, the underparts paler to whitish; a large black eyespot with broad white margin at upper part of base of caudal fin; dorsal and caudal fins with rows or bands of dark brown spots.

Here described from eleven specimens, 70 to 114 millimeters in length, collected at Coron, Busuanga. I obtained a specimen, 28 millimeters long, in a tide pool at the Martin ranch, Siasi, and one, 104 millimeters long, at Cebu, and have also examined numerous specimens from Hongkong, Amoy, Samoa, and other localities.

This rather variable but very easily recognized fish may be recognized at sight by the eyespot on the tail, no other Phil- 
ippine eleotrid having any similar recognition mark. It is said to reach a length of "ten inches," about 255 millimeters. The Cebu specimen, collected September 15, and a specimen, 96 millimeters long, collected in January, were both nearly full of ripe eggs.

First described from the southern coast of China, it is known to occur from Shanghai to the Fiji Islands in the South Pacific, and through the East Indies to the Andaman Islands in the Indian Ocean.

\section{Genus 7. GOBIOMORPHUS Gill}

Gobiomorphus GiLl, Proc. Acad. Nat. Sc1. Phila. 15 (1863) 270.

Small, stout, short-bodied eleotrids having the snout and sides of head marked by numerous rows of skinny ridges which bear rows of fibrils or papillæ; the small, slender, subequal teeth are in four or five rows in each jaw, without canines; cheeks naked or with cycloid scales; scales in lateral series, 30 to 43 ; isthmus broad. Dorsal VI to VII, 9 to 11 ; anal I, 8 to 11.

\section{GOBIOMORPHUS ILLOTUS sp. nov.}

Plate 3, Fig. 4

Dorsal VI, I-9; anal I, 8; there are 30 scales in a longitudinal series and 10 in a transverse series.

The body rather stout, laterally compressed, the dorsal profile not elevated and nearly a straight line, the ventral profile very little curved so that the two are nearly parallel, the depth 45 times in the length; the head large, its breadth equal to the depth of the body and its length contained 3.2 times in head and trunk together; the eyes large, high up, and very close together, so that they gaze upward, their diameter 4.5 times in head and equal to the blunt snout; the interorbital space very narrow, its breadth about 18 times in head and equal to about $\frac{1}{4}$ of an eye diameter; a depressed space under anterior portion of eye gives a pinched appearance to snout in contrast to the broad head; the mouth is small, oblique, with a projecting chin, and does not extend back as far as eye; the slender pointed teeth are small to minute and in four or five rows in upper jaw, those of outer row larger than the rest and widely spaced; there are four rows in lower jaw; the dorsal length of caudal peduncle is $\frac{1}{4}$ greater, the ventral length $\frac{1}{2}$ more than its own depth; the fins all of moderate height; the pectoral reaches to anal papilla and is longer than ventral, which does not reach anus; the caudal $\frac{8}{9}$ as long as head. 
Only the snout and chin scaleless; the posterior half of body covered with coarsely ctenoid scales; the forward half has cycloid scales; snout and sides of head have rows of skinny ridges bearing more or less fibrillose papillæ.

The color in alcohol pale brown, with the fins more or less spotted and barred with blackish; the papillæ on head are dark or blackish, giving the appearance of adhering dirt or trash.

Here described from the type and only specimen, 29 millimeters long, collected at Polillo by E. H. Taylor.

Illotus, dirty, in allusion to the appearance of the head.

Genus 8. BUTIS Bleeker

Butis BLEFK BR, Nat. Tijd. Ned. Ind. 11 (1856) 42.

The body moderately long to elongate, and more or less cylindrical anteriorly; the height of the very pointed prismatic head equal to its breadth; the lower jaw very prominent; the head scaled, with bony crests on the flat interorbital space and around eyes; the temporal region smooth or scarcely scaled; 26 to 30 scales in a longitudinal series. The small, crowded teeth are in several rows in the jaws, and of equal or nearly equal size, or those of the outer row a little longer; there are no canines.

The species included in this genus are all small fishes of both fresh and salt water, living in shallow bays, estuaries, and the lower reaches of rivers where they are more or less affected by the tides. They lie on the bottom or attach themselves to any object that will serve as a hiding place, their dark colors blending with the environment so that they are almost invisible. All our species agree in having a conspicuous black spot on the base of the pectoral fin.

Key to the Philippine species of Butis.

$a^{1}$. Interorbital region and preorpecle, including region below eyes, covered with scales.

$b^{1}$. Scales of trunk without secondary scales; no scales between eye and orbital ridge.

B. amboinensis.

$b^{2}$. Scales of trunk with secondary scales; two or three rows of minute scales between eye and orbital ridge.

B. butis.

$a^{2}$. Interorbital region and preopercle scaleless; no secondary scales on trunk

B. gymnopomus.

14. BUTIS AMBOINENSIS Bleeker

Eleotris amboinensis BLFEKER, Nat. Tijd. Ned. Ind. 5 (1853) 343; GüNTHER, Cat. Fishes Brit. Mus. 3 (1861) 117.

Butis amboinensis BLwokeR, Act. Soc. Sci. Indo-Neerl. 8 (1860) 44; Rev. Espèces Eleotriformes, Versl. Akad. Amsterdam 11 (1875) 66; JoRDAN and Richardson, Bull. Bur. Fisheries 27 (1908) 276. 
Tagalog name, bia sunog, or kaple, at Cavite.

Dorsal VI, I-8 or 9 ; anal I, 8; scales in a longitudinal series, from opercle to caudal fin, 28 to 30 ; there are no secondary scales; the number of scales between the first dorsal and the interorbital space is variable, ranging from 14 to 19 , usually about 16.

The dorsal profile not so strongly arched as in $B$. butis and the body more elongate-cylindrical, the depth contained from 5.6 to 6.2 times in the length; the head long, low, nearly flat on top, and contained 2.8 to 3 times in length; the snout broadly rounded, its length 2.6 to 3 times in head and $\frac{1}{2}$ or $\frac{4}{5}$ more than an eye diameter; the eyes more on top of head than lateral, and contained 4.4 to 5 times in head and equal or nearly equal to interorbital space; the mouth large, oblique, with strongly projecting lower jaw, the curved maxillary extending to front margin of eye, or exceptionally a little beyond; the anterior nostril small, with a short, thin-walled, flaccid tubule; the posterior nostril much larger, open; least depth of caudal peduncle from 2.8 to 3 times in its own length; the short ventrals reach about halfway to anal fin; the pectorals extend to anus or to anal fin; the rounded caudal about $\frac{1}{4}$ as long as head and trunk.

The very low orbital ridges smooth or nearly so, close to margin of eye, and without scales on skin between eyes and ridges; the preorbital ridges very low, short, and inconspicuous; a wide naked band extends from snout along inner side of each orbital ridge, the conical space between them more or less scaled, and becoming almost naked posteriorly; the band continues to the upper extremity of pectoral base; the entire body except snout, lips, preorbital space, and underside of head scaled; the scales on base of pectoral, breast, and midline of belly cycloid, the rest all ctenoid. The cycloid scales all small to very small.

The color of alcoholic specimens varies from blackish brown to yellowish brown; six blackish crossbands more or less evident, the first extending from base of first dorsal; a double black stripe extends along each side from base of pectoral to caudal; a black stripe extends from snout, where it is often double, through eye to opercle; each scale on side has a pale spot, the spots forming longitudinal rows; behind interorbital space is a large, more or less reddish brown spot; in front of first dorsal is an elongate pale spot extending along midline of predorsal space; vertical fins more or less blackish or barred, the membranes black-dotted; upper part of caudal has a whitish band which is 
broadest at rear; base of pectoral has a large dark spot with a pale spot above and below it, the fin itself colorless; ventrals more or less dusky to black, with pale outer margin.

I have examined thirty-two specimens of this fish, from 36 to 78 millimeters in length, from the following localities: Luna, La Union Province; Santa Inez, Rizal Province; Manila; Libog and Arimbay River, Albay Province; Baco River, Mindoro; Naganahan River, Calapan, Mindoro; San Jose and Mariri River, Antique Province; Molo, Iloilo Province; Butuan, Agusan Province; Placer, Surigao Province.

This small and obscure fish dwells in rivers not far from the sea and occurs throughout the Philippines, as well as in Amboina, Celebes, and Buru. Day's Eleotris amboinensis I cannot include here, since he himself is doubtful that his fish is identical with Bleeker's species.

\section{BUTIS BUTIS (Buchanan Bamilton)}

Plate 4, Fig. 1

Cheilodipterus butis Buchanan Hamilton, Fishes Ganges 57 (1822) 367.

Eleotris humeralis CuvibR and Vatanciannes, Hist. Nat. Poiss. 12 (1837) 246.

Eleotris butis CANToR, Cat. Malayan Fishes (1850) 196; GüNTHER, Cat. Fishes Brit. Mus. 3 (1861) 116 (in part); DAY, Fishes of India (1878) 315, pl. 67, fig. 3 (in part); VAlluANT, Nouv. Arch. Mus. III 5 (1893) 57; Boulenger, Ann. \& Mag. Nat. Hist. VI 15 (1895) 186.

Butis butis BLFFk Vers, Versl. Akad. Amsterdam 11 (1877) 62; JoRdaN and Richardson, Bull. Bur. Fisheries 27 (1908) 275; Seare, Philip. Journ. Sci. \& D 9 (1914) 74.

Butis leucurus Jordan and Seate, Proc. U. S. Nat. Mus. 28 (1905) 794, fig. 13; Bull. Bur. Fisheries 26 (1907) 40; EvermanN and SEALE, Bull. Bur. Fisheries 26 (1907) 104.

Butis prismaticus JordaN and RICHARDson, Bull. Bur. Fisheries 27 (1908) 275 (not of Bleeker).

Ibanag name, pasel.

Dorsal VI, I-7 or 8; anal I, 7 to 9 . There are from 28 to 30 scales in a longitudinal series; very small accessory scales of varying sizes are more or less abundant at the base of the scales on the body, their number ranging from one to half a dozen; 18 to 20 scales between first dorsal and interorbital space.

The body strongly compressed behind, the part behind the head subcylindrical; the back arched, highest at origin of first dorsal, the depth contained 4.6 to 5.2 in the length; the 
profile descends very steeply toward front, and is slightly concave from behind eyes to tip of snout; the head depressed, wide, and very long, contained 2.7 to 3 times in length; the snout long, $2 \frac{2}{3}$ to 3 times in head, and twice the diameter of an eye; interorbital space broad, thickly scaled, about 4 times in the length of the head; the eyes high up but lateral, rather small, and contained 1.25 to 1.5 times in interorbital space and 5.3 to 6 times in the length of the head; the mouth large, with strongly projecting lower jaw, oblique, the curved maxillary not reaching eye or extending to a point scarcely beyond anterior margin; the anterior nostril very small with a correspondingly small tubule; the posterior nostril much larger and open or partly covered by a thin flap; the depth of caudal peduncle from 7.5 to 8 times in the length and 1.9 to 2.1 times in its own length; the short ventrals do not reach anus, the pectorals extending beyond them, sometimes reaching anal fin; the caudal broad, rounded, its length about 4 times in head and trunk.

A low ridge, but little or not at all serrated, curves about each eye, above and behind it and at some distance away, two or three rows of small scales lying between it and the eye; the preorbital ridges are very low and inconspicuous, serrate, and approach each other very closely near tip of snout; on the inner side of the interorbital ridges is a broad naked or scaleless strip which continues as a well-marked irregular line from end of orbital ridge immediately behind eye to upper extremity of pectoral base; the entire body except tip of snout, lips, and chin covered with scales; those on bases of pectoral and the region in front of the ventrals cycloid, the rest all ctenoid. Interorbital scales and those around eyes, on snout, and on throat all small to very small.

The color of a living spawning female, 82 millimeters long, taken from Pasig River several kilometers above its mouth, was as follows: General color gray, with five or six blackish crossbands, obscure anteriorly but well defined on rear half of body; top of head was irregularly lined and mottled with grayish and dusky; a blackish streak extended from snout through eye to opercle; each scale had a pale spot, the spots forming longitudinal rows along the sides; on base of pectoral were two elongate pink spots with a much larger, nearly circular black spot between them, the pectoral itself being colorless; first dorsal had greenish black and pale transverse blotches; second dorsal was clear with dark spots basally and posteriorly; ventrals and 
anal had alternate rows of blackish and pale spots on the rays, with a pink margin; caudal was pale at its base, with dark or blackish rays and clear membrane.

Several living specimens, from 90 to 105 millimeters in length, from the same locality, were dark olive green, with greenish yellow on the lips, about the nostrils, and over a large part of the preopercle. On the lower half of the body the longitudinal rows of spots were brick red; a broad, bright brick red margin on ventrals and anal; in other respects the colors were as already given. The red colors were very noticeable owing to the habit these fishes have of attaching themselves head downward to the glass front of the aquarium. They prefer fastening themselves by their ventrals to vertical objects, such as water pipes or rubber tubing, to lying on the bottom. In this way they are fairly well concealed and out of the way of other fish.

In alcohol the colors are similar, but the rows of white or pale spots on the sides are more conspicuous until the lapse of years makes the fish a more uniform yellowish brown; the sides of snout and cheeks covered with few to many dark brown or black spots; the ventrals black with a pale or whitish outer margin; the other fins black or very dark, except the caudal, which has a whitish or pale band along its upper margin, this widest toward the rear; the pink spots on the pectoral are white or whitish.

The above description was written after many living specimens had been examined, from Pasig River, Manila, and a large number of alcoholic specimens, from 42 to 117 millimeters in length, obtained at the following localities:

Abulug, Cagayan Province, Luzon.

Vigan, Ilocos Sur Province, Luzon.

Gulf of Lingayen, Luzon.

San Fabian, Pangasinan Province, Luzon.

Agno River, Dagupan, Pangasinan Province, Luzon.

Orani and Orion, Bataan Province, Luzon.

Obando and Baliuag, Bulacan Province, Luzon.

Malabon, Rizal Province, Luzon.
Manila, Luzon.

Laguna de Bay, Luzon.

Nasugbu, Batangas Province, Luzon.

Polillo.

Baco, Mindoro.

Capiz, Capiz Province.

Iloilo, Iloilo Province.

Dumangas, Leganes, Molo, Vi-

lla, and Zarraga, all of Iloilo Province, Panay.

Buenavista and Navalas, Guimaras Island.

Davao, Mindanao.

Hongkong and Amoy, China.

Spawning females varied from 45 to 82 millimeters in length. 
Many individuals are much darker in life than is the one described from Pasig River, the general color being very dark purplish brown, almost black. The margins of the soft dorsal and anal and the upper and lower margins of the caudal are also yellow in some specimens.

In the Bureau of Science collection is also a specimen from India determined by the eminent authority on Indian fishes, Dr. Francis Day. This agrees with Philippine specimens in every respect except the size of the mouth. Day says, "The maxilla reaches to below the middle of the eye," with which statement his specimen agrees perfectly.

This species has been recorded previously from the "Philippine Islands;" Manila, Cavite, and Bacon, Sorsogon, Luzon; Iloilo, Panay; Negros, Cuyo, and Palawan. It occurs from the coast of Bengal eastward throughout the Indo-Australian Archipelago as far as New Guinea.

\section{BUTIS GYMNOPOMUS Bleeker}

Eleotris gymnopomus BleEKER, Nat. Tijd. Ned. Ind. 4 (1853) 274.

Butis gymnopomus BLEEKER, Nat. Tijd. Ned. Ind. 12 (1856) 215 (name only) ; Rev. Espèces Eleotriformes, Versl. Akad. Amsterdam 11 (1877) 70.

Dorsal VI, I-8 or 9 ; anal I, 8 or 9 ; there are 26 to 28 scales in a longitudinal series and 10 in a transverse series; there are 14 scales between the first dorsal and the interorbital space; secondary scales are lacking.

The body elongate with arched dorsal profile, cylindrical anteriorly, and much compressed laterally on the posterior half; the depth greatest at first dorsal, 4.75 to 5 times in the length; the long head much depressed and 2.8 times in the length; the broad rounded snout 2.7 to 2.8 times in the head; the eyes contained 1.8 times in snout; the interorbital space varies from a little more to a little less than an eye diameter; mouth large, oblique, with projecting lower jaw, the maxillary extending to or beneath anterior margin of eye; the teeth of outer row in each jaw noticeably larger and more widely spaced than the rest; nostrils as in $B$. amboinensis; the orbital and preorbital ridges very low, smooth, and inconspicuous; the head naked except on opercles and nape, with no interocular scales; the rest of body scaled as in $B$. amboinensis; the least depth of caudal peduncle from 2.25 to 2.6 times in its length; the ventrals about $\frac{7}{8}$ as long as the distance to the rather large lanceolate genital papilla; the pectorals are much larger and extend to the genital papilla or even to the anal fin; the soft 
dorsal and caudal similar in outline, posterior rays greatly elongated but not quite reaching caudal when depressed; the caudal contained from 3.5 to 3.8 times in head and trunk.

In alcohol the color dusky gray to blackish, with a broad, very dark brown lateral band extending from before eye, back across its lower part, and on to base of caudal fin; in the La Union specimens each scale had a pale or yellow spot, the spots forming longitudinal rows; there is a black spot in the curve of the interorbital ridge behind eye and a blackish crossbar on base of pectoral; a large black spot on basal or central portion of spinous dorsal; the anal blackish with a narrow pale margin; the caudal black, with a broad white upper margin, widest posteriorly.

Here described from three specimens, 57 to 71 millimeters in length, collected by G. A. Lopez in Daguitan River, Dulag, Leyte, and three specimens, 52 to 61 millimeters in length, collected by J. Montilla at Rabon, La Union Province. The Bureau of Science collection also contains two small poor specimens from Capiz, Panay, and an excellent specimen, 54 millimeters long, from Lake Buhi, Camarines Sur Province.

This well-marked species seems to have been recorded only by Bleeker, who obtained it from Sumatra, Nias, Singapore, Banka, Java, and Borneo. My specimens agree with Bleeker's description except in the number of scales in a longitudinal series, which he gives as about 30 .

\section{Genus 9. PRIONOBUTIS Bleeker}

Prionobutis BleEker, Arch. Néerl. Sci. Nat. 9 (1874) 305.

This genus is differentiated at once by the teeth and the form of the head and body, which differ markedly from those of the species of Butis, to which it is closely akin. The head is short, obtuse, with convex profile and strongly elevated and serrate bony crests. The lower jaw is but little or not at all projecting. The teeth are in bands of several rows, those of the outer row conspicuously longer; no canines are present; scales in a lateral series 28 to 30 .

\section{PRIONOBUTI8 KOILOMATODON Bleeker}

PeATE 4, FTg. 2

Eleotris koilomatodon BLझßKER, Verh. Bat. Gen. 22 (1849) 21.

Prionobutis koilomatodon BLbEKER, Arch. Neerl. Sci. Nat. 10 (1875)

105 (name only); Versl. Akad. Amsterdam 11 (1877) 73.

Eleotris caperatus CANTOR, Cat. Malayan Fishes (1850) 197.

Eleotris caperata GüNTHER, Cat. Fishes Brit. Mus. 3 (1861) 1.17;

DAY, Fishes of India (1878) 315. 
Prionobutis serrifrons RUTTER, Proc. Acad. Nat. Sci. Phila. (1897) 84. Butis serrifrons JORDAN and SEALE, Bull. Bur. Fisheries 26 (1907) 40. Butis koilomatodon JORDAN and RICHARDSON, Bull. Bur. Fisheries 27. (1908) 274.

Butis caperata SbaLE, Philip. Journ. Sci. \& D 9 (1914) 74.

Dorsal VI, I-8; anal I, 8; scales in lateral series, 28 to 30 ; in transverse series, 9 or 10 .

The body wedge-shaped, triangular in cross section, with short, deep head and short, blunt snout; the depth contained 3.5 to 3.6 times, the head barely 3 to 3.2 times in the length; the greatest breadth of head contained 1.25 to 1.35 times, and its depth measured just behind eyes 1.6 to 1.8 times in the length of head; the snout blunt, somewhat elevated anteriorly; eyes contained from 4.3 to 5.4 times in head and from 1.2 to 1.6 times in snout, which is about 3.4 times in head; above and behind each eye an irregular, bony, serrated ridge; between the ridges is the depressed, flat or slightly concave and scaleless interorbital space, which is equal to or 1.5 times an eye diameter; in front of each eye two low serrated ridges which converge at the front but do not meet; the region in front of first dorsal is broad, elevated, covered with much smaller scales than those on sides of trunk; the scales on belly and breast also small; those in front of ventrals are smallest and, unlike those of rest of body, cycloid; small ctenoid scales on base of pectoral, larger ones on opercle, and very small ones on posterior part of upper half of cheek; the anterior part of upper half has three or four short rows of very small papillæ extending at right angles to eye, with or without a few minute ctenoid scales between their lower extremities; no scales between the eyes and the crests above them. The mouth strongly oblique, the maxillary not quite reaching a point under front margin of eye; anterior nostril large, with a prostrate tubule which is flaplike behind; the posterior nostril smaller, with a small valve on each side; in small specimens the maxillary may extend to middle of eye; the depth of caudal peduncle contained from 1.8 times to twice in its length.

The soft dorsal and anal much higher than the spinous dorsal, the last rays of anal the longest; the ventrals reach almost to anus or beyond it; the large pectorals extend beyond the ventrals, in some cases as far as second or third ray of anal; the caudal rather broad, rounded, its length from $3 \frac{2}{3}$ to 4 times in head and trunk.

The color in alcohol yellowish brown, with transverse dark brown crossbars which run diagonally downward and back- 
ward, one across the head behind the eyes, one above the posterior part of the opercles, one between this and the first dorsal; a broad band at base of first dorsal divides on the sides of body; two narrow bands from second dorsal, one on caudal peduncle and one at base of caudal. There are some broad irregular stripes on snout and cheeks; a white spot on each scale on the sides, the spots forming longitudinal rows. The first dorsal black; the rays of the soft dorsal, anal, and caudal alternately barred with pale and dark brown, with dusky or black membranes; the ventrals blackish; a large black spot on base of pectoral with smaller pinkish or white spots above and below it; the pectorals dusky or faintly crossbarred.

Here described from six specimens from Amoy, China, ranging in length from 86 millimeters (107 millimeters over all) to 45 millimeters. The largest two specimens are ripe males.

The color of a fresh specimen, collected from Pasig River, was gray, with alternate light and dark longitudinal lines on sides and with transverse dusky bands as previously described; the fins were all black or blackish. The Bureau of Science collection also contains specimens from Hongkong; from Malabon, a wellknown fishing town near Manila ; from Molo and from Zarraga, Iloilo Province, Panay; and from Navalas, a barrio of Buenavista, Guimaras Island. I have collected it from Pasig River, several kilometers from Manila Bay, and in the city markets of Manila, the specimens having been caught in Manila Bay. This species has been recorded from Cavite and from Iloilo, and undoubtedly occurs throughout the Philippines, probably never beyond the influence of salt water. Its geographical range is from the coast of India and the Andaman Islands to Celebes and Amboina, and northward on the coast of China at least as far as Amby.

\section{Genus 10. ODONTOBUTIS Bleeker}

Odontobutis BLझвквR, Arch. Neerl. Sci. Nat. 9 (1874) 305.

The body stout, not much compressed, the sides covered with rather large ctenoid scales, 36 to 46 in a longitudinal series. The large pointed and depressed head wider than high, scaled above and on the sides, with wide flat crown; the interorbital crests smooth and naked; the oblique mouth rather large with projecting chin; the teeth fine, short, crowded in broad bands, the external row little longer and without canines; the first dorsal fin normally of seven spines. Dorsal VI-VIII, I-8 to 10 ; anal I, 6 to 8. 
18. ODONTOBUTIS OBSCURA (Schlegel)

Eleotris obscura ScHLeged, Fauna Japonica, Poissons (1847) 149, pl. 77, figs. 1-3; GüNTHER, Cat. Fishes Brit. Mus. 3 (1861) 115; KNER, Zool. Reise Novara, Fische (1865) 185.

Odontobutis obscura. BLFEKKR, Rév. Espèces Eleotriformes, Versl. Akad. Amsterdam 11 (1877) 56; JORDAN and SNYDER, Proc. U. S. Nat. Mus. 23 (1900) 370.

Odontobutis obscurus JORDAN and SNYDER, Proc. U. S. Nat. Mus. 24 (1901) 43; SeAlle and BeAN, Proc. U. S. Nat. Mus. 33 (1908) 248.

Dorsal VII, I-8; anal I, 7; there are 46 scales in a lateral series, 16 in a transverse series.

The body thick, subcylindrical, and laterally compressed; the large depressed head broader than the body, and contained 3 times in the length, the depth 5 times; the snout a little longer than eye, 3.7 to 4 times in head; the eyes about $5 \frac{1}{8}$ times in head and $1 \frac{1}{3}$ or 1.5 times in interorbital space; the oblique mouth large, with a projecting lower jaw; the maxillary extends to a point beneath pupil of eye; the anterior nostril has a thinwalled tube but there is none on the posterior nostril; the caudal peduncle deep, its depth about $2 \frac{2}{3}$ times in length of head; the caudal fin broadly rounded, its length about $4 \frac{2}{8}$ times in head and trunk.

The entire body covered with scales except the very tip of snout, the space in front of eyes, lips, and chin; those on sides are ctenoid, the rest cycloid; the scales on forward part of head, bases of pectorals, and throat small to very small. The ventral fins much shorter than the long broad pectorals, which extend to anal papilla or beyond; the first dorsal small, much lower than second dorsal and anal.

The color in alcohol dark brown, with numerous obtusely angled darker crossbands along sides, the interspaces paler; two obscure blackish circular spots at base of caudal; all the fins are more or less crossbarred with brown and paler spots.

In the Bureau of Science collection are two specimens, 50 and 80 millimeters long, collected at Zamboanga by Maj. E. A. Mearns and determined by Seale and Bean. Günther gives the number of scales in a lateral series as 36 to 40 , while Jordan and Snyder give 36, and Bleeker says 40 . The scales in my specimens agree in number and arrangement with Schlegel's figure. According to Bleeker the dorsal spines may vary from six to eight, but seven is the usual number. The spines, fin rays, and scales are evidently rather variable. 
This fish is common in estuaries and river mouths in central and southern Japan, where it reaches a length of 300 millimeters. It also occurs in Korea and along the coast of northern China, and has been recorded from Java. It is apparently very rare in the Philippines.

\section{Genus 11. PALOA g. nov.}

Dorsal V, I-10; anal I, 8; scales in longitudinal series 85 or more; before first dorsal 55 or more; six rows of teeth in upper jaw, those of outer row much enlarged, stout, conical; the remaining teeth minute except the four central ones of the innermost row, which are enlarged and strongly curved backward; in lower jaw is an outer row of a few widely spaced, enlarged conical teeth, followed by three rows of minute teeth.

The robust body little elevated, laterally compressed, with a large, wide, depressed head, full cheeks, oblique mouth, and projecting chin; the eyes small, dorsolateral, the interorbital space broad; the vertical fins all low, the dorsals far apart, the height of first dorsal less than half the depth of trunk; the pectorals and ventrals narrow and short; the broad rounded caudal much shorter than head; the entire body, except lips, tip of snout, and ventral surface of head, covered with small cycloid scales, which extend upon pectoral and caudal fins; radiating from eyes and also running longitudinally and vertically on cheeks are numerous lines of very minute papillæ.

Paloa, from palo, the Visayan name of certain gobies. Generic type, $P$. polylepis sp. nov.

19. PALOA POLYLEPIS ap. not.

Plate 4, Fig. 3

Dorsal V, I-10; anal I, 8; there are 88 to 92 scales in a longitudinal series, 36 in a transverse series, and 58 to 62 before the first dorsal.

The robust body subcylindrical anteriorly, the posterior part strongly compressed laterally, the ventral profile gently convex, dorsal profile nearly horizontal, its depth 4 times in the length; the large head very broad, much depressed, its length 3.4 times in the total length, wider than the trunk, its greatest breadth 0.75 to 0.9 of its length and 0.25 more than its depth; the snout broad and rounded, its length 4 times in that of head; the eyes noticeably small, dorsolateral in position, more than 10 times in head, 2.5 times in snout, and 3.5 times in the broad, somewhat depressed interorbital which is 2.85 times in head; the 
mouth strongly oblique or nearly vertical, the posterior extremity of maxillary under anterior portion of eye or much in advance of eye; the lower jaw strongly projecting; the dentition is that given under the generic diagnosis; the cheeks very full and round; radiating from eye, above and below it, and on preopercle, are lines of minute papillæ; the scalation is given under the generic diagnosis, the posterior scales largest, the scales on trunk irregularly arranged; scales extend upon caudal for more than half its length.

The first dorsal very low, second and third spines longest, and contained 3 times in the depth; second dorsal low, posterior portion highest, longest ray 0.6 of the depth; the anal shorter than second dorsal, low, its longest ray a little shorter than that of second dorsal; the pectoral rather small, a little shorter than the small, rounded caudal, which is 0.6 the length of head; the ventrals small, narrow, their length equal to 0.6 of the depth; the caudal peduncle deep, strongly compressed, its depth 0.8 that of trunk, twice in head, and 1.1 times in its own length.

The color in alcohol olive brown, very dark above, and lighter on sides, becoming whitish on belly; a blackish brown band runs from snout back above eye and along upper part of side to caudal peduncle, where it converges downward toward second band; this starts behind eye, goes back above opercle and above pectoral, curving slightly downward along the side, then straight back to base of caudal; from axil of pectoral a third band passes down along lower part of side, curving upward posteriorly toward posterior end of middle band; from interorbital region a blackish median band runs back to first dorsal; the fins without special markings.

Here described from the type specimen, 68 millimeters in length, obtained at the market in Iloilo, Panay. I have recently received another specimen, 73 millimeters long, collected by $F$. Reveche at San Jose, Antique Province, Panay. It differs from the type in having more scales, 92 instead of 88 in lateral series, and 62 before the first dorsal; the first dorsal also has a very small sixth spine posteriorly. It has lost the longitudinal color bands.

This eleotrid seems to be unique, its dentition, scales, and color , marks being unlike those of any others known to me.

Polylepis, in allusion to the many scales in a longitudinal series. 
Genus 12. BORODA g. nov.

This genus is well differentiated from other Philippine eleotrids by the dentition, the very large broad head, and the scalation.

The body wedge-shaped and laterally compressed, with very large, wide, depressed head, and strongly projecting lower jaw; four rows of teeth anteriorly in both jaws, the outer and inner rows enlarged and more or less caniniform; the scales all cycloid, or only those on sides of body ctenoid; from 50 to 60 scales in a lateral series and from 17 to 20 in a transverse series; the head entirely scaled, with from 32 to 42 scales before first dorsal; the pores on head conspicuous; caudal broad, rounded, much shorter than head, its basal portion scaled. Dorsal VI, I-9; anal I, 8 or 9. Generic type, $B$. expatria sp. nov. Borod, a Visayan name for certain gobies.

\section{Key to the species of Boroda.}

$a^{1}$. Scales in lateral series 50 to 52 ; before dorsal 32 to 34 .. B. albo-oculata. $a^{2}$. Scales in lateral series 60 ; before dorsal 42 .

B. expatria.

20. BORODA ALBO-OCULATA sp. nov.

Dorsal VI, I-9; anal I, 8; there are 50 to 52 scales in a lateral series from opercle to caudal, 17 or 18 in a transverse series, and 32 to 34 scales before dorsal fin.

The thick, wedge-shaped body little elevated, the depth from 4.5 to 4.8 times in the length; the broad, low, depressed head 3 to 3.2 times in the length, its greatest breadth equal to the depth of body; the eyes very high up, 5.2 to 5.5 times in head; the length of the wide blunt snout but little greater than that of eye; the interorbital space broad, flat, 3.4 to 4.2 times in head; the length of caudal a little more than half that of head; the dorsal and anal low, without elongated rays; caudal peduncle broad, laterally much compressed, and elongate, its least depth more than twice in its length.

The mouth wide, strongly oblique, its maxillary angle extending beneath anterior portion of eyes, and with a projecting lower jaw; the teeth in four rows anteriorly in each jaw; the outer row in upper jaw fixed, enlarged, and widely spaced; those of the remaining rows small, depressible, and of uniform size; in lower jaw fixed enlarged teeth, irregularly disposed, are distributed in both the outer and the inner rows, especially far back; the other teeth small, uniform, and depressible.

There is a large pore on inner side of each nostril, one above and one behind eye, the latter at origin of the groove running 
above operculum; two more farther back on this groove and four on hind margin of preopercle; the entire body, except lips, tip of snout, space between eyes and lips, and chin, covered with scales; those on middle of sides, behind pectoral and back to caudal ctenoid, and much larger than elsewhere; the remainder cycloid; scales extend upon the caudal fin but not on the other fins; radiating downward from eye are a number of rows of minute papillæ, with very small scales between the posterior ones.

The color in alcohol yellowish brown, dusky on top of head and pale on belly, with narrow, alternating, longitudinal light and dark lines along sides; the posterior half of trunk vaguely marked with broad dark crisscross bands; two blackish rounded spots on base of caudal, one on upper, the other on lower part; the dorsals, anal, and caudal more or less crossbarred with alternate rows of dark and light spots; the other fins faintly marked with dusky specks; the pupils of eyes noticeably white.

Here described from the type, No. 10577 Bureau of Science collection, 86 millimeters long, and twelve cotypes, ranging in length from 22 to 60 millimeters. They were collected in a small fresh-water stream at Taytay, Palawan, by the Bureau of Science expedition in May, 1913. The type is a female with eggs, nearly ready for spawning.

Albus, white; oculatus, having eyes, or "eyed."

\section{BORODA EXPATRIA sp. nov.}

Plate 5, Fig. 1

Dorsal VI, I-9; anal I, 9; scales in lateral series, from opercle to caudal, 60 ; scales in transverse series, from origin of second dorsal to that of anal, 20 ; scales from first dorsal to tip of snout 42.

The wedge-shaped body laterally compressed, with a broad, flat caudal peduncle; the very large depressed head wider than the trunk and contained from 2.4 to 2.7 times in the length; the depth from 4.1 to 5 times in length, averaging about 4.6 times; the dorsal profile moderately convex, sloping anteriorly almost in a straight line to interorbital space, then curving up in a large hump on snout; the ventral profile nearly straight (in the illustration a trifle too curved); the short snout is very broad and rounded and equals the interorbital space; the eyes rather prominent, very high up, and contained from 4.8 times to nearly 6 times in head, and equal to or 1.2 times in snout; the mouth large, with a strongly projecting lower jaw; the 
angle of maxillary extends to a point beneath pupil; four rows of teeth in upper jaw, those of outer row enlarged; the four central teeth of inner row are much enlarged and point backward; the outer row long, inner row short; the lower jaw has four rows of teeth anteriorly, but only one or two rows posteriorly; the teeth of outer row enlarged; those of inner row also enlarged, the posterior ones being like stout pointed canines; as in related forms, the anterior nostril is tubulate but the posterior one is entirely open; a large pore on inner side of each nostril, one above and one behind eye, four on rear margin of preopercle, and three above operculum on the groove running from eye to top of gill opening; the entire body except lips, tip of snout, and chin covered with cycloid scales, which also extend upon pectoral and caudal fins; the fins all rather short, and none have elongated or filamentous tips.

The color in alcohol brown, with darker diagonal and angled crossbars on sides; each scale on side has an obscure pale spot, the spots together forming definite longitudinal lines; second dorsal has four rows of darker spots; the other fins are uniform brown.

Here described from the type, No. 11468 Bureau of Science collection, 76 millimeters long, and five cotypes, ranging in length from 65 to 144 millimeters. They were collected by Prof. A. L. Day, formerly of the department of zoölogy of the University of the Philippines, but he was unable to give me the exact locality where they were obtained.

I also refer here sixteen specimens, one of them 46 millimeters in length, the others all very much smaller, down to 16 millimeters in length. They were caught in Lake Manguao, May 23,1913 , by A. L. Day, and it is very likely that the type specimens were obtained by him at the same time and place.

This strongly marked species is easily separated from other Philippine eleotrids. The larger specimens were only half covered with alcohol when they came into my possession, so that they are black from oxidation and are in poor condition; but their characters are so well differentiated that they cannot be placed with anything else in the collection or in the literature.

Expatria, without a country, or homeless, in reference to their unknown origin.

Genus 13. BUNAKA g. nov.

The wedge-shaped body very thick and robust, with a broad depressed head and a deep caudal peduncle which is strongly 
compressed laterally. There are 55 to 60 scales in a lateral series, 17 to 20 in a transverse series, and 40 to 45 between the dorsal fin and the tip of the snout; on each side of the scaled interorbital space is a broad naked furrow, between which and the eye is a single row of small scales; minute scales extend upon the pectoral and caudal fins; the small villiform teeth in broad bands in each jaw, without canines; the teeth of the outer and innermost rows may be slightly enlarged; cheeks large, full, completely scaled, with two or more longitudinal furrows; a prominent groove runs from eye back to upper posterior angle of opercles. The vertical fins low, the dorsals well separated. Dorsal VI, I-8 or 9 ; anal I, 8 or 9 . The pectoral very broad, the caudal large and gently rounded. The gill openings wide, the isthmus moderately broad.

This genus is easily separated from Eleotris by the absence of a preopercular spine; from Ophiocara it differs in scales and teeth; from Boroda it differs most in the character of the teeth; from both it differs in lacking pores on the head. and in the arrangement of the scales and naked grooves on the head. The genus is widely distributed in the Philippines, in rivers near the sea. Generic type, Bunaka pinguis sp. nov.

Bunaka is from bunak, a Negrito name for the only species known.

22. BUNAKA PINGUIS sp. nov.

Plate 27, Fig. 2

Ilocano name, boto-bot; the Negrito name, in Nueva Vizcaya, near Casiguran, is bunak.

Dorsal VI, I-8 or 9; anal I, 8; there are from 56 to 58 scales in a longitudinal series from angle of opercle to caudal, and 17 in a transverse series from origin of second dorsal to that of anal (one specimen has 19 on one side); there are 42 scales before the dorsal fin and 6 or 7 rows between the naked grooves on interorbital space; a single row of small scales between the eye and the naked groove.

This is a very thickset and robust fish with a round, plump body, depressed head, full cheeks, and the posterior third of body strongly compressed laterally; the depth contained 4 to 4.6 times in the length; the head very large, its breadth equal or almost equal to depth of body and its length contained 2.8 to 3 times in head and trunk together; the eye 6.5 to 7.5 times in head and 1.4 to 1.6 times in the low, broadly rounded snout; the top of snout has a strong hump, behind which is a transverse 
groove between eyes; the interorbital space contained 3.6 to 4 times in head and is $\mathbf{1 . 7 5}$ times to a little more than twice an eye diameter; the oblique mouth very wide, with strongly projecting lower jaw; the angle of maxillary beneath middle of eye; the small villiform teeth in broad bands, with eight to ten rows in each band; the outer and inner rows a little larger than the others; a short row of stouter teeth in front of lower jaw.

The first dorsal very low, the second spine longest, and contained twice in the depth of body; second dorsal low, its base short, the posterior rays longest and about 1.7 in the depth; anal farther back than second dorsal with a shorter base, but higher, its longest rays about 1.4 in depth and extending farther back than the dorsal rays when depressed; the long, very broad, rounded pectoral extends beyond the ventrals almost to or as far as vent, and equals or almost equals the broad, gently rounded caudal, which is 3.6 to 4 times in head and trunk; the caudal peduncle very deep, its depth 1.5 to 1.66 times in its own length and about 1.7 times in the greatest depth of trunk. The entire body, except tip of snout, lips, and chin, covered with scales, which extend upon pectoral and caudal fins; those on sides from head to tail are ctenoid; all others are cycloid; the scales on cheeks and snout very small; beginning on inner side of anterior nostril a broad, naked furrow, marked by minute papillæ and separated from eye by a single row of small scales, extends backward and curves around eye to a point opposite upper margin of pupil; here it is joined by a similar but less noticeable furrowbeginning below the forward margin of eye, and continues on back along the side of head to a point above posterior angle of operculum; similar but much narrower grooves extend from the furrow below eye diagonally backward upon cheek.

The color in alcohol varies from reddish brown to blackish, above and on sides, with yellowish to whitish belly; the sides marked by narrow dark longitudinal lines; a broad blackish crossband on upper half of spinous dorsal; the margin is clear and the lower half has narrow alternate bands of blackish and white; all the other fins crossbarred with numerous alternate dark and light spots or stripes; base of pectoral yellowish with two large dark brown spots, the markings resembling those in the genus Butis.

Here described from the type, No. 10594 Bureau of Science collection, and three cotypes. The type is a male, 136 millimeters long, collected in March from Dumaguete River, Orien- 
tal Negros. A cotype, 167 millimeters long, from Pulangui River near Reina Regente, Cotabato Province, Mindanao, is a female; another cotype, 228 millimeters long, I collected from Abra River, near Bangued, Abra Province; unfortunately the viscera were accidentally removed, but it is probably a male. The fourth specimen, a female with eggs fairly well developed, was taken in Lapid Lapid River, Tawitawi, July 26, 1924. It has the same length as the Abra specimen, but the depth is much greater (3.86 times in the length) than in the other specimens, owing to nearness to the spawning season; the head is longer than in the Abra specimen, the difference being in the longer snout of the Sulu Archipelago specimen.

In addition to the above, I have obtained five specimens, 60 to 76 millimeters in length, from Kabatohan River, near Iba, Zambales Province, and a very fine specimen, 137 millimeters long, from Kabulig River, Nueva Vizcaya Province, near Casiguran, on the east coast of Luzon. I have just received three specimens, 47 to 57 millimeters in length, from F. Reveche, San Jose, Antique Province. These young specimens lack some of the characters of mature specimens; the caudal has a large black basal band and behind it a very broad white band, with dark bars on the rest of the fins.

During the latter half of 1925 and most of 1926 I have had under continuous observation four large living specimens taken from Pasig River by Mr. Thomas Cary Welch, at his residence in Santa Ana, Manila, the largest one 207 millimeters long, or 257 millimeters with the caudal fin, the others nearly as large. Their colors are as follows: Above velvety dark brown, merging into alternate longitudinal lines of dark brown and greenish gray on the sides, the belly grayish-or gray with numerous longitudinal lines of light brown; six broad, poorly defined, lightercolored dorsal crossbands, one on the head, one before the first dorsal, one at the posterior part of the first dorsal, one at the anterior and one at the posterior part of the second dorsal, and one behind the second dorsal; the three under the dorsals are most distinct; from the mouth a dark streak goes back through the eye and divides, one branch going along the upper margin of the opercle and a broader and more distinct one backward and downward from the eye across the preopercle; between these bands the snout is paler, with a central blackish spot on the projecting lower lip as well as on the upper; the lower sides and underpart of the head, especially around the 
mouth and below the gills, are irregularly spotted and marked with white or whitish; the base of the pectoral is conspicuously marked with four large spots, a pinkish light brown and a velvety dark brown one alternately; the spinous dorsal is crossed by two broad dusky bands, and in some specimens is also banded by pink or red; the second dorsal is deep brown along the rays, with colorless membranes; the remaining fins are all crossbarred by numerous alternate umber and pale spots; the base of the caudal and its rays are dark velvety brown.

When the fish is much disturbed the crossbands become wider, more distinct, and extend down the sides, or large pale blotches appear on the sides, while the pale or greenish gray parts begin to assume a pinkish or reddish hue, and the same color appears on the fins.

When the fish is brought near a window or placed in a small glass tank set upon a light-colored surface and in strong daylight though not in direct sunlight, the whole dorsal region becomes a dull gray or gray clay color, often faintly suffused with reddish; the sides are then blackish brown, more or less definitely marked by longitudinal lines of blackish and gray or indistinct pink; the snout, chin, sides, and entire underside of the head are irregularly marked by pale whitish or pinkish spots and short bars; on the upper opercular region is a large, irregular, pinkish gray blotch with streaks running from it; the base of the pectoral has a pink band and two large grayish pink blotches on the base of the pectoral, surrounding and sharply defining two large dark brown blotches; the first dorsal is marked by three alternate stripes of pale red and two wide bands of dark violet; the soft dorsal and anal are marked by alternate stripes of pale red and dark brown, only the basal portion of the membranes with color, their outer half colorless; the pectoral rays are umber, the fin marked by numerous crossbars of alternate whitish and brown; the caudal is velvety blackish brown, with several cross stripes of pink on the basal half; the ventral membranes are colorless, the rays cross marked by numerous lines of alternate pale pink and light umber.

This is the largest Philippine goby known. Glossogobius giurus is longer but not nearly so bulky, and the largest specimens I have seen do not weigh as much as does this eleotrid. Though so large and powerful it is very sluggish as a rule, lying almost motionless in some dark corner hour after hour.

Pinguis, fat or plump. 


\section{Genus 14. OPHIOCARA Gill}

Ophiocara Gul, Proc. Acad. Nat. Sci. Phila. 15 (1863) 270.

The robust, wedge-shaped body more or less cylindrical anteriorly, and laterally compressed behind; the broad flat head strongly depressed, thickly scaled above and on the sides, without spines; the scales on top of head large, giving it something of the appearance of the Ophicephalidæ; the scales of the trunk ctenoid, 28 to 40 in a longitudinal series; the mouth large, oblique, with prominent lower jaw, and six to ten rows of teeth in each jaw; teeth small, no canines, those of outer row in both upper and lower jaws larger than the rest; the posterior margin of preopercle has two to five pores, conspicuous in some species; the isthmus is broad, the gill openings widely separated. Dorsal VI, I-8 or 9; anal I, 7 to 9.

The Philippine species of this genus are very abundant and one of them is of much economic importance in the Islands. The members of the genus range from Madagascar and the east coast of Africa eastward to the Caroline and Pelew islands.

Key to the Philippine species of Ophiocara.

$a^{2}$. Only two preopercular pores, rarely conspicuous; two dark diagona! bands from eye to opercle; 13 to 17 predorsal scales O. aporos. $a^{2}$. Five preopercular pores, at least three conspicuous; no diagonal opercular bands; 22 to 26 predorsal scales.

o. porocephala.

23. OPHIOCARA APOROS Bleeker

Plate 5, Fig. 2; Plate 28, Fig. 3

Eleotris aporos BLअKER, Nat. Tijd. Ned. Ind. 6 (1854) 59; GüNTHER, Cat. Fishes Brit. Mus. 3 (1861) 109; Petbrs, Monatsber. Akad. Wiss. Berlin (1868) 268; Boulenger, Ann. \& Mag. Nat. Hist. VI 15 (1895) 185.

Ophiocara aporos BLBGKER, Versl. Akad. Amsterdam 11 (1877) 33.

Ophiocara aporos JORDAN and RICHARDSON, Bull. Bur. Fisheries 27 (1908) 274.

Eleotris hoedti BLFBKER, Nat. Tijd. Ned. Ind. 6 (1854) 496; Gủ NTHER, Cat. Fishes Brit. Mus. 3 (1861) 110.

Ophiocara hoedti BLअआKRR, Versl. Akad. Amsterdam 11 (1877) 35. ? Eleotris laglaizei SAuvage, Bull. Soc. Philomat. VII 4 (1880) 54.

Bicol name, labanag; Tagalog, bañgayñay; at Lake Taal, palowon; Negrito name at Casiguran, simawar.

Dorsal VI, I-8 or 9 ; anal I, 8 to 10 ; there are 30 scales in a longitudinal series and 10 or 11 in a transverse series; usually there are from 13 to 15 scales before the dorsal fin, rarely 16 or 17. 
The wedge-shaped body strongly compressed laterally, with a thin, broad caudal peduncle; from the region before the dorsal fin the dorsal profile descends steeply toward snout, so that the anterior part of head is very much depressed; the depth contained from 3.6 to 4.6 times in length, the shape of head and body varying considerably with age; the length of head from 2.9 to a little mors than 3 times in length, its breadth greater than that of body and equal to or greater than the distance from posterior margin of eye to that of opercle; the eye contained 5 to $5 \frac{1}{8}$ times in head and twice in the broad, flat interorbital space; the snout short, blunt, and broadly rounded, its length 3.3 to 4 times in head or 1.2 to 1.5 times eye; in large specimens the head is longer and wider and the interorbital may be nearly 3 times the eye; the lower jaw strongly projecting, and mouth oblique and large; the maxillary does not reach to eye in small specimens but in large ones extends beyond front border of eye; the small teeth in broad bands of uniform size except those of outer row in upper jaw, which are much larger and rather widely spaced; on posterior edge of preopercle are two pores which are sometimes large and conspicuous but ordinarily are small and obscure; the groove from eye back over opercle conspicuous; the entire body covered with scales except tip of snout, lips, and chin; those on the sides and behind ventrals ctenoid, the rest cycloid; those on nape as large as, or even larger than, those on trunk; pectorals broad, rounded, and equal to or greater than depth of body; the ventrals long and slender, extending beyond pectorals to anus; the vertical fins comparatively low as a rule, but the soft dorsal and anal may be elongated and pointed posteriorly, the last rays reaching at least to base of caudal when depressed; the last named broadly rounded, usually a little shorter than head and rarely exceeding it in length; the anal papilla broad and thick, with rounded or notched tip.

The color of a living specimen, 80 millimeters long, was as follows: The general effect was dark green and gold, dark green above and darkest on top of head; the belly was whitish; the chin and branchiostegals were dark muddy green; there were two irregular rows of large golden spots connected by crossbars along the sides and extending on the caudal fin as elongate dashes; two dark green stripes passed from lower margin of eye to edge of opercle and an indistinct but broader one went from pre- 
opercle to base of pectoral, where it bisected a large golden spot and connected with a dusky transverse bar; the interspaces between the stripes were golden; the soft dorsal had a row of large golden spots, its posterior part black, and a pale yellow line along its anterior upper margin; the anal had a similar row of golden spots, a black spot above its posterior extremity, and a narrow red stripe on its anterior lower margin; a large black spot on base of caudal; the eyes were very dark ruby red.

In alcohol the golden spots on the sides disappear, leaving the interspaces as a broad black bar, often with a large terminal black spot at base of caudal; rarely their disappearance gives rise to a disconnected series of large black spots intermingled with pale or whitish areas; the general color is usually blackish above and pale beneath, but it may vary from nearly uniform brown to pale green on the sides and back; the golden spots on the fins become yellowish or whitish, or may disappear entirely.

In living specimens the number and size of the golden spots vary, and they are sometimes interspersed with red or orange spots; the dark green of the body may vary to pale green or even steel blue; the soft dorsal may have two rows of golden spots, sometimes on a blue or green membrane, and the spinous dorsal may also be spotted; the lateral stripes on the head may be lavender or violet, and there may be green, violet, or lavender markings on the sides and on the caudal fin.

This is one of the most brilliantly colored gobies and it is unquestionably the handsomest of Philippine fresh-water fishes. So far as I know, it is the only gorgeously colored fish living almost permanently in the muddy dark-colored waters of the Philippine lowland rivers. In the Bureau of Science aquarium are three living specimens, the largest of which is 235 millimeters long at the time of writing, November, 1924 ; it measures 300 millimeters with the caudal fin included, and is thickset and bulky, its depth being 65 millimeters.

Two of these specimens have been in captivity six years and have about doubled in length during that time, though their bulk has increased much more, proportionately; when taken from the water their brilliant golden and red colors disappear almost entirely in a few moments, but return when replaced in the tank. This species would make a very fine aquarium pet in the United States and Europe. 
In addition to observing a great many living specimens, both large and small, I have examined several hundred alcoholic specimens, from 13 to 180 millimeters in length, mainly collected in fresh water at the following localities:

Lake Paoay, Ilocos Norte Province.

Karowan, Cagayan Province.

San Fernando, La Union Province.

Kabulig River, Casiguran, Tayabas Province.

Kabatohan River neat Iba, Zambales Province.

Pasig River, Manila.

Laguna de Bay.

Manang River, Antipolo, Rizal Province.

Cayman Lake, Los Baños, Laguna Province.

Molawin Creek, College of Agriculture, Laguna Province.

Balanak River, Pagsanjan, Laguna Province.

Nasugbu, Batangas Province.

Lake Taal, Batangas Province.

Pansipit River, Batangas Province.

Alabat Island.

Mangso River, Albay Province.
Puru, Legaspi, Albay Province. Tambo River, Ambil Island.

Calapan, Mindoro.

Naujan River, Mindoro.

Mambach and Subaan Rivers, Lake Naujan, Mindoro.

A fresh-water stream, Tablas Island.

Sibuyan.

River at Catarman, Samar.

Anahawan, Leyte.

Dumaguete River; Oriental Negros.

San Jose, Antique Province, $\mathrm{Pa}$ nay.

Cuyo.

Culion.

Taytay, Palawan.

Balabac.

Basilan.

Zamboanga, Mindanao.

Tatayan and Saub Rivers, south coast of Cotabato Province, Mindanao.

Lapid Lapid River, Tawitawi.

The Bureau of Science collection also contains a large specimen received from the museum at Calcutta, India.

This species apparently spawns about the first of September; my largest specimen, 225 millimeters long over all, collected in a river on Tawitawi, July 26, 1924, had the ovaries distended with eggs which were nearly fully developed.

Most of my specimens are the Ophiocara hoedti of Bleeker, distinguished by the presence of 13 to 15 scales before the dorsal fin and by a black lateral band along each side. However, I have gradations from those with 13 up to those with 17 scales before the dorsal fin, and from those with an exceedingly distinct lateral bar to those in which it is almost or quite lacking. I am therefore unable to separate $O$. aporos and O. hoedti. Neither can I agree with Günther's statement in Fische der Südsee 
that $O$. hoedti is the young of $O$. aporos, since specimens of the same size may vary within the limits here given.

This species has been previously recorded in the Philippines from Loquilocon and Basey River, Samar; Palawan; Balabac; Mindoro; and Sibuyan. It occurs in the sea and in fresh-water lakes and streams from Sumatra to the Fiji Islands.

Sauvage described an eleotrid from Manila, under the name Eleotris (Giurus) laglaizei. His imperfect diagnosis does not agree with any fish known to me, but apparently comes nearest to Ophiocara aporos. He gives the formula D. VI-1-6; A. I-7; 1. lat. 30 ; his specimen was 135 millimeters long.

\section{OPHIOCARA POROCEPHALA (Cuvier and Valenciennes)}

Plate 5, FIG. 3

Eleotris porocephala Cuvier and Valenciennes, Hist. Nat. Poiss. 12 (1837) 178.

Ophiocara porocephalus BLEEKER, Rev. Espèces Eleotriformes, Versl. Akad. Amsterdam 11 (1877) 30.

Ophiocara porocephala JORDAN and RICHARDSON, Bull. Bur. Fisheries 27 (1908) 274.

Eleotris porocephalus DAY, Fishes of India (1878) 312, pl. 167, fig. 1 . Eleotris ophiocephalus GüNTHER, Cat. Fishes Brit. Mus. 3 (1861) 107; Peters, Monatsber. Akad. Wiss. Berlin (1868) 268; Seale and Bean, Proc. U. S. Nat. Mus. 33 (1908) 248.

Ophiocara ophiocephalus Gill, Proc. Acad. Nat. Sci. Phila. (1863) 270; BLEEKER, Rev. Espèces Eleotriformes, Versl. Akad. Amsterdam 11 (1877) 29.

Eleotris porocephaloides BLEEKER, Nat. Tijd. Ned. Ind. 5 (1853) 511; GÜNTHER, Cat. Fishes Brit. Mus. 3 (1861) 109.

Eleotris cantoris GüNTHER, Cat. Fishes Brit. Mus. 3 (1861) 108.

Bicol name, palu; Ibanag names, palace, baranog; local name on Busuanga Island, paku.

Dorsal VI, I-8 or 9 ; anal I, 7 or 8 ; there are from 35 to 40 scales in a longitudinal series from the upper angle of the gill slit to the caudal fin, and 12 to 14 in a transverse series from the origin of the second dorsal to that of the anal; there are from 22 to 26 rows of scales before the first dorsal. On the snout is a large pore on the inner side of each nostril ; there are two pores above each eye and a large pore is just behind each eye; on the lower posterior margins of the preopercle are five large pores, of which at least three are conspicuous; on the supraopercular groove are at least three pores. 
The robust, wedge-shaped body has the dorsal profile but little elevated and is very wide behind the flat depressed head, which is still wider; the posterior half of trunk laterally compressed, with a broad, laterally flattened caudal peduncle; the depth from 4.1 to 4.8 times in length; the large head contained 2.8 times in the length; snout contained about 3.5 times in head; the circular eye placed very high up and contained between 5 and 6 times in head and twice or nearly twice in the broad, flat, interorbital space, which is contained 2.8 times in head; mouth of moderate size, with prominent lower jaw; the cleft of mouth extends to a point below front margin of eye, the end of the maxillary to a point below center of pupil; in the upper jaw there are eight or ten rows of depressible villiform teeth forming a wide band, with a few larger ones in the inner row and six or eight rows on the lower jaw with a few larger ones in the outer row; the anterior nostril has a well-developed tubule; the posterior nostril has a membranous flap on its anterior side; the entire body except tip of snout, lips, and chin covered with rather large scales; the basal portion of caudal also scaled; scales on head, nape, throat, and belly cycloid, on the sides ctenoid; a large groove extends from eye to upper posterior angle of opercle and a smaller one extends from mouth back about halfway across preopercle; the second, third, and fourth dorsal spines longest, with elongate, slender tips, their height from half to two-thirds the depth of trunk; posterior part of second dorsal higher than first dorsal, fifth and sixth or sixth and seventh rays usually with elongate, threadlike tips, the latter much longer than any others; the pectorals extend beyond the rather short ventrals; the caudal fin broad and bluntly rounded, its length less than that of head.

The color in alcohol commonly varies from yellowish to blackish brown, top of head and back darkest; there are usually six or more longitudinal rows of pearl-colored spots along each side, a spot on each scale; from mouth back to pectoral fin large pearlcolored spots are also scattered; fins all dark; second dorsal and caudal each marked by several transverse rows of white spots or alternate rows of white and dusky spots; the anal has a pale margin which was probably red in life. Some specimens are greenish, with about four very broad, dusky, greenish transverse bands on back, in addition to the rows of light spots on sides. 
I have studied the following specimens, ranging in length from 39 to 163 millimeters:

Bangui, Ilocos Norte Province, 1.

Abulug, Cagayan Province, 2. Buguey River, Mission, Cagayan Province, 5.

Obando, Bulacan Province, 1.

Polillo, 4.

San Miguel Bay, Camarines Sur Province, 1.

Aringay River, Legaspi, Albay Province, 6.

Naganahan River, Puerto Galera, Mindoro, 4.

Puerto Galera, Mindoro, 5.

Bintoan, Busuanga, 1.
Langbuan River, Busuanga, 5. Tablas, 1.

Dumangas, Iloilo Province, $\mathrm{Pa}$ nay, 1.

Iloilo, Iloilo Province, Panay, 1.

Leganes, Iloilo Province, $\mathrm{Pa}$ nay, 1.

Villa, Iloilo Province, Panay, 4. Navalas, Guimaras, 1.

Catarman, Samar, 2.

Taytay, Palawan, 2.

Balabac, 1.

Buan Island, Sulu Province, 1. Bungau, Sulu Province, 1.

The specimen from Camarines Sur is the largest one, 212 millimeters over all, and is badly diseased, the skin being greatly thickened and distorted with curious, large, flattened outgrowths and great warty masses. These cover the head and protrude from between the scales all over the body.

In addition, from Naganahan River, Puerto Galera, Mindoro, I have eight specimens, $\mathbf{4 3}$ to $\mathbf{7 3}$ millimeters long, which are in most respects typical of Ophiocara ophiocephalus of Bleeker. The body has two broad whitish or yellowish crossbands, the first passing from the anterior part of the second dorsal downward and forward to the lower part of the body; the second encircles the middle of the caudal peduncle; the base of the caudal is marked by large spots of the same color as the bands. A careful comparison fails to show any essential difference to warrant the recognition of $O$. ophiocephalus, at least as far as the Philippines is concerned.

Specimens collected at Davao in April and at Polillo in June were spawning.

This species occurs in both fresh and salt water and is probably found throughout the Philippines, though apparently not in as great abundance nor over such a wide range as is $O$. aporos.

This species was listed from Calayan and Mindoro by Jordan and Richardson; as Eleotris ophiocephalus it was listed from 
Samar by Peters, from the "Philippine Islands" by Günther, and from Zamboanga by Seale and Bean. Elsewhere it occurs throughout the East Indies, westward in the Indian Ocean to the Seychelles, and eastward in the Pacific to New Ireland and the Fiji and Caroline Islands.

\section{Genus 15. EVIOTA Jenkins}

Eviota JENkins, Bull. U. S. Fish Comm. 22 (1902) 501.

Very small eleotrids, 30 millimeters or less in length, with elongate and laterally compressed body; the scales are ctenoid, 22 to 28 in longitudinal series, the head and body naked as far back as the first dorsal, and not compressed into a keel; the mouth oblique, with several rows of teeth in each jaw, those of outer row larger and fewer in number; the large eyes much longer than snout, dorsolateral in position, very close together; the preopercles entire; the ventrals long, narrow, more or less sickleshaped, their rays and the lower rays of pectoral fringed. Dorsal VI, I-8 to 10 ; anal I, 7 to 9 .

Some of the species of Eviota are among the smallest living vertebrates. The members of this genus are abundant in the coral reefs of the South Sea Islands, ranging northward to the Philippines and southern Japan. They are difficult to collect except by diving for coral masses, which are then broken up over a cloth or the deck of a boat. Owing to their minute size they are able to live in the intricate passages and crevices of coral, where it is impossible to catch them by other means. Further study is needed before their generic characters and position can be more thoroughly defined. It is believed that careful collecting will show the presence of a number of additional species of this genus in the Philippines.

\section{Key to the Philippine species of Eviota.}

$a^{1}$. Scales 25; eight dark spots along the side E. gymnocephalus. $a^{2}$. Scales 22; eight dark bands on dorsal and ventral surfaces.... E. sealei.

25. EVIOTA GYMNOCEPHALUS Weber

Eviota gymnocephalus WeBER, Fische der Siboga Exp. (1913) 452, fig. 87.

Dorsal VI, I-9; anal I, 8 ; there are 25 scales in a longitudinal series and 7 in a transverse series.

The body compressed, its depth 5.5 in the length; the head bluntly conical, hardly wider than high, its length 4.75 times in the total length; the large eyes touch one another, their diameter $\frac{1}{3}$ or more of the length of head and twice as long as snout; 
the mouth is oblique and the maxillary reaches below middle of eye; the teeth in several rows; those of outer row larger, few in number, and widely spaced; the isthmus very broad. The sides covered with ctenoid scales which extend forward to a line from middle of first dorsal to base of pectoral ; beyond this they become smaller and the anterior ones are cycloid; the head, nape, and forward part of back naked. In one specimen the first spine of first dorsal is distinctly elongated, so that it is greater than the depth of the body; those following diminish in length; the base of second dorsal hardly united to first, the rays all divided and approximately equal and half the height of body; the bluntly rounded caudal approximately 0.2 of total length; the anal fin like the second dorsal; the pectoral approximately equal to length of head, its upper rays undivided; the ventrals separate, longer than head, their four rays so divided that the whole fin is distinctly sickle-shaped.

The color is that of yellow sand from the lower part of pectoral base to caudal fin are approximately eight translucent dark spots, which are especially distinct along base of anal fin; six are plainly seen, but spots may be absent. In the middle of base of caudal is a large dark spot. The caudal fin has rows of dark spots. The head and nape have groups of small black dots. In one specimen each scale had fine black dots or groups of dots, especially along the back. The anal fin spotted with dark, the dorsal less so. The ventrals and pectorals uniformly clear.

The description here given is taken from Weber's account. He collected thirty-one specimens of this tiny fish at twelve stations, from Sanguisiapo in the Sulu Archipelago, the coast of Borneo, and eastward to Celebes, Saleyer, Sula Besi, Timor, and Waigeu. His largest example was only 25 millimeters long.

26. EVIOTA SEALEI sp. nov.

Dorsal VI, I-8; anal I, 8; there are 22 scales in a longitudinal series and 7 in a transverse series.

The body strongly compressed laterally, its depth $4 \frac{1}{8}$ times in the length; the stout heavy head contained 3.25 times in the length and its breadth equal to its greatest depth; the large eyes 4 times in head and twice the length of the short, blunt, but pointed snout; the eyes are very high up but do not quite touch each other; the mouth strongly oblique, its cleft reaching below anterior part of eye and angle of maxillary extending to below center of pupil; the ventrals very long and narrow, extending to anal fin; the first dorsal moderately elongated, its longest 
spine a little less than the depth; the second dorsal and anal similar in outline and rather low; the caudal rounded and equal to head in length; the scales on sides ctenoid.

The color in alcohol yellowish brown, with eight or more dark brown spots, made up of many fine specks, on head, and two similar spots on base of pectoral; two short dark brown bands over nuchal region, and eight faint bands on ventral and dorsal surfaces which scarcely extend upon the sides; a dark spot on side of caudal peduncle; the dorsals, anal, and caudal marked by dark punctulations, first dorsal distinctly barred.

Here described from the type and only specimen, No. 7372 Bureau of Science collection, 13 millimeters in length or 17 millimeters over all, obtained by Alvin Seale at Puerto Galera, Mindoro. This minute fish seems to be distinct from the other species of this genus known from the East Indies and Samoa.

\section{Genus 16. OXYELEOTRIS Bleeker}

Oxyeleotris BleEkER, Esq. Syst. Nat. Gobioides, Arch. Neerl. Sci. Nat. 9 (1874) 302; Rev. Espèces Eleotriformes, Versl. Akad. Amsterdam 11 (1877) 21.

The subelongate to elongate body is cylindrical anteriorly. The head is acutely depressed above, densely scaled on the sides, not bearing spines. The scales of the trunk are ctenoid, 60 to 90 in a longitudinal series. The teeth in each jaw are in few rows, the upper jaw with a longer outer row, the lower jaw with the outer row longer anteriorly and the inner row conspicuously longer posteriorly, without true canines. The lower jaw is prominent, the mouth oblique. The gill openings are separated by a medium isthmus. Dorsal VI-I-8 to 10 ; anal I 8 to 9 . [Bleeker.]

I have seen no specimen of this genus.

\section{OXYELEOTRIS MARMORATA Bleeker}

Eleotris marmorata BlEEKkR, Nat. Tijd. Ned. Ind. 3 (1852) 424; GüNTHER, Cat. Fishes Brit. Mus. 3 (1861) 123; A. B. Meyer, Ann., Soc. España Hist. Nat. 14 (1885) 30.

Oxyeleotris marmorata BLEEKER, Rév. Espèces Eleotriformes, Versl. Akad. Amsterdam 11 (1877) 22.

Dorsal VI, I-9.or 10 ; anal I, 8 or 9 ; there are 85 to 90 scales in a longitudinal series and 22 to 25 in a transverse series; about 70 scales between the first dorsal and the snout.

The elongate body cylindrical anteriorly, compressed posteriorly, its depth 5.5 to 6 times in its length; the depressed pointed head $3 \frac{1}{3}$ to 4 times in the length; the profile of snout convex, the supraorbital space concave; the eye from 7 to 9 times in length 
of head, and 1.5 to 2.5 times in interorbital space; the lower jaw prominent; the maxillary extends to below middle of eye or stops just before posterior margin; the acute teeth in villiform bands, the outer row in upper jaw subequal and longer than the rest; in the lower jaw the posterior teeth of outer row and the inner row unequal, longer than the others, and in part subcanine; the groove from eye above operculum conspicuous; two or three grooves run obliquely from eye downward and backward across cheek; above two widely separated longitudinal grooves, united by two vertical, widely separated grooves; the scales on head, nape, and belly cycloid, those on sides ctenoid; the scales on preopercle and front of snout smaller than the rest of the scales on head; the anal papilla compressed and oblong; the first dorsal anteriorly obtuse, the depth of body twice or more than twice the shortest spine, the second and third spines longer than the others; the second dorsal obtuse, posteriorly rounded to angulate; the anal shorter but not or scarcely lower than second dorsal, and rounded to angulate posteriorly; the ventrals much shorter than the pectoral; the caudal obtusely rounded, longer than that part of the head behind eye.

The color above dusky green to dark olive brown, paler beneath; the iris green, the margin of pupil golden; the lower half of head irregularly spotted with pale rose; the forward part of body irregularly clouded and banded; posterior with three irregular transverse rosy or yellowish bars or stripes; the first dorsal very dark brown above, and sometimes also pale rose below; the other fins pale rose variegated with dark brown to dusky violet; the second dorsal and anal marked by longitudinal brown stripes, the pectorals, ventrals, and caudal with crossbars.

The above is taken from Bleeker's description in his Révision des Espèces Eleotriformes. Günther states that alcoholic specimens are yellowish, largely marbled with brown and with brown stripes along the series of the scales.

This handsome species reaches a length of 460 millimeters and inhabits the rivers and river mouths from Borneo to Sumatra. Meyer collected specimens in Laguna de Bay, but there is no other Philippine record.

\section{Genus 17. VALENCIENNEA Bleeker}

Valenciennea BLEEKER, Nat. Tijd. Ned. Ind. 11 (1856) 412; JoRDAN and SNYDer, Proc. U. S. Nat. Mus. 24 (1901) 42.

Valenciennesia BlEkKkR, Arch. Néerl. Sci. Nat. 8 (1874) 372; Esq. Syst. Nat. Gobioides, Arch. Néerl. Sci. Nat. 9 (1874) 307. 
This genus has the general shape of Eleotris but lacks an opercular spine and has no bony crests; the body moderately elongate, the obtuse head but little depressed; the mouth of medium size with subequal jaws; the upper teeth in one row, or with rudimentary additional inner rows on the premaxillaries; on the lower jaw they are in several rows, those of outer row conspicuously longer and unequal in size, with one or more lateral posterior canines on each side; the pharyngeal teeth needlelike, erect, with slightly hooked tips; the body covered with small ctenoid scales, 70 to 110 in a longitudinal series, the head naked; there are six dorsal spines, more or less than twice as high as the dorsal rays; the caudal obtusely rounded to lanceolate.

This genus includes five or six species of the East Indies and South Pacific, some of them very handsome in life.

Key to the Philippine species of Valenciennea.

$a^{1}$. Scales more than 100 .

$b^{1}$. Scales 105 to 110 ; dorsal VI, I-12; anal I, 12; five larğe ocellated spots on the side. V. longipinnis.

$b^{2}$. Scales 105; dorsal VI, I-18; anal I, 16 or 17 ; no ocellated spots on side. V. strigata.

$a^{2}$. Scales 90 or less.

$c^{1}$. Scales 80 to 90 ; teeth in one row above; side of head with three or four longitudinal roseate bands. V. muralis.

$c^{2}$. Scales 75; teeth in two rows above; side of head with six violet spots.

28. VALENCIENNEA LONGIPINNIS (Bennett)

V. violifera.

Plate 6, Fig. 1

Eleotris longipinnis BENNETT, Zoology, Beechey's Voyage (1839) Fishes, 64, pl. 20, fig. 3; GüNTHER, Fische der Südsee 2 (1875) 190; WEBER, Fische, Siboga Exped. 57 (1913) 449.

Valenciennesia longipinnis BLEEKER, Versl. Akad. Amsterdam 11 (1877) 93.

Eleotris muralis JoRdAN and SNYDER, Proc. U. S. Nat. Mus. 24 (1901) 42 (in part).

Dorsal VI, 1-12; anal I, 12; scales in a longitudinal series 105 to 110 ; in a transverse series, from origin of second dorsal to anal, about 40 .

The body elongate, low, subcylindrical, the posterior half wedge-shaped and laterally compressed, the depth 4.8 to 5 times in length; the head large, 3.4 times in length, with large bulging cheeks, elevated occipital region, and a well-developed, rounded, fleshy nuchal ridge extending back to first dorsal; the snout bluntly rounded, with convex profile, its length 2.5 times in head; the eyes very high up, obliquely directed downward and 
forward, and contained $5 \frac{5}{6}$ to 6 times in head, $2 \frac{1}{3}$ times in snout, and $1 \frac{1}{6}$ times in interorbital space; the jaws equal; the cleft of mouth does not quite reach a point under middle of eye; the teeth in upper jaw sharp and curved inwardly; those of lower jaw of irregular size, but all rather small for the size of the fish; the head naked except for posterior half of the region above opercle; all the rest of body covered with finely ctenoid scales except those on breast and belly which are cycloid; the dorsals very close together, the membrane of first being attached to first spine of second dorsal; the first dorsal rather high, third, fourth, and fifth spines longer than body depth, all the spines but the first two with threadlike tips; the last ray of both second dorsal and anal is elongated and extends upon base of caudal when depressed; the pectoral rather short and obtusely rounded; the caudal obtusely lanceolate to lanceolate, and contained about 2.9 times in length.

The color in alcohol pale yellowish brown, darker above and paler on lower half; on the sides are five large ocellated ringlike or hasplike brown spots with the upper side open and prolonged toward the back where they disappear; the first concealed by pectoral fin, the last just before base of caudal. In the middle of each ringlike part is a large brown spot; on the back are nine short, dark brown transverse bars; the first above the margin between preopercle and opercle, the second and widest above the posterior margin of opercle and pectoral base; the remaining seven uniformly spaced, the last in advance of the fifth lateral spot; on the sides are four longitudinal rows of spots, badly faded by the preservative; on side of head are three pearl-white narrow bands with broad dark margins; the first ends at upper end of gill opening; the lowest one begins at angle of mouth and, like the second, extends upon base of pectoral; on top of head and snout are scattered dark spots; the first dorsal has about seven narrow bands running diagonally upward and backward; the second dorsal has three rows of ocellated spots; the anal has a pearl-colored longitudinal band near its base; the caudal decorated with large ocellated spots; the entire mouth and gill cavity lined with purplish black.

This description is based upon two fine specimens, 120 and 124 millimeters long, or 167 and 161 millimeters long over all, from Canigao, an islet off the southwest coast of Leyte.

This beautiful fish has been confused with $V$. muralis, but is quite distinct, the number of scales being markedly different. The only previous Philippine record is that of Weber, who col- 
lected it at Sanguisiapo, an islet off the southeast coast of Tawitawi. It is known to occur from the Riu Kiu Islands, where it was discovered, to the Fiji Islands.

I have just received from San Juan, Siquijor Island, two specimens, 94 and 62 millimeters long, respectively. The ocellated rings on the sides and ten crossbands on the back were of a very beautiful shade of violet-red; the pearly bluish white bands on the sides of the head were bordered by red-violet. In life this fish must be of extraordinary beauty.

29. VALENCIENNEA STRIGATA (Broussonet)

Gobius strigatus BroussoneT, Ichthy. (1782) 1, Table 1.

Eleotris strigata BLOCH and ScHNEIDER, Syst. Ichth. (1801) 65; CUVIBR and VALENCIENNes, Hist. Nat. Poiss. 12 (1837) 189; GüNTHER, Cat. Fishes Brit. Mus. 3 (1861) 131; BubEKrR, Rev. Espèces Eleotriformes, Versl. Akad. Amsterdam 11 (1877) 89; GüNTHER, Fische der Südsee 2 (1875) 190, pl. 3, fig. E.

Valenciennea strigata JORDAN and SEALE, Bull. Bur. Fisheries 25 (1906) 383; EvmomanN and Seale, Bull. Bur. Fisheries 26 (1907) 104.

Dorsal VI, I-18; anal I, 16 or 17; there are 105 scales in a longitudinal series and 35 in a transverse series.

The elongate, laterally compressed body wedge-shaped, its depth 4.75 or 5 times and the pointed head 3 to 4 times in the length; the eyes lateral, their diameter 4 to 4.5 times in head, and equal to or 1.5 times in the convex blunt snout; the interorbital space equal to or $\frac{2}{3}$ of an eye diameter; the jaws equal, the maxillary extending to or failing to reach anterior margin of eye; the teeth in a single row, with two to four unequal canines in upper jaw and four to six backward-curving canines in the lower jaw, the other teeth smaller and more or less inclined to form two rows. The head and nape naked, with very small scales on sides of nape; the scales on trunk soon slightly ctenoid. The dorsal subcontinuous, second and third spines of first dorsal excessively elongated, with threadlike tips, fourth and fifth much shorter; the second dorsal and anal similar in height and outline, obtusely rounded anteriorly, acutely angled behind, their posterior rays reaching the obtusely rounded caudal when depressed.

In life the color greenish rose above, yellowish on sides and pearly on belly, all fading to white in alcohol; a blue, darkedged band extends from angle of mouth to posterior margin of opercle; there is a similar but smaller band on preoperculum and another on suboperculum; behind eye some circular spots 
of like color; the dorsals are crossed by a number of longitudinal rose or red stripes and the caudal has a broad red longitudinal band near upper and lower margins.

The above description is a compilation; I have not seen the species. Two very small specimens from Bacon, Sorsogon, were described by Evermann and Seale. This beautiful species occurs from Java to Tahiti.

30. VALENCIENNEA MURALIS (Quoy and Gaimard)

Eleotris muralis Quoy and Gaimard, MS., CUVIER and VALENCIENNES, Hist. Nat. Poiss. 12 (1837) 253, pl. 357; Günther, Cat. Fishes Brit. Mus. 3 (1861) 130; Fische der Südsee 2 (1875) 189.

Valenciennea muralis JoRdAN and SNYDER, Proc. U. S. Nat. Mus. 24 (1901) 42 (in part).

? Eleotris lineato-oculatus KNER, Sitzungsber. Akad. Wiss. 56 (1867) 720 , pl. 3, fig. 1 .

Valenciennesia muralis BLEEKgR, Versl. Akad. Amsterdam 11 (1877) 96.

Dorsal VI, I-12, but the soft rays varying from 11 to 15 ; anal I, 12; there are 80 to 90 scales in a longitudinal series from the gill opening to the base of the caudal fin and 25 to 30 between the origins of the second dorsal and anal fins.

The body elongate, fusiform and subcylindrical, with caudal peduncle laterally compressed; the depth contained from 5 to nearly 5.5 times in the length; the head blunt, its length about 3.25 to $3 \frac{1}{8}$ times in the total length; the snout convex, bluntly rounded, and contained 2.5 to 2.7 times in head; the eyes high up, oblique, their longest diameter directed diagonally downward and forward; they are contained $4 \frac{2}{8}$ to 6 times in head and $1 \frac{5}{6}$ or 2 times in snout; the interorbital space narrow, varying from $\frac{2}{3}$ to almost an eye diameter; the mouth slightly oblique, its gape extending to front margin of eye or a little more; the jaws subequal, with broad fleshy lips, the upper lip protractile; the teeth in one row in upper jaw, with three to five unequal, large, curved teeth anteriorly on each side; in the lower jaw the teeth in two rows anteriorly, one row posteriorly; the outer row ends laterally in one or two canines; beginning in front of dorsal fin is a low, rounded, fleshy, median scaleless ridge, which extends forward a distance equal to that from tip of snout to pupil; the dorsal spines have threadlike endings, second, third, and fourth prolonged much beyond membrane; the interspace between dorsals very short; the last dorsal ray much longer than the rest; the large pectoral as long as head without opercle; the ventrals small, and the rather broad, obtusely pointed cau- 
dal equals head in length. The head, bases of pectoral fins, and breast naked; the rest of body covered with ctenoid scales, very small anteriorly but becoming larger posteriorly.

The color of body in life greenish rose above, diluted below to rosy pearl; on each side of head are three or four longitudinal, slightly oblique, and more or less wavy red bands; on each side of upper half of trunk are two or three longitudinal roseate bands, which may be broken into spots; sometimes there are a few vertical red bands crossing these at right angles; there are several narrow diagonal red bands on first dorsal, and a black blotch at its summit between third and fourth spines; the second dorsal has two red lines running lengthwise, and the caudal is decorated with red spots; the anal has a red line running along its base; a black mucous membrane lines the back part of mouth.

In alcohol the red disappears and the general color is brownish gray or light brown; the bands on sides fade until often only the lower one is visible while the red spots and bands on fins vanish or but traces remain.

This handsome, trimly built little eleotrid is represented in the Bureau of Science collection by twenty specimens, from 37 to 92 millimeters in length, from the following localities: Bantayan Island; Puerto Princesa, Palawan; Balabac; Samal Island, Davao Gulf; and Sitankai.

This species occurs throughout the East Indies and ranges from the coasts of Ceylon and India to northern Australia and to Vanicolo and the Fiji Islands.

\section{VALENCIENNEA VIOLIFERA Jordan and Seale}

Valenciennea violifera JORDAN and SEALE, Bull. Bur. Fisheries 25 (1906) 383, pl. 52, fig. 2.

Head 3.45 in length; depth 5 ; eye 5 in head; Dorsal VI-I, 12; anal I, 12 ; scales 75 ; interorbital 5.50 ; snout 3.10 .

Body elongate, compressed; snout rounded; mouth large, lips rather thick, the angle of the jaws under middle of eye; jaws with 2 rows of small, curved, sharp-pointed teeth; opercle and preopercle entire; gillrakers short, soft, with elongate point on lower limb; caudal peduncle strong, its depth 2.50 in head; origin of spinous dorsal on line with base of ventrals; third and fourth spines of first dorsal slightly elongate, 1.14 in head; base of soft dorsal equal to head, its longest ray about 2 in head; base of anal 1.20 in head, its longest ray 1.25 in base, its origin midway between base of caudal and posterior margin of eye; pectoral 1.30 in head; ventral 1.90 in head; caudal rounded, equal to head.

Life colors of a specimen from Apia (very young), very pale olive, with two faint livid blue lateral streaks connected with cross lines of the same color; fins all pale; dorsal tipped with black. 
An adult specimen from Pago Pago was light olive, mottled with pale pinkish brown; a pinkish brown stripe from lower pectoral axil straight to base of caudal; six violet spots darker edged, on side of head; one on base of pectoral; dorsal light reddish, a jet black spot edged with white on the tips of the longest spines; caudal pale, mottled light green and pink at base; the larger examples have a black spot on upper part of caudal; blue spots plainer; anal light yellow; pink brown at base and dark-edged, often pink at base and edge; ventral and pectoral pale; pectoral without dark in axil.

Color in spirits dull yellowish white with tint of brown; some specimens show traces of 7 dusky blotches along back; five or six bluish white spots on opercle and cheek; an indistinct brownish line from axil of pectoral to caudal; belly and chin bluish white; third and fourth spines of dorsal tipped with black; spinous and soft dorsal with indistinct blue lines; caudal (except in young) with a black blotch on its upper middle portion; anal with narrow dark line at margin and another near the base; some specimens show a dusky tip to caudal; pectoral and ventral unmarked.

This handsome species is common in the crevices of the coral reefs about Apia and Pago Pago. It seems to be distinct from the two species muralis and sexguttata of the western Pacific. It has the head markings of the latter with the body markings of the former.

Seven specimens from Pago Pago and 23 from Apia. Specimens also from the island of Negros, P. I., collected by Dr. Bashford Dean. [Jordan and Seale.]

The above is quoted from The Fishes of Samoa, by Jordan and Seale, as I have no specimens for examination, though while I was in the United States I saw some of those collected by Dean on the south coast of Negros.

\section{Genus 18. PARVIPARMA g. nov.}

The elongate subcylindrical body is little compressed except the posterior fourth, while the dorsal and ventral profiles are nearly straight and parallel; the entire body covered with minute cycloid scales, more or less embedded and difficult to see, about 165 in a lateral and about 40 in a transverse series; the breast scaled over its posterior half; very small scales extend upon pectoral and caudal fins and on head above opercle; the remainder of head scaleless; the cheeks crisscrossed by lines of minute papillæ; the head rather short, broad, with a very heavy lower jaw and nearly vertical mouth, with several rows of teeth in each jaw; in upper jaw outer row composed of relatively large conical teeth; then follow four or five rows of minute villiform teeth; behind these are two backward-pointing canines, one on each side of median line; the outer row in lower jaw has four large coarse teeth on each side of symphysis; behind these are four rows of minute teeth like those in upper jaw; the eyes 
small, partly superior and partly lateral; the interorbital space broad, at least twice an eye diameter; the posterior margin of preoperculum marked by large pores which are also noticeable behind eye and beside each nostril; the vertical fins low, none of the rays elongated; the dorsals well separated, the distance between them greater than the length of the longest spine. Dorsal VI, I-10; anal I, 10. The pectorals and ventrals short, reaching less than halfway to anus; the caudal short and rounded.

The single species does not agree with any definition known to me. Type of genus, $P$. straminea sp. nov.

Parvus, small; parma, a small shield; in allusion to the small scales.

32. PARVIPARMA STRAMINEA sp. nov.

Plate 6, Fig. 2

Dorsal VI, I-10; anal I, 10; there are about 165 scales in a longitudinal series and 38 to 40 in a transverse series.

The depth contained 6.5 times, the head 5 times in the length; the head wider than the trunk, its greatest breadth $1 \frac{4}{9}$ in its length; the eye contained 6.5 times in head, and 2.5 times in the broad, very gently convex interorbital space; the snout very broad and blunt, its length 3.25 times in head and twice as great as the diameter of eye; the mouth very oblique, with a thick, heavy jaw and strongly projecting chin, giving a bulldoglike appearance; the dorsals widely separated, the length of base of first dorsal about 0.625 of the distance between the two fins; the caudal peduncle broad but not strongly compressed, its greatest depth contained 1.375 times in its length; the broad caudal fin rather short, its length equal to that of head; the anal papilla thin, short, and triangular. The other characters are given under the generic description.

The general color in alcohol straw yellow, bleaching to nearly white in front of ventrals, and darker on top of head and back; two parallel narrow brown bands extend along each side to base of caudal, the upper one beginning a little way back of eye, the other in the axil of pectoral; the caudal marked with semicircular bars of pale and dark brown spots; the other fins uniform pale brownish, like belly.

Here described from the type and only specimen, 65 millimeters long, collected by E. H. Taylor, in Saug River, a freshwater stream on the southern coast of Cotabato Province, Mindanao.

Stramineus, straw-colored. 


\section{Genus 19. PTERELEOTRIS Gill}

Ptereleotris GiLl, Proc. Acad. Nat. Sci. Phila. 15 (1863) 271.

Dorsal VI, I-24 to 32 ; anal I, 24 to 32 , the scales minute, cycloid, 150 to 170 in a longitudinal series; the sides of head naked; the caudal mostly scaled.

The body elongate, laterally compressed, not elevated, eyes large, mouth curved and oblique; the upper jaw has three rows of teeth, the outer one much larger than the others; the prominent lower jaw has one or two pairs of canines near the symphysis, the rest of the teeth small to minute; the gill openings separated by a wide isthmus; the lunate caudal as long as head; the dorsal and anal rays all undivided.

33. PTERELEOTRIS DISPERSUS sp. nov.

Plate 6, Fig. 3

Dorsal VI, I-24 to 25; anal I, 24; there are about 154 scales in a longitudinal series and about 42 in a transverse series.

The dorsal profile of the elongate, compressed body forms an almost straight line from occiput to caudal fin; the ventral profile gently curved, the greatest depth of body 6 times in its length; the head 4.5 times in length; the full, circular eye high up, its diameter 3.6 times in head, a little greater than the blunt snout which goes 4 times in head; the interorbital space a little more than an eye diameter and contained 3.2 times in head; the strongly curved, oblique mouth of moderate size, with a projecting lower jaw; the posterior extremity of the maxillary under front margin of eye; three rows of teeth in upper jaw, the outer one of large, conical, rather widely spaced teeth, the other rows of very small teeth; two pairs of canines near symphysis in lower jaw, with a few very small teeth behind these; between and in front of the canines some similar but much smaller teeth; the nostrils small and high up; the caudal peduncle short and deep, its depth $\frac{2}{7}$ more than its length; the pectorals of moderate size and approximately equal to the slender ventrals; the third dorsal spine longest, equal to or slightly exceeding depth; the tips of spines all elongated; the soft dorsal and anal both long and of similar shape; their anterior rays longest and equal to depth; the caudal lunate, and equal to head in length.

The entire body covered with very small cycloid scales, which extend forward on top of head as far as the line between opercle and preopercle; the remainder of head and the isthmus naked; 
the caudal scaled for most of its length and there are minute scales on the base of the preopercle; a line of widely spaced pores begins under anterior margin of eye and circles around beneath and behind eye; from above the last one a line of small dotlike warts crosses over to the other side; there are two pores on posterior margin of preopercle and one at its upper angle.

The color of the type in alcohol blackish brown; the first dorsal, pectorals, and ventrals lighter brown, second dorsal and anal blackish brown; the central rays of caudal brownish yellow, the marginal rays blackish brown. The cotype pale brownish, with dusky anal and second dorsal fins, and broad dusky upper and lower margins to the caudal fin, leaving its middle area pale; the pectorals and ventrals pale, first dorsal pale anteriorly with a dusky posterior portion.

Here described from two specimens, the type, 81 millimeters long, collected at Santo Domingo de Basco, Batan Island, Batanes Province, and the cotype, 54 millimeters long, from the south coast of Cotabato Province, Mindanao.

Dispersus, scattered, in allusion to its distribution.

\section{GOBIID AE}

THE TRUE GOBIES

This large, important, and difficult group comprises the typical gobies and contains the great mass of gobioid fishes. It includes those gobies in which the ventral fins are united to form a single organ, nearly always entire, rarely notched; across the base is a membrane, or frenum, which converts the united ventrals into a kind of vacuum cup, or sucking disk, by means of which the fish attach themselves more or less firmly to objects. The ventrals are composed of one spine and four or five rays; they may be long or short, pointed or rounded, even circular, with entire, lobate, or incised margins, and the frenum may be thin or thick, entire, crenate, lunate, or bilobed. The ventrals may be attached only at the base or may be fastened to the belly along their whole extent. In the species that live in mountain torrents the ventrals are a very efficient organ of adhesion. The spinous dorsal is present in all Philippine species, with from three to nine spines, but the vast majority have six spines. The dorsals are separate or may be united at their base, close together or far apart. The number of second dorsal and anal rays varies from five to thirty, but the majority of species have from eight to eleven. The pectorals are always well developed, 
but never have a scaly muscular base used for locomotion on land. The body may be covered with large to minute scales, 20 to 200 , ctenoid or cycloid, or may be partially or wholly naked; it may be more or less elongate, cylindrical, or laterally compressed; the eyes are not stalked or unusually prominent.

The teeth may be in one to many rows and may be fixed or depressible, erect or horizontal, simple and pointed, caniniform, or their tips enlarged, bilobed, or tricuspid, in either the upper or the lower jaw or in both jaws. The lips may have a band of movable teeth, but the palatines and vomer are without them except in a Samoan genus, which has three vomerine teeth.

The character of the teeth is a good one for the limitation of genera, but has been relied upon too much by Bleeker, since many descriptions merely state "wide band of teeth" or "bands of fine teeth," or similar, indefinite statements. The proper observation of the teeth is a very difficult matter in many species, and in the case of the smaller gobies involves the constant use of the compound microscope. The characters given by Bleeker in his Esquisse are often untenable, as he never saw the types and merely compiled his definitions; yet some of the genera thus created are valid, but must stand on other characters than those given by him.

The Gobiidæ are abundant in and about coral reefs, rivers, lakes, and mountain streams. A number of the small or minute kinds living in lakes or brooks are exclusively fresh-water fishes; but the vast majority, including all those of much economic importance, spawn in the sea, and the young ascend rivers and live in streams until mature. Indirect evidence is conclusive that those which survive the perilous journey to the sea return to their fresh-water haunts and continue to make the trip each way every year as long as they live.

Most of the true gobies are dull or plain-colored little fishes, their colors harmonizing so well with their surroundings that they are nearly invisible when at rest. Like many other fishes, many of them can change their markings or colors to suit the amount of light or to match changes in their environment. Some of them, however, are very beautifully colored and a few, especially of the coral-reef dwellers, are brilliantly colored. The males of some of the catadromous species are also very handsome, at least during the breeding season, when their colors vie in beauty and delicacy with those of the typical coral-reef fishes. Practically all of them are bottom dwellers, at home on sand, 
gravel, or mud, but not habitually swimming freely in the open waters of sea, river, or lake. Some species live in the interstices of coral; others hide under stones at or near tide mark, or dwell in tide pools. So far as I am aware, none burrow in the mud as do various species of the eel-like Gobioididæ.

Luzon seems to be particularly rich in genera and species of small lake and brook gobies, each geographical unit of the island having species apparently limited to that particular watershed or fluvial system. When the streams of all the large islands have been as well worked as have those of parts of Luzon and Panay, we may confidently expect a very large increase in the number of Philippine species of Gobiidæ known. However, no great increase is to be expected in Mindanao, since over a large part of the island Cyprinidæ take the place of Gobiidæ as brook dwellers.

There are described here forty-eight genera and one hundred twenty-seven species of Gobiidæ, of which ten genera and fiftyfour species are new. This large number is probably less than three-fourths of the species actually occurring in the Philippines.

\section{Gobiidr from the Philippines and the China Sea.}

[New generic names are printed in bold-faced type.]

\begin{tabular}{|c|c|c|c|c|c|}
\hline Genus. & Species. & $\underset{\text { species. }}{\text { New }}$ & Genus. & Species. & $\begin{array}{c}\text { New } \\
\text { species. }\end{array}$ \\
\hline Aboma & 1 & 0 & Itbaya & 1 & 1 \\
\hline Acanthogobius & 1 & 0 & Lophiogobius & 1 & 0 \\
\hline Amblychaeturichthys & 1 & 0 & Macgregorella & 2 & 1 \\
\hline Amblygobius & 7 & 2 & Microsycidium & 3 & 3 \\
\hline Amoya & 1 & 0 & Mirogobius & 2 & 2 \\
\hline Aparrius & 2 & 1 & Mistichthys & 1 & 0 \\
\hline Apocryptichthys & 1 & 1 & Oplopomus & 2 & 0 \\
\hline Apocryptodon & 3 & 3 & Oxyurichthys & 8 & 3 \\
\hline Bathygobius & 4 & 1 & Pandaka & 2 & 2 \\
\hline Biat & 1 & 0 & Parachaeturichthys & 1 & 0 \\
\hline Caragobius & 1 & 0 & Paragobiodon & 3 & 0 \\
\hline Chaeturichthys & 1 & 0 & Parapocryptes & 2 & 1 \\
\hline Chlamydes & 1 & 1 & Redigobius & 1 & 0 \\
\hline Chonophorus & 4 & 0 & Rhinogobius & 12 & 4 \\
\hline Cingulogobius & 1 & 1 & Sicyopterus & 6 & $\mathbf{5}$ \\
\hline Creisson & 1 & 0 & Synechogobius & 1 & 0 \\
\hline Cristatogobius & 1 & 1 & Tamanka & 4 & 4 \\
\hline Cryptocentrus & 5 & 2 & Triaenopogon & 1 & 0 \\
\hline Galera & 1 & 1 & Tridentiger & 2 & 0 \\
\hline Glossogobius & 3 & 0 & Tukugobius & 3 & 3 \\
\hline Gnatholepis & 7 & 2 & Vaimosa & 9 & 7 \\
\hline Gobiodon & 3 & 1 & Waitea & 1 & 0 \\
\hline Gobiosoma & 2 & 1 & Zonogobius & 1 & 0 \\
\hline Gobius & 4 & 0 & & - & - \\
\hline Illana & 1 & 0 & & 127 & 54 \\
\hline
\end{tabular}


Key to the Philippine and China Sea genera of Gobiidx.

$a^{1}$. Ventral fins not forming a short, rounded, cup-shaped disk more or less adherent to belly; lower lip without a band of movable horizontal teeth; lips never with bands of teeth.

$b^{1}$. First dorsal always with fewer than six spines.

$c^{1}$. Body naked; first dorsal with four or five spines; teeth in one row

in both jaws, with an inner pair of canines behind symphysis of lower jaw. Mirogobius. $c^{2}$. Body scaled.

$d^{2}$. Dorsal spines three, very low; head naked; teeth in one row; no canines

Mistichthys.

$d^{2}$. Dorsal spines five; cheeks and opercles covered with large scales; teeth in several rows. Redigobius.

$b^{2}$. First dorsal with six or more spines.

$e^{1}$. Body scaled.

$f^{2}$. Teeth all simple.

$g^{1}$. No barbels.

$h^{2}$. Conspicuous ridges and flaps of skin on top and sides and underparts of head.

$i^{1}$. Scales 38 to 48 ; pectoral and caudal not greatly elongate, narrow, and pointed. Macgregorella.

$i$. Scales 70 ; pectoral and caudal very narrow, pointed, and elongate Galera.

$h^{2}$. No conspicuous ridges and skinny flaps on top and sides of head.

$j^{1}$. Pectoral with free silky rays above.

$k^{1}$. Sides of head naked.

$l^{1}$. Tip of tongue rounded.

Gobius.

$l$. Tip of tongue more or less notched......... Bathygobius.

$k^{2}$. Sides of head more or less scaled.

$j^{2}$. No free silky rays on upper part of pectoral.

$m^{1}$. Ventrals very short, nearly circular but not adnate to belly, with a thick bilobed or deeply crenate frenum; head large, cheeks bulging, lips thick; first dorsal spines seven or six; scales 36 to 44 .......... Tukugobius. $m^{2}$. Ventrals not as above.

$n^{1}$. Scales mostly large, ctenoid, not over 38 ; second dorsal and anal short, never more than 1-11.

$o^{1}$. Caudal fin not lanceolate and greatly lengthened.

$p^{2}$. First dorsal with six spines.

$q^{1}$. Sides of head more or less scaled.

$r^{2}$. Cheeks and opercles covered with large scales.

Gnatholepis.

$r^{2}$. Cheeks and opercles never both entirely covered with scales.

$\mathbf{8}^{\mathbf{1}}$. Upper half only of cheeks and opercles covered with small scales. Creisson.

$\boldsymbol{8}^{2}$. Cheeks naked; opercles covered with large scales; 26 to 38 scales in a longitudinal series

Vaimosa. 
$q^{2}$. Sides of head naked, or with only a few small scales on upper part of opercle.

$t^{2}$. Tongue deeply notched, head depressed anteriorly; chin strongly projecting.

Glossogobius.

$t^{2}$. Tongue truncate or rounded at tip; chin not strongly projecting.

$u^{2}$. Rear margin of preopercle toothed; first spine of both dorsals hard, stiff, sharppointed

Oplopomus.

$u^{2}$. Rear margin of preopercle never toothed; dorsal spines never hard, stiff, sharppointed.

$v^{2}$. Head with a high thin skinny crest.

Cristatogobius.

$v^{2}$. No thin high skinny crest on head.

$w^{1}$. Head very deep, subglobose, body short, plump; canines behind symphysis of lower jaw.

Paragobiodon.

$w^{2}$. Head not subglobose; no symphysial canines behind teeth in lower jaw.

$x^{2}$. Gobies of ordinary size and appear. ance; neither minute nor with numerous pale or white vertical crossbands

Rhinogobius.

$x^{2}$. Either minute and plain, or small and crossbanded with pale stripes.

$y^{1}$. Body before dorsal naked.

$z^{1}$. Color plain; adults minute, 7.5 to $\mathbf{1 6 . 5}$ millimeters long; scales 22 ; dorsal VI, I-6 or 7; anal I, 5. Pandaka.

$z^{2}$. Color red or brown, seven or eight vertical crossbands on anterior half ....... Zonogobius.

$y^{2}$. Body scaled before dorsal; twelve vertical white crossbands from snout to caudal.. Cingulogobius.

$p^{2}$. First dorsal spines seven or eight; scales 28 or 29

in Philippine species

Aboma.

$o^{2}$. Caudal fin lanceolate and greatly lengthened.

$a a^{2}$. Maxillary normal; scales 26 to 29.

Aparrius.

$a a^{2}$. Maxillary greatly prolonged backward; scales 36 to 38

Waitea.

$n^{2}$. Scales small to minute, 40 or more, mostly 50 or more except in Aparrius, Tamanka, and Tukugobius.

$b b^{1}$. Ventrals very short, rounded, not adnate; frenum thick, bilobed or deeply crenate; first dorsal spines seven or six; scales 36 to 44 .... Tukugobius

$b b^{2}$. Ventrals and frenum of ordinary type. 
$c c^{2}$. First dorsal spines six only.

$d d^{2}$. Inner edge of shoulder girdle with two or more

fleshy flaps or papillæ.

Chonophorus.

$d d^{2}$. No fleshy flaps or papillæ on inner edge of shoulder girdle.

$e e^{2}$. Caudal rounded or pointed, irut not lanceolate and elongated.

$f f^{1}$. Cheeks naked; opercles covered with small scales; 38 to 54 scales in longitudinal series; second dorsal and anal rays seven or eight Tamanka.

$f f$. Cheeks and opercles both naked.

$g g^{1}$. Scales ctenoid, 46 to 70 .

$h h^{1}$. Nape naked to first dorsal; scales 46 to 48; cheeks with two longitudinal rows of papillæ Amoya.

$h h^{2}$. Nape scaled to eyes except in one species; 52 to 70 scales in lateral series; no longitudinal rows of papillæ on cheeks. Amblygobius.

$g g^{2}$. Scales cycloid, 75 to 105 ; mouth large, not opening widely, chin prominent.

Cryptocentrus.

$e e^{2}$. Caudal lanceolate, much lengthened.

$i i^{2}$. Head and nape naked, with many conspicuous ridged lines and seams of papilla on top and sides; body elongate; caudal and pectoral very narrow, elongate, pointed; scales 70 ; second dorsal I, 13; anal $I, 11$. Galera.

$i i^{2}$. Top and sides of head scaled, or naked and smooth, without conspicuous papillate ridged lines and seams.

$j j^{2}$. Lower jaw with two rows of teeth and an inner row of stout curved canines; scales 104; second dorsal I, 15; anal I, 16

Biat.

$j j^{2}$. Inner row of teeth in lower jaw not canines.

$k k^{2}$. Teeth in lower jaw erect, not in one row.

$l l$. Scales 38 to 42 ; tongue notched; two or three rows of teeth in each jaw; second dorsal I, 10 to 11; anal I, 9 to 11 Aparrius.

$l l^{2}$. Scales 40 to 90 ; tongue rounded; one row of teeth in upper jaw, two to four rows in lower jaw; an ocular tentacle in some species; second dorsal I, 10 to 13; anal I, 10 to 14.

Oxyurichthys. 
$k k^{2}$. Teeth in lower jaw more or less horizontal, in one row.

$m m^{1}$. Teeth in lower jaw inclined outward with a pair of symphysial canines behind; scales 65 to 75 ; no snout flap with teatlike projections; second dorsal with 12 to 27 rays; anal 13 to 26 rays.

Parapocryptes. $m m^{2}$. Lower jaw with long, blunt, horizontal teeth, no symphysial canines; head very flat anteriorly; scales 75 to 90 ; a pair of large teatlike snout flaps hanging down over mouth; second dorsal with 24 to 26 rays; anal 23 to 26 rays Apocryptichthys.

$c c^{2}$. First dorsal spines more than six.

$n n^{1}$. Dorsal VIII, I-14 to 18; scales 68 to 72 ; cheeks more or less scaled. Acanthogobius. $n n^{2}$. Dorsal IX or VIII, I-18 or 19 ; scales 88 to 90 ; cheeks entirely naked; posterior part very slender and greatly elongated.

Synechogobius.

$g^{2}$. Barbels on chin, or edge of lower jaw, or underside of head, or on all of them.

$0 o^{1}$. First dorsal spines six.

$p p^{1}$. Two fleshy barbels on chin; head naked; caudal rounded, shorter than head, without an ocellus. Illana.

$p p^{2}$. Many small barbels under lower jaw; head scaled; caudal pointed, much longer than head, a black ocellus near its base.

Parachaeturichthys.

$0 o^{2}$. First dorsal spines more than six.

$q q^{1}$. First dorsal seven; head very large, broad, flat, with many barbels on underside; first row of teeth in each jaw entirely exposed.

Lophiogobius.

$q q^{2}$. First dorsal eight; three pairs of barbels under lower jaw.

$r^{2}$. Second dorsal I, 14 to 16 ; anal I, 12 to 13 ; scales 35 to 40; no fleshy papillæ on inner edge of shoulder girdle.

Amblychaeturichthys.

$r r^{2}$. Second dorsal I, 21 to 24 ; anal I, 17 to 19 ; scales 47 to 57; three fleshy papillæ on inner edge of shoulder girdle

Chaeturichthys.

$f^{2}$. Teeth more or less bilobed or tricuspid.

$\mathbf{8 8}^{\mathbf{1}}$. One row of teeth in each jaw, bilobed and more or less horizontal in lower jaw, with a pair of postsymphysial canines.

Apocryptodon.

$88^{2}$. Two rows of teeth in each jaw, the outer row tricuspid.

$t t^{1}$. Sides of head with rows of barbels. Triaenopogon.

$t t^{2}$. No barbels on head Tridentiger. 
$e^{2}$. Body nearly or entirely naked.

$u u^{1}$. Posterior third with minute cycloid scales, the rest naked; eyes minute, under the skin; dorsal and anal very long, continuous with caudal. Caragobius. $u u^{2}$. Entirely naked or a few barely visible scales at posterior end, dorsal and anal not continuous with caudal.

$v v^{1}$. Teeth in lower jaw tricuspid; an erect crest from tip of snout to nape Itbaya. $v v^{3}$. Teeth all simple; no crest on head.

$w w^{1}$. No symphysial canines in lower jaw; body spindle- or tadpole-shaped Gobiosoma. $w w^{2}$. Canines behind symphysis of lower jaw.

$x x^{1}$. Body very small, elongate, of ordinary shape; teeth in one row; first dorsal spines four or five. Mirogobius. $x x^{2}$. Body very deep, oval, much flattened laterally; teeth in two or more rows; first dorsal spines six.... Gobiodon. $a^{2}$. Ventral fins very short, nearly circular, cup-shaped, more or less adherent to belly; teeth unlike those of other gobies; in upper jaw tricuspid under microscope, or bicuspid or clavate; lower lip with a row of movable, more or less horizontal teeth; lower jaw with symphysial canines and a row of hooked teeth or canines.

$y y^{2}$. Teeth of upper jaw more or less club-shaped, blunt, fixed, in one row; scales 30 to 40 . Microsycidium.

$y y^{2}$. Teeth of upper jaw movable, curved, tricuspid in Philippine species; scales 50 to 85 . Sicyopterus.

\section{Genus 20. MIROGOBIUS g. nov.}

The body laterally compressed, with a robust blunt head, the dorsals far apart; the mouth large, oblique, with a single row of long, stout, widely spaced, curved teeth in each jaw and a pair of postsymphysial canines in lower jaw, behind the outer row; in one species the males only have canines; the tongue notched; the skin is naked or there may be a few tiny cycloid scales at or near base of caudal fin; the caudal and pectoral both rounded, shorter than head; the ventrals narrow, pointed, shorter than head, not adherent to belly, with a broad frenum which forms a subtubulate sucking disk; the gill openings large, extended forward along throat, the isthmus narrow, branchiostegals five. Dorsal IV or V, I-7: anal I, 8 to 10.

In the combination of characters found in its fins, teeth, and scaleless body this genus stands alone. Type of genus $M$. stellatus sp. nov.

Mirus, wonderful.

Key to the Philippine species of Mirogobius.

$a^{1}$. Anal I, 10; a pair of post-symphysial canines in lower jaw of both sexes; color darkened by many black stellate spots. M. stellatus. 
$a^{2}$. Anal I, 8 or 9 ; post-symphysial canines present in lower jaw of males only; females with minute, males with large teeth; color yellowish white

M. lacustris.

34. MIROGOBIUS STELLATUS sp. nov.

Plate 6, Fig. 4

First dorsal usually IV, sometimes V; second dorsal I-7; anal I, 10.

The body laterally compressed with elongate caudal peduncle and large blunt heavy head, the dorsal profile slightly convex, becoming much arched in ripe females, the depth 4.3 to 5.25 times in the length; the head 3.16 to 3.4 times in the length, much wider than body, with full cheeks, its depth and breadth equal to or the depth 0.1 greater than the breadth, approximately 0.75 of its length; the short snout bluntly rounded, equal to eye, 3.6 to 3.875 times in head; the eyes lateral, very high up, the broad interorbital space an eye diameter in width; the mouth large, strongly oblique, its origin as high or nearly as high as upper margin of eye, lower jaw prominent, projecting, chin strongly oblique, posterior angle of maxillary beneath front margin or middle of eye; the teeth as given for the genus; the body naked, covered with a tough skin only, often lined in such a way as to simulate the presence of scales, but neither the lens nor the compound microscope reveals the presence of any except on a few of the largest males, which may have from two to several tiny cycloid scales at base of caudal or on caudal peduncle; the first dorsal composed of four, or sometimes five, very slender spines connected by a membrane, the first or the second longest, about 0.75 of the depth and about twice in head; the remaining spines little shorter except that the fifth spine, if present, is much shorter; the second dorsal distant from first, the spines of the latter reaching scarcely halfway to the former; the second dorsal and anal of similar shape, sharply angulate posteriorly, the rays of nearly uniform height or the posterior rays elongate but never reaching base of caudal when depressed, the two fins of equal height or more often the second dorsal higher than the anal, 1.25 to 2 times in head, usually about 1.66 times; the caudal bluntly rounded, 4 to 4.75 times in the length, never as long as head; the depth of the long slender peduncle 2.3 to 2.7 times in its length, which is $\frac{5}{6}$ to 0.9 the length of head; the pectoral broad, rounded, 1.25 to 1.65 times in head; the ventrals small, narrow, usually 
pointed, basal third subtubulate, 2 to 2.2 times in head, not nearly reaching anal papilla, which is short, thick, and cylindrical in females, very elongate, slender, and pointed in males.

The color in alcohol varies from yellowish to whitish, more or less thickly spattered over sides and dorsally with small black stellate or dendritic spots, with a clear linear space left running longitudinally from axil of pectoral to middle of caudal; the top of head, snout, and cheeks more or less blackish or black marbled or spotted, lips black; some specimens not otherwise different are nearly white, with the black spots on head and body reduced to fine specks; the first dorsal is finely'specked with dusky or may be entirely colorless; the remaining fins, except the colorless ventrals, more or less thickly dotted with fine black specks.

I have examined one hundred ten specimens, ranging in length from 12 to 21 millimeters, collected January 26, 1926, by G. A. Lopez from the small mountain lake beside the sitio Lanigay, Polangui municipality, Albay Province. This species reaches maturity when about $\mathbf{1 5}$ millimeters long, females of that length having the abdomen enormously distended with eggs ready to spawn. Unlike most of the other minute Philippine gobies, this species is firm and tough, its fins not readily breakable, and it endures much handling without harm.

Stellatus, covered with stars.

35. MIROgobiUS LACUSTRIS sp. nov.

Tagalog name, dolong.

Dorsal V (rarely IV), 1-7; anal I, 9 or 8.

The laterally compressed body has an elongate caudal peduncle, with a large blunt heavy head in males, the head slenderer in females, the dorsal profile slightly convex, the depth 4.4 to 4.8 times in the length; the head about 3.6 times in length, wider than body; the snout very wide and blunt in males, narrower but equally blunt in females, equal to or slightly larger or smaller than eye, 4.1 to 4.6 times in head; the eyes high up, lateral, the convex interorbital space more than an eye diameter in width; the large mouth is strongly oblique, with prominent, projecting lower jaw, the chin strongly oblique, the posterior angle of maxillary beneath front margin or anterior portion of eye; in males the teeth are long, stout, curved, widely spaced, those of lower jaw all visible when mouth is closed; a pair of canines behind symphysis of lower jaw, back of outer row of teeth; 
in females the teeth are minute, in one row only, without a pair of inner canines in lower jaw, and with none of the teeth visible when mouth is closed; the skin naked, with fine longitudinal striæ; the first dorsal has five (rarely four) slender spines, the first and second longest, the fifth very much shorter; the first dorsal reaches less than halfway to second dorsal, the anterior spines of the latter much longer and twice as stout as the first dorsal spines, highest posteriorly except the last, which is very short; the second dorsal and anal of similar shape, angulate posteriorly, falling far short of caudal when depressed, the anal lower than second dorsal; the caudal subtruncate, shorter than head; the pectoral pointed, equal to or a little shorter than head; the small narrow ventrals very short, with subtubulate basal portion, about 2.66 times in head, reaching much less than halfway to anal papilla, which is very short and thick in females, threadlike and pointed in males.

The color in alcohol yellowish white or rich cream, the eyes silvery blackish to steel gray; most specimens have a few black specks on snout and chin, and some have specks scattered over back of head and a row along base of anal; the fins all colorless, but the caudal shows indications of being crossbarred by many rows of minute specks.

This species is caught in large quantities in Laguna de Bay near Calamba, Los Baños, Lumbang, Santa Cruz, and in fact all around the lake shore during the rainy season. At other times the shrimp fishermen catch the fish in limited quantities, mixed with the common lake shrimp. It is probable that they live on or near the bottom in the deeper parts of the lake, and are only seen in large schools when they come to shoal water along shore in the rainy season.

They are fried in cakes, cooked with vinegar, made into sinagong, or stew, and pickled, and are a greatly esteemed delicacy. At times they occur in the Manila market.

Mature adults vary from about 15 to over 19 millimeters in length, the males averaging shorter than the females. The last named are much distended when in spawning condition.

I am indebted to Miss Uichanco, biology instructor of the University of the Philippines High School, and to Dr. L. B. Uichanco, professor of entomology, College of Agriculture, Los Baños, for calling my attention to this little goby, and to Doctor Uichanco for securing for me a large series of specimens.

Lacustris, dwelling in lakes. 
Genus 21. MISTICHTHYS H. M. Smith

Mistichthys H. M. SMITH, Science N. S. 15 (1902) 30; Bull. U. S. Fish Comm. 21 (1902) 167.

The body elongate, compressed, head rather large; dorsal fins widely separated, the first very low, of three weak spines joined by a membrane, the second dorsal high, with one spine and six to eight branched rays; anal fin similar to second dorsal, I, 8 to 10 ; pectorals long, pointed; ventrals I, 5, coalescent, not adnate to abdomen; caudal well developed, blunt or truncate; a single row of rather long, curved, conical teeth in each jaw; scales large, ctenoid, 20 to 25 in a longitudinal series, the head naked; gill membranes joined to isthmus; a large genital papilla in each sex; coloration plain; size minute, the males rather smaller than the females.

A Philippine genus with but one singular species.

36. MISTICHTHYS LUZONENSIS H. M. Smith

Plate 7, Fig. 1

Mistichthys luzonensis H. M. SMITH, Science N. S. 15 (1902) 30;

Bull. U. S. Fish Comm. 21 (1902) 167, 22 plates and 2 text figures.

Bicol name, sinarapan.

Dorsal III, I-6 to 8 ; anal I, 8 to 10 ; there are 23 or 24 scales in a longitudinal series and 6 in a transverse series.

The body elongated, subcylindrical anteriorly, posterior half laterally compressed, dorsal profile nearly horizontal, belly convex, depth 3.9 to 4.1 in length, females slightly deeper than males; the head large, gently convex above, round pointed, 3.3 times in length; the short, bluntly pointed snout gently curved or with an anterior hump, its length $\frac{2}{8}$ the diameter of eye; the eyes large, lateral, 3.1 to 4 times in head; the interorbital space about twice in eye; the mouth large, strongly oblique, lower jaw projecting, posterior angle of maxillary beneath anterior or central part of eye; the body covered with readily deciduous scales, which extend forward of first dorsal as far as posterior margin of opercle, but head entirely naked; the dorsals far apart, the distance between them a little less than half the length of head; the first dorsal low, of weak spines, their height varying from less than half to more than an eye diameter; the second dorsal and anal similar in shape, their origins opposite, but base of anal longer; the anterior rays of second dorsal twice as long as the last two; the anal rays all about the same height except the last two, which are much shorter; the longest rays 
of vertical fins about $\frac{2}{8}$ the length of head; the depressed fins reach about halfway to caudal; the pointed pectorals reach as far back as above anal papilla; the ventrals very small, slender, pointed, extending much less than halfway to anus; the caudal large, nearly truncate, its length 0.75 to 0.875 that of head; the anal papilla large and conspicuous, in males long, slender, tapering, its length varying from a little less to much more than an eye diameter; the papilla in females twice as thick, and about half as long, bluntly rounded.

In life these minute fish are transparent, the large eyes showing the only color, black. Alcoholic specimens have the body uniform whitish, with a few dark or black spots scantily sprinkled over sides, back, and head; the large prominent iris deep black, the pupil white; the caudal faintly crossbarred by many rows of minute dark brown specks; the other fins colorless; in some specimens tip of snout black or dark; there may be a faint black vertical stripe under eye and a row of black or dark brown spots at base of anal.

Here described from many specimens collected by me in Lake Buhi, Camarines Sur, Luzon, the only place where this exceedingly interesting species occurs. The fins of my specimens do not agree with Smith's figures.

This fish is probably next to the smallest known vertebrate, having an average length of $\mathbf{1 2 . 5}$ millimeters, the males somewhat smaller than the females, averaging shorter and slenderer. It is a little larger than Pandaka pygmaea sp. nov.; there are several other species of fish nearly as short, notably of the genus Eviota; but all of them, as far as I am aware, are bulkier. Males are sometimes mature when under 10 millimeters in length, their maximum size being 13.5 millimeters. Occasionally one finds ripe females a little over 11 millimeters long, while the largest I have examined are only 14 millimeters in length.

This tiny goby occurs in vast numbers in the lake, from near the shore line out to where the water is at least 10 or 12 meters deep, and it breeds throughout the year. According to the inhabitants of Buhi, the eggs float at the surface of the lake, covering large areas, especially during sunny days in March and April. Specimens collected by me in the latter part of September, and by Mr. Alejo G. Arce in January, were breeding. When hatched the young swim at first at the surface, but after a short time go to the bottom to live. 
I believe that sinarapan rise to the surface with the diurnal movement of the plankton on which they feed. The unusual method used to capture them is based on this habit and provides a roosting place on which they gather in swarms. From time immemorial they have been caught in large quantities by the people living about the lake and are regarded by them as a staple article of diet of superior delicacy. The right to catch them is let by the municipality to the highest bidder, who then has the exclusive fishing privilege for such part of the lake as he has leased.

A full-grown bamboo stalk, 10 meters or more in length, is cut, the butt sharpened, the branches removed except the three or four uppermost twigs, and a palm leaf wrapped around the topmost meter or two. The contrivance, called abung, is then set firmly into the lake bottom where the water is deep enough to leave a little of the tip and a spur of the palm leaf protruding above the surface so the fisherman can find it easily. During the day the sinarapan come to rest upon the palm leaf. About the middle of the afternoon the fisherman goes out to the abung which he has scattered about in his leasehold, and begins to fish with a triangular net, or sarap, made of sinamay, a kind of cloth made of abacá fiber. The sarap is mounted on a Yframe of bamboo and with it the abung is swept from the bottom of the palm leaf to the top, and usually from a half liter to a liter of sinarapan are caught on each. The fish are dumped into a large basket from which the water drains at once, leaving what appears to be a mass of some strange wriggling, skipping, transparent, insect larvæ, in which the large black eyes are the only conspicuous part.

The sinarapan cannot be caught along shore, though they can readily be seen there, because in the shallow water they are protected by the dense masses of Potamogeton, water hyacinth, algæ, and other plants amid which they dwell, and where a net cannot be used.

Mingled with the sinarapan and feeding upon them are larger fishes of various kinds, so that occasionally eels, kotnog (Hemiramphus cotnog $\mathrm{H}$. M. Smith), and several kinds of larger gobies are caught when the fisherman sweeps his net over an abung.

Sinarapan are fried in oil, or boiled with vegetables, and have a delicious flavor. When more are caught than the local market demands the surplus is salted or dried in cakes and exported to the neighboring towns in Camarines Sur and Albay Provinces. 
Lake Buhi is a beautiful expanse of water, of irregular bilobed shape, about 50 meters in average depth, and about 4 or 5 kilometers wide by 7 or 8 kilometers long. It lies at an elevation of about 100 meters and is surrounded by lofty rugged mountains, which along much of its coast line rise precipitously from the shore. The lake is well supplied with a goodly variety of fishes, some of them known from only Bicol River and its tributaries, of which Lake Buhi is a feeder, but sinarapan occur only in the lake.

Jagor was the first writer to notice these tiny gobies and he stated that they were caught and eaten daily in enormous quantities. His specimens, collected in November, 1859, were sent to Doctor Peters of Berlin, along with other fishes from Buhi. Peters evidently did not examine them closely and probably thought they were the young of Gobius dispar, one of his new species, also from Lake Buhi.

They received no further notice until the American occupation, when Dr. Zeller and Dr. F. W. Richardson, of the United States Army, stationed at Buhi, sent specimens to Dr. H. M. Smith, of the Bureau of Fisheries, who described them as a new genus and species. The Bureau of Science collection contains several thousand specimens.

Genus 22. REDIGOBIUS g. nov.

This genus is established to receive Gobius sternbergi H. M. Smith, a species described by him from Lake Buhi, Camarines Sur Province, Luzon. It is said to have five first dorsal spines; in other respects it agrees with Gnatholepis. The published figure bears a remarkable resemblance to female specimens of Vaimosa dispar (Peters), except that it has scaled cheeks. Extensive collecting in Lake Buhi during the past year has failed to reveal this fish there. It is known from only six specimens in the United States National Museum, collected in 1901.

Redigo, reduced in number, in allusion to the reduced number of dorsal spines.

\section{REDIGobiUs STERNBERgI (H. M. Smith)}

Gobius sternbergi H. M. SMrTH, Bull. U. S. Fish Comm. 21 (1901) 169, with figure.

Gnatholepis (?) sternbergi JORDAN and RICHARDSON, Check List Phil. Fishes (1910) 47.

Dorsal V, I-7; anal I, 7; 25 or 26 scales in a longitudinal series, 8 in a transverse series, and 12 before first dorsal. 
The form elongate, rather robust, slightly compressed laterally, the depth 4 times in length; the head large, about $\frac{1}{3}$ the length (3.36 times, according to the figure), both the upper and the lower profiles convex; the mouth rather small, terminal, nearly horizontal, the posterior angle of maxillary not extending to a vertical from anterior edge of pupil; the snout short and very blunt, boldly convex, about 0.75 of an eye diameter in length; the eye large, bulging, lateral, less than 4 in head; the interorbital breadth one-half eye; the teeth in upper jaw in about three irregular rows, those of outer row largest; teeth in lower jaw in a band, some larger than others and caninelike; scales large, those on sides, abdomen, and most of back finely ctenoid, those on anterior part of back mostly cycloid; posterior edges of scales angular; opercle, preopercle, and top of head as far forward as interorbital space covered with large cycloid scales; the first dorsal highest anteriorly; the second dorsal and anal similar in shape, the posterior rays longest, not nearly reaching caudal when depressed, the next to the last ray of second dorsal 1.7 times in head, anal a little lower; the depth of caudal peduncle twice in its own length, 2.27 times in head; the broadly pointed caudal as long as head; the pectorals long, the central rays produced and extending back above origin of second dorsal; the ventrals long, reaching nearly or quite to vent.

Color in alcohol, head, sides, and back dusky, underparts white; sides marked by about a dozen short, irregular, vertical, blackish blotches, a prominent one above base of pectorals; muzzle dark; a dark area on opercle; anterior dorsal pale at base, blackish distally; second dorsal irregularly marked with dark stripes; anal and caudal dusky; pectorals and ventrals plain.

Types (No. 50536, United States National Museum), six specimens, 20 to 27 millimeters long, collected in Lake Buhi, by Dr. F. W. Richardson, July 5, 1901.

The above description is compiled from Smith's account, plus measurements taken from his figure.

Extensive collecting in Lake Buhi has failed to obtain this fish. In general appearance and color markings the figure bears a remarkable resemblance to female specimens of Vaimosa dispar (Peters), which abounds in the lake. The opercles of Vaimosa dispar often appear to be covered with scales, and only a critical examination with lens and needle can demonstrate that they are actually naked. If it were not for the five spines of the first dorsal and the larger number of predorsal scales, I should place this fish under $V$. dispar. 


\section{Genus 23. MACGREGORELLA Seale}

Macgregorella SEALE, Philip. Journ. Sci. § A 4 (1909) 533.

Dorsal VI, I-10; anal I, 8; scales 36 to 50 .

The body elongate, low, with broad flat depressed head; the body covered with small cycloid scales, those near tail much enlarged, not always regularly disposed, those in front of first dorsal very small and extending forward to above anterior part of opercles, or beyond this nearly to eyes; the sides of head, snout, and nape behind eyes scaleless, or sides of head may be scaled; the pectoral bases and breast scaled; the top, sides, and underparts of head marked by a number of very noticeable transverse and longitudinal ridges and elongated flaps of skinny tissue, much as in Gobiomorphus; no barbels, though a side view may cause the short ridges below jaw to look like barbels; the mouth small, oblique, with thick lips, fringed within; the teeth very small, without canines, in three or four rows in each jaw, outer row largest, tip of tongue rounded; the dorsals separate but close together; the dorsals and anal not high, equal to or not greatly exceeding depth; the caudal sharp-pointed or roundpointed, equal to or longer than head; the pectoral without silken rays above.

Obscure little reef-dwelling gobies with head of singular appearance. There are two closely related species.

Key to the Philippine species of Macgregorella.

$a^{1}$. Scales 38 to 40 in a longitudinal series; sides of head naked.. M. intonsa. $a^{2}$. Scales about 48 in longitudinal series; sides of head scaled.. M. moroana.

38. MACGREGORELLA INTONSA sp. nov.

Plate 7, fig. 2

Dorsal VI, I-10; anal I, 8; there are 38 to 40 scales in a longitudinal series, 14 in a transverse series, and about 14 before the first dorsal.

The low, elongated, plump, and rounded body laterally compressed only on posterior fourth, dorsal and ventral profiles nearly horizontal and parallel, depth about 6.5 times in length; the head broad, flattened, 3.7 to 4 times in length, wider than trunk, its depth 1.5 times in its breadth; the blunt snout nearly horizonal, 3.66 times in head, a trifle longer than eye, which is 4 to 4.3 times in head; the eyes dorsolateral, gazing upward more than to the side, the interorbital about half an eye diameter; the mouth small, very oblique, with a thick, protractile upper 
lip, lower jaw prominent with projecting and nearly vertical chin, posterior angle of maxillary concealed but considerably in front of a vertical from anterior margin of eye; the upper jaw has an outer row of enlarged teeth, followed by two or three rows of fine teeth; the lower jaw has an outer row of larger teeth and two inner rows of very small teeth; there are five perpendicular and two longitudinal ridges or folds on cheek, several short diagonal ridges and a long vertical one on opercle, and a row of about a dozen beneath chin and along underside of subopercle; on top of snout are several very short ridges and behind each eye a transverse and two longitudinal ridges; in front of and behind each eye and anteriorly and posteriorly on interorbital are large pores with tumid, projecting, almost tubulate lips; three pores on the supraopercular gronve and three on the posterior margin of preopercle; the body covered everywhere with cycloid scales, except on sides and on top of the back as far as posterior margin of preopercle; the middle spines of first dorsal longest, a trifle greater than the depth; the first dorsal well in advance of second, barely reaching origin of second dorsal when depressed; the second dorsal higher than first, the next to the last ray longest, about 1.1 or 1.2 in head, and about 1.4 times depth, the longest rays extending to caudal when depressed; the anal base much shorter than second dorsal, its posterior rays longest and equal to or a little less in height than second dorsal, not reaching caudal when depressed; the caudal peduncle little constricted, its depth over 0.8 that of body, and $\frac{5}{6}$ of its own length on dorsal side or 0.625 on ventral side; the broad, rounded pectoral equals head in length; the length of the wide short ventrals equals the height of anal; they fall far short of reaching anus, covering but 0.6 of the distance; the anal papilla in males elongated, slender, and pointed; in females very short, thick, and rounded.

The color in alcohol uniform chocolate brown, the fins concolorous or darker; the first dorsal mottled with darker; the base of pectoral rays very dark brown with some small obscure pale spots.

Here described from a male specimen, 52 millimeters long, and a female, 40.5 millimeters long, collected near Saub on the south coast of Cotabato Province, Mindanao.

I have just received from F. Reveche, of San Jose, Antique Province, Panay, two fine male specimens, each 44 millimeters in length; the median region before the dorsal is mostly naked, 
the sides scaled forward as far as the opercle extends, in one specimen about four rows directly in front of the dorsal, the other approximately like the types.

Intonsa, unshorn, from the shaggy appearance of the head.

39. MACGREgORELLA MOROANA Seale

Plate 28, Fig. 1

Macgregorella moroana SeALE, Philip. Journ. Sci. § A 4 (1909) 533.

Dorsal VI, I-10: anal I, 8; there are 48 to 50 scales in a longitudinal and 16 in a transverse series.

The depth of the laterally compressed, elongate body 5.5 times in length; the very large, broad, flat head 3.5 times in length, triangular when viewed from above, its depth 1.5 times in its breadth; the snout convex, bluntly rounded, 3 times in head; the eyes close together, high up, their gaze directed upward, 4.8 in head; the interorbital very narrow, about 2.5 in eye; the distance from tip of snout to posterior margin of eye equal to postorbital length of head; the mouth small, oblique, lower jaw projecting, posterior angle of maxillary in advance of front margin of eye; the lips are fringed within; the upper jaw has a short outer row of a few widely spaced, enlarged teeth and two rows of minute teeth behind it; in lower jaw is a band of three rows of pointed, slender, depressible teeth of uniform size; five perpendicular papillate ridges of folded skin on side of snout and below eye, one on opercle, and a dozen below chin and beneath subopercle; those on cheeks pocketlike, those beneath head superficially resemble barbels; the top of snout crossbarred by similar short ridges; a short cross ridge behind each eye; each nostril has a long flaccid tube; on the interorbital are two prominent pores, one behind each eye, three on supraopercular groove, and three on posterior margin of preopercle; the opercles and preopercles covered with scales embedded in the skin and not easily seen; those in upper posterior angle of preopercle very small, the others much larger; those on opercle deeply embedded and almost invisible; the dorsals separated, rather low, the middle spines of first dorsal longest, about $\mathbf{1 . 5 5}$ in head; the first dorsal of nearly uniform height, the next to the last ray a trifle the longest and scarcely exceeding first dorsal, about 1.5 times in head; the anal base much shorter than that of second dorsal, the rays longest posteriorly, 1.4 in head; the caudal peduncle short, its depth 0.8 of its length; the caudal elongate, pointed, 1.4 times the length of head; 2.375 times in length of head and trunk; the pectoral broad, pointed, 
equal to the length of head and extending to a point over anus; the ventrals elongate, 1.2 in the length of head, not reaching anus; the anal papilla very small, slender and pointed.

Color in life yellowish white, marbled and mottled with brown and grayish; three irregular-shaped oblique dusky bands backward and downward, one from spinous dorsal, two from soft dorsal; some dusky. stripes on sides of head, one from snout to eye, another from eye to upper margin of opercle, another from posterior margin of eye obliquely backward, two others on lower sides of cheeks. Dorsal yellowish with dusky blotch in lower central portion and some other slight shadings of dusky scattered over the fin. Soft dorsal with about three oblique dusky bars, the middle one most distinct, posterior tip of fin dusky. Caudal yellowish gray with three dark bands triangular in shape, the angle pointing backward. Anal yellow with thrce dusky oblique bars, posterior tip of fin dusky. Ventrals pinkish with slight blotches of dusky. Pectorals yellowish, a dusky irregular bar running out on upper half of fin. [Seale.]

The color in alcohol after seventeen years almost uniform yellowish brown, the head mottled brown; the first dorsal pale with a central dusky blotch; the middle part of soft dorsal dark brown, posterior tip blackish; the intervening part with crossbars of pale and dark brown spots; the caudal mottled dark and pale brown; the pectoral crossbarred with pale and dark brown spots; the other fins specked with brown.

Here described from the type, 38 millimeters long, or 54 millimeters including tail, collected by Seale at Jolo.

Seale was mistaken in stating that there are no scales in front of the dorsal and that the head is entirely naked.

I also place here a specimen collected by E. H. Taylor from the coral reef at Odiongan, Tablas. In this one, a female, the proportions are a trifle different. Scales in a longitudinal series, 50 ; length 44 millimeters; depth 6 times in length, head 3.66 times, caudal 3 times. In addition to the three rows of slender needlelike teeth in the lower jaw mentioned before, there are six longer and stouter fixed teeth in front of them; in the upper jaw there are three rows of minute teeth behind the enlarged outer row; the scales on the cheeks and opercles are plainly evident, the ridges and flaps less developed than in the type specimen. The color is very close to that already given.

\section{Genus 24. GALERA g. nov.}

Dorsal VI, I-12 to 15; anal I, 10 to 12.

The body very long and slender, with exceedingly elongate and pointed caudal, about twice in the length and more than twice as long as head, and very elongate pointed pectoral, much longer than head; the body covered with minute cycloid scales, 
about 70 in a lateral series, which are entirely absent forward of first dorsal, clear round the body; the head broad, flat; mouth small, nearly vertical, wholly anterior to eyes, with projecting lower jaw and chin, teeth minute, in three rows in each jaw, without canines; the tip of tongue rounded; on the top and sides of head and underside of suborbital and maxilla are short transverse, diagonal, and longitudinal seams rather than ridges; large pores on head as follows: One before upper anterior part of eye, one at posterior end of interorbital, and a row of three from eye back to opercle; the dorsals separated, none of the spines or rays of the vertical fins elongated or filiform; no silky rays above on pectoral; the gill openings narrow, restricted, no wider than base of pectoral and extending slightly below it, the isthmus broad; branchiostegals five.

This genus is close to Gobionellus Girard, but does not agree with Bleeker's diagnosis of that group. Galera differs in having no scales forward of the dorsal, in the seams on the head, and in the shape of the lower jaw. Generic type, Galera producta sp. nov.

Galera, from Puerto Galera, Mindoro, where it was collected. 40. GALERA PRODUCTA sp. nov.

Plate 7, Fig. 3

Dorsal VI, I-13; anal I, 11; there are about 70 scales in a longitudinal series and 18 or 20 in a transverse series.

The body slender and much elongated, the dorsal and ventral profiles nearly parallel, laterally much compressed posteriorly, probably plump and rounded anteriorly in life, but now much shriveled and wrinkled, the depth 7.6 times in the length; the head very broad, flat, 4.9 times in length, its breadth 0.8 of its length, 1.6 times its own depth, and much wider than body; the snout very broad, blunt, with a median posterior hump and two anterior lateral ones, four times in head; the eyes dorsal, upward gazing, equal to snout in length, postorbilal length of head a little more than the distance from tip of snout to posterior rim of eye; the interorbital 2.5 times in eye; the mouth small, oblique, with projecting lower jaw, the posterior angle of maxillary not extending back as far as front margin of eye; three rows of minute teeth in each jaw, those of outer row larger than the others and more widely spaced, all teeth slender, needleshaped, and more or less depressible; the body covered posteriorly with minute cycloid scalez which disappear anteriorly, head and body naked forward of origin of first dorsal; the snout, sides, and top of head and nape marked by dark longitu- 
dinal and transverse lines of minute papillæ; the dorsals well separated, first dorsal low, barely reaching second dorsal when depressed, third spine longest, a trifle more than depth; the second dorsal nearly twice as high as first, of nearly uniform height, equal to length of head, posterior rays reaching caudal when depressed; the anal similar to second dorsal but much shorter, its posterior rays longest, 0.8 of second dorsal, and not reaching caudal when depressed; the depth of caudal peduncle about 0.75 that of body and $\frac{2}{8}$ of its own length; the caudal exceedingly elongate, pointed, twice in the length; the pectoral very long, pointed, extending back to a point above third anal ray, half again as long as head and 3.26 times in length; the ventral has a deep frenum and equals head in length, but falls far short of anus, its length 1.6 times in the distance from its axil to anus; the anal papilla thin, pointed.

The color in alcohol uniform yellowish brown, the ridges of skin on head blackish; all fins except caudal, which is concolorous with body, are crossbarred by many rows of faint brown spots.

Here described from the type and only specimen, 49 millimeters long, or 70 millimeters with the caudal fin, collected by Mr. Alvin Seale at Puerto Galera.

Producta, elongated, in reference to the long-drawn-out body, caudal, and pectoral.

Genus 25. GOBIUS (Artedi) Linnæus

Gobius ARTEDI, Genera (1738) 28; LINNeUs, SYST. Nat., 10th ed. (1758) 262.

This genus is recognized at once by having a naked head, the upper rays of the pectoral converted to free silky filaments, and the tip of the tongue rounded.

Dorsal VI, I-10 to 11 ; anal I, 8 to 12 ; scales in a longitudinal series 22 to 42 .

The stout oblong body has the sides of the posterior half compressed; the head is large, broad, moderately depressed, with broadly rounded snout and convex profile; the eyes large, high up, dorsolateral, close together, in anterior half of head; the mouth of medium size, terminal or inferior, more or less oblique, with thick lips which are usually if not always fringed on the inside, and three or more rows of teeth in each jaw, those of outer row in upper jaw always enlarged; the isthmus broad; the body covered with ctenoid scales of moderate size, which may extend forward to eyes in some species or in others may be completely absent before first dorsal; the sides of head always 
entirely naked; the pectoral bases and breast scaled; the dorsals not close together, the vertical fins all comparatively low, less than the depth; the pectorals large, broad, the upper rays converted to free silky filaments; the ventrals broad, rounded, not adnate to belly; the caudal fin broad, rounded, blunt.

The members of this genus are mostly little fishes of shallow bays and estuaries, some of them handsomely colored.

Key to the Philippine species of Gobius.

$a^{1}$. Scales 41 in a longitudinal series and 16 in a transverse series; color grayish G. panayensis. $a^{2}$. Scales 28 or less.

$b^{2}$. Scales 25 to 28 .

$c^{2}$. A pair of lateral canines in lower jaw; a violet vertical band through eye to behind angle of mouth. G. cauerensis.

$c^{2}$. No canines; no band across eye and cheek; body with many lengthwise rows of blackish and pearl white dots; two rows of large dark spots on lower half of body.

G. ornatus.

$b^{2}$. Scales in a longitudinal series 22 ; a violet black band from eye to opercle; no canines. G. oligolepis.

41. GobIUS PANAYENSIS Jordan and Seale

Gobius panayensis JORDAN and SeAle, Bull. Bur. Fisheries 26 (1907) 42 , fig. 15.

Dorsal VI, I-10; anal I, 8; there are 41 scales in a longitudinal and 16 in a transverse series.

The body moderately elongate, compressed, the depth 4.25 times, the head 3.4 times in the length; the head broader than deep, cheeks full and rounded, snout bluntly rounded, 3.6 times in head; the eyes large, oblique, very high up, dorsolateral, equal to snout, close together, the interorbital space equal to pupil; the mouth moderate, jaws equal, posterior angle of maxillary under hind margin of pupil ; each jaw has wide bands of minute teeth, without canines; the tongue bluntly rounded, entire; the head naked, scales above pectoral very small, those on caudal peduncle much the largest; the dorsals continuous at base; the origin of first dorsal posterior to origin of ventrals, the fin low, the middle spines longest, twice in head; the second dorsal of nearly uniform height, equal to first dorsal in height, the posterior ray not reaching caudal when depressed; the anal low anteriorly, the posterior rays elongate, twice as high as first and twice in head, not reaching caudal when depressed; the round-pointed pectoral 1.3 times in head; the broad rounded caudal 1.15 times in head; the ventrals fall far short of the slender, pointed, rather prominent anal papilla, 1.5 times in head. 
The color of the type specimen in alcohol grayish, without distinctive markings; a black spot on first dorsal on upper part between fifth and sixth spines, the rest of the fin dusky except upper margin which is clear; pectorals and caudal uniform gray; ventrals and anal blackish.

The above is taken from the original description by Jordan and Seale; they had one specimen, 2.45 inches long, from Iloilo, Panay.

After Mr. Seale's departure from the Philippines the Bureau of Science fish collection had no qualified custodian for a number of years. Mr. Seale had collected a large series of specimens from the following localities: Manila market, south coast of Luzon, Siquijor, Zamboanga, Davao, Balabac, and Sitankai. These specimens were all placed in one jar and all spoiled, so that there are none now in the collection; nor have I ever seen anything in my own collections which could be this species. There are several rough color sketches of this species among those left by the late T. S. Espinosa, former Bureau of Science scientific artist; one or two of them are evidently not $G$. panayensis, although so labeled, but the others are just as evidently correct. From Mr. Seale's field book I take the following color notes:

Grayish olive, the top of the head black; first dorsal grayish olive, the tip dusky; second dorsal grayish fading into dusky, with a narrow yellowish margin anteriorly; caudal, anal, and ventrals black; the upper part of the pectoral yellowish, with short blackish cross bars fading into black on the lower half of the fin.

Another specimen was olive, the first dorsal with a broad dusky band through the middle; the lower two-thirds of the second dorsal dusky with a row of dark dots and some dusky middle rays, the upper third dull yellowish, tipped with grayish red; the caudal has slight indications of dusky cross bars; the anal is white at the base, dusky at the tip; the ventral is black; the pectoral with a black centre and a light area surrounding this, the tip dusky.

\section{GOBIUS CAUERENSIS Bleeker}

Gobius cauerensis BLEEKER, Nat. Tijd. Ned. Ind. 4 (1853) 269; GüNTHER, Cat. Fishes Brit. Mus. 3 (1861) 41; WEBER, Fische, Siboga Exped. (1913) 460.

Gobius ophthalmotaenia BLwerer, Nat. Tijd. Ned. Ind. 7 (1854) 46; GüNTHER, Cat. Fishes Brit. Mus. 3 (1861) 37.

Dorsal VI, I-10 to 12 ; anal I, 11 to 12 ; scales in a longitudinal series 25 to 27.

The depth of the elongate, laterally compressed body contained 5.5 to 5.66 times, the head 4.5 to 4.66 times in the length; the width of head is nearly equal to its depth and is twice in its 
length; the snout obtuse, convex; the eyes very close together, their diameter 3 to 4 times in length of head; the mouth oblique, jaws equal, posterior angle of maxillary before eye; the outer row of teeth in each jaw enlarged; in the young there are canine teeth in both jaws, in the adults there is a pair of lateral canines in the lower jaw ; the supraopercular groove conspicuous; the preopercles, upper part of opercles, and crown of head scaled; the dorsals very close together, first dorsal lower than second, which equals or is lower than depth of body; the pectoral obtusely rounded, 4.25 to 4.33 times in length; the caudal obtuse, convex, about 5 times in length of body; the ventrals reach anus, 4.75 to 5 times in length; the anal scarcely lower than second dorsal.

The color green or olive, clouded with darker and dotted with brown and bluish; a violet-blue vertical band passes through eye and down behind angle of mouth; the snout and opercles covered with yellow or blue dots; in the young there are seven or eight brown longitudinal bands, and a series of five circular brown spots behind pectoral; the first dorsal has blackish spots anteriorly, yellow spots posteriorly; the second dorsal is brown spotted; the pectoral and ventral fins reticulated with brownish violet and minutely dotted with bluish, or may be yellow, dotted with brown; the caudal has many brownish and blue dots, its lower margin violet; the anal has a broad black margin.

The above description is compiled, as I have seen no specimens. The measurements probably include the caudal fin, as Bleeker in his earlier work gave the length from tip of snout to tip of tail.

The only Philippine record is by Weber, who obtained specimens at Sanguisiapo, an island in the Tawitawi group. According to him it is widely distributed in the Indo-Australian Archipelago and the South China Sea. It lives upon the reefs, at low tide hiding in the puddles left under coral masses.

The very apt name ophthalmotaenia must be superseded by cauerensis, as the latter, first described by Bleeker, is merely the young of ophthalmotaenia.

\section{GOBIUS ORNATUS Rüppell}

\section{Plate 7, Fig. 4}

Gobius ornatus RüPPELL, Atlas Fische des Roten Meers (1828) 135; GüNTher, Cat. Fishes Brit. Mus. 3 (1861) 21; PETERS, Monatsber. Akad. Wiss. Berlin (1868) 263; GüNTHER, Fische der Südsee 2 (1876-1881) 172, pl. 111, fig. A; DAY, Fishes of India (1878) 294, pl. 63, fig. 1; JoRDAN and RICHARDSON, Bull. Bur. Fisheries 27 (1908) 277; Valllant, Nouv. Arch. Mus. Hist. Nat. III 5 (1893) 57. 
Gobius interstinctus RIcHaRDson, Voy. Erebus and Terror, Ichthyology (1844-1848) 3, pl. 5, figs. 3-6.

Gobius periophthalmoides BLEEKER, Nat. Tijd. Ned. Ind. 1 (1851) 249.

Dorsal VI, I-10 or 11 ; anal I, 8 or 9 ; there are 26 to 28 scales in a longitudinal series, 9 in a transverse series, and 10 or 12 before the first dorsal.

The robust body full and rounded or wedge-shaped anteriorly, the posterior part much compressed laterally, the depth 4.6 times in the length; the head large, broad, pointed anteriorly, 3.4 to 3.6 times in length; the breadth of head 1.3 to 1.5 times in its length and a little more (about 10 to 12 per cent) than its depth; the snout long, convex, 3.1 times in head; the eyes very high up and close together, laterodorsal in position, 1.3 to 1.4 times in snout and 4.2 to 4.4 in head; the interorbital contained 2.5 times in eye; the mouth inferior, with projecting upper jaw and protractile upper lip, the thick fleshy lips fringed on inner side, and the posterior angle of maxillary extending beneath anterior part of eye or even beneath pupil; the teeth all depressible, the outer row in each jaw enlarged and widely spaced, followed by three rows of very small teeth; the body covered with firm ctenoid scales, which are a little smaller anteriorly, those on nape still smaller, extending to eyes and curving a little forward between them; the remainder of head naked; the base of pectoral and breast completely scaled; two interorbital pores, three on the conspicuous supraopercular groove, and three large pores on posterior margin of preopercle; the first dorsal low, 1.4 times in depth, well separated from second dorsal and scarcely or not at all reaching it when depressed; the second dorsal increases in length posteriorly, the last ray reaching caudal when depressed, its length 0.875 of or slightly exceeding depth; the anal base shorter than that of second dorsal, the fin similar in shape to second dorsal but a trifle lower, the last ray not reaching caudal when depressed; the caudal rounded, shorter or longer than head; the pectoral round pointed, a little longer or shorter than caudal but always less than head, its tip over anal papilla; the ventrals broad, with a deep cup formed by the broad frenum, $\frac{1}{6}$ or $\frac{1}{7}$ shorter than pectoral and not extending beyond anus; the anal papilla slender, pointed, leaflike in males, broader and thicker in females.

The ground color of alcoholic specimens varies from whitish to very pale brown, with many longitudinal rows of brown or blackish spots and pearl white dots or spots; on lower half 
of body two rows of large dark brown or blackish spots, the lower ones rounded, those of upper row elongated or rectangular; the dark spots on upper half of body all small; the sides and top of head sprinkled with dark brown or blackish spots; the first dorsal diagonally marked with many rows of dark brown or black spots and lines on the membrane, interspersed with pearly white spots; the anterior half of first dorsal has a broad yellow or white upper margin; the second dorsal, caudal, and pectoral crossbarred by many rows of black or brown spots, alternating with white spots; the basal portion of anal faintly brown crossbarred, with a dusky margin and a white marginal line on tips of rays; the ventrals brown to black.

I have examined the following specimens, varying in length from 18 to 79 millimeters:

$\begin{array}{ll}\begin{array}{c}\text { Currimao, Ilocos Norte Prov- } \\ \text { ince, 5. }\end{array} & \begin{array}{l}\text { Canigaran, Palawan, 1. } \\ \text { Puerto Princesa, Palawan, } 1 .\end{array} \\ \text { Nalvo, Luna, La Union Prov- } & \begin{array}{l}\text { Cuyo, 1. } \\ \text { ince, 2. }\end{array} \\ \text { Zamboanga, Mindanao, 1. } \\ \text { Nasugbu, Batangas Province, 3. } & \begin{array}{l}\text { Davao, Mindanao, 1. } \\ \text { Puerto Galera, Mindoro, 6. }\end{array} \\ \begin{array}{l}\text { Samal Island, Davao Gulf, } 3 . \\ \text { Odiongan, Tablas, 7. }\end{array} \\ \begin{array}{l}\text { San Jose, Antique Province, } \\ \text { Panay, 1. }\end{array}\end{array}$

The species has been listed previously from the "Philippine Islands" by Günther; from Paracale, Camarines Norte, by Peters, and from Ticao by Jordan and Richardson.

This little goby, which in life well deserves the name ornate, occurs throughout the Philippines and is not rare. It was originally described from the Red Sea and is found from the east coast of Africa eastward to Yap, the north coast of Australia, and the Fiji and Samoan Islands.

\section{GOBIUS OLIGOLEPIS Bleeker}

Gobius oligolepis BLEEkrR, Nat. Tijd. Ned. Ind. 5 (1853) 508; Peters, Monatsber. Akad. Wiss. Berlin (1868) 263.

Dorsal VI, I-10 or 11; anal I, 11 or 12.

The body elongate compressed, the height 5.5 to 6 in the length, the breadth about 1.5 in the height; the obtuse convex head about 5 in body length; the breath of head 1.75, the height about 1.5 in its length; the diameter of eye 3 or less in length of head, less than half a diameter apart, placed in anterior halt of head; the snout obtuse, soon convex; the maxillæ equal, the upper one extending beneath posterior half of eye; 
the teeth in several rows in jaws, the external row much larger than the inner rows in upper jaw, those of lower jaw scarcely larger, no canines or caninelike teeth; the mouth slightly oblique; the oculoscapular groove conspicuous; the head and nape, back to first dorsal, entirely naked; about 22 large scales in a longitudinal series; anal appendage oblong conical; the dorsals basally approximate, the highest dorsal spines flexible, produced anteriorly, scarcely higher than body; the soft dorsal obtuse, angulate posteriorly, the first ray flexible; the pectorals rounded, the upper rays threadlike, 5 or less, the ventrals 6 , the obtusely rounded caudal about 3.8 in length of body; the anal not lower than second dorsal, angulate posteriorly.

The color of body dilute green, with a violet-black band from eye to operculum; a few violet-green spots on head and body, those on sides large to medium, about nine, oblong, irregularly transverse, and disposed in longitudinal series; the second dorsal dilute violet, the apex becoming yellow, with two or three longitudinal black stripes; the other fins yellowish, the dorsal and caudal rays spotted with violet; the ventrals violaceous in the middle.

The above is a translation of Bleeker's original description. It is given here because specimens collected by Jagor at Tibi, Albay Province, Luzon, were determined by Peters as this species.

According to Günther it inhabits the coasts and rivers of Java, Madura, and Sumatra.

\section{Genus 26. BATHYGOBIUS Bleeker}

Bathygobius BLFBKER, Arch. Neerl. Sci. Nat. 13 (1878) 58. Mapo SMITT, Ofv. Vet. Ak. Vorh. (1899) 543.

Dorsal VI, I-8 to 10 ; anal I, 7 to 8 ; scales in a longitudinal series 35 to 42 ; the nape is always more or less scaled.

This genus agrees in most respects with Gobius, but the tongue is more or less notched, instead of having the tip rounded. In Bathygobius the tongue is not of uniform thickness, but the central part of the tip seems as though it had been mortised out and is much thinner than the sides, so that these not only rise higher but seem to project farther forward than they actually do. When seen from below, as in opening the mouth, ordinarily, the tongue appears to be strongly notched. When viewed from above and the tip flattened, it is seen to be more or less notched, or subtruncate with indented tip. The scales are a little smaller than in Gobius. 
I have been unable to get a copy of Bleeker's diagnosis of this genus.

This group includes small dull-colored fishes of tide pools, rocky, shallow, coastal waters, and river mouths. One of the species is the most widely diffused of all gobies.

Key to the Philippine species of Bathygobius.

$a^{1}$. Round black spots thinly sprinkled over trunk, head, and nape B. bravoi. $a^{2}$. No black spots on body as above.

$b^{1}$. Sides with longitudinal rows of white spots; four or five dark brown dorsal crossbands, six or seven daŕk brown lateral spots B. fuscus.

$b^{2}$. No white spots on sides.

$c^{2}$. Color greenish or grayish; some indistinct marks on side; a dusky blotch on posterior part of first dorsal.

B. mearnsi. $c^{2}$. Color of body and fins uniform dark to blackish brown

B. nox.

45. BATHYGOBIUS BRAVOI sp. nov.

Plate 8, Fig. 1

Name at Cabalian, Leyte, amogu.

Dorsal VI, I-8; anal I, 7 ; there are 36 or 37 scales in a longitudinal series, 13 in a transverse series, and about 16 before the first dorsal.

The wedge-shaped body strongly compressed posteriorly, with very broad head, the depth 4.5 in the length; the head 3 times in length, its breadth equal to depth of body, and 0.2 more than its own depth; the broad rounded snout 3.6 times in head; the mouth terminal, slightly oblique, jaws equal, posterior angle of maxillary beneath pupil; the outer row of teeth in upper jaw enlarged, with three inner rows of very small teeth; in lower jaw an outer row of larger teeth and two inner rows of minute teeth; the tongue notched; the eyes very high up, laterodorsal in position, equal to snout, and in forward half of head; the interorbital space narrow, 2.5 times in eye; the body covered with small scales a little larger posteriorly; those on nape extend to eyes and are very small; a few small scales on upper margin of opercle; the dorsals well separated, the height of first equal to $\frac{2}{8}$ the depth of body; the second dorsal and anal a little higher, 0.75 to $\frac{5}{6}$ of depth, reaching about halfway to caudal when depressed; the caudal equal to the pointed pectoral in length, about $\frac{1}{6}$ more than the depth and $\frac{7}{9}$ of head; the pectoral reaches to a point beyond anus but not to anal fin; the ventrals rather thin, broad, and short, extending halfway or 0.7 of the distance to anus.

The color in life was gray, with obscure darker crossbands and black dots over back, harmonizing with the dead coral 
about. In alcohol the color is scarcely changed, the sides of trunk, head, and nape thinly sprinkled with black spots, as in Gobius sadanundio and shown in Bleeker's and Day's figures of that species; the first dorsal has a dusky crossbar on basal portion; the second dorsal, caudal, and pectoral each crossbarred with several rows of dark spots; the anal and ventrals dusky; the prominent pupil of eye white.

Here described from two specimens, 26 and 27 millimeters in Jength, collected in a coral-reef pool at Romblon. From Gobius sadanundio, to which it is closest in dorsal and anal formulæ and in general coloration, it differs markedly in scalation. The lack of white spots on the body and the black spots sprinkled here and there separate it from Bathygobius fuscus.

I place here six specimens, 30 to 39 millimeters in length, from Cabalian, Leyte; they differ in some respects but are closest to the Romblon specimens. Dorsal VI, I-9; each scale darkened centrally, with black spots scattered thinly over body and head and a large dark spot on opercle; the fins colored as in the types, or second dorsal may have a broad dusky crossbar near the middle. I also have another specimen, 35 millimeters long, from the south coast of Cotabato Province, Mindanao; dorsal VI, I-9, anal I, 8.

I take pleasure in naming the species for one of my artists, Pablo Bravo, who helped me capture the type specimens.

\section{BATHYGOBIUS FUSCUS (Räppell)}

Plate 8, Fig. 2

Gobius fuscus RüPPHL, Atlas Reise, Fische (1828) 137.

Gobius punctillatus RÜPPEL, Atlas Reise, Fische (1828) 138.

Gobius nebulo-punctatus RÜPPEL, Neue Wirbelt., Fische (1835) 139; GüNTHER, Cat. Fishes Brit. Mus. 3 (1861) 26.

Gobius soporator CUVIER and VALENCIENNES, Hist. Nat. Poiss. 12 (1837) 43; GÜNTHBR, Cat. Fishes Brit. Mus. 3 (1861) 25; Fische der Südsee 2 (1876-1881) 172, pl. 110, fig. A; DAY, Fishes of India (1878) 294, pl. 63, fig. 7.

Gobius paajangensis BLEEKER, Nat. Tijd. Ned. Ind. 1 (1851) 24.9.

Gobius breviceps BLYTH, Journ. Asiat. Soc. Bengal (1858) 271.

Gobius homocyanus ValluaNt and Sauvage, Rev. Mag. Zool. III 3 (1875) 280.

Glos8ogobius giurus Strems, Bull. U. S. Nat. Mus. No. 7 (1877) 60 (not of Buchanan Hamilton).

Gobius sandvicensis GüNTHæR, Shore Fishes, Challenger, Zoology 1 (1880) 60.

Mapo fuscus Jordan and EvermanN, Bull. U. S. Fish Comm. $23^{2}$ (1903) 484, fig. 212; Jordan and Seaue, Bull. Bur. Fisheries 26 (1907) 43; Seale and Bean, Proc. U. S. Nat. Mus. 33 (1907) 248. 
Dorsal VI, I-10; anal I, 8; there are 36 to 38 scales in a longitudinal series and 12 in a transverse series.

The somewhat elongate body wedge-shaped when viewed from above, with strongly compressed sides and tapering caudal peduncle, the depth 4.4 to 5 in the length; the head large, with convex upper profile, 3.3 to 3.4 in the length, its breadth greater than its depth and 1.4 to $\mathbf{1 . 5}$ in its own length; the broad blunt snout equals or is 0.875 of eye, which is contained 3.5 to 3.875 times in head; the eyes dorsolateral and very close together, the interorbital half an eye diameter or less; the mouth large, terminal, with thick fleshy lips fringed on the inside, the posterior angle of maxillary beneath pupil of eye; the outer row of teeth in upper jaw enlarged and widely spaced; behind it three rows of much smaller teeth, the teeth of the last two minute; in lower jaw the outer row enlarged, but the teeth are a little smaller than in outer row above; in forward half of jaw a broad band of four rows of small teeth lies behind outer row, which continues to posterior limit of mouth; in one specimen a pair of small lateral canines terminates the inner band; the body covered with ctenoid scales, large posteriorly, becoming very small and crowded before first dorsal, and extending on nape a little forward of opercle, but not to eyes; the head naked except on part of nape; the pectoral bases scaled and the breast partially scaled; there are small but conspicuous pores as follows: One in front of eye, two on the interorbital space, one in the naked space behind eye, one on posterior margin of eye at origin of supraopercular groove and three more on the groove, and two on posterior margin of preopercle; the dorsals are separated, the height of first 1.5 to 1.8 times in depth; the second dorsal and anal similar in height and shape, the anterior rays shortest, the posterior rays of Philippine specimens not reaching caudal when depressed, 1.47 to 1.1 in depth; the pectoral broad, rounded, the upper rays silky, its length equal to or slightly more than depth; the ventrals broad, not quite reaching anus, equal to or slightly less than depth, about a tenth less than pectoral; the broadly rounded caudal a little less than head, 1.1 to 1.2 (not 2 in head as given by Jordan and Evermann), and more than the depth.

The color of alcoholic specimens varies greatly, as indeed is the case with living specimens; in some there is a series of four or five broad, dark brown crossbands over back, with six 
or seven dark brown blotches along side; these are united by a dark brown bar extending from upper base of pectoral to middle of caudal base, terminating there in a large dark brown spot; the snout dusky; a large dark brown spot on preopercle, and a small black spot behind each eye; on the sides are six to ten longitudinal rows of small white spots, one to a scale, most distinct on lower half of body; the sides of head specked with small white spots; the first dorsal dark brown to blackish, with a white margin above; the second dorsal heavily crossbarred by four to many rows of brown spots; the upper twothirds of caudal heavily crossbarred by numerous rows of brown spots; the pectoral faintly crossbarred in the same manner, with two dark brown spots on its base; the anal and ventrals dusky.

In specimens seventeen years in alcohol the brown crossbars have faded very much, though they are still visible, and the ten or twelve rows of small white spots are very evident, so that they give the dominant color; the white spots are also very distinct on the opercles and preopercles, and the pectorals are crossbarred by white spots. In other respects the markings are as given above, but paler.

I have studied the following specimens, ranging in length from 16 to 56 millimeters:

Tacloban, Leyte, 3.

Kolambugan, Mindanao, 2.

Caldera Bay, Mindanao, 1.

Siasi, Sulu Province, 11.
Bungau, Sulu Province, 3. Sibutu, Sulu Province, 3. Sitankai, Sulu Province, 2. Balabac, Palawan, 1.

The Bureau of Science collection also has a specimen from the Andaman Islands, received from the Indian Museum.

The species has been recorded previously from Cavite by Jordan and Seale, and from Zamboanga by Seale and Bean. Among the islands of the Sulu Archipelago it is abundant in the shallow water of salt-water lagoons where it is more or less exposed at low tide, when it seeks shelter in pools and holes in the coral sand; it can evidently thrive in water of rather high temperatures since the puddles in which it stays when the tide is out soon become excessively warm.

It is the most widely distributed of gobies. I have been unable to detect any valid differences between specimens from India, the East Indies, Samoa and other South Pacific localities, Marcus Island, the Hawaiian islands, and the West Indies. 


\section{BATHYGOBIUS MEARNSI (Evermann and Seale)}

Mapo mearnsi Evermann and Seale, Proc. U. S. Nat. Mus. 31 (1907) 510, fig. 2.

Head 3.30 in length; depth 5; width of head much greater than its depth, which is 1.80 in its length; cheeks prominent; D. VI, 10; A. 9; scales 38 , about 10 in vertical series; head without scales except on the crown; eye 4 in head; snout 4 ; interorbital about equal to pupil; about 14 of the upper pectoral rays detached and silky; tongue emarginate, free anteriorly; teeth small, in several rows.

Color in spirits, greenish or grayish; some very indistinct dusky markings on middle line of side; no white dots; dorsal blotched with dusky; a dusky blotch on posterior part of spinous dorsal.

Two specimens, the type, Cat. No. 55624, U. S. N. M., a specimen 2.5 inches long, from Zamboanga, Mindanao, and a cotype, No. 1495, Bureau of Fisheries, a specimen 1.55 inches long, from same place.

We take pleasure in naming this interesting species for Dr. Edgar A. Mearns, U. S. Army, who collected the type. [Evermann and Seale.]

The above account is Evermann and Seale's original description, and no additional specimens have been collected. I have seen the types and they appear distinct from Gobius fuscus.

Since the above was written I collected a fine plump specimen, 48 millimeters long, from a coral reef at Bungau, Sulu Province. The color is greenish gray, everywhere densely punctulate with dark specks, the head brown, with three transverse dark brown bands across the back, these divided into two each on the sides; the second dorsal and the upper three-fourths of the caudal are crossbarred by numerous rows of small brown spots; the pectorals and ventrals are finely punctulate with dark specks; the eyes are large, prominent, about 3.6 times in the head; the pores on the head are conspicuous; the posterior angle of the maxillary extends to a point beneath the posterior margin of the pupil; there are about thirteen rows of very small scales before the first dorsal, extending as far forward as above the posterior margin of the preopercle; the large rounded caudal is shorter than the head; the pectoral is longer than the caudal, almost equal to the head, and reaches as far back as above the origin of the anal.

\section{BATHYGOBILS NOX (Bleeker)}

Gobius nox BleEker, Nat. Tijd. Ned. Ind. 1 (1851) 248; GüNTHER, Cat. Fishes Brit. Mus. 3 (1861) 28.

Dorsal VI, I-9 ; anal I-8; there are about 35 scales in a longitudinal series, 16 in a transverse series, and 18 before the first dorsal. 
The body elongate, wedge-shaped, the sides strongly compressed posteriorly, the anterior part broad and rounded, the depth 4.4 times in the length; the dorsal profile moderately arched, the head convex, very broad with bulging cheeks, 4 times in length, its breadth equal to depth of body, a little more than 0.7 of its own length and 1.44 times its own depth; the convex, broad, bluntly rounded snout 4 times in head; the eyes dorsolateral, looking upward as much as sideways, a little less than snout, 4.5 in head, close together, the interorbital space 1.6 times in an eye diameter; the mouth terminal, oblique, the lower jaw slightly projecting, the lips thick and fringed on the inside, the posterior angle of maxillary beneath the middle of pupil; the outer row of teeth in each jaw enlarged, with a band composed of three rows of very small teeth behind; in lower jaw also some enlarged teeth in posterior part of inner row; the tongue notched; the body covered with ctenoid scales not very regularly disposed, largest on caudal peduncle, with very small scales before first dorsal as far as in line with anterior margin of opercle; the head naked; the pectoral bases and breast partially scaled; pores distributed on head as in Gobius fuscus; the supraopercular groove prominent; the dorsals separated, the second, third, and fourth spines of first dorsal longest, 2.25 times in head and 1.6 times in depth; the second dorsal and anal similar in shape and height, the longest rays 1.8 times in head and 1.3 times in depth, the anal base shorter than that of second dorsal, the posterior ray of each reaching caudal when depressed; the depth of caudal peduncle 0.7 of its own length and $\frac{7}{9}$ of depth of body; the caudal round pointed, a little longer than body depth, 1.3 times in head, 3.8 in length; the pectoral broad, somewhat pointed, equal to depth, and extending to a point beyond anal papilla; the ventrals broad, 1.3 times in depth and extending over $\frac{5}{6}$ of distance to anus, their breadth 1.66 times in their own length.

The color in alcohol uniform dark brown over entire body except head, which is entirely blackish brown; the fins concolorous, blackish or dark brown; a few blackish spots occur on the membranes of second dorsal.

Here described from a male specimen, 53 millimeters long, collected at Hongkong by Alvin Seale. Previously known only from a few specimens collected by Bleeker on the coasts of western Sumatra, Nias, and Solor. The Bureau of Science specimen agrees in all essentials except that it has more scales than Bleeker's specimens, which had about 30 . 


\section{Genus 27. CHLAMYDES Jenkins}

Chlamydes Jenkins, Bull. U. S. Fish Comm. 22 (1903) 503.

This genus agrees with Gobius except for the presence of scales on the sides of the head, the opercles and preopercles being more or less completely scaled, and in the tongue being decidedly notched. The cheeks are full and rounded, the teeth in bands in each jaw, with the outer series in the upper jaw enlarged; the ventrals are short, very broad, with a thick bilobed frenum, forming a sucking disk like that of the gobies of mountain torrents.

Previously known from a single specimen captured at Honolulu by Dr. O. P. Jenkins.

\section{CHLAMYDES LEYTENSIS sp. nov.}

\section{Plate 8, Fig. 3}

Dorsal VI, I-8 or 9 ; anal I, 7 or 8 ; there are 36 to 38 scales in a longitudinal series, 13 or 14 in a transverse series, and about 22 before the first dorsal.

The body wedge-shaped, narrowed dorsally and broader below, the sides of posterior half strongly compressed, the dorsal and ventral profiles nearly parallel, the depth 4.5 to 4.9 times in length; the large, broad, rather depressed head 2.75 to 3.1 times in length; the cheeks full, the width of head 0.7 to 0.85 of its length and about a half more than its depth; the snout broadly rounded, slightly convex, 3.5 to 4 times in head, and a little more than eyes, which are almost on top of head, dorsolateral, 4 to 4.25 times in head; the postorbital portion of head equals or slightly exceeds distance from snout to posterior margin of eye; the interorbital region is $\frac{1}{2}$ or $\frac{1}{3}$ an eye diameter; the mouth terminal, with very thick, fleshy lips, fringed within, slightly oblique, the posterior angle of maxillary beneath middle of pupil; the outer row of rigid teeth in upper jaw much enlarged, followed by a band of three rows of fine depressible teeth, the inner teeth larger than those of the other two; the lower jaw has a band of three or four rows; anteriorly the outer and inner rows enlarged; posteriorly the inner row much the largest, though not as large as the outer row in upper jaw; in one specimen there is a pair of small lateral canines in lower jaw; the scales before first dorsal are much smaller than those on sides of body and extend forward to eyes, from which they are separated by a mucus channel; the opercles covered on upper half by tiny scales, which also may occur on upper 
margin of preopercle; a broad furrow, marked by a row of minute papillæ and covered by a fold, extends from behind angle of mouth back across opercle; there are conspicuous pores on the head as follows: On snout, anterior margin of eye, central and posterior interorbital, postorbital, three on the very prominent supraopercular groove, and three on the posterior margin of preopercle. The dorsals are far apart, the last spine of first dorsal barely touching origin of second dorsal when depressed; the central spines of first dorsal longest, 0.7 to 0.8 of depth, or 2.1 to 2.4 in head; the second dorsal angulate, the longest rays 0.8 to 0.9 of depth, the last rays reaching caudal when depressed; the anal shorter, its longest rays about equal to first dorsal, not reaching caudal when depressed; the caudal peduncle broad, its depth equal or nearly equal to its length and 0.7 of depth of body, and 2.3 to 2.4 in head; the caudal truncate with rounded corners, 3.6 in length; the broad, pointed pectoral, contained about 4 times in total length, is a trifle shorter than the caudal and extends back to a point above the anal papilla; the ventrals are as broad as long, 0.8 of depth, twice or more than twice in head, and extend two-thirds of the distance to anus; the anal papilla short, slender, triangular, pointed.

The color in alcohol uniform deep blackish brown, or paler and with a greenish tinge on belly; the fins all concolorous or black.

Here described from three specimens, 44 to 49 millimeters in length, from Cabalian, Leyte.

From Chlamydes laticeps, known from only a single specimen, 38 millimeters long, this species differs in the less-complete scalation of the sides of the head, in the proportions, and in the number of fin rays. In other respects it closely agrees, and has the characteristic and peculiar cheek fold shown in the figure of $C$. laticeps but not mentioned by Jenkins in his description.

\section{Genus 28. TUKUGOBIUS g. nov.}

Dorsal spines 6 or 7 ; head naked ; nape naked back to first dorsal or to above opercle with 12 or 14 rows of minute scales in front of dorsal; scales in lateral series 36 to 44, in transverse series 12 to 16 ; scales on sides ctenoid, becoming very small and cycloid above pectoral and never extending forward of opercle on nape; base of pectoral and breast always naked; belly behind ventrals naked to anus or scaled; head large, broad, with bulging cheeks, the mouth small, the upper lip noticeably 
thick; the teeth in bands of four to six rows in each jaw, the outer row largest, no canines; the tongue rounded; the dorsals far apart, both dorsals and anal short and comparatively low; the caudal rounded and shorter than head; the ventrals very short and rounded, forming a nearly circular, powerful, adhesive disk, with a characteristic thick, bilobed or deeply crenate frenum; no flaps on shoulder girdle; no silklike rays on pectoral. Dorsal VI or VII, I-8 or 9; anal I, 7, 8, or 9. Branchiostegals 5 ; the isthmus broad, the gill openings rather narrow.

This genus is remarkable among gobies for the enormous size, comparatively speaking, of its eggs. A spawning female, 40 millimeters long, contained about 135 eggs, each from 1.5 to 2 millimeters in diameter. This is in marked contrast to all other gobies I have examined, most of which lay a large number of very small eggs.

This is a group of small, dull-colored, inconspicuous gobies, scarcely ever attaining a length of over 65 millimeters. They inhabit mountain creeks exclusively, living among stones in the swiftest water; species few, one probably generally distributed over Luzon and the Visayas, the others apparently confined to central and northern Luzon. One species lives at an elevation of 1,000 to 2,000 meters. The species are very close and might with some reason be lumped together in a single, very variable kind. Tukugobius philippinus can be regarded as the parent stock, the others being comparatively recent offshoots still in process of evolution, and not yet completely separated by absolutely fixed characters.

This genus is closely allied to Rhinogobius of authors, from which it differs in the absence of canines and the absence of scales on the breast and about the ventrals; from Aboma, to which it is also close, it differs in the character of the spinous dorsal, which may have either six or seven spines in the same species, in the broad head with fat cheeks, and in the weaker teeth; it likewise seems near to Bleeker's Hypogymnogobius, but differs in scalation. If the first dorsal always had seven spines, the species should be placed in Aboma, where I placed the specimens first examined. Study of additional material showed that this disposition was not tenable unless the diagnosis of Aboma were altered which, in the absence of Mexican and Japanese material for comparison, I did not feel justified in doing. Generic type, $T$, carpenteri sp. nov.

Tuku, a Tagalog word for lizard; one of the species is called tuku ng bia (lizard goby) by the Tagalogs. 
Key to the species of Tukugobius.

$a^{1}$. Dorsal spines usually seven; a naked area under ventrals; predorsal scales 8 or 10 .

T. bucculentus.

$a^{2}$. Dorsal spines six or seven.

$b^{1}$. Belly partly or entirely naked back to anus; predorsal region naked or with very few scales.

T. carpenteri.

$b^{2}$. Belly not naked behind ventrals; twelve to fourteen rows of predorsal scales. T. philippinus.

50. TUKUGOBIUS BUCCULENTUS sp. nov.

Plate 8, Fig. 4

Dorsal VII, I-8 or 9 ; anal I, 8 or 9 ; there are from 40 to 44 scales in a longitudinal series and 14 to 16 in a transverse series; in one specimen the first dorsal has eight spines and some specimens have irregular scalation; 8 or 10 rows of minute scales before the first dorsal.

The body little elevated, its posterior half strongly compressed, and the depth $4 \frac{1}{3}$ to 5 times in length; the large head is contained 3.1 to 3.4 times in length, and is broad, with bulging cheeks, its breadth 1.5 times to twice its depth; the eyes on top of head, 5 to $5 \frac{5}{6}$ times in head, 2 to 2.5 times in the convex, broadly rounded snout, and close together, the interorbital space about $\frac{2}{3}$ an eye diameter; the mouth subterminal or inferior, the lower jaw shorter than the upper, the posterior angle of maxillary not extending to eye, except rarely; the upper jaw has an outer row of enlarged teeth, with a broad band of four or five rows of minute teeth behind it; the outer row in lower jaw is of smaller teeth than the outer row above, with a band of three or four rows behind it; the caudal peduncle broad, its depth two-thirds to one-half of its own length; under the ventrals and next its base is a small naked area; small scales extend forward as far as the region above the gill openings, leaving the entire head, breast, base of pectorals, and region beside the ventrals naked; the second and third spines of first dorsal more or less elongate, with filiform tips, their length equal to or nearly as great as depth; the second dorsal angulate posteriorly, its height equal to depth of trunk beneath it; the anal similar in outline but slightly lower; the rounded caudal slightly exceeds pectoral in length and is $\frac{2}{8}$ to $\frac{4}{5}$ of length of head; the ventrals are typical of the genus and extend much less than halfway to anus.

The color in alcohol yellowish brown, with a more or less evident, dark, longitudinal line or stripe along the middle of each side; in some specimens there are traces of large dusky 
spots along the sides; the interorbital space and top of snout dusky grayish brown; the pupils white; all the fins more or less blackish or dusky; a transverse dusky bar often present on base of caudal.

Here described from the type, 62 millimeters long, and seventeen cotypes, 21 to 62 millimeters in length, from the creek at Santa Fé, Nueva Vizcaya Province, Luzon, and twenty-eight cotypes, 20 to 52 millimeters in length, from a creek at Dupax, Nueva Vizcaya Province, Luzon. The largest Dupax specimen has but 12 scales in a transverse row and 36 in a longitudinal series; some of the others from Dupax also presented enough differences to warrant considering them a separate species, but every gradation between was also found. Most of the specimens have from 40 to 42 scales in a longitudinal series.

The Bureau of Science collection also contains ten specimens from Santa Fé, 16 to 27 millimeters long. I also place here a specimen, 62 millimeters long, from Santa Fé, which has but six dorsal spines and has all the dorsal spines elongated; the second dorsal and anal are also more elongate posteriorly than in any of the other specimens.

Since the above was written I have received some specimens from barrio Diviguen, San Mariano, Isabela Province, and fifty specimens from a creek on Mount Moises, Isabela Province. This species evidently occurs throughout the Cagayan Valley.

This species is very close to Tukugobius carpenteri (Seale), differing in having seven instead of six spines in the first dorsal, in having scales before the first dorsal, and in the more com. plete scalation of the belly.

Bucculentus, having full cheeks.

\section{TUKUGOBIUS CARPENTERI (Seale)}

Plate 29, Fig. 2

Rhinogobius carpenteri SEALE, Philip. Journ. Sci. § A 4 (1909) 535.

Kuchu, in Bontoc Igorot.

Dorsal VI (rarely VII), I-8 or 9; anal I, 8; there are 36 to 40 , usually 38 , scales in a longitudinal series and 14 in a transverse series.

The body low, plump, the dorsal and ventral profiles nearly parallel, the depth 4.5 to 5 in length; the large, broad, depressed head 3 to 3.2 in length; the cheeks very full and rounded, the width of head much more than that of body, 0.75 to 0.8 its length, the depth $\frac{2}{8}$ to $\frac{8}{4}$ its width; the convex, broadly rounded snout 2.5 to 3 times in head; the obliquely set eyes very high 
up, laterodorsal, 4.5 to 5 times in head, 1.5 to 2 times in snout; the interorbital 1.5 to 2 times in eye; the mouth oblique, with large thick lips, the lower jaw slightly included, the posterior angle of maxillary in advance of or beneath front margin of eye; the outer row of teeth in upper jaw enlarged, slightly recurved; the outer row in lower jaw of similar but much smaller teeth; behind outer row in each jaw two or three rows of minute teeth; no canines; the body covered with firm ctenoid scales, largest posteriorly, those above pectoral becoming very small toward angle of opercle, where they cease; the entire head naked and nuchal region naked down to posterior angle of opercles and back to origin of first dorsal; sometimes there are a few scales before first dorsal; the pectoral bases scaleless and the entire region about ventrals naked, including the breast, the region between ventral and pectoral insertion, and a median strip behind ventrals which may extend to anus; the dorsals small and far apart, of equal height, or first dorsal with a short filamentous tip on second spine, rarely equaling depth, the longest spine or ray twice or a little less than twice in head; the anal may equal but usually is less than second dorsal in height; the posterior rays of second dorsal and anal are longest but do not reach caudal when depressed, the fins angulate or round-angled posteriorly; the depth of caudal peduncle 2.2 to 2.5 times in head and 0.6 to 0.7 of its own length; the caudal broadly rounded, its length $\frac{2}{3}$ to 0.8 that of head; the pectoral broadly rounded, equal to or a little longer than caudal; the ventrals typical of the genus, 2 to 2.5 in head, and reaching less than halfway to anus; the small anal papilla short and triangular.

According to Seale the color in life is "dull yellow-brown, uniform whitish on under jaw, eyes blue, fins grayish, 2 anterior spines silvery white, rays of anal silvery white, caudal washed with dusky at tip."

Alcoholic specimens are dull yellowish brown, the underside of head paler; the fins somewhat dusky or clear. Some specimens have the sides of the head thickly sprinkled with dark brown specks.

Here described from Seale's four type specimens, and sixtynine cotypes collected by E. A. Mearns and W. D. Carpenter in May, 1907, from Trinidad River at Baguio, at an approximate elevation of 1,360 meters. These specimens range from 19 to 54 millimeters in length. I have also examined twenty-seven 
specimens collected by E. H. Taylor and four specimens collected by W. Schultze, all from the same locality, the largest 59 millimeters long. One of the cotypes and three of the Taylor collection have seven dorsal spines.

I also place here two specimens collected by me from Rio Chico, Bontoc, 41 and 46 millimeters in length; in these the posterior margin of the caudal is white. Six young specimens, each about 20 millimeters long, from Balete Pass, Nueva Vizcaya Province, altitude 860 meters, also belong here.

\section{TUKUGOBIUS PHILIPPINUS sp. nov.}

Tagalog name, biang tuku (lizard goby).

Dorsal VI, or VII, I-8 or 9 ; anal I, 7 or 8 ; 36 to 40 scales in a longitudinal series, 12 to 14 in a transverse series, and 12 to 14 rows of scales before the first dorsal.

The body low, with nearly parallel dorsal and ventral profiles or the belly a little protuberant, plump and subcylindrical anteriorly, wedgelike seen from above, laterally compressed posteriorly, the depth 4.4 to 5.5 in length; the large, broad, depressed head 3.2 to 3.66 in length, its upper profile descending at an angle of about $45^{\circ}$ to tip of snout; the cheeks fat, so that the head is much wider than the body, its breadth $\frac{2}{3}$ its length and its depth 0.7 its width; the snout broadly rounded, 2.4 to 3 in head; the eyes dorsolateral, rather small, 5 to 5.5 in the head in adults, 4 or less in those not fully grown, 1.3 to 2 times in snout; the interorbital 1.5 to 2 in eye; the slightly oblique terminal mouth low down, with large thick lips, the jaws equal or the upper lip slightly projecting, the posterior angle of maxillary beneath front margin of eye or scarcely reaching it; the teeth of outer row in upper jaw curved and a little enlarged; some distance behind are three rows of minute, sharppointed teeth; in the lower jaw are three rows of very small teeth, those of the outer row larger than the others and curved outward; the head and nape naked except for the minute scales before first dorsal; the pectoral bases and the region down to and including the breast naked; the belly scaled; the dorsals small, far apart, approximately equal in height or first dorsal a little higher, usually equal to depth, rarely exceeding it; the second and third dorsal spines usually have filamentous tips but the first dorsal rarely reaches second dorsal when depressed; the short anal may equal but is usually a little less than second 
dorsal in height, the posterior rays of both somewhat elongate and angulate, never reaching caudal when depressed; the depth of caudal peduncle 2.3 to 2.5 times in head and 1.5 to 2 times in its own length, which equals depth of body; the broadly rounded caudal 3.5 to 3.75 in length and 0.8 to 0.9 as long as head; the pectoral a little shorter than caudal, 0.7 to 0.8 of head; the ventrals are typical of the genus, very short and rounded, twice or more than twice in head and reaching less than halfway to anus; the anal papilla small and triangular in males, much broader and blunter in females.

The color in alcohol dark brown or blackish, clouded with darker; five or six transverse bands more or less evident on many specimens; in the smaller specimens there is a black crossbar or spot on base of caudal; the sides of head sprinkled with minute, dark brown spots, which may extend upon pectoral base; all the fins more or less brown to blackish, the ventrals palest, with traces on second dorsal of cross rows of darker spots; the tips of the two anterior spines of first dorsal and the tips of second dorsal rays usually silvery white; the tip of caudal white.

Here described from fourteen specimens, 33 to 53 millimeters in length, from Irid River, Santa Ines, Rizal Province, and twenty-two cotypes, 30 to 60 millimeters long, from Banaban River, Angat, Bulacan Province. Two of them are females, 40 millimeters long, ready to spawn; their eggs are few and very large, 1.75 millimeters in diameter.

The Banaban River specimens have the ground color pale yellowish or yellowish gray, with five broad, blackish, dorsal crossbands which divide on the sides and form a series of broad lateral bands or spots more or less united along the middle of the sides; the posterior bands may be divided so as to form a series of zigzag bands, with the ground color forming pale or golden spots dorsally and laterally between them; there is a black crossband at the base of the caudal with a transverse black spot behind it; the sides of the head are sprinkled with tiny, dark brown specks, which may extend upon the pectoral; the first dorsal is blackish, with the upper anterior part silvery white; the other fins are more or less golden, with blackish rays, or the membranes may be partly violet-red, and with a white or golden margin; the second dorsal is obscurely crossbarred with faint, dark brown dots; the pupils are white. 
The Bureau of Science collection also contains the following additional specimens, 22 to 60 millimeters long:

Nalvo, Luna, La Union Province, 2.

Kalumpang River, Norzagaray, Bulacan Province, 9.

Ibo Creek, near Angat River, Bulacan Province, 5.

Irid River, Santa Ines, Rizal Province, 9.

Nanang River, Antipolo, Rizal Province, 4. One of these is a female, 40 millimeters long, the belly distended with enormous eggs, 2 millimeters in diameter.

Hinagianan River, Camarines Sur Province, 4.

Fabrica, Occidental Negros, 2. San Jose, Leyte, 2.

Without locality label, 15 fine specimens.

Three of the specimens from Irid River, Rizal Province, have but five spines in the first dorsal; in several of them the second and third spines are greatly elongated, reaching beyond the origin of the second dorsal when depressed.

\section{Genus 29. GNATHOLEPIS Bleeker}

Gnatholepis BLEEKER, Arch. Neerl. Sci. Nat. 9 (1874) 318; JoRDAN and SeAle, Bull. Bur. Fisheries 25 (1906) 394.

Hazeus Jordan and SNYder, Proc. U. S. Nat. Mus. 24 (1901) 51.

Exyrias Jordan and Seale, Fishes Samoa, Bull. Bur. Fisheries 25 (1906) 405.

This genus is separated from all other small, slender gobies without silky rays on the pectoral by having the cheeks entirely and the opercles partly or entirely covered with large scales. The dorsals are close together, not elevated, VI, I-8 to 11 ; anal I, 8 to 11 ; the scales are moderately large, 24 to 32 in a longitudinal series; the head is convex, the mouth oblique, the tongue notched in our species, except in the subgenus Exyrias, the body laterally compressed and moderately elongate; the caudal is rounded, shorter or longer than the head; the teeth are in two to four rows in each jaw, fixed or depressible, those of the outer row enlarged; a posterior canine may be present in the lower jaw; exceptionally canines may be present in the upper jaw in front of the other teeth; the gill opening is of moderate width, not extended forward, the isthmus broad; no silky rays above on the pectoral.

Exyrias does not seem to me to be a well-founded genus, though it might be considered a subgenus, separated by having two conspicuous longitudinal grooves on the preopercle; the tip of the tongue is rounded, while in other Philippine species of Gnatholepis it is notched. Some species of Gnatholepis elsewhere are said to have it rounded. 
The authors of Exyrias failed to give a diagnosis of their proposed genus, merely designating the type, Gobius puntangoides Bleeker. They further stated "This East Indian species, not seen by us, resembles an Awaous, although figured as having the cheeks fully scaled." I fail to find any resemblance to any species of Chonophorus (formerly Awaous) known to me, and the fleshy papillæ or flaps on the shoulder girdle, so characteristic of Chonophorus, are totally lacking.

Coral-reef fishes, ranging from Japan through the East Indies to Samoa and north again to Hawaii; the genus occurs also in the West Indies.

\section{Key to the Philippine species of Gnatholepis.}

$a^{1}$. Exyrias: Two prominent longitudinal grooves on cheek, dividing scales into three groups

G. puntangoides.

$a^{2}$. Gnatholepis: Cheek not as above.

$b^{1}$. No line from eye across cheek.

$c^{1}$. A prominent groove below upper row of scales on cheek; no canines

G. calliurus.

$c^{2}$. No groove on cheek; large canines in lower jaw; outer teeth above caniniform

G. volcanus.

$b^{2}$. A vertical dark line from eye across cheek.

$d^{1}$. Line not intersected.

$e^{1}$. Anal I, 11, bluish; a large brown spot on cheek, from which two diverging lines continue downward, forming the Greek letter delta on lower side of head

G. deltoides.

$e^{2}$. Anal I, 10, checkered with round black and white spots; black line from eye to throat neither intersected nor divided.

G. davaoensis.

$d^{2}$. Line from eye to throat usually intersected by one or two short transverse lines.

$f^{1}$. Side of head with pearly circular spots; body with vertical stripes or longitudinal rows of pearly white spots; one or two pairs of canines in front of upper jaw; scales 25 to 27 ; before first dorsal, 8 .

G. gemmeus.

$f^{2}$. No pearly spots or lines on head or body; no anterior canines in upper jaw; scales 30 ; before first dorsal, 10. G. knighti.

53. GNATHOLEPIS PUNTANGOIDES (Bleeker)

Plate 9, Fig. 1

Gobius puntang BLEEKER, Nat. Tijd. Ned. Ind. 3 (1852) 692, not 2 (1851) 486; DaY, Fishes of India (1878) 288, pl. 62, fig. 1; VaILLANT, Nouv. Arch. Mus. Nat. III 5 (1893) 58.

Gobius puntangoides BLEEKrR, Nat. Tijd. Ned. Ind. 5 (1853) 242;

GünthrR, Cat. Fishes Brit. Mus. 3 (1861) 19; Fische der Südsee 2 (1875) 171, pl. 108, fig. A ; MEYkR, Ann., Soc. España Hist. Nat. 14 (1885) 29.

Exyrias puntangoides Jordan and Seale, Fishes of Samoa, Bull. Bur. Fisheries 25 (1906) 405. 
Bicol name, kamumbon; Cebu-Visayan name, burok.

Dorsal, VI, I-10; anal, I, 9; there are 28 or 29 scales in a lateral series and 9 or 10 in a transverse series; 10 or 11 scales before first dorsal.

The deep, robust, oblong body laterally compressed, with wide, flat, caudal peduncle; the cheeks full and the region above opercles elevated and laterally compressed; the dorsal profile strongly convex, often with a marked rise behind eyes; the depth 3.6 to 4.3 times in length; the head equals or is greater than the depth, 3.2 to 3.75 in the length; the snout short, descending in a very steep curve, its length '2.7 to 3 times in head; the oblique eyes high up, close together, dorsolateral in position, 3.8 to 4.5 times in head and 1.5 times in snout; the interorbital space 0.5 to $\frac{2}{3}$ an eye diameter in width; the mouth small, slightly oblique, the posterior angle of maxillary not extending beyond front of eye and usually not reaching its anterior margin; the anterior nostril has a short membranous tubule, the posterior one is larger and open; above the last is a pore, and there are two pores in interorbital space, the anterior one large and conspicuous; the opercles and preopercles covered with large scales, those on last named divided into three groups by grooves bearing lines of fine papillæ; large pores distributed as follows: One behind middle of eye, one behind eye at origin of conspicuous supraopercular groove and four more distributed along its course, and three on posterior margin of preopercle; the depth of caudal peduncle contained 1.7 to twice in length of head; the dorsal spines flexible, with more or less threadlike tips, the first three longest, the second sometimes excessively elongate, even extending to axil of second dorsal; the base of anal shorter than that of soft dorsal, the two fins similar in outline, with elongate posterior rays which reach base of caudal when depressed, those of anal longest and greater than depth of body at their base; the pectorals pointed, longer than the broad ventrals, which extend to anal but not to the small pointed anal papilla; the pointed caudal approximately half again as long as head.

The color in alcohol varies from gray to blackish brown, paler or yellow on belly; the snout and cheeks below eyes deep brown to blackish and the nape nearly as dark; the scales along sides each marked by a central pale or white spot, these forming longitudinal rows; two or three rows of black spots more or less evident along back below dorsal fins; all spots may disappear 
in old specimens; the dorsals, caudal, and pectorals are barred by rows of dark spots; the anal is clear or has only traces of longitudinal streaks; the ventrals are blackish; specimens from Albay Province show four to eight narrow, vertical crosslines, most prominent on the yellow belly; the first dorsal crossbarred by alternate rows of violet-brown and golden yellow spots; the second dorsal, caudal, and pectorals barred by many rows of dark spots; the anal is clear or has only traces of longitudinal streaks; the ventrals blackish. In a specimen from Sandakan, Borneo, the caudal and anal are crossbarred by many rows of crimson spots.

In life the sides are spotted with rows of beautiful blue dots, making this one of the handsomest of gobies.

From the following localities I have examined seventy-six specimens, varying from 31 to 114 millimeters in length:

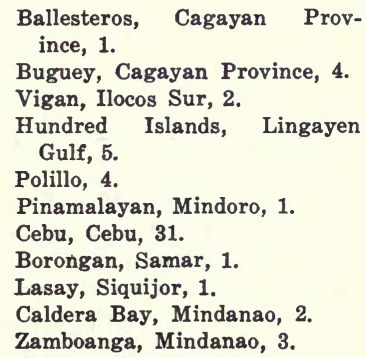

Pasay, Manila Bay, 1. Balayan Bay, Batangas, 1.

Puru River, Legaspi, Albay Province, 8.

Bacon, Sorsogon, 1.

Puerto Galera, Mindoro, 4.

Davao, Mindanao, 4.

Balabac, 1.

Jolo, Sulu Province, 2.

Bungau, Sulu Province, 17.

Sandakan, Borneo, 1.

Guindulman, Bohol, 2.

Meyer collected this species at Cebu, where it is common in the market, and Whitehead obtained it in Palawan, as recorded by Vaillant.

The descriptions by Bleeker, Day, and Günther contain discrepancies, the chief one being the presence or absence of canines. I find, in a series taken at one time and place, that there is considerable variation in this respect. Only a few specimens have teeth that can really be called canines, though in all of them the posterior teeth of the outer row in the mandible are more or less enlarged. In other specimens the caniniform teeth have evidently been broken out. The teeth of the outer row in both jaws seem to be subject to much breakage or injury.

This goby occurs from the Andamans eastward throughout the East Indies, to Shortland Island, one of the Solomon Islands, and Ponape in the Caroline Islands. 
54. GNATHOLEPIS CALLIURUS Jordan and Seale

Plate 9, Fig. 2

Gnatholepis calliurus JoRdan and SeALE, Proc. U. S. Nat. Mus. 28 (1905) 796, fig. 14.

Dorsal VI, I-10; anal I, 9; there are 28 to 30 scales in a longitudinal series, 10 in a transverse series, and 9 or 10 before the first dorsal.

The oblong, moderately elongate body laterally compressed, the dorsal profile nearly horizontal to moderately arched, with rounded belly and narrow dorsally, the depth 4.5 to 4.83 in length (3.1 in one female about to spawn); the large head narrowed anteriorly, with moderately convex profile and slightly projecting lower jaw, and contained 3 to 3.2 times in length; the snout short, with a large median hump, from 3.6 to 4.66 times in head, usually about 4 in adult specimens; the full prominent eyes high up, close together, dorsolateral in position, and equal to or a little longer than snout, 3.5 to 4 in head; the interorbital space very narrow, its breadth 5 times in eye; the mouth oblique, the posterior angle of maxillary under anterior part of eye; four rows of teeth in each jaw, those of outer row largest and fixed, the others all depressible; the teeth of fourth row next in size but very much smaller, and those of the two inner rows minute; the teeth of outer row in upper jaw much larger and more widely spaced than any of the others; the tongue rounded; the cheeks covered by three rows of large cycloid scales, with a prominent longitudinal groove below upper row; the opercles naked below, with one or two rows of cycloid scales along their upper margin; the rest of body covered with large ctenoid scales, extending forward on nape between posterior parts of eyes, except for a few cycloid scales on anterior angle of breast; the depth of caudal peduncle 2.25 to 2.5 times in head; the first dorsal small, the second spine longest but not more than $\frac{5}{6}$ of depth, the tips of the spines but little or not at all extended beyond the membrane, seldom reaching the origin of second dorsal when depressed; the first ray of second dorsal equals the depth, the others progressively increase slightly in length; the anal similar to second dorsal but with a base about 0.75 as long as that of second dorsal, its longest rays equal to depth; the pectoral is rather pointed, about as long as caudal, and extends back as far as a point above origin of anal; the pointed ventrals never quite reach origin of anal, their length equal or nearly equal to the depth; the caudal gently rounded or nearly truncate, its length less than 
head but greater than depth; in males anal papilla long, slender, and pointed, about 0.75 an eye diameter in length; in females short, broad, cylindrical, round-tipped, its length less than diameter of pupil.

The color in alcohol pale brown above, merging into white beneath, with a whitish spot in the center of each brown scale, the spots forming longitudinal lines; a large, nearly circular, blackish spot on base of caudal peduncle and four similar but much paler spots along median lateral line, the anterior one beneath pectoral and in line with first dorsal; in some specimens these spots are connected by a blackish line; on the opercle, in front of pectoral, is a large, dusky, iridescent silver spot; the upper part of eye covered by a heavily pigmented blackish band; the pupil white, the cornea with more or less blue iridescence; the dorsals and anal sprinkled with minute specks of dark brown; the caudal dusky with several white crossbars or rows of spots; the ventrals and pectorals faintly marked with dusky specks or the central part of the ventrals may be blackish; the base of pectoral marked with a dusky spot on upper part.

Here described from twelve female and five male specimens, 43 to 58 millimeters in length, obtained by me in the Manila market in November, 1924. The smallest and the largest specimens are females, and all the females are nearly ready to spawn, one only being actually ripe.

The Bureau of Science collection also contains the following specimens, ranging from 46 to 77 millimeters in length:

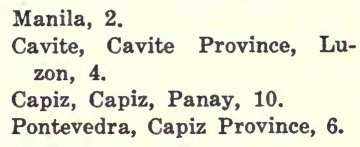

Estancia, Panay, 1.

Zarraga, Iloilo Province, $\mathrm{Pa}$ nay, 1.

Sandakan, Borneo, 5.

The Bureau of Science collection contains, in addition to the above, ten specimens from Manila Bay, killed in 1917, by an influx of "red water," or a plague of Peridinium.

This species was described by Jordan and Seale from specimens collected by Dr. Bashford Dean on the southern coast of Negros.

The six specimens from Pontevedra, Capiz, are all females about ready to spawn, measuring 60 to 63 millimeters in length. They were obtained August 3, 1925.

55. GNATHOLEPIS VOLCANUS sp. nov.

Dorsal I-10; anal I, 11; there are 30 scales in a longitudinal series, 9 in a transverse series, and 12 before the first dorsal. 
The elongate body laterally compressed, the dorsal profile horizontal from the full rounded nape to the caudal, convex anteriorly, the ventral profile horizontal to anal, then ascendant to caudal, the depth 6 times in length; the head narrowed above, 3.58 times in length; the snout narrowed, convex, 3.7 times in head; the eyes large, very high up, laterodorsal, inclined toward each other and their inner margins touching, looking up as much as sideways, equal to snout; the mouth oblique, with projecting chin, the posterior angle of maxillary beneath front margin of eye; the teeth in upper jaw in four rows, the outer row with two or three pairs of stout, downward-pointed, somewhat curved canines anteriorly, the remaining teeth of outer row of moderate size, widely spaced; the next two rows minute; the fourth row has the anterior teeth much longer, slender, pointed, inclined backward, and depressible, the remaining teeth very small; the lower jaw has a short outer row of moderate teeth, ending on each side in a stout curved canine; behind this are two rows of small, slender, pointed teeth extending far back; the tongue slightly crenate emarginate; four rows of large scales on cheek, with a fifth row of small scales between second and third rows; the opercles scaled on upper half; the body covered with large, very finely ctenoid scales, those before first dorsal smaller and extending forward to eyes; the tips of second, third, and fourth dorsal spines elongated, threadlike, the second a trifle the longest, 1.5 times the depth and 1.12 times in the head, reaching beyond base of third ray of second dorsal when depressed; the second dorsal slightly lower than depth, the posterior ray not reaching caudal when depressed; the anal highest posteriorly, the last ray not quite reaching caudal when depressed, the longest ray slightly exceeding depth; the depth of caudal peduncle $1 \frac{1}{8}$ times in its length and $2 \frac{1}{3}$ times in head; the caudal shorter than head, 4.54 times in length; the pectoral rather narrow, pointed, the central rays longest, almost equal to head, 3.8 times in length; the broad, roundtipped ventrals have a wide, deep, but thin frenum, 1.4 times in head, their tip not nearly reaching the very short, blunt, cylindrical anal papilla.

Here described from a specimen, 100 millimeters in length, collected by me in Lake Taal, Batangas Province, Luzon. Several subsequent trips have failed to yield more specimens, though the fish is well known to the fishermen. During certain seasons it retires to deep water, and later trips have all been made at those times. 
Volcanus, because a resident of the lake in which Taal Volcano is located.

\section{GNATHOLEPIS DELTOIDES (Seale)}

Gobius deltoides Seate, Occ. Papers Bishop Museum 1 (1901) 125; JoRdAN and Seale, Proc. U. S. Nat. Mus. 28 (1905) 796.

Dorsal VI, I-11; anal I, 11; there are 28 scales in a longitudinal series and 10 in a transverse series; 10 or 12 scales before the first dorsal.

The body elongate, compressed posteriorly, the depth in a spawning female about 4 times in the length; the head 3.57 times in the length, with narrowed nape, the broad, blunt, rounded snout 2.8 times in head and longer than eye, which is 3.5 times in head; the eyes very high up, obliquely placed so that they look up as well as laterally, close together, the interorbital about 3 times in an eye diameter; the mouth small, terminal, oblique, the jaws equal, the posterior angle of maxillary just reaching a point below front margin of eye; in the upper jaw the outer row has the teeth more widely spaced, with some comparatively large caniniform teeth in front; the other teeth minute, in two rows anteriorly but only one posteriorly; in the lower jaw three pairs of caniniform teeth in outer row, the posterior ones stoutest and backward-curved, with an inner row of teeth somewhat larger than those in upper jaw; the first dorsal low, the tips of some of the spines slightly elongate, third spine longest, 1.75 in head; the soft dorsal and anal angulate posteriorly, the posterior portion longest and extending upon caudal when depressed, the dorsal a little higher, its longest ray 1.4 times in head; the round pointed caudal a trifle longer than head, $3 \frac{1}{3}$ times in length; the pointed pectoral is slightly shorter than head and extends beyond tip of ventrals.

The color in alcohol yellowish white, with six or seven reddish brown dorsal crossbars, alternating with blotches of like color along sides; on the upper part of eye a short black transverse bar; below the pupil a small circular white spot beside which a brownish black line begins and extends vertically downward to a large brown spot on cheek; from the lower edge of this spot one line continues downward under head, and another is directed obliquely forward and downward, the two thus forming the Greek letter delta; a dark brown diagonal line extends upward and backward across opercle, and a similar line extends lengthwise on middle of pectoral base; the first dorsal is marked, at least anteriorly, by three transverse rows of dark 
brown spots; the caudal and pectorals crossbarred by many rows of dark spots; the second dorsal marked by spots and streaks of brown; the anal bluish; the ventrals bluish with longitudinal rows of fine, dark brown specks on the membranes.

Of this distinct species I have one mature female specimen in spawning condition, 50 millimeters long, collected by Jose Montilla, of the division of fisheries, at San Juan, Siquijor, March $10,1926$.

Originally collected by Seale at Guam, its presence elsewhere has been more or less doubtful, but there can be no question of the determination of this specimen from Siquijor.

\section{GNATHOLEPIS DAVAOENSIS Seale}

Gnatholepis davaoensis SEALE, Philip. Journ. Sci. § A 4 (1909) 537.

Dorsal VI, I-11; anal I, 10 ; "scales about 26 in lateral series."

The body elongate, the posterior part laterally compressed, the upper and lower outlines of body about evenly and equally curved, the depth 4.2 times, the head 3.75 times in length; the bluntly rounded snout 3.75 times in head; the eyes equal to snout, very high up, dorsolateral, close together, the interorbital space a mere ridge; the mouth oblique, the jaws equal, the posterior angle of maxillary beneath front margin of eye; the teeth in several rows in each jaw, those of outer one enlarged and curved, with a large, recurved, posterior canine on each side in lower jaw; the tongue strongly notched; the whole fish covered with large thin scales, those on preopercle in three rows; the longest spine of first dorsal 1.3 times in head and equal to the longest ray of second dorsal; the anal a little higher, its longest ray equal to head; the rounded caudal 0.25 longer than head; the ventrals very long, equal to caudal, their tips reaching anal; the pectorals equal head.

The color dull yellowish gray with six dusky blotches along the side, three or four distinct black dots at base of caudal, a black band from eye to middle of throat, some scattered black specks over body, and indistinct, dusky, dorsal crossbars; the spinous dorsal grayish with several scattered dusky spots and ten black dots on lower part of fin; the soft dorsal grayish, the anterior part with faint, darker crossbars; the anal peculiarly checkered with round black and white spots; the caudal grayish, with numerous indistinct brownish dots and several larger, distinct black spots on lower half of fin; the pectoral gray, the ventral gray with a black margin. 
The foregoing description is adapted from Seale. His type, 45 millimeters long, obtained by him at Samal Island, in Davao Gulf, Mindanao, is no longer in the Bureau of Science collection.

\section{GNATHOLEPIS GEMMEUS sp. nov.}

\section{Plate 9, Fig. 3}

Dorsal VI, I-11 or 12; anal I, 11; there are 25 to 27 scales in a longitudinal series and 10 in a transverse series; 10 scales before the first dorsal.

The elongate oblong body strongly compressed laterally, the dorsal profile more or less gently arched, the greatest depth 4 to 4.6 in length; the head of moderate size, broader than body but deeper than wide, with convex anterior profile and narrowed, almost ridgelike nape, its length about 3.5 times (3.46 to 3.7) in that of head and trunk together; the convex snout short, blunt, 3 to 3.4 times in head; the eyes high up, close together, dorsolateral in position, their length equal to or slightly less than that of snout; the interorbital narrow, about 3.5 times in eye; the mouth small, terminal, oblique, the jaws equal, the posterior angle of maxillary extending or almost extending to a point beneath front margin of eye; in the upper jaw are two rows of curved, depressible teeth, preceded by one or two pairs of long, slender, inward-curved caniniform teeth on either side of median line of jaw; in lower jaw are two rows of teeth, the outer one of ten or twelve large, widely spaced teeth, terminating in a pair of backward-curved canines; the caudal peduncle wide, 2.3 to 2.4 in head; the first dorsal low, the tips of the spines filamentous but not elongated, reaching second or third ray of second dorsal when depressed, the longest 1.14 to 1.4 times in depth and 1.4 to 1.7 in head; the second dorsal and anal approximately equal in height and equal to or higher than first dorsal, the posterior rays reaching base of caudal when depressed, 1.1 to 1.25 in depth and 1.3 to 1.5 in head; the caudal truncate or with rounded corners, equal to or a trifle more or less than head, 3 to 3.75 times in length; the pectoral and ventral approximately equal in length, equal to or a trifle less than head in length, and reaching to or beyond the small pointed anal papilla or reaching anal.

The body covered with loosely attached, large, ctenoid scales which extend forward to eyes; there are four rows of large scales on preopercles and three on opercle; the base of pectoral 
also covered with large scales; the teeth of these anterior scales are easily rubbed off, so that they often appear to be cycloid; no papillæ or grooves on cheeks.

The color in alcohol varies from dark yellowish brown to very pale yellowish brown; along the sides are six broad, dark crossbands, the posterior ones large, circular spots in young specimens; each band margined by a wide stripe of pearly white, which with age breaks up, so that longitudinal rows of pearly white spots are formed along the sides; a narrow dark brown stripe passes vertically through eye and down across cheek; sometimes it is crossed by one or two short transverse lines; a longitudinal, faint, brown line passes across middle of opercle and on across base of pectoral, where it is darker; the preopercles, opercles, and pectoral bases are marked by large circular pearly spots; the nape and sides below dorsal dotted with small, dark brown spots; the first dorsal crossbarred by brown and white spots; near base of sixth spine a circular blackish brown spot and a paler one on basal part of fourth spine; the second dorsal has dusky rays, with brown up-and-down streaks more or less developed on the membrane; the anal crossed by two rows of large, conspicuous, circular black spots, alternating with white; the pectoral crossbarred by small brown spots; the ventrals dusky or specked with brown, or gray, with a dark brown margin; there is a dark brown spot on base of caudal, followed by several blackish spots, the rest of the fin more or less crossbarred by small brown spots.

Here described from twenty-five specimens, most of them faded and in very poor condition, ranging from 25 to 45 millimeters in length. The type is a specimen from Samal Island, in Davao Gulf, Mindanao. There are seventeen other specimens in the collection from the same locality, one from Davao and five from Sitankai, Sulu Province. I place here also an aberrant specimen from Dumaguete, Oriental Negros. In life this must have been very handsome, as the pearly spots were probably blue then.

This species is close to Gnatholepis knighti Jordan and Evermann, but differs in dentition, scalation, and markings, and in having a shorter snout and larger eye; from $G$. davaoensis Seale it differs in dentition, and particularly in color markings. In dentition it is unique among the Philippine representatives of this genus.

Gemmeus, jeweled, in reference to the beautiful pearly spots. 
Since the above was written I received a gorgeously colored male specimen, 38 millimeters long, from San Juan, Siquijor. The tips of the second and third dorsal spines are filamentous, 1.2 times in the head; the second dorsal is high, the antepenultimate ray longest, 1.1 times in the head; the anal is similar but lower, the longest ray equal to the first dorsal.

The color in life was yellowish gray with four broad vertical crossbands, of a very dark reddish violet or violet-brown hue, most prominent on the ventral half, the first behind the pectorals, the fourth near the posterior end of the second dorsal; a row of about eight large circular spots on the side, the first at the axil of the pectoral, the others high up on the side between or above the crossbands, the last two on the middle of the side of the caudal peduncle; the bands and spots all with a wide pearl margin; the sides of the head and pectoral base are thickly sprinkled with circular or elongate pearl spots; a red streak along the supraopercular groove to beyond the pectoral, and another one longitudinally across the opercle and base of the pectoral; a black band starts from the upper margin of the eye, crosses the cheek diagonally behind the mouth, and meets its fellow beneath the throat; the first dorsal is yellow with irregular golden brown crossbars; behind the base of the fourth and sixth spines is a small violet-red ocellated spot; the second dorsal membrane is dark brown; the anal membrane is banded by three rows of deep violet, alternating with two rows of bright yellow spots, all more or less circular; the caudal is crossbarred by many alternate rows of bright red and brown spots; the ventrals have yellow membranes, densely sprinkled with minute blackish specks.

59. GNATHOLEPIS KNIGHTI Jordan and Evermann

Plate 29, Fig. 1

Gnatholepis knighti JoRDAN and EvermanN, Bull. U. S. Fish Comm. 22 (1902) 204, pl. 58.

Dorsal VI, I-11; anal I, 11; there are 30 scales in a longitudinal series, 10 in a transverse series, and 8 before the first dorsal.

The body short, strongly compressed laterally, the depth about 4.25 times in length, the dorsal profile nearly horizontal, the ventral one convex, sloping up posteriorly to caudal, the head 3.45 or 3.5 times in length, deeper than broad, its breadth 0.875 of its depth, which is nearly equal to that of body and contained 
1.37 times in its own length; the nape not rounded but appressed, almost ridged; the snout convex, bluntly rounded, 3.1 times in head and a little more than eye, which is 3.66 times in head; the eyes very high up, lateral, close together, the interorbital about 4 times in eye diameter; the oblique mouth small, with protractile upper lip, wholly anterior, the jaws equal, the posterior angle of maxillary before front margin of eye; the teeth of outer row in upper jaw enlarged, hooked or curved, followed by an inner row of minute depressible teeth; in the lower jaw is a short row of small outer teeth, the posterior ones hooked, with an inner row of erect, depressible, smaller teeth; the cheeks entirely covered by three rows of scales, the opercles with four rows; the entire body scaled, including nape to eyes; the depth of caudal peduncle 2.2 times in head and about 0.8 of its own length; the caudal pointed, a little longer than head, 3.16 times in length; the first dorsal low, $\frac{7}{9}$ of the depth, the middle spines longest and reaching base of second dorsal ray when depressed; the spines of second dorsal of nearly uniform height, the next to the last posterior ray longest, reaching well on to caudal when depressed and equal to depth; the anal similar but lower, its posterior ray $\frac{7}{9}$ of the depth and reaching base of caudal when depressed; the pointed pectoral is as long as head and extends back to anterior part of anal; the ventrals are pointed and reach origin of anal.

The color in alcohol uniform yellowish, with a row of six large brown spots on lower half along each side; each scale on upper half of body marked by a black dot, these forming longitudinal rows; a dark brown line crosses interorbital and iris and extends below eye across cheek, where it is intersected by two short lines which meet behind it; the dorsals, pectoral, and caudal crossmarked by bars or small spots of brown; the anal colorless, the ventrals dusky.

Here described from a specimen, 38 millimeters long, collected at Polillo by E. H. Taylor. Another specimen, 30 millimeters long, from Nalvo, Luna, La Union Province, was whitish, the markings about as above; the anal was boldly marked with alternate rows of deep black and milk-white spots, two rows of each kind.

A fresh specimen, collected by Alvin Seale and drawn by $T$. S. Espinosa, was yellow, shading off to bluish white on the belly, with the scales of the head and trunk punctulated with groups of fine dots and a row of large brown spots along the lower half of the side; on the lower part of the iris was a red spot, and in a 
line behind it was a red spot on the preopercle and one on the opercle; a dark brown line crossed the upper part of the eye and extended from the lower margin of the eye downward, intersecting twice a curved line behind the angle of the mouth; a brown bar on the base of the pectoral ; the first dorsal was crossbarred with brown, the second dorsal, pectoral, and caudal with numerous rows of small brown spots; the anal and ventrals were dotted with very pale brown.

This species is common in the Hawaiian Islands, and has been collected several times in the Philippines.

Genus 30. CREISSON Jordan and Seale

Creisson Jordan and Seale, Bull. Bur. Fisheries 26 (1907) 43.

The authors state that "this genus is characterized by the naked lower half of cheek and the scaleless interorbital region. There are several rows of teeth in each jaw, the outer row enlarged; scales on anterior part of the body and head small."

To this can be added body robust, compressed laterally, profile convex. Dorsal VI, I-10; anal I, 7 or 8 ; there are 29 to 32 scales in a longitudinal series, 10 or 11 in a transverse series, and about 17 before the first dorsal; there are four to six rows of teeth at front of mouth in each jaw, which are reduced to two or three on the sides; the outer row more or less enlarged, with a pair of lateral backward-curving canines in lower jaw; the tongue truncate, not notched; the anterior nostril tubulate; the caudal broad and rounded.

60. CREISSON VAlidus Jordan and Seale

Plate 10, Fig. 1

Creisson validus Jordan and Seale, Bull. Bur. Fisheries 26 (1907) 43, fig. 16.

Tagalog name, bia ng sapa (brook goby); Visayan name at Busuanga, sisigui.

Fins and scales as given under the genus.

The robust body laterally compressed, with well-arched back, and the dorsal profile forming a bold curve from origin of dorsal to tip of snout; the head full and rounded, the depth and breadth approximately equal, and the predorsal region elevated and swollen; the depth of body 3.8 to 3.9 , the head 3.3 to 3.4 times in length; the snout short, blunt, rounded, 3.4 times in head; the eyes high up, laterosuperior, obliquely placed, close together, $1 \frac{1}{6}$ to 1.3 in snout; the convex interorbital space half or a trifle more than half an eye diameter in breadth; the oblique 
mouth small, with projecting chin, and usually not extending back as far as eye; rarely the posterior angle of maxillary under forward margin of eye; the tongue truncate; the upper half of preopercle, upper part of opercle, and base of pectoral covered with small scales; minute scales extend upon pectoral and caudal rays; occasionally a specimen has a row of scales below midline of papillæ on preopercle; the cheeks swollen, and below the scaled areas are one or more longitudinal lines of fine warts or papillæ and a marginal row on both opercle and preopercle; the large, open, posterior nostril in front of middle of eye; above it a large pore, and a large pore at both anterior and posterior margins of interorbital space; large pores behind and beneath eye, along supra-opercular groove, and on posterior margin of preopercle; about seventeen rows of scales before dorsal, smaller than those on sides and extending to eyes and advancing into interorbital space; the broad caudal peduncle contained twice to 1.75 times in head; the tips of second, third, and sometimes fourth dorsal spines elongate, reaching soft dorsal when depressed; in some specimens they become threadlike and greatly elongate, so that they reach to posterior axil of soft dorsal, as in the type of the species; the soft dorsal and anal similar in outline, the posterior rays elongate, reaching base of caudal when depressed, and longer than depth of body at their base; the base of anal approximately 0.75 as long as that of second dorsal; the pectorals rather narrow and pointed, little longer than the large broad ventrals, which sometimes extend to anus or even to the long slender anal papilla; the length of the large broad caudal equals or is greater than that of head.

The color in alcohol varies from greenish to reddish and yellowish brown, much darker dorsally, becoming pale or whitish underneath, with five large, dark brown or blackish spots along middle of side, the last at base of caudal; sometimes these are connected by a dark bar; along the back are seven indistinct dark brown crossbands, the last on top of the caudal peduncle; sometimes the crossbands are reduced to a series of lateral spots high up, with narrow brown stripes showing along middle of back; the nape sprinkled with small brown spots and several short dark brown lines lie behind eye and between it and origin of first dorsal; a dark brown line extends diagonally downward from lower margin of eye to base of pectoral and another, more horizontal one, from behind angle of mouth to base of pectoral; the last two lines may be broken into oblong spots; both dorsals and caudal more or less marked or barred by large spots of dark 
brown; the base of first dorsal may be yellow, especially anteriorly; the caudal tipped with a broad band of yellow or white, delimited by a conspicuous dark brown line along its inner side; the other fins more or less dusky, or the ventrals may be yellow; the base of the first dorsal and the caudal marginal band evidently yellow in life.

I have examined the following specimens, ranging in length from 28 to 93 millimeters:

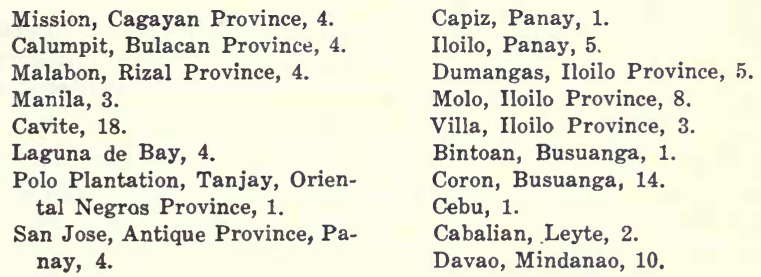

Most of these were compared with the type at Stanford University and, though there is some variation among them, all are readily placed here.

This is a well-marked species previously known only from the type specimen from Cavite.

Genus 31. VAIMOSA Jordan and Seale

Vaimosa Jordan and SeALe, Fishes of Samoa, Bull. Bur. Fisheries 25 (1906) 395.

This genus is separated from Rhinogobius and Gnatholepis by having the opercles covered with large scales, but the cheeks naked; the body is covered with large ctenoid scales, 26 to 38 in a longitudinal series, extending forward on the nape to the eyes; the anterior ones usually large, rarely smaller than those on the sides; the scales on the nape and opercles may appear cycloid but the microscope shows them to be ctenoid; the teeth are very small to microscopic, in bands of three to five rows in each jaw, without canines; the tip of the tongue is rounded or subtruncate; the dorsals are separated, often widely, the vertical fins rather short and low in our species, the caudal peduncle long; the caudal longer or shorter than the head, variously shaped; no silky free rays on the upper part of the pectoral.

Dorsal VI, I-6 to 9, anal I, 6 to 8 ; branchiostegals 5 .

A genus of small, sometimes handsomely decorated fishes, living among the rocks and gravel of swift streams or in mountain lakes, although at least one species also occurs in the sea. 
Species numerous in the Philippines, most of them confined to

a single lake, river system, or watershed.

Hitherto known only from the type species from Samoa.

Key to the Philippine species of Vaimosa.

$a^{1}$. Scales, 26 to $30 ; 6$ to 10 large scales before first dorsal.

$b .{ }^{1}$ Body and head much compressed laterally, as in the Apogonichthyidæ;

first dorsal with a clear band across middle; males with very large mouth and maxillary greatly lengthened backward.......... v. dispar.

$b^{2}$. Body of ordinary goby shape.

$c^{1}$. Mouth very large, extending beyond eye, both sexes with maxillary extending to posterior angle of preopercle........ V. macrognathos.

$c^{2}$. Mouth of ordinary size or small, the maxillary not lengthened backward.

$d^{1}$. Mouth inferior, snout more or less protuberant.

$e^{1}$. First dorsal with a basal black spot between fifth and sixth spines; no circular black spots on caudal base V. microstomia. $e^{2}$. First dorsal with a black spot at top between fifth and sixth spines; two conspicuous circular black spots on base of caudal V. piapensis.

$d^{2}$. Jaws equal, mouth not inferior.

$f^{2}$. First dorsal deep black except first spine on anterior basal part; opercle with a black spot divided by a white or pale diagonal bar. v. rivalis.

$f^{2}$. First dorsal and opercle not as above.

$g^{2}$. No longitudinal bands; a median lateral row of large black spots; first dorsal all black or golden whitish with a large black spot between fifth and sixth spines.

V. bikolana.

$g^{2}$. Body with one or more prominent black or dark brown longitudinal bands or lines.

$h^{1}$. A black bar on middle of side, from shoulder to base of caudal; first dorsal clear with a black blotch on upper posterior or central part. V. sapanga.

$h^{2}$. Four dark brown lateral lines from head to tail, inclosing whitish spots separated by crosslines; a row of six dark brown rectangular spots between the middle lines. V. tessellata. $a^{2}$. Thirty-eight scales; 18 very small scales before first dorsal.... V. villa.

\section{VAMMOSA DISPAR (Peters)}

Gobius dispar PeTERs, Monatsber. Akad. Wiss. Berlin (1868) 263.

Bicol name, irin-irin.

Dorsal VI, I-7; anal I, 7; there are 28 to 30 scales in a longitudinal series, 8 in a transverse series, and 10 before the first dorsal.

The body much compressed laterally, with arched back and convex dorsal profile, the depth 3 to 3.5 in males, 3.6 to 4.25 in females; the head laterally compressed, pointed when viewed 
laterally, its length 2.85 to 3.16 in males, 3.1 to 3.3 in females; the head deeper than broad, the depth $\frac{2}{3}$ to 0.75 of its length; the short, convex, bluntly rounded snout 3.25 to 4.1 times in head in males, 4.2 to 5 times in females; the eyes lateral, high up, the upper rim flush with profile, 4 to 4.8 times in head, the postorbital part of head always more than the distance from tip of snout to posterior margin of eye; the interorbital from 0.5 to 0.8 an eye diameter; the oblique mouth terminal, the jaws equal; in males the mouth very large, the posterior angle of maxillary extending to posterior margin of eye or more often much farther, upon preopercle; in females the mouth much smaller, the maxillary extending usually to a point just back of anterior margin of eye, rarely to middle of eye; the outer teeth of upper jaw slender, curved, enlarged, in a short row, followed by three rows of minute teeth; in lower jaw about four rows of very small slender teeth at forward end, reduced in number laterally, the inner row much enlarged posteriorly, the others disappearing; the body covered with large ctenoid scales, slightly reduced in size and becoming cycloid above opercles, extending forward of dorsal to eyes, the anterior scales in the midline behind eyes enlarged; the opercles covered with large cycloid scales, the preopercles naked; the pectoral bases and breast scaled; the dorsals well separated, the height of the spinous dorsal 2 to 2.5 times in head, in some specimens reaching second dorsal when depressed, in others not, the middle rays longest; the second dorsal and anal of similar shape, of equal height or anal a little the lower, the fifth and sixth rays usually longest; in males the second dorsal 1.5 to 1.8 times in head, the anal 1.6 to 2 times; in females the dorsal and anal usually equal, 1.8 times in head, the ventrals thin, broad, about equal to anal in length, never reaching anus; the pectoral thin, pointed, 1.2 to 1.4 times in head, scarcely reaching to a point above anus; the depth of caudal peduncle 1.8 to 1.95 in its own length in males, 2.1 to 2.2 in females; the tip of caudal gently rounded, its length 1.1 to 1.3 in that of head; the anal papilla very small, inconspicuous, thin, flat, triangular in males, thick and rounded in females.

The color in alcohol varies from dark brown or blackish to pale yellowish, with a black or dark brown spot on shoulder, followed by a row of eight or ten closely spaced, more or less poorly defined, dark spots which continue back to base of caudal; in males the sides and underpart of head strewn with white spots or small irregular lines and bars; in females they show indistinctly or are absent; the top of snout and interorbital dark 
brown; a small circular dark spot on posterior part of upper margin of eye; the fins all brownish or dusky, the first dorsal with a broad clear band across middle and upper margin also clear; the second dorsal and anal with three clear crossbars.

Here described after an examination of two hundred five specimens, ranging from 18 to 40 millimeters in length, the males averaging much larger than the females; these fish were picked out of masses of sinarapan, Mistichthys luzonensis, upon which they were feeding when caught. Many of them had the mouth greatly distended with sinarapan when captured, the tails of as many as three or four protruding. Many of the males were ripe and had the belly greatly swollen but none of the females was in breeding condition.

The Bureau of Science collection also contains five specimens, from 28 to 45 millimeters in length, collected by Alejo G. Arce, at Lake Buhi.

Specimens were collected by Jagor at Lake Buhi and Lake Bato, Camarines Sur Province, and two streams in either Albay or Camarines, Kolabós and Lebmanan.

This remarkable species is noticeable for its shape, unusual in gobies, for the extraordinary mouth and jaws of the males, and for the fact, also unusual in gobies, that the males average larger than the females.

Since the above was written Mr. Lopez has collected extensively in Camarines Sur Province, and I have examined three hundred sixty-five additional specimens from Lake Buhi, from 15 to 40 millimeters in length. They were obtained January 24, 1926; many are gravid females ready to spawn. This species reaches maturity when 24 millimeters or less in length; the eggs are numerous, rather large, greenish to whitish in color.

Many specimens had the underpart of the head black; the pectoral is usually golden or golden with a black tip.

Mr. Lopez also obtained one hundred sixty specimens from Lake Bato. From Buhi River, a tributary of Lake Buhi, he obtained seventeen specimens, from 17 to 32 millimeters in length, which present many differences from typical $V$. dispar. They are more rotund, like ordinary gobies, the color is more uniform golden yellow, the first dorsal has a broad blackish band posteriorly from the top to the base, or in some the entire upper and posterior part of the fin blackish. I therefore call them variety aurea.

These recently collected specimens show a wider range of scalation than do my previous specimens. The scales are often 
27 or even 26 in longitudinal series, and the number before the first dorsal may be as few as 6 . All, however, show the marked sexual dimorphism of the mouth.

\section{VAMOSA MACROGNATHOS sp. nov.}

Plate 10, Fig. 2

Dorsal VI, I-7; anal I, 6; there are 24 scales in a longitudinal series, 8 in a transverse series, and 7 before the first dorsal.

The body compressed laterally, the back arched, highest at first dorsal, the ventral line nearly straight, the depth 4.3 to 4.5 times in the length; the head rather large, blunt, broader than body but deeper than wide, 2.95 to 3 times in length; the snout blunt, rather narrow, convex, 4.3 to 5 times in head and equal to eye; the eyes high up, oblique, dorsolateral, the gaze directed partly upward as well as sideways; the interorbital about 2.3 to 2.4 times in eye; the very large, oblique mouth terminal, with protractile upper lip, the long sloping chin prominent but not projecting, the gape extending beyond eye and the angle of maxillary extending on preopercle nearly to its lower posterior angle; the upper jaw has an outer row of enlarged, curved, pointed teeth and two inner rows of very minute teeth; on the inner jaw are three or four rows of teeth, some of them enlarged and hooked, especially the outer and inner rows; the body covered with large scales, becoming smaller before first dorsal but the central ones largest anteriorly; about five scales on opercle; the dorsals rather far apart, the first spine of first dorsal elongate with delicate threadlike tip, extending to second or third ray of second dorsal when depressed, 0.7 to more than 0.9 the length of head; the second dorsal and anal short, of similar outline, rather high, the posterior rays longest and sometimes touching base of caudal when depressed, their height about the same, 1.46 to 1.75 times in head; the caudal peduncle long, its depth 1.75 to 2 times in its length and 2.6 times in head; the caudal pointed, a little shorter than head; the pectoral broadly pointed, 1.3 to 1.45 in head; the ventrals pointed, with incised margin, the frenum comparatively large and thick, 1.3 to 1.4 in head, reaching the small anal papilla; this is thin and triangular in males, cylindrical and short in females.

The color in alcohol yellowish gray, the upper half more or less dusky, with traces of obscure, short, dark crossbands over the back, and a broad blackish band from beneath pectoral to base of caudal. and often extended upon it along its lower half; the sides of head covered with broad curved bands of dark olive 228798-10 
brown, the original ground color appearing between as curved bands or rounded spots; a dark crossbar or spots at base of caudal and several black crossbands or rows of black spots upon it, the tip dusky; the first dorsal more or less dusky, the elongated tip of first spine black, and a black spot on upper margin behind third spine; the second dorsal has two black or dusky crossbands; the anal black, the ventrals black to nearly clear with blackish center, and the pectorals clear or with dusky tips.

Here described from thirteen specimens, 15.5 to 31.5 millimeters long, from Lake Taal, Batangas Province, Luzon. They are closely related to $V$. dispar (Peters), but the number of scales and the shape of the first dorsal are quite different. The huge mouth and maxillary are a characteristic of both sexes, instead of being confined to the males, as in $V$. dispar.

I also discovered in the Bureau of Science collection a female specimen, 26 millimeters long, obtained in Momboc River, Lake Naujan, Mindoro, by A. L. Day. It differs in having 26 scales in longitudinal series, and the color markings of the body have disappeared after twelve years in alcohol. It is uniform reddish brown, with traces of darker markings on the side. The fins are colored as in the types.

I likewise place here a specimen, 38 millimeters long, collected by me under the wharf at Bungau, Sulu Province. It also has 26 scales in longitudinal series, and the head is much narrower than in the other specimens. This is the only marine specimen thus far known to me.

Maxpós, long; yvatos, jaw.

63. VAImosa MiCrostomia Seale

Vaimosa microstomia SeALE, Philip. Journ. Sci. § A 4 (1909) 538.

Dorsal VI, I-7; anal I, 7; there are 27 scales in a longitudinal series, 8 in a vertical series, and 7 before the first dorsal.

The body stout, broader than head, laterally compressed, the upper and lower outlines about equally curved, the depth 3.5, the head 3.8 times in length; the convex snout bluntly rounded, heavy, projecting beyond mouth, 5.25 times in head; the eye high up, lateral, larger than snout, 3.75 times in head; the interorbital about half an eye diameter in breadth; the mouth small, inferior, the posterior angle of maxillary under anterior third of eye; the teeth minute, in a narrow band of three rows in each jaw; the body covered with large ctenoid scales which extend forward on nape to eyes; the opercles covered by nine or ten 
large scales not of uniform size; the cheeks crossed by two short longitudinal lines of mucus pores; the dorsals well separated, all the vertical fins of the same height, 1.5 times in head; the second dorsal and anal fall far short of reaching base of caudal when depressed; the caudal peduncle very long, its depth twice in its own length, 1.7 times in head; the caudal broken and badly damaged, but according to Seale was "rounded and considerably longer than the head;" the pectorals broad; both pectorals and ventrals are damaged, but when described by Seale they were equal to the head in length; the anal papilla thick, cylindrical, with rounded tip.

The color in alcohol yellowish, specked and blotched with brown; several large, broad, dark brown blotches on the median line form a broken bar from under pectoral to tail; seven short, dark brown crossbars over back; a curved, broken, brown band extends from shoulder back to top of caudal peduncle; a dark bar extends from eye downward diagonally to lower margin of preopercle; a large blackish spot on opercle; the spinous dorsal has a large black spot on basal portion of fifth and sixth spines; soft dorsal crossbarred by six rows of small brown dots, the caudal by eight brown lines; the other fins all yellowish.

This distinct species is only known from the type specimen, 32 millimeters long, No. 827 of the Bureau of Science collection, collected at Malabon, Rizal Province, Luzon, by Alvin Seale in July, 1909. It is a female distended with eggs.

64. VAIMOSA PIAPENSIS sp. nov.

Plate 10, Fig. 3

Dorsal VI, I-7; anal I, 7 ; there are 28 scales in a longitudinal series, 8 in a transverse series, and 6 or 7 before the first dorsal, the anterior one largest.

The body laterally compressed, with pointed head, the dorsal profile nearly horizontal, the ventral profile but little curved, the depth 4 to 4.8 times in the length; the head a little convex, short, broad across opercles, 4.1 to 4.25 in length, the breadth about equal to its own depth; the snout short, blunt, convex, broadly rounded, $4 \frac{2}{8}$ to 5.5 times in head and 2 to $1 \frac{2}{8}$ times in eye, which is 2.4 to 2.8 times in head; the eyes very high up, the upper margin protruding above the profile line, dorsolateral, and looking up as well as sideways, very close together; the interorbital space 2.5 times in the eye diameter; the mouth small, slightly oblique, the snout a little protuberant, the lower jaw thin and weak and the mouth therefore somewhat inferior, the 
posterior angle of maxillary beneath anterior third of eye; in the upper jaw an outer row of very small pointed teeth, behind which are several rows of microscopic, pointed, erect teeth; in the lower jaw an outer row of erect pointed teeth as in the upper jaw, with what under the microscope seem to be two similar rows of slightly smaller teeth behind it; the head scaled to the eyes, the opercular scales large, equal or nearly equal to those adjoining on nape; the scales on base of pectoral smallest, those on breast next in size; the dorsals far apart, the anterior spines longest, usually the second one longer than the rest, about 7 times in length, 1.5 to 1.8 times in depth, and 1.6 to 1.75 times in head, none of the spines approaching second dorsal when depressed; the second dorsal a trifle higher than first, the rays of nearly uniform length, the posterior rays reaching less than halfway to base of caudal; the anal equals or is lower than first dorsal in height; the depth of caudal peduncle 2.25 to 2.6 times in its own length; the caudal somewhat pointed, longer than head, about 3 or 3.2 times in the length; the pointed pectoral equals or slightly exceeds head in length; the ventrals thin, slender, 1.2 to 1.4 in head; the anal papilla small, somewhat pointed in males, thick, round-pointed in females.

The color in alcohol light yellowish brown, the back crossbanded with six broad bars of large, dark brown spots, the first on the nape, the second before first dorsal; the third one is most conspicuous and often descends as a dark bar diagonally forward halfway down the side; four or five small, dark brown blotches form a row along the middle of the side, with small, dark brown spots sprinkled along the whole upper half of body; on base of caudal are two conspicuous circular black spots; on the upper posterior extremity of first dorsal between fifth and sixth spines is a black blotch, the rest of the fin clear or more or less specked with brown; the second dorsal and caudal conspicuously crossbarred by four or more rows of dark brown spots; the other fins clear; below eye a broad brown bar descends to a point behind angle of mouth; the opercles and the region behind eyes more or less brown specked or blotched.

Here described from twelve specimens, 21.5 to 29 millimeters in length, six of them females, ready to spawn. They were collected by me March 5, 1922, from Piapi Creek, Dumaguete, Oriental Negros.

The Bureau of Science collection has three specimens, 19 to 27 millimeters long, collected by Alvin Seale in 1907 at Malabon, a town on Manila Bay just north of Manila; eight specimens, 
28 to 30 millimeters long, collected by H. R. Montalban at Capiz, Panay; three specimens, about the same size, from Iloilo; and twenty from Molo, Iloilo Province, Panay.

The collection contains eight specimens, 23 to 30 millimeters in length, in atrocious condition, which evidently belong here; they also came from Malabon in 1907. The scales vary from 25 to 28 , and in the larger ones, which are males, the dorsal spines and posterior dorsal rays are more or less elongated, the spines reaching to the second dorsal and the posterior ray almost touching the base of the caudal; in other respects they are like the types. I also place here seven specimens in vile condition and mostly denuded of scales, collected from Mariri River, San Jose de Buenavista, Antique Province; they are from 25 to 28 millimeters in length.

I list here also six specimens, 23 to 29 millimeters long, from Molo, Iloilo; they are faded and most of them have lost the characteristic spots on the base of the caudal; the largest one is a female, distended with eggs, which exude from the swollen genital papilla.

Rather than call them new I refer here eight specimens from Lake Taal, 12 to 19 millimeters in length; the scales are 26, and there are several black markings not present in the type specimens, including four black spots on the belly along the base of the anal.

Piapensis, from Piapi Creek, the type locality.

65. VAIMOSA RIVALIS sp. nov.

Plate 11, Fig. 1

Dorsal VI, I-7 or 8 ; anal I, 7; there are 27 to 29 scales in a longitudinal series, 8 or 9 in a transverse series, and 7 or 8 before the first dorsal, the anterior one or two larger than the others.

The body elongate, much compressed laterally, the back strongly arched, and highest at base of first dorsal, the depth 4.3 to 5 times (in one specimen 5.6) in length; the head moderately convex, 3.4 to 3.65 times in length, its depth $\frac{1}{9}$ or 0.1 less than its breadth, which is 1.5 to 1.6 times in its own length; the small convex snout round-pointed, 5 to 5.2 times in head; the eyes large, lateral but high up, longer than snout, about 3 to 3.5 times in head, very close together, the interorbital width less than the diameter of the small pupil, about 4 to 6 times in eye; the jaws equal, the mouth of moderate size, oblique, the lips rather broad, thick, the posterior angle of the maxillary extending back to beneath anterior half of eye or front margin of 
pupil; the very slender needlelike teeth in three rows in each jaw, the inner row excessively minute, the other two rather elongate and nearly uniform in size; the body scaled to eyes, the scales on caudal peduncle a little smaller; the opercle covered with from three to five large scales; the dorsals moderately far apart, the third spine of first dorsal longest, or the first three of almost uniform length, about twice in head; the second dorsal and anal alike in shape and height, always higher than first dorsal, the posterior rays longest, angulate, falling far short of caudal when depressed, about 1.5 to 1.7 times in head; the caudal peduncle elongate, slender, its depth 1.9 to 2.2 times in its own length, which equals or is 0.875 of head; the caudal slightly rounded, sometimes equal to head but usually shorter, 3.5 to 4 times in length; the long pointed pectoral equals or nearly equals head, 3.5 to 3.8 times in length; the ventrals ovate, with a broad frenum, 1.29 to 1.4 times in head, 4.6 to 5.1 times in length; the small anal papilla short, cylindrical in females, very small and pointed in males.

The color in alcohol gray-brown, the scales on upper two-thirds of body thickly punctate with dark specks, with a blackish band along the side from beneath pectoral to base of caudal; on the opercle is a conspicuous black spot, nearly circular, and divided by a yellowish or whitish line crossing diagonally from upper posterior part to lower anterior corner; a black longitudinal bar begins above angle of mouth and crosses check, slightly ascending as it does so; the first dorsal deep black except first spine or basal half of first and second spines, this anterior portion golden; the second dorsal vaguely crossbarred with darker spots or it may be almost clear; the caudal has a blackish crossbar on its base and five or six dark crossbars on the rays; the anal clear or golden, with a vague blackish or dusky margin; the pectorals clear, the tips dusky, with a blackish spot on base; the ventrals clear.

Here described from four specimens, 21 to 28 millimeters long, the account checked by eleven additional specimens ranging down to only 8 millimeters in length, all collected from Talakop Creek at the foot of Mount Isarog, municipality of Calabanga, Camarines Sur Province. In the small specimens the eyes are larger, the snout shorter than as given in the description.

In addition to the above Mr. Lopez collected eight cotypes, 16 to 33 millimeters long, from Hinagianan River, Camarines Sur Province, which agree in all essentials with the specimens from Talakop Creek; the color is more golden, the second dorsal, 
anal, pectorals, and ventrals are mostly clear; the thick fleshy lips are orange; the eyes are farther apart in the large specimens, the interorbital 2 in eye.

This is a very distinct and handsome species.

Rivalis, belonging to a brook.

66. VAIMOSA BIKOLANA sp. nov.

Plate 11, Fig. 2

Dorsal VI, I-7; anal I, 6 ; there are 26 scales in a longitudinal series, 8 in a transverse series, and 7 before the first dorsal.

The body greatly compressed laterally, the back strongly arched, the belly forming a long convex arch, deeply arched in spawning females, the depth 3.2 to 3.46 times in length; the head boldly convex with very full nape, 3.25 to 3.3 times in length; the convex, bluntly rounded snout 0.72 to 0.75 of eye, 4.5 to 5.2 times in head; the large eyes placed obliquely and very high up, their upper margin forming a hump in the dorsal profile, 3.2 to 3.9 times in head; no interorbital space, the margin of the eyes touching; the jaws equal, the mouth terminal, oblique, the posterior angle of maxillary reaching a vertical from middle of eye or, in males, extending beyond pupil but not beyond eye; the teeth in three rows in each jaw, the outer ones scarcely enlarged; the opercles covered by four large scales; the dorsals far apart, the first spine of first dorsal elongate, or the first three spines may be of nearly the same length, all very slender, reaching to or slightly beyond origin of second dorsal, 0.75 or 0.8 of head; the second dorsal much lower, of nearly uniform height, the posterior rays falling far short of caudal when depressed, 1.6 to almost twice in head; the anal like second dorsal, equal to it in height or a tenth lower; the caudal moderately pointed, a little shorter than head; the pectoral and ventrals equal in length, long pointed, not reaching anus, 0.75 to 0.875 as long as head.

The color in alcohol varies from whitish to blackish gray, with four more or less evident, short, broad, dorsal crossbands and a median lateral row of four prominent black spots; a black spot at tip of opercle and pectoral axil; two spots at base of caudal; four short black crossbars on underside, two beneath anal, and two on caudal peduncle; the scales on sides of body more or less outlined with bands of dusky dots, their pale centers forming longitudinal rows between blackish lengthwise lines; the sides of head irregularly barred and spotted; females much paler than males; the first dorsal black, or all golden whitish with a large black spot between fifth and sixth spines; the second 
dorsal alternately crossbarred with black and golden or clear; the anal black; the caudal crossbanded alternately with black and golden or clear; the pectorals clear or faintly dusky; the ventrals black or blackish with a broad pale margin.

Here described from six specimens, 23 to 26 millimeters in length, collected from the creek at barrio Puru, Legaspi, Albay Province. The smallest specimens, 23 millimeters long, were females ready to spawn, February 4, 1926.

Bikolana, a native of the Bicol provinces.

67. VAIMOSA SAPANGA sp. nov.

Plate 11, Fig. 3

Dorsal VI, I-7; anal I, 7; there are 26 or 28 scales in a longitudinal series, 8 in a transverse series, and 7 or 8 before the first dorsal, the first one largest.

The body and head laterally compressed, the trunk moderately plump, the dorsal profile convex, the ventral profile nearly horizontal except in spawning females, when it is curved downward as much as the back is upward, the depth 3.9 to 4.4 times in length; the upper profile of head convex, pointed in lateral view, 3.3 to 3.7 times in length; the head deeper than broad, the breadth 0.8 of its depth; the snout short, convex, rounded, about 5 times in head, and $\mathbf{1 . 5}$ to 1.6 times in eye; the eyes high up, lateral, 3 times in head; the interorbital 3 times in eye; the mouth moderately large, oblique, the jaws equal, the posterior angle of maxillary beneath the middle or posterior margin of pupil ; a narrow band of three rows of tiny erect needlelike teeth in upper jaw and four rows of similar teeth in lower jaw; the body covered with large ctenoid scales which apparently become cycloid anteriorly and extend to eyes; the opercle covered by five large cycloid scales; the supraopercular groove conspicuous; the dorsals well separated, the first spine or first, second, and third spines longest, 1.5 times in head and 5.5 times in length, not reaching second dorsal when depressed; the second dorsal and anal angulate posteriorly, the posterior rays longest but not extending more than halfway to base of caudal, equal to or a little lower than first dorsal, 1.5 to 1.7 in head and 5.5 to 6.25 times in length; the caudal peduncle as long as head, its depth 2.3 times in its own length; the caudal truncate, shorter than or equal to head in length, 3.5 to 4 times in length; the broadly pointed pectoral equals head in length and extends posterioriy to a point above origin of anal; the pointed ventrals $\frac{6}{7}$ as long as pectoral, 4.1 to 4.3 times in length; the anal papilla small, thin, flat, triangular, larger in females than in males. 
The color in alcohol whitish with a wide, vaguely limited, black band from shoulder to base of caudal, and two similar but narrow and much fainter black bands above, between it and the dorsal fins, or all the scales above the middle band may be lightly black margined, leaving the middle of each scale as a whitish spot; the opercles and preopercles reticulated or diagonally marked by a few broad brown bands composed of minute dots; a black blotch on upper part of posterior or central part of first dorsal, the remainder of fin clear except for a black spot or two on the first spine; three or four crossbars of blackish brown dots on second dorsal and about five transverse or diagonal blackish transverse bars on caudal; the anal and ventrals blackish or dusky, the pectorals clear.

Here described from twenty-one specimens, 16 to 26 millimeters long, from Sapanga Creek, Angat, Bulacan Province, Luzon. The larger specimens are adults, some of them females ready to spawn at the date of their collection, September 24, 1925. I also collected four specimens, 15 to 22 millimeters in length, from Gumay River, Pampanga Province, the coloration of which is much darker. This little fish unquestionably occurs in gravelly brooks throughout the whole region tributary to the northern part of Manila Bay.

I refer here a specimen, 25 millimeters long, collected by me in the Tagmatay, a brook on the Allen ranch near Cagayan, Misamis, Mindanao. The specimen is brown with a well-defined, very dark brown band on the side from the axil of the pectoral to the caudal.

Sapanga or sapa ng a is Tagalog for "the A brook," the local name for the streamlet where the type specimens were collected.

68. VAIMOSA TESSELLATA sp. nov.

Plate 12, Fig. 1

Dorsal VI, I-6; anal I, 6 ; there are 26 scales in a longitudinal series, 7 in a transverse series, and 7 before the first dorsal.

The head and elongate body laterally compressed, the dorsal profile but little elevated, the depth 3.8 to 4.2 times in length; the head 3.3 to 3.8 times in length, the depth greater than the breadth, which is 1.5 to 1.8 times in length of head; the head pointed, the ventral profile and convex snout converging; the snout and eye approximately equal in length, each 3.5 to 3.7 times in head; the eyes very high up, lateral, the narrow interorbital 2.2 to 3 times in an eye diameter; the mouth small, low, slightly oblique, the jaws equal, the posterior angle of maxillary beneath anterior third of eye; in the upper jaw are four rows of very 
minute teeth, in the lower jaw a broad band of six rows in front, with fewer rows on the sides posteriorly; the entire body covered to the eyes with large, firm, ctenoid scales; five large scales cover the opercle; the dorsals far apart, the fourth and fifth spines of first dorsal longest, not reaching second dorsal when depressed; the dorsals equal in height, 1.85 to 1.6 in head; the anal a trifle higher than second dorsal but of the same shape, angulate posteriorly, 1.7 to 1.4 in head; the second dorsal and anal are placed forward with a long caudal peduncle, and fall far short of caudal base when depressed; the depth of caudal peduncle twice or more than twice in length of head and 2.4 or 2.5 times in its own length; the caudal nearly truncate, shorter than head, 4 to 4.3 times in length; the pectoral broadly pointed, longer than caudal and a trifle shorter than head; the ventrals broad, with a deep lobulate frenum, extending nearly or quite to anus, about 1.2 times in head.

The color in alcohol brown, with four darker brown longitudinal lines running along the side from head to tail, and inclosing: a series of whitish spots separated by fine crosslines; between the two middle longitudinal lines is a series of six dark brown rectangular spots; five short, dark brown, dorsal crossbars, two before first dorsal, one beneath it, two under second dorsal, and one on top of caudal peduncle; the sides of head marked with spots and bars; a dark spot at upper posterior angle of opercle, and two small blackish brown spots on base of pectoral and also on base of caudal; a large, deep black blotch across upper part of first dorsal, the remainder of the fin clear; the second dorsal diagonally crossbarred by three rows of dark brown spots, the caudal crossbarred by numerous rows of similar spots; the anal brown, with a vertical blackish brown bar on each membrane; the pectorals and ventrals unmarked.

Here described from five specimens, 23.5 to 38 millimeters in length, one, a female, 34.5 millimeters long, nearly ready to spawn. They were obtained by me May 26, 1921, from Titunod River, a mountain torrent at Kolambugan, Lanao Province, Mindanao.

Tessellatus, in allusion to the beautifully decorated and checkered sides.

69. VAIMOSA VILLA sp. nov.

Plate 12, Fig. 2

Dorsal VI, I-8; anal I-8; there are 38 scales in a longitudinal series, 12 in a transverse series, and 18 before first dorsal. 
The body elongate, somewhat flattened before first dorsal, laterally compressed, the head broad, plump-cheeked, a little depressed anteriorly; the dorsal and ventral profiles nearly parallel, the depth 5.5 times, the head 3.6 times in length; the breadth of head exceeds a little the depth of trunk and is 1.25 times its own depth; the profile concave between eyes, the snout steep, 4.5 times in head and a little shorter than eye, which is 3.85 times in head; the eyes very high up, dorsolateral in position, close together, the interorbital 2.6 times in an eye diameter; the mouth large, oblique, the lower jaw and chin very slightly projecting, the lips thick, the posterior angle of maxillary below middle of pupil; in the upper jaw is an outer row of slightly enlarged teeth, followed by a band of either two or three rows of minute teeth; in the lower jaw is a broad band of four rows of small, slender, erect teeth of uniform size; the posterior half of body covered with large ctenoid scales; anteriorly they become smaller, those before first dorsal very much smaller and passing into cycloid which extend to eyes, the one extending into interorbital space large; about sixteen cycloid scales on opercle; the dorsals far apart, the anterior and middle spines longest, not nearly reaching second dorsal when depressed, 1.6 times in depth and 2.5 times in head; the second dorsal and anal of the same height, the posterior rays longest, falling far short of caudal base when depressed, 1.3 times in depth and twice in head; the broad caudal peduncle twice in head and 1.6 times in its own length, which is 0.8 of the length of head; the somewhat pointed caudal 0.95 of the length of head or 3.8 times in total length; the broadly pointed pectoral 0.8 of the length of head and 4.5 times in total length; the round-pointed ventrals are contained nearly 1.8 times in head and fall very far short of reaching the very small cylindrical anal papilla.

The color in alcohol greenish white, the sides irregularly spotted with blackish brown, with about eight narrow elongate spots in a row on the median lateral line, the last at base of caudal; on top of head, nape, and upper sides are sprinkled circular black dots; a blackish bar passes from eye diagonally downward and forward over angle of mouth and across chin to meet a similar one on the other side; a similar bar passes from cheek to throat to meet its fellow from the other side; two short bars go downward from eye to join the one on cheek; a black blotch on forward part of opercle and another on upper part of pectoral base; two black bars on upper anterior part 
of first dorsal; three crossbars of black dots on second dorsal and eight on caudal, besides three spots at its base; the anal dusky; the pectoral and ventrals dusky brown with narrow white margin.

Here described from the type, 36 millimeters long, collected at the town of Villa, Iloilo Province, Panay, and one cotype, 35 millimeters long, from Molo, Iloilo Province. This very wellmarked species is close to $V$. fontinalis Jordan and Seale, of Samoa.

Villa, from the locality where it was collected.

\section{Genus 32. GLOSSOGOBIUS Gill}

Glossogobius Gill, Proc. Acad. Nat. Sci. Phila. 1859 (1860) 146.

The body elongate, with a large, broad, and anteriorly depressed head; the chin strongly projecting, the mouth large, oblique, and the tongue deeply notched or its tip is even bilobed; the teeth in about four rows in each jaw, those of outer row much larger or caniniform and fixed; the other teeth all depressible; the trunk covered with rather large ctenoid scales, 28 to 33 in longitudinal series in Philippine species, those on the nape smaller; the sides of head naked except for small scales on upper part of opercle; the gill openings wide, with narrow isthmus; branchiostegals 4 ; pseudobranchiæ well developed; no free silky rays on upper part of pectoral; the dorsal and anal fins short, the caudal large, nearly as long as head.

Dorsal VI, I-8 to 10 ; anal I, 7 to 9 .

This Oriental genus, distributed from the east coast of Africa to Japan, includes the most valuable of the East Indian gobies.

Key to the Philippine species of Glossogobius.

$a^{x}$. Scales, 14 to 17 before first dorsal.

$b^{1}$. A circular projection from upper iris into pupil of eye; two ocelli on first dorsal. G. biocellatus.

$b^{3}$. No projection from iris into pupil; no ocelli on first dorsal G. celebius. $a^{3}$. Scales, 21 to 26 before first dorsal. G. giurus.

70. GLOSSOGOBIUS BIOCEllatUS (Cuvier and Vaienciennes)

Plate 12, Fig. 3

Gobius biocellatus CUvirr and ValendeIennes, Hist. Nat. Poiss. 12 (1837) 55; GüNthbR, Cat. Fishes Brit. Mus. 3 (1861) 20; DAY, Fishes of India (1878) 289, pl. 63, fig. 8; WEBER, Siboga Exped. Fische (1913) 470.

Glossogobius biocellatus EvermanN and SEALE, Bull. Bur. Fisheries 26 (1907) 104; Smith and Seale, Proc. Biol. Soc. Washington 19 (1906) 81. 
Glossogobius aglestes JoRdAN and SeALe, Proc. U. S. Nat. Mus. 28 (1905) 798, fig. 16.

Bicol name, mulug; Tagalog, biang tulog (sleeping goby).

Dorsal VI, I-9, rarely 8; anal I, 8; there are from 28 to 30 scales in a longitudinal row, 9 in a transverse series, and from 14 to 17 before the first dorsal.

The depth contained 5.2 to 6 times, the head 3 to 3.3 times in length; the eyes dorsolateral in position, very close together, and from upper margin of iris of each eye a circular extension projects into pupil, as shown in the figure; the eyes contained 4.4 to more than 5 times in head and 1.2 to 1.5 times in the rather sharp-pointed snout, which goes $3 \frac{1}{3}$ to $3 \frac{2}{3}$ times in head; the distance from tip of snout to posterior margin of eye less than or rarely equal to the postorbital part of head; the lower jaw strongly projecting, the mouth large, with the maxillary extended to below rear margin of eye, or rarely only to below center of pupil; the teeth similar to those of other Philippine species, but the outer and inner rows larger proportionately than in G. giurus; except rarely, the naked interorbital space does not extend posteriorly beyond rear margin of eyes, and has a prominent anterior interorbital pore and a less conspicuous posterior one; occasionally a very narrow or linear naked space is behind eyes; the head entirely naked except for a partial or complete row of rather large scales along upper margin of opercle; the longitudinal rows of papillæ, so conspicuous on preopercle of most species of this genus, are but little evident and are either reduced in number and size or are absent.

The color of alcoholic specimens varies from yellowish brown to dusky gray or blackish; in some there are five broad crossbars of dark brown over the back and down the sides; pupil of eye white with a black circular extension from iris into it on upper side; the first dorsal usually dark brown; on the upper part is a very dark or black elongate spot between first and second spines and a rounded black spot between fifth and sixth spines; it may have a very broad red band above and before it; across the front half just beneath the first spot is a broad irregular white bar, with usually one or two narrower white bars near base; the other fins brown to blackish, more or less marked by crossrows of alternate pale and dark spots; many specimens have the lower side of head marked by rather large white spots, forming the species Glossogobius aglestes Jordan and Seale; sometimes specimens have small, circular, dark brown or black spots sprinkled over the top of the head. 
I have examined a great number of specimens, ranging in length from 30 to 90 millimeters, from the following localities:

Mission, Cagayan Province.

Vigan, Ilocos Sur Province.

Agno River, Pangasinan Province.

Subic, Zambales Province.

Malabon, Rizal Province.

Manila.

Lake Taal, Batangas Province.

Pansipit River, Batangas Province.

Nasugbu, Batangas Province.

Arimbay River, Albay Province.

Puru, Legaspi, Albay Province. Mangarin, Mindoro.

San Jose, Antique Province, Panay.

Capiz, Panay.
Loboc, Iloilo Province, Panay. Cebu, Cebu.

Dumaguete, Oriental Negros.

Lasay, Siquijor.

Cagayan, Misamis Province, Mindanao.

Caldera Bay, Zamboanga Province, Mindanao.

Zamboanga, Mindanao.

Rio Grande, Cotabato Province, Mindanao.

Davao, Mindanao.

Samal Island, Davao Gulf, Mindanao.

Balabac.

Hongkong.

This is a small species, and specimens from 56 to 60 millimeters in length are sexually mature. It spawns in November and December. Although widely distributed, it is not so abundant as are some other members of the genus. It has been previously listed from Bacon, Sorsogon Province, Luzon, by Evermann and Seale; from the Rio Grande de Mindanao by Smith and Seale; and under the name of $G$. aglestes from southern Negros by Jordan and Seale.

It was originally described from Pondicherry, Hindustan, and is known from the Sind eastward through the Malay Archipelago.

71. GLOSSOGOBIUS CELEBIUS (Cuvier and Valenciennes)

Plate 12, Fig. 4

Gobius celebius Cuvier and VAlenciennes, Hist. Nat. Poiss. 12 (1837)

56; BLEEKER, Nat. Tijd. Ned. Ind. 7 (1854) 317; WeBER, Siboga Exped., Fische (1913) 468.

Gobius phaiosoma BLEEKER, Verh. Bat. Gen. 22 (1849) 30.

Gobius fusiformis BLEEKER, Verh. Bat. Gen. 22 (1849) 30.

Gobius pavo STEINDACHNER, Sitzungsber. Akad. Wiss. Wien $55^{1}{ }^{1}(1867)$ 715.

Vernacular names; Bicol, taporak; Ilocano, bal-la; Tagalog, bia $n g$ bato (rock goby); Calamianes Visayan, tabula.

Dorsal, VI, I-8 or 9 ; anal I, 7 or 8 ; there are from 28 to 30 (32?) scales in a longitudinal row, 9 or 10 in a transverse series, and from 14 to 17 before the first dorsal. 
The general appearance is that of G. giurus, but the head is usually a little larger in proportion, with much fuller and rounder checks, and from 2.7 to 3 times in the length; the eyes nearly superior and usually close together, the interorbital space varying from $\frac{1}{3}$ to $\frac{3}{4}$ of an eye diameter; their length 5.2 to 5.5 in head and a little less than 2 to 2.7 times in snout, which is 2 to 2.9 times in head; the distance from posterior margin of eye to tip of snout usually greater than, rarely equal to, postorbital length of head; above eye is a low narrow bony ridge which begins at the supraopercular groove behind eye; the mouth large, with projecting lower jaw; the maxillary extends back to a point below front margin of eye or even center of pupil; in both jaws the outer row of teeth widely spaced, large, strong, fixed; the other teeth all depressible, the next two rows very small and sharp, the innermost row'much larger; the naked interorbital space extends backward beyond eyes and contains a central pore and three more in the space behind eyes, although often only the middle one of these is visible; the head may be entirely naked or there may be three rows of scales extending from upper inner corner of opercle, halfway or entirely across to rear; on the preopercle are about five parallel longitudinal lines of very fine papillæ; one or two similar diagonal lines more or less evident on opercle; the lower edge of preopercle, subopercle, and a line under lip fringed with papillæ, barely evident in some but large and fringelike in others; in some specimens one or two or more of the lines on preopercle are of similar coarse papillæ; the fins are much as in $G$. giurus, except that the males have the tips of the dorsal spines and rays prolonged.

The color in life more or less yellowish, with dusky or blackish spots on sides, the one at base of caudal plainest, and with short, irregular, dusky crossbars or marblings on back; the ventrals dusky to blackish; the pectorals, anal, and second dorsal each with two longitudinal rows of dark spots; the caudal has many crossrows of blackish or dark spots; the first dorsal mostly clear, or golden yellow, with fine dusky specks, a large dark spot posteriorly, and a row of dark spots on spines near margin of membrane; sometimes there is a basal row of large dark spots.

The color in alcohol varies from gray-brown to yellow-brown, with markings as above described; the spots on the naked top of head more or less reddish or brownish red; the head and 
back may be dark brown or blackish; usually a dark brown bar extends forward and downward from eye and a similar one from eye diagonally across preopercle and opercle; the cheeks often darkened by other bars and spots; the dorsals may have the upper or anterior part golden yellow; the caudal and second dorsal crossbarred with blackish spots; the ventrals dusky to clear.

I have examined living and alcoholic specimens, varying in length from 12 to 108 millimeters, from the following localities :

Mission, Cagayan Province, 6.

Laoag River, Ilocos Norte, 94.

Pinacanawan River, Lamug, Peña Blanca, Cagayan Province, 4.

Dupax, Nueva Vizcaya Province, 4.

Santa Fe, Nueva Vizcaya, 24.

Baguio, Benguet Subprovince, 9.

Bangar, La Union Province, 19.

Bauang Sur, La Union Province, 1.

Gulf of Lingayen, 1.

Agno River, Pangasinan Province, 1.

Gumay River, Pampanga Province, 10.

Banaban River, Angat, Bulacan Province, 3.

Kalingay brook, iron mine, Angat, Bulacan Province, 28.

Pinagsangkan River, Angat, Bulacan Province, 8.

Angat River, Bulacan Province, 5.

Ibo Creek, Bulacan Province, 8.

Sapanga Creek, Angat, Bulacan Province, 11.

Sibul Springs, Bulacan Province, 5 .

Calumpang River, Norzagaray, Bulacan Province, 18.

Santa Ines River, Rizal Province, 10 .

Irig River, Rizal Province, 1.
Marikina River, Montalban, 4.

Manang River, Antipolo, Rizal Province, 2.

Malabon, Rizal Province, 1.

Mayondon, Laguna de Bay, 1.

Molawin Creek, Los Baños, Laguna Province, 6.

Balanak River, Pagsanjan, Laguna Province, 2.

Lamul, Cavite Province, 8.

Lake Taal, Batangas Province, 80.

Lucban, Tayabas Province, 45.

Talakop Creek, Camarines Sur Province, 4.

Bacon, Sorsogon Province, 1.

Polillo, 1.

Mambac River, Lake Naujan, Mindoro, 8.

San Jose, Antique Province, $\mathrm{Pa}$ nay, 12.

Capiz, Panay, 3.

Dumangas, Iloilo Province, 1.

Zarraga, Iloilo Province, 1.

Concepcion, Busuanga, 1.

Dumaguete River, Dumaguete, Oriental Negros, 1.

Siquijor, 3.

Daguitan River, Dulag, Leyte, 1.

Kolambugan, Lanao Province, 2.

Rio Grande de Mindanao, Cotabato Province, 1.

Davao, Mindanao, 3.

Taytay, Palawan, 2.

Balabac, 4.

This species does not grow to the size of $G$. giurus and matures when still rather small. Specimens, 54 and 55 millimeters long, collected in Santa Ines River in the mountains north of Laguna 
de Bay, Rizal Province, were full of eggs and ready for spawning. It spawns in October and November in the region near Manila. Glossogobius celebius takes the hook eagerly, and I have seen old men and women catch large strings of this species in the mountain streams of Nueva Vizcaya. It is one of the important ipon fishes. The Bureau of Science collection contains ninety-two specimens of ipon, 20 to 30 millimeters in length, collected by E. A. Mearns " 3 miles up the Laoag River," which belong here.

This species is readily distinguished from other members of the genus by the eyes, by the number of scales before the first dorsal, and by the distance from the tip of the snout to the rear margin of the eye being greater than the remaining length of the head. Specimens with the papillæ greatly developed on the head and with very fat cheeks present a very different appearance from the general run of the species, and only the presence of intermediary stages enables one to determine them as $G$. celebius. The Tagalog fishermen of Lake Taal differentiate this species from G. giurus without hesitation.

Originally described from Celebes, it has also been recorded from Nias, Amboina, Timor, Flores, New Guinea, and the Aru Islands.

Although Steindachner's description of Gobius pavo omits some characters used in my diagnosis, I have no hesitancy in pronouncing his specimen an example of G. celebius.

72. GLOSSOGoBIUS GIURES (Buchanan Hamilton)

Plate 27, Fig. 1

Gobius giurus Buchanan HammtoN, Acct. Fishes Ganges (1822) 51, 366, pl. 33, fig. 15; GüNther, Cat. Fishes Brit. Mus. 3 (1861) 21 (in part); Petras, Monatsber. Akad. Wiss. Berlin (1868) 263; A. B. MEYRR, Ann., Soc. España Hist. Nat. 14 (1885) 29; Boulenger, Ann. \& Mag. Nat. Hist. VI 15 (1895) 185.

Glossogobius giurus EvrrmanN and Seate, Bull. Bur. Fisheries 26 (1907) 104; Smith and Seale, Proc. Biol. Soc. Washington 19 (1906) 79; JoRDAN and RICHARDSON, Bull. Bur. Fisheries 27 (1908) 277.

Gobius spectabilis GÜNTHER, Cat. Fishes Brit. Mus. 3 (1861) 45; MEY⿸R, Ann., Soc. España Hist. Nat. 14 (1885) 29.

Vernacular names: Bicol, ba-tug; Ibanag, bunog; Ilocano, bala; Maguindanao, dolog: Tagalog, bia, biang puti (white goby), palo; Tao Sug, kapalo; Calamianes Visayan, tabula.

Dorsal, VI, I-9; anal, I, 8; there are 30 to 32 scales in a longitudinal series, 9 or 10 in a transverse series, and 21 to 26 before the first dorsal. 
The elongate slender body laterally compressed, with a deep flat caudal peduncle and a very large, wide, and long head which is contained from 2.8 to 3.3 in length; the greatest depth from 5.2 to 5.6 times in length; the eyes partly superior and rather small, less than an eye diameter apart, their length 6 to 8 times in head and 2.5 to more than 3 times in snout, which is 3 or a little more or less than 3 times in head; the distance from tip of snout to posterior margin of eye less than postorbital length of head; the dorsal profile descends uniformly from first dorsal to the tip of the smooth, convex snout, but in preserved specimens the snout is usually flatter, with a hump near its tip; a bony ridge begins at supraopercular groove and curves forward above each eye, extending to region of nostrils; the naked interorbital space is flat or slightly concave between the ridges, and extends appreciably behind eyes; it contains a pore near the center and another one a little behind each eye; the oblique mouth large with strongly projecting lower jaw; the maxillary extends backward as far as a point below front of eye or even to front margin of pupil; in both jaws the outer row of teeth is fixed, large, strong, and caninelike; then follow several rows of fine, sharp, depressible teeth, the innermost one much larger than the others; at the sides these disappear, leaving only the outer and inner rows of large teeth; the scales on nape smaller than those on trunk; the head naked except for three or four rows of small scales on upper part of opercle; four or five parallel longitudinal seams or lines of very fine papillæ on preopercle; the ventrals are very large and form an admirable sucking disk; the pectorals are large and extend posteriorly beyond ventrals; the vertical fins of moderate size; the caudal large, its length nearly equal to that of head.

The ground color in life varies from pale fawn or buff to yellowish, with a more or less golden glint on sides; there are five large dark to black spots on sides, the last at base of caudal; alternating with them are five short, broad, dorsal crossbars of similar color, the first one above the opercles, the second including base of first dorsal; the head may be pale but usually varies from brownish to black, with four or five pale longitudinal lines on cheeks; usually a brown bar extends from lip upward to eye and another one from eye diagonally across cheek; there are two dark brown or blackish longitudinal bars on basal part of pectoral in a pale or golden ground color; the dorsals and caudal crossbarred by dark bands or rows of dark spots, those on first dorsal but little developed, those on caudal stopping 
before lower margin is reached; the pectorals and anal clear, the ventrals dusky, with a broad clear margin; the eye blue. During the breeding season, at least, the anal papilla becomes orange.

Specimens from Lake Buluan, and large specimens generally, are darker; those from Lake Buluan are blackish over most of the back and sides, with the fins also heavily pigmented.

Alcoholic specimens are much paler than living ones, as a rule, but are otherwise similar. This species loses its coloration very rapidly after death, and those in the markets are often uniformly pale yellowish to whitish.

I have kept under observation hundreds of living specimens and have examined thousands in the markets; I have also studied the following alcoholic specimens, varying in length from 17 to 265 millimeters, or 349 millimeters with the caudal fin. The localities represented in the Bureau of Science collection are:

Buguey, Cagayan Province, 2.

Tuguegarao, Cagayan Province, 5.

Barrio La Paz, Laoag, Ilocos Norte Province, 7.

Abra River, Vigan, Ilocos Sur Province, 7.

Santa Maria, Ilocos Sur Province, 3.

Lingayen Gulf, La Union Province, 5.

Agno River, Dagupan, Pangasinan Province, 11.

Angat River, Bulacan Province, 8.

Baliuag, Bulacan Province, 2.

Calumpang River, Norzagaray, Bulacan Province, 3.

Calumpit, Bulacan Province, 13.

Salt-water fish pond, Bulacan Province, 1.

Sibul Springs, Bulacan Province, 1 .

Malabon, Rizal Province, 1.

Manila market, 2.

Pasig River, Manila, 25.

Mayondon, Laguna de Bay, 10.

Balanak River, Pagsanjan, Laguna Province, 4.

Bunkal River, Darakap, Zambales Province, 2.
Talisay, Lake Taal, Batangas Province, 8.

Lake Taal, Batangas Province, 74.

Pansipit River, Batangas Province, 20.

San Miguel Bay, Camarines Sur Province, 1.

Bicol River, Camarines Sur Province, 2.

Lake Buhi, Camarines Sur Province, 8.

Legaspi, Albay Province, 1.

Puru, Albay Province, 1.

Baco, Mindoro, 2.

Mamboc River, Lake Naujan, Mindoro, 5.

Budbudan River, San Jose de Buenavista, Antique Province, 3.

Mambugan swamp, San Jose de Buenavista, Antique Province, 3.

Dumarao, Capiz Province, 2.

Dumangas, Iloilo Province, 9.

Villa, Iloilo Province, 2.

Iloilo, Iloilo Province, 4.

Navalas, Guimaras, 2.

Concepcion, Busuanga, 2.

Taytay, Palawan, 2.

Balabac, 1. 
Dumaguete River, Oriental Negros, 2.

Lasay, Siquijor, 1.

Daguitan River, Dulag, Leyte, 1.

Malabang spring, Malabang, Lanao Province, Mindanao, 1.
Agusan River, Mindanao, 6.

Lake Buluan, Cotabato Province, Mindanao, 6.

Davao, Mindanao, 6.

Hongkong, 2.

Indian Museum, Ganges River, and Bengal, India, 3.

Previous Philippine records are as follows: Günther, "Philippine Islands;" Peters, Lebmanan River, Luzon, and Lake Bito, Leyte; Meyer, Laguna de Bay and Cebu; Boulenger, Palawan; Evermann and Seale, San Fabian, Pangasinan Province, and Bacon and Bulan, Sorsogon Province; Smith and Seale, Rio Grande de Mindanao, Cotabato Province; Jordan and Richardson, Aparri, Mindoro, and Iloilo.

This goby is a valuable food fish in many localities, its size and abundance making it an important market fish. It is much the largest Philippine representative of the true gobies, but is not nearly so bulky as some of the large eleotrids. It is also one of the most important of the young fishes caught in northern Luzon under the name of ipon.

It occurs in both fresh and salt water, but appears to reach its maximum size in fresh-water lakes; my largest specimens were caught in Lake Buluan. This goby is a bold and vigorous biter and is angled for in nearly every lowland stream and lake throughout the Islands.

Specimens that were kept in captivity a long time laid eggs which they fastened to the concrete walls of the tank. In nature the eggs are attached to the underside of rocks, near or in the mouths of rivers where they are influenced by the tides.

This valuable species occurs from the east coast of Africa eastward at least as far as Celebes and northward to Swatow, China.

\section{2a. GLOSSOgobIUS GIURUS var. OBSCURIPINNIS (Peters)}

Gobius obscuripinnis Peters, Monatsber. Akad. Wiss. Berlin (1868) 263.

Oro-on in Bicol.

Dorsal VI, I-8 or 9; anal I, 7; there are 29 or 30 (29-33, Peters) scales in a longitudinal series and 10 or 11 in a transverse series; 20 or more scales in front of the first dorsal.

The trunk laterally compressed, the posterior part strongly so, with very moderately curved dorsal and ventral profiles; the depth 4.5 to 5 times in length; the long broad head contained about 3 times in length; the snout short, rounded, its length 3.1 to 3.4 times in head; the eyes partly superior and partly 
lateral, 1.9 to 1.5 in snout and 4.8 to 6 times in head; the interorbital space equal to or 0.25 less than the diameter of an eye; the mouth strongly oblique, with slightly projecting lower jaw, and with the posterior end of maxillary reaching to front margin of pupil; the teeth in four rows in each jaw, the fourth row larger than the second and third, the outer row larger and stronger than the fourth; the outer row fixed, the others all depressible; the caudal peduncle rather wide, its least depth twice or nearly twice in its length; the head naked except the region behind eyes and a few rows of small scales on upper part of opercle; the scales between dorsal fin and occiput much smaller than those elsewhere; the longest rays of second dorsal and anal equal, their length equal to depth of body; the rather pointed caudal fin $\frac{5}{6}$ of head in length.

The color in life a sort of golden brown, with a longitudinal series of five or six large dark spots along each side, the last one at base of caudal, and a series of five dark crossbars over back; the first dorsal has a broad blackish crossband across its middle, the base and upper part clear, or it may be crossbarred with heavy spots; the second dorsal strongly crossbarred by four or five rows of black spots forming wavy lines; the caudal heavily crossbarred by many alternate wavy black and yellow bands on the upper two-thirds or three-fourths; the remaining lower part uniform dusky; the anal and ventrals dusky to black, the pectorals dusky.

In alcohol the color is dusky yellowish with markings as in life; the cheeks are marked by four or five longitudinal dark brown bands, the body color appearing between as narrow pale stripes; the pectoral is almost colorless, with a short blackish bar on the upper part of its base; the ventral is blackish.

I have examined twenty-four specimens, from 45 to 90 millimeters in length, collected by me in Lake Buhi, Camarines Sur Province. This species has previously been known only from the specimens collected by Jagor in 1859 in Bicol River, Camarines Sur Province, and Kalabos brook near Daraga, Albay. It is apparently confined to that part of Luzon.

I refer here also four badly preserved specimens from Lake Bato, Camarines Sur Province, collected by Alejo Arce, and five excellent specimens from the same locality, collected by G. A. Lopez.

Since writing the above I have studied a large series from Lake Buhi, ranging in length from 22 to 105 millimeters. Most of them are sufficiently different from $G$. giurus to be given 
specific rank; especially is this true of the iarger specimens. However, I am of the opinion that G. obscuripinnis is not worthy of more than subspecific rank, since there are specimens which have some of the characters of both G. giurus and G. obscuripinnis.

\section{Genus 33. OPLOPOMUS (Ehrenberg) Steindachner}

Oplopomus (Ehrenberg MS.) STEINDACHNER, Sitzungsber. Akad. Wiss. Wien 42 (1860) 291.

The body moderately elongate, laterally compressed, covered with 26 to 32 scales in a longitudinal series; the head abruptly convex anteriorly, entirely naked, or cheeks and nape may be scaled; the posterior margin of preopercle toothed with from one to five stout sharp spines, usually but one or two present, the number often different on the two sides of the same fish; the first spine of both first and second dorsals stiff, hard, stout, and very sharp; the remaining spines of first dorsal flexible, with elongate, threadlike tips; the teeth in three or four rows in each jaw, the outer ones enlarged, the lower jaw with a pair of lateral canines; the tongue truncate; the caudal shorter than head; the isthmus wide; branchiostegals 4. Dorsal VI, I-9 or 10 ; anal I, 9 or 10 .

This genus includes two beautiful species, one of wide distribution, the other thus far known only from the Philippines. 'The number of spines on the preopercle is of no importance in separating species, since they vary in size and number with age and with the individual. No other Philippine gobies have a hard sharp spine at the beginning of each dorsal.

Key to the Philippine species of Oplopomus.

$a^{1}$. Head naked

O. oplopomus.

$a^{2}$. Nape scaled to eyes; cheek with five to seven rows of small scales.

0. vergens.

73. OPLOPOMUS OPLOPOMUS (Cuvler and Valenciennes)

Plate 29, Fig. 3

Gobius oplopomus Cuvier and Valenciennes, Hist. Nat. Poiss. 12 (1837) 50; Günther, Cat. Fishes Brit. Mus. 3 (1861) 15; Fische der Südsee 2 (1876) 170, pl. 110, fig. B.

Oplopomus pulcher EhrenBerg, Zool. Pisc., pl. 9, fig. 6, footnote in Cuvier and Valenciennes, Hist. Nat. Poiss. 12 (1837) 50.

Gobius bitelatus Cuvier and Valenciennes, Hist. Nat. Poiss. 12 (1837) 67; GüNther, Cat. Fishes Brit. Mus. 3 (1861) 35.

Gobius notacanthus BleEkER, Nat. Tijd. Ned. Ind. 15 (1858) 210; GüNther, Cat. Fishes Brit. Mus. 3 (1861) 35.

Oplopomus notacanthus StEINDACHNER, Sitzungsber. Akad. Wiss. Wien 42 (1860) 290,'pl. 1, fig. 2. 
Dorsal VI, I-9 or 10 ; anal I, 9 or 10 ; there are 28 to 30 scales in a longitudinal series and 8 or 9 in a transverse series; Steindachner's specimens had 26 scales.

The body moderately elongate, laterally much compressed, the depth nearly equal to length of head, 4.3 to 4.5 in length; the head much deeper than wide, nearly as deep as body, its length 3.5 to 3.7 in total length; the convex snout short, blunt, steeply descending, 3.75 times in head; the eyes very high up and close together, equal to or slightly longer than snout; the interorbital contained twice in eye; the mouth strongly oblique with lower jaw a little projecting, the posterior angle of maxillary under front margin of eye or extending to its anterior part; the teeth in three rows in upper jaw, an outer row of enlarged curved fixed teeth, and two rows of minute depressible teeth; in the lower jaw a short row of enlarged teeth in front, terminating laterally in a pair of backward-curving canines, and two inner rows of minute depressible teeth; the body covered with ctenoid scales, largest posteriorly, becoming minute above opercles; the head entirely naked; the nape naked back as far as above middle of opercles, the median region naked back almost to first dorsal, with only a row or two of scales or none at all directly in front of it; a stout spine on lower posterior margin of preopercle, or more rarely there are two; the spines of first dorsal, except first, elongated, with threadlike tips, the fifth or fourth and fifth longest and equal to head; the second dorsal and anal of moderate height, the posterior rays $\frac{2}{3}$ as long as head and reaching base of caudal when depressed; the pectorals broadly rounded, a little shorter than head; the long pointed ventrals 0.8 as long as head and nearly or quite reaching anus; the depth of caudal peduncle $2 \frac{1}{7}$ times in head or $1 \frac{4}{7}$ in its own length; the round pointed caudal about 0.9 as long as head; the anal papilla small, slender, and pointed in males, short, thick, and rounded in females.

The color markings of a fresh specimen were very beautiful; the body was pale yellowish green, with brilliant red, orange, or blue ocelli on sides of trunk, one to a scale; there were five blackish spots along middle of side, the first under pectoral, and a sixth, circular one on base of caudal fin; the opercles were marked by bright blue spots and the yellow cheeks by a few large blue spots; the nape was pale orange red; above opercle was a diagonal, short, blue bar; the first dorsal was crossed by a series of large red blotches, with yellow beneath them and a bright yellow margin and a large black spot on upper posterior 
angle; the second dorsal was crossed by three rows of red ocelli, its margin reddish brown; the anal had a basal row of large blue spots, then a bar of red, another row of blue, then pinkish yellow fading into a marginal band of red; the caudal had a central band of red, with the upper margin red, the lower black; the anal was black.

In alcohol specimens fade to pale gray or to yellowish brown, the ocelli and blue spots on head becoming pearly; the black lateral spots remain, but the fins lose their brilliant coloration, only the black remaining.

Here described from a specimen collected by me at Polillo and three specimens collected by Seale at Cebu, Puerto Princesa, and Balabac. They range in length from 38 to 56 millimeters.

This beautifully marked species was first collected by Ehrenberg in the Red Sea; later it was described under another name by Bleeker from Goram. Steindachner described specimens from "Insulae Philippinae," and Günther recorded it from Tahiti and the island of Maiao, which I take to be one of the small islands of the New Hebrides. It is apparently not very common anywhere.

\section{OPLOPOMUS VERGENS Jordan and Seale}

Oplopomus vergens JoRDAN and SeALe, Bull. Bur. Fisheries 26 (1907) 44, fig. 17.

Dorsal VI, I-9 or 10 ; anal I, 9 or 10 ; there are 28 to 30 scales in a longitudinal series, 9 or 10 in a transverse series, and about 10 rows before the first dorsal.

The body elongate, laterally flattened, the ventral profile arched, the upper much less so, the depth 3.8 to 4.3 times in length; the depth of head much greater than its breadth, its profile moderately convex, its length 3.4 to 3.7 times in total length; the blunt, steeply inclined snout 3.6 to 3.8 times in head; the eyes very high up, dorsolateral, obliquely set, their diameter equal to length of snout; they are very close together, the interorbital 2.5 times in an eye diameter; the mouth strongly oblique, the lower jaw a little projecting, the posterior angle of maxillary beneath or scarcely reaching front margin of eye; the teeth of outer row in upper jaw fixed, enlarged, and slightly curved inward; behind them are two rows of minute depressible teeth, the outer row in lower jaw short, the teeth larger than in upper row, ending in one or two pairs of backward- 
curving lateral canines; behind are two or three rows of minute depressible teeth; the body covered with ctenoid scales, which are largest posteriorly; the nape scaled to eyes, the scales becoming much smaller anteriorly, the last few rows very small and cycloid; there are from five to seven longitudinal rows or partial rows of somewhat deciduous scales on preopercle, with three or four longitudinal lines of very minute papillæ separating them, some of the rows being of comparatively large scales, others of very small ones; the upper part of opercle and the bases of pectorals also scaled; near the lower posterior angle of preopercle are stout spines, ordinarily two but varying from one to five, the two opercles often having a different number; the dorsals and anal of moderate height, the longest spines or rays about $\frac{2}{3}$ as long as head and never equal to depth; the fourth and fifth spines longest, all the spines but the first with elongated tips; the spine of second dorsal much shorter than the rays, which are longest posteriorly, the last two or three reaching caudal when depressed; the anal is similar to the soft dorsal but about $\frac{10}{1}$ as high, the last rays the longest; the pectoral rather broad, equal to or a little shorter than the broad, triangular, pointed ventrals, which extend to anus or to anal papilla, and are approximately equal to depth; the depth of caudal peduncle is approximately half the depth of body, and is $\frac{2}{8}$ of its own length; the caudal broad, with a round pointed tip, and approximately equal to depth; the anal papilla very slender and pointed in males, short, very broad, and round pointed in females,

The color in alcohol varies from yellowish white to reddish yellow or brown, with five oblong black spots along middle of side, the first beneath posterior part of pectoral, the last at base of caudal and extended upon it; a series of about five smaller rounded black spots on upper half of body in a longitudinal series, beginning above opercle and running back; each scale on upper half bears a small ocellated spot; a black or brown spot on upper part of base of pectoral rays; two faint dark longitudinal bands on cheeks, the upper one beginning at lower margin of eye, the other behind angle of mouth; the first dorsal has a transverse row of circular black spots on the membranes near base, and a blackish transverse line across second, third, and fourth spines about a third of the distance from top, and running out to tip of fourth spine; a black spot on posterior tip of fin; the second dorsal has a basal row of circular black spots on the membranes and two black crosslines on upper half; 
the anal uniformly dusky, the ventral black or very dark; the caudal has some large black spots on its base above and below the median spot, and from three to six curved crossbars of black spots on the remainder of the fin.

Here described from a specimen, 65 millimeters long, from Nasugbu, Batangas Province, and twenty-five specimens, ranging in length from 36 to 65 millimeters, from Iloilo, Panay. I have five specimens from Inabanga, Bohol.

This species has been known heretofore only from the type specimens described from Cavite by Jordan and Seale. The original description is in error in stating "no canines."

\section{Genus 34. CRISTATOGOBIUS g. not.}

Dorsal VI, I-10; anal I, 10.

This genus is separated at once from all other East Indian gobies by the high, thin, skinny crest on its nape; from Lophogobius Gill, of the West Indies and Florida, to which it is closely allied, it is particularly separated by differences in dentition. The teeth are in four rows in each jaw, with a posterior pair of large, curved canines in lower jaw, whereas in Lophogobius there is but a single row of teeth in each jaw, without canines.

Body rather slender, laterally compressed, covered with large ctenoid scales, 28 to 30 in a longitudinal series, those on the nape much smaller, cycloid; head naked, with rows of minute papillæ on its sides; fins small, dorsals separate, caudal pointed, longer than head. Generic type, $C$. lophius sp. nov.

Cristatus, having a comb.

75. CRISTATOGOBIUS LOPHIUS sp. nov.

Plate 13, Fig. 1

Dorsal VI, I-10; anal I, 10; there are 28 to 30 scales in a longitudinal series and 10 in a transverse series.

The body rather slender, oblong, laterally compressed, with arched dorsal profile, moderately broad caudal peduncle, the depth 4.4 to 4.5 in length; the head much wider than body, and contained 3.57 to 3.66 times in length; the snout short, convex, 4.6 to 5 times in head, $\frac{3}{4}$ to $\frac{4}{7}$ of an eye diameter; the eyes high up, very close together, 3.4 to 3.5 times in head; the interorbital space very narrow, almost linear; the mouth nearly vertical, with projecting chin, the posterior angle of maxillary under anterior margin or anterior third of eye; the teeth in four rows in each jaw, those of outer and inner rows enlarged, 
with a posterior lateral pair of large, backward-curved canines in outer row of lower jaw; the head naked; there are two widely separated rows of minute papillæ crossing preopercle longitudinally, and one running downward and backward on opercle; on the nape a thin, high, skinny crest, beginning between posterior part of eyes and extending back almost to origin of first dorsal, its height more than half an eye diameter; there is a large open pore on anterior part of interorbital space and an inconspicuous one on posterior part; there are about four large pores in the groove running back from eye above opercle, and two large pores on posterior margin of preopercle; the sides of body covered with rather loosely attached ctenoid scales; the sides of nape more or less covered with very small cycloid scales, a series of seven to ten forward of first dorsal, but not extending more than halfway to eyes; the first dorsal small, with flexible spines, the second and third longest, but less than the depth; the second dorsal and anal alike in shape and height, the height a trifle more than that of first dorsal but still less than greatest depth of body, their posterior rays scarcely reaching caudal when depressed; the pectorals and ventrals pointed, equal in length, reaching origin of anal; the pointed caudal $\frac{1}{6}$ or $\frac{1}{7}$ longer than head; the anal papilla slender, pointed, almost threadlike.

The color in alcohol dark brown, with five or six paler crossbands on sides; on base of pectoral are two large black spots, and scattered thinly over sides of head and forward half of body are black dots; the nuchal crest deep chocolate brown; the first dorsal dark brown, with a large blackish brown spot on posterior part beyond fifth spine; the other fins are all plain brown to blackish.

Here described from two specimens, 25 and 22 millimeters in length, collected by me under the wharf at Bungau, Sulu Province.

From Mr. F. Reveche, San Jose, Antique Province, Panay, I have just received a fine adult male specimen, 36 millimeters long, which differs in some respects from the above; the head is 4.23 times in the length; the tips of the first dorsal spines are elongate, threadlike, 2.57 times in the length, 1.64 times the depth; the second dorsal and anal are slightly less than the depth, elongate and sharply angulate posteriorly, reaching the caudal when depressed; the length of the pectoral equals that of the head and is a tenth greater than that of the ventrals; 
the crest on the nape is more strongly developed than in the original specimens; the color bluish slate, the fins all dusky, the first dorsal with a posterior blackish basal spot; no black spots on sides or pectoral base.

Lophius, from $\lambda$ ỏ $\phi o s$, a crest.

\section{Genus 35. PARAGOBIODON Bleeker}

Paragobiodon BleEker, Ned. Tijd. Dierk. 4 (1873) 129.

Paragobiodon BlEEkER, Arch. Neerl. Sci. Nat. 9 (1874) 309.

The body oblong ovate, with 22 to 24 firm ctenoid scales in a longitudinal row, the head and nape naked back to first dorsal fin; the height of the thick head less than twice the breadth; the upper jaw may have one row of comparatively stout curved teeth, or two rows, the inner ones very small, but not in several rows as stated by Bleeker, "dentibus maxillibus pluriseriatis fixis;" in the lower jaw there are two rows of teeth of about equal size or outer row the larger, or an outer row of stout teeth with two inner rows of minute teeth; two canines behind symphysis; the mouth short and curved; the tongue round pointed; the gill openings do not extend under base of pectorals; the small dorsals very close together; the ventrals very short, rounded, forming a cup-shaped disk, the frenum bilobed, unlike the ventrals of any other fish.

This is a small group of insignificant little gobies, some of them of strange appearance, abounding in the interstices of coral heads and under rocks along shore.

\section{Key to the Philippine species of Paragobiodon.}

$a^{2}$. Head more or less covered with short hairlike prickles P. echinocephalus. $a^{2}$. Head smooth.

$b^{2}$. Color black; pectoral rays 21 or 22 .............................. P. melanosomus.

$b^{2}$. Color yellow; pectoral rays 19 .

P. xanthosomus.

\section{PARAgOBIOdON ECHINOCEPHALUS (Rüppell)}

Plate 13, Fig. 2

Gobius echinocephalus RüPPELL, Atlas, Fische des Rothen Meers (1828) 136, pl. 34, fig. 3; GüNTHER, Cat. Fishes Brit. Mus. 3 (1861) 34 ; Fische der Südsee 2 (1876) 175 , pl. 108, fig. D; Report Challenger, Zoology, 1 (1880) Shore Fishes, 53.

Paragobiodon echinocephalus BlEEkER, Ned. Tijd. Dierk. 4 (1873) 129; Jordan and Seale, Fishes of Samoa, Bull. Bur. Fisheries 25 (1905) (1906) 397.

? Paragobiodon melanosomus JoRdaN and SEALE, Bull. Bur. Fisheries 26 (1907) 45. 
Dorsal VI, I-9 or 10; anal I, 9; pectoral rays 21 ; there are 23 or 24 scales in a longitudinal series.

The depth of the stout, short, plump body varies with age, 3 to 4 times in length, or less in the very young, which are deeper proportionately; head deep and broad, with boldly convex profile, its depth equal to or $\frac{6}{7}$ of its length, which is equal to or less than depth of trunk, and 3.3 to 4.8 times in length; breadth of head 0.7 to 0.8 its own length; the short snout equal to or shorter than the circular eye, which is 3 to 3.5 times in head; eyes lateral, the broad convex interorbital space 0.25 to 0.5 more than eye diameter; mouth small, strongly curved downward so that it is nearly vertical, lips thick, jaws equal, chin heavy, square, and often projecting; entire head naked back to first dorsal, more or less covered above, on opercles, and especially beneath, with soft short prickles or fibrils which may become hairlike; they may be scattered about very thinly, or may form a dense beardlike mat, especially on underside of head; ventrals also often covered with similar prickles; dorsals very close together, or their base subcontinuous, low, first dorsal less than half the depth; second dorsal higher, posterior rays elongate, angulate, and equal to or slightly more than half the depth; anal similar to second dorsal but lower; in no case do dorsal and anal reach caudal when depressed; caudal rounded, equal to distance from front margin of eye to posterior end of head; pectoral broad, its length equal to or greater than caudal; ventrals typical of the genus.

The color variable; some are uniform yellowish or brownish yellow, with paler fins; others vary from dark brown to brownish black, with black fins; the whole body may be dark or the front part may be brownish red.

According to the artist T. S. Espinosa, a fresh specimen from Zamboanga had the head of clear sepia, shading off to burnt sienna; the body, fins, and fibrils on the head ivory black. Two specimens from Guindulman, Bohol, are black all over, except the brownish red head.

The Bureau of Science collection contains the following specimens, varying from 12 to 30 millimeters in length:

Puerto Galera, Mindoro, 22.

Zamboanga, Mindanao, 1.

Samal Island, Davao Gulf, 4.

Guindulman, Bohol, 2.

Günther is the only author who has recorded this species from the Philippines, the Challenger Expedition having obtained it at Cebu. The Bureau of Science has a color sketch, made 
from a fresh specimen at Zamboanga, where the Moros call it tibak. The description by Jordan and Seale of $P$. melanosomus, from Manila, would indicate that their specimen was $P$. echinocephalus.

This tiny and most extraordinary goby was first described from the Red Sea, where it is common. It occurs on the coast of Madagascar, in the China Sea, and southeastward to Samoa, Tahiti, and Tonga, an enormous range for such a feeble fish.

\section{PARAgOBIOdON MELANOSOMUS (Bleeker)}

Gobius melanosoma BLEEKrR, Ceram, Nat. Tijd. Ned. Ind. 3 (1852) 703; Peters, Monatsber. Akad. Wiss. Berlin (1868) 265.

Paragobiodon melanosoma BlEEKER, Esq. Syst. Nat. Gobioides, Arch. Neerl. Sci. Nat. 9 (1874) 309; (?) Jordan and Seale, Bull. Bur. Fisheries 2.6 (1907) 45.

Dorsal VI, I-10; anal I, 10; pectoral 21 or 22 ; there are 23 or 24 scales in a longitudinal series.

The depth of the short thickset body 3.2 to 3.8 times in length; the head very large, broad and deep, its length greater than its depth, 3 to 3.5 times in length; the breadth of head equals its own depth and also that of body; the profile boldly convex, the broad, short snout equals the circular eye, 2.75 to 3 times in head; the eyes high up, the interorbital space little elevated, equal to or 0.75 an eye diameter; the mouth small, curved, strongly oblique; the teeth in upper jaw in two rows, the outer much larger; in the lower jaw there are two rows of fine teeth behind a short outer row of large teeth, with two canines behind symphysis; the head and nape naked; the lower edge of preopercle and sometimes of subopercle has a fringe of tiny papillæ, or tubercles; the rugæ of throat may also be tuberculate; the vertical fins all low, the tips of first dorsal elongated into short threads, the height of both dorsals about $\frac{2}{8}$ the body depth; the anal a little lower; the caudal 0.75 as long as head.

The color of alcoholic specimens varies from black to dark brown, with black fins. There is a tendency for specimens to. bleach to yellowish brown.

The Bureau of Science collection contains the following specimens, from 16 to 23 millimeters in length: From Puerto Galera, Mindoro, 2; and from Zamboanga, Mindanao, 4.

This species was collected by Jagor on a coral reef at Mambulao, Camarines Norte, according to Peters.

The fish recorded under this name by Jordan and Seale was $P$. echinocephalus, according to their description. 
Paragobiodon melanosomus has been recorded from Madagascar to New Guinea; it is very close to $P$. echinocephalus.

\section{PARAGOBIODON XANTHOSOMUS (Bleeker)}

Gobius xanthosoma Blmқker, Nat. Tijd. Ned. Ind. 3 (1852) 703.

Paragobiodon xanthosoma BleEkeR, Arch. Neerl. Sci. Nat. 13 (1878) 54.

Paragobiodon xanthosomus JoRdan and SEALE, Fishes of Samoa, Bull. Bur. Fisheries 25 (1906) 397.

Tapug, name on Samal Island, Davao Gulf.

Dorsal VI, I-9-10; anal I, 8-9; pectoral 19; there are 23 scales in a longitudinal series.

The body of this fish is slenderer than is that of its congeners, the body being narrower and the head smaller, though the depth is about the same, 3 to $3 \frac{1}{6}$ in the length; the head more pointed than in the other species, 3.375 to 3.5 in length; the depth of head a little less than its length and the breadth still less, 1.2 to $1 \frac{1}{8}$ times in its length; the snout 3.2 times in head and equal to eye, which is high up; the interorbital space little elevated and a little more than an eye diameter in breadth; the mouth small, nearly vertical; there are two rows of very small teeth in each jaw, the outer one the larger, with a pair of postsymphysial canines in lower jaw; the lower margin of preopercle and chin usually with a row of short tubercles; the vertical fins small, their shape and height as in $P$. melanosomus; the base of first dorsal continuous with second dorsal; the caudal about $\frac{5}{6}$ the length of head; the scales less firmly attached in this species than in the others.

The color of alcoholic specimens uniform yellow, the fins all clear.

A Samal Island specimen, sketched from life by T. S. Espinosa, was uniform yellow, the fins and head pale yellow, with pinkish buff on belly. Another one from the same locality was grass green all over, with light yellow fins.

The Bureau of Science collection contains six specimens, 20 to 27 millimeters in length, from the following localities: From Dumaguete, Oriental Negros, 1 ; from Samal Island, Davao Gulf, 3; and from Sitankai, 2.

This species occurs in the Moluccas, New Guinea, and Samoa. It is very close to $P$. melanocephalus, but differs in the number of pectoral and anal rays, and in the shape and size of the head.

In his treatment of the fishes of the Siboga Expedition Weber unites the three species under Gobius echinocephalus; this appears to me to be unwarranted, although the three species are all very close. 


\section{Genus 36. RHINOGOBIUS Gill}

Rhinogobius GruL, Proc. Acad. Nat. Sci. Phila. (1859) 145.

Drombus Jordan and Seate, Proc. U. S. Nat. Mus. 28 (1905) 797.

This genus seems to be a convenient catchall for a heterogeneous assemblage of small to medium-sized gobies not conveniently placed elsewhere, and not having any decided characters in common for convenient generic distinction.

Dorsal VI, I-8 to 11; anal I, 7 to 9 ; scales in longitudinal series 23 to 38 .

The body may be slender and elongate or bulky and subcylindrical anteriorly, laterally compressed, the head always rather large, 3 to 4 times in length, convex above; the body covered with ctenoid scales, largest posteriorly, the nape entirely naked or partly scaled, or scaled to eyes, and the anterior scales very small; the preopercles may be entirely naked and smooth, or may have two to several longitudinal lines of minute papillæ, which may be connected by one to many crosslines and with few or many radiating down and back from eye; the opercles are naked and may also be lined as the preopercles sometimes are, and may have a small patch of minute scales along upper margin'; the base of pectoral and breast scaled; the mouth small to moderate, oblique, the jaws equal or lower jaw projecting; the teeth in bands of three to nine rows in each jaw, those of outer row enlarged and fixed; the lower jaw usually has a posterior pair of canines and may have a pair at the center of the outer row; the tip of the tongue rounded or truncate; the spines of first dorsal may or may not have elongated threadlike tips; the dorsals close together, the second dorsal and anal short; the pectorals without silky rays above; the caudal varies from truncate to round pointed, shorter than, equal to, or slightly more than head.

The genus, as here defined, includes species which are undoubtedly widely divergent and which would seem to fall readily into different genera; but the numerous intergrading characters prevent any real division according to any plan I can devise or have found in the literature. Those with the body naked before the first dorsal link with those scaled to the eyes, and the presence or absence of canines fails as a dividing character. Rhinogobius neophytus may represent a divergent group, but even that is doubtful.

The authors of Drombus stated "this genus differs from $R$ hinogobius in the presence of mucus channels bearing cross lines of minute cirri as in Gobiomorphus." Unfortunately, this char- 
acter is common to many species of Rhinogobius and presents every stage of development, from those with none or with only one or two lines across the cheeks, up to those with an extensive and elaborate system of crisscross lines over the sides of the head, so that at no place am I able to make a hard and fast distinction. Species with or without a scaled nape, with more or fewer scales and fin rays, may have the same complicated system of lines on the cheeks or may have them equally smooth; the presence or absence of these papillæ does not link with any other character. From the other species of Rhinogobius one might separate Drombus palackyi and Drombus viridi-punctatus by the dentition, but there hardly seems enough difference to warrant the segregation.

I regard Rhinogobius as treated here and by other authors as very unsatisfactory; probably many of the species should go to Ctenogobius, of which Rhinogobius is probably a synonym, and the rest should be distributed into new genera.

A genus of general distribution.

Key to the Philippine and China Sea species of Rhinogobius.

SECTION DROMBUS

$a^{1}$. Nape scaled to eyes.

$b^{1}$. Teeth in six to nine rows in each jaw.

$c^{1}$. Thirty-one lateral scales; 18 or 19 before first dorsal, not extending to eyes.

R. palackyi.

$c^{2}$. Thirty-four to 38 lateral scales; 30 to 32 before first dorsal, extending to eyes. R. viridi-punctatus.

\section{SECTION RHINOGOBIUS}

$b^{2}$. Teeth in three to five rows in each jaw.

$d^{1}$. Not more than 10 scales before first dorsal.

$e^{1}$. Lower jaw inferior.

$f^{1}$. Scales before first dorsal 6 to 8 ; in lateral series 26 to 28 ; second dorsal 1-8; anal 1-8; six longitudinal brown lines; five large black spots along middle of side; eight large brown spots between fifth and sixth lines; a black ocellus between first and second dorsal spines

R. decoratus.

$f^{2}$. Scales before first dorsal 9 ; in lateral series 26 ; second dorsal 1-10; anal 1-9; sides with several longitudinal dusky bands and rows of black spots; no black ocellus on first dorsal.

R. calderae.

$e^{2}$. Jaws equal; scales before first dorsal 10; in lateral series 25; second dorsal I-11; anal I, 10; color brown, with about fourteen small circles of darker brown along middle of sides.

R. hongkongensis.

$d^{2}$. Scales before first dorsal 15 or more; lower jaw projecting. $223793-12$ 
$g^{1}$. Scales before first dorsal 15; in lateral series 29; second dorsal I-8; anal I, 7; a dark brown spot on posterior part of opercle; color uniform brownish, no crossbands

R. schultzei.

$g^{2}$. Scales before first dorsal 16 to 23; in lateral series, 28 to 30 ; second dorsai I-9; anal I, 9; a large emerald or black spot above angle of gill opening; five wide crossbars on back... R. caninus. $a^{2}$. Nape largely or entirely naked.

$h^{1}$. Three rows of scales before dorsal; scales in lateral series 27 or 28;

transverse 7 or 8 ; first dorsal I-8; anal I, 8; a dark bar from eye to upper lip and under lower jaw to other side.................. b. baliuroides.

$h^{2}$. No scales before first dorsal.

$i^{1}$. Scales 28 to 30 in lateral series; transverse 9 to 12 , first dorsal I-9; anal $\mathrm{I}, 9$.

$j^{1}$. Body encircled by ten to fourteen dark brown crossbands or black lines R. multifasciatus.

$j^{2}$. Body not encircled by bands or lines.

$k^{1}$. Twelve transverse scales; four dark spots on sides; no longitudinal dark lines; first dorsal with two rows of elongate blackish spots.

R. criniger.

$k^{2}$. Nine transverse scales; five dark spots on side between two brown lines running from pectoral axil to tail; first dorsal dusky brown with a clear band near base.

R. suluensis.

$i^{2}$. Scales 23 or 24 in a lateral series, 7 in a transverse series; first dorsal I-8; anal I, 9; snout long, pointed; translucent in life, whitish in alcohol, a vertical elliptical black spot at caudal base; a black spot between first and second dorsal spines.. R. neophytus.

\section{RHINOGOBIUS PALACKYI (Jordan and Seale)}

Drombus palackyi JoRdan and Seale, Proc. U. S. Nat. Mus. 28 (1905) 797, fig. 15.

Dorsal VI, I-10; anal I, 8; there are 31 scales in a longitudinal series, 14 in a transverse series, and 18 or 19 before the first dorsal.

The body laterally compressed and wedge-shaped, heavy anteriorly, the head large and much wider than high, with full rounded cheeks; the depth contained 4.4 to 4.8 times, the head 3 to 3.33 times in length; the short blunt convex snout equals eye and is 3 to $3 \frac{1}{8}$ times in head; the eyes are placed high up, looking upward as well as laterally, and are very close together, the interorbital space almost covered by the tumid margin of eyes; the oblique mouth small, with prominent chin, the angle of maxillary falling short of, or extending to beneath anterior margin of eye; the upper jaw has an outer row of enlarged teeth followed by a narrow band of very fine teeth; the lower jaw has an outer row of five or six enlarged teeth on each side, terminating in a pair of lateral canines; behind these is a band of very fine teeth, the innermost row slightly enlarged; the 
naked preopercles and opercles marked by a few rows and crossrows of minute papillæ; pores present on head as described under $D$. viridi-punctatus; the scales on nape are small, cycloid, and do not extend to eyes, which have a bare scaleless area for some distance behind them; the depth of caudal peduncle is $2 \frac{1}{6}$ to $2 \frac{1}{4}$ times in head; the first dorsal low, with short threadlike tips to spines; the dorsal and anal similar in outline, the base of anal shorter than that of dorsal; the posterior rays of dorsal longer than those of anal and reaching base of caudal when depressed; the caudal rounded and a trifle shorter than head; the pectoral broad, round pointed, and longer than ventrals, which do not reach anus.

The color of one old alcoholic specimen is brown with indistinct darker crossbands on back and sides, small dark brown spots on dorsal region and anteriorly, and pale centers to the scales on the sides, especially posteriorly, these forming longitudinal rows; the caudal crossbarred with rows of brown spots and the ventrals blackish.

Another specimen is a bluish brown; the first dorsal has a large blackish brown spot on its upper part between third and fourth spines; the other fins brown, with darker brown rays, the base of pectorals blackish brown.

Here described from two specimens, one 40 millimeters long, collected at Malabon, a town on Manila Bay just north of the City of Manila; and the other, 30 millimeters long, from Mariveles, at the entrance to Manila Bay. Another excellent specimen, 39 millimeters long, is without locality or other data.

The type was collected by Dr. Bashford Dean in southern Negros.

I place here also five small specimens in very bad condition, 22 to 34 millimeters in length, collected at Kanoan, Siquijor, in 1907 , by Mr. Alvin Seale.

80. RHINOGOBIUS VIRIDI-PUNCTATUS (Cuvier and Valenciennes)

Plate 30, Fig. 1

Gobius viridi-punctatus Cuvier and VALencrennes, Hist. Nat. Poiss. 12 (1837) 47; Günther, Cat. Fishes Brit. Mus. 3 (1861) 24; DAY, Fishes of India (1878) 286, pl. 59, fig. 5, pl. 61, fig. 4, and pl. 63, fig. 4.

Panay Visayan name, paló.

Dorsal VI, I-10; anal I, 9 or 8 ; there are 34 to 38 scales in a longitudinal series and 12 in a transverse series; there are 30 to 32 scales before the first dorsal. 
Viewed from above the body is robust, wedge-shaped, with compressed sides, tapering to a broad but thin caudal peduncle; the dorsal and ventral profiles but little arched, the depth 3.9 to 4.4 in length; the large head goes 3.38 to 3.6 in length, with a convex, sharply descending profile and projecting jaw; the cheeks very plump so that the width of head is equal to or greater than its depth; the snout 3.8 to 4.2 times in head, and but little longer than eyes; these are placed very high up and close together, their gaze directed upward more than laterally, their length 0.75 to $\frac{8}{9}$ that of snout, and 4.2 to 4.6 times in head; the width of the naked interorbital half or less than half an eye diameter; the nape scaled to eyes and into interorbital space; the oblique mouth moderate, the lips fringed within, the posterior angle of maxillary reaching a point below front margin of eye or, more rarely, below middle of eye; the upper jaw has a long outer row of enlarged, conical, fixed teeth, erect or projecting, followed by a band of six or eight rows of very fine teeth; the lower jaw has a short outer row of enlarged teeth, six or eight on each side, with a pair of canines at the symphysis and a pair of posterior lateral canines; behind this row is a band of about five rows of very fine teeth, followed by a long inner row of enlarged stout conical teeth, the largest behind symphysis; the large, rounded, naked preopercle marked by several longitudinal and many crosslines of minute warts; a few similar lines on opercle; a large pore above and midway between nostrils; two large pores on interorbital space; two pores behind eye, three more on supraopercular groove, and three on posterior border of preopercle; the depth of caudal peduncle contained about twice in head; the dorsal spines moderately flexible, with short threadlike tips, the third one longest, its height 0.5 or $\frac{2}{8}$ that of body; the base of anal much shorter than that of second dorsal, both fins similar in outline, their posterior rays elongate, those of anal a little the longer, and usually reaching base of caudal when depressed, rarely falling short of it; the caudal varies from rounded to pointed but not lanceolate, its length usually a little greater than head; the broad rounded pectorals extend slightly beyond the broad ventrals, sometimes as far as above anal opening; the anal papilla slender and pointed.

In life this is a goby of great beauty; the body and fins are dusky gray, tinged with roseate, blue, and lavender; there is a large, dark, emerald green shoulder spot, one nearly as large before it on the side of the nape, and another behind it, and 
there are several smaller ones on the opercle and preopercle, while many of the lateral scales have a central spot of the same color; the anal has a basal green band and the second dorsal and caudal each a submarginal one, the tips of the latter fins lavender; the eye is blue.

In alcohol the color varies from dusky gray and dusky olive green above and whitish below, to yellowish brown or dark brown above and pale yellowish below; the beautiful spots and fin markings all disappear, leaving traces of a lateral band of dark blotches in some specimens, and in most specimens many of the lateral scales have a white spot; the fins vary from dusky to uniform brown, the caudal often with a few crossrows of dark spots.

Here described from specimens, 44 to 117 millimeters long, from the following localities:

$\begin{array}{ll}\text { Malabon, Rizal Province, 5. } & \text { Dumangas, Iloilo Province, } 6 . \\ \text { Manila market, 6. } & \text { Villa, Iloilo Province, 1. } \\ \text { Calapan, Mindoro, 1. } & \text { Buena Vista, Guimaras, 1. } \\ \text { Capiz, Panay, 1. } & \text { Navalas, Guimaras, 2. } \\ \text { Molo, Iloilo Province (specimen } & \text { Kanoan, Siquijor, 2. }\end{array}$

aberrant, faded), 1.

This very handsome goby, originally described from Bombay, ranges eastward through the East Indian Archipelago.

Gobius chlorostigma Bleeker, from Java, is probably the same species.

\section{RHINOGOBIUS DECORATUS sp. nov.}

Plate 13, Fig. 3

Dorsal VI, I-8; anal I, 8 ; there are 26 to 28 scales in a longitudinal series, 8 or 9 in a transverse series, and 6 or 8 before the first dorsal.

The elongate slender body subcylindrical anteriorly, the posterior two-thirds laterally compressed, the depth 5 to 5.8 times in length; the head rather small, gently convex and somewhat pointed, 3.6 to 3.8 times in length; the snout convex, rounded, protuberant, 3.4 to 4 times in head; the eyes very high up, dorsolateral and looking up as well as sideways, equal to snout; the interorbital space very narrow, about 4 times in eye; the mouth very low down, nearly horizontal, the upper lip thick, protractile, the lower jaw inferior, the posterior angle of maxillary beneath middle of eye; in upper jaw an outer row of slightly enlarged teeth, and behind it two rows of minute teeth; in lower jaw a band of four rows of minute teeth, with a pair of lateral canines, nearly horizontal and curved backward; the body 
covered with large, firm, ctenoid scales which extend forward on nape to eyes; the scales on breast and pectoral base cycloid; the dorsals well separated, the first dorsal reaching origin of second when depressed, second and third spines longest, about twice in head; the second dorsal short, angulate posteriorly, the last ray longest but not reaching caudal when depressed, 1.6 to 1.8 times in head; the anal like second dorsal, equal to or a little less in height; the caudal round pointed, equal to or a trifle longer than head; the caudal peduncle broad, its depth 1.6 to 1.8 times in its own length; the long round-pointed pectoral equals caudal and extends back to a point above origin of anal; the ventrals long, broad, with serrated margin, the frenum broad and forming a deep cup, the tip of fin reaching anal papilla or origin of anal, about 0.9 as long as head.

The color in alcohol pale whitish yellow, with six longitudinal lines of brown running from top and sides of head back to tail, the bottom line broken into spots posteriorly; along the middle of the side is a row of five large black spots, the last one on base of caudal; below this, between fifth and sixth brown lines, is a row of eight large brown spots; running back from shoulder is a row of large, more or less circular black dots, which end on top of caudal peduncle; above this is a less conspicuous row of smaller black spots running from eye to second dorsal; between all these lines and spots the ground color of body shows up as large and usually circular pale or whitish spots arranged in six longitudinal rows; the first dorsal has a black ocellus between first and second dorsal spines, with one or two black spots on fifth spine; the second dorsal has three, the caudal six crossbars of dark brown spots; the anal has a basal row of blackish lines; the base of pectoral has two dark brown longitudinal bars.

Here described from three specimens, 38 to 51 millimeters long, collected by G. A. Lopez at Cabalian, Leyte.

This is a very handsome little fish and well deserves the name decoratus, adorned.

82. RHINOGOBIUS CALDERAE (Evermann and Seale)

Gobius calderae Evermann and Seale, Proc. U. S. Nat. Mus. 31 (1907) 511, fig. 3.

Rhinogobius calderae JORDAN and RICHARDSON, Check List Phil. Fishes (1910) 48.

Dorsal VI, I-10; anal I, 9; there are 26 scales in a longitudinal series, 9 in a transverse series, and 9 before the first dorsal. 
The moderately plump body has nearly parallel dorsal and ventral profiles, the posterior part laterally compressed, the depth 5.4 times in length; the head 3.8 times in length, its breadth $\frac{6}{7}$ of depth of body, 0.6 of its own length, and slightly more than its own depth; the steeply inclined, round-pointed snout 3.3 times in head; the large eye a trifle more than length of snout; the eyes very high up, laterodorsal in position, their superior margins touching; the distance from tip of snout to posterior margin of eye less than distance from eye to posterior margin of opercle; the mouth small, inferior, the snout slightly projecting, the posterior angle of maxillary beneath pupil of eye; the teeth of outer row in upper jaw slightly enlarged, with two rows of minute teeth behind them; in lower jaw four rows of minute teeth, the outer one slightly enlarged; the tip of tongue almost rounded, not emarginate; the body covered with rather large ctenoid scales, those on nape cycloid, large, and extending to eyes; the head entirely naked except on nape; the bases of pectorals and the breast covered with large cycloid scales; the first dorsal a little lower than depth of body, the second and third spines longest; the second dorsal and anal similar in shape and height, about $\frac{6}{7}$ of body in height, and a little lower than first dorsal, the posterior rays not longer than the others and not nearly reaching caudal when depressed; the caudal somewhat rounded at tip, equal to head in length; the pectoral is 1.1 times length of head and extends back to a point beyond anus but does not reach anal; the pointed ventrals are 0.9 length of head and extend to anus.

The color in alcohol whitish with several longitudinal dusky bands and rows of black spots; one conspicuous row of circular black spots extends from eye to top of caudal peduncle; a row of larger circular or quadrangular black spots extends from pectoral to base of caudal; below this a row of smaller black spots and two rows of small black spots along nape and sides below dorsals; the dusky bands pale and inconspicuous; a dusky stripe extends from upper lip back to base of pectoral, ending in a black spot on pectoral; the cheek marked by vertical and longitudinal bars of fine brown dots; the dorsal spines spotted black with a blackish transverse bar on the membrane, near base; the second dorsal crossbarred with four rows of black spots; the caudal obscurely crossbarred with dark and pale, with a few black spots scattered over the membrane; the ventrals and anal faintly marked with dusky. 
This species has a strong resemblance to Gobius ornatus, with which it would be readily confused if it were not for the pectorals.

Here described from two specimens, 31 and 38 millimeters long, collected at the barrio of Nalvo, Luna, La Union Province, Luzon. It has been previously known solely from the type specimens collected at Caldera Bay, a few kilometers north of Zamboanga, Mindanao.

\section{RHINOGOBIUS HONGKONGENSIS Seale}

Rhinogobius hongkongensis SEALE, Philip. Journ. Sci. \& D 9 (1914) 74, pl. 1, fig. 2 .

Dorsal VI, I-11; anal I, 10; there are 35 scales in a longitudinal series, 9 in a transverse series, and 10 before the spinous dorsal.

The body elongate, plump and rounded anteriorly, the posterior half laterally compressed, the dorsal and ventral profiles nearly horizontal and parallel, the depth 5.6 in length, greatest anteriorly and tapering slightly to the long broad caudal peduncle; the head large, broad, 4 times in length; the nape plump, the groove above opercles prominent; the boldly convex snout 3.1 times in head; the eyes equal to snout, dorsolateral, placed very high up and close together, their inner margins touching; the mouth moderately large, low down, nearly horizontal, the jaws equal, the posterior angle of maxillary extending to a point beneath forward part of pupil; four rows of teeth in upper jaw, those of first row larger, the others very small and crowded; in lower jaw four rows of small, sharp pointed teeth, the outer row of stouter enlarged teeth with a large, posterior, recurved canine on each side; the body covered with ctenoid scales, those on posterior half larger, the nape scaled to eyes; the second spine of first dorsal longest, 1.75 times in head; the soft dorsal longer than anal, the two fins alike in shape and height, angulate behind, their posterior rays longest, about 1.5 times in head; the depth of caudal peduncle 2.33 times in head and a little less than twice in its own length; the rounded caudal 1.2 times in head; the pectoral pointed, slightly shorter than head; the ventrals pointed, 1.4 times in head, their tips reaching anus; the anal papilla small, slender, pointed.

The color in alcohol pale wood brown with a series of about fourteen small, more or less complete circles of darker brown (sepia) along the median line of sides, margin of scales on upper half of body also slightly shaded with sepia; one or two narrow, paler, longitudinal lines above the 
row of median circles; a black line from posterior margin of eye to upper base of pectoral fin; four or five blue spots on opercles and an irregular brown blotch on cheek below eye; two brownish blotches on base of pectoral; the dorsals crossbarred by four rows of brown spots; the caudal crossbarred by five rows of brown spots; the anal shades into slate gray on outer third; the pectorals and ventrals pale yellowish brown. [Seale.]

I have examined Seale's type, No. 6474, 70 millimeters long, and two cotypes, Nos. 6489 and 6541, of the Bureau of Science collection, obtained by him from the market in Hongkong, China. They are now in very bad condition and the color markings have largely disappeared.

84. RHINOGOBIUS SCHULTZEI ap. nov.

Dorsal VI, I-8; anal I, 7 ; there are 29 scales in a longitudinal series, 9 in a transverse series, and 15 before the first dorsal.

The trunk strongly compressed laterally, with arched back and horizontal ventrally, the depth 4.66 in length; the head large, broad, depressed, its length 3 to 3.1 in head and trunk together; its breadth equal or almost equal to body depth, about $\frac{2}{8}$ of its own length, and greater than its depth which is half or less than half its length; the snout convex, bluntly rounded, contained 4 times in head; the eye equals snout and is in the forward half of head; the interorbital two-thirds an eye diameter in breadth; the mouth terminal, oblique, with thick lips and projecting chin, the posterior angle of maxillary extending to a point beneath forward part of pupil; three rows of teeth in upper jaw, the outer row enlarged, and a band of four rows in lower. jaw; there are no canines; the tongue broad, truncate; the body covered with ctenoid scales, those in front of first dorsal smaller and extending to eyes; the remainder of head naked; there are two interorbital pores, one behind eye at the beginning of the prominent supraopercular groove, and two on posterior margin of preopercle; the dorsals far apart, the first one low, its height one-half that of body; the second dorsal and anal short, angulate posteriorly, the longest ray of second dorsal 0.75 to $\frac{5}{6}$ of depth, falling far short of caudal when depressed; the caudal truncate with rounded corners, its length $\frac{8}{9}$ that of head and a little more than that of pectoral which extends posteriorly to a point above anal papilla; the ventrals short, round-pointed, scarcely reaching anus, $\frac{2}{8}$ as long as head.

The color in alcohol uniform brownish, paler beneath, with a conspicuous dark brown spot on posterior part of opercle; the first dorsal sprinkled with minute violet-brown specks form- 
ing two crossbands; the second dorsal and caudal crossbarred by three or four irregular dark bands; there is a vertical bar of violet-brown specks at base of pectoral rays; the other fins all clear.

Here described from two specimens, 28 and 37 millimeters in length, collected from the river at Fabrica, Occidental Negros, by my colleague Mr. W. Schultze, entomologist of the Bureau of Science, for whom I take pleasure in naming the species.

\section{RHINOgobius CANINUS (Cuvier and Valenciennes)}

Plate 13, Fig. 4

Gobius caninus Cuvier and Valenciennes, Hist. Nat. Poiss. 12 (1837) 65; GüNtherR, Cat. Fishes Brit. Mus. 3 (1861) 38; Fische der Südsee 2 (1876) 175, pl. 109, fig. C; A. B. MEYER, Ann., Soc. España Hist. Nat. 14 (1885) 29 (misprinted as G. cazinus).

Rhinogobius caninus Jordan and SEALE, Proc. U. S. Nat. Mus. 28 (1905) 796; JORDAN and RICHARDSON, Bull. Bur. Fisheries 27 (1908) 277; Seale, Philip. Journ. Sci. § D 5 (1910) 285.

Gobius grandinosus Valmnciennes, Voy. Bonite Poiss. (1842) 177, pl. 5, fig. 4.

Dorsal VI, I-9; anal I, 9; there are from 28 to 30 scales in a lateral series, 10 in a transverse series, and 16 or 23 scales before the first dorsal.

The robust body laterally compressed, with a large broad head; the depth contained from 4.3 to 4.7 times, the head 3.3 to 3.6 times in length; the eyes near dorsal profile, of medium size, their diameter $4 \frac{1}{6}$ to $4 \frac{1}{2}$ times in head, twice as great as the interorbital space, and about 0.75 as long as the blunt convex snout; the mouth oblique with a slightly projecting lower jaw; the posterior angle of maxillary sometimes extends to beneath anterior margin of eye; the teeth very small and in fine bands; those of outer row enlarged and widely spaced, then follow two or three rows of minute teeth and an inner row a little larger; the lower jaw has one or two canines on each side at the end of the short outer row; the caudal peduncle rather short and deep, its depth about 0.75 or 0.8 of its length.

The first dorsal usually low, about $\frac{7}{9}$ of depth of trunk, but in specimens from Sandakan, Borneo, the spines have filamentous tips, the third one especially being elongated until it may equal the head in length; the second dorsal and anal elongated and angulate posteriorly, the last rays in large specimens reaching caudal; the pectorals extend beyond the broad ventrals and 
may reach anus; the caudal is obtusely rounded and is shorter than or may equal head; the anal papilla very small.

The trunk covered with large scales which are finely ctenoid, except on the ventral surface; before the dorsal the scales are small and extend forward to eyes; in some specimens there are 16 scales before dorsal; others, similar in other respects, have 23 ; the base of pectoral partially scaled and upper part of opercle covered with fine scales; two or three rows of minute papillæ extend longitudinally across cheek, the larger one across middle, a much smaller one (sometimes two) on lower part; a similar line runs above the supraopercular groove from posterior angle of opercle to eye, with a branch curving forward under eye; a vertical row on anterior part of opercle and one or two short crossrows; several large mucus pores on head as follows: One a short distance from inner side of second nostril, one right behind eye on supraopercular groove, two more on the same groove farther back, and one at forward and one at posterior end of interorbital space.

The color in life dark green above, paler below, the region about the ventrals pearly; five short, wide, black crossbars along back, the first on head behind eyes, the second in front of first dorsal, the third beneath first dorsal, the fourth and fifth under second dorsal; along the middle of the side five large black spots, the last and most conspicuous on base of caudal; above angle of gill opening is a large, brilliant, emerald green spot with a narrow black margin; on sides of head are small green spots, either in two rows or many small scattered ones; they may extend upon the base of pectoral; along the sides are longitudinal rows of golden green spots, a spot on each scale; the dorsals are marked by vertical black bars and have a golden band along upper margin; the anal dusky, with two longitudinal rows of white spots; the caudal blackish; the pectorals and ventral dusky, the latter encircled by a white margin.

The color in alcohol brown above to very pale yellowish on belly; the dorsal bands become dark brown and the large, lateral, black spots fade more or less; the shoulder spot turns to blue or black and the golden green spots fade to yellow or pearl, or disappear entirely, while no trace remains of the spots on the cheeks.

I have observed numerous living specimens of this brilliantly decorated little goby, from the estuaries of Malabon. The above 
description was written after examination of alcoholic specimens, 38 to 106 millimeters in length, obtained from the following localities:

Malabon, Rizal Province, 16.

Manila, 2.

Cavite, 2.

San Miguel Bay, Camarines Sur Province, 1.

Buhi River, Camarines Sur Province, 1.

Guinobatan, Masbate, 1.
Iloilo, Panay, 7.

Zarraga, Iloilo Province, 5. Navalas, Guimaras, 4.

Cebu, 1.

Davao, 1.

Balabac, 5.

Sandakan, Borneo, 15.

Amoy, China, 2.

My largest specimens are spawning females, obtained June 30 ; the smallest spawning female is 75 millimeters long, collected July 14. This species was recorded by Meyer from Cebu, by Jordan and Seale from Negros, and by Jordan and Richardson from Iloilo and Lubang Island. Undoubtedly it occurs throughout the Philippines in bays and estuaries, but rarely in fresh water. Elsewhere it is known along the China Sea from Amoy southward, and in the East Indies.

All the Philippine specimens I have seen agree in having the first dorsal lower than that in specimens from elsewhere, without filiform tips, and nearly all have larger scales on the nape. In other respects they are identical with those figured and described by authors.

The Philippine form above mentioned may be called Rhinogobius caninus magnisquamatus, to distinguish it from the typical form, which seems to be rare in the Philippines.

\section{RHINOGOBIUS BALIUROIDES (Bleeker)}

Gobius baliuroides BLEEKER, Verh. Bat. Gen. 22 (1849) 26; GÜNTHER, Cat. Fishes Brit. Mus. 3 (1861) 42.

Rhinogobius baliuroides JoRdAN and Richardson, Bull. Bur. Fisheries 27 (1908) 276.

Dorsal VI, I-8; anal I, 8 ; there are 27 or 28 scales in a longitudinal series and 7 or 8 in a transverse series.

The body elongate, slender, the dorsal and ventral profiles nearly parallel, the depth 5.2 to 5.6 times in length; the head long, low, broad, its depth behind eyes about 0.8 its width, 3.7 to 3.9 in length; the snout short, 3.5 to 3.75 in head, equal to eyes, which are laterodorsal in position, looking up as much as sideways, and very close together, the interorbital space negligible; the mouth oblique, the upper lip above lower margin of eye, the lower jaw projecting, the posterior angle of maxillary extending to beneath or almost beneath front margin of eye; 
the teeth of outer row in upper jaw enlarged and widely spaced; behind them four rows of minute teeth; in lower jaw four rows of minute teeth with a short outer row of enlarged teeth, terminating on each side in a stout backward-curved canine; the body covered with ctenoid scales, the head naked; in front of first dorsal about three rows of smaller scales, which curve down to preopercular groove and forward along it a short distance, the nape largely naked; the breast and pectoral bases covered with cycloid scales; pores occur on head as in $C$. criniger; the height of first dorsal is $\frac{2}{3}$ to 0.9 the depth, the second dorsal spine elongate with threadlike tip, its length a little more than head, or even $\frac{1}{3}$ longer; the posterior rays of second dorsal elongate, equal to depth, the fin angulate posteriorly; the anal similar in shape and nearly or quite as high; the depth of caudal peduncle 2.5 times in head and nearly twice in its own length; the caudal a trifle shorter than head, about 4 times in length; the pectoral about equal to depth; the ventrals equal or exceed pectoral, and reach the slender, notched anal papilla or the anal fin.

The color in alcohol brownish yellow, with five dark brown lateral blotches along middle, the last on base of caudal; there are five broad saddlelike crossbars, two predorsal, and one under first dorsal, one under second dorsal, and one just behind it; each of the bars under dorsal fins sometimes divided into two; the head irregularly blotched with dark brown spots; a dark bar from eye to upper lip and continued on underside of lower jaw to meet a similar one on the other side; the first dorsal has a very broad blackish crossbar; the second dorsal has four to six crossbars of blackish brown spots; the anal has a broad blackish margin; the pectoral has a circular brown spot on upper part of base and several crossrows of small brown spots which usually disappear; the ventrals blackish; the caudal conspicuously crossbarred with about six rows of dark brown spots.

The Bureau of Science collection contains the following specimens of this species:

Vigan, Ilocos Sur Province, 17.

San Fabian, Pangasinan Province, 2.

Malabon, Rizal Province, 9.

South coast of Luzon, 1.

Molo, Iloilo Province, Panay, 1.

Dumaguete, Oriental Negros

Province, 1.
Kanoan, Siquijor, 1.

Cuyo, 1.

Cagayan, Misamis Province, 6.

Caldera Bay, Zamboanga Province, 1.

Davao, Mindanao, 7. 
They range in length from 26 to 56 millimeters.

This species has been previously reported from Aparri by Jordan and Richardson. It was described originally from Madura. It is close to $C$. criniger but is readily distinguished by its protruding lower jaw, well-developed canines which are prominent even in very small specimens, the different scalation, and the somewhat different color markings.

\section{RHINOGOBIUS MULTIFASCIATUS sp. nov.}

Plate 14, Fig. 1

Dorsal VI, I-9; anal I, 9 ; there are 28 scales in a longitudinal series and 10 in a transverse series.

The body moderately full and rounded anteriorly, laterally compressed on caudal peduncle; the dorsal profile gently arched; the depth 3.8 to 4 times in length; the head of moderate size, and contained 3.45 to 3.55 times in length; the boldly convex snout rather broad and rounded at tip, 3.4 to 3.75 in head; the eyes high up, dorsolateral in position, oblique, equal to or 0.875 as long as snout; the interorbital space varies from 0.25 to 0.5 an eye diameter; the mouth moderately oblique, with equal jaws, the posterior angle of maxillary extending to beneath front margin of eye; the teeth of outer row in upper jaw slender, sharp-pointed, enlarged; behind this a band of about three rows of minute teeth; the lower jaw has a short row of enlarged teeth in front, ending in a pair of lateral canines curved backward; behind this is a band of four or five rows of minute teeth; the body covered with large ctenoid scales, which become much smaller above base of pectoral; the full rounded nape usually naked as far as posterior margin of opercles, with a naked central portion extending back as far as first dorsal; the breast covered with large cycloid scales; the depth of caudal peduncle from 2.3 to 2.5 times in head and 1.5 times in its own length; the first dorsal small, the tips of the spines extended but little beyond the membrane; the longest spines from 1.65 to 1.85 times in head and about 1.5 times in depth; their tips may or may not reach origin of second dorsal when depressed; the second dorsal and anal approximately equal the longest spines of first dorsal in height, their posterior rays not reaching caudal when depressed; the caudal subtruncate or round pointed, its length equal to greatest depth of body; the pectorals and ventrals are of the same length, about $\frac{5}{6}$ of depth, and may extend to anus; the anal papilla inconspicuous, slender and pointed in males, and very short, thick, and rounded in females. 
The color in alcohol yellowish gray, with ten to fourteen narrow vertical dark brown crossbands which become black lines on belly; before first dorsal are two short, broad crossbands; each scale on upper half marked by small dark brown or umber spots, which form longitudinal rows on the sides; the naked top of snout and head marked by numerous irregular spots of umber; a black or dark brown spot beneath eye between it and upper lip; the first dorsal spine spotted alternately with black and white; there is a black or dark brown transverse bar on lower part of first dorsal, ending posteriorly in a large black spot; sometimes there is a second narrow dark bar above the first one; the second dorsal crossbarred with about four rows of very dark spots; the membranes of anal more or less blackish, the rays white; the caudal has two rather large basal spots forming an irregular crossband and about six crossbars of dark brown spots, the posterior portion clear; the pectorals faintly crossbarred by rows of dark spots, with a dark spot on upper portion of base; the ventrals blackish.

Here described from 65 specimens, 25 to 54 millimeters in length, collected in Iloilo, July 23, 1925. Specimens over 40 millimeters long are sexually mature and would apparently spawn early in August, as many of the females when collected were almost ready to spawn. These specimens came from the mouth of Jaro River, where the water is salt.

\section{RHINOGOBIUS CRINIGER (Cuvier and Valenciennes)}

Plate 14, FIG. 2

Gobius criniger Cuvier and Valenciennes, Hist. Nat. Poiss. 12 (1837) 62; RICHaRdson, Ichthyology, Voy. Erebus \& Terror (1844) 2, pl. 1, figs. 3 and 4; GüNTHeR, Cat. Fishes Brit. Mus. 3 (1861) 29; DAY, Fishes of India (1878) 288, pl. 62, fig. 2.

Ctenogobius criniger BlEEKeR, Arch. Neerl. Sci. Nat. 13 (1878) 54.

? Gobius nebulosus Forskål, Descrip. Anim. 24 (1775); CuVIER and Valenciennes, Hist. Nat. Poiss. 12 (1837) 63.

Rhinogobius nebulosus JoRDAN and Seade, Bull. Bur. Fisheries 26 (1907) 41; JoRDAN and RICHARDSON, Bull. Bur. Fisheries 27 (1908) 276.

Rhinogobius lungi JoRdaN and SEALE, Bull. Bur. Fisheries 26 (1907) 41, fig. 13.

\section{Ibanag name, laginlagen.}

Dorsal VI, I-9; anal I, 9; there are 28 to 30 scales in a longitudinal series and 12 in a transverse series.

The body wedge-shaped, robust anteriorly, the compressed sides tapering rapidly back to caudal peduncle, the depth 4 to 
4.3 in length; in adult specimens the width of the large thick head equal to or greater than its depth behind eyes, its length 3.1 to 3.3 in head and trunk together; the boldly convex snout bluntly rounded, 2.6 to 3.4 in head; the oblique eyes very high up but lateral, and equal to or 0.8 of length of snout; the eyes very close together, the interorbital space 3 to 4 times in length of eye; the mouth low down, moderately oblique, rather small, the lower jaw rather weak and equal to upper jaw or sometimes barely projecting beyond it, the posterior angle of maxillary beneath front margin of eye; there are four rows of teeth in upper jaw, those of outer row enlarged, widely spaced, the others very small; the lower jaw has five rows, the outer one short with enlarged teeth and a small lateral canine hardly larger than the rest at its posterior extremity; the remaining four rows all of very small teeth; the body covered with firm ctenoid scales which become much smaller between pectoral and first dorsal; the entire head and nape naked back to first dorsal, or there may be a few very small cycloid scales above opercle, forward almost to eyes, with a few scattered scales just in front of first dorsal; a double row of papillæ crosses middle of preopercle from front to back, with other rows above and below more or less developed; there is a large open pore at anterior extremity of interorbital space; the supraopercular groove prominent; at its origin behind eye is a large pore, with one or two pores behind it; on posterior margin of preopercle are three large pores; the base of pectoral and breast covered with small cycloid scales; the first dorsal rather low, a little less than $\frac{2}{8}$ depth of body, the tips of first four spines greatly elongated and threadlike, longer than head and extending to base of fifth or sixth ray when depressed; the second dorsal about as high as first dorsal, the anal a little lower; both second dorsal and anal have elongated ray tips, their posterior rays longest, the fins sharply angulate posteriorly, usually not reaching caudal when depressed; the pectoral round pointed, of moderate size, its length nearly equal to depth; the ventrals are broad and do not reach anus; the depth of caudal peduncle approximately 0.75 its length; the round-pointed caudal shorter than head, 3.6 to 3.8 times in length; the anal papilla small, slender and pointed in males, subglobose in females.

The color in alcohol whitish brown to red brown, with three large quadrangular brown or blackish brown spots on side and a fourth, darker, and nearly circular spot at base of caudal; on the nape two broad brown crossbands, each more or less divided 
into two by vermiculate pale lines; under the first dorsal a very dark, broad, saddlelike crossband and two smaller, lighter ones under second dorsal; a blackish brown spot extends from eye to upper jaw; beneath eye is a broad, irregular, vaguely defined brown mark extending down behind mouth; a wide diagonal dark brown or blackish bar extends from shoulder downward across opercle to lower posterior margin of preopercle; the upper half or two-thirds of body irregularly blotched with dark brown spots; the upper part of eye covered by a blackish brown mark; the first dorsal has two rows of elongate blackish spots, its elongate tips black; the second dorsal has four or five rows of black spots running diagonally downward and backward; the anal clear with a black margin; the caudal crossbarred by numerous rows of small black spots; the pectoral has a couple of brown spots on its base; the ventrals are blackish.

The Bureau of Science collection contains specimens as follows, ranging from 32 to 95 millimeters in length:

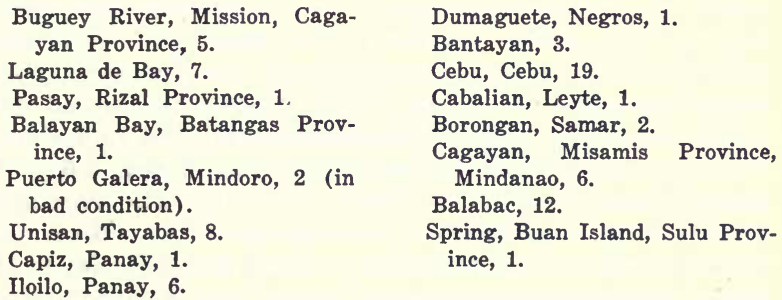

This remarkably handsome goby, so distinct from all its congeners by reason of its naked head and nape and its striking markings, has been previously recorded from the Philippines from Aparri, Manila, Cavite, and Panay. It occurs from Zanzibar to the East Indies and the northwest coast of Australia.

While it may be the Gobius nebulosus of Forskål, there is not enough detail in his description to convince me that his species is the same as rriniger.

The people at Mission, near Buguey, Cagayan Province, say that the flesh of this goby is poisonous.

89. RHINOGOBIUS SULUENSIS sp. nov.

Plate 14, Fig. 3

Dorsal VI, I-9; anal I, 9; there are 28 to 30 scales in a longitudinal series and 9 in a transverse series. 
The body slender, elongate, the dorsal profile very little elevated, the depth 5.35 to 5.5 times in length; the rather blunt, somewhat convex head broader than body, 3.4 to 3.5 times in length, its breadth equal to or a little less than its depth and 1.8 to 1.96 times in its own length; the snout short, steep, blunt, 3.6 to 4 times in head; the eyes large, 3 to 3.33 times in head, very high up, dorsolateral, their inner margins touching; the mouth oblique, the jaws equal, the posterior angle of maxillary beneath anterior part of eye or front margin of pupil; the upper jaw has an outer row of large, widely spaced, curved teeth and three rows of minute teeth behind, which become two rows posteriorly; the lower jaw has a short outer row of somewhat enlarged teeth terminating at each side in a large curved canine or two; behind this is a broad but rather short band of four rows of small teeth; the tip of the tongue rounded; the body covered with large ctenoid scales, which become smaller above pectoral base and disappear anteriorly; the region before first dorsal and head naked; on cheek are two parallel longitudinal lines of papillæ; any one or all of the first three dorsal spines may be elongated, with threadlike tips, which extend well back on second dorsal when depressed, 1.8 to 1.125 times in head; the second dorsal lower, not reaching caudal when depressed, 1.66 to 2 times in head; the anal a little higher than second dorsal, 1.5 to 1.96 times in head; the depth of caudal peduncle a little more or less than twice in its length; the pointed caudal 3.1 to 3.8 times in length; the pectoral extends back to a line perpendicular to anus, 1.3 to 1.4 times in head; the ventrals pointed, equal to or nearly equal to pectoral; the anal papilla small, narrow, pointed in males, subglobose in females.

The color in alcohol reddish brown with four rectangular dark brown spots on the side, inclosed between two brown longitudinal lines running from under pectoral to tail; at base of caudal a fifth spot, more rounded, with one or two dark brown spots immediately behind and often coalescing with it; over the back are six short, broad, dark brown bands, the first two on nape, the others under the dorsals; the spaces between the crossbars more or less sprinkled with irregular short brown lines and spots; a black spot or diagonal bar on opercle; some irregular dark marks on sides of head; the first dorsal dusky brown with a clear band near base; the second dorsal transversely barred by three or four rows of brown spots; the caudal crossbarred by five or more rows of brown spots, those near base much larger and darker; the anal faint brown; the pectoral 
clear, with a large, dark brown spot on upper part of its base; the ventrals blackish, the margins paler.

Here described from six specimens, 25 to 35 millimeters in length, collected by me at Bungau, Sulu Province. This handsome little fish is close to $R$. criniger, but presents marked differences.

Suluensis, from Sulu.

90. RHINOGOBIUS NEOPHYTUS (Günther)

Plate 14, Fig. 4

Gobius neophytus GüNTHER, Fische der Südsee 2 (1875) 174, pl. 108, fig. E.

Rhinogobius neophytus JoRdAN and SeALE, Bull. Bur. Fisheries 25 (1906) 400, pl. 37, fig. 2.

Dorsal. VI, I-9; anal I, 8 ; there are 23 or 24 scales in a lateral series and 7 in a transverse series.

The body slender, elongate, narrowed dorsally, the ventral line but little curved, the back arched, the depth 4.85 in length; the head elongate, the upper profile convex, with long and pointed snout, imparting a very characteristic appearance, 3.2 times in length; the snout 3 times in head; the eyes very high up, dorsolateral, large, protuberant, the upper margin extending above the profile, equal to snout, very close together so that the interorbital space is linear; the mouth oblique, with broad upper lip and projecting lower jaw, the posterior angle of maxillary barely extending back to a point beneath front margin of eye; there is a band of four rows of very small, slender, pointed teeth in each jaw, the outer row larger than the others; the head entirely naked, as is the nape back to first dorsal; the rest of the body, including pectoral bases and breast, covered with large ctenoid scales loosely attached and easily lost; the dorsals well separated, the first spine of first dorsal longest, equal to depth; the second dorsal and anal of the same shape and height, next to the last ray longest and equal to 0.9 of the depth, falling much short of caudal when depresed; the caudal peduncle long, slender, its depth 2.25 times in its own length; the bluntly rounded caudal a trifle shorter than head; the large pointed pectoral equals caudal in length and extends to a point over origin of third anal ray; the ventrals 0.8 as long as head, their tip touching origin of anal.

The color in alcohol whitish, with numerous scattered dusky spots more or less definitely arranged in rows over head and body, a median longitudinal row of larger spots, ending at base 
of caudal in a conspicuous elliptical spot; there is a black spot at top of membrane between first and second dorsal spines, the rest of the fin specked with black; the second dorsal and caudal crossbarred by several rows of faint blackish spots; the other fins colorless.

Here described from a specimen, 34 millimeters long, collected at Canigaran, near Puerto Princesa, Palawan, by R. C. McGregor.

In life this delicate little fish is translucent, with spots of dark orange and pure black. Our specimen is almost an exact duplicate of the one figured by Jordan and Seale.

I have since discovered three specimens of this species in the Bureau of Science collection. They were collected by Alvin Seale at Puerto Galera, Mindoro, in 1912, and are in very bad condition, the scales almost entirely gone. They are all of the same length, 40 millimeters.

This unique, easily recognized dwarf goby has been recorded previously from Ponape of the Caroline Islands, and from the Samoan and the Society Islands.

\section{Genus 37. PANDAKA g. nov.}

The minute gobies placed under this title are distinguished by their teeth and fins. There are two rows of very small, slender, pointed teeth in each jaw, or the upper jaw may have three rows, the outer row in upper jaw larger and more widely spaced, the inner row excessively minute; the two rows in lower jaw of approximately equal size; the first dorsal short, well in advance of second, the anterior rays highest; the second dorsal and anal are both short and lower than first dorsal. Dorsal VI, I-6 or 7; anal I, 5. The body covered with large, firm ctenoid scales, about 22 in longitudinal series, the head and nape naked back to origin of first dorsal; the caudal round pointed, shorter than head; the gill openings restricted, the isthmus broad, the branchiostegals 5. Generic type, $P$. pusilla sp. nov.

Pandaka, a kind of dwarf, in several Filipino languages.

Key to the species of Pandaka.

$a^{\mathbf{x}}$. First spine of dorsal elevated, in males much elongated, equal to or much greater than depth; body bulky, depth 3.6 to 4.1 in length which is 13 to 16.5 millimeters. P. pusilla.

$a^{2}$. First spine of dorsal not elevated, 1.25 times in depth; body much slenderer, depth 4 to 4.8 in length in females, 5 to 5.6 in males; length 7.5 to 11 millimeters.

P. pygmaea. 
91. PANDAKA PUSILLA sp. nov.

Plate 15, Figs. 1 ANd 2

Dorsal VI, I-6; anal I, 6; there are 22 to 24 scales in a longitudinal series and 7 or 8 in a transverse series.

The body stout, the sides of posterior half strongly compressed, the dorsal profile arched, the depth 3.6 to 4.1 in length; the large head 3.1 to 3.5 times in length, its breadth a little greater than its depth and about 0.75 of its own length; the convex, broad, rounded snout a fourth of head and shorter than eye, which is placed very high up on the side, its superior margin flush with or projecting above the profile, 3 to 3.3 times in head; the distance from tip of snout to posterior margin of eye equals or slightly exceeds the postorbital region of head; the broad, flat, interorbital space usually equals diameter of eye; the mouth strongly oblique, the lower jaw projecting, the posterior angle of maxillary extending beneath anterior third of eye; the teeth in upper jaw in three rows, an outer row of enlarged, slender, incurved teeth, the others minute; the lower jaw has two rows of teeth about equal in size, not so large as outer row in upper jaw; the body covered with firm ctenoid scales of nearly uniform size; the head, nape back to first dorsal, pectoral bases, and breast naked; the dorsals well separated, the first or first and second spines elongated; in males they are very long, often extending beyond axil of second dorsal when depressed, or 2.3 times in total length; in females the first spine of first dorsal is elevated but never reaches beyond base of first ray of second dorsal when depressed, or about 3.7 times in total length; the second dorsal and anal of approximately equal height and shape, the posterior rays not elongated and falling far short of caudal when depressed, the longest rays 5 to 6 times in length or about is the length of head; the caudal broad, bluntly rounded, 0.7 as long as head; the pectoral broad, rounded, 0.7 to 0.8 as long as head; the ventrals elongate, pointed, extending to anal papilla, which in males is long, tapering, pointed, and in females short, thick, and rounded.

The color in alcohol nearly uniform yellowish brown, with small, blackish brown dots sprinkled over entire body; careful inspection from above shows them to be arranged in four bread transverse bars over back; a large red-brown quadrangular spot between and behind eyes; a large black spot at base of caudal; a smaller black spot on base of anal and two others on underside of caudal peduncle; in males there is a large black spot on basal 
part of membrane between fifth and sixth dorsal spines; there is a black spot on upper part of base of pectoral; the dorsals and anal faintly sprinkled with fine brown dots.

Here described from twenty-seven specimens, collected near the shore at Sitankai, by Alvin Seale; twenty-two are males, ranging in length from 13 to 16.5 millimeters, with an average length of 14.6 millimeters; five are gravid females ready to spawn, four of them $\mathbf{1 4 . 5}$ millimeters in length, the other one $\mathbf{1 5 . 5}$ millimeters. In both spawning males and females the belly is protuberant, broad and rounded, while a few males are slenderer than given in the description. Although not much longer than the sinarapan (Mistichthys luzonensis Smith) of Lake Buhi, this tiny marine goby is very much bulkier and, even when of the same length, is a much larger fish.

Pusillus, very little.

92. PANDAKA PYGMAEA sp. nov.

Plate 15, fig. 3

Dorsal VI, I-6 or 7; anal I, 5; there are 22 scales in a longitudinal series and 6 in a transverse series.

The body moderately elongate, robust, wedge-shaped when viewed from above, the males comparatively slender, the dorsal and ventral profiles nearly straight; the females much stouter, the dorsal profile little curved, the belly protuberant and the ventral outline strongly arched, the depth 4 to 4.8 in length, in males 5 to 5.6 ; the head large, blunt, the upper and lower profiles converging and pointed when viewed from the side, 3.25 to 3.36 times in length in females, 3 times in males; the head much broader than deep, the depth 0.6 of the breadth; the snout very short, broad, rounded, 6 to 6.6 times in head and 2 to 2.4 times in eye; the large, full eyes lateral, 2.5 to 3.2 times in head; the mouth very oblique, the lower jaw and chin projecting, the posterior angle of maxillary extending beneath anterior part of eye or to middle of pupil; there are two rows of teeth in each jaw, the outer one in upper jaw larger and more widely spaced, the inner row very minute, like the teeth of a microscopic saw; the first dorsal low, much in advance of second dorsal, not reaching second dorsal when depressed, the longest spine 1.25 times in depth, and 1.5 times in head; the second dorsal and anal are very low and extend not more than halfway to base of caudal, the longest rays 0.75 the height of first dorsal; the depth of caudal peduncle 2.2 of its own length and 2 to 2.5 times in depth; 
the caudal about 1.1 to 1.5 times in head; the pectoral pointed, 1.33 to 1.5 times in head and 4 to 5 times in length; the ventrals pointed, about as long as pectoral or longer; the anal papilla very short and rounded in females, longer and very slender in males.

The color in alcohol yellowish brown with a blackish brown spot at base of caudal and four similar but smaller spots on underside, the first under anterior part of anal fin, the second immediately behind it, the third midway of caudal peduncle, the fourth at base of caudal; the top of head back to first dorsal sprinkled with black dots, which also extend upon side of head; over back are five broad, dark brown crossbands, at the beginning and posterior part of both dorsals, and over caudal peduncle; a small spot present at upper side of base of caudal; base of pectoral also lightly spotted.

Here described from seventy-five specimens, 7.5 to 11 millimeters in length. Adult males are less than 9 millimeters long; adult females, with the belly distended with eggs, are from 10 to 11 millimeters long. The specimens were in a bottle with fishes collected in 1907 in Malabon, but whether they also came from there is uncertain.

This is unquestionably the smallest fish yet described, averaging 2.5 or 3 millimeters less in length than the famed sinarapan (Mistichthys luzonensis Smith) of Lake Buhi. I have examined all the minute fish thus far known from Polynesia and North America, and none is as tiny as this species.

Pygmaeus, dwarf.

\section{Genus 38. ZONOGOBIUS Bleeker}

Zonogobius BLEFK

The fishes of this genus are tiny gobies, plain or of uniquely variegated coloration, with the large head and nape back to first dorsal entirely naked; the body covered with firm ctenoid scales, 22 to 30 in longitudinal series; the mouth large, very oblique; the teeth slender, needle-pointed, in two or more rows in each jaw, the outer row in upper jaw enlarged; the other teeth minute; the dorsals separate, the spinous dorsal higher than second dorsal; the caudal obtuse or rounded, shorter than head; the pectoral has no silklike rays above.

Dorsal VI, I-8 to 10 ; anal I, 7 or 8 .

Bleeker was in error when he stated that each jaw has two rows of teeth. 


\section{ZONOGOBIUS SEMIDOLIATUS (Cuvier and Valeneiennes)}

Plate 30, Fig. 2

Gobius semidoliatus CUVIER and VALEnCIENnes, Hist. Nat. Poiss. 12 (1837) 51; GÜNTHER, Cat. Fishes Brit. Mus. 3 (1861) 31; Fische der Südsee 2 (1876-1881) 174, pl. 109, fig. H; DAY, Fishes of India (1878) 295, pl. 59, fig. 6; W FBER, Fische, Siboga Exp. (1913) 462.

Zonogobius semidoliatus JoRdaN and SEALE, Fishes of Samoa, Bull. Bur. Fisheries 25 (1906) 397, fig. 86; Proc. U. S. Nat. Mus. 28 (1905) 796.

Tatok-layam, name at Puerto Princesa, Palawan.

Dorsal VI, I-8 or 9 ; anal I, 7 or 8 ; there are 27 scales in a longitudinal series and 9 or 10 in a transverse series.

The body strongly compressed laterally, with thick heavy head equal to depth and 2.7 to 3 times in length; the short snout a little less than eye, 3.5 to 4 in head; the eyes high up, dorsolateral, 3 or a little less than 3 times in head; the interorbital space about 3 times in eye; the body covered with ctenoid scales, the head, nape, breast, and pectoral base naked; the large mouth very oblique, almost vertical, with strongly projecting lower jaw; the posterior angle of maxillary is beneath front margin of eye or may extend a little beyond it; the teeth in upper jaw in four rows, an outer row of enlarged teeth curved inward, and three rows of minute teeth, with a group of larger teeth in center behind middle of front row; in the lower jaw there is a band of three (four?) rows of very small teeth, followed by an inner row of enlarged erect needlelike teeth; the dorsals are separated, the second, third, and fourth spines of first dorsal elongated and threadlike, the longest spine 3 times in length, equal to or a little less than head (according to Günther's figure it may equal half the total length); the second dorsal and anal similar in shape, the posterior rays longest and reaching caudal when depressed, about $\frac{2}{8}$ depth; the caudal broadly rounded, shorter than head; the broad pectoral shorter than caudal; the long slender ventrals reach anal papilla.

The color of alcoholic specimens brown, with seven or more conspicuous, broad, pale crossbands edged with dark brown on anterior half of body; the fins all uniformly colored except first dorsal, which is crossbarred by rows of red spots.

A specimen, sketched from life by T. S. Espinosa, was dark wine red, with whitish crossbands on anterior half; the fins paler than body, and all, except ventral, crossbarred with many rows of red spots. 
The Bureau of Science collection contains one specimen from Puerto Princesa, Palawan, and one from Sitankai, 18 and 19 millimeters long, respectively.

Mr. Seale obtained this species from Samal Island, Davao Gulf, and it was recorded by Jordan and Seale from southern Negros; Weber obtained it also at Sanguisiapo, an island of the Tawitawi group, Sulu Province.

This uniquely marked and easily recognized goby is found on coral reefs from the Red Sea eastward throughout the East Indies, and southeast in the Pacific Ocean to the Samoan and Tonga Islands.

\section{Genus 39. CINGULOGOBIUS g. nov.}

This genus is very close to Zonogobius, from which it may be at once distinguished by the nape being scaled instead of naked.

The body covered with very finely ctenoid scales, which extend forward to eyes, their teeth visible only with a compound microscope; the scales on sides of nape reduced in size; a few small scales on upper part of opercle, the cheeks naked; fine scales on breast and base of pectoral; the mouth large, oblique, with three rows of teeth in upper jaw, two rows in lower, the outer row in each enlarged and widely spaced, but without canines; the tip of tongue free, subtruncate; the dorsals separate, the first dorsal lower than second; the caudal rounded, shorter than head; no free silklike rays on upper part of pectoral.

Dorsal VI, I-10 to 12; anal I, 9 to 11; gill openings wide, extended forward, isthmus narrow; branchiostegals 4. Generic type, Pleurogobius boulengeri Seale.

Cingulus, a girdle or belt.

94. CINGUlOgOBIUS BOULENGERI (Seale)

Plate 16, Fig. 1

Pleurogobius boulengeri Seale, Philip. Journ. Sci. § A 4 (1909) 536.

Dorsal VI, I-11; anal I, 10; there are 28 or 30 scales in a longitudinal series, 9 in a transverse series, and 8 before the first dorsal.

The body strongly compressed laterally, with large heavy head, the dorsal outline moderately convex, the ventral one slightly so, the depth 3.75 , the head 3 times in length; the head a little broader than deep, its width 1.35 times in its length; the snout convex, broad, gently rounded, shorter than eye, 4.5 times in head; the eyes very high up, oblique, dorsolateral and gazing up as well as sideways, very close together, 3 times in head; the 
interorbital space less than width of pupil; the mouth oblique at an angle of about $45^{\circ}$, the lower jaw projecting, the posterior angle of maxillary under front margin of eye; the outer row in upper jaw has enlarged, curved, widely spaced teeth, followed by two rows of very small teeth, the middle ones of inner row enlarged; the lower jaw has two rows, the outer one enlarged; the dorsal spines slender, the second one longest, 2.25 times in head, none reaching second dorsal when depressed; the second dorsal and anal longest posteriorly, not reaching caudal when depressed, higher than first dorsal, the longest dorsal ray 1.75 times in head, the anal a little lower, its longest ray 1.85 in head; the caudal peduncle depth 2.5 times in head; the rounded caudal 1.25 times in head; the pectorals round-pointed, a trifle shorter than head; the ventrals 1.1 in head, not reaching the short, thick, rounded anal papilla.

Color dark brown banded by 12 narrow white, dark-margined vertical bands which completely encircle the body and are of much less width than the interspaces; four of these bands are on the head, the first over the snout just in front of eyes and down to angle of mouth, the second from outer part of nuchal region down through eyes, the third and fourth from nuchal region down sides of head, the fifth from origin of dorsal over base of pectorals, the remainder at regular intervals on body, there being one around the middle of caudal peduncle and another at base of caudal; these last two indistinci. Vertical fins uniform dark grayish, pectorals and ventrals yellowish white. [Seale.]

The type and sole specimen is No. 5505 of the Bureau of Science collection, obtained by Alvin Seale at Puerto Princesa, Palawan. Its length is 35 millimeters. It is now badly damaged, most of the fins are broken, and the white bands much faded. It must have been very handsome in life.

So far as I am aware, no such genus as Pleurogobius has ever been published, and it is not recognized by Jordan in his work on the genera of fishes. In the Bureau of Science accession book the specimen was cataloged under the name of Pterogobius, but from that genus it is far removed.

\section{Genus 40. ABOMA Jordan and Starks}

Aboma Jordan and Starks, Proc. Calif. Acad. Sci. II 5 (1895) 497.

This genus is distinguished by the presence of seven or eight dorsal spines; the head is naked, rounded in profile, narrow, not depressed between the eyes; the mouth moderate, not very oblique, the chin not very prominent, the tip of tongue not notched, the outer teeth somewhat enlarged; dorsals and anal 
short, no fleshy flaps on shoulder girdle, and no silklike rays on pectoral.

Species rather numerous in Japan and several from the west coast of Mexico; all of them are small fishes of mottled coloration.

\section{ABOMA VIGANENSIS (Steindachner)}

Gobius viganensis STEINDACHER, Sitzungsber. Akad. Wiss. $102^{1}$ (1893) 230 .

Dorsal VII, I-9; anal I, 11; there are 28 to 29 scales in a longitudinal, 9 in a transverse series.

The compact body is strongly compressed, the dorsal profile of the head and back is arched like a bow, ascending to the origin of the first dorsal, moderately so in an example that is 67 millimeters long, very little in one of 48 millimeters, the depth 4 to $4 \frac{1}{3}$ times in the length; the sides of the head are plump, its length something more than 3.6 times in the total length; the breadth of the head is nearly $1 \frac{3}{3}$ times, its height about $1 \frac{1}{8}$ times in its own length; the snout is about 3.5 times, the rather small oval eyes about 4 times in the head; the interorbital is 0.5 the length of the eye; the mouth is diagonal, the maxillary reaching to a little before the middle of the eye, the length of the gape $\frac{1}{3}$ of the length of the head; there is a broad band of short, tender teeth in each jaw; in front of it in the lower jaw is a short row of widely spaced, much larger, crooked teeth of which the last are most strongly developed and with the points turned backward, as in Rhinogobius caninus; in the upper jaw along the outer margin of the dental band is a row of teeth a little stouter and longer, of which the anterior central ones are a little larger than the lateral ones, which reach back to the middle of the gape; the sides and top of the head are completely scaleless back to the posterior end of the very narrow interorbital; the scales on the nape back to the beginning of the first dorsal and laterally to upper margin of the opercle and base of the pectoral are about half as large as the scales on the caudal peduncle; the large posterior scales, and especially those below the base of the first dorsal back the length of the horizontally laid pectoral have their posterior margin mostly bluntly angular with a sharply distinct angular tip, the rest as a rule with the hind margin weakly arched; the second, third, and fourth spines of the first dorsal have their tips elongated, threadlike, the second longest, nearly equal to the head, the first 3 as long as the head, the last very short; with the exception of the first ray, the second dorsal is of nearly uniform height to the third from the end, which is about $1 \frac{2}{7}$ times, the first scarcely more than 3 times, the second contained more than 2.5 times in the head; the anal is of uniform height to the third from the end, which is about .6 the length of the head; the depth of the caudal peduncle is twice in the head and somewhat less than twice in the depth of the body; the rounded caudal is a little shorter than the head; the pectoral is about $1 \frac{2}{2}$ times in the head; the ventral is more than $1 \frac{1}{3}$ times in the head, not reaching the anus, and with a broad frenum.

The ground color of the body is yellowish brown; a small narrow indigo blue stripe along the hind margin of the opercle in the large example, in the smaller it is spread out in spots; the scales on the upper posterior half with small brown spots, forming tolerably regular longitudinal lines; 
four large, dark brown spots along the upper middle of the side of the posterior half of the trunk; three to four sharply defined indigo blue crosslines on the lower half of the body between the base of the pectoral and the anus; the posterior one of these lines lies very close before the first of the four large spots on the side of the trunk (in the larger example a large, deep brown spot with indistinct margin lies between the upper margin of the opercle and the center of the nape on the one side but is lacking on the other side, while the smaller example lacks it on both sides); the ventral is violet-gray, with a olear margin. [Steindachner.]

This species is known only from the two specimens described by Steindachner, found by him in the Vienna Museum and collected at Vigan, Ilocos Sur.

\section{Genus 41. APARRIUS Jordan and Richardson}

A parrius JoRdAN and Richardson, Bull. Bur. Fisheries 27 (1908) 278.

The teeth are minute, in two or three rows in each jaw, with or without small posterior canines in the lower jaw; the notched tongue short, adnate nearly to tip; the tail very long and pointed; dorsal VI, I-10 or 11, at least some of the spines with elongated, threadlike tips; the second dorsal short; anal I, 9 to 11 ; the cheeks and opercles naked; the pectorals without silklike rays above; scales in longitudinal series 26 to 42 .

According to the authors, the teeth are "very fine, in bands in both jaws." This genus is very close to Rhinogobius, differing in dentition, shape and length of caudal, and shape of tongue.

Key to the species of Aparrius.

$a^{1}$. Scales 26 to 29 ; no black longitudinal bands on side A. acutipinnis. $a^{2}$. Scales 38 to 42 ; two black longitudinal bands on side A. moloanus.

96. APARRIUS ACUTIPINNIS (Cuvier and Valenciennes)

Plate 16, Fig. 2

Gobius acutipennis Cuvier and VALenciennes, Hist. Nat. Poiss. 12 (1837) 60 .

Gobius acutipinnis GÜNTHER, Cat. Fishes Brit. Mus. 3 (1861) 44; DAY, Fishes of India (1878) 291, pl. 61, fig. 2.

Acentrogobius acutipinnis Smith and SeALe, Proc. Biol. Wash. 19 (1906) 81.

Aparrius acutipinnis JORDAN and RICHARDSON, Bull. Bur. Fisheries 27 (1908) 278.

(?) Rhinogobius ocyurus JoRDAN and RICHARDsoN, Bull. Bur. Fisheries 27 (1908) 42, fig. 14.

Dorsal VI, I-10 or 11 ; anal I, 10 or 11 ; there are usually 27 (26 to 29 ) scales in a lateral series and 7 or 8 in a transverse series. 
The body rather broad, much compressed from side to side; the ventral profile more arched than the dorsal, which is nearly horizontal, the depth $4 \frac{1}{8}$ to $4 \frac{2}{8}$ times in length; the head broad, deep, 3.25 to 3.5 times in length; the short blunt snout descends abruptly, its length 3 to $3 \frac{2}{8}$ times in head; the upper lip protractile; the mouth oblique, rather small, the lower jaw included; the posterior angle of maxillary sometimes barely reaches front margin of eye, but usually it extends to middle of eye or even to its posterior margin; in large males it is broad, the posterior angle very prominent, extending beyond eye; the teeth of upper jaw in two rows, the outer ones gently curved and slightly larger than those of inner row; the lower jaw has two or three rows of teeth, the third row is more or less imperfectly developed; the eyes high up, very close together, laterodorsal, their diameter 0.75 of snout or sometimes equal to its length; the interorbital space very narrow, its width $\frac{1}{3}$ or less that of eye; the entire head naked, with no scales forward of dorsal fin or on base of pectoral, except that the sides of nape may be partially scaled; the caudal peduncle contained about twice in greatest depth of body and 2.4 to 3 times in head; the tips of dorsal spines all elongated, those of first five often threadlike and longer than head, reaching to fourth or fifth ray of second dorsal or even upon caudal peduncle when depressed; the second dorsal rays high, the longest ones greater than depth and extending upon caudal when depressed; the anal is much lower and barely reaches or does not reach caudal when depressed; the caudal elongate, pointed, the central rays much the longest and easily broken, about 2.5 times in length when uninjured, twice in some young specimens; the pectoral a little longer than depth; the ventrals about the same length; both pectorals and ventrals may extend back as far as origin of anal; the anal papilla slender, pointed, almost threadlike.

The color in alcohol pale yellow, brownish yellow, or gray, with a series of about five dark brown blotches along midlateral line, the last and most conspicuous at base of caudal, and five obscure, double, transverse lines over back; a small, dark brown spot between each two lateral blotches; two to four transverse brown lines on predorsal region, or the nape marked by spots and vermiculations; a heavily pigmented blackish spot on top of eye; a conspicuous brown bar or black line passes from middle of lower rim of eye downward across preopercle to behind angle of mouth; it may be straight or become curved in large 
males with maxillaries produced backward; a dark spot or bar on base of pectoral; the first dorsal spine alternately clear and black-spotted; the membrane of first and second dorsal and anal dusky with minute dark specks; the caudal faintly barred with dusky bands; the ventrals blackish with paler or white margins.

In fresh specimens, the lines and vermiculations before the dorsal and the spots and marks on the dorsal part of the body were dark red; the eye spot or bar on the iris was of the same color; the band from the eye to the underside of the head was black; the dorsals were crossbarred by rows of brown spots; at least the upper half of the caudal was crossed by rows of small dark spots; the pectorals were golden; the anal was golden with a broad dusky margin.

Here described from a number of specimens, from 32 to 50 millimeters long. They are part of a lot of fifty-two specimens, ranging down to a length of 18 millimeters, collected by me from Abra River, Cauayan, Ilocos Sur Province. I have also examined the generic type at Stanford University, and the following specimens in the Bureau of Science collection:

Vigan, Ilocos Sur Province, 13.

Agno River, Dagupan, Pangasinan Province, 10.

Baliuag, Bulacan Province, 1.

Subic, Zambales Province, 1.

Lake Taal, Batangas Province, 56.

Pansipit River, Batangas Province, 1.
Bigaa and Arimbay Rivers, Albay Province, 35.

Libog River, Albay Province, 18.

Puerto Galera, Mindoro, 1.

San Jose, Antique Province, 5.

Capiz, Capiz Province, 13.

Molo, Iloilo Province, 9.

Villa, Iloilo Province, 1.

The largest specimens of this variable species are 66 millimeters long. I place here also a specimen, 52 millimeters long, collected by Alvin Seale at Caldera Bay, Mindanao, in 1908. It is in bad condition and differs from the others in having small circular black spots scattered thinly over the entire head, including the jaws, and the upper half of the body back to the tail; other color markings have entirely disappeared, with the exception of the conspicuous brown bar from the eye to the lower margin of the preopercle.

This species was listed by Jordan and Richardson from Aparri, at the northern end of Luzon, and by Smith and Seale from Cotabato, Mindanao. The Rhinogobius ocyurus of Jordan and Seale is probably this species.

This fish occurs from the coasts of India to the Philippines. 
97. APARRIUS MOLOANUS sp. nov.

Plate 16, Fig. 3

Dorsal VI, I-10 or 11; anal I, 9 or 10 ; there are 38 to 42 scales in a longitudinal series and 13 or 14 in a transverse series.

The body elongate, plump, laterally compressed, the depth in sexually mature males about 5 times in length, in ripe females 4.3 to 4.9 times; the head 4 to 4.3 in length; the very short, convex, blunt snout from $3 \frac{2}{8}$ to 4 times in head; the eyes high up, dorsolateral, their gaze almost as much upward as sideways, equal to snout; the interorbital space very narrow, 3 to 6 times in eye; the small mouth oblique, the jaws equal, the posterior angle of maxillary under anterior third of eye or anterior part of pupil; the minute teeth in two rows above and two or three in lower jaw, with a pair of small, outward-curving posterior canines in outer row; the tongue very slightly notched; the head entirely naked; the trunk covered with ctenoid scales, largest posteriorly, except on breast, pectoral bases, and nape, where they are very small and cycloid; the scales on nape do not extend forward beyond opercles, about fifteen or sixteen rows in front of first dorsal; a pore on the anterior and one on the posterior part of interorbital space, four in the supraopercular groove running from eye to pectoral base, and three on the posterior margin of preopercle; the dorsals well separated, their height in general the same and a little more than $\frac{2}{3}$ the depth of body; the second dorsal spine may have the tip elongated and threadlike in males, when it may be longer than the head and extend to third dorsal ray when depressed; the posterior ray of second dorsal longest, reaching base of caudal when depressed; the anal similar in shape, but with a shorter base, its height equal to or seven-eighths that of second dorsal, but its posterior rays never reaching caudal; the pectorals and ventrals pointed, of equal length or the ventrals a little shorter, equal to or a little shorter than head; the depth of caudal peduncle 0.6 of its own length and $1 \frac{5}{6}$ times in head; the caudal pointed, 2.7 to 2.8 times in length in males; in females it may be as long or shorter, to 3.3 times in length; the anal papilla small, slender, and pointed in males, stout, rounded, and short in females.

The color in alcohol pale whitish, with two black longitudinal bands on sides; the first begins behind eye and extends back to upper origin of caudal; the other and wider band begins in axil of pectoral and ends at middle of base of caudal; on it are six 
black spots, the last two very close together; from eye a black bar extends diagonally downward behind angle of maxillary; a black spot on opercle and a small one on upper margin of eye, usually back of center; the pupil white; the first dorsal has a dark band along its base, the first spine or all the spines alternately black and light spotted; there is a basal row of dark spots on membranes of second dorsal or there may be three such rows; the outer half of anal blackish; the pectoral has two black spots on base, or a longitudinal bar above and a spot below; the ventrals dusky, with whitish margin; the basal portion of càudal black-spotted, its tip black.

Here described from twelve adult specimens, 41 to 48 millimeters in length, collected at Molo, Iloilo Province, Panay, August 15, 1925. Four others were collected at Capiz, Panay, one immature, 32 millimeters long, the others about 45 millimeters long.

A specimen, 47 millimeters long, has just been received from Mr. F. Reveche, San Jose, Antique Province, Panay.

\section{Genus 42. WAITEA Jordan and Seale}

Waitea Jordan and Srawe, Fishes of Samoa, Bull. Bur. Fisheries 25 (1906) 407.

This genus is close to Gobionellus, according to its authors, but is separated therefrom by having the maxillaries produced backward to or almost to the lower posterior angle of the preopercle. The large head and nape are naked, with the entire region before the first dorsal naked or with a few very small scales on posterior part; the mouth very large, the tip of the tongue rounded; in the upper jaw an outer row of large teeth and two inner rows of very minute teeth; in the lower jaw a band of four rows of very small, slender, needlelike, depressible teeth, the inner and outer rows the largest; the pectoral without silken rays above. Dorsal VI, I-10; anal I, 9. There are 36 to 38 scales in a longitudinal series, and 16 in a transverse series.

One species, known from Java, Samoa, and the Philippines.

98. WAITEA MYStACINA (Cuvier and Valencienues)

Gobius mystacinus CUVIBR and VALFNCIBNNEs, Hist. Nat. Poiss. 12 (1837) 94; GüNther, Cat. Fishes Brit. Mus. 3 (1861) 48.

Waitea mystacina JoRdAN and SEALE, Bull. Bur. Fisheries 25 (1906) 407, fig. 94; JORDAN and RICHARDSON, Bull. Bur. Fisheries 27 (1908). 279.

Dorsal VI, I-10; anal I, 9; there are 36 or 38 scales in a longitudinal series and about 16 in a transverse series. 
The head and body laterally compressed, the dorsal profile nearly horizontal, the depth 4.6 to 4.7 times in length; the head very large, pointed when viewed laterally, 2.6 to 3 times in length, its depth equal to or a little greater than that of body; the snout convex, with a small median hump, 4.25 times in head; the eyes lateral, 3.5 to 4.25 in head, high up, the upper margin of eye flush with profile, the narrow interorbital 4 times in eye; the distance from tip of snout to posterior margin of eye less than postorbital length of head; the mouth very large, oblique, the upper jaw very slightly projecting, the upper lip protractile, the maxillary very long and produced backward across cheek to lower corner of preopercle, though angle of mouth is below pupil or posterior part of eye; the teeth as given under the genus; the body covered with moderately large ctenoid scales posteriorly, which become much smaller and less regularly disposed anteriorly; the dorsals separated, the anterior rays of first dorsal highest, equal to or slightly exceeding depth, extending to second or third ray of second dorsal when depressed; the second dorsal high, the sixth and seventh rays produced most and filamentous, 1.15 to 1.3 times in head and extending upon caudal more than $\frac{1}{8}$ of its length; the anal shorter and lower than second dorsal, the posterior rays elongated, equal to depth; the caudal peduncle narrow and short, its depth a little more than half the depth of body and about 1.28 times in its own length; the caudal moderately pointed, $1+$ to 1.3 times in head; the pectoral pointed, the central rays elongate, equal to or 1.2 times in head; the ventrals narrow, 1.35 to 1.7 times in head, extending to anus; the anal papilla minute, very thin in the male; in the female it is very short, thick, and rounded.

The color in alcohol yellowish gray, with broad dark crossbars, three showing distinctly on posterior half and running diagonally forward and downward; there are large circular spots on the naked nape and extending back on each side below first dorsal; the sides of head and pectoral bases sprinkled thickly with oval or circular spots, largest on cheeks and very small cn pectorals; all these spots dark greenish olive; those on sides of head are ocellated and were probably blue or pearl in life, with a dark margin; small circular olive dots on sides beneath pectoral; the fins in our specimens are all black or violet-black.

Here described from a male and a female specimen, 45 and 46 millimeters long, respectively, collected at Iloilo, Panay.

$223798-14$ 
This species was previously reported from Aparri, Luzon, by Jordan and Richardson. It was obtained in Samoa by David Starr Jordan, and was originally collected in Java by Kuhl and Van Hasselt, whose specimen was described by Cuvier and Valenciennes.

My specimens are unmistakably the same fish as that shown in Jordan and Seale's figure 94, but the upper lip in their figure has been extended so that the snout is unnaturally long; the dorsal fins are unlike those of our specimens in shape, and the caudal in their figure is greatly elongated and lanceolate. This is probably correct for some specimens, since Weber gives the shape as lanceolate. No author mentions the spots on head and sides, but they are shown, though poorly, in the figure of the Samoan example.

\section{Genus 43. CHONOPHORUS Poey}

Chonophorus Poex, Poíssons de Cuba 2 (1860) 274 (replaces Awaous, issued a few days later).

Awaous Stmindachner, Sitzungsber. Akad. Wiss. Wien 42 (1860) 289; Blabker, Esq. Syst. Nat. Gobioides, Arch. Neerl. Sci. Nat. 9 (1874) 320.

This group is separated from its congeners by the presence of two or more small fleshy flaps, or papillæ, on the inner margin of the shoulder girdle, and by the peculiar physiognomy of some species.

The robust body elongate, strongly compressed laterally, and covered with 40 to 80 ctenoid scales in longitudinal series, 50 to 60 in Philippine species; they become cycloid and smaller on the nape, extending forward to eyes, from which they are separated by a mucus channel; the upper part of opercles, the posterior part of preopercles, and the base of pectorals covered with small cycloid scales; the head is large, with a long, convex snout, a thick, protractile upper lip, a rather small oblique mouth, and is naked except as above stated; three or more rows of sharp pointed subequal teeth form a band in each jaw, without canines, those of outer row erect and not longer than the others in most species, though in some foreign representatives of the genus the outer row may be enlarged; the tongue broad, thick, mostly adnate, with convex or subtruncate tip; the gill openings wide but not extended forward, restricted below, the isthmus wide, with three fleshy flaps (in our species) on inner edge of shoulder girdle; the dorsals well separated, the tips of first dorsal often greatly elongated and threadlike; the second dorsal and anal similar in shape, the posterior rays more or less 
elongated; the pectorals large, without silky rays above; the ventrals are very well developed, long, broad, and pointed, and form an exceedingly powerful adhesive organ; the caudal broad, truncate to pointed, and may be shorter or much longer than head. Dorsal VI, I-10 to 12 ; anal I, 10 or 11 ; branchiostegals 5 .

A genus of medium-sized to large gobies, abundant in rocky, gravelly, tropical rivers, of wide distribution in the Indo-Pacific and tropical Atlantic regions. One of the species is a very important ipon goby in northern Luzon, and the adult is one of the chief food fishes in the valley of Cagayan River.

\section{Key to the Philippine species of Chonophorus.}

$a^{1}$. Sides with eight to twelve dark brown or blackish crossbars; no lines from eye to margin of snout.

$b^{1}$. Ten or twelve narrow crossbars; a small, vertical, dark brown streak on each scale on upper half of body; a broad dark bar from eye diagonally behind maxillary

C. genivittatus.

$b^{2}$. Eight or ten broad, crescentic crossbars; scales on upper half with irregular dark spots; a large black spot beneath eye.

C. lachrymosus.

$a^{2}$. Sides without eight to twelve crossbars; two lines from eye to margin of snout.

$c^{1}$. First dorsal lightly barred; no ocellus

C. melanocephalus.

$c^{2}$. First dorsal spotted with dark brown; a large, black, white-margined ocellus on posterior half.

C. ocellaris.

99. CHONOPHORUS GENIVITTATUS (Cuvier and Valenciennes)

Plate 16, Fig. 4

Gobius genivittatus Cuvier and Valenciennes, Hist. Nat. Poiss. 12 (1837) 48; GüNTHER, Cat. Fishes Brit. Mus. 3 (1861) 13; Fische der Südsee 2 (1876) 170, pl. 110, fig. C.

A waous genivittatus Fowler, Proc. Acad. Nat. Sci. Phila. (1900) 517; Jordan and EvermanN, Bull. U. S. Fish Comm. 23 (1903) 492 (fig. 218, after Günther).

Dorsal VI, I-10 or 11 ; anal I, 10 or 11 ; there are 50 to 52 scales in a longitudinal series, 14 in a transverse series, and 16 to 18 before the first dorsal.

The body elongate and laterally compressed, the large blunt head much wider than trunk; the greatest depth varies from 3.5 to $4 \frac{2}{8}$ times, the head 3.5 times in length; the snout wide, blunt, and very convex in profile, its length 3 times in that of head; the rather small eyes high up, lateral, their length 4 times in head and 0.75 that of snout; the distance from tip of snout to rear margin of eye equals postorbital length of head; the interorbital space narrow, its breadth 0.5 to $\frac{5}{6}$ that of eye; the subterminal, thick-lipped oblique mouth rather small, with very protractile upper lip; the maxillary may not reach eye or may 
extend beneath its anterior margin; there is a large pore behind eye at origin of supraopercular groove; the scales on nape much smaller than those on sides; the cheeks and opercles swollen, smooth, and scaleless except for a few tiny scales at upper inner angle of opercle; the first dorsal spines have filiform tips which may be much elongated and equal to greatest depth of body; the second dorsal and anal similar in outline, the posterior rays longest, equal to or greater than the depth beneath and extending to caudal, which is elongate, moderately pointed, 2.5 to 2.8 times in length; the ventrals large with a very broad frenum, and equal in length to the wide, rounded pectoral.

The color in alcohol varies from pale greenish or nearly white to pale or yellow-brown, with ten to twelve narrow dark brown or blackish crossbars on each side and a small vertical dark brown streak on each scale on upper half of body; a broad, dark brown bar extends from eye to lower edge of preopercle; a short dark bar on upper part of base of pectoral; the dorsals marked with irregular dark crosslines.

I have examined seventy-one specimens, ranging in length from 32 to 84 millimeters, from the following localities:

Limbones Cove, Batangas Province, Luzon, 1.

Bigaa and Arimbay Rivers, Albay Province, 38 .

Sibuyan Island, 1.

San Jose, Antique Province, Panay, 17.
Dumarao, Capiz Province, Panay, 1.

Lasay, Siquijor Island, 10.

Cagayan, Misamis Province, Mindanao, 2.

Balabac Island, 1.

I also place here four specimens, about 34 millimeters each in length, from Lasay, Siquijor, all in bad condition.

This handsome species occurs in the fresh-water streams of the Society, Samoan, and Fiji Islands of the South Sea and is common in the Hawaiian Islands.

A female specimen, 45 millimeters long, taken in February at San Jose, Antique Province, Panay, was ready to spawn.

100. CHONOPHORUS LACHRYMOSUS (Peters)

Frontispiece

Gobius lachrymosus PETERs, Monatsber. Akad. Wiss. Berlin (1868) 265; MEYER, Ann., Soc. España Hist. Nat. 14 (1885) 29.

Local names, biang tulis, and biang pakiu.

Dorsal VI, I-10; anal I, 10; there are from 52 to 55 scales in a longitudinal series, and 12 or 13 in a transverse series; 18 or 20 scales before first dorsal. 
The elongate body strongly compressed on sides, even in spawning females, the posterior half of body especially flattened laterally; the dorsal profile moderately arched, the ventral profile nearly horizontal; the depth from 4 to 4.4 times in length in males, 3.7 to 3.8 times in females; the broad short head wider than trunk, with boldly convex snout, and contained 4 to 4.2 times in length; the snout rounded, the anterior part nearly or quite vertical, 2.8 to 3.25 times in head; the eyes high up, dorsolateral, 5 to 5.8 times in head, 1.6 to 1.8 times in snout, and 1.16 to 1.6 times in the full interorbital, which is ordinarily arched and 3.6 to 4.2 times in head; the mouth rather small, slightly oblique, the jaws equal, the lower jaw rather thin and weak, the upper lip protractile; the posterior angle of maxillary may extend from as far as beneath front margin to center of eye, or even a little beyond; four or five rows of minute to small, more or less hooked teeth in each jaw, the outer row more or less enlarged in males; a large pore behind middle of eye at origin of supraopercular groove and one near middle of posterior margin of preopercle; the scales before first dorsal become smaller anteriorly; the sides of head, snout, and interorbital naked, except for a few small cycloid scales present on upper part of opercle, and a few small scales on posterior part of preopercle; the tips of first dorsal spines threadlike and more or less elongated, in females never equal to depth and usually their length not more than 0.8 of depth; in males the tips of third, fourth, and fifth spines may be very much elongated, up to $1 \frac{2}{8}$ times depth; the second dorsal elevated, the posterior rays longest and forming an acute angle which extends upon caudal when depressed, the longest rays 0.8 to 0.86 as long as first dorsal in males and equal to or longer than first dorsal in females; the anal resembles second dorsal, which it almost or sometimes equals in height; the pectoral of moderate breadth, rounded in males, more pointed in females, equal to or a little more or less than head in length; the ventrals broad, with a wide frenum forming a large deep vacuum cup for adhesion, about equal to pectorals in females but falling far short of reaching anus; the ventrals perceptibly longer in males, extending to anus or beyond; the caudal peduncle very much flattened laterally, rather narrow to moderately wide, its depth varying from less than 0.5 to 0.75 the length of head, and 1.25 to 1.6 in its own length; the large caudal round pointed, its length about twice that of head in males and approximately 1.3 to 1.4 times head 
in females; the anal papilla elongate, slender, and pointed in males; the female anal papilla short, thick, and more or less cylindrical.

The color in alcohol brownish to yellowish brown above, fading to whitish or whitish yellow on belly; on the sides, beginning immediately behind head, are eight or ten broad curved dark brown bands, their concave side forward; the scales on nape and upper part of body more or less irregularly flecked with small, dark brown spots; beneath eye is a large, irregular, blackish brown spot extending downward toward corner of mouth; on upper part of pectoral base a perpendicular blackish brown or blackish violet bar; on males the first dorsal has two black and two or three white crossbands boldly alternating on basal half; the first two spines spotted alternately to their tips with yellow and blackish or violet, and the remainder of the fin boldly spotted and banded with the same contrasting colors; the females have the same pattern but the colors are paler; the second dorsal has many narrow, longitudinal bands of black and white alternating on basal half in males, on the whole fin in females; the membrane in males reddish violet; the first spine spotted alternately with black and yellow; the anal of males is a beautiful cerise, with dusky blue along margin of rays; the females have the anal bluish with whitish rays and a white margin; the upper part of caudal more or less spotted with light and dark; the marginal membranes reddish violet, the central ones blue; the pectorals yellowish to colorless; the ventrals dark dull blue to colorless. This must be a very handsome and strikingly colored goby in life.

Here described from eleven males, 100 to 130 millimeters in length, and 20 females, 96 to 121 millimeters long, from Quingoa River, Calumpit, Bulacan Province, Luzon, the type locality. The only specimens previously known were collected there by Jagor in 1859, and from Manila Bay by A. B. Meyer in 1872 .

This species evidently spawns in the latter half of September. Our specimens are either nearly ready to spawn or have just spawned. They were taken in a baclad, or fish corral, near Calumpit, and were said by the people to have come down from Angat River. From statements made by people at Norzagaray it is evident that this fish lives in the upper Angat, a swift mountain river with rock-strewn channel, and descends to tidewater near Calumpit to spawn. Calumpit is in the delta of 
Pampanga River, where the tides of Manila Bay make its lower reaches salt, or at least brackish.

Chonophorus lachrymosus is related to C. genivittatus, but is well separated from that species. It is to be expected in other mountain streams flowing into the northern part of Manila Bay.

In the Bureau of Science collection is a specimen, 85 millimeters long, labeled Talacogon, Agusan Province, Mindanao, 1907, which I place here. Although it varies in some particulars from the Quingoa River specimens and has lost all trace of the characteristic crossbands, it is beyond doubt Chonophorus lachrymosus (Peters).

The body elongated, oblong, much flattened laterally, the dorsal profile nearly horizontal, the belly gently curved; the depth 5 times, the head 3.7 times in length; the snout wide, convex, blunt, 3.28 times in head; the teeth in upper jaw sharp, slender, widely spaced, in three rows; in lower jaw in two closely crowded rows; the eyes high up, lateral, their diameter $\frac{6}{7}$ of the length of snout and 3.82 times in head; the interorbital space $\frac{2}{3}$ as wide as eye; there are broad muciferous channels above and behind eye and crossing over behind interorbital, a large mucus pore behind eye, two pores behind preopercular margin, and two above opercle; all the dorsal spines elongated and threadlike, the third the longest, $\frac{1}{8}$ of total length and reaching to base of sixth dorsal ray when depressed; the second dorsal and anal of similar shape, both longest posteriorly; the last ray of second dorsal equal to head in length, the last ray of anal more than greatest depth of body; the pectoral is injured but was evidently equal to head in length; the ventrals extend to anus and are a little longer than head; the broad, flat, caudal peduncle contained 2.3 times in head and 1.4 times in its own length; the caudal is damaged but was evidently slightly longer than head; the long, slender, pointed anal papilla is equal to the interorbital.

The color after nearly twenty years in alcohol uniform yellowish, darker above and paler below, with a broad triangular reddish brown spot extending from base of eye downward across cheek; a reddish violet spot on upper part of pectoral base; the first dorsal marked by a broad, transverse, basal band of violet-black, above which is a white crossbar and another violet-black band; higher up are four other alternate white and violet-brown spots; the second dorsal has a basal transverse 
band of violet-black on the membranes; above this the membranes are specked with minute reddish violet dots, the rays all colorless; the anal, caudal, and ventral membranes also faintly dotted with similar minute specks.

101. CHONOPHORUS MELANOCEPHALUS (Bleeker)

Plate 17, Fig. 1

Gobius melanocephalus BLEеквR, Verh. Bat. Gen. 22 (1849) 33.

Gobius personatus BleEkm, Verh. Bat. Gen. 22 (1849) 34; Nat.

Tijd. Ned. Ind. 1 (1851) fig. 4.

Gobius grammepomus BLझЕкER, Verh. Bat. Gen. 22 (1849) 34; GüNTHER, Cat. Fishes Brit. Mus. 3 (1861) 64; Boulenger, Ann. \& Mag. Nat. Hist. VI 15 (1895) 185.

Awaous personatus BLBEKER, Contrib. faune Ichthy. 1'île Maurice, Verh. Akad. Amsterdam 18 (1879) 17.

Gobius litturatus Heckel MS., STEINDACHNBR, Sitzungsber. Akad. Wiss. Wien 42 (1861) 289, pl. 1, figs. 4 and 5.

Local names.-Bukto in Ilocano; bunog and totot in Abra Province; biang bato (rock goby) in Tagalog; batog in Bicol.

Dorsal VI, I-9 or 10; anal I, 10; there are from 50 to 56 scales in a longitudinal series, 14 to 16 in a transverse series, and 14 to 20 in front of the first dorsal.

The plump, wedge-shaped body laterally compressed, with a large, very broad head, wider than body; the greatest depth at nape above gill opening and 4.6 to 5.7 times in length; the head from 2.9 to 3.8 in length; the snout long, strongly convex, 2.3 to 3 times in head and equal to or but little shorter than postorbital length of head; the eye rather small, 5 to 6 times in head, 2.5 to 3 times in snout; the interorbital space equals or nearly equals eye ; the mouth slightly oblique with a very large, thick, overhanging upper lip and rather weak lower jaw; the physiognomy of snout and mouth very characteristic; the maxillary usually does not extend to eye, but may reach beyond its anterior margin; the scales on nape extend nearly to eyes and are smaller than those on sides; the rest of the head naked except for a few scales on upper part of opercle; a large pore above each eye and a larger one in the central area behind eyes; the tips of the spines of first dorsal very little elongated, occasionally (in old males?) equal to depth of body; the second dorsal and anal of similar outline, the anal lower than second dorsal, and both lower than body, their posterior rays longest but not reaching caudal in any of my specimens: the caudal broad, nearly truncate with rounded angles, its length about 0.75 that of head; the ventrals are broad, with a 
strong frenum, and form a very powerful adhesive organ; the pectorals broad, their length equal to or greater than that of caudal but not quite that of head.

The color of living specimens from Saltan River was dusky greenish with about eight broad, blackish crossbars over back, the first between the opercles, the second over the pectorals in front of first dorsal, two under first dorsal, three under second dorsal, and one just before caudal; a series of irregular dark blotches along middle of each side; the head was irregularly marbled with spots and lines; two lines extended forward and downward from eye to margin of snout; there was a blackish spot at upper posterior angle of opercle and a dark blotch on upper part of base of pectoral; the first dorsal lightly barred and second dorsal and caudal strongly crossbarred by many rows of dark spots.

Alcoholic specimens fade to yellowish brown, with the markings as already described; the snout may become blackish and many of the markings may fade, but the lateral blotches, especially the posterior ones, the pectoral and opercular blotches, and the two lines on the snout, are always more or less evident.

Chonophorus melanocephalus presents considerable variation in color, specimens from wide shallow streams being much paler than those living under rocks in mountain torrents. It is an important food fish in Cagayan Valley, and is also one of the chief ipon gobies of northern Luzon, ascending Cagayan River in February and March. The flesh of the adults is sweet and savory. Its horizontal ventral profile, broad fins, and powerful sucking disk adapt it for life in the swiftest rivers, where it clings to the bottom under the shelter of bowlders. Its peculiar mouth is also an adaptation for life as a bottom dweller as it nuzzles around for food under the rocks.

In addition to large numbers examined in the field, I have studied alcoholic specimens, ranging in length from 20 to 135 millimeters, from the following localities:

Laoag River, Bacarra, Ilocos Norte Province, 8.

Barrio La Paz, Laoag, Ilocos Norte Province, 33.

Laoag River, Laoag, Ilocos Norte Province, 13.

Laoag River, Ilocos Norte Province, 22.

Abra River, 5.
Bangued, Abra Province, 15.

Kalaba, Abra Province, 3.

Bauang Sur, La Union Province, 11.

Buguey, Cagayan Province, 11. Tuguegarao, Cagayan Province, 3.

Lamug, Pinacanawan River, Cagayan Province, 9. 
Karoan, Cagayan Province, 4. Nayon, Ifugao Subprovince, 1.

Chico River, Calbayan, Kalinga Subprovince, 8.

Saltan River, Limos, Kalinga Subprovince, 3.

Kabulig River, Casiguran, Tayabas Province, 1.

Pansipit River, Batangas Province, 2.

Bigaa River, Legaspi, Albay Province, 81.
Arimbay River, Legaspi, Albay Province, 24.

Libog River, Albay Province, 7. Mangso River, Albay Province, 13.

Yawa River, Albay Province, 1. Baco, Mindoro, 9.

San Jose, Antique Province, $\mathrm{Pa}$ nay, 6.

Amoy, China, 10.

This species was described by Heckel from Philippine material and was listed by Boulenger from fresh water in Palawan.

Originally the species was described from Java under three separate names by Bleeker but he afterward united them under the name Gobius grammepomus. It has been found from the Andamans, Ceylon, and Madras eastward to Celebes, Buru, and Amboina, usually occurring in rivers. All my Philippine specimens are from swift gravelly streams.

Chonophorus melanocephalus is very close to $C$. ocellaris, but there is no difficulty in separating them and they are apparently both valid species, although the first named presents a wide range of variation.

102. CHONOPHORUS OCELLARIS (Broussonet)

Plate 17, Fig. 2

Gobius ocellaris Broussonet, Cop. Encycl. Meth., Dec. Ichthy. (1782)

fig. 142; Cuvibr and Valmancignnes, Hist. Nat. Poiss. 12 (1837)

74; GüNTher, Cat. Fishes Brit. Muș. 3 (1861) 64 ; Fische der Südsee

2 (1876) 177, pl. 108, fig. C.

Awaous ocellaris BlEEKER, Esq. Syst. Nat. Gobioides, Arch. Neerl.

Sci. Nat. 9 (1874) 320; Jordan and Seale, Fishes of Samoa, Bull.

Bur. Fisheries 25 (1906) 405; JoRdAN and Richardson, Bull. Bur.

Fisheries 27 (1908) 277.

Dorsal VI, I-10; anal I, 10; scales in a lateral series 55 , in a transverse series 15 ; there are from 16 to 20 scales before the first dorsal.

The wedge-shaped body plump and rounded, its width equal to its depth, which is 4.2 to 4.4 in length; the head large, 3 to 3.3 times in length, with a rather long, convex, abruptly descending snout which is from 2.3 to 2.5 times, in head; the snout equals or is a trifle shorter than postorbital length of head; the rather small eyes contained from 4.8 to $5 \frac{1}{6}$ times in head and 2 to $2 \frac{1}{3}$ times in snout; the interorbital space equal to or a little less than an eye diameter; the upper jaw projects beyond 
lower; the mouth rather small, slightly oblique, with thick upper lip; the maxillary does not extend back to eye; the roof of mouth covered with conspicuous pendant papillæ; the scales on nape extend forward nearly to eyes and are but little smaller than those on sides; the rest of the head naked except for a few scales along upper margin of opercle; the tips of first dorsal spines elongate and filiform, equal to depth of body; the second dorsal and anal similar in outline, both lower than body, exceptionally the posterior rays elongated sufficiently to reach caudal, which is slightly rounded and shorter than head; the ventrals large, with a broad disk.

The color of alcoholic specimens varies from pale to dark yellow-brown, with numerous short, irregular, dark brown marks and blotches on upper half, which may form a series of crossbars over back; a row of large, dark brown or black rounded spots extends along middle of each side, the last one at base of caudal darker and more distinct than the rest; the sides of head irregularly marked with dark brown lines or bands and spots, two of the bands extending forward and downward from eye to lip; there is a dark blotch or black bar on base of pectoral; the first dorsal is spotted with dark brown and has a large, black, white-margined ocellus on its posterior half; the second dorsal and caudal crossbarred by four or more rows of dark brown spots.

Here described from twenty-two specimens, ranging in length from 31 to 111 millimeters, from the following localities: Pansipit River, Batangas Province; Chicago, Baco River, Mindoro; Naujan River, Mindoro; Sibuyan Island; San Jose, Antique Province, Panay; Lasay, Siquijor; Cabalian, Leyte.

I have also twenty-five specimens, 19 to 26 millimeters in length, from Bangar, La Union Province, where they were being caught in large quantities in November as ipon, and used for making bagoong.

This species has been previously recorded from Mindoro by Jordan and Richardson. My specimens agree in all respects with Günther's description and figure except that they do not have the cheeks or opercles scaled. Evidently this is a variable character, as Jordan's Samoan specimens had only the upper part scaled.

This well-marked and easily recognized species was first described from Otaheite, and is known from the Samoan, Society, and Fiji Islands; it also occurs on Mauritius and Rodriguez Islands in the Indian Ocean. 
Genus 44. TAMANKA g. nov.

This genus is close to Vaimosa Jordan and Seale, from which it is separated by the much smaller and more numerous scales (38 to 54 in a longitudinal series), and by having many small cycloid scales on the opercles instead of a few large ctenoid ones; the rest of the head is naked; the nape is covered with very small scales forward, at least to a point above front margin of opercles ; the breast and pectoral base also scaled.

The body thick and robust or laterally compressed and slender, with a large, broad head flattened on top; the dorsals separated, the dorsals and anal much lower than depth, the caudal broad, rounded, shorter than head, with numerous, short, accessory spines extending well up on caudal peduncle above and below; the mouth large, oblique, not inferior, with thick lips minutely fringed within; four or five rows of very small teeth in lower jaw and a band of three or four rows of similar teeth in upper jaw, with an outer row of larger, more widely spaced teeth; no canines present; the gill openings wide, with a rather broad isthmus; the upper rays of pectoral not free and silky. Dorsal VI, I-7 or 8 ; anal I, 7 or 8 ; branchiostegals 5 .

Type of the genus, Tamanka siitensis sp. nov.

Tamanka is the Tao Sug name for small gobies of the Gnatholepis and Rhinogobius groups.

$\boldsymbol{a}^{1}$. Scales 52 to $\mathbf{5 4}$.

Key to the species of Tamanka.

$b^{1}$. Body robust, uniform brown to black; scales before first dorsal 20 to 24 . T. siitensis.

$b^{2}$. Body slender, brownish yellow, with ten vertical crossbars; scales ${ }^{\prime}$ before first dorsal 25 to 30 .

T. tagala. $a^{2}$. Scáles 38 to $\mathbf{4 5}$.

$c^{1}$. Color uniform dark brown, without bands or stripes T. umbra.

$c^{2}$. Uniform brown, with two longitudinal dark brown bands T. bivittata.

103. TAMANKA SIITENSIS sp. nov.

\section{Plate 17, Fig. 3}

Dorsal VI, I-8; anal I, 8; there are 52 to 54 scales in a longitudinal series, 18 in a transverse series, and 20 to 24 before the first dorsal.

The body thickset, robust, with a very large, broad, blunt, dorsally flattened head, laterally compressed, the middle of the back more or less arched, the ventral profile nearly straight but the belly often protuberant, the depth 3.25 to 4 times in length; the length of head contained 2.44 to 2.6 times in entire length; the width of head accentuated by the full, rounded cheeks, 1.35 
to 1.6 times in its own length and 1.2 times its own depth; the length of the very broad, rounded snout 3.25 to 3.85 times in head; the eyes high up, lateral, shorter than snout, in which they are contained 1.2 to 1.6 times and 4.3 to 5 times in head; the broad flat interorbital a little wider than length of snout; the mouth large, oblique, the thick protractile upper lip slightly projecting, the chin full and somewhat prominent, the posterior angle of maxillary beneath middle or posterior part of eye, the mouth opened with difficulty in preserved specimens; the teeth in outer row of upper jaw very small but a little coarser and more widely spaced than the others, closely followed by a wide band of three or four rows of minute teeth; in lower jaw a wide band of five rows of tiny teeth anteriorly, gradually reduced to three or two posteriorly, none of them enlarged; the body everywhere covered with small scales, apparently cycloid because of the dense coat of thick mucus covering the whole body but really ctenoid except on nape, those before first dorsal a little smaller and extending forward as far as above front margin of opercles, or centrally a little more; the scales on opercles in seven or eight rows, the scales about as large as those before first dorsal; minute scales extend upon caudal a short distance; three lines of minute papillæ extend from upper jaw horizontally across cheek and a double line runs along lower and posterior margin of preopercle; a transverse line lies immediately behind preopercle on opercle; the dorsals distinctly separated, the vertical fins all low, the middle spines of first dorsal longest, 2 to 2.3 times in body depth; the second dorsal and anal of similar shape, all but the anterior rays of nearly uniform height, more or less angulate posteriorly, the second dorsal 1.5 to 1.8 in depth; the anal usually a little higher, 1.5 to 1.75 in depth; the depth of caudal peduncle 2.8 to 3 times in head and 1.2 to 1.37 times in its own length; the caudal fin very broadly rounded, its width equal to its length, which is usually equal to the depth or a trifle more or less, 1.4 to 1.5 times in head; the length of the broadly rounded pectoral equals that of caudal and extends back to a point above anus, or may reach to origin of anal fin; the ventrals very broad, with a thick fleshy frenum forming a very deep suction cup, their length 1.8 to 2 times in head, not extending to anus; the anal papilla in males thick, triangular, pointed, $\frac{2}{8}$ as long as eye; in females it is thicker, much shorter, not pointed.

The color of very large males black to umber; younger ones deep brown; the fins black, with a series of white spots forming a crossband near margin of first dorsal, and a white crossband 
near margin of second dorsal; sometimes the ventrals have a narrow pale or whitish margin along sides.

Here described from a series of males, 45 to 65 millimeters in length; the type is No. 11452 Bureau of Science collection. I have examined a series of one hundred thirty-six specimens, from 19 to 65 millimeters in length, collected by me in June, 1921, from Lake Siit, a small, deep, fresh-water crater lake beside the sea on the north coast of Jolo Island. A female specimen, 29 millimeters long, was much distended with eggs and about ready to spawn. In small specimens the crossband on the dorsals may be colorless instead of white.

The Bureau of Science collection also contains six typical specimens, 31 to 54 millimeters in length, collected by me from Titunod River, Kolambugan, Lanao Province, Mindanao.

Siitensis, from Lake Siit.

\section{TAMANKA TAGALA sp. nov.}

Dorsal VI, I-7; anal I, 7; there are 52 scales in a longitudinal series, 16 in a transverse series, and 25 to 30 before the dorsal fin.

The body slender, laterally compressed, with a large, broad, dorsally flattened head, the dorsal and ventral outlines nearly parallel, the back slightly arched, the depth 4.7 times, the head 3 times in length; the head much broader than deep, the depth 1.44 times in the breadth, which is 1.37 in its length; the broad, bluntly rounded snout 4.1 times in head; the eyes high up, lateral, a tenth shorter than snout, and equal to interorbital; the mouth rather large, oblique, the jaws equal, the pasterior angle of maxillary beneath middle of eye; the teeth in upper jaw in four rows, the outer one of large, widely spaced teeth, the others minute; the lower jaw has a band of four rows of minute teeth; the body everywhere covered with scales, largest and ctenoid on sides and posteriorly, becoming smaller and cycloid before first dorsal, where they extend forward beyond a line above posterior margin of preopercles; the opercles covered with about seven rows of small cycloid scales; the dorsals widely separated, the first dorsal falling far short of touching second dorsal when depressed; the third spine longest, 1.44 times in depth, 2.3 times in head; the second dorsal short, the fifth ray longest, lacking much of reaching base of caudal when depressed, equal to depth; the anal much lower, the posterior ray longest, about 1.6 times in depth and 2.5 times in head; the caudal peduncle large, its depth 1.67 times in its own length and 
2.14 times in head; the caudal round-pointed, badly damaged, but evidently about 3.7 times in length; the pectoral longer than caudal, round-pointed, 3.65 times in length and 1.2 times in head; the ventrals broadly pointed, scarcely reaching halfway to origin of anal fin, less than depth and nearly 1.7 times in head.

The color in alcohol very pale brownish yellow, with about ten irregular brown or dark brown crossbars over back, each dividing into two bars which extend down the sides vertically; a large, blackish brown spot on opercle; a blackish brown bar on basal part of caudal; two broad brown bars cross cheek, one behind eye, one behind mouth; a large black blotch on upper part of first dorsal, from third to fifth spines inclusive, the second dorsal faintly specked with brown, the caudal crossbarred with brown; the other fins uniform pale brown or like the body.

Here described from the type specimen, 31 millimeters long, No. 820 Bureau of Science collection, and a cotype, 33 millimeters long, No. 804 Bureau of Science collection, both collected by W. D. Carpenter in July, 1907, at Malabon, Rizal Province. The cotype is a female nearly ready to spawn, the body much plumper therefore than in the type.

Since writing the above I discovered in the Bureau of Science collection two tiny specimens, 13.5 and 21 millimeters long, collected at Sitankai in 1908, by Alvin Seale.

Tagala, because native to a Tagalog province.

105. TAMANKA UMBRA sp. nov.

Dorsal VI, I-8; anal I, 8 ; there are 38 scales in a longitudinal series, 12 in a transverse series, and 20 to 22 before first dorsal.

The elongate body low, much compressed laterally, the dorsal profile horizontal or moderately convex, the head very large, broad, depressed anteriorly and flattened above, the form wedgeshaped, viewed from above, the depth 4.8 to 5.1 times, the head 2.6 to 2.7 times in length; the cheeks full, the breadth of head much more than depth, 1.86 to 1.96 in its own length; the snout broad, rounded, with a median bony hump and two smaller lateral ones very close to it, the anterior part steep, 4 to 4.2 times in head; the eyes very high up, lateral, 5.25 to 5.5 times in head; the broad interorbital space equal to or slightly more than snout; the mouth large, strongly oblique, the jaws equal, the posterior angle of maxillary beneath posterior margin of pupil or even hind margin of eye, almost to lower border of pre- 
opercle; the teeth of first row in upper jaw large and widely spaced, closely followed by a band of very fine depressible teeth in four rows; in lower jaw a band of four rows of erect needlelike teeth of uniform size, slightly larger than inner teeth above; the scales largest posteriorly, becoming smaller anteriorly, those before dorsal extending to a point above posterior margin of preopercles; eight rows of small scales on opercles; the middle spines of first dorsal longest, their tips prolonged, reaching beyond origin of second dorsal, 2.33 to 2.5 times in head; the second dorsal angulate posteriorly, the last spine longest but not reaching caudal when depressed, 2.2 times in head; the anal similar but a trifle lower; the caudal slightly rounded at tip, shorter than head, 3.5 to 4 times in length; the caudal peduncle depth 1.5 to 1.7 times in its own length, which is equal to body depth and 1.8 to 2.1 times in head; the pectoral pointed, a little shorter than caudal, extending to a point above anus or anal papilla; the ventrals pointed, their length a little more or less than depth, 1.9 to 2 times in head; the anal papilla slender and pointed in males, much broader and thicker in females.

The color in alcohol uniform dark brown; the first dorsal irregularly blotched above with blackish brown, especially between third and fourth spines and posteriorly; the second dorsal and anal brown, darker than body, with a black bar on the membrane between each two rays, the bar broad above and tapering downward, ending about halfway down; the other fins all uniform brown, darker than body.

Here described from the type, No. 10600 Bureau of Science collection, and six cotypes, varying in length from 42 to 60 millimeters. They were collected by Alvin Scale in 1910, in Palawan.

Umbra, modern Latin for dark or olive brown.

106. TAMANKA BIVITTATA sp. nov.

Plate 17, Fig. 4

Dorsal VI, I-7; anal I, 7 ; there are 44 scales in a longitudinal series, 13 in a transverse series, and about 22 before first dorsal.

The body rather stout, the posterior part laterally compressed, the back convex, the depth 4.8 times in length; the head broad, blunt, 3.4 times in length, the cheeks bulging, its breadth 1.4 times its depth and 1.18 times in its length; the mouth terminal, oblique, the lower jaw slightly included, the posterior angle of maxillary beneath middle of pupil; the scales on nape and on side anterior to front portion of first dorsal are much smaller 
than those posteriorly and extend forward nearly to eyes; the dorsals rather far apart, the first dorsal low, the tips of the spines threadlike, scarcely reaching origin of second dorsal when depressed, 1.7 times in head; the second dorsal lower, falling far short of caudal when depressed, about 2.3 times in head; the anal still lower, 2.5 times in head; the caudal peduncle broad, 1.7 times in its own length, over twice in head; the caudal broadly rounded, 1.2 times in head; the pectoral pointed, about $\mathbf{1 . 5 5}$ times in head; the ventrals moderately broad with rounded tip, 1.8 times in head.

The color in alcohol uniform brown, darker above on head, the posterior half yellowish brown beneath; from above preopercle a dark brown, slightly convex band goes back to base of caudal, continuing back on fin as a blackish line; a similar band goes from under pectoral to base of caudal and on fin as a blackish line; the bands much more distinct on posterior half of body; on the pectoral a blackish vertical mark; on the sides of anterior half of trunk several vague dark crossbands; on upper margin of caudal a black bar and below it a dark brown lengthwise stripe; the first dorsal light brown with a large black spot on upper part of membrane between fifth and sixth spines; the second dorsal brown with darker markings; the other fins uniform in color with body.

Here described from the type and only specimen, 29 millimeters long, collected by Prof. S. F. Light at Hoihow, Hainan. Bis, twice; vittatus, banded.

Genus 45. AMOYA g. nov.

This genus is separated from Rhinogobius by the smaller and more numerous scales (46 to 50 in a longitudinal series), and by the teeth being in but two rows in each jaw.

Body plump, laterally compressed, little elevated, covered with ctenoid scales, largest posteriorly, minute above opercles; the head and nape naked; longitudinal rows of papillæ on preopercle, and perpendicular and transverse rows on opercle; head with conspicuous pores; dorsals close together, low; caudal pointed, longer than head, with well-developed short accessory rays; pectoral pointed, without silky rays above; gill openings vertical, narrow, restricted, isthmus broad. Dorsal VI, I-10; anal I, 9.

Generic type, Gobius brevirostris Günther.

Amoya, from Amoy, China.

$228793-16$ 
107. AMOYA BREVIROSTRIS (Günther)

Plate 18, Fig. 1

Gobius brevirostris GÜNTHeR, Cat. Fishes Brit. Mus. 3 (1861) 41.

Dorsal VI, I-10; anal I, 9; there are 46 to 48 scales in a longitudinal series and $\mathbf{1 6}$ in a transverse series.

The elongate, rather plump body laterally compressed, the dorsal and ventral profiles nearly horizontal and parallel, the depth 5.2 to 5.4 in the length; the head convex above, broader than trunk, 4 to 4.1 times in length, its breadth equal to or slightly exceeding its depth and 0.6 to 0.7 of its own length; the snout broad, rounded, convex, equal to or exceeding eye, 3.25 to 3.8 in head; the mouth terminal, slightly oblique, the jaws subequal or the lower very slightly prominent; the posterior angle of maxillary may extend back to a point beneath pupil; in each jaw are two rows of teeth, the outer enlarged, with a lateral pair of canines in lower jaw; the eyes very high up, dorsolateral, 4 times in head, close together, the interorbital $\frac{1}{3}$ to 0.25 an eye diameter; the eyes in forward half of head, the distance from tip of snout to posterior margin of eye less than postorbital length of head; the body covered with ctenoid scales, largest posteriorly, those along dorsal base much smaller and becoming minute and disappearing above opercles; the head and nape entirely naked and a central naked area extends back to base of dorsal; tiny scales on base of pectoral and on breast; conspicuous pores on head as follows: On snout beside posterior nostril, two on interorbital, two behind eye, four on supraopercular groove, and three on posterior margin of preopercle; two parallel longitudinal rows of minute papillæ across middle of preopercle, and a perpendicular and a transverse row on opercle; the first dorsal about equal to depth, the tip of second spine elongated; the second dorsal a little lower than the depth, the posterior ray longest and extending upon caudal when depressed; the anal still lower, the posterior ray not quite reaching caudal when depressed; the somewhat pointed caudal longer than the head, 3.25 to 3.6 times in length, the accessory rays well developed and extending forward upon the broad caudal peduncle, the depth of which is 0.75 or 0.8 of its own length, and contained about twice in head; the pointed pectoral a trifle shorter than head, its tip not extending to a point above anus; the ventrals broad, thin, much shorter than the distance to anus, 0.8 to 0.9 of the depth; in males the anal papilla is very small and slender, in females, subglobose. 
The color in alcohol uniform brownish, with a faint, dark brown, lateral band from axil of pectoral to base of caudal; a large vague dusky spot on opercle; the fins all uniform in coloration, paler than body, the second dorsal with traces of dark spots, the anal and caudal with blackish margins.

Here described from two specimens, 54 and 62 millimeters long, collected at Amoy, China, by Prof. S. F. Light. Hitherto Günther's type in the British Museum, from "China," has been the only specimen known.

\section{Genus 46. AMBLYGOBIUS Bleeker}

Amblygobius Bleeker, Esq. Syst. Nat. Gobioides, Arch. Neerl. Sci. Nat. 9 (1874) 322.

Odontogobius Bleiker, Esq. Syst. Nat. Gobioides, Arch. Neerl. Sci. Nat. 9 (1874) 323.

The compressed body varies from slender to rather deep, usually the latter, with broad flat caudal peduncle; the body covered with ctenoid scales with from 50 to 70 in a longitudinal series, those on nape smaller than those on sides; rarely the anterior scales may be cycloid or absent; the compressed blunt head has a convex profile and is naked to posterior margin of eyes or a trifle farther, except that the upper margin of opercle may be more or less scaled; large pores on head as follows: One near inner side of first nostril, two in a longitudinal row on interorbital space, one behind upper part of eye, a row of five along supraopercular groove, the first immediately behind eye, a row of three on posterior margin of preopercle; the mouth more or less oblique, with the teeth in each jaw in two or more rows, those of outer row larger and fixed, with a stout, backward-curving posterior canine on each side of lower jaw; tongue rounded at tip; isthmus broad; the dorsals without sharp spines, the tips of first dorsal more or less elongated; dorsal VI, I-11 to 16 ; anal I, 10 to 16 ; the second dorsal less than twice as long as first; the caudal rounded-truncate; no silky rays on upper part of pectoral.

This genus is composed of small, mostly deep-bodied gobies, more or less banded or striped, often brilliantly colored and very beautiful in life. It is confined to the East Indies and the south Pacific Ocean.

Key to the Philippine species of Amblygobius.

$a^{1}$. Body with longitudinal brown bands.

$b^{1}$. One band from eye back to beneath origin of first dorsal.. A. inornatus.

$b^{2}$. With two or three longitudinal brown bands. 
$c^{1}$. No ocelli on nape; scales 55 to 60 .

$d^{n}$. Two longitudinal bands; five dorsal crossbands.. A. perpusillus.

A. perpusillus buanensis.

$d$. Three longitudinal bands; no crossbands.

A. linki.

$c^{2}$. A double row of circular, blue-edged, brown ocelli on nape; scales 65 to 70

A. bynoensis.

$a^{2}$. Body with crossbands; no longitudinal bands.

$e^{1}$. Scales 70 ; ten or eleven crossbands inclined backward and downward at an angle of $70^{\circ}$

A. insignis.

$e^{2}$. Scales 50 to 55 .

$f^{1}$. Nape with two rows of dark red circular spots; crossbands wide with narrow blue-black margins.

A. phalaena.

$f^{2}$. No rows of red spots on nape; crossbands not blue-margined; each scale on side with a pearly spot.

A. sphynx.

108. AMBLYGOBIUS INORNATUS sp. nov.

Dorsal VI, I-11; anal I, 10; there are 68 scales in a longitudinal series.

The depth of the low elongate body 6.45 times in length; the head 3.4 times in length, its breadth approximately equal to its depth, 2.2 times in its length; the narrow blunt snout convex, 4.5 times in head; the eyes dorsolateral, oblique, 4.09 times in head, the interorbital very narrow; the mouth oblique, the lower jaw slightly projecting, the posterior angle of maxillary beneath front margin of pupil; the teeth of upper jaw in three rows, the outer row enlarged; in the lower jaw a short row of enlarged teeth, terminating in a backward-curved canine, followed by three more rows, the teeth of the middle rows minute, those of the innermost row larger than the two middle ones; the head and nape naked back to first dorsal; the scales on posterior half of body much larger than those on anterior portion; the scales appear cycloid but are really ctenoid, their teeth minute and very fragile; the first dorsal considerably in advance of second, not reaching latter when depressed, the middle rays longest, 2.25 times in head; the second dorsal and anal alike, angulate posteriorly, not reaching caudal when depressed, equal to first dorsal in height; the depth of caudal peduncle about 1.3 times in its own length, a trifle more than twice in head; the narrow subtruncate caudal 3.875 times in length and $\frac{8}{9}$ of head; the pointed pectoral and ventrals of the same length, 1.5 times in head.

The color in alcohol uniform brown with an inconspicuous, wide, dark brown band passing back from eye along upper part of side and disappearing beneath origin of second dorsal; the first dorsal light brown basally, above this a wide, clear, hori- 
zontal band, the remainder of the fin blackish brown; the second dorsal dark brown, vaguely crosisbarred by two rows of pale spots; the caudal light brown, with crossbars of blackish brown; the anal light brown with a blackish margin; the pectorals are the color of body; the ventrals brown, the middle blackish brown.

Here described from the type and only specimen, 31 millimeters long, collected by me in a tide pool on the Martin ranch, Siasi, Sulu Province.

Inornatus, unadorned.

\section{AMBLYgobiUS PERPUSILLUS (Seale)}

Rhinogobius perpusillus SEALE, Philip. Journ. Sci. § A 4 (1909) 534.

Dorsal VI, I-13; anal I, 13; there are 56 scales in a longitudinal series, about 20 in a transverse series, and 28 before the first dorsal.

The body somewhat obiong, laterally compressed, the dorsal and ventral outlines about equally curved, the depth 4 times, the rather bluntly pointed head 3.85 times in length; the snout 4 times in head, the eye a little smaller, 3.85 times in head; the interorbital broad, equal to snout; the mouth oblique, the lower jaw very slightly projecting, the posterior angle of maxillary under anterior margin of pupil; the teeth in two rows in each jaw, those of outer row enlarged, curved, the outer ones in lower jaw projecting; there is a large recurved posterior canine on each side of lower jaw; the whole body covered with finely ctenoid scales, those on nape much smaller and extending to eyes; the upper part of opercle has about three rows of very small scales, the rest of the head naked; the first dorsal elevated, the spines nearly uniform in length, twice in head; the dorsal and anal of similar shape, the posterior rays longest, 1.5 times in head; the depth of caudal peduncle twice in head; the slightly rounded caudal and round-pointed pectoral each about equal to length of head; the ventrals pointed, their length 1.2 times in head.

Color in life a distinct whitish with a slight wash of yellow, with three very dark brown stripes on each side, the first from interorbital to dorsals and along their base, the second from tip of snout to caudal, running along top of caudal peduncle, the third a wide, heavy band from around lower lip across cheek and upper base of pectoral to middle of caudal, where it ends in a black spot on the rays of the middle of base; the lower half of body uniform whitish, without marks; the dorsal whitish crossed by a dark band on upper third; the soft dorsal 
grayish, darker on posterior part and with a dark bar near top of fin; the caudal yellowish with a dark brown line extending on upper and lower margins; the anal yellowish at base, becoming dark on outer half; ventrals yellowish with slight grayish shading; pectorals yellow.

"Color in alcohol is similar to above but is less bright." (Seale.)

The above is modified from Seale's original description. His type specimen, 45 millimeters long, from Zamboanga, has disappeared. He had two other specimens, of which apparently but one, No. 5106 Bureau of Science collection, 35 millimeters long, collected in Puerto Princesa, Palawan, in 1908, is now in existence. Of these Seale said "they may be a distinct form."

The Puerto Princesa specimen is in very poor condition, but agrees with a fine one, 60 millimeters long, obtained from a fresh-water spring on Buan Island, lying off the east coast of Tawitawi. These two might be called variety buanensis.

109a. AMBLYOGOBIUS PERPUSILLUS BUANENSIS var. nov.

Plate 18, Fig. 2

Dorsal VI, I-14; anal I, 13; 58 scales in a longitudinal series, 20 in a transverse series, and about 22 scales before first dorsal.

The laterally compressed body oblong, deep, with protuberant belly, the dorsal profile but little curved, the depth 4 times in the length; the head blunt, its width a little less than its own depth or the width of trunk; the anterior profile convex, its length a little more than depth of body, 3.5 times in head and trunk together; the short, broad snout equals eye in length, and is contained 4.25 times in head; the eyes high up, oblique, lateral, the broad interorbital equal to 0.75 of eye or snout; the mouth oblique, rather small, terminal; the posterior angle of maxillary reaches just beyond front margin of eye; the outer row in lower jaw has five short, thick teeth on each side, terminating in a very large backward-curved canine; the head naked except for four rows of small scales on upper part of opercle; the scales on nape are smaller than those on sides and extend forward almost to margin of eyes; the base of pectoral scaled; the depth of caudal peduncle about equals its length and is 2.4 times in length of head; the broadly pointed caudal 3.6 times in length of head and trunk; the first dorsal low, its height 1.36 times in depth of body; the second dorsal and anal low, of equal height, the posterior ray longest, 0.6 of depth of body; 
the pectoral equals depth; the ventral short, 1.36 times in depth, its tip lacking six scales of reaching the short blunt anal papilla.

The color in alcohol dusky brownish above, very pale below; a narrow, dark brown band runs around snout on upper lip to eye, and from its posterior margin continues on back to upper part of base of caudal, the posterior part very faint; a similar band encircles chin, goes from corner of mouth across preopercle and opercle to base of pectoral, where it apparently stops, but really continues beneath pectoral back along middle of side to a large, circular, blackish brown spot on base of caudal; five wide blackish bands with indefinite margins cross back and descend on sides, thus forming six oblong whitish spots along middle of side, between the two longitudinal bands; each scale on back and side has a more or less evident, small, central whitish spot, these spots forming longitudinal rows; the top of snout dark brown; the dorsals and anal brownish, the membranes faintly specked with minute brown dots; the other fins without distinctive markings.

\section{AMBLYGOBIUS LINKI sp. nov.}

Plate 18, Fig. 4

Dorsal VI, I-13; anal I, 12; there are 60 scales in a longitudinal series and 16 in a transverse series.

The slender wedge-shaped body less elevated than in our other species of Amblygobius, its depth 4.7 times in length; the head broader than trunk, and contained 3.7 times in length; the short, blunt, convex snout equals eye and is contained 3.5 times in head; the distance from tip of snout to posterior margin of eye equals postorbital length of head; the breadth of the interorbital space 0.75 that of snout or eye; the mouth strongly oblique, the posterior angle of maxillary extending beneath center of eye; the pores on head typical of the genus; the nape covered with scales smaller than those on sides and there is a small patch of tiny scales along forward part of upper margin of opercle; the depth of caudal peduncle 1.25 times in its length; the pectorals equal head and are longer than the ventrals, which are about 0.7 of the distance from their origin to anus; the caudal exceeds head in length; the fifth dorsal spine most elongated, its length more than the greatest depth of body; the second dorsal and anal similar in outline, their posterior rays extending upon caudal when depressed and much longer than depth of body beneath them. 
The color in alcohol uniform reddish brown with three chocolate brown longitudinal stripes on each side; the first extends from above front of eye back on side of nape to fourth or fifth ray of second dorsal and is then continued on fin as a basal bar; the second passes around snout on upper lip, through eye, and continues back with a slight upward slant to top of caudal peduncle and on to upper part of caudal fin; the third passes around chin to corner of mouth, slants upward across cheek to base of pectoral where it apparently ends in a large spot, but continues on from axil of pectoral as a broad lateral stripe to base of caudal; a diagonal dark stripe on lower part of caudal; the cheek band bordered above and below by rows of large and more or less circular pearly spots; a dark blotch between tips of fourth and fifth dorsal spines.

Here described from the type, 52 millimeters long, collected by me under the wharf at Bungau, Sulu Province. The Bureau of Science collection also contains a specimen, 35 millimeters long, in poor condition, collected by Alvin Seale at Caldera Bay, Mindanao.

Linki, in tribute to Capt. Francis Link, of Jolo, for his indefatigable labors in advancing our knowledge of the Sulu Archipelago, and its fauna, flora, and people.

\section{AMBLYGOBIUS BYNOENSIS (Richardson)}

Plate 19, Fig. 1

Gobius bynoensis RICHARDSON, Voy. Erebus and Terror, Fishes (1844-1848) 1, pl. 1, figs. 1 and 2; GüNTHER, Cat. Fishes Brit. Mus. 3 (1861) 70; Petras, Monatsber. Akad. Wiss. Berlin (1868) 266; DAY, Fishes of India (1878) 284, pl. 61, fig. 3.

Gobius stenophthalmus BLEEKER, Nat. Tijd. Ned. Ind. 1 (1851) 248, fig. 7.

Odontogobius bynoensis BLFakER, Esq. Syst. Nat. Gobioides, Arch. Neerl. Sci. Nat. 9 (1874) 323.

Amblygobius bymoensis JoRdAN and SEALE, Proc. U. S. Nat. Mus. 28 (1905) 795.

Dorsal VI, I-14 to 16 ; anal I, 15 to 16 ; there are 65 to 70 scales in a longitudinal series and 26 in a transverse series (not 16 as given by Day).

The somewhat elongate body laterally and also dorsally compressed, the greatest depth behind pectorals and 4 to 4.4 times in length; the obtusely convex head 3.4 to 3.5 times in length; the eyes rather large and full, 3.8 to 4.8 times in head and 1.2 to 1.8 times in the strongly arched snout, which is 2.8 to 3 times in head; the interorbital space equals or nearly equals eye; the mouth terminal, oblique, of moderate size, the angle 
of maxillary reaching front margin of eye; there are two rows of teeth in upper jaw, the inner one some distance behind the much larger outer one; the lower jaw has three rows of teeth, the outer one larger than the others, with a stout, curved canine on each side; the nape covered with very fine scales which extend forward nearly to eyes; the rest of the head entirely naked, with crossrows of very fine tubercles on opercles and nape; a large pore lies on inner side of each anterior nostril, and two similar ones are on midline of interorbital space; beginning immediately behind eye is a row of five large pores in the supraopercular groove and a row of three on posterior margin of preopercle; some of the tips of first dorsal spines are more or less elongated, but there is much individual variation; the second dorsal and anal low, similar in outline, their posterior rays reaching caudal; the broad, rounded pectoral and caudal approximately of the same length and equal or nearly equal the length of head; the ventrals large but shorter than pectoral.

In life the body is yellowish above, pearly beneath; there are five to eight brownish violet crossbars over back to middle of sides, the posterior ones very broad and extending nearly to anal; a blue-edged, brownish violet band encircles snout and passes through eye back as far as beneath middle of first dorsal, widest posteriorly; a similar band extends across opercle and terminates in a large spot on base of pectoral; on preopercle is a similar narrow bar running diagonally downward and forward; on the nape is a double row of circular, dark brown, blue-edged ocelli; the dorsal fins spotted with pearly white with a violet marginal band; the anal has a similar margin; the caudal has a brown spot on upper part of its base.

Alcoholic specimens pale brownish, with the brownish violet markings becoming blackish, and the blue edgings and spots becoming pearl white.

Here described from twelve specimens, 48 to 84 millimeters long, from the following localities: Polillo; Busuanga; Bantayan Islands; Canigao Island, Leyte Province; Balabac. The specimen from Balabac is the smallest and is referred here with some doubt; it is much faded and is somewhat aberrant.

Since the above was written I received four specimens, 38 to 65 millimeters in length, from Inabanga, Bohol.

This species was collected at Paracale by Jagor, and Jordan and Seale listed it among the fishes collected by Bashford Dean on the coast of southern Negros. 
Originally described from western Australia, this very beautiful little goby has since been collected throughout the Malay Archipelago to the Andaman Islands, but does not seem to be abundant anywhere.

\section{AMBLYGOBIUS INSIGNIS Seale}

\section{Plate 18, Fig. 3}

Amblygobius insignis SeALE, Philip. Journ. Sci. § D 5 (1910) 116, pl. 2, fig. 1.

Dorsal VI, I-12; anal I, 12; there are 70 scales in a longitudinal series and about 30 in a transverse series.

The body subcylindrical in front, strongly laterally compressed behind, narrowed dorsally, the dorsal and ventral profiles nearly parallel, the depth about 5 times, the head 3.7 times in length; the eyes as long as the short, blunt, convex snout, which is contained 4 times in head; the interorbital space very narrow, 4 to 6 times in eye; the mouth small, oblique, the posterior angle of maxillary beneath front margin or forward third of eye; the teeth of upper jaw in four rows, those of the outer one much larger than the others, which are minute; in lower jaw are three rows, the teeth of outer row much the largest, five on each side, the last one a stout, curved canine; the posterior ctenoid scales largest, becoming smaller anteriorly and changing to cycloid near pectorals; the head and region forward of dorsal entirely naked, a few small scales extending above pectoral as far forward as posterior margin of opercle; on nape is a low skinny crest extending forward from dorsal nearly to eyes; the second dorsal spine longest, 0.75 or a little more than 0.75 as long as head and equal to or slightly exceeding depth; the second dorsal highest posteriorly, extending upon caudal when depressed, the longest rays less than the greatest depth of body; the anal similar but lower, the posterior rays reaching base of caudal when depressed; the depth of caudal peduncle 2.5 times in head; the rounded caudal about as long as head; the broad pectorals approximately equal to caudal in length; the ventrals short, about $\frac{2}{3}$ as long as head, not nearly reaching the short, broad, anal papilla.

The color in alcohol brown or yellowish brown, with about ten or eleven oblique darker crossbands, running downward and backward at an angle of about $70^{\circ}$; posteriorly they are broader and very distinct, but below the spinous dorsal they are indistinct and somewhat broken; two short, dark brown cross- 
bands over nape; the preopercles, opercles, bases of pectorals, and region back of eyes thickly sprinkled with small, dark brown spots, which are likewise thinly scattered along sides; the second dorsal has a series of short black stripes running downward and forward near margin, on the membrane between the rays; bands of body extend upon fin; the caudal crossmarked with alternate blackish brown and pale bars; anal light brown, with a broad dark margin; ventrals dusky.

Seale stated that on his specimen "Two oblique narrow dusky lines extend forward across cheeks and around the throat, the anterior one just back of angle of jaw." With the lapse of time these markings have disappeared.

Here described from two specimens, Seale's type, 46 millimeters long, from Bantayan Island, and one, 45 millimeters long, from Polillo.

This species is very strikingly and characteristically marked, and is quite unlike any other goby. In order to include it in Amblygobius I have had to amend the generic diagnosis. Amblygobius insignis differs from the other members of the genus in having cycloid scales anteriorly, a nuchal crest, and fewer dorsal and anal rays. It probably should be made the type of a new genus. Its color pattern is unique among gobies.

\section{AMBLYGobiUS PHALAENA (Cuvier and Valenciennes)}

Plate 30, Fig. 3

Gobius phalaena Cuvier and Valenciennes, Hist. Nat. Poiss. 12 (1837) 70; GüNTHER, Cat. Fishes Brit. Mus. 3 (1861) 67; Fische der Südsee 2 (1876) 178, pl. 111, fig. C.

Amblygobius phalaena JoRdan and SEALE, Fishes of Samoa, Bull. Bur. Fisheries 25 (1906) 405; JoRdAN and Richardson, Bull. Bur. Fisheries 27 (1908) 278.

Dorsal VI, I-14; anal I, 14 ; there are from 50 to 52 scales in a longitudinal series and 20 in a transverse series.

The body comparatively deep, oblong, laterally compressed, with nearly parallel or similarly slightly arched dorsal and ventral profiles and laterally compressed, rather bluntly rounded head; the depth contained 3.8 times, the head 3.5 times in length; the short, broad, convex snout contained 3.25 times in head; the full round eye but little less in diameter than length of snout, 3.5 to 4 times in head; the mouth moderately oblique, rather small, the posterior angle of maxillary reaching as far as anterior margin of eye; the full, broad interorbital space equals or may slightly exceed eye; a large pore on inner side and midway between nostrils, and two large pores on interor- 
bital space, the anterior one the larger; a pore behind upper part of eye and a row of five large pores along supraocular groove, the first one immediately behind eye; a row of three similar pores along hind margin of preopercle; very fine scales, much smaller than those on sides, cover nape as far as posterior margin of eye; the upper part of opercle scaled but the rest of head naked; the depth of the broad, flat caudal peduncle equals its length; the pectoral and caudal fins approximately equal in length and equal to or greater than depth of body; the length of ventral varies from a little less to much more than pectoral and extends to anus or even upon anal fin; the tips of third and fourth dorsal spines more or less elongated, sometimes much greater than depth of body; the second dorsal and anal similar in outline, the dorsal highest, their posterior rays longest.

A specimen, collected by Alvin Seale at Sitankai, had the following colors in life: The general color was yellowish, washed with greenish brown; across the body were five wide, brown bands, each narrowly margined with blue-black; two rows of dark red, circular spots on each side of nape; the cheeks with short blue lines and rounded or oblong spots; a black spot behind eye and a large, dark spot above upper posterior angle of opercle, followed by several smaller spots; the first dorsal with a black edge, some violet spots anteriorly and a large, dark purplish spot between fourth and fifth spines; the second dorsal with a central crossbar of violet-brown, bordered by pearl white dots on inner side; above it a yellowish band, bounded by a black line, the tips of the rays violet; a crossbar of violet-brown on anal, bordered by pearl white dots, the margin of fin black; the caudal suffused with salmon, its posterior margin violet, with a large black spot on upper part of basal portion and some blackish violet spots scattered on distal portion; the pectorals yellowish, with a horizontal blue bar on base.

Alcoholic specimens vary from greenish brown to light brown, with body markings as above described but duller, the spots on nape and head partially lost; the dorsal and anal fins much darker, their delicate markings lost.

Here described from thirteen specimens, ranging in length from 26 to 87 millimeters, from Puerto Galera, Mindoro; Cabalian, Leyte; San Juan, Siquijor; Sibutu and Sitankai, Sulu Province.

A specimen, 40 millimeters long, from Canigaran, near Puerto Princesa, Palawan, has five dark crossbands, the last one at 
base of tail very narrow; on the first three the black marginal lines extend only halfway down; the lower half of each of the crossbands, except the fifth, bordered on each side by a wide, pearly white band; on upper half of body these pearly bands are continued as two pearly white spots; a dark blue band on tip of snout from eye to eye; a wide blue band from angle of mouth diagonally upward across preopercle and opercle, and forming a horizontal bar on base of pectoral; between it and eye a broad, pearly white band upward and backward to base of pectoral, and a similar band below it and extending upon base of pectoral; a dark blotch behind eye and another at upper posterior angle of opercle; the fins marked approximately as in the Sitankai specimen. This specimen lacks the red spots on nape, but agrees in essentials with $A$. phalaena.

Other Philippine localities are Cagayancillo, recorded by Jordan and Richardson, and Samal Island in Davao Gulf, where it was obtained by Seale.

I collected, on September 15, 1925, eleven specimens at Cebu, 65 to 108 millimeters long. They are all big-headed, thick, robust fishes; the largest two are spawning females, their depth 3 and 3.5 times in the length. I received seven more from Tagbilaran, Bohol.

This very handsome goby occurs only in the sea. It was first collected at Vanikolo, and occurs throughout the East Indies and from the Pelew to the Samoan and Society Islands.

114. AMBLYGOBIUS SPHYNX (Cavier and Vaienciennes)

Gobius sphynx Cuvier and Valenclennes, Hist. Nat. Poiss. 12 (1837) 70.

Gobius sphinx GüNTHER, Cat. Fishes Brit. Mus. 3 (1861) 67.

Amblygobius sphynx BleEker, Arch. Neerl. Sci. Nat. 13 (1878) 54.

Amblygobius sphinx JoRdan and Seale, Proc. U. S. Nat. Mus. 28 (1905) 795.

Dorsal VI, I-14; anal I, 14; there are 52 to 54 scales in a longitudinal series and 20 in a transverse series.

The body oblong, compressed, with convex anterior profile, the depth equal to head and about 3.4 in length; the short snout is 3.45 to 3.6 in head and equals or very little exceeds eye, which is 3.6 to 3.8 in head; the interorbital space 4.4 to 4.7 in head; the mouth rather large, strongly oblique, the angle of maxillary reaching a point beneath front margin of pupil; the teeth larger and more prominent than in A. phalaena; the pores on head present as in $A$. bynoensis and $A$. phalaena, but they 
are not very evident in our poorly preserved specimens; the upper part of opercle scaled but the rest of the head naked; the scales on nape a little smaller than those on sides; the depth of the wide flat caudal peduncle a little greater than its length and about 2.2 times in head; the length of caudal equals head and is greater than that of pectoral; the ventrals usually do not reach anus; the tips of dorsal spines more or less elongated, the fifth one the longest and extending upon second dorsal when depressed but only about $\frac{2}{8}$ of the depth; the second dorsal and anal similar in outline, the dorsal the higher, their posterior rays greater than the depth beneath them and extending upon caudal.

The color of a living specimen collected at Tawang, Samal Island, was pale greenish, becoming whitish below, with five brown crossbands widest dorsally, a small blackish spot on upper part of caudal base, several large pearl white spots on side below soft dorsal, and numerous, small, bluish white spots scattered on sides in the crossbands; the snout was dusky, the sides of head marked with alternate irregular streaks of pink and white; white spots on opercle, with brown marks on posterior margin; the first dorsal irregularly blotched and margined with violet, the second dorsal with a basal series of pink spots, perpendicular stripes of pink alternating with white specks, and a pink margin; the anal pinkish, spotted with white, and with a pink margin; the ventrals similar to anal but paler and without the pink margin; the pectoral lemon yellow, with a basal pink vertical bar; the caudal with longitudinal pink stripes and dark green margins.

In alcohol specimens are brown above and more or less silvery below, with five darker crossbands more or less evident, and a small black spot on upper part of caudal base; the scales on sides each with a pearly spot, forming longitudinal rows; the sides of head and base of pectoral covered with oblong to circular, bluish or pearly spots; usually a blackish spot present over upper posterior angle of opercle; the dorsal fins and anal dusky, the original markings disappearing.

Here described from nineteen specimens, varying in length from 30 to 84 millimeters, from the following localities:

Puerto Galera, Mindoro, 7.

Bacon, Sorsogon Province, 1.

Dumaguete, Oriental Negros, 5.

Cagayan, Misamis Province, Mindanao, 2.
Samal Island, Davao, Mindanao, 1.

Canigaran, Palawan, 1.

Balabac, 2. 
I also place here a specimen in bad condition, 85 millimeters long, collected at Jolo.

This species was recorded from southern Negros by Jordan and Richardson and occurs throughout the East Indies to New Guinea, where it was originally collected by Quoy and Gaimard.

\section{Genus 47. CRYPTOCENTRUS (Ehrenberg) Bleeker}

Cryptocentrus (Ehrenberg MS.) BLEEKER, Esq. Syst. Nat. Gobioides, Arch. Neerl. Sci. Nat. 9 (1874) 322; JoRDAN and SNYDER, Proc. U. S. Nat. Mus. 24 (1901) 72.

The body moderately elongate, covered with minute cycloid scales, 75 to over 100 in a longitudinal series; the naked head large, broad, narrowed above, blunt, with strongly convex snout, the eyes high up and close together; the mouth large, oblique, not opening readily, the maxillary extending beyond eye, the chin prominent; the teeth in several rows in each jaw, rather large, those of outer row enlarged, and a pair of more or less well-developed canines posteriorly in lower jaw; the first dorsal short, the spines flexible and sometimes filamentous; the second dorsal longer than anal, both extending to base of caudal or beyond when depressed; pectorals without silky rays above; the ventrals long; the caudal round-pointed to somewhat acute, and longer than head; the gill openings very broad, the isthmus narrow. Dorsal VI, I-10 to 20 ; anal I, 9 to 21 ; branchiostegals 4.

This genus comprises numerous species of brightly colored gobies occurring from the Red Sea to southern Japan.

Key to the Philippine and China Sea species of Cryptocentrus.

$a^{1}$. A black spot between first and second dorsal spines.

$b^{1}$. Spot near tip of membrane; 85 scales in longitudinal series, 32 in transverse series C. cebuanus.

$b^{2}$. Spot near base of membrane; 105 scales in longitudinal series, 40 in transverse series. C. filifer.

$a^{2}$. No black spot between first and second dorsal spines.

$c^{1}$. Body with five dark brown crossbands; 90 to 104 scales in longitudinal series, 27 in transverse series; first dorsal pale brown; second dorsal pale brown with yellow spots along base.

C. fontanesii.

$c^{2}$. Body without five dark brown crossbands.

$d^{1}$. About 75 longitudinal scales, 30 transverse scales; first dorsal deep black from first to third spines inclusive; a large basal black spot between spines 5 and 6 ; body uniform yellowish.... C. vagus.

$d^{2}$. About 90 longitudinal scales, 27 transverse scales; first dorsal purplish brown; sides of head with widely scattered blue or dark brown spots; body light brown with a dark brown saddle from back to belly. C. venustus. 
115. CRYPTOCENTRUS CEBUANUS sp. nov.

Plate 19, Fig. 2

Dorsal VI, I-10; anal I, 10; there are about 85 scales in a longitudinal series, 32 in a transverse series, and about 20 scales in front of first dorsal.

The body elongate, strongly compressed laterally, the dorsal profile horizontal, the greatest thickness a little more than half the depth, which is contained 5.56 times in length; the head large, its thickness equal to its depth, with short, blunt, steeply descending snout and slightly projecting chin; the length of head 3.56 times in head and trunk together; the snout 0.2 of head and shorter than the large, obliquely set eyes which are dorsolateral in position, very close together, and $4 \frac{1}{6}$ times in head; the convex interorbital 0.25 of an eye diameter in breadth; the mouth large, oblique, the maxillary extending a little beyond eye; teeth in four rows in each jaw, the posterior canines in lower jaw small; in upper jaw some of the teeth in inner row behind symphysis enlarged; the scales are closely set, distinct, and extend forward upon nape as far as in line with front margin of opercle; the snout, cheeks, opercles, and naked space behind eyes covered with lines of minute papillæ; the first dorsal high, the tips of the spines not extended beyond the membrane, the second spine longest and 0.2 greater than the depth; the base of second dorsal much longer than that of anal, the fins similar in outline, the posterior rays longest and greater than the depth, both reaching caudal when depressed, the second dorsal higher than anal; the depth of caudal peduncle 1.6 times in depth and 2.5 times in head; the caudal pointed, its length $\frac{1}{8}$ of head and trunk; the broad, round-pointed pectorals exceed depth very slightly; the slender, pointed ventrals longer than pectorals, and 0.25 more than depth, but do not reach anus; the anal papilla short and bluntly rounded.

The color in alcohol reddish brown, with a lilac cast anteriorly, becoming yellowish brown on posterior third; on sides are ten (?) crossbars of darker brown; the bars on posterior third have faded considerably, so that their number cannot be determined exactly; two similar short bands cross nape, one just in front of first dorsal, the other above opercles; a dark brown band crosses behind eyes and divides, one part passing diagonally downward and forward to posterior angle of maxillary, the other passing back and down to opercle; below this is a large pale spot, apparently pearly blue in life, covering most of preopercle; the 
sides of head spotted with large, dark brown circular dots; near tip of membrane between first and second spines of first dorsal a deep black spot; the upper margin of caudal tip a broad black line; no other markings left on caudal, second dorsal, anal, or pectorals; the ventrals black centrally, fading to light brown at outer margins.

Here described from the type and only specimen, 89 millimeters long, collected at Cebu by Prof. A. L. Day.

116. CRYPTOCENTRUS FILIFER (Cuvier and Valenciennes)

Gobius filifer CUvigR and VALEnciennes, Hist. Nat. Poiss. 12 (1837) 80.

Gobius knutteli BlEeKre, Act. Soc. Sci. Indo-Neerl. 3 (1858) 16, pl. 1,

fig. 2; Günther, Cat. Fishes Brit. Mus. 3 (1861) 73.

Cryptocentrus filifer JORDAN and SNYDER, Proc. U. S. Nat. Mus. 24 (1901) 72, fig. 12.

Dorsal VI, I-10; anal I, 9; there are about 105 scales in a longitudinal series and 40 in a transverse series.

The body moderately elongate, somewhat rounded or laterally compressed, both profiles converging from origin of first dorsal to caudal peduncle, the depth 5.1 to 5.4 times in length; the head large, 3 to 3.3 times in length, broader than trunk but deeper than wide; its depth sometimes greater than that of body, the blunt convex snout very steep, 4 times in head; the eyes placed very high, lateral, 4.4 to 4.6 times in head and about $1 \frac{1}{6}$ times in snout; the interorbital space narrow, its breadth about 3 times in eye; the gape of the large oblique mouth extends back to a point below posterior margin of eye or beyond, the maxillary extending more than halfway across preopercle; the teeth of upper jaw in four or even five rows anteriorly, those of outer row more than twice as large as the others; in lower jaw are five rows of slender teeth of nearly uniform size, with a pair of rather small and easily lost lateral canines in outer row; the scaleless head and nape marked by many longitudinal and crosslines of minute papillæ; the body covered with minute cycloid scales, largest posteriorly, deeply embedded in the skin and rather widely spaced anteriorly, their position over most of body indicated by shallow pits; the first dorsal very high, all the spines with more or less elongated tips, the first or second spine longest, more than twice depth of body and nearly half again as long as head; the second dorsal high the posterior rays longest, equal to or greater than greatest depth of body, extending upon caudal when depressed; the base of $223793-16$ 
anal much shorter, but its longest rays are higher than those of second dorsal and extend to or upon caudal when depressed; the depth of caudal peduncle 3.2 to 3.5 times in head; the caudal broad, with round pointed tip, its length a little more than that of head; the pectorals are broad and rounded, and extend back as far as posterior extremity of first dorsal; the broad ventrals reach the small triangular anal papilla.

In alcohol brown or yellowish brown, paler on throat and belly; the sides have four or five broad, dark brown, vertical bands, the first under first dorsal, the last at base of caudal; a short, broad, dark brown crossband on nape between preopercles and another in front of first dorsal above pectoral base; the opercles and preopercles sprinkled with small pearly white spots (said to be bright blue in life); the first dorsal has an elongated black spot on lower part of membrane between first and second spines; the second dorsal crossbarred by two rows of large dark spots on membrane between rays; the anal has a dark brown margin; the upper half of caudal crossbarred by alternate rows of dark brown and white spots; the ventral rays dark.

This strongly marked species is common about the rocky coasts of southern Japan and China. Here described from several specimens, from 80 to 98 millimeters in length, obtained at Hongkong by Seale, and a fine specimen from Amoy, collected by Light.

It may be expected along the western coast of northern Luzon. 117. CRYPTOCENTRUS FONTANESII (Bleeker)

Gobius fontanesii BlEekER, Nat. Tijd. Ned. Ind. 3 (1852) 764; GüNTHER, Cat. Fishes Brit. Mus. 3 (1861) 74.

Gobius (Cryptocentrus) fontanesii W BBER, F'ische Siboga Exped. (1913) 474.

Oxyurichtus fontanesii Fowler and BeAN, Proc. U. S. Nat. Mus. 62 (1922) 72.

Dorsal VI, I-15; anal I, 16; there are 90 to 104 scales in a longitudinal series, about 27 in a transverse series, and 30 before first dorsal.

The body slender, elongate, laterally compressed, the depth 6.3 , the head 3.6 times in length; the depth of head twice in its length; the convex, obtuse snout shorter than eye, 4.3 times in head; the eye 4.8 times, the maxillary 2.4 in head, its posterior extremity below middle of eye; the eyes very close together, high up, the interorbital 2.4 times in eye; the mouth oblique, the outer teeth enlarged; one to four lateral canines 
on each side in lower jaw, the latter number typical; the scales on posterior part of body much larger than anterior ones; the dorsal fins higher than body in males, lower in females, the third spine longest; the obtusely rounded caudal 3.5 times in length; the rounded pectoral scarcely shorter than head; the very large, broad, posteriorly pointed ventrals reach beyond anus.

The color in alcohol reddish brown to dull brownish, with five broad, obscure, dark brown crossbands or blotches, the first at occiput, second at middle of spinous dorsal, the third and fourth below soft dorsal, the fifth at base of caudal; the head may have yellow dots on top; the fins all pale brown, the soft dorsal with a series of yellow spots along its base; the margin of anal dusky with a narrow pale or gray submarginal line.

The above description is compiled, as I have seen no authentic specimens. Fowler and Bean had a specimen, 150 millimeters long, from Cebu. Originally described from Celebes and Amboina, it is known westward to Java.

118. CRYPTOCENTRUS VAgUS sp. nov.

Plate 19, Fig. 3

Dorsal VI, I-10; anal, I, 10; there are about 75 scales in a longitudinal series and 30 scales in a transverse series.

The body elongate oblong, flattened laterally, the head thicker than body, the anterior dorsal and ventral profiles convex, the depth 5 times, the head 3.14 times in length; the head rather blunt, the lower jaw prominent, the short convex snout with a large central hump; the snout contained 5.6 times in head and 1.2 times in eye diameter; the eyes are high up, dorsolateral, 4.66 in head, close together, the interorbital 3 times in eye; the mouth is large but does not open wide, strongly oblique, the maxillary extending beyond eye to lower margin of preopercle; three rows of teeth above, and two rows in lower jaw, with two pairs of canines back on either side from symphysis and outside the rows of teeth; the body covered with rather easily displaced scales posteriorly, smaller and closely adherent anteriorly, and disappearing above base of pectoral; no scales in front of first dorsal; the head naked, without papillæ or other growths on the smooth cheeks, opercles, and nape; the cheeks broad and evidently moderately full in life, the opercles narrow; the first dorsal very high, the second and third spines exceedingly elongate with a fine, silklike tip, the second spine twice in head and trunk together and reaching almost to base of caudal 
when depressed; the second dorsal and anal similar in shape, high, the posterior rays longest, extending beyond base of caudal when depressed, 0.875 as long as head and 3.66 in length, as is also the narrow pointed pectoral; the narrow ventrals have a wide, thin frenum and extend to the very small pointed anal papilla, their length 1.4 in head and 4.4 in total length; the caudal peduncle is 2.8 times in head and 1.6 times in its own length; the much elongated and very narrow caudal 0.5 the total length.

The color in alcohol is uniform yellowish, with a large dark brown blotch on upper part of opercle; the pupil of eye white; the membrane between first, second, and third spines of first dorsal deep black; between fifth and sixth spines is a large black spot on basal part of membrane; the remainder of the fin is minutely specked with dusky, the basal half of the spines black; the second dorsal and anal have a blackish margin, their membranes gray with minute dusky specks; the caudal brownish, becoming dusky toward tip, the ventral blackish, the pectoral colorless.

Here described from the type, 44 millimeters long, of unknown origin, but from Mindoro or Mindanao.

Since writing the above a specimen, 35 millimeters long, has been collected at Iloilo by Mr. H. R. Montalban. The snout has been partly destroyed, but it is the same species as the type.

Vagus, wandering or vagrant.

119. CRYPTOCENTRUS VENUSTUS Seale

Cryptocentrus venustus SEALE, Philip. Journ. Sci. § D 9 (1914) 76, pl. 2, fig. 2.

Dorsal VI, I-9; anal I, 10; about 90 scales in a longitudinal series, about 27 in a transverse series, and about 20 before first dorsal.

The head and body laterally compressed, the depth 5.5, the head 3.75 times in length; the head strongly convex, a little broader than body, its width nearly $\frac{6}{7}$ of its depth, which is $\frac{2}{3}$ of its length; the snout very steep, shorter than eye, 5 times in head; the large circular eyes very high up, lateral but looking upward as well, 4.2 times in head, close together, the interorbital space 3 times in an eye diameter; the mouth large, the gape extending to posterior margin of the large pupil, the posterior angle of maxillary extending beyond posterior margin of eye; there are five rows of teeth in each jaw, those of outer row widely spaced and slightly enlarged, those of inner row 
horizontal, pointing inward, enlarged, the posterior ones very much so, the inner rows minute; the scales on forward portion of body very small, becoming much larger posteriorly; they extend before first dorsal as far as front margin of the very narrow opercle; the first dorsal high, the middle spines longest, 0.9 of the length of head; the sixth spine separated by a considerable space from fifth; Seale was in error in stating it to have seven spines and the figure is incorrect in showing the first spine as longest; there is a projecting filament of skin behind sixth spine but no additional spine; the second dorsal and anal sharply angulate posteriorly, the last or next to the last ray longest, 1.5 times in head, or 2 its length; the caudal pointed, 3.25 times in the length and $\frac{1}{7}$ longer than head; the rather narrow pointed pectaral $\frac{6}{7}$ as long as head; the ventrals have a wide frenum forming a very deep cup, their length equal to head, the narrow pointed tip reaching the small, conical anal papilla.

The color, according to Seale, was light brown, with a wide, dark brown saddle over back under first dorsal and extending downward on sides and belly; a dark brown area along middle of sides to base of caudal; a brownish area behind eyes and one below them; about fifteen blue spots on sides of head and base of pectoral; the first dorsal and anal dark purplish, lighter basally, and approaching black above; the ventrals dark purplish; the second dorsal blackish basally and along margin, the rest of the fin with three longitudinal rows of white spots and two longitudinal lines of blackish spots; the caudal and pectorals uniform brown. After fifteen years in alcohol the markings have changed little; the second dorsal, however, is now practically all brown and the spots on the sides of the head are blackish brown.

The type and only specimen is a male, 80 millimeters long, collected by Seale in Hongkong.

\section{Genus 48. BIAT Seale}

Biat Seale, Philip. Journ. Sci. \& A 4 (1909) 532

The body elongate, the sides strongly compressed, the head large, blunt, broad, the body deepest at origin of ventrals; the mouth of medium size, oblique, with strongly projecting chin; the upper jaw has an outer row of enlarged fixed teeth, some of those in front caninelike, and four rows of very small depressible teeth; the lower jaw has two rows of small fixed teeth and a short inner row of stout, backward-curved canines; the 
body covered with ctenoid scales not very regularly arranged, the posterior ones largest, becoming smaller anteriorly, and passing into cycloid scales, those before first dorsal very small; there is a patch of minute scales on base of pectoral; the opercles, preopercles, snout, top of head, and nape scaleless back as far as front margin of opercles; the tip of tongue convex, adnate; the gill openings wide and carried forward to a line below the preopercles, the isthmus rather narrow; the dorsals close together, both lower than body; the ventrals long, the caudal longer than head, lanceolate; no silky rays on pectorals. Dorsal VI, I-15; anal I, 16; scales in a longitudinal series, 100 to 110 .

But a single species is known.

\section{BIAT LUZONICUS Seale}

Plate 20, Fig. 1

Biat luzonica SEALE, Philip. Journ. Sci. § A 4 (1909) 532.

Dorsal VI, I-15; anal I, 16; there are 104 scales in a lengthwise series, 30 in a transverse series, and about 20 before first dorsal.

The body elongate, oblong, strongly compressed laterally, the greatest depth 5.1 in length; the head large, blunt, broad, its width equal to its depth, and contained 3.8 times in length; the snout short, steep, rather broad, with a conspicuous median hump, and contained 4.2 times in head; the eyes large, very high up but lateral in position, almost equal to snout in length, 4.4 in head; the interorbital space very narrow, its breadth less than $\frac{1}{8}$ that of eye; the mouth moderately oblique, with projecting lower jaw, the posterior angle of maxillary reaching to pupil; the upper jaw has five rows of teeth, those of outer row much enlarged and fixed, about four in the forward part caniniform and curved backward, the other four rows of very fine, sharp-pointed, depressible teeth; the lower jaw has three rows of teeth, apparently all fixed, the inner row much the shortest, of about five stout, curved canines on each side; the nostrils in front of middle of eye, the anterior one small, closed (tubulate?), the posterior one larger and open; above and about midway between is a large pore; a large pore at anterior and one at posterior end of interorbital space; a pore behind upper part of eye, one behind middle of eye at beginning of supraopercular groove and three more along it, and three on posterior 
margin of preopercle; the scalation is given under the generic description; the tips of the dorsal spines slender and somewhat elongate, the third and fourth longest but less than the depth; the base of anal shorter than that of second dorsal, the fins similar in outline; the second dorsal the highest, its longest rays a little shorter than third dorsal spine; the posterior rays of second dorsal and anal reach caudal when depressed; the depth of caudal peduncle 2.4 in head; the damaged caudal slightly exceeds the head in length, but Seale states it is almost 0.25 longer than head; the frenum of ventrals very broad, forming a very deep cup and sucking disk; the ventrals long, reaching anal; the pectorals broad and rather short, their length about 1.25 times in head; the cylindrical anal papilla short, thick, and blunt.

The color in alcohol yellowish brown, with five broad, dark brown bands, without distinct margins, over back and sides, and a spot of the same color on snout and interorbital space; the first band crosses nape and descends upon opercle; the second is from middle of base of first dorsal to belly; the third from anterior portion, the fourth the posterior portion of second dorsal; the fifth on basal portion of caudal fin; there are traces of a few pale spots on upper part of head behind eye; the first dorsal, except anterior third, very dark brown; the second dorsal and caudal yellowish, the latter with a black band along its lower margin; the anal yellowish with very dark brown tips to the rays; Seale says "with" two or three narrow submarginal lines." Pectorals yellowish; ventrals dark brown.

Here described from the type and only specimen, $145 \mathrm{milli}$ meters in length, collected in June, 1907, by Mr. W. D. Carpenter, on the east coast of Luzon.

This fish is close to Gobius fontanesii Bleeker, but differs from it in several important points. The species seems to be unique.

\section{Genus 49. OXYURICHTHYS Bleeker}

Oxyurichthus BLbEKar, Esq. Syst. Nat. Gobioides, Arch. Neerl. Sci. Nat. 9 (1874) 324.

Oxyurichthys BLEEKER, Versl. Med. Akad. Amsterdam II 9 (1875) 139.

Gobiichthys KiUnzINGER, Synopsis Fische des Rothen Meeres 2, Verh.

Zool. Bot. Gesell. Wien 21 (1871) 479.

Prelaphias JoRdan and Seale, Fishes of Samoa, Bull. Bur. Fisheries 25 (1906) 406. 
The spelling in the first citation is evidently a typographical error, since Bleeker had used the correct form for at least sixteen years prior to this, but I am unable to find any generic diagnosis prior to the appearance of his Esquisse. The spelling is correct in the type species given.

The body elongate, laterally compressed, the dorsal and ventral profiles but little arched; the head short, broader than trunk, with blunt, strongly convex snout; the scales irregularly arranged in most species, loosely attached, 40 to 90 in a longitudinal series, ctenoid and larger posteriorly, passing into cycloid on forward part of trunk, those on nape very small and more or less disappearing, so that it may be nearly naked; running forward from first dorsal is a low naked ridge, terminating in a more or less evident skinny crest; above each eye and curving behind it is a low, smooth, bony ridge, the interorbital space very narrow; the preopercles, snout, opercles, and naked space behind eyes marked by furrows or rows of excessively minute papillæ, as shown in the figures; the mouth more or less oblique, with projecting chin; the teeth fixed, pointed, in one row in upper jaw in all Philippine species, and two to four rows in lower jaw, without canines, at least the outer row extending to posterior angle of mouth; the tip of the tongue convex, the isthmus broad; the dorsals contiguous or nearly so, with elongate tips to spines and rays, some of the dorsal spines often excessively long and threadlike; the pectorals without silky rays above; the lanceolate pointed caudal much elongated; the ventrals broad, with a very wide frenum, which forms a very deep cup, or sucking disk, for attaching the fish to objects. Dorsal VI, I-10 to 13 ; anal I, 10 to 14 .

I am unable to separate those species with a tentacle on the eye under the generic name Gobiichthys. The various species present every gradation in the development of an ocular tentacle, from those with ordinary eyes or with a pigmented spot or bar, on through those with a slight protuberance in its place, up to species with a tentacle as long as the eye.

In counting the scales before the first dorsal, I have counted those beside the median naked ridge, beginning opposite the origin of the first dorsal forward as far as the scales extend.

This genus occurs from the coasts of Hindustan to Australia and north to the southern coast of China and Formosa. 
Key to the Philippine and China Sea species of Oxyurichthys.

$a^{1}$. No tentacle present; a black spot on eye above pupil.

$b^{x}$. Black-margined blue ocelli on head and body; pectorals and ventrals with white dots.

O. argulus.

$b^{2}$. No blue ocelli on head or body.

$c^{2}$. Scales 48 to 50 in a longitudinal series.

$d^{1}$. Twenty-one scales in a transverse series; no circular black spots on scales

O. amabilis.

$d^{2}$. Fourteen to 16 scales in a transverse series; each scale on upper half of body with a small circular black spot........ O. microlepis.

$c^{2}$. Scales 75 to 80 in a longitudinal series.

$e^{1}$. Depth 7 times in length; first dorsal low, scarcely exceeding depth

O. papuensis.

$e^{2}$. Depth 5 to 5.4 times in length; first dorsal high, with elongated threadlike tips; 25 scales in a transverse series.... 0 . visayanus.

$a^{2}$. A tentacle present on upper part of eye.

$f^{1}$. Scales 72 to 76 in a longitudinal series; tentacle very short, stout, teatlike O. oculo-mirus.

$f^{2}$. Scales 50 to 56 in a longitudinal series.

$g^{2}$. Tentacle slender, pointed, 1.6 to 3 times in eye; scales 54 to $56 ; 20$ to 23 before first dorsal on side of nape. o. ophthalmonema.

$g^{2}$. Tentacle very short, 2.5 to 5 times in eye; scales $52 ; 17$ to 18 before first dorsal on side of nape. o. viridis.

121. OXYURICHTHYS ARGULUS (Peters)

Gobius argulus PETERS, Monatsber. Akad, Wiss. Berlin (1868) 266.

Oxyurichthus argulus JoRDAN and RICHARDSON, Check List Phil. Fishes (1910) 50.

Dorsal VI, I-12; anal I, 12.

In its whole habit, in the shape of the body, in the teeth, and in the form it is extraordinarily like Gobius arabicus, but is unique in the coloring of the body and head with small blue, black-margined ocelli, and white-dotted pectoral and ventral fins, and in the much larger scales which are in only thirteen rows between the end of the second dorsal and the anal.

On one specimen the first dorsal is dark with white longitudinal lines, the second dorsal dark brown with a few white dots and a clear margin, the anal black with numerous white dots and a broad white base, the caudal uniform, dark, without clear margin and unspotted. The second specimen has the first dorsal as on the first specimen, the second dorsal with alternate clear and dark, with oblique bands from above anteriorly to below posteriorly, the anal colored as in the first example, and the caudal with numerous perpendicular black crossbands. 
They both lack the blue spots on the base of the pectoral and the yellow submarginal band on the caudal which one usually notices on $G$. arabicus.

Two examples from a coral reef at Paracale, Luzon (Peters).

The above highly unsatisfactory description is all that we know about this species. It is evidently an Oxyurichthys, but the description is remarkable for what it omits rather than for what it gives.

Gobius arabicus has "very small scales; the height of the body 7 times in the total length, the length of the head 4.5; cheeks swollen, head as broad as high, but a third longer than high; canine teeth in the upper and lower jaws; the second and third dorsal spines higher than the body; caudal pointed, onefifth of the total." (Günther.)

The "total length" probably includes the caudal fin.

122. OXYURICHTHYS AMABILIS Seale

Oxyurichthys amabilis SeALe, Philip. Journ. Sci. § D 9 (1914) 76, pl. 2, fig. 1.

Dorsal VI, I-12; anal I, 13; there are 50 scales in a longitudinal series, 21 in a transverse series, and 24 before first dorsal.

The body elongate, the head and trunk laterally compressed, the dorsal profile of head convex, the dorsal and ventral outlines tapering gradually from head to caudal peduncle, the depth 6 times in length; the head large, 4 times in length, the anterior profile strongly convex, its breadth $\frac{6}{7}$ of its depth, which is scarcely more than 0.6 of its length; the snout 3.3 times in head; the eyes very high up, dorsolateral in position, about 4 times in head, their inner margins very close together and projecting above dorsal outline of head, the interorbital space linear; the teeth in upper jaw in one row, of moderate length, stout, somewhat curved; in lower jaw there are two rows of very small teeth, not one row as stated by Seale; the mouth large, oblique, the posterior angle of maxillary beneath front margin of pupil; the scales on posterior part of body large, those on anterior portion much smaller, those in front of first dorsal very small and extending forward to mucus channel behind eyes; the first dorsal spine highest, a little more than 1.5 times in head, the sixth spine separated from fifth by a wide interspace, all the spines with elongate tips; the second dorsal elongate posteriorly, the central and posterior rays longest but the last two shorter, about 0.6 of head or 1.64 times in head; the anal angulate posteriorly, gradually increasing in length from the front back- 
ward, next to the last ray longest, 1.9 times in head; the posterior rays of second dorsal and anal extend upon caudal when depressed; the very long pointed caudal 2.55 to 2.6 times in length; the broad pointed pectoral is a trifle shorter than head and extends back beyond a line from anus; the ventrals are from 0.74 to 0.87 of head and do not extend to the small flat triangular anal papilla.

The color in alcohol uniform pale yellowish brown, lighter beneath, the fins concolorous, the anal with a blackish margin; the ventrals seem to have been dusky.

The type, 92 millimeters long, and two cotypes, 88 and 89 millimeters in length, were collected in the Hongkong market by Alvin Seale and are now in the Bureau of Science collection. A third cotype, formerly in the collection, is not now there.

123. OXYURICHTHYS MICROLEPIS Bleeker

Plate 20, Fig. 2

Gobius microlepis BLझвknR, Verh. Bat. Gen. 22 (1849) 35; Nat. Tijd. Ned. Ind. 7 (1854) 436; Günther, Cat. Fishes Brit. Mus. 3 (1861) 49.

Oxyurichthys microlepis BLEEKER, Enumeratio specierum piscium, Act. Soc. Sci. Indo-Neerl. 6 (1859) 120.

Oxyurichthus cristatus JoRdAN and SeALE, Bull. Bur. Fisheries 26 (1907) 44; EvermanN and Seale, Bull. Bur. Fisheries 26 (1907) 104; JoRdan and Richardson, Bull. Bur. Fisheries 27 (1908) 278; SEALE, Philip. Journ. Sci. \& D 9 (1914) 75.

Dorsal VI, I-12; anal I, 13; there are 48 or 50 scales in a lateral series, 14 to 16 in a transverse series, and 16 or 18 scales before first dorsal.

The body slender, elongate, much compressed laterally, the head much broader than body, the dorsal line nearly straight but the ventral line ascending posteriorly to tail, the depth 5.4 to 6.3 in length; the width of the head equal to its depth, its length 3.9 to 4.4 in head and trunk together; the snout short, blunt, boldly convex, and 3.3 to 3.8 times in head; the eyes very high up, more dorsal than lateral in position, equal to snout in length, close together, the interorbital space equal to $\frac{1}{3}$ or less of an eye diameter; no orbital tentacle; the mouth strongly oblique, with thin projecting lower jaw, the posterior angle of maxillary beneath middle of eye; there are 18 or 20 rather widely spaced, moderately large teeth on each side of upper jaw, and, two rows of much smaller teeth in lower jaw; the opercles and preopercles scaleless, the latter with two length- 
wise lines and several crosslines of exceedingly minute warts; similar short longitudinal lines on the naked nape behind eyes, no scales on base of pectoral; the scales on nape do not extend forward beyond posterior margin of preopercle; from the first dorsal to the scaleless portion a low, fleshy, scaleless ridge, or crest, occupies the central part of nape; the tips of all the dorsal spines, but especially the first, may be greatly elongated and threadlike, up to 1.8 times in length of head and body together; the second dorsal and anal about equal in the length of their base, of similar outline, and both with much elongated tips tc their rays, the posterior rays longest and reaching beyond base of caudal when depressed; the depth of caudal peduncle 2.2 to 2.5 in head; the caudal greatly elongated and pointed, its length 1.8 to 2.3 in length of head and trunk; the long pectorals may extend back beyond beginning of anal; the ventrals usually short, but rarely reaching anus or the slender, conical, pointed anal papilla.

The color in life dark greenish gray to golden above, pearly beneath; each scale along back and upper half of sides has a small, circular, black spot before its posterior margin; five or six broad, rather vague, brown crossbands over back; alternating and often coalescing with them on the sides and lower half is a series of similar indistinct bands; the sides of head iridescent greenish gold; the crest on nape tipped with black; on upper part of eye, just within its margin, where a tentacle occurs in some gobies, is a more or less circular black spot; the eyes are lapis lazuli or green, with a pearly luster; below eye is a large, irregular, blackish brown blotch; the spinous dorsal has two longitudinal, broad, irregular, pearly bluish bands on basal portion; the spines crossbarred with black and the upper part of membrane behind last spine is black; the soft dorsal crossed by many lines of black spots; the upper half of caudal has many circular to oblong black spots on the membrane, the lower half uniform violaceous, with yellow margin; the anal violet-blue, with yellow margin; the pectorals more or less violet; the ventrals deep violet, with a yellow base.

The color in alcohol similar but much paler, the yellow and blue or violet disappearing, but the dusky crossbands and lateral spots often more evident; the black scale spots and crest distinct, as are the black spot above iris, the dark spot below eye, and the black spots on dorsals and caudal; the pupil is white and conspicuous; the large, very fat specimens from Obando are golden above, the pectoral and caudal bases butter yellow. 
Here described from ninety-three specimens obtained in the Manila market, most of them living, and six from Cebu. They range in length from 38 to 82 millimeters. I have also examined the following specimens:

Agno River, Dagupan, Pangasinan Province, 6.

Obando, Bulacan Province (very fine, 84 to 102 millimeters in length), 10.

Malabon, Rizal Province, 6.

Manila Bay, Pasay, Rizal Province, 4.

Estancia, Panay, 1.
Pontevedra, Capiz Province, 3. Capiz, Panay, 3.

Iloilo, Panay, 1.

Dumangas, Iloilo Province, 1.

Molo, Iloilo Province, 5.

Zarraga, Iloilo Province, 89.

Navalas, Guimaras, 2.

Hongkong, 1.

This slender little goby occurs in large quantities in the Manila markets during November, December, and January, being taken from the bangos ponds and estuaries about Malabon. It agrees with Bleeker's long description in his diagnosis of the new and little-known fishes of Java, except that he does not mention the very characteristic spot above the iris of the eye.

From Oxyurichthys cristatus Day this species differs in color, in having no ocellus on the pectoral or the soft dorsal, and in scalation. The probabilities are great that $O$. cristatus is no more than a variety of $O$. microlepis. An examination of the Philippine specimens labeled $O$. cristatus, in the United States National Museum and the Leland Stanford Junior University, shows them to be identical with my material and to be distinct from Day's O. cristatus.

This species occurs elsewhere on the coasts of the Malay Peninsula, Java, Madura, and in the China Sea.

124. OXYURIChthyS PAPUENSIS (Cuvier and Valenciennes)

Gobius papuensis CUVIER and VAlenciennes, Hist. Nat. Poiss. 12 (1837) 80; GüNTHeR, Cat. Fishes Brit. Mus. 3 (1861) 49.

Gobius (Oxyurichthys) papuensis WEBER, Siboga Exped. Fische (1913) 476.

Gobiichthys papuensis JoRdAN and SEALE, Proc. U. S. Nat. Mus. 28 (1905) 796.

Oxyurichthus papuensis JORDAN and RICHARDSON, Check List Phil. Fishes (1910) 50.

Dorsal VI, I-12; anal I, 13; there are 75 to 80 scales in a longitudinal series.

The height of body $\frac{1}{7}$ of total length (without caudal), the length of head 0.25 ; the head $\frac{1}{8}$ longer than high and $\frac{1}{3}$ higher than broad; the eyes very close together, their diameter 
5 times in length of head; the mouth oblique, the maxillary extending to below middle of eye; the teeth of outer series enlarged; the very pointed caudal 0.25 of total length; the first dorsal scarcely exceeds height of body; the rays of second dorsal equal to first or a little less, increasing in length posteriorly.

The color in alcohol grayish brown, clouded with darker; there is a brown spot at base of caudal, another at base of pectoral; the dorsal fins with fine reticulated brownish lines; usually there are three lines under eye, and two longitudinal ones upon jaw and opercle.

The above description is compiled, as I have had no specimens for study. Jordan and Seale had three specimens from the southern coast of Negros.

\section{OXYURICHTHYS VISAYANUS sp. nov.}

Dorsal VI, I-12; anal I, 13; there are 75 to 80 scales in a longitudinal series and about 25 in a transverse series.

The strongly compressed elongate body little elevated, the dorsal and ventral profiles but slightly arched, the depth 5 to 5.4 times in length; the breadth of head greater than that of body and 1.3 in its depth; this is 1.45 to 1.6 in its length, which is 3.88 to 3.95 times in head and trunk together; the profile is convex, the boldly curved snout $3 \frac{1}{5}$ to $3 \frac{1}{6}$ times in head, and with a median bony hump; the eyes dorsolateral, 4.75 times in head and 1.5 times in snout; the narrow interorbital half an eye diameter in breadth; the posterior angle of maxillary extends to beneath pupil or posterior part of eye; about twenty teeth on each side of upper jaw, in a single row, and three rows in lower jaw, those of the inner one much the largest; the entire head naked and the central part of nape scaleless back to origin of first dorsal; in some specimens the entire predorsal region is almost scaleless, only a few, minute, scattered scales being present; on the nuchal ridge is a low, thin, skinny crest; no scales on breast or pectoral bases; the spines of first dorsal have produced tips which sometimes are excessively elongated and threadlike, up to 1.5 times the head for the first and second spines; the second dorsal and anal long, high, increasing in height posteriorly, but the last ray shorter than the two preceding it, when depressed reaching far out on caudal, the posterior rays usually shorter than head but sometimes noticeably longer, the anal a little lower than the soft dorsal; the very long, pointed pectoral is longer than head, sometimes 
almost a half longer, and extends to base of fifth anal ray; the large pointed ventrals sometimes extend to anal and equal or exceed head in length; the narrow caudal peduncle very short, its depth 0.875 of its length and 2.7 times in head; the caudal greatly elongated, the central rays with filamentous tips, 1.5 to 2.2 times in length and $\mathbf{1 . 7 5}$ to more than twice the length of head; the anal papilla elongate and pointed in males, short and subglobose in females.

The color in alcohol gray or yellowish gray, with a series of six oblong, blackish brown blotches along middle of side, the first under pectoral, the last on base of caudal; alternating with these is a series of blackish dorsal blotches, the first in front of spinous dorsal, the last on top of caudal peduncle; on ventral side a series of six blackish bands going upward from anal fin, the first at second and third anal rays; a dark brown spot under eye, and a small circular black spot on upper part of eye, directly above pupil; a dark brown crossband on the naked space behind eyes, passing from the origin of one oculo-opercular groove to that of the other; two brown longitudinal lines, the characteristic papillæ of the genus, on each cheek, and two similar ones on opercle; a blackish diagonal bar on opercle, from upper posterior region running downward and forward; on upper part of pectoral base a large, irregular, dark brown spot; the nuchal crest blackish; the first dorsal dusky with one or two whitish crossbars on upper part, the filamentous prolongations black; the soft dorsal has four or five alternating crossbands of whitish or clear and blackish spots and bands, the tips black; the anal has a basal row of large black spots on the membranes, the margin blackish; the basal portion of pectoral rays yellow, the rest dusky; the ventrals more or less black; the upper half of caudal has circular blackish spots on the membranes, the fin black posteriorly.

Here described from twelve specimens, 52 to 75 millimeters long, collected by me at Cebu, September 16, 1925. None of them was in breeding condition.

This species recalls Gobius papuensis Cuvier and Valenciennes, but is stouter, the depth one-fifth instead of one seventh the length, has a characteristic eyespot not mentioned by either Cuvier and Valenciennes or Günther, the dorsal fins are much higher, and the color markings are different. It differs strongly from the other Philippine members of the genus.

Visayanus, because a native of the Visayan Islands. 
126. OXYURICHTHYS OCULO-MIRUS sp. nov.

Dorsal VI, I-12; anal I, 13; there are 72 to 76 scales in a longitudinal series, about 24 in a transverse series, and 17 to 20 scales before first dorsal.

The long, deep body strongly compressed laterally, the dorsal profile nearly straight, the ventral profile but little curved and tapering upward from origin of anal to caudal; the depth from 5.1 to 6 times in length; the width of head greater than that of body but less than its own depth, its length 3.8 to 4.1 times in head and trunk together; the length of the strongly convex, blunt snout from 3 to 3.4 times in head; the eyes high up, dorsolateral, close together, 3.9 to 4.4 in head; on posterior half of upper part of eye the sclerotic coat forms a low fold which culminates in a teatlike projection; the mouth strongly oblique, with projecting lower jaw, the posterior angle of upper jaw extending to a point below pupil of eye; there are from twentytwo to twenty-four rather widely spaced, fixed, pointed, slightly curved teeth, in each half of upper jaw, extending posteriorly to the extreme angle of mouth; in lower jaw are two rows of much smaller and more closely set teeth which also extend back to posterior angle of mouth; the base of pectoral, the nuchal crest and a space behind eyes, the opercles, and preopercles all scaleless; the snout, preopercles, and a naked space behind eyes all marked by furrows; the anterior nostril very far forward, low down, covered by a very thin walled tubule; the posterior nostril large, open, and on a level with or below lower margin of eye; the scales on trunk irregularly arranged, the posterior ones largest, those on nape smallest; the naked nuchal portion surmounted by a very low skinny fold; the tips of the dorsal spines threadlike, the longest spines equal to depth of body, the first dorsal joined to second dorsal; the base of second dorsal equals that of anal in length, their outline is similar, and the posterior rays of each reach beyond base of caudal when depressed; the next to the last ray in each fin is longest, that of anal equal to or slightly greater than the depth, that of second dorsal considerably longer; the depth of caudal peduncle 2.2 to 2.3 in head; the very long and pointed caudal contained 2.1 to 2.5 times in head and trunk together; the large, broad pectoral extends back as far as above second ray of anal; the tip of the ventrals may reach the short, conical, pointed anal papilla.

The color in alcohol dusky gray above, with a more or less yellowish cast, lighter below and white on belly; eight more or less distinct, dusky crossbands extend from base of dorsal to 
belly or anal; a broad dusky band, ill defined in most of my specimens, extends along the side to the farther end of caudal peduncle and ends in a large, transverse, blackish blotch; the opercle is covered with irregular pearly spots and blotches and has a wide, dark band running diagonally downward and forward; a more or less well-defined large, semicircular, dark brown blotch on base of pectoral fin; the teatlike ocular tentacle white; below eye is a small ill-defined dark patch; the skinny nuchal crest brown; the first dorsal marked by poorly defined dark cross stripes and wider pale bands, the filiform tips black; the soft dorsal barred by four dark crossbands alternating with lighter; the anal and ventrals dusky lilac; the caudal without markings except in one specimen, which shows that in at least the upper half the membrane was dusky, sprinkled with pearly spots.

Here described from seven specimens, 84 to 132 millimeters in length, collected by me in the market at Cebu.

I also place here three specimens, 76 to 105 millimeters in length, collected by Alvin Seale; one specimen is from Cebu, and two are from Davao, Mindanao.

I have a specimen, 112 millimeters long, dredged from about 25 meters near San Nicolas lighthouse, Manila Bay, and two specimens, 77 and 108 millimeters long, from Calape, Bohol.

Oculus, eye; mirus, astonishing.

127. OXYURICHTHYS OPHTHALMONEMA Bleeker

Plate 20, Fig. 3

Gobius ophthalmonema BLEEKER, Nat. Tijd. Ned. Ind. 8 (1856-1857) 208; Günther, Cat. Fishes Brit. Mus. 3 (1861) 48; MEyer, Ann., Soc. Espan̄a Nat. Hist. 14 (1885) 29.

Oxyurichthys ophthalmonema BLEEKER, Act. Soc. Sci. Indo-Neerl. 6 (1859) 120.

Euctenogobius ophthalmonema GüNTHER, Fische der Südsee 2 (18761881) 180 , pl. 111, fig. B.

Pselaphius ophthalmonemus JORdAN and SEALE, Bull. Bur. Fisheries 25 (1906) 406.

Oxyurichthys tentacularis JoRdAN and SEALE, Bull. Bur. Fisheries 26 (1907) 45.

Gobiichthys tentacularis JORDAN and RICHARDSON, Bull. Bur. Fisheries 27 (1908) 278; Seale, Philip. Journ. Sci. § D 9 (1914) 76.

Dorsal VI, I-12; anal I, 13; there are 54 to 56 scales in a lengthwise series, 16 in a transverse series, and 20 to 23 before first dorsal.

The body elongate, thick, plump, with rounded sides, the greatest thickness 1.3 to 1.6 times in the depth, posteriorly compressed, the dorsal profile nearly straight, the ventral one 223793-17 
gently arched from chin to base of caudal, the depth 4.5 to 5.1 times in length; the head of moderate size, 3.5 to 3.8 times in length, its breadth equal to its depth; the snout short, blunt, convex, its length 3 to 3.5 times in head; the eyes dorsolateral, high up, 4.16 to 4.8 times in head and 1.3 to 1.6 times in snout, the posterior margin of eye about equidistant between tip of snout and posterior extremity of head; on upper posterior part of eye, just within the margin, is a slender, pointed tentacle. an outgrowth of the sclerotic coat, its length 1.6 to 3 times in diameter of eye; the interorbital space very narrow, its breadth $\frac{1}{8}$ or a little more than $\frac{1}{3}$ of eye; the posterior angle of maxillary extends to a point beneath pupil or beyond; there are about twenty-five teeth on each side of upper jaw, in a single row; the teeth of lower jaw in three or four rows; in the first instance the two outer rows are minute, those of the innermost one at least twice as large; when four rows are present both the outer and the inner rows are larger than the middle ones; the opercles, preopercles, snout, and nape above the preopercles are scaleless and marked by the lines characteristic of the genus; a low scaleless ridge bearing a low skinny crest extends from first dorsal forward on nape; no scales on base of pectoral; the tips of the dorsal spines more or less threadlike, those of the first four usually elongated and longer than head; sometimes the first one is excessively long and threadlike, extending back beyond posterior end of base of second dorsal; the first four rays of second dorsal lower than body, but the rest all higher than body, the second from the posterior end longest and equal to head; the anal similar in shape but not quite so high, the longest rays a little less than head; the posterior rays of both dorsal and anal extend well upon caudal when depressed; the depth of caudal peduncle $2 \frac{1}{3}$ to $2 \frac{2}{3}$ in head; the caudal elongate and pointed, about 1.8 times in head and body together and a little more or less than twice the length of head; the elongate pointed pectorals may extend to above the third or fourth anal ray; the ventrals may extend to origin of anal; the anal papilla short, slender, pointed.

The color in alcohol dark reddish brown to whitish, with six short, blackish brown crossbars on back and a row of five or six large, blackish brown blotches along middle of side, the one at base of tail darkest; the dorsal scales on anterior half may each have a small dark bar or spot along posterior margin; there are traces of narrow crossbands extending from dorsal bars to 
belly between the lateral blotches and a dusky patch on top of caudal penduncle; there is a dark brown or blackish blotch under eye; the ocular tentacle red to blackish brown; the dorsal fins crossbarred by many, small, black, circular spots and irregular marks; the pectorals crossbarred by black spots, at least on lower half; a diagonal white bar on base of pectoral has a broad, dark brown band above and a smaller one below it; the ventrals and anal blackish; the upper half of caudal marked by oblong black spots, the lower half dusky.

Here described from seventy-two specimens, 50 to 91 millimeters in length, from the zoölogical department of the College of Agriculture at Los Baños. The specimens came from Manila Bay at Pasay. While they differ from Bleeker's description in some minor particulars, they agree in all essentials. Bleeker states "orbita superne tentaculo," which Günther renders "above the orbit;" later Günther, with a specimen before him, wrote "Ein kurzes Tentakel über jedem Auge." In all gobies with ocular tentacles that I have examined, whether in the Philippines or elsewhere, the tentacles have always been an outgrowth of the eye itself, and not placed above it. In a few specimens from Panay only one eye has a tentacle.

In addition to the above I place here a number of specimens, many in bad condition, but apparently all agreeing in scale count; in many of them the coloration is considerably faded or has vanished, except on the fins. They are from 42 to 100 millimeters long. The list follows:

Vigan, Ilocos Sur, 12.

Agno River, Dagupan, Pangasinan Province, 48.

Malabon, Rizal Province, 1.

Pasig River, Manila, 1.

Tondo, Manila, 1.

Cavite, Cavite, 3.

Balayan Bay, Batangas Province, 1.

San Jose, Antique Province, $\mathrm{Pa}$ nay, 5 .
Pontevedra, Capiz Province, 11. Iloilo, Iloilo, 5.

Molo, Iloilo, 5.

Villa, Iloilo, 5.

Dumangas, Iloilo, 15.

Zarraga, Iloilo, 6.

Navalas, Guimaras, 13.

Cebu, Cebu (good specimens), 10.

Davao, Mindanao, 4.

Hongkong, 6.

Meyer collected this species at Cebu; it was recorded under the name Oxyurichthys tentacularis by Jordan and Seale from Cavite and under the name Gobiichthys tentacularis by Jordan and Richardson from Aparri and Iloilo and by Seale from Hongkong. It occurs along the coast or in brackish water and in fresh-water streams not far inland. 
The species is very closely related to O. microlepis Bleeker, but is usually much thicker and plumper. Slender individuals, on which the lateral spots have faded, have a remarkable resemblance to $O$. microlepis, but are readily distinguished by the presence of the tentacle on the eye.

Originally described by Bleeker from Ternate, it has been found in fresh water in the Fiji, Samoa, and Society Islands.

\section{OXYURICHTHYS VIRIDIS sp. nov.}

Dorsal VI, I-12; anal I, 13; there are about 52 scales in a lateral series, 18 in a transverse series, and 17 or 18 scales before first dorsal.

The body elongate, thin, with strongly compressed sides, its greatest thickness twice in the depth, which is 5.4 to 6 times in the length; the head 3.8 to 4 times in length, its breadth less than its depth, 0.85 to 0.95 of the latter; the snout short, blunt, 3.5 to 4 times in head; the eye as long as snout or $\frac{5}{6}$ as long; the tentacle on eye very short, its length 2.5 to 5 times in eye; the posterior margin of eye a trifle nearer tip of snout than to posterior extremity of ilead; the breadth of interorbital area contained 2.5 times in eye; the oblique mouth moderately large, the posterior extremity of maxillary reaching to middle of pupil or beyond; there are eighteen or twenty teeth on each side of upper jaw and two or three rows on lower jaw, the inner row largest, the middle row smallest, if present; the teeth in upper jaw much larger than those of lower jaw; the depth of caudal peduncle is 2.1 to 2.3 times in head; the long pointed caudal 1.8 to 2.1 times in head and body together; the dorsal spines elongate, threadlike, the first one as long as or 0.2 longer than head; the penultimate posterior ray of second dorsal equals the longest dorsal spines, the ultimate one much shorter; the anal similar but lower, its posterior rays longer than body depth; the posterior rays of both anal and second dorsal extend well upon caudal when depressed; the pointed pectoral may extend back as far as first anal ray; the ventrals rather short, not nearly reaching anus; the anal papilla long, slender, and pointed. In other respects it agrees with $O$. ophthalmonema.

In life the color was pale yellowish gray, with about five indistinct, dusky crossbands over back, the sides more or less shot with golden green; the head and inside of mouth were also golden green; the eyes were lapis lazuli, with a deep red tentacle; a rounded blackish spot at base of caudal; a whitish bar on base of pectoral with a dusky bar above and below it. 
In alcohol the green, blue, and red disappear, leaving the general color as in life but paler; the dorsal spines and rays are lightly crossbarred by dark spots; the lower half of the pectoral is crossbarred by pale and dark spots; the membrane of the ventrals, anal, and lower half of the caudal blackish.

Here described from four specimens obtained from the Manila market, varying in length from 72 to 86 millimeters.

I also refer here fourteen specimens, 49 to 78 millimeters long, from Navalas, Guimaras Island, and four from Capiz, Panay.

Viridis, green.

\section{Genus 50. PARAPOCRYPTES Bleeker}

Parapocryptes BleEker, Arch. Neerl. Sci. Nat. 9 (1874) 327.

The upper jaw has a single row of sharp-pointed, curved teeth, some of them more or less caniniform, or it may have at the center four enlarged, stout teeth, with a long row of small, sharppointed teeth running back on each side; in the lower jaw is a single row of small, slender, outward-inclined teeth, which may terminate in one or two larger, almost caninelike teeth; behind symphysis is a pair of canines; all teeth have entire tips; the elongate body covered with small scales, much larger posteriorly, 65 to 75 in a longitudinal series, the body and head naked before first dorsal, or the scales extending forward to eyes and over opercles, where they are minute; the first dorsal has six flexible spines and is placed some distance before the long second dorsal, which has from 12 to 30 rays; the anal long, with 13 to 26 rays; the ventral fins are attached only at their bases; no silky pectoral rays; the caudal lanceolate; gill openings as wide as pectoral base, the isthmus rather broad; branchiostegals 4 .

Species few, occurring in estuaries and the tidal reaches of rivers along the coasts of Asia from India to China, and in the East Indies.

This genus, as here limited, may be divided into two sections. Paeneapocryptes is distinguished by the small number of dorsal and anal rays, and by the naked head, nape, and adjacent parts. True Apocryptes may be limited to those having more than 20 rays in the dorsal and anal fins.

Key to the China Sea and Philippine species of Parapocryptes.

$a^{1}$. Paeneapocryptes: Dorsal VI, I-12; anal I, 13. P. mindanensis.

$a^{2}$. Parapocryptes: Dorsal VI, I-25 to 30 ; anal I, 26 to $29 . .$. P. serperaster. 
129. PARAPOCRYPTES (PAENEAPOCRYPTES) MINDANENSIS sp. nov.

Plate 20, Fig. 4

Dorsal VI, I-12; anal I, 13; there are about 70 scales in a longitudinal series.

The depth of the slender elongate body 7.17 times in the length; the head large, blunt, wider and deeper than body, 3.75 times in length, its depth 1.76 times in its length, its breadth 0.9 of its depth; the broad, bluntly rounded snout descends from eyes in a bold curve, and equals eye, 3.8 times in head; the eyes very high up, dorsolateral, their inner margins a hair's breadth apart; the mouth oblique, the lower jaw projecting, the enlarged posterior angle of maxillary reaching beneath posterior part of eye; the teeth in upper jaw of unequal size, some of them large, hooked; the teeth in lower jaw much smaller, none of them enlarged, the postsymphysial canines minute; the head, nape back to the first dorsal, breast, and base of pectorals naked; the dorsals close together, the first spine of first dorsal much elongated, with hairlike tip, a little longer than head, 3.66 times in length; the second dorsal and anal approximately equal, the posterior rays longest, 1.76 times in head, the fins reaching caudals when depressed; the caudal peduncle 1.4 times in its length, $3 \frac{1}{7}$ times in head; the long, pointed caudal 2.5 times in length; the pectoral 1.46 times in head; the pointed ventrals nearly reach anus, 1.25 times in head.

The color in alcohol uniform very pale yellowish brown, with a series of four light brown, elongate spots along middle of side, and a large, nearly circular spot on base of caudal; at base of each dorsal spine and ray is a brown spot; the first dorsal pale brown, with a large, dark brown basal spot behind sixth spine; the second dorsal very pale brown; the anal clear with a dark brown margin; the ventrals blackish, the outer margins pale; the other fins clear.

Here described from the type and only specimen, 33 millimeters long, obtained on the south coast of Cotabato Province.

Mindanensis, from Mindanao.

130. PARAPOCRYPTES SERPERASTER (Richardson)

Apocryptes serperaster RICHARDson, Ichthy. China, Report Brit. Ass. Ad. Sci. 15 (1845) 206; GüNTHER, Cat. Fishes Brit. Mus. 3 (1861) 82; DAY, Fishes of India (1878) 300, pl. 6, fig. 2.

Dorsal VI, I-25 to 27 ; anal I, 26 ; scales in a longitudinal series 65 to 70 . 
I place here a poor specimen, 52 millimeters long, collected at Fu-chow, Fukien Province, China, by Light. Dorsal VI, I-25; the scales numerous, their number uncertain as many have been lost anteriorly, but between 70 and 80 in a longitudinal series; the scales on posterior half large, those before first dorsal very small, those on opercles minute, in many rows; the cheeks, snout, and interorbital naked; the body elongate, subcylindrical anteriorly, the posterior half laterally compressed, the dorsal and ventral profiles nearly horizontal, the depth 8 times in length; the robust head 4.33 times in length, its breadth much more than that of body, greater than its own depth, 1.9 in its own length; the truncated snout convex in profile, 4.6 times in head and slightly more than eye, which is 4.8 times in head; the eyes dorsal, placed obliquely, very close together, the interorbital 2.66 times in an eye diameter; the mouth large, oblique, the posterior angle of maxillary reaching below posterior margin of eye; in upper jaw is a row of four enlarged, stout teeth and beginning behind the two lateral ones is a long row of very small, sharp pointed teeth; in lower jaw is a row of small semihorizontal teeth, the last two on each side a little larger, with a pair of stout, divergent canines behind symphysis; the first dorsal rather high, the fifth spine half as long as head, the tips of the spines extending upon second dorsal when depressed; the second dorsal and anal low, the posterior rays highest and extending upon caudal when depressed; the narrow elongate pointed caudal 3 times in length and 1.4 times head; the pectoral broadly pointed, 1.5 times in head and 6.5 times in length; the ventrals broad, with pointed tip, 0.125 shorter than pectorals, 7.42 times in length, 1.71 times in head.

The color in alcohol uniform yellowish brown.

This species occurs along the coast of southern China, westward to Bengal. I believe it occurs on the llocano coast of the Philippines, though I have no authentic specimens from there.

\section{Genus 51. APOCRYPTICHTHYS Day}

Apocryptichthys DAY, Fishes of India (1878) 302.

The body elongate, the flat head anteriorly depressed, the mouth low down, very large, extending beyond eye; in upper jaw is a single row of small, blunt, subcylindrical teeth, with two or four long downward-curved pointed canines at front; in lower jaw is a single row of rather long, blunt, horizontal teeth of uniform size, with no canines behind symphysis; no bar- 
bels; a pair of large, pointed flaps hang from snout down over mouth opposite eyes; the body covered with cycloid scales, 70 to 90 in a longitudinal series, rather large near base of caudal, becoming very small on anterior half, minute anteriorly; the predorsal region naked along median line or only apparently naked with the scales deeply embedded in the skin, and difficult to make out with a strong lens, becoming more prominent on the bony occiput; the top and sides of head entirely covered to eyes, not naked as stated by Day; the dorsals separate but very close together, or their membranes more or less connected basally; the first dorsal of six flexible spines, the sixth one widely spaced from the first five; the second dorsal and anal elongate, nearly reaching caudal but entirely distinct from it; the caudal lanceolate, shorter than head; the ventrals united, not adnate to belly; the pectorals moderate, pointed; the gill opening small, about half as wide as pectoral base, beginning before lower half of pectoral and running diagonally forward, the isthmus broad; branchiostegals 5. Dorsal VI, I-24 to 26; anal I, 23 to 26.

Heretofore known only from the coast of Madras and the Andaman Islands.

\section{APOCRYPTICHTHYS SERICUS sp. nov.}

Plate 21, Fig. 1

Dorsal VI, I-24 to 26; anal I, 23 to 26 ; scales in a longitudinal series 75 to 85 , in a transverse series about 22 to 24 .

The long, low body subcylindrical anteriorly, laterally compressed on posterior half, the tail shorter than head and trunk together, 42 to 44 per cent of total length, the depth $6: 2$ to 7.2 times in length; the low flat head depressed anteriorly, inclined downward from nape to tip, its undersurface flat, 3.4 to 3.66 times in length; its breadth 1.8 to 2.18 times in its own length and from a little more to nearly a half more than its own depth; the snout short, truncate, 4.33 to 4.6 times in head, exceeding eyes which are $\frac{1}{6}$ or $\frac{1}{7}$ of head, dorsal, prominent, from $\frac{2}{8}$ to more than an eye diameter apart; the upper lid of eye wide, colored like the skin on top of head, the eyes in a large, shallow, bony pit; a large angular, pointed, teatlike flap of skin projects at each forward angle of snout opposite eye and hangs down over lower jaw; the jaws equal; the very large mouth commences below lower edge of eye, the posterior angle of maxilla extending far beyond a vertical from posterior margin 
of eye, up to at least two eye diameters beyond, the length of maxilla 1.5 to 1.7 times in head; at the center front of upper jaw a shallow notch with one or two very large curved canines protruding downward beyond lower jaw like miniature walrus tusks; running back from these along edge of jaw is a single row of small teeth as given for the genus; the teeth in lower jaw embedded on the under, outer side, conspicuously visible when the fish is turned over, their characters as given for the genus; at symphysis is a hump fitting into the notch in upper jaw; the entire body covered with small cycloid scales, those on tail much larger than those on trunk; the median predorsal region may be practically naked, but a strong lens usually shows the presence of very small scales deeply embedded in the skin; above the preopercles they are more prominent, and extend forward to the margin of the ocular pits; the opercles and preopercles covered with minute scales to eyes; the snout and region below eyes naked; the first dorsal entirely separated from second in one specimen, but in the others more or less completely united; the sixth spine separated by a wide space from the rest of the spines but the membrane continuous; the first spine very low, the fifth and sixth longest, 3.5 to 4 times in head; the second dorsal very long, ending just before caudal, the posterior rays longest, a trifle higher than first dorsal, 2.7 to 3.5 times in head; the anal like second dorsal but lower, its last rays equal to first dorsal in height; the caudal broadly lanceolate, 4.25 to 5.3 times in length, from a little more than 0.5 to 0.75 the length of head; the pectorals broadly pointed, 1.5 to 1.8 times in head; the round, pointed ventrals equal to or a little shorter than pectorals.

The color in alcohol dull bluish to brownish, paler beneath; the smallest specimen shows seven or eight dorsal crossbands posteriorly, the last at base of caudal, the first two near middle of length and very vague; the top of head and predorsal region marbled with many small, irregular, dark brown spots, blotches, and lines; the upper lip blackish brown; there is a large, deep violet-brown or bluish brown blotch on base of pectoral, extending upon rays, the remainder of the fin dusky to yellowish; on upper part of the elongated posterior second dorsal rays is a large black spot; the membrane of second dorsal more or less brown between the rays; the caudal dusky with pale margin above and below; the ventrals and anal yellowish.

Here described from four excellent specimens, 51 to 80.5 millimeters in length, from Amoy, China, and one specimen, 41 milli- 
meters long, in poor condition, from Fu-chow, Fukien Province, China, all collected by Light. The type is No. 11009 Bureau of Science collection.

In general appearance this species is very close to Day's $A$. cantoris; his figure, though poor, shows the characteristic form of the head.

Sericus, Chinese.

\section{Genus 52. ACANTHOGOBIUS Gill}

Acanthogobius GIL, Proc. Acad. Nat. Sci. Phila. (1859) 145.

The elongate body rounded, little compressed posteriorly; the head large, wide, snout long, the mouth large, inferior; the tongue truncate or very slightly notched; 48 to 72 scales in a longitudinal series, the nape scaled, some rows of minute scales on cheeks; dorsals separate, VIII, I-14 to 18; anal I, 11 to 15; caudal pointed or rounded, less than or equal to head; no silky rays above on pectoral ; isthmus broad, the gill openings slightly continued forward at their lower end; branchiostegals 4 .

Rather large gobies, from the coasts of China and Japan.

132. ACANTHOGOBIUS OMMATURUS (Richardson)

Gobius ommaturus RICHARDson, Zool. Voy. Sulphur, Ichthyology, part 3 (1845) 146, pl. 55, figs. 1-4; GüNTHER, Cat. Fishes Brit. Mus.

3 (1861) 77; Rendahl, Arkiv Zoologi 16 (1924) 23.

Acanthogobius ommaturus BleEker, Ned. Tijd. Dierk. 4 (1873) 128;

Jordan and Seale, Proc. U. S. Nat. Mus. 29 (1906) 528.

Dorsal VIII, I-16 to 18 ; anal I, 14 or 15 ; there are 68 to 72 scales in a longitudinal series and about 16 in a transverse series.

The slender body much elongated, the rounded belly more prominent than the dorsal profile; the depth 9 times in length in large specimens, 6.5 in small ones; the large broad head contained 4.15 times in length, its depth equal to 0.75 its own width; the eye high up, partly dorsal and partly looking obliquely sideways, 5.7 to 5.8 times in head, twice in the convex snout, and longer than the width of interorbital space; the mouth inferior, the lower jaw shorter than the upper, the posterior maxillary extremity reaching to beneath front margin of eye; the teeth in several rows, the outer one enlarged; the caudal peduncle slender and elongated, its least depth $3 \frac{1}{3}$ times in its length; the entire trunk and bases of pectorals scaled; the head naked except along nape, a few small scales below groove running from eye to posterior angle of opercle, and a row or two of minute scales 
running horizontally across middle of cheek; below the lastnamed is a row of minute beadlike pores and there is a pair of similar rows on each limb of lower jaw; the vertical fins of moderate height, the caudal elongated, nearly or quite equal to head.

The color in alcohol yellowish, becoming whitish on belly; a large dark spot at base of caudal and traces of ten similar spots along middle of sides; the dorsals and caudal crossbarred by rows of dark spots.

Here described from five specimens, 80 to 172 millimeters in length, collected at Amoy, China, by Light.

This strongly marked species is known only along the coast of China, north to the Gulf of Chihli, but is to be expected in Formosa and the Batan Islands.

\section{Genus 53. SYNECHOGOBIUS Gill}

Synechogobius GiLl, Proc. Acad. Nat. Sci. Phila. (1863) 266.

This genus is distinguished by its elongate, almost eel-like form, and by the presence of eight or nine first dorsal spines.

The head is very large, deeper and broader than the trunk, which is strongly compressed, with a ribbonlike caudal peduncle; the mouth large, oblique, low, with two rows of coarse teeth in each jaw; the eyes large, dorsolateral; the body covered with minutely ctenoid scales, rather large posteriorly, very small before first dorsal and extending almost to eyes; the upper part of opercle covered with small scales; the cheeks, snout, and interorbital naked; the pointed caudal longer than head; the pectorals and ventrals broad, the dorsals widely separated; the gill opening large, inclined forward, the isthmus broad, branchiostegals 4.

Dorsal VIII or IX, I-18 or 19 ; anal I, 15 or 16 ; scales in a longitudinal series 88 to 90 .

A single species is known; it ranges from Nagasaki in southern Japan to Swatow, China.

133. SYNECHOGOBIUS HASTA (Schlegel)

Plate 21, Fig. 2

Gobius hasta Schleger, Fauna Japonica, Pisces (1842) 144, pl. 75, fig. 1; Günther, Cat. Fishes Brit. Mus. 3 (1861) 78.

Synechogobius hasta BLEEKER, Ned. Tijd. Dierk. 4 (1873) 129; JoRDAN and SNYDer, Proc. U. S. Nat. Mus. 24 (1901) 102.

Dorsal IX, I-18; anal I, 15; scales in a longitudinal series, 88 ; in a transverse series, 14. 
The body very elongate, with a notably elongate caudal peduncle, very strongly compressed, especially the tail which is $\frac{10}{19}$ of the total, longer than head and trunk together, the deptin 10.66 times in length; the large, blunt, oblong head 4.8 times in length, its breadth a trifle more than half its length and greater than its depth, which nearly equals that of body; the long, convex snout broadly rounded, 2.8 times in head; the eyes laterodorsal, in a large bony pit, twice in snout and 5.7 times in head; the interorbital $1 \frac{1}{6}$ times in eye, $2 \frac{1}{3}$ times in snout; the mouth very large, with thick lips, moderately oblique, the posterior angle of maxillary beneath pupil of eye; the teeth coarse, stout, not very long, in two rows in each jaw, reduced to one row posteriorly, the teeth in upper jaw a trifle lower than those below; the scales as given for the genus; the first dorsal of nearly uniform height, the tips of the spines filiform, not quite equaling depth, 2.28 times in head, not reaching second dorsal when depressed; the second dorsal longer posteriorly, the next to the last ray longest, the last two rays with elongate tips, 1.9 in head; the anal similar to second dorsal, but scarcely as high, the last two rays elongate, 2 in head; the depth of the long, slender, caudal peduncle 4.4 times in its own length, which is 0.1 longer than head, and 0.44 of the length of tail; the long, narrow, pointed caudal fin 1.225 times the length of head and 3.9 times in total length; the pectorals pointed, a little more than 1.5 times in head; the ventrals broad, round pointed, 0.6 of the length of head and reaching a little more than halfway to anus; the anal papilla long, conical.

The color in alcohol uniform light brownish, paler beneath, the caudal blackish; a pale lunate mark near base of caudal rays; the soft dorsal has four longitudinal rows of elongate brown spots; the other fins uniform very pale yellowish.

Here described from a specimen, 192 millimeters long, or 242 millimeters including caudal fin. It was obtained at Amoy by Light. This fish occurs from southern Japan to the coast of southern China.

\section{Genus 54. ILLANA Smith and Seale}

Illana Smith and SeaLe, Proc. Biol. Soc. Washington 19 (1906) 79.

This genus is characterized especially by the presence of two fleshy barbels on chin; the mouth small, oblique, with projecting lower jaw; in upper jaw is a row of large, stout teeth, followed by three rows of minute, depressible teeth; in lower jaw is an outer row of stout teeth much smaller than those of upper jaw, 
behind which are two rows of minute depressible teeth; no canines; the body moderately elongate, compressed above, with large ctenoid scales, 30 to 32 in a longitudinal series; the head large, naked, with prominent longitudinal lines of minute warts on cheeks. Dorsals VI, I-9, the second spine of first dorsal elongated; anal I, 9; no silky rays on upper part of pectoral; the rounded caudal shorter than head.

Only a single species is known of this Philippine genus.

\section{ILLANA CACABET Smith and Seale}

\section{Plate 21, Fig. 3}

Illana cacabet Sмiтн and Seale, Proc. Biol. Soc. Washington 19 (1906) 80 , with text figure.

Dorsal VI, I-9; anal I, 9; there are 30 to 32 scales in a longitudinal series, 10 in a transverse series, and 13 before first dorsal.

The body elongate, laterally compressed with long, slender caudal peduncle, the dorsal profile well arched, descending in a steep, nearly straight line from first dorsal to tip of snout, the ventral profile nearly horizontal, the depth 6 in length; the head large, its breadth equal to body depth, blunt, with projecting jaw, and contained 3.6 times in head; the eyes close together, high up, obliquely dorsolateral in position, nearly as long as snout, $1 \frac{1}{9}$ times in snout; the flat interorbital contained 2.25 times in eye; the caudal peduncle contained 10 times in length, a little less than 3 times in head, and $2 \frac{1}{6}$ times in its own length; the plump naked cheeks crossed by five longitudinal rows of minute papillæ and warts on their lower half; the lower margins of preopercle and subopercle are fringed with fine papillæ, and on opercle is a similar row running diagonally backward and downward; the barbels on chin are very short, 2.5 times in eye; the anal papilla small, rounded, conical; in my specimen the fins are too badly mutilated to show their original condition, except the ventrals which reach beyond anal papilla almost to origin of anal; the original description says, "spinous dorsal with the second spine elongate, in males extending to or beyond middle of soft dorsal; longest dorsal ray 1.6 in head; pectorals 1.1 in head; ventrals 1.35 in head; origin of anal fin midway between tip of snout and base of caudal; base of anal 1.2 in head, its longest ray 1.75 in head; caudal rounded, 1.1 in head."

The color in alcohol brown, with five large, dark reddish brown spots along midline of side, the last at base of caudal; three 
broad, indistinct, dark brown crossbands over back, the first under posterior part of first dorsal and behind it, the second under anterior part of second dorsal, the third under posterior part of second dorsal and over anterior part of caudal peduncle; the interorbital space marked by irregular brown spots and lines.

Here described from one of the cotypes, a specimen, 61 millimeters long, collected from the Rio Grande de Mindanao, Cotabato, Mindanao, in 1903, by Doctor Morse.

This unique species is known only from three specimens secured by Doctor Morse; the type and the other cotype are in the United States National Museum.

\section{Genus 55. PARACHAETURICHTHYS Bleeker}

Parachaeturichthys BLEEKER, Arch. Neerl. Sci. Nat. 9 (1874) 325; Jordan and SNYder, Proc. U. S. Nat. Mus. 24 (1901) 103.

The moderately elongate body covered with rather large ctenoid scales; the head rounded in profile, not depressed above, the eyes close together; the body covered everywhere with large scales, which extend forward upon interorbital space to posterior part of snout and on cheeks, those on head, nape, and anterior underparts cycloid, the rest ctenoid; the mouth oblique, of medium size, the teeth simple, in narrow bands of about five rows in each jaw, the outer ones enlarged, without true canines; the chin bears many small barbels on each side along underside of jaw; the dorsal fins short, separate; the pointed caudal much longer than head, with a conspicuous black ocellus on upper part near base; there are no free silklike rays on upper margin of pectoral; the isthmus broad, the gill openings narrow, not continued forward below; branchiostegals 4 ; dorsal VI, I-10; anal I, 9 ; scales in a longitudinal series, 28 to 32 .

There is but one species known; it occurs along the coasts of India, China, and southern Japan, and in the Philippines.

135. PARACHAETURICHTHYS POLYNEMA (Bleeker)

Plate 21, Fig. 4

Chaeturichthys polynema BuEEKER, Verh. Bat. Gen. 25 (1853) 44, fig. 4.

Gobius polynema GÜNTHaR, Cat. Fishes Brit. Mus. 3 (1861) 46; DAY, Fishes of India (1878) 286, pl. 61, fig. 8 .

Parachaeturichthys polynemus JoRdAN and SNYDER, Proc. U. S. Nat. Mus. 24 (1901) 103; Jordan and Seale, Proc. U. S. Nat. Mus. 29 (1906) 528. 
Dorsal VI, I-10; anal I, 9; there are 28 to 32 scales in a longitudinal series, 9 in a transverse series, and 16 to 19 before first dorsal.

The body elongate, somewhat compressed, with deep, much compressed caudal peduncle and large, broad head, the depth 5.1 to 5.5 times, the head 3.4 to 3.7 times in length; the head broader than deep, the blunt, broad convex snout 3.6 to 4 times in head; the eye equals or is slightly longer than snout; the eyes very high up, dorsolateral, their gaze upward as well as sideways; the interorbital 1.5 to 1.8 times in eye; the mouth slightly oblique, the jaws equal, the posterior angle of maxillary beneath anterior part of eye or front margin of pupil; in upper jaw the outer row is of enlarged, curved, caniniform teeth, followed by a band of four rows of small, slender, depressible teeth, those of the innermost row a little longer than the rest; the teeth of lower jaw have the same arrangement, but those of outer row are hardly as large as in outer row above, while those of the inner band are coarser than those in upper jaw; rows of slender barbels occur on underside of lower jaw, along median line of chin and on the branchiostegal region; the body covered with rather deciduous scales, those on sides ctenoid, those on nape, head, and anterior underparts cycloid, the scales extending forward on head between eyes and almost to tip of snout; the middle spines of first dorsal longest, extending upon second dorsal when depressed, 1.8 to 2 times in head; the second dorsal and anal high, the latter slightly exceeding the former, angulate, the posterior rays longest, reaching caudal when depressed, equal or nearly equal to depth, and 1.4 to 1.8 times in head; the depth of caudal peduncle 1.75 times in its own length, which is equal to the depth; the very long, pointed caudal $\frac{1}{3}$ longer than head and 2.7 to 2.8 times in length; the pointed pectoral 0.1 longer than head; the ventrals broad, with a wide strong frenum, their margin incised, pointed, 1.3 times in head, the tip never reaching anus; the anal papilla slender and pointed.

The color in alcohol dusky brown, paler below, without distinct markings; the fins all dusky or blackish; a large, black, yellow-margined oval ocellus lies on basal part of caudal, just below its upper margin.

Here described from a specimen, 51 millimeters long, collected at Iloilo by Montalban in July, 1925, and seven specimens, 44 to 82 millimeters long, collected at Amoy, China, by Light. 
This easily recognized species has heretofore been known only from Madras, India, and the coasts of China and southern Japan.

Since writing the above I have obtained three specimens, 73 to 86 millimeters in length, dredged from Manila Bay near San Nicolas lighthouse, at a depth of about 25 fathoms.

\section{Genus 56. LOPHIOGOBIUS Günther}

Lophiogobius GüNTHER, Ann. \& Mag. Nat. Hist. IV 12 (1873) 241.

Body rather elongate, covered with 36 to 40 scales of moderate size, larger posteriorly, the caudal peduncle very slender; the head large, depressed, the mouth wide, oblique, the lower jaw large, prominent, projecting; the teeth of outer row in each jaw rather large, subhorizontal, projecting, widely spaced, entirely exposed, outside the thin lips; some distance within outer row is another row of much smaller teeth pointing inward; the tongue large, broad, the tip nearly truncate; the palate smooth; the sides of head papillate across cheeks, and an extraordinary growth of barbels over the flat undersurface of head from chin back to posterior margin of preopercle and running up the latter; the dorsals comparatively far apart; the ventrals not adherent to belly; the gill openings wide, the isthmus narrow; branchiostegals 5. Dorsal VII, I-15 or 16.

Günther stated that the first spine of the dorsal is "stiff and pungent." I do not find it so, it being merely a little less flexible than the others, but otherwise similar. Günther fails to mention the remarkable development of barbels. I have seen no specimens other than my own; there can be no doubt of their belonging to this peculiar genus, which is known only from the coasts of China and southern Manchuria.

136. LOPHIOGOBIUS OCELLICAUDA Günther

Plate 22, Fig. 1

Lophiogobius ocellicauda GüNTHER, Ann. \& Mag. Nat. Hist. IV 12 (1873) 241; Evermann and Shaw, Proc. Calif. Acad. Sci. IV 16 (1927) 120.

Ranulina fimbriidens JoRdan and StaRks, Proc. U. S. Nat. Mus. 31 (1906) 523, fig. 3.

Dorsal VII, I-15 or 16 ; anal I, 16 or 17 ; there are 38 to 40 scales in a longitudinal series, 12 in a transverse series, and 18 or 20 before first dorsal.

The long, low, slender body laterally compressed, the posterior half very slender and low, the depth just before first dorsal 6.3 to 6.7 times, the depth of caudal peduncle 19.6 to 20 times in length; the head very large, broad, flat, depressed, tad- 
polelike, 3.1 or 3.2 , exceptionally 3.66 times, in length, its breadth 1.5 to 1.7 times its depth and about 1.5 times in its own length; the very broad, rounded snout 3.1 to 3.5 times in head; the eyes very small, laterodorsal, set in a depression, 2.66 to 3 times in snout, 2 to 2.4 times in interorbital, and 9 to 9.5 times in head in older specimens, 5 or 6 times in younger ones, the eye in anterior half of head, the postorbital much longer than preorbital; a low bony ridge on interorbital some distance above eye is met at nearly a right angle by one behind eye which crosses head, making a depression on central part of interorbital; the mouth very large, oblique, beginning at upper profile on a level with or above eyes, the lower jaw very prominent, projecting, its tip as high as eye, the posterior angle of maxillary extending downward to underside of head and very far back behind eye nearly to posterior inferior angle of preopercle; the teeth as given under the genus; the margin of the preopercle, the rami of the jaws, and the branchiostegal margins and the whole flat lower surface of chin fringed or thickly sprinkled with barbels; the scales posteriorly very large, gradually becoming smaller anteriorly, those before first dorsal much smaller and extending forward in line with anterior margin of opercles; the opercles covered with small scales and there are four rows of scales on upper posterior part of preopercles, these reduced to two rows of larger scales beneath eye; a row of papillæ crosses cheek beneath the scales, its anterior part becoming barbels; some barbels present above angle of mouth; the vertical fins low, approximately of the same height, about 2.4 to 2.8 in head, the second spine of first dorsal longest, not nearly touching second dorsal when depressed, the anterior rays of second dorsal longest, the posterior rays not reaching caudal when depressed; the anal a little lower, the posterior rays usually longest and reaching caudal when depressed; the depth of the attenuated caudal peduncle 2.5 to 2.6 times in its own length; the caudal small, elongate, pointed, a good deal shorter than head, 4 to $4 \frac{1}{3}$ times in the length; the large, broad, long-pointed pectoral equals or nearly equals head; the ventrals large, broad, with dactyliform, lobulate margin, 1.3 to $\mathbf{1 . 5}$ times in head.

The color in alcohol pale yellowish brown, darker above, paler below; the scales on upper half margined with blackish specks, which are arranged in irregular, vermiculated, broken bands on top of head; on base of caudal rays is a large black, yellowmargined ocellus, with three lunate black crossbands on fin beyond it; the other fins all clear. 
Here described from six specimens, 76.5 to 91 millimeters in length, collected by Light at Fu-chow, Fukien Province, China.

Hitherto known only from Günther's original description of specimens from Shanghai.

\section{Genus 57. AMBLYCHAETURICHTHYS Bleeker}

Amblychaeturichthys BleEker, Esq. Syst. Gobioides, Arch. Neerl. Sci Nat. 9 (1874) 324.

This genus is separated from Chaeturichthys by having a smaller number of scales, fewer rays in the soft dorsal and anal, and by the absence of fleshy papillæ on the inner edge of the shoulder girdle. The body laterally compressed, with 32 to 40 scales in a lateral series; the head is scaled and has three pairs of small barbels under lower jaw; the teeth of upper jaw in two rows, the outer ones enlarged, fixed, straight, awl-shaped; those of lower jaw in three rows in front, two at sides, those of outer row longest, straight, depressible, directed obliquely inward; the tongue truncate. Dorsal VIII, 15 to 17 ; anal I, 12 or 13; caudal pointed or rounded, a little more or less than head; no silky rays above on pectoral.

This group comprises a few small, plainly colored gobies from the coasts of China and Japan.

\section{AMBLYCHAETURICHTHYS HEXANEMA Bleeker}

Chaeturichthys hexanema Blekker, Verh. Bat. Gen. 25 (1853) 43, fig. 5; JoRdAN and SNYDer, Proc: U. S. Nat. Mus. 23 (1901) 372.

Amblychaeturichthys hexanema BLEEKER, Esq. Syst. Nat. Gobioides, Arch. Neerl. Sci. Nat. 9 (1874) 325.

Gobius hexanema GüNTHER, Cat. Fishes Brit. Mus. 3 (1861) 77; SteiNdACHNER, Sitzungsber. Akad. Wien 102 (1893) 237.

Chaeturichthys hexanemus JoRDAN and SNYDER, Proc. U. S. Nat. Mus. 24 (1901) 106.

Dorsal VIII, I-15 or 16 ; anal I, 12 or 13 ; there are about 38 to 40 scales in a lateral series and 14 or 15 in a transverse series.

The body subcylindrical anteriorly, soon much compressed laterally, with thin, flat caudal peduncle; the head rather large, blunt, its breadth equal to distance from tip of snout to rear margin of eye; the dorsal and ventral profiles but little curved, the greatest depth 5.8 times, the head 3.2 to 3.3 times in length; the eyes large, very high up but more lateral than superior, 3.5 to 3.6 in head and very close together, the interorbital space 0.2 to almost $\frac{1}{3}$ an eye diameter; the snout short, broadly rounded, 
with a prominent median hump, its length 1.2 in eye and 4.2 to 4.4 in head; the mouth oblique, the maxillary not quite extending to a point under front edge of pupil; the body covered everywhere with scales except on snout, lower jaw, and throat, those on opercles and preopercles smaller than elsewhere.

The longest dorsal spines contained twice in head; when depressed the spines of first dorsal reach origin of second dorsal; the anal shorter than second dorsal, similar in outline and of approximately the same height, the posterior rays longest and equal to greatest depth of body; the depth of caudal peduncle contained 3 times in head; the pointed caudal a trifle longer than head; the pectorals slightly exceed the ventrals in length, and fall far short of reaching anus.

The color in alcohol yellowish brown, without distinctive markings, the scales having been largely rubbed off; the tips of dorsal spines blackish; the other fins all more or less dusky.

Here described from two specimens, 58 to 70 millimeters long, collected at Fu-chow, Fukien Province, China, by Light. This little fish is abundant throughout Japan, in bays and estuaries, and was recorded by Steindachner from Swatow, China. It may occur on the northwest coast of Luzon.

\section{Genus 58. CHAETURICHTHYS Richardson}

Chaeturichthys RICHARDson, Zoology, Voy. Sulphur, Ichthyology, (1844) 54; JoRdAN and SNYDER, Gobioid Fishes of Japan, Proc. U. S. Nat. Mus. 24 (1901) 104.

The distinctive characters of this genus are the presence of three small barbels on each side of lower jaw, the elongate,dorsal and anal, and the presence of three fleshy papillæ on inner edge of shoulder girdle. The moderately elongate body covered with medium-sized cycloid scales very easily rubbed off; the head broad, with arched profile, scaly cheeks, and eyes close together; the mouth oblique, with truncate tongue, and pointed teeth in two rows in each jaw, those of outer row longest, close together, fixed, curved, and directed obliquely inward; the isthmus narrow, the gill openings continued well forward; the first dorsal has 8 slender spines, the second dorsal 21 to 25 rays, the anal I, 17 to 20 ; the caudal is more or less pointed, longer than head; the pectorals pointed, without silky rays.

This genus includes a few species of medium-sized, dull-colored gobies from the seas of Japan and China. 
138. CHAETURICHTHYS STIGMATIAS Richardson

Chaeturichthys stigmatias RICHARDSON, Zoology, Voy. Sulphur, Fishes (1844) 55, pl. 35, figs. 3-5; JORDAN and SNYDER, Gobioid Fishes of Japan, Proc. U. S. Nat. Mus. 24 (1901) 105; JoRdAN and METZ, Cat. Fishes of Korea, Mem. Carnegie Mus. 6 (1913) 57.

Gobius stigmatias GüNTHER, Cat. Fishes Brit. Mus. 3 (1861) 78.

Dorsal VII, I-21 or 22; anal I, 17 to 19 ; the scales are almost all gone in my specimens but the scale pockets in the skin indicate from 47 to 50 scales in a lateral series and 14 or 15 in a transverse series. Günther gives 53 scales, Jordan and Snyder give 57 , in a lateral series.

The body elongate, the posterior half much compressed laterally; the head large, blunt, broad, its width equal to or greater than its postorbital length; the eyes obliquely superior, 5.5 to 6 times in head and 1.5 to 1.7 times in the broadly rounded snout; the interorbital space equal to or 0.25 greater than eye; the mouth oblique, the posterior angle of maxillary extending to middle or posterior part of eye; there are two rows of teeth in each jaw, those of outer row much the larger, caniniform, and curving inward; there are three fleshy papillæ on inner edge of shoulder girdle; fine scales between first dorsal and eyes, and on opercles and preopercles; the scales on body become larger posteriorly.

The dorsals widely separated, the first dorsal not reaching second when depressed; the dorsal rays become longer posteriorly, and reach caudal when depressed; the anal shorter and lower and its rays do not reach caudal; the very long pointed caudal exceeds head and may be nearly twice as long; the short accessory dorsal and ventral rays of caudal grow far forward on caudal peduncle; the pectorals are pointed and sometimes extend to vent; the ventrals free except at base.

Alcoholic specimens usually pale, due to the loss of scales, but where they are present the top of head, back, and upper part of sides are spotted and mottled with groups of dark brown specks; the first dorsal has a large black spot from sixth spine to hind margin; the second dorsal, anal, pectorals, and caudal black or crossbarred by dark spots.

Here described from eight specimens, 96 to 135 millimeters in length, collected during the summer of 1923, at Amoy, China, by Light. Three of them are females ready to spawn, with greatly distended bodies; they are from 106 to 108 millimeters in length. I also have a specimen, 51 millimeters long, in bad condition, obtained by Light at Fu-chow, Fukien Province, China. 
This species occurs on the coasts of China, Korea, and Tsushima, a Japanese island in the Strait of Korea. It may be expected in the Batan Islands and along the northwestern coast of Luzon.

\section{Genus 59. APOCRYPTODON Bleeker}

Apocryptodon BleEker, Esq. Syst. Nat. Gobioides, Arch. Neerl. Sci. Nat. 9 (1874) 327.

This genus is distinguished by the teeth of the lower jaw, which are in one row, deeply bilobed, and more or less horizontal; those of upper jaw are also in one row but are more or less bluntly conical to caninelike, and erect; there are two canines in lower jaw behind symphysis. The elongate body covered with 40 to 60 small scales in a longitudinal series, which are larger posteriorly or along the middle of the sides, and are very easily rubbed off in some species; the dorsal fins may be very close together or well separated. Dorsal VI, I-22; anal I, 21 or 22.

The genus occurs from the coasts of India to New Guinea. The type is Apocryptodon madurensis, from Java and Madura.

Key to the Philippine species of Apocryptodon.

$a^{1}$. A black line along side from pectoral to caudal; scales about 56 , before first dorsal 24.

A. montalbani. $a^{2}$. No lateral band.

$b^{1}$. Head and sides with conspicuous small black spots; scales 52 , before first dorsal 22.

A. sealei.

$b^{2}$. Body and nape with crossbars; spots on sides of head and pectorals; scales 60 , before first dorsal 34 .

A. taylori.

139. APOCRYPTODON MONTALBANI sp. nov.

Plate 22, FIG. 2

Dorsal VI, I-21; anal I, 21 ; there are 56 scales in a longitudinal series, 16 in a transverse series, and 24 before first dorsal.

The elongate subcylindrical body low, the dorsal profile very little elevated and nearly parallel with the ventral profile; the depth contained 7.3 times in body; the head large, broad, its width equal to depth and greater than that of trunk; the short snout convex, with a median terminal hump, 4.8 times in head; the eyes dorsolateral, upward gazing, close together, 0.8 of snout and 6 times in head; the interorbital space 8 times in head; the oblique mouth large, the lower jaw included, the posterior angle of maxillary extending beyond eye to lower margin of preopercle; there are twenty-four teeth in upper jaw, the anterior ones long and curving downward outside over lower jaw; the lower jaw 
has twenty-four bifid teeth, inclined outward and not extending as far back as upper teeth; the entire head except interorbital and snout closely covered with scales, those on nape extending to eyes; those on cheeks do not extend entirely over the space beneath eyes; the depth of caudal peduncle twice its own length and contained 3 times in head; the vertical fins all low, the longest spines equal to depth of trunk; the height of second dorsal and anal $\frac{5}{6}$ of depth; the pectoral rather pointed, its length $\frac{2}{3}$ that of head; the ventrals are pointed, their origin apparently anterior to that of pectoral, which they equal in length, and extend twothirds of the distance to the cylindrical, round-topped anal papilla; the elongate, pointed caudal a little longer than head, $3 \frac{1}{3}$ times in length.

The color in alcohol silvery gray, with numerous small, circular, black dots scattered over sides of head and trunk, particularly on upper half; a median longitudinal black line extends from axil of pectoral to base of caudal; along it are five faint black blotches, the last and most distinct at base of caudal; the dorsal and anal rays dusky; the pectoral blackish, its lower margin white; the caudal crossbarred by four rows of dark spots, the elongated tip black.

Here described from the type and only specimen, 44 millimeters long, collected by my colleague Mr. H. R. Montalban, at Zarraga, Iloilo Province, Panay.

140. APOCRYPTODON SEALEI sp. nov.

Dorsal VI, I-21; anal I, 22 ; there are 52 scales in a longitudinal series, 18 in a transverse series, and 22 before first dorsal.

The elongate, laterally compressed body low, the dorsal and ventral profiles nearly horizontal and parallel, inclined toward each other posteriorly, the depth 5.77 times in length; the head broad, flattened above, 3.7 times in length, its breadth greater than its depth and about 1.68 times in its own length; the convex snout almost vertical anteriorly, 3.8 times in head; the eyes oblique, dorsal, a trifle more than $\mathbf{1 . 2}$ times in snout and 4.66 times in head; the interorbital very narrow, 3 times in eye and 14 times in head; the large mouth very slightly oblique, low down, the lower jaw included, the posterior angle of maxillary reaching lower posterior angle of preopercle, the gape itself extending beyond eye; there are ten conspicuous but rather small conical teeth on each side in upper jaw, curving downward outside the lower jaw, which has fourteen small, bilobed, outwardinclined, and nearly horizontal teeth on each side, not extending 
back as far as upper teeth; the canines behind symphysis small; the body and head covered with cycloid scales, largest along middle of sides, smaller dorsally, and extending forward on nape to eyes, those on opercles very small; on cheeks they are larger and do not extend forward of posterior third of eyes; the pectoral base naked but there are a few scales along base of pectoral rays; the dorsals well separated, the first dorsal spines with elongate, threadlike tips, reaching second dorsal when depressed, the third one longest, lower than body and 1.75 times in head; the second dorsal lower than first, the posterior rays apparently shorter, the longest rays about 1.8 times in depth and 2.8 times in head; the anal equals second dorsal, but is lower anteriorly; the caudal peduncle very short, its depth twice its length and 2.8 times in head; the pointed caudal very badly damaged, equal to head; the rounded pectoral and ventrals equal in length, 1.55 times in head and almost twice in the distance to origin of anal.

The color in alcohol pale brown, whitish under head, with numerous conspicuous small black spots along the side, from snout to caudal base; along middle of side are five largé, inconspicuous brown spots, the last at base of caudal, made up of fine punctulations but little darker than the ground color of body; the pectoral base and lower part of its rays covered with spots similar to those on sides of body; the posterior margin of lower half of pectoral broadly margined with reddish brown, the membrane with dark bars of the same color; the caudal and second dorsal show that they were crossbarred with dark brown spots, now almost entirely gone.

Here described from the type and only specimen, 52 millimeters long, with damaged fins, collected by Alvin Seale, at the Manila market in 1908.

This species is nearest to Bleeker's Apocryptes glyphisodon, but a comparison with his original description shows it to be quite distinct.

I take pleasure in naming this species for Mr. Alvin Seale, long-time student of Philippine fishes.

141. APOCRYPTODON TAYLORI sp. nov.

Plate 22, Fig. 3

Dorsal VI, I-22; anal I, 21; scales in a longitudinal series about 60 , before first dorsal 34 .

The body subcylindrical anteriorly, laterally compressed toward tail, with a large blunt head much wider than body, and with the dorsal and ventral profiles nearly parallel; the depth 
contained a little more than 6 times, the head 3.77 times in length; the short snout very wide, convex, then almost truncate in front, 4.5 times in head; the eyes dorsal, prominent, approximately equal to snout, and very close together, the interorbital space less than half an eye diameter; the horizontal mouth terminal, low down, the lower jaw somewhat included. The posterior angle of maxillary beneath hind margin of eye; eighteen or twenty teeth in upper jaw, vertical, strong, extending a little farther back than in lower jaw, which has sixteen strongly bifid teeth inclined outward; the snout and sides of head naked, the nape covered with very fine scales, the anterior ones scattered; the depth of caudal peduncle equals distance from dorsal to base of caudal but is 2.5 times greater than distance from anal to caudal; the narrow pointed pectorals equal the ventrals in length; the dorsal spines equal depth; the soft dorsal and anal similar in outline, their rays equal in length, shorter than the dorsal spines; the lanceolate caudal equals the length of head; the posterior scales on sides of body are larger than those anteriorly and are easily dislodged.

The color in alcohol yellowish, with underside of head and belly muddy gray; circular dark brown spots on sides of head and base of pectoral ; a series of irregular brown spots and crossbands along sides of body; the tips of pectorals black; margins of vertical fins and caudal more or less dusky or blackish.

Here described from the type and only specimen, 34 millimeters long, collected at Odiongan, Tablas, by Edward H. Taylor, an authority on Philippine Reptilia, for whom I take pleasure in naming this distinct species.

This is close to $A$. sealei sp. nov., but the scalation is different and the color markings also differ. In default of more material the gap between them is too great to warrant placing them together.

\section{Genus 60. TRIAENOPOGON Bleeker}

Triaenopogon BLEEKER, Arch. Neerl. Sci. Nat. 9 (1874) 312.

This genus is recognized at once by the presence of conspicuous fringes of barbels along the edge of the preorbital and suborbital regions and on the lower jaw and margin of the preopercle, and by the possession of two rows of teeth in each jaw, the outer tricuspid, the inner smaller, simple, pointed.

The body robust, with a very broad, low head, 35 to 40 scales in a longitudinal series, the head and nape scaleless except for a few rows before first dorsal and above opercle; the vertical 
fins all low; there are no free silky rays on pectoral; the caudal rounded, shorter than head; the gill openings rather wide but not extended forward, the isthmus broad; branchiostegals 4 . Dorsal VI, I-10 or 11; anal I, 9 to 11 .

A single species is known from the coasts of China and Japan; specimens in the Vienna Museum are from the Philippines or Celebes.

142. TRIAENOPOGON BARBATUS (Günther)

Plate 22, Fig. 4

Triaenophorichthys barbatus GüNTHER, Cat. Fishes Brit. Mus. 3 (1861) 90.

Tridentiger barbatus STEINDACHNER, Sitzungsber. Akad. Wiss. Wien $80^{1}$ (1879) 151.

Triaenopogon barbatus JORDAN and SNYDER, Proc. U. S. Nat. Mus. 24 (1901) 111, fig. 23; RendaHL, Arkiv Zoologi 16 (1924) 25.

Triaenopogon japonicus RENDAHL, Arkiv Zoologi 16 (1924) 27.

Dorsal VI, I-10; anal I, 9 ; there are 38 scales in a longitudinal series, and 15 in a transverse row in my specimens; Günther found 35 in the length, Jordan and Snyder 36, and Rendahl gives 35 and 12 for the number in longitudinal and transverse series.

The body robust, the posterior part strongly compressed laterally, more rounded anteriorly, with a very large, broad, depressed head, the dorsal profile arched, highest before first dorsal, the ventral profile nearly horizontal; the depth 4.1 to 4.5 times, the head 3 or 3.1 times in length; the cheeks very much wider than the narrow opercles and very bulging, making the breadth of head much greater than its depth and 0.85 to 0.91 of its own length; the edge of suborbital has a row of barbels with a shorter row beneath it, both extending across cheek more than halfway; the lower jaw has a double row of barbels which continue upward, one along margin of preopercle and one on anterior margin of opercle; there is a barbel beside the tubulate anterior nostril; a fleshy flap behind eye conceals a large pore; two similar flaps above opercle likewise conceal large pores; the snout broad, bluntly rounded, 3.25 to 3.5 times in head; the eyes small, very high up, dorsolateral, and looking up as much as laterally, a little more than twice in snout, far apart, 2 to 2.25 times in the broad, flat, interorbital space; the mouth moderately large, broad, slightly oblique, the lips thick and fleshy, the posterior angle of maxillary reaching a point below middle of eye or beyond, in some extending much past eye; in most of my specimens the lower jaw projects, though other authors state the jaws are equal; the teeth are in two rows in 
each jaw, those of outer row tricuspid, and set alternately so that they can almost be said to form two rows; the inner row is some distance behind, of simple, sharp, small but stout teeth; the head entirely naked; the body covered with ctenoid scales which are smaller above pectoral base and extend forward of first dorsal, greatly reduced in size as far as above posterior margin of preopercle; the first dorsal low, the central spines longest, not reaching second when depressed, 2.5 to 2.9 times in head and twice to 1.66 times in depth; the second dorsal and anal alike in shape and height, the anal shorter than dorsal, not touching base of caudal when depressed, higher than first dorsal, 2 to 2.33 times in head, and 1.4 to 1.7 times in depth; the depth of caudal peduncle is 1.33 to 1.6 times in its own length and varies from a little more than 10 to 15 per cent of total length; the caudal of moderate size, rounded, the accessory spines extending well up on caudal peduncle, 1.3 to 1.5 times in head and 4.1 to 4.5 times in length; the broad, round-pointed pectoral equals or is greater than depth, and is a trifle longer than caudal, which equals or is slightly less than depth; the ventrals nearly as broad as long, semicircular, with a fleshy frenum, 1.6 to 1.85 times in head, falling far short of anus; the anal papilla thin, slender, pointed in males; in females it is stout, subcylindrical, with a bifid point.

The color in alcohol yellowish brown or olive brown, with vaguely defined, blackish vertical or diagonal crossbars as follows: A short bar on top of head a little behind eyes, a larger one a little back of this, and a third one above pectorals; a fourth bar passes under posterior half of first dorsal; the fifth crosses under middle of second dorsal, the sixth just behind it, the last two inclined diagonally forward; there is a dark circular spot below eye and a dark blotch from eye diagonally back upon cheek; a large dark spot on base of pectoral and one on upper and one on lower part of caudal base; the first dorsal crossed by one or two broad diagonal blackish crossbands or the whole fin may be blackish except basal part of first three spines; in some specimens the anterior third of second dorsal is whitish with longitudinal rows of dusky spots on membrane, and upper margin blackish; the rest of the fin blackish; in others the second dorsal is barred alternately with whitish and blackish bands, the membranes everywhere specked with dark dots; the caudal obscurely barred with five or six rows of dark spots; the pectorals crossbarred by numerous rows of blackish spots; the ventrals dull yellow. 
Here described from fifteen specimens, 40 to 81 millimeters long, the larger specimens in spawning condition. They were collected at Amoy, China, by Light, late in the summer of 1922.

Rendahl's separation of the Japanese specimens as a distinct species will not stand. The depth of the caudal peduncle and the number of crossbars on the first dorsal, the characters upon which he made the separation, are worthless for this purpose, as my specimens show.

Steindachner showed long ago that this species is variable in color.

This peculiar-looking goby occurs along the coast of China and in Tokyo Bay, Japan, and Steindachner's specimen came from "Celebes or from the Philippines." I have no doubt that it does occur here.

\section{Genus 61. TRIDENTIGER Gill}

Tridentiger Gill, Ann. Lyc. Nat. Hist. New York (1858) 16.

The robust body little compressed, subcylindrical, covered with ctenoid scales of moderate size; the head broad, naked, more or less flattened above, with blunt snout, the mouth moderately oblique, the lower jaw somewhat prominent, the cheeks usually bulging; the teeth rather large, in two rows in each jaw, those of outer row tricuspid, the inner row smaller, simple, pointed; the tongue rounded at tip; the eyes of medium size, rather far apart; there are no barbels on head, and no free silky rays on pectoral; the dorsals low, the caudal rounded, shorter than head; the gill openings narrow, the isthmus broad; branchiostegals 4 . Dorsal VI, I-10 to 12 ; anal I, 9 or 10 ; there are 54 to 58 scales in a longitudinal series and 16 to 22 in a transverse series.

Species few, on the coasts of Siberia, Japan, and China, south to Hongkong, and in all probability occurring in the northern Philippines.

Key to the species of Tridentiger occurring in the China Sea.

$a^{2}$. Body with two conspicuous longitudinal blackish bands; longitudinal scales 54 to 56; transverse scales 16 to 20 T. bif asciatus. $a^{2}$. Color uniform brown; longitudinal scales 55 to 58 ; transvierse scales 16 to 22

T. trigonocephalus.

143. TRIDENTIGER BIFASCIATUS Steindachner

Tridentiger bifasciatus STEINDACHNER, Stzungsber. Akad. Wiss. Wien $83^{1}$ (1881) 190, pl. 7, figs. 2 and 2a; JORDAN and SNYDER, Proc. U. S. Nat. Mus. 24 (1901) 117, fig. 25; SkaIs, Philip. Journ. Sci. § D 9 (1914) 77; ReNDahl, Arkiv Zoologi 16 (1924) 27, fig. 1.

Tridentiger ioturus JORDAN and SNYDER, Proc. U. S. Nat. Mus. 23 (1900) 373. 
Dorsal VI, I-11 or 12; anal I, 10; there are 54 to 56 scales in a longitudinal series, 18 to 20 in a transverse series, and 20 or more before first dorsal.

The body laterally compressed, the back moderately arched, the belly a little less so, the head more or less depressed, the depth 3.9 to 4.2 , the head 3.25 to 3.5 times in length; the breadth of head varies greatly according to the tumidity of the cheeks, in my specimens ranging from 60 to 90 per cent of its own length; the head may be very broad and flat above, or may be more or less convex and pointed; the snout bluntly rounded, 4 to 4.1 times in head; the eyes small, lateral, 5 to 5.8 times in head; the interorbital equals or is a half greater than eye; the mouth slightly oblique, the jaws equal, the upper lip thick, the posterior angle of maxillary approximately beneath middle of eye; the teeth are as given for the genus, the middle cusp of the three-pointed teeth largest; the last three teeth on each side of inner row in lower jaw enlarged; the scales largest on the sides posteriorly, those before first dorsal very small and extending forward on nape to a line above middle of preopercle; the second spine of first dorsal longest, the posterior rays reaching origin of second dorsal when depressed, 1.9 to 2 times in head; in adult males, the tips of the spines elongated; the second dorsal and anal equal to first dorsal or the anal slightly lower, the middle rays longest, the fins not reaching caudal when depressed; the caudal peduncle deep, 2.1 to 2.3 times in head and nearly as deep as long; the caudal bluntly rounded with accessory spines growing well up on caudal peduncle, its length 4.1 to 4.2 times in total, 0.8 to 0.9 the length of head; the broad, round-pointed pectoral a little longer than caudal, equal to or 0.9 the length of head; the ventrals broad, rounded, with a thick frenum, about 1.5 times in head; the anal papilla large, broad, flat, triangular in males; in females subcylindrical, tumid, with a faintly bilobed tip.

The color in alcohol dull olive brown, paler beneath, with two broad, black, lateral bands, the upper one beginning on tip of snout, passing over upper part of eye, and extending back below dorsals to upper base of caudal; the lower one begins at posterior margin of eye and runs directly back across cheek, apparently ending in a dark spot at upper angle of pectoral base, but continues beneath back to middle of caudal base; the first dorsal varies from entirely black to nearly colorless, with only the upper margin darkened; the second dorsal varies from uniform dusky or blackish to those with three vague crossrows of brownish spots; the anal dusky with a pale outer margin; the 
caudal has an upper and lower blackish spot at the end of the longitudinal bands, and numerous (five to eight) crossbars of dark spots, usually only those near base clearly defined; the pectoral and ventrals uniform yellowish.

Here described from seven specimens from Amoy and thirteen from Fu-chow, Fukien Province, China, collected by Light; they vary in length from 33 to 67.5 millimeters. A female, 55 millimeters long, is enormously distended with eggs about to be spawned. The Bureau of Science collection also contains four typical specimens, 33 to 44 millimeters long, collected by Seale at Hongkong. On them the lower color band continues on the caudal fin for half or all its length. In one of the adult males from Fu-chow the two longitudinal bands are connected by six or seven crossbands on the sides of the body.

The Bureau of Science collection also has twenty-four specimens, 39 to 64 millimeters in length, collected by the Albatross at Shiogama, Rikuzen, Japan.

This species was originally described from near Vladivostok, and is known from the coasts of Japan and China.

144. TRIDENTIGER TRIGONOCEPHALUS (GIII)

Triaenophorichthys trigonocephalus GiLl, Proc. Acad. Nat. Sci. Phila. (1859) 195; GüNTHER, Cat. Fishes Brit. Mus. 3 (1861) 89.

Tridentiger trigonocephalus RENDAHL, Arkiv Zoologi 16 (1924) 27.

Dorsal VI, I-11 or 12; anal I, 10 or 11; there are 56 to 58 scales in a longitudinal series, 22 in a transverse series, and about 28 before first dorsal.

The robust body rounded anteriorly, the posterior two-thirds laterally compressed, the dorsal outline but little elevated or slightly convex, depressed anteriorly, the depth 4.8 to 5 times in length; the head very broad, low, flat, with enormously developed cheeks on the larger specimens, 3.25 times in length; the breadth of head always exceeds its depth, being 0.5 to 0.6 more than the latter, and 0.75 to more than 0.9 of its own length; the snout short, bluntly rounded, 3.5 to 4 times in head; the eyes almost on top of head, looking up as well as laterally, 1.25 to 1.5 times in snout and 4.75 to 5.2 times in head; the flat interorbital equals or is a little wider than eyes; the mouth rather small, oblique, the jaws equal, the lips fleshy, especially the upper one so that the lower jaw appears inferior, the posterior angle of maxillary beneath middle of eye or extending as far as posterior margin; the teeth are as given for the genus, those of outer row densely crowded; the body covered with small, 
closely set scales, which become much smaller before first dorsal, and extend forward above opercles as far as above middle of preopercles; the scales and fins more or less obscured by a heavy coat of mucus; the second and third spines of first dorsal longest, 1.8 to 2 times in head; the second dorsal and anal alike in shape, approximately equal to first dorsal in height, not touching base of caudal when depressed; the caudal peduncle broad, short, its depth equal to or exceeding its length and 2.1 times in head; the obtusely rounded caudal 3.78 to 4 times in length; the round pointed pectoral equals or slightly exceeds caudal; the rounded ventrals as broad as long, about 1.7 to 1.8 times in head; the anal papilla large, pointed, triangular.

The color in alcohol brown or dusky brown, the fins all blackish or the first dorsal pale at base, the first spine with black spots, the rest of the fin blackish; the second dorsal may be pale anteriorly along base; the pectoral always has a broad yellowish or whitish crossbar near base, and is narrowly margined with the same color.

Here described from six specimens, 64 to 85 millimeters in length, collected at Fu-chow, Fukien Province, China, by Light. I also have seven specimens, 50 to 80 millimeters long, collected on the mainland near Amoy, by Light, May 4, 1923; a female, 65 millimeters long, was ready to spawn when taken.

This species is known only along the China coast from Hongkong northward. It may well occur in the Batan Islands or on the Ilocano coast of Luzon.

\section{Genus 62. CARAGOBIUS Smith and Seale}

Caragobius Smith and Seale, Proc. Biol. Soc. Washington 19 (1906) 81.

The body elongate, laterally compressed, only the posterior third covered with minute cycloid scales; the remainder, including the large, oblong, heavily built head, naked; the chin heavy, rounded, protruding; the mouth small and very oblique; there are two rows of depressible teeth in each jaw, the outer one of widely spaced, long, slender, pointed teeth, those of inner row minute; no canines; the tip of the tongue rounded; the tiny, widely spaced eyes on top of head, underneath skin; the gill openings narrow, restricted, with wide isthmus; the dorsal fin and anal long, low, and continuous with caudal, which is shorter than head; the pectorals short, broad, and rounded; the ventrals completely united, moderately long, pointed, with a thin frenum of medium width. 
According to the original description there is "a small pore above each gill opening which opens into a cavity separate from gill cavity." A careful examination of seven specimens fails to reveal the existence of any such pore or cavity where the skin is unbroken. The skin is easily torn and might then seem to have a pit as described above.

145. CARAGOBIUS TYPHLOPS Smith and Seale

Plate 23, Fig. 1

Caragobius typhlops Smith and Seale, Proc. Biol. Soc. Washington 19 (1906) 81, with text figure.

Dorsal VI, I-28 or 29 ; anal I, 33 or 34.

The body slender, elongate, much compressed laterally, with large, almost quadrangular head; the upper and lower profiles nearly horizontal, tapering gradually toward caudal; the greatest depth 6.7 to 9 times, the head 5.3 to 5.5 times in length; the head very broad, its width equal to or five-sixths of its depth, which is equal to or 0.6 of the depth of body; the snout short, convex, very wide and blunt, $3 \frac{1}{3}$ to $3 \frac{2}{3}$ times in head; the mouth nearly vertical, with a very heavy, projecting, blunt lower jaw; the eyes are black dots under the skin; the interorbital space broad, $3 \frac{1}{3}$ to 5 times in head, equal to or 1.5 times in snout; the caudal peduncle narrow, its depth 3.3 to 5 times in head; the dorsals connected, the dorsal and anal low; the caudal probably pointed, shorter than and apparently about 2 in head; the pectorals very broad, rounded, 2 to 2.5 in head; the ventrals pointed, equal to or a little more or less than depth, 0.55 to 0.8 of head; anal papilla short, round tipped.

The color in alcohol uniform yellowish, becoming whitish on belly and underside of head or uniform yellowish gray posteriorly, the anterior third bluish gray.

Here described from seven specimens, 35 to 54 millimeters in length, collected by Doctor Morse in 1903, from the Rio Grande de Mindanao, at Cotabato. They are cotypes; the type is in the United States National Museum.

Owing to the distorted condition of the specimens and the mutilated condition of the dorsal, anal, and caudal fins the description is necessarily imperfect. In the original description the depth is given as 2 , which is evidently a typographical error. The probabilities are that the depth is about 7 times in the length in life. This is a unique species, not to be confused with anything else. 


\section{Genus 63. ITBAYA g. nov.}

This genus is distinguished by its entire lack of scales, by the possession of an outer row of enlarged tricuspidate teeth in the lower jaw, and by its erect skinny crest on the front of the head.

The body is elongate, laterally compressed, the head blunt, scales wanting; the teeth are in bands of four or five rows in both jaws, the outer row enlarged and simple in the upper jaw, three-pointed in the lower jaw, without canines; the vertical fins all low, the dorsals well separated, the caudal shorter than head; no free silky rays on upper part of pectoral; the gill openings narrow, restricted, the isthmus tolerably wide; branchiostegals 4. Dorsal VI, I-12 or 13; anal I, 8. Generic type, I. nuda sp. nov.

Itbaya, from Itbayat Island, the type locality.

146. ITBAYA NUDA sp. nov.

Plate 23, Fig. 2

Dorsal VI, I-12; anal I, 8.

The depth of the elongate, compressed body 6 times in the length; the dorsal and ventral profiles nearly horizontal, tapering gradually to base of tail; the head blunt, with a conspicuous crest beginning on nape behind eyes and running forward to tip of snout, 4.18 times in length; the depth of head almost equals that of body, its breadth $\frac{5}{6}$ of its depth; the boldly convex snout 1 times in head; the eye lateral, a trifle shorter than snout, 4.5 times in head; the interorbital breadth 0.6 that of eye; the mouth small, slightly oblique, low down, the upper lip rather thick, the lower jaw a little shorter than upper, the posterior angle of maxillary beneath anterior third of eye; in upper jaw is an outer row of slightly enlarged pointed teeth, followed by a band of three rows of minute teeth; in lower jaw is a short outer row of enlarged tricuspid teeth, the middle cusp longest; behind this is a wide band of four rows of minute pointed teeth; the first dorsal is low, not reaching second dorsal when depressed, the second and third spines longest, $\frac{2}{3}$ of the depth and 2.25 times in head; the second dorsal of almost uniform height, the posterior ray reaching caudal base when depressed, the central rays a trifle longer and a little higher than first dorsal, 1.95 in head; the anal as high as but much shorter than second dorsal, the posterior ray falling far short of reaching caudal; the depth of caudal peduncle equal to height of first dorsal, 2.25 times in head; the caudal bluntly rounded, a little shorter than head, 4.37 times in length; the pointed pectoral equals caudal; the ven- 
trals are pointed, with dissected, sharp-lobulate margins, and extend less than halfway to the minute anal papilla.

The color in alcohol uniform deep, dull olive brown, paler under head; the first dorsal has a brown crossband near upper margin, the basal half of fin minutely specked with dark; a dark band along upper margin of second dorsal; the anal and caudal plain brown, the pectorals and ventrals a little paler.

Here described from the type and only specimen, 18.8 millimeters long, from Itbayat, one of the Batan Islands, north of Luzon. This remarkable little goby possesses a unique combination of characters.

Nudus, naked.

\section{Genus 64. GOBIOSOMA Girard}

Gobiosoma Girard, Proc. Acad. Nat. Sci. Phila. (1858) 169.

The body entirely naked, short and plump or elongate and cylindrical; the head cylindrical or laterally compressed, with convex or pointed snout; the mouth horizontal, medium to large; the teeth small, in several rows in each jaw, without canines; there are no barbels or papillæ on head in our species; the first dorsal has five to seven spines, six in Philippine species; the second dorsal and anal low and short, ending some distance before the rounded caudal. Dorsal VI, I-9 or 10; anal I, 9.

These naked gobies are small, easily recognized fishes of shallow bays and the mouths of rivers. They lie on the gravelly bottom, where their colors blend exactly with their environment. The species are mostly American.

Key to the Philippine species of Gobiosoma.

$a^{1}$. Dorsal VI, I-9; body tadpole-shaped, with three dark crossbands. G. insignum. $a^{2}$. Dorsal VI, I-10; body spindle-shaped, brown with darker marbling. G. marmoratum.

147. GOBIOSOMA INSIGNUM sp. nov.

Plate 27, Fig. 3

Dorsal VI, I-9; anal I, 9.

The body tadpolelike because of the rounded protuberant belly, the depth 4 to 4.25 times in the length; the dorsal profile nearly horizontal, the head convex, laterally compressed, wedgeshaped viewed from above, 3.4 to 3.6 times in length; the snout short, convex, steeply descending, $3 \frac{2}{3}$ to 4.5 times in head; the eye rather small, high up, not conspicuous, equal to or a little 
less than snout, 32 to 5 times in head; the interorbital space narrow, about 3 times in eye; the large oblique mouth terminal, with equal jaws, the upper lip protractile, the posterior angle of maxillary free and produced backward, reaching to posterior margin of eye or nearly an eye diameter beyond; the tongue notched; the teeth slender, erect, pointed, in three rows in each jaw, the outer row in lower jaw short with widely spaced teeth, the outer row in upper jaw shorter than the other two; the dorsals well separated, the first dorsal small, low, the longest spines 2.25 to 2.5 times in depth; the second dorsal and anal low, equal in height, their longest rays 1.6 to 2 times in depth; the pectorals and ventrals are equal in length, with pointed tips, and equal or exceed the length of head; the frenum broad and strong, the ventrals more or less tubulate; the caudal peduncle slender, its depth about 3 times in that of body; the caudal truncate, shorter than head, 4.3 to 4.8 times in length; the anal papilla very short and blunt.

The color in alcohol whitish with three broad, brown crossbars over back, running diagonally forward down sides to belly; the first under first dorsal, the second under second dorsal, and the third immediately behind second dorsal; a wide, brown blotch or crossband in front of first dorsal, above base of pectoral; a series of brown or black reticulations on lower half of body behind pectoral; between all these bands the body is sprinkled with minute brown specks, leaving the ground color as a series of white spots and dots; the cheeks and the region behind eyes more or less dotted with small, dark brown spots; the first dorsal marked by two brown to black longitudinal bands or two or three rows of deep brown spots; the second dorsal crossbarred by four rows of dark brown spots; on base of caudal is a white spot surrounded by a broad, dark brown band; behind this are two large white spots near upper and lower margins; the remainder of fin crossbarred by large brown spots; the pectoral crossbarred by three or four rows of large brown spots; the ventrals and anal colorless.

This strikingly beautiful little goby is here described from ten specimens, 24 to 40 millimeters in length, collected by me in March in Dumaguete River, Oriental Negros. The clear bil. liant coloration of this plump little fish harmonizes exactly with the gravel and sand in which it lies.

I have recently received thirty-eight specimens, 11 to 36 millimeters in diameter, from Bangar, La Union Province, Luzon. All those over 30 millimeters in length were ready to spawn at 
the date of collection, November 12. Where the types were white these were clear yellow, while the large, blackish brown band on the base of the caudal contained no white spot; in other respects they were identical.

As this copy leaves my hands Mr. F. Reveche, of Antique Province, sends me four handsome specimens, 38 to 44 millimeters in length; they are ready to spawn, February, 1926.

Insignis, distinguished, in reference to its handsome coloration.

148. GOBIOSOMA MARMoratum Peters

Gobiosoma marmoratum PETERs, Monatsber. Akad. Wiss. Berlin (1868) 267.

Dorsal VI, I-10; anal I, 9.

Body spindle-shaped, scaleless; the height in the length as $1: 5$, the head length in the same as $1: 4$. The eyes are near together and are hardly an eye diameter from the tip of the snout. Teeth in narrow rows, those of the outer row long. Brown with darker marbling, with a dark spot in front of the base of the caudal fin. (Peters.)

Peters's specimens were collected by Jagor at Loquilocon, Samar.

The above description is my translation of that given by Peters. It is possible that my $G$. insignum is a synonym, but Peters's description is too brief to make certain without an examination of his type. The porportions and color of $G$. insignum are apparently different from those of Peters's species, and there is a difference of one ray in the second dorsal.

Genus 65. GOBIODON (Kuhl and Van Hasselt) Bleeker

Gobiodon (Kuhl and Van Hasselt) BleEker, Nat. Tijd. Ned. Ind. 11 (1856) 407.

Dorsal VI, I-9 to 11 ; anal I, 8 or 9 .

This is a group of very small, naked fishes with the dorsals united more or less completely, but always connected, at least at the base; the teeth are in two or more rows in each jaw, with two to four comparatively large canines behind the symphysis of the lower jaw; the gill openings are vertical, not extending below the pectorals; branchiostegals 4 .

The body short, deep, oval, strongly compressed, with a broad, deep, and boldly arched profile, the head not much broader than the body, and short, rather strong fins. The leathery skin is entirely bare or may have scales so rudimentary that they resemble minute pits. Large pores with tumid lips are conspicuous on 
the head as follows: One by the posterior nostril, four in the interorbital space, two behind the eye, three on the supraopercular groove, and three or more on the posterior edge of the preopercle. Some species have the body covered with a very thick slime, which is hardened by alcohol into a firm false skin, entirely concealing the true skin.

Fifteen or more species have been described, at least half of them probably not valid. The colors are rather variable, and the earlier descriptions omitted details so that, without comparison with the types, it is impossible to be certain what they were.

These little fishes abound in the coral reefs of the Indian and Pacific Oceans.

\section{Key to the Philippine species of Gobiodon.}

$a^{1}$. Second dorsal with 11 rays; no crosslines on head; a conspicuous black spot at upper angle of opercle.

G. fulvus.

$a^{2}$. Second dorsal with 10 rays; head with four or more crossbands; no spot on opercle.

$b^{1}$. Four canines on each side of lower jaw; first or first and second dorsal spines longest, higher than second dorsal; a black-edged, blue stripe on base of dorsals and anal

G. hypselopterus.

$b^{2}$. One canine on each side of lower jaw; first dorsal a fourth lower than second; no basal stripe on vertical fins. G. quinquestrigatus.

\section{GOBIODON FULVUS sp. nov.}

Dorsal VI, I-11; anal I, 8 or 9 ; pectoral 18 or 19.

The naked body oblong-ovate, much flattened laterally, the depth 2.4 to 2.6 times in length; the upper profile convex, the front of head nearly vertical, the head 3.8 to 4.1 in length, its depth greater than its length, 2.8 to 3.6 times in total length; the head little wider than body, its breadth 1.7 to 2.1 in its own length; the snout rather variable in length, 2.6 to 4 times in head; the small eyes placed very near front margin of profile, 4 to 6 times in head; the interorbital space narrow, rising high above eyes, which it equals in width; the mouth small, curved, oblique to nearly horizontal, the posterior angle of maxillary beneath middle or latter part of eye; there are two rows of teeth in each jaw, with one or two canines on each side of lower jaw behind symphysis; the teeth of outer row larger and more widely spaced than those in inner row, which are excessively minute; the first dorsal low, 0.6 to 0.8 of height of second dorsal and a little more than half (0.53) the depth of body; the height of second dorsal $\frac{2}{3}$ to 0.86 of depth of body; the anal equals second 
dorsal in shape and height, but is shorter; the rounded caudal only a little shorter than head, and the broad rounded pectoral just a little shorter than caudal; the ventrals slender, delicate, half or nearly half as long as head.

The color in alcohol uniform pale brown, with a conspicuous blackish brown spot at upper posterior angle of opercle; a broad, pale yellow band runs along base of both dorsals and anal; the outer portion of dorsals, anal, and caudal clear, or tinged with dusky.

Here described from seventeen specimens, 18 to 36 millimeters in length, from Calapan, Mindoro.

Two specimens, each 31 millimeters long, from Maricaban Island, in Verde Passage, Batangas Province, were a beautiful clear orange color when coliected.

Fulvus, tawny or brownish yellow.

150. GOBIODON HYPSELOPTERUS Bleeker

Plate 28, Fig. 2

Gobiodon hypselopterus BLEEKER, Gobioid. species insulind. novae, Arch. Neerl. Sci. Nat. 10 (1875) 120.

Dorsal VI, I-10; anal I, 9; pectoral 19; caudal VII, 15-VII.

The depth of the naked oblong compressed body 2.6 times in length; the head deep, the dorsal and ventral profiles both strongly convex, 3.4 times in length, its depth a tenth more than its length; the head a little thicker than the trunk, its breadth twice in its own length; the snout rather broad, blunt, descending steeply, 3.6 times in head, shorter than eye which is very high up and 2.85 times in head; the interarbital contained 1.7 times in eye; the mouth small, horizontal, the posterior angle of maxillary beneath forward third of eye; four canines on each side of lower jaw; the pores on head conspicuous, more or less elevated, with two rows on margin of preopercle; the first or first and second dorsal spines longer than the others, 0.25 higher than second dorsal and 0.61 of the depth of body; the second dorsal goes a trifle more than twice in depth; the anal as high as first dorsal and shorter than second dorsal; the caudal bluntly rounded, its length equal to that of head; the broadly rounded pectoral 0.2 longer than head; the small ventral $\frac{1}{8}$ the length of head.

The color in alcohol uniform brown, with darker fins; the upper posterior angle of opercle deep black; two vertical stripes from eye, one from nape to opercle, and one from shoulder above pectoral down across base of fin; on base of both second dorsal 
and anal is a longitudinal stripe; according to Bleeker all these lines are blue, but they have lost their original color in alcohol.

Here described from a specimen, 34 millimeters long, collected at Calapan, Mindoro. It has been previously known from Bleeker's description, based on specimens from the Moluccas.

I place with the above four specimens, 26 to 35 millimeters in length, collected in November, 1925, from a coral head at Canigaran, near Puerto Princesa, Palawan. The largest two were clear lemon yellow, with dusky yellow fins and pale blue stripes on the head; the others were dusky yellow, with blackish fins; on the base of the dorsals and anal was a blue stripe edged with a deep black line above and below. The other color markings and the dentition are as in the Calapan specimens already described. These specimens do not agree in every particular, but are all of the same species. In the two smaller Palawan specimens the first dorsal is lower than the second.

151. GOBIODON QUINQUESTRIGATUS (Cuvier and Valenciennes)

Gobius quinquestrigatus CUvier and Valenciennes, Hist. Nat. Poiss. 12 (1837) 101.

Gobiodon quinquestrigatus BleEkeR, Arch. Neerl. Sci. Nat. 10 (1875)

117; WEBER, Fische Siboga Exped. (1913) 454.

Gobiodon ceramensis GüNTHER, Cat. Fishes Brit. Mus. 3 (1861) 88.

Daing sahasa, Samal name at Zamboanga.

Dorsal VI, I-10; anal I, 8; pectoral 17.

The naked body short, deep, much flattened laterally, its depth 2.75 in length; the head deep, with equally convex dorsal and ventral profiles, 3 times or a trifle more in length, the depth a little more or less than length; the head much thicker than trunk, its breadth 1.75 to 1.88 in its own length; the horizontal mouth small, the posterior angle of maxillary extending beneath the forward half or center of eye; the two canines in lower jaw very small; the snout very convex, 3.5 to 3.75 in head; the eye rather small, high up, equal to snout, the convex interorbital equal to or 0.75 of an eye diameter; the pores on head very conspicuous; the low dorsals continuous, the first dorsal 0.75 as high as second, which goes twice in depth; the first or first and second spines of first dorsal not higher than the rest; the anal as high as second dorsal but shorter; the length of the rounded caudal equals the pectoral and is $\frac{6}{7}$ of head.

The color in alcohol brown or yellowish brown, the head paler, becoming whitish on throat; there are five nearly vertical 
pearl white lines on head, inclined backward, the first descending from forward part of eye; the second starts above rear margin of eye and passes down behind pupil to throat; the third and fourth cross the cheeks; the fifth crosses base of pectoral; behind angle of pectoral is a sixth, very short line; all these lines tend to disappear in alcohol; the fins are all uniform dark brown.

Here described from three specimens, 20 to 23 millimeters in length, collected by me at Dumaguete, Oriental Negros.

I also place here thirty-nine specimens, from 16 to 29 millimeters in length, collected at Puerto Galera, Mindoro. In life these specimens were uniform wine red; the vertical lines on the head were opalescent blue. After some years in alcohol, they vary in color from uniform clear brownish yellow to dark brown with paler head, very light throat, and dark brown or blackish fins; in some of the specimens there are ten or twelve lines, six or seven on the head and the rest on the trunk behind the angle of the pectoral; in a few cases no traces are left of the crosslines on the head. They also vary in shape, especially that of the head, but are all connected by intermediate stages, so that they cannot be separated. The Bureau of Science collection also contains two faded specimens from Zamboanga, Mindanao, and two from Sitankai, Sulu Province.

I include here also two clear yellow specimens from Zamboanguita, Oriental Negros, 28 and 31 millimeters long, which each have a small, light brown spot on the upper posterior angle of the opercle, but agree in other respects.

A specimen, 33 millimeters long, from Cabalian, Leyte, is uniform dark red-brown, with a small, blackish brown spot on the upper posterior angle of the opercle; the fins are larger and higher than in any other Gobiodon in the collection. It seems to be intermediate between G. hypselopterus and G. quinquestrigatus, having the pectoral count of the former; the head stripes are so faded as to be largely illegible.

According to Weber this species is confined to the Indo-Australian Archipelago.

A color sketch from life by T. S. Espinosa, of a specimen from Zamboanga, shows the lines on the head lavender, margined with wine red. The specimen is no longer in the collection.

\section{Genus 66. MICROSICYDIUM Bleeker}

Microsicydium Bleeker, Esq. Syst. Nat. Gobioides, Arch. Neerl. Sci. Nat. 9 (1874) 314. 
As defined by Bleeker, the genus would not include the Philippine species or the Society Island species described by Steindachner. I therefore amend his diagnosis to read as follows:

The teeth of upper jaw slender, more or less club-shaped, obtuse, closely crowded together in a single row; the lower jaw has two rows, the outer teeth needlelike, more or less embedded in a movable band fastened to inner margin of lower lip; the inner row composed of a few, backward-curved caniniform teeth of nearly equal size. The body elongate, low, cylindrical anteriorly, with obtuse head and convex snout, the mouth inferior, with thick lips, the tip of the tongue rounded; there are no barbels on lower jaw; the scales are large, ctenoid, 30 to 40 in a longitudinal series, the head and forward part of trunk naked, or the nape more or less covered with cycloid scales nearly to eyes; tip of tongue rounded; dorsals small, well separated; caudal rounded, equal to or longer than head; the ventrals form a circular disk, free, or but slightly attached to belly; the upper rays of pectoral are not free and silky. Dorsal V or VI, I-7 to 11 ; anal I, 8 to 11 .

This genus is known elsewhere from Celebes and the Society Islands.

Key to the Philippine species of Microsicydium.

$a^{2}$. Color uniformly dark, without longitudinal bands, scales 36 ; dorsal VI, I-9 or 10 ; anal I, 9 or 10 . M. atro-purpureum. $a^{2}$. Head and body with longitudinal bands.

$b^{1}$. Scales 38 ; dorsal VI, I-7; anal I, 8 .

$b^{2}$. Scales 30 ; dorsal VI, I-9; anal I-10

M. formosum. M. pulchellum.

152. MICROSICYDIUM ATRO-PURPUREUM sp. nOv.

Dorsal VI, I-9 or 10 ; anal I, 9 or 10 ; there are 36 scales in a longitudinal series, 10 in a transverse series, and about 10 before first dorsal.

The body low, elongate, slender, the dorsal and ventral profiles nearly parallel, the posterior half laterally compressed, the top of head and nape broad and more or less flattened, the depth 6.18 times in length; the head $4.5+$ times in length; its depth and breadth approximately equal, about 1.75 times in length of head; the snout broad, blunt, rounded, projecting, 3.75 times in head; the eyes very high up, dorsolateral, equal to snout and to the wide, flat interorbital; the mouth inferior, with weak lower jaw, nearly horizontal, the posterior angle 
of maxillary concealed and extending beneath anterior half of eye; the outer row of teeth in lower jaw is horizontal and projects beyond lip so that it is plainly visible; the inner row composed of three hooked canines on each side, the anterior ones largest; the scales before first dorsal extend forward to opposite posterior margin of opercles; the dorsals far apart, the fourth spine of first dorsal longest, barely touching origin of second dorsal when depressed, a little greater than depth; the second dorsal and anal of similar shape, the posterior rays longest and equal to longest first dorsal spine but not reaching caudal when depressed; the caudal peduncle broad, its depth about 1.9 times in head and 1.8 in its own length; the caudal broad, nearly truncate, 1.2 times head; the pectoral broad, pointed, nearly as long as head; the broad short ventrals reach less than halfway to the slender pointed anal papilla.

The color in alcohol everywhere dark purplish brown, with sides of head purplish black and a large violet-black spot covering base of pectorals; the dorsals, anal, and forward two-thirds of caudal deep velvety black; the pectorals concolorous with body; the ventrals and posterior third of caudal colored like body, with a narrow lateral margin of white.

Here described from the type specimen, 34 millimeters long, from Irid River, Santa Ines, Rizal Province.

I place here also three immature specimens, 23 to 28 millimeters long, from Bangar, La Union Province. They are much paler, being uniform dark slate color all over.

Ater, black; purpureus, purple.

153. MICROSICYDIUM FORMOSUM 'sp. nov.

Plate 23, Fig. 3

Dorsal VI, I-7 ; anal I, 8 ; there are 38 scales in a longitudinal series, 10 in a transverse series, and 13 or 14 rows of scales before first dorsal.

The body low, slender, elongate, cylindrical anteriorly, the diameter equal to or greater than the depth, laterally compressed from second dorsal back, the depth 5.7 in length; the head flat above, broad, its depth two-thirds of its width, and contained 4.4 times in length; the convex snout bluntly rounded, 4.5 times in head; the circular eyes high up, lateral, equal to snout, as is also the broad interorbital; the mouth rather small, slightly oblique, the posterior angle of maxillary beneath an- 
terior third of eye; the upper jaw has a single row of immovable, thickly crowded, small, brownish teeth; the lower lip has a row of horizontally placed minute teeth, which do not reach the surface of the membrane in which they are thickly set; behind these on jaw are two pairs of very small, hooked, slender canines, near symphysis; the scales large, ctenoid, becoming cycloid on nape, where they are smaller and extend forward nearly to eyes, to a point over middle of opercles; the caudal peduncle depth 2.5 times in head and 1.75 times in its own length; the dorsals far apart, the distance between them almost equal to length of base of first dorsal, small, equal in height which is 1.4 times in depth and 1.8 in head; the anal slightly higher than second dorsal, 1.27 in depth; the second dorsal and anal do not reach base of caudal when depressed; the pectoral rather broad, a seventh longer than depth of body and 5 times in length; the ventrals short, forming a free, deep, circular cup, attached only at base, its length equal to height of dorsal, the distance from its tip to the small notched anal papilla 1.4 times its own length; the caudal rounded, equal to head in length.

The color in alcohol yellowish brown with blackish brown longitudinal stripes as follows: The widest one passes around tip of snout and back across cheeks upon base of pectoral; then from beneath pectoral it passes along middle of side to base of caudal; just beyond its posterior end is a large, circular, black spot, surrounded by a broad white band; the second band passes around the brow, across upper part of eye and back along the side to upper end of base of caudal; it is connected with its fellaw by two crossbands on caudal peduncle; a third, narrow stripe begins a short distance behind upper margin of eye and passes back along dorsal region as far as posterior end of second dorsal, the latter part of it more or less obscure; from upper margin of eye a line curves inward and backward beside the median line of nape to base of first dorsal; a few blackish spots on posterior part of first dorsal; three transverse rows of blackish spots on second dorsal; the anal has a single row of blackish marginal spots; the central part of caudal marked by elongate blackish spots, in addition to the large spot on base already mentioned; the basal part of pectoral has a few blackish brown spots.

Here described from the type and only specimen, 40 millimeters long, collected in the Titunod, a small stream near 
Kolambugan, Lanao Province, Mindanao. It lives in stony, brawling hill creeks, where numbers of specimens were seen. It is difficult to secure, as it slips into crevices between the rocks at the least sign of danger. It is evidently related to Sicydium elegans Steindachner, from the Society Islands, but is separated by differences in the scalation, fins, and color.

Formosum, beautiful.

154. MICROSICYDIUM PULCHELLUM sp. nov.

Plate 23, Fig. 4

Dorsal VI, I-9; anal I, 10 ; there are 30 scales in a longitudinal series, 9 in a transverse series, and 8 before first dorsal.

The depth of the slender, elongate body 6.4 times in length, the dorsal and ventral profiles nearly horizontal and parallel; the head rather short, 4.7 times in length, its breadth 1.58 times in its length and 1.26 times its own depth; the snout short, blunt, wide, steeply descending to its tip, concave, 4 times in head; the eyes very high up, dorsolateral, a little longer than snout, 3.77 times in head; the interorbital breadth equals length of snout, the mouth small, slightly oblique, the posterior angle of maxillary beneath anterior part of eye; the upper jaw has a single row of small, immovable, closely set, colorless teeth with brownish tips; the lower jaw has a pair of hooked canines near symphysis, and fastened to lip is a horizontal row of slender, colorless teeth projecting well beyond its margin; the large ctenoid scales become cycloid in front of first dorsal and extend as far as above middle of opercle; the dorsals far apart, the third spine of first dorsal longest and equal to 0.88 of the depth, 1.54 times in head, the spines of first dorsal falling far short of second dorsal when depressed; the anterior rays of second dorsal longest, 0.9 the depth, and lacking much of reaching caudal when depressed; the anal similar to second dorsal but lower, its longest ray but 0.8 the depth; the caudal round pointed, 1.1 times head and 4.2 times in length; the pectoral long, pointed, 1.6 times depth, 1.18 times head, and 4 times in length; the ventrals broad, rounded, 0.5 the length of pectoral.

The color in alcohol uniform pale sandy yellow, lighter under head; a broad, dark brown band passes around snout on upper lip and extends back below eye to base of pectoral where it terminates in a darker blotch; beneath pectoral it continues as a broader brown band to base of caudal; beginning behind eye 
a narrower paler band continues back along upper part of side to upper edge of caudal base; on basal part of caudal is a conspicuous, blackish brown, rounded spot; the other fins are all colorless, the anal with some brown spots along its base.

Here described from the type, 32 millimeters long, collected by me in Dumaguete River, Dumaguete, Oriental Negros. Another specimen, 28 millimeters long, collected at the same time and place, has a bluish pearly band around snout on upper lip, back over lower part of eye to base of pectoral, ending in a bluish pearly spot; the caudal is conspicuously crossbarred with six dark brown bands, its tip blackish, and a dark brown spot at its base; the dorsals are brown, the second dorsal crossbarred with darker spots; the anal is brown with a blackish margin.

This species is close to Steindachner's Sicydium elegans, from the Tonga Islands.

Pulchellus, beautiful little.

\section{Genus 67. SICYOPTERUS Gill}

Sicyopterus Gill, Proc. Acad. Nat. Sci. Phila. (1860) 101; BleEker, Arch. Neerl. Sci. Nat. 9 (1874) 313; Revision des Sicydinii, Versl. Akad. Amsterdam II 9 (1876) 272.

Sicydium GüNTHER, Cat. Fishes Brit. Mus. 3 (1861) 91 (pro parte); Grant, Proc. Zool. Soc. (1884) 152 (pro parte).

The teeth in upper jaw of singular shape, small, closely appressed in a single row, movable, attached by ligaments, strongly curved, their tips projecting from the gum, honey colored and tricuspid in Philippine species, bicuspid in a Samoan species. The form and arrangement of the cusps of the teeth are altogether different from the two types of tricuspid teeth described and figured by Grant in the exceedingly valuable paper cited above. Behind the outer visible row of teeth lie numerous parallel rows of young teeth or buds hidden in the gum, their tips disproportionately large and coarsely trident-shaped, the prongs of uniform size; as the teeth of the first row are worn out or broken they are replaced by the buds next in line; the shape of the teeth, both cusps and basal portion, or root, varies in the different species, each having its characteristic pattern.

The body low, the dorsal but little elevated, convex or flattened anteriorly, the ventral profile nearly horizontal, thick, rounded, only the posterior part laterally compressed, the caudal peduncle deep, the head usually large, blunt, broader than deep, with a 
long convex or nearly perpendicular, obtusely rounded snout, thick upper lip, and an inferior mouth, very low down and usually nearly horizontal. The body densely covered with rather small ctenoid scales, 50 to 85 in a longitudinal series, which extend forward on nape nearly to eyes, and back upon caudal fin and basal part of pectoral; the head naked except for those on nape; the scales may be of nearly uniform size, or those on middle of trunk may be larger to much larger than those anteriorly and on caudal peduncle, or those on belly and neck may be smaller to much smaller than the rest, which are of about equal size.

The upper lip may be $(a)$ entire, $(b)$ with a median more or less linear cleft, $(c)$ with a median and two lateral clefts each halfway to angle of mouth and about opposite eye, or $(d)$ with the whole lip crenulate-dentate and with two small lateral clefts nearer angle of mouth than middle of lip. The lateral clefts in $(c)$ are shaped like a sac, or alveolus, with a narrow mouth and rounded subcircular margin; the inner margin of upper lip may be entire, rugose, or covered with tubercles or papillæ; in Philippine species with $(b)$ and $(c)$ types of cleft lips the median fissure has a long conspicuous papilla beneath it, and stouter shorter papillæ or large tubercles beneath the lateral clefts. The lower lip has a row of slender, more or less pointed, horizontal teeth, their tips alone visible as a rule; behind symphysis of lower jaw is a pair of large, stout, recurved canines; on each side is a row of four to eight curved teeth, more or less enlarged, the middle ones usually small, the posterior ones usually rather large.

The dorsals are well separated, VI (V or VII), I-10 or 12, the spines of first dorsal elongate in many species, often excessively so, their tips free and threadlike or the fin membrane carried to the tips of the elongate spines; the second dorsal and anal moderate or low, angulate posteriorly; the caudal rounded, longer or shorter than head. The ventrals very characteristic, forming a short, thick, semicircular, powerful sucking cup, in many species broader than long, more or less adherent to belly, the frenum thick. The gill openings of moderate width, not extended forward, the isthmus broad; branchiostegals 4 ; no air bladder.

In Grant's paper, which is apparently the only general study ever made of the group, twenty-four species are described under 
the generic name Sicydium. This name can be limited to those members of the group without enlarged teeth at the symphysis of the mandible, and under it can be placed the first seven species described by Grant.

Of the remainder, two species have been placed by other authors under Bleeker's genus Microsicydium. This leaves fifteen species which, with Sicyopterus japonicus (Tanaka), two species from Ceram described by Beaufort, and the five new species now presented, make up the genus Sicyopterus as here understood.

The various species range from Japan to Samoa and the Society Islands, and from Hawaii to Burmah and the Isle of Réunion, their center of distribution being in the East Indies.

The diagnoses by Gill and Bleeker are incorrect and unsatisfactory, not being based on a critical examination of the teeth under a high power of the microscope. Under a simple lens the tricuspid teeth appear simple or perhaps bifid. Guichenot's genus and Bleeker's subgenus Cotylopus, if based on the supposed bilobed character of the teeth, cannot stand, for the teeth are really tricuspid. However, Cotylopus and Jordan and Evermann's genus Sicyosus are probably valid through the presence of other characters.

These dull-colored, inconspicuous fishes abound in bowlderstrewn mountain streams where the current is moderately swift. They love to lie above large rocks where they bask in the sunlight, protected by a shallow stratum of rippling water. Here they nibble at minute algæ, ready to slip out of sight beneath the bowlder at the first movement made by man or bird. Although authors state they are "confined to fresh waters near the sea," they really go down to the sea to spawn, in common with many other fresh-water gobies. Their fry, which ascend the Ilocano and Cagayan streams, form one of the most important sources of ipon during the autumnal months. In both Mindanao and Luzon they ascend to an altitude of 1,000 meters or more.

The Philippine species, with the exception of one record from Palawan by Boulenger. (of which I have seen no authentic representative), include three sections of the genus; one with the upper lip entire, one having a type of cleft upper lip close to that found in Sicyopterus stimpsoni Gill, from Hawaii, but 
different in detail, and one unlike any hitherto described, with two lateral clefts and the whole lip margin more or less denticulate-crenulate.

The superficial resemblance between quite divergent species of Sicyopterus is very great and it is only possible to separate some of them by a critical examination of the lips, supplemented by a microscopic examination of the teeth. The differences in the mouth and teeth, together with the scale count, may be relied upon to separate species almost identical in general appearance and color markings.

Key to the Philippine species of Sicyopterus.

$a^{1}$. Upper lip entire; scales 65 in a longitudinal series, 16 to 18 in a transverse series, and 25 to 30 before first dorsal.................... S. lacrymosus. $a^{2}$. Upper lip cleft.

$b^{1}$. Upper lip with a very slight median cleft and no lateral clefts; longitudinal series of scales 75 to 80 , transverse, $17 \ldots$... S. cynocephalus.

$b^{2}$. Upper lip with two lateral clefts; a median cleft absent or present.

$c^{\mathbf{1}}$. Upper lip with two lateral alveoluslike clefts opposite eyes and with a median cleft; papillæ or tubercles on gum beneath it. $d^{1}$. Scales more than 65 in a longitudinal series.

$e^{1}$. About 75 scales in a longitudinal series, 20 in a transverse series, 26 to 32 before first dorsal............................ S. crassus.

$e^{2}$. Seventy scales in a longitudinal series, 20 to 22 in a transverse series, 36 to 40 before first dorsal.

S. fuliag.

$d^{2}$. Fifty-five to 57 scales in a longitudinal series, 14 or 15 in a transverse series, 14 to 16 before first dorsal.... S. extraneus.

$c^{2}$. Upper lip with two narrow lateral clefts, not saclike, and no median cleft; lip margin denticulate-crenate; no papillæ or tubercles on gum beneath it.

S. panayensis.

155. SICYOPTERUS LACRYMOSUS sp. nov.

Plate 24, Fig. 1

Ilocano name, paliling.

Dorsal VI, I-10; anal I, 10; there are 65 scales in a longitudinal series, 16 to 18 in a transverse series, and 25 to 30 before first dorsal.

The body robust, laterally compressed, the dorsal and ventral profiles nearly horizontal, the depth 4.8 to 5.1 times in length; the broad blunt head 4 to 4.17 times in length, flat above, its breadth slightly exceeding its depth and 0.75 to 0.9 of its own length; the snout full, rounded, protuberant, 2.2 to 2.6 times in head; the eyes small, lateral but very high up so that their 
gaze is partly upward, 1.66 to 2.3 times in snout and 4.5 to 5.3 times in head; the flattened interorbital 1.66 to 2 times eye; the mouth low, inferior, the upper lip entire, thick and fleshy, its inner margin more or less rugose but neither papillate nor
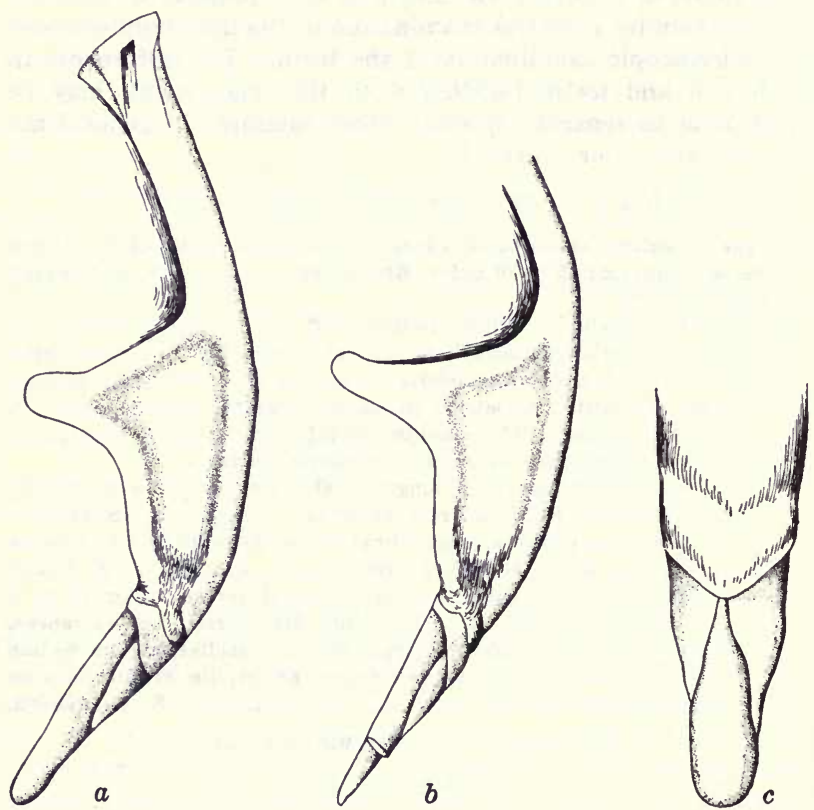

Fic. 1. Sicyopterus lacrymosus sp. nov,; $a$, right side of a tooth; $b$, right side of a broken tooth, showing the relation of the three cusps; $c$, reconstructed drawing, showing the dorsal aspect of the tooth.

tuberculate; the posterior angle of maxillary beneath anterior margin or pupil of eye; the teeth in upper jaw have the cusps all erect, the central cusp much larger than the others, with broadly rounded tip, the other cusps acute, the basal part of teeth with a different shape from that of other species (see text figure); on outer edge of lower lip is a row of simple horizontal microscopic teeth, usually covered with a thick coat of slime and therefore invisible; besides the pair of stout, recurved canines at symphysis of lower jaw there are six or eight curved white teeth on each side, the last two much larger and stronger than 
the others; the scales largest along middle of sides, smaller on posterior half of caudal peduncle and beneath pectoral, much reduced in size before first dorsal, extending forward on nape nearly to eyes; the scales behind ventral very small, none in front of it; the dorsals well separated, the third and fourth, or second, third, and fourth spines with elongated and threadlike tips, sometimes excessively lengthened, the fourth always longest; sometimes all the spines may have more or less elongated tips; the first dorsal always extends to second dorsal when depressed and the fourth spine may reach almost to posterior end of base of second dorsal, and is contained from 4.25 to 2.3 times in length of head and trunk; the second dorsal low, the middle rays longest, their tips extended much beyond the membrane, sometimes elongate and the rays then equal to or exceeding depth but typically about $\frac{2}{8}$ to 0.8 the depth, 1.77 times in head or exceptionally equal to head, rarely touching the accessory caudal rays when depressed and typically falling much short of caudal base; the anal lower, the posterior rays longest but always falling far short of caudal when depressed, 1.4 to 1.85 in depth and 1.4 to 2.2 times in head; the caudal peduncle wide, 1.25 to 1.5 times in its own length; the caudal varies from somewhat pointed to rounded, 3.9 to 4.5 times in length, usually a little shorter than head but sometimes slightly exceeding it; the pointed pectoral equals caudal; the ventrals nearly circular, often broader than long, 1.85 to 1.95 times in head and 2.3 tc 2.66 times in distance to anus.

The color in alcohol dull brownish gray, which may change to yellowish brown in specimens long kept; there are about seven blackish double dorsal crossbars, the four posterior ones running diagonally forward down the side, the anterior ones short, the first one on nape; the belly and throat white.

The top and sides of snout marbled with darker; the front of snout and upper lip more or less purplish dusky; a conspicuous deep black spot or bar, as wide as eye at its upper end, beginning on lower margin of eye and extending downward to above posterior angle of maxillary; a vague dusky blotch on opercle; a blackish bar begins under pectoral and passes back along side to tip of caudal fin, which is all black with a narrow pale margin above and below; the lateral band often disappears in old specimens; the first dorsal clear, the posterior part marbled with irregular, wavy, dark longitudinal lines, or irregular spots; the rays of second dorsal dusky greenish, the membranes 223798-20 
covered with many dusky spots; the anal whitish with a narrow dusky margin; the pectoral blackish margined by yellowish or whitish; the ventrals white or faintly yellowish.

Here described from nine type specimens, 47 to 68 millimeters long, from Abra River, Bangued, Abra Province; nineteen cotypes, 50 to 63 millimeters long, from Laoag River, Ilocos Norte Province, the largest one of which is a female with eggs about half developed, and one cotype, 58 millimeters long, from Titunod River, Kolambugan, Lanao Province, Mindanao; after five years in alcohol it is deep brown, the markings blackish brown.

The Bureau of Science collection also contains specimens, 25 to 76 millimeters long, as follows:

Buguey River, Cagayan Province, 18.

Laoag River, Ilocos Norte Province, 16.

Abra River, Ilocos Sur Province, 1.
Bangar, La Union Province, 130.

Dumaguete River, Oriental Negros Province, 4.

Zamboanguita, Oriental Negros Province, 1.

In addition to the above, I have.a couple of thousand fry of this species, 15 to 25 millimeters long, caught at the mouth of Abra River, Ilocos Sur Province, and Bauang River, La Union Province, or purchased as ipon at Vigan, Ilocos Sur Province. In all probability this species is also present in our other catches of ipon; but, in fishes less than 15 to 18 millimeters long, scales are not usually present, the teeth are not properly developed, and the species of most ipon cannot be determined with exactitude in the present state of our knowledge. Specimens, 15 to 20 millimeters long, have the characteristic crossbands, and the posterior part of the body is scaled as far forward as in line with the hind end of the first dorsal; all forward of this line is still naked; the spot below the eye is also present.

This little fish is a very important source of ipon along the Ilocano coast during the period from the last of August to December, about three months, the exact dates fluctuating according to weather conditions and other factors.

This species is close to Sicyopterus longifilis Beaufort.

Lacrymosus, tearful.

156. SICYOPTERUS CYNOCEPHALUS (Cuvier and Valenciennes)

Sicydium cynocephalum CUVIER and VALENCIEnnes, Hist. Nat. Poiss. 12 (1837) 134, pl. 352; GüNTHER, Cat. Fishes Brit. Mus. 3 (1861) 94 ; Grant, Proc. Zool. Soc. (1884) 166; Boulenger, Ann. \& Mag. Nat. Hist. VI 15 (1895) 185. 
Sicyopterus cynocephalus BLEEKER, Versl. Med. Akad. Amsterdam II 9 (1876) 275.

Sicydium parvei (non Bleeker) GüNTHER, Cat. Fishes Brit. Mus. 3 (1861) 94.

Dorsal VI, I-10 or 11 ; anal I, 10 or 11 ; there are 75 to 80 scales in a longitudinal series and about 17 in a transverse series.

The depth about 5 times, the head 4.5 times in length; the width of head rather greater than height and about $\frac{2}{3}$ of length; the diameter of eye 6 times in head and half the interorbital space; the posterior angle of maxilla beneath posterior margin of eye; the upper lip has a very slight median cleft, with a small papilla beneath it; a row of small papillæ on gum beneath upper lip; the horizontal teeth of lower lip conspicuous; the scales on sides of body larger than those on caudal peduncle and much larger than those on anterior part of body and occiput; the first dorsal higher than body, the third spine produced into a short filament; the second dorsal not so high as body; the caudal contained 4.33 times in length; the pectoral longer than head.

The color above deep violet or greenish violet or dark green, below whitish or yellowish, with six or seven more or less indistinct, broad, oblique, brownish or darker crossbands; a brown spot below eye; the dorsal and anal fins orange, the second dorsal sometimes with large, regularly disposed brown spots on rays; the anal has a broad violet or brown margin; the caudal olive with the superior and inferior edges yellow; the pectoral yellowedged.

The above description is compiled, as I have seen no authentic specimens. Boulenger listed this species among those collected by Whitehead in Palawan. It is an East Indian species, occurring from Sumatra to the Moluccas, and is "found in fresh waters 3000 feet above the level of the sea." According to Bleeker it attains a larger size than does any other species of the genus; his largest specimens were 160 millimeters in length.

157. SICYOPTERUS CRASSUS sp. nov.

Plate 24, Fig. 2

Dorsal VI, I-11; anal I, 10; there are about 75 (73 to 76 ) scales in a longitudinal series, 20 in a transverse series, and 26 to 32 before first dorsal.

The thick, heavy, rounded body laterally compressed only at posterior part, the dorsal and ventral profiles nearly parallel, 
the head and nape slightly convex or nearly flat above, the depth 4.6 to over 5 times in length; the head very large, though not very long, depressed anteriorly, 4 to 4.28 times in length, its breadth a little more than its depth and 78 to 82 per cent of its own length; the snout long, convex, broadly rounded, 2 to 2.3 times in head; the eyes lateral, very high up, their upper margin even with upper profile, 3 to 4 times in snout, and 6.66 to 9 times in head; the flat interorbital usually equal to or may be 1.25 times in snout; the mouth slightly oblique, the upper lip with a median cleft behind which is a conspicuous,

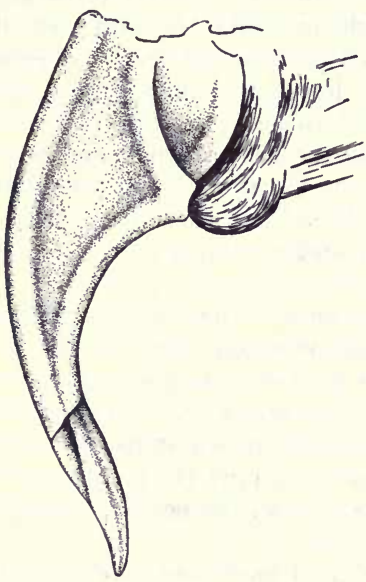

Fic. 2. Sicyopterus crassus sp. nov.; left side of a tooth.

long-pointed papilla and with a median saclike or alveoluslike incision on each half of lip, each with a stout but rather short papilla behind it, the inner margin of lip with rugose tubercles; the posterior angle of maxillary may be under anterior or posterior margin of eye; the teeth in upper jaw in a closely packed row, their honey yellow tips long and pointed; the central cusp long, its tip curved backward, very acute in lateral view, the lateral cups much smaller, sharp pointed, erect, as shown in the figure; on lower lip is a row of simple, pointed, horizontal teeth set close together; besides the hooked canines at symphysis there are six to eight stout conical teeth on each side of lower jaw, the middle ones small, the others almost or quite as large as the symphysial teeth; posteriorly from a line drawn opposite fifth dorsal spine the scales are comparatively large and of uniform size; anteriorly from this point the scales are much smaller, becoming very small on nape; the axil of pectoral, the belly beneath the ventrals, and the breast in front of them all naked; the dorsals well separated, the first dorsal elevated, the third spine longest, the tips more or less elongated and threadlike, 3.2 to 4.6 times in length; the second dorsal has the posterior rays pointed, angulate, extending upon base of caudal when 
depressed, 1.37 to 1.47 times in head; the anal similar in shape but the anterior rays higher or the fin may be of uniform height, the posterior rays not reaching caudal when depressed, 1.7 to 1.75 times in head; the depth of the large caudal peduncle about $\frac{2}{8}$ the length of head and more than its own length, which is 0.75 to 0.8 per cent of the depth; the broad rounded caudal is 3.5 to 4 times in length and exceeds head; the pectoral very broad, rounded to somewhat triangular, pointed, equal to head; the ventrals wider than long, 1.7 to 1.95 times in head and 2.3 to 2.8 times in the distance to the very short, thick anal papilla.

The color in alcohol uniform dull brownish gray, paler on sides and posteriorly, whitish beneath, darker and brownish plum color on snout and cheeks; the first dorsal clear, the spines brownish gray; the second dorsal crossbanded by four or five diagonal rows of dull brown bars on lower three-fourths of spines only, the membranes colorless, the fin with a broad, reddish brown margin; the anal dull gray with a broad violet blackish margin; the caudal yellowish gray with a broad violet blackish posterior margin; the pectorals are gray, but seem to have been yellowish with a pale violet margin; the ventrals whitish.

Here described from five specimens, 97 to 128 millimeters in length, collected by Taylor in Craan River, on the southern coast of Cotabato Province.

Crassus, fat or burly.

158. SICYOPTERUS FULIAG sp. nov.

Ibanag name, fuliag.

Dorsal VI, I-10; anal I, 9 or 10 ; there are 70 scales in a longitudinal series, 20 to 22 in a transverse series, and 36 to 40 before first dorsal.

The low, rounded body laterally compressed on posterior fourth, the depth 5.3 to 5.8 times in length; the broad head and nape slightly convex, the snout depressed, the underside flat as far back as and including ventrals, 4.2 to 4.37 times in length; the breadth of head 0.25 to 0.5 more than its depth and 70 to 85 per cent of its own length; the snout depressed, nearly vertical in front, very broad, gently rounded, 2.2 to 2.3 times in head; the small eyes lateral but very high up, their gaze upward as well as sideways, 3 to $3 \frac{2}{3}$ times in snout and $6 \frac{2}{3}$ to 8 times in head; the broad flat interorbital space a little less than snout, 2.4 to 2.5 times in head, and 2.7 to 3.3 times eye; the 
mouth horizontal, wide, the broad, fleshy, upper lip with three clefts, a linear one at the middle, and a baylike or saclike one on each side halfway to corner of mouth, the inner margin of lip tuberculate; the posterior angle of maxillary before or beneath front margin of eye; behind the middle cleft a short nipplelike papilla, and a short, very stout one below each lateral cleft; the teeth in upper jaw in a closely packed row, their honey yellow tips composed of three cusps, the middle one longest

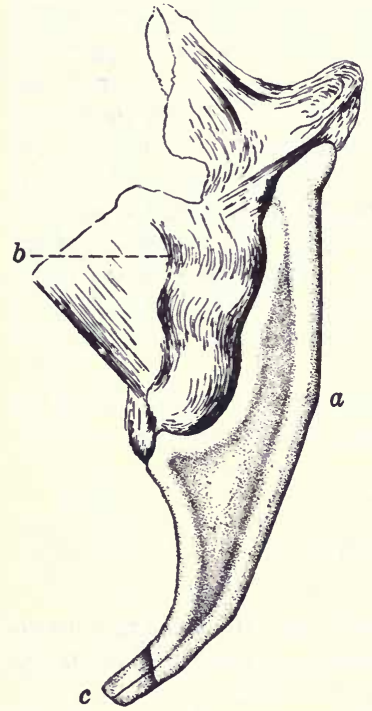

FiG. 3. Sicyopterus fuliag sp. nov.; $a$, base of a tooth; $b$, muscles of sttachment; $c$, broken cusps. with rounded tip, the others shorter and very sharp pointed, the tips projecting very little beyond the gum; on outer edge of gums of lower lip is a row of simple, horizontal, widely spaced teeth; in addition to the pair of strong canines at symphysis, the inner row has four to six teeth on each side, the last two enlarged, caniniform, and usually as large as the anterior canines; below base of first dorsal and anteriorly the scales are much smaller than those posteriorly, those on nape very small and extending nearly to eyes; the body beneath and in front of ventrals and in axil of pectoral naked; the dorsals well separated, the first dorsal elevated, the first four or five spines elongated but united, the membrane extending to their tips, the third or second and third longest, 2.9 to 4 times in length but usually just a little longer than head; the second dorsal low, pointed posteriorly, the posterior ray sometimes elongate and then touching base of caudal, 1.25 to 2 times in head; the anal like second dorsal but lower, the posterior ray never touching base of caudal; the depth of the broad caudal peduncle equals or exceeds its length, 1.25 to 2 times in head; the truncate or slightly rounded caudal equals or more often slightly exceeds head; the very broad, pointed pectoral may equal head but is usually shorter, 1.2 to 1.25 in 
head; the ventrals broader than long, twice or nearly twice in head, and 3 or nearly 3 times in the distance to the very short, thick, rounded anal papilla.

The color in alcohol dusky olive brown, paler to yellowish or whitish beneath, with about seven blackish crossbars, wider than the interspaces, which descend to belly and are most apparent on posterior half; a forward-curved, heavy black line descends from eye to angle of mouth; a more or less waved heavy black line crosses interorbital from eye to eye, terminating in a black spot on upper eye margin; in front of it are two similar lines and behind it is another line or series of dashes; the first dorsal uniform dull olive brown; the second dorsal pale olive, with numerous crossbars of dusky brown lines or spots, running diagonally downward and backward; the caudal uniform with the body color, the tip darker; the anal very dark olive brown; the pectoral blackish with a narrow yellowish margin; the ventrals yellowish.

Here described from the type and cotypes, seven specimens, from 72 to 105 millimeters in length, collected by me from Pinacanawan River, at Lamug, a barrio in the mountains east of Tuguegarao, Cagayan Province.

Since writing the above I received twenty-eight specimens, 82 to 140 millimeters long, from the same river, collected at the barrio of Karoan.

This is an important ipon goby in the Cagayan Valley.

159. SICYOPTFRUS EXTRANEUS sp. nov.

Sicyopterus taeniurus JORDAN and RICHARDSON (not of Günther), Bull. Bur. Fisheries 27 (1908) 279.

Dorsal VI, I-11; anal I, 10; there are 55 to 57 scales in a longitudinal series, 14 or 15 in a transverse series, and 14 to 16 before first dorsal.

The low, plump, nearly cylindrical body laterally compressed on posterior third, the nape and head more or less flattened, the depth of body usually equal to its breadth, 5 to 5.4 (4.7 in a gravid female), the head 4.2 to 4.375 times in length; the head rather small, its depth 75 to 85 per cent of its breadth, which is 0.7 to 0.75 of its own length; the snout convex, rounded, comparatively narrow, 2.16 to 2.5 times in head; the small eyes lateral, but high up and able to gaze up as well as sideways, 2 to 2.6 times in snout, 5 to 6 times in head, and 1.75 to 2.3 times in interorbital, which is less than snout; the low inferior 
mouth horizontal, the wide upper lip with three clefts, the middle one very narrow and short with a large bulbous papilla, the lateral ones shaped like a sac, or alveolus, each with a thick, tubercular papilla beneath it, the inner margin of lip tuberculate; the posterior angle of maxillary extends beneath pupil of eye; the teeth of upper jaw have the central cusp very large, broad, inward-curved, the tip rounded in face view; the lateral cusps almost or quite as long as the middle one, incurved, very acute (see text fig. 4); the horizontal teeth of lower lip very

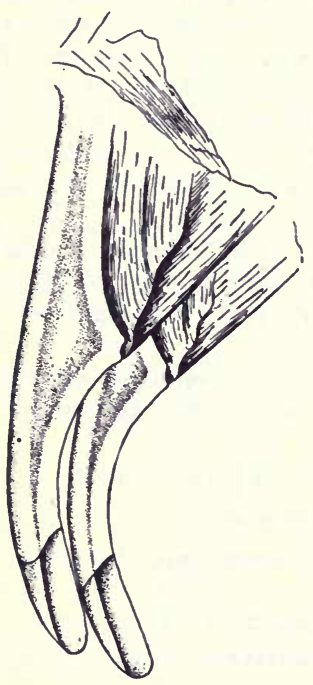

Fic. 4. Sicyopterus extraneus sp. nov.; left side of two teeth. slender, sharp-pointed, widely spaced; from three to six stout, curved teeth on each side of lower jaw, all smaller than the large symphysial canines; the scales of almost uniform size, those on caudal peduncle and before first dorsal somewhat smaller, only the last few anterior rows on nape much reduced in size; the dorsals well separated, the first moderately elevated, the membrane extending to tip, the third spine longest, equal to depth; the second dorsal low, 1.3 to 1.6 times in depth, 1.5 to 1.9 times in head, angulate, pointed posteriorly, the last ray barely reaching caudal base; the anal similar but a little lower, the anterior rays longest, 1.6 to 2 times in depth and 2 to 2.25 times in head, the pointed posterior ray usually falling short of caudal base when depressed; the depth of caudal peduncle equals its length; the bluntly rounded caudal equals head; the pectoral has an elongate round-pointed tip, approximately equal to depth, 1 to 1.3 in head; the ventrals broader than long, 1.75 to 1.85 in head and 2.75 to 3 times in distance to anal papilla; this is very small, short, and thick in males; larger, subglobose, with notched tip in females.

The color in alcohol dull dark brown, paler beneath and whitish under head and on belly, with seven broad, vertical crossbands, the last three most distinct, the first before first dorsal; a faint indistinct black bar runs along middle of side to tip of caudal; a narrow blackish band near upper and lower 
margins of caudal, converging and joining middle band at tip, leaving the upper and lower parts of tip clear; a black or dark brown forward-curved band extends from eye to angle of mouth; a blackish stripe runs around lower margin of snout; the first dorsal uniform dusky brown; the second dorsal dull dark brown, vaguely crossbarred with darker indistinct spots; the anal blackish or dull brown with a violet blackish margin; the pectorals the color of body, the ventrals pale yellowish.

Here described from three female and two male specimens, 60.5 to 74 millimeters in length, collected at Cabalian, Leyte, May 28, 1921. The largest specimen is a female nearly ready to spawn.

I place here a specimen, 60 millimeters long, collected in 1909 from Cagayan River, Misamis Province, Mindanao, at an altitude of 250 meters. It has faded to yellowish brown, but the crossbands and caudal markings are very distinct. It agrees with the Leyte specimens in scalation, teeth, lips, and fins.

Jordan and Richardson had two small specimens, one from Mindoro and one from Sibuyan, which they called S. taeniurus, which is however quite distinct, having but one median cleft on upper lip and having no crossbars but being uniformly colored.

Extraneus, a stranger.

160. SICYOPTERUS PANAYENSIS sp. nov.

Dorsal VI, I-10; anal I, 10; there are 64 to 66 scales in a longitudinal series, 18 or 20 in a transverse series, and 24 to 26 before first dorsal.

The body low, plump, nearly cyclindrical, below first dorsal its breadth equal to its depth, only caudal peduncle laterally compressed, gently convex from first dorsal to tip of snout, the depth 4.6 to 5 times in length; the blunt head rather low, flat above, 4.1 to 4.3 times in length, its breath $\frac{5}{6}$ to more than 0.9 its length and 0.25 or more greater than its depth; the snout protuberant, bluntly rounded, 2.125 to 2.25 times in head; the small eyes high up, lateral, 5.5 to 6 times in head, 2.5 to 2.66 times in snout; the broad, flat interorbital equals snout; the low inferior mouth almost horizontal, the posterior angle of maxillary beneath pupil of eye; the upper lip very broad, especially posteriorly; it has no median cleft but has a small, narrow, curved cleft on each side nearer posterior end of lip than middle; the margin more or less denticulate-crenate; the inner side of lip and gum smooth, without papillæ or tubercles; the teeth of upper 
jaw inward-curved with a large broad median cusp with a chisel edge, the two lateral cusps much smaller and sharppointed; the horizontal teeth of lower lip slender, sharp-pointed, widely spaced, often entirely concealec, ind never showing well in my specimens; there are five or six siout, curved teeth on each side of lower jaw, all smaller than the pair of large symphysial canines; the scales of nearly uniform size except those on caudal peduncle and forward of a line intersecting the origin of first dorsal, which are smaller, those on nape and belly much smaller; the tips of all the first dorsal spines more or less elongate, the second, third, and fourth longest and extending beyond origin or to fourth or fifth ray of second dorsal when depressed, longer than head, 3.95 to 4.3 times in length; the second dorsal 1.33 to 1.5 times in head, $\frac{4}{7}$ to $\frac{2}{8}$ as high as first dorsal, angulate poste-

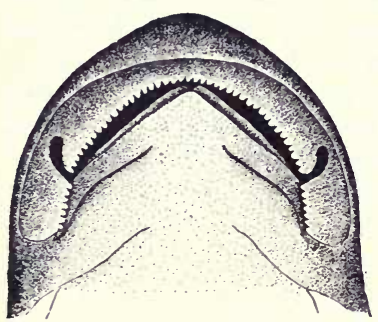

Fic. 5. Sicyopterus panayensis sp. nov.; upper lip. riorly, not reaching caudal when depressed, the middle rays longest; the anal like second dorsal but only $\frac{2}{3}$ or 0.75 as high; the depth of caudal peduncle equals its length or is 0.75 its length, 1.65 to 1.8 times in head; the caudal truncate to bluntly rounded, a little more or less than head; the pectoral broadly ovatepointed, 4.7 to 4.93 times in length, 1.1 to 1.2 times in head; the ventrals broader than long,

1.8 times in head and 2.3 to 2.5 in the distance to anus.

The color in alcohol uniform bluish gray to brownish or blackish gray, with eight or nine broad brown or blackish dorsal crossbands, two before first dorsal, the last just before caudal fin, the underparts white; the pectoral dusky with a broad white margin; the caudal dusky, the upper and lower margins white, with a more or less distinct vertical dark band on its base; the membrane of second dorsal and posterior part of first dorsal thickly sprinkled with small, elongate, dark spots; the anal whitish with a broad dusky margin; the ventrals white.

Here described from six specimens, 71 to 74 millimeters in length, collected by F. Reveche at San Jose, Antique Province, Panay. 


\section{PERIOPHTHALMID $Æ$}

The members of this family are separated from the other gobioid fishes by the structure of the ventral fins, the eyes, and the pectoral fins.

The latter have a long, scaly, and very muscular base, which enables them to use the fins as organs of locomotion on land; by means of them, together with the aid given by the elongate, slender, muscular body, they can make surprising leaps, and progress with astonishing speed over rough, stony ground as well as on smooth muddy or sandy beaches.

The ventral fins are more or less united, or entirely separate, with a thick muscular base, enabling them to cling with considerable force to perpendicular surfaces. The eyes are very close together, on short thick stalks, by means of which they may be elevated for purposes of observation, or they may be drawn in flush with the head; the outer eyelid is very well developed.

The body elongate, laterally compressed to subcylindrical, the head large, broad, and deep, abruptly convex or truncate anteriorly; the body densely covered with small scales, 50 to more than 100, which extend upon the tip and sides of head, or the scales may be very small or rudimentary; the teeth in the jaws are in one or two rows, conical, fixed; there are three large patches of pharyngeal teeth, partly needlelike, partly coarser, and conical; the dorsal fins are separate, the first fan-shaped, highest anteriorly; the caudal is lanceolate or obliquely rounded and in some genera has the lower margin obliquely truncated; the gill openings are rather narrow, the isthmus broad; branchiostegals 5 .

Tropical shore fishes of wide distribution. Some of the species soon drown if placed in deep water from which they cannot emerge, at least in part. Four genera occur in the Philippines.

\section{Key to the China Sea genera of Periophthalmidx.}

$a^{1}$. Teeth erect in both jaws.

$b^{1}$. Scales small, 75 to 100 , first dorsal X-XV, the ventrals divided, merely united at base. Periophthalmus.

$b^{2}$. Scales larger, 50 to 60 , first dorsal $0-X V$, the ventrals nearly completely united in adults, separated in the young.... Periophthalmodon. $a^{2}$. Teeth horizontal in lower jaw, the ventrals united.

$c^{1}$. Scales 60 to 100 , dorsal V, I-23 to 27 ; teeth in lower jaw with dilated tips, truncated or slightly emarginate or lobate.. Boleophthalmus. 
c." Scales microscopic; dorsal V or VI, I-24 to 26; teeth in lower jaw acute, simple, or medium size. Scartelaos.

\section{Genus 68. PERIOPHTHALMUS Bloch and Schneider}

Periophthalmus BLOCH and ScHNEIDER, Syst. Ichth. (1801) 63.

The teeth erect and in a single row in both jaws, some of them stout, conical, and resembling canines; two large oval patches of pharyngeal teeth above and a triangular one below, each with few to many rows of fine, sharp to coarser conical teeth; the ventrals more or less suborbiculate, united basally; the pectorals long, with very large muscular scaly bases, which the fish is able to use as legs or arms; the dorsal spines flexible, variable in number, the dorsals far apart; the entire body covered with a greatly variable number of small cycloid or minutely ctenoid scales, which extend forward of eyes and on sides of head to snout, the anterior scales minute.

There is apparently but a single polymorphic species, varying greatly in size, coloration, scale count, and fins, but all intergrading so that the ten or more named members of this genus are probably all of the same species. It is one of the most extraordinary of all fishes, and detailed accounts of.its habits may read like an extravaganza to one who has never seen it performing on some mud flat or beside some jungle-embowered tidal creek.

\section{PERIOPHTHALMUS BARBARUS (Linnzus)}

Plate 24, Fig. 3

Gobius barbarus LiNNAEUS, Syst. Nat. ed. 12 (1766) 450.

Periophthalmus papilio BLOCH and SCHNEIDER, Syst. Ichth. (1801) 63, pl. 14 (caudal fin bad); CuVier and Valenciennes, Hist. Nat. Poiss. 12 (1837) 143, pl. 353 (caudal fin bad).

Periophthalmus koelreuteri BLOCH and ScHNEIDER, Syst. Ichth. (1801) 65; Günther, Cat. Fishes Brit. Mus. 3 (1861) 97; DAY, Fishes of India (1878) 303, pl. 64, fig. 8; MEYER, Ann., Soc. España Hist. Nat. 14 (1885) 29; HICKsoN, A Naturalist in North Celebes (1889) $30-32$, colored frontispiece.

Periophthalmus barbarus JoRdAN and Seale, Bull. Bur. Fisheries 25 (1906) 393, fig. 1; Proc. U. S. Nat. Mus. 28 (1905) 794; JoRdAN and Richardson, Bull. Bur. Fisheries 27 (1908) 276.

Periophthalmus chrysospilus JORDAN and SEALE, Bull. Bur. Fisheries 26 (1907) 41.

Bicol name, tambasakan; Ilocano, banasak; Tao Sug, tamindak; Tagalog, talimosak; Visayan, tambasakan, at Romblon; tamasak, in Leyte and Panay; mud skipper. 
No attempt is here made to cite the exceedingly voluminous synonymy or the many papers upon the life and habits of this incredible little fish.

Dorsal X-XV, I-11; anal I, 10; scales in a longitudinal series 76 to 100 , in a transverse series 24 to 26 .

The body elongate, laterally compressed, the dorsal and ventral profiles tapering back to caudal, the depth 5.2 to 5.9 in length (4.75 in gravid females); the head very large and broad, 3.3 to 3.8 times in length, its breadth 0.75 to 0.8 of its length, and 1 to 1.2 times its depth, which equals or nearly equals that of body; the large broad blunt snout nearly vertical, its length 2.25 to 2.35 times in head; the snout ends in a broad, loose, lobulate flap almost concealing upper lip, and with two terminal sensory lappets which hang below mouth; the eyes as given for the genus, 1.6 to 2.16 times in snout and 3.1 to 4.8 times in head, the interorbital space exceedingly narrow; the horizontal mouth inferior, almost ventral, the lips thick and fleshy, the upper lip trilobate, the lateral lobes large flaps covering that portion of mouth beneath them, the central lobe-almost concealed by the snout flap already mentioned, so that only its margin shows, its inner surface covered with sensory papillæ; the lower lip rugosepapillate within the central portion, with a large, thick, lateral flap at each corner, connecting with the one above which conceals it; the teeth and scales as given for the genus; the first or first and second spines of first dorsal longest, sometimes reaching second dorsal when depressed, highly variable in length, 1.5 times in head and equal to or a little more or less than depth; the second dorsal lower, the posterior rays longer, angulate, not reaching caudal when depressed, 1.9 times in head; the anal shorter and much lower, the two rays before the last longest, 2.8 to 3 times in head, 1.9 to 2.2 times in depth; the depth of caudal peduncle 0.6 to 0.66 of its length, which is 1.66 to 1.9 times in head; the rather narrow caudal equals or is a little more or less than head, the tip moderately rounded; the shorter rays on lower side near base have pointed, free, thick, and rather rigid tips; on the upper side short accessory spines advance forward on caudal peduncle for some distance; the thick, powerfully muscled base of pectoral makes up a third of its length, the whole fin equal to or longer than head; the ventrals more or less separated but never united except basally, thick, flat, subor bicular, but the width much more than the length, which is twice or more than twice in the distance to anal papilla and 1.7 to 
1.9 in head; in males the anal papilla elongate-ellipsoid, thin, flat; in females the anal papilla is remarkable in shape, large, flat, suborbicular, with a deeply notched apex.

The color of this remarkable species is exceedingly variable; in life it is often gray or olive brown, with white, blue, silvery, brown, or black spots and dots, the light spots usually on head; the first dorsal brown or dusky violet, with a black or dark brown transverse band near and parallel to the white margin; the first spine white and white spots may be scattered over basal and posterior part of fin; the second dorsal has a white upper margin; below this is a wide black crossband, edged below by a narrow white band; the rest of the fin reddish brown, brown, or black, sprinkled with white dots and spots; the pectoral and caudal marked by numerous crossbars of brown dots; the lower or ventral rays of caudal yellowish or whitish; the anal and ventrals whitish or colorless.

Other specimens pale bluish green to bluish brown, with eight to ten dark or blackish brown bands over back and running diagonally forward and downward on sides, the head more or less dotted with bluish; the fins as already given, except that the dorsal fins may nave a decided yellow instead of white color on them; the second dorsal often has the margin colorless, then a white stripe, a broad black band, and another white stripe; the rest of the fin brown, sprinkled with white.

The color in alcohol is not greatly different, the bright silver, white, or blue spots fading, and the whole fish becoming browner, the spots on the pectoral and caudal less evident.

This extraordinary creature has excited curiosity from time immemorial. Its strange habits, so unfishlike, its astonishing acrobatic feats of agility, its ability to send its eyes aloft and keep one fixed on the human observer while the other rotates in its conning tower and scans the countryside for prey or foe, its enterprise in leaving the water and capturing its crustacean and insect food on land, its habit of leaping along the surface of the water and then taking refuge on land instead of at the bottom of a pool-all these and many other singular traits have caused it to be observed and studied by the ordinary tourist as well as by the fisherman and naturalist. One of its favorite attitudes is to cling to some rock or lie on the shore line with only the tail end of its body in the water. Experiment and observation have shown that it can obtain sufficient 
oxygen in this way to satisfy its needs, thus enabling it to keep all the rest of its body, including its gills, out of the water indefinitely.

Sir Francis Day expresses it well when he says: "They climb on to trees and large pieces of grass, leaves, and sticks, holding on by their pectoral fins exactly as if they were arms. Now and then they plant these firmly as an organ of support, the same as one places one's elbows on a table, then they raise their heads and take a deliberate survey of surrounding objects."

This fish is very common in all parts of the Philippines, abounding on rocky reefs, mud flats, in mangrove swamps, and muddy estuaries, equally at home in them all. Though occasionally seen for sale in the markets, it is not ordinarily caught by the fishermen, except as it may be taken with other and moredesirable fishes.

The Bureau of Science collection contains the following specimens, though ordinarily we purposely refrain from taking this fish:

Malabon, Rizal Province, 14.

Olongapo, Zambales Province, 1.

Limbones Bay, Batangas Province, 1.

Ambil Island, 2.

Puerto Galera, Mindoro, 2.

Romblon, 12.

Tablas, 4.

Aroroy, Masbate, 4.

Guinobatan, Masbate, 1.

Port Sula, Cagraray Island, Albay Province, 3.
Dumaguete, Oriental Negros Province, 11.

San Jose, Antique Province, Panay, 3.

Busuanga, 2.

Balabac, 10.

Zamboanga, Mindanao, 1.

Davao, Mindanao, 1.

Siasi, Sulu Province, 1.

Bungau, Sulu Province, 21.

Sitankai, Sulu Province, 1.

Amoy, China, 8.

Japan, 1.

These specimens range in length from 30 to 102 millimeters. Several specimens, 90 to 100 millimeters long, are breeding females, nearly ready to spawn, all of them taken in midsummer. It has been recorded previously in the Philippines from Aparri, Luzon, and from Ticao, Panay, Negros, and Cebu.

Specimens reach a length of 250 millimeters, though I have seen none of more than 150 millimeters from the Philippines, and the usual length is not more than half of that. The species occurs from the coast of China and Japan to northwestern Australia, east to the Pelew and Samoan Islands, west to the Red Sea and the Seychelles, and on the west coast of Africa at Sierra Leone and southward in the Tropics. 


\section{Genus 69. PERIOPHTHALMODON Bleeker}

Periophthalmodon BLFEK

The teeth in upper jaw in two rows, the outer one with canines present anteriorly, the inner row sometimes wanting; in lower jaw there is a single row, of which part may be canines; the pharyngeal teeth in few rows, most of them strong and conical. The ventrals united in adults, separate in the young; the first dorsal exceedingly variable, spines 0 to $\mathrm{XV}$, second dorsal I, 11 or 12 ; the pectorals have an exceedingly thick, long, muscular base, the fin scaled for more than half its length; the' scales are moderate, 48 to 60 in a longitudinal series, cycloid, not smaller anteriorly except on the sides of head and on snout.

Jordan, in his work on the genera of fishes, states that Periophthalmodon is a synonym of Periophthalmus, as restricted by Gill. As I am unable to get a copy of Gill's paper, I have followed what seems to me to be Schneider's arrangement, as restricted by Bleeker, vide Bloch and Schneider, Systema Ichthyologica.

\section{PERIOPHTHALMODON SChLOSSERI (Pallas)}

Gobius schlosseri Pathas, Spicilegia 8 (1769) 3, pl. 1, figs. 1-4.

Periophthalmus schlosseri BLOCH and ScHNEIDER, Syst. Ichth. (1801) 64; GüNTher, Cat. Fishes Brit. Mus. 3 (1861) 100; DAY, Fishes of India (1878) $304, \mathrm{pl}$. 66, fig. 4.

Periophthalmodon schlosseri JoRDAN and SEALE, Bull. Bur. Fisheries 26 (1907) 40.

Periophthalmus freycineti Cuvier and VALEncibannes, Hist. Nat. Poiss. 12 (1837) 148.

Dorsal $0, \mathrm{XV}, 1$ to 12 ; anal I, 12 ; there are 48 to 60 scales in a longitudinal series and 16 to 20 in a transverse series.

The variety named $P$. freycineti by Valenciennes is most characteristic of this species in the Philippines and is represented in the Bureau of Science collection by a fine male specimen, 101 millimeters long, collected at Iloilo; it has 4 dorsal spines, the base of the first dorsal very short, scales in longitudinal series 49 , in transverse 16 . The following description is based upon this specimen:

Body plump, laterally compressed, the depth 5.3 times in length; the subcylindrical head somewhat flattened dorsally, 3.8 times in length, its breadth equal to depth of body and slightly more than its own depth, 1.6 times in its own length; the convex snout nearly vertical anteriorly, bluntly rounded, 2.6 times in head and twice the prominent, stalked, erectile eyes; the 
lower part of snout terminates in a broad, loose, crenately lobed flap of skin, which has two long, teatlike sensory tabs hanging down over the upper lip, which is broad, fleshy, rugosepapillate within; the lower lip rather thin, but with a thick fleshy flap at each angle, connecting with upper lip; the mouth low, horizontal, the posterior angle of maxillary concealed, beneath middle of eye; the teeth of upper jaw in two rows, the anterior ones of outer row large, stout, erect, caniniform; those of inner row few, small, concealed in the gum and difficult to make out, largely wanting; the teeth in lower jaw similar to those in upper jaw, but smaller, only two near the symphysis at all caniniform; the entire body covered with scales which extend forward on cheeks and snout, those below and anterior to nape much smaller; the other scales comparatively large, those on nape not reduced in size; the pectorals scaled for two-thirds or more of their length and the caudal covered basally with rather large scales for a third of its length; the height of first dorsal 2.6 times the length of its base, 1.77 times in the depth of body, and 2.2 times in the length of head; the second dorsal low, angulate and pointed posteriorly, 2.1 times in depth and 3.2 in head; the anal of nearly uniform height, the posterior rays longest, angulate, pointed, 1.9 in depth and 2.9 in head; the depth of caudal peduncle 0.7 of its own length, and 2.66 times in head; the round-pointed caudal equals head; the pectoral shorter than head, in which it goes 1.2 times, its tip elongate-pointed; the thick fleshy ventrals united for two-thirds their length, with a thick, well-developed frenum, about twice in head and nearly 1.9 times in distance to anal papilla, which is small, somewhat spatulate, and considerably in advance of anal fin.

The color in alcohol bluish black on head and upper surface of body, with numerous, black, longitudinal lines on sides, extending downward to margin of belly and running back to caudal, the underparts whitish, probably green in life; the first and second dorsals black, with a narrow, white, upper margin; the anal uniform in color with belly; the caudal nearly black, the lower margin pale; the pectoral dusky greenish.

A male specimen, 68 millimeters long, from Perez, Bondoc Peninsula, Tayabas Province, with 11 spines in first dorsal and 58 scales in a longitudinal series, was brownish, with seven dark brown, dorsal crossbands, running diagonally forward to middle of side, the first one before first dorsal; a similar dark brown bar on nape, curved forward above opercle nearly to eye; black line 
along middle of side from angle of pectoral to caudal; the first dorsal brown, with upper margin white, under it a black crossband, and beneath that a narrow clear stripe; on posterior basal region are circular white spots; the second dorsal brown with a darker, submarginal crossband, the lower part brown spotted; the caudal has eight crossrows of brown spots; the pectoral uniform pale brown, the anal and ventrals colorless.

The scale count, dorsal spines, and color of this remarkable fish vary greatly. In many specimens the color scheme of the dorsals is like that of Periophthalmus barbarus.

The Bureau of Science collection contains also six specimens, 58 to 85 millimeters in length, from Odiongan, Tablas, which I place here, though with some misgivings. They have the large scales and general appearance of $P$. schlosseri, but have only one row of teeth in each jaw while the dorsal fin and body colors are much like those of $P$. barbarus. In the males the first dorsal spine is much elongated.

Jordan and Seale recorded a specimen from Cavite, but in general this species has been overlooked by all collectors, largely because of its close similarity to Periophthalmus barbarus in habits and habitat. What has been said about the last-named species applies to the present species, and it probably occurs all along our coasts, though less plentifully than $P$. barbarus.

Owing to its great variabiiity five or more specific names have been applied to this mud skipper, but no attempt is here made to give all of its synonymy.

It ranges from the coasts and estuaries of Bengal eastward through the East Indies. It reaches a length of 230 millimeters or more.

I received, since the above was written, three very fine specimens through the kindness of $\mathrm{Mr}$. Detrick, manager of the Polo Coconut Plantation at Tanjay, Oriental Negros. The largest one is $\mathbf{1 7 5}$ millimeters long and is very bulky; the smallest, $\mathbf{1 3 2}$.

\section{Genus 70. BOLEOPHTHALMUS Valenciennes}

Boleophthalmus Valenciennes in Cuvier and Valenciennes, Hist. Nat. Poiss. 12 (1837) 149.

The teeth in upper jaw conical, sharp, simple, in a single row, the front ones curved canines; in lower jaw is a single row of horizontal teeth dilated above, their tips truncate or slightly emarginate or obliquely lobed; behind these on each side of symphysis is a strong canine. The scales small to very small, 60 to 100 in a longitudinal series, extending forward upon head, and 
covering half or more than half of pectoral. The dorsals far apart, V, I-23 to 27, the first dorsal higher than long; the second dorsal more than twice to three times as long as first; the ventrals completely united; the lower margin of caudal obliquely truncated; the gill openings narrow, the isthmus broad; branchiostegals 5 .

This genus includes a few species of the coasts of southern and eastern Asia and the East Indies, northward to Japan. In habits they are like Periophthalmus. According to Day these mud dwellers rapidly drown if placed in deep water.

163. BOLEOPHTHALMUS CHINENSIS (Osbeck)

Plate 25, Fig. 1

Apocryptes chinensis OsBeck, Aman. Acad. (1754) 29, fig. 23; Voy. China (1771) 200.

Gobius pectinirostris GMELIN, Syst. Nat. 1 (1788) 1200.

Boleophthalmus pectinirostris GüNTHER, Cat. Fishes Brit. Mus. 3 (1861) 102.

Boleophthalmus chinensis JORDAN and SNYDER, Proc. U. S. Nat. Mus. 24 (1901) 47; Seale, Philip. Journ. Sci. § D 9 (1914) 74.

Dorsal V, I-23 or 24 ; anal I, 23 or 24.

The depth of the elongate, laterally compressed body 5.5 to 5.75 times in length, the dorsal profile nearly horizontal; the head large, broad, flattened above, 3.8 to 3.85 times in length, its breadth equal to the body depth and 0.25 more than its own depth; the steeply inclined snout bluntly round-pointed, about 3.75 times in head; the eyes covered above with skin like that of head, 5 times in head and 1.33 times in snout; the interorbital space very narrow, a linear furrow; the mouth strongly oblique, the upper lip thick, especially posteriorly, and partly concealed by two lateral snout flaps, the posterior angle of maxillary extending almost to or even beyond hind margin of eye; the tip of the tongue rounded, adherent; three or four enlarged canines on each side of center of upper jaw, the teeth posterior to these sharp-pointed, very small; in lower jaw the central teeth simple with rounded tips; laterally they are broader at the tips, notched or obliquely lobate, the posterior side of the cutting edge lowest; the head and body back to first dorsal, or even beyond, covered with rather conspicuous, conical tuberculate papillæ; posteriorly the body is covered with rather large cycloid scales which become much smaller anteriorly, and continue forward on nape to eyes, but are very sparse and disappear upon cheeks; the dorsals rather far apart, the spines of first dorsal long, slender to filamentous, the second and third projecting beyond the membrane 
for half their length, longer than head and reaching far along second dorsal when depressed; the second dorsal elongate, its base extending almost to caudal, low, its height 0.75 the depth of body, and twice or nearly twice in head, the posterior rays reaching far out on caudal when depressed; the low anal likewise has a very long base, the posterior rays a little the longer, 2.5 to 3 times in depth, 3.75 to 4 times in head; the caudal peduncle very short, its depth about 2.8 to 3 times in head, about twice in depth, and twice its own length; the caudal narrow, sharply rounded to acute, equal to or a little shorter than head, the lower margin obliquely truncate: the pectoral acutely pointed, its muscular scaled base nearly half its length, 1.4 to 1.8 times in head; the short ventrals a third or half as long as head and about 2.5 times in the distance to anus; the anal papilla small, elongate-triangular, pointed.

The color in alcohol bluish gray or slate to brown, paler beneath; the first dorsal blue slate or bluish, with many white spots, which may form short horizontal lines; the second dorsal has the same ground color, with from four to seven longitudinal rows of elongate white spots; the caudal with elongate, oval, or round white spots between the rays; the other fins pale, unspotted.

Here described from three specimens, 96 to 115 millimeters in length, collected by Light at Amoy, China. The Bureau of Science collection also contains five specimens, a little smaller, collected by Seale at Hongkong.

This species ranges from Burma to Japan. It may well occur along the Ilocano coast of Luzon.

\section{Genus 71. SCARTELAOS Swainson}

Scartelaos Swainson, Nat. Hist. Fishes 2 (1839) 279.

Dorsal V or VI, I-24 to 26; anal I, 23 to 25.

The anterior teeth of upper jaw unequal, awl-shaped canines, curved inward; in lower jaw the teeth are horizontal, simple, medium in size, acute; the scales small to microscopic and rudimentary, few, not conspicuous or else absent on head and forward part of trunk; the body elongate, the dorsals far apart, the spinous dorsal more than 3 times as high as the length of its base, the base of second dorsal more than 5 times the length of that of first; the caudal long, pointed, its lower margin obliquely truncated; the muscular base of pectorals shorter and less developed than in the other Philippine genera; the ventrals 
completely united; the narrow restricted gill openings begin about opposite middle of pectoral base and extend very little below it; the isthmus broad; branchiostegals 5 .

A small group of slender, half-burrowing mud dwellers, confined to the coasts of tropical Asia and the Malay Archipelago.

164. SCARTELAOS VIRIDIS (Buchanan Hamilton)

Plate 25, Fig. 2

Gobius viridis Buchanan Hamilton, Fishes Ganges (1822) 42, 366, pl. 32, fig. 12.

Boleophthalmus viridis CUvier and VAlenciennes, Hist. Nat. Poiss. 12 (1837) 160; GüNTher, Cat. Fishes Brit. Mus. 3 (1861) 104;

DAY, Fishes of India (1878) 307, pl. 66, fig. 5 .

Scartelaos viridis BleEkER, Esq. Syst. Gobioides, Arch. Neerl. Sci.

Nat. 9 (1874) 328; Jordan and Seale, Proc. U. S. Nat. Mus. 28 (1905) 794, fig. 12 .

Boleophthalmus aucupatorius RICHARDson, Voy. Sulphur, Ichthyology, part 3 (1845) 148, pl. 62 , figs. $1-4$.

Dorsal V, I-25; anal I, 25.

The body very low, elongate, subcylindrical, the dorsal and ventral profiles nearly horizontal but tapering gradually toward each other from head to caudal, the depth 8.75 to 10 times in length; the head low, broad, nearly rectangular, 4.3 to 4.5 times in length, much wider than trunk, its breadth greater than its own depth and about 0.1 more than the depth of body, 1.8 to 2 times in head; the convex snout broadly rounded, 3.6 to 4 times in head; its lower margin ends in a broad, loose, lunately lobed flap, with an elongate nipplelike extension on each side below eye; the eyes very close together, the upper lid like the skin of head, the wide lower lid whitish, the pit in which they lie when not elevated large, the diameter of eye about 1.4 times in snout and $\mathbf{5 . 7 5}$ to $\mathbf{6 . 5}$ times in head; the large mouth low, horizontal, the lower jaw shorter than the upper, the posterior angle of maxillary beneath hind margin of eye or beyond; there are twelve or fourteen prominent, pointed, downward-projecting teeth in upper jaw, with several much smaller teeth posterior to them; in lower jaw there are twenty-four to thirty small, pointed, horizontal or nearly horizontal teeth; the curved canines behind symphysis much larger than any of the other teeth; beneath point of chin a small barbel, and running back on each ramus of jaws a row of much smaller barbels; the minute but readily visible scales of posterior region become much smaller and more widely spaced anteriorly, usually disappearing by the 
time a line is reached even with the origin of second dorsal; the skin of head and anterior part dorsally finely rugose; the vertical fins densely enveloped in thick skin in our specimens; the dorsals widely separated, the base of first dorsal very short, 4 or 5 times in its height; the first dorsal much elongated, the central spine much the longest, 3.6 to 3.8 times in length, about 2.5 times the depth, the thick skin envelope often extending to its tip; the very elongate second dorsal highest posteriorly, the last ray often connected with caudal by a membrane, 3.33 times in head; the anal similar but a little lower, but never connected with caudal, at least in my specimens, about 4 times in head; the depth just before caudal about twice in greatest depth of body; the lanceolate caudal sharply oblique on lower margin, 3 times in length; the muscular pectoral base much shorter than in our other representatives of this family, the fin rounded, 1.66 to 1.9 times in head and 7.3 to 8.2 times in length; the pointed ventrals equal the pectorals and are contained twice in the distance to anal papilla; in males this is small, somewhat pointed; in females it is very thick, subglobose.

The color in alcohol slaty blue to brownish, paler to whitish on belly, darker to brown dorsally; our specimens show no trace of the green color mentioned by other authors; upon head, both sides of pectoral bases, dorsals, and sides of body are some small circular black spots widely separated; on all our specimens there are four to six short, transverse, brownish black bars on lower half of each side, the first below interspace between the two dorsals, the last approximately below middle of second dorsal ; the upper part of caudal diagonally crossbarred by numerous (eight or more) black bands or rows of closely placed black dots, the lower part of fin white, its tip black.

Here described from eight specimens in the Bureau of Science collection; they range in length from 86 to 102 millimeters, and were collected by H. R. Montalban as follows: Seven at Navalas, Guimaras, and one at Zarraga, Iloilo Province.

The Bureau of Science collection also contains four very fine specimens, 67 to 102 millimeters in length, collected by Light at Amoy, China, in May, 1922. They are drab slate above; the upper margin and tip of caudal are purplish slate; they lack the lateral crossbands of the Philippine specimens.

The only previous Philippine record is from southern Oriental Negros, the specimens collected by Dr. Bashford Dean and determined by Jordan and Seale. 
This species was originally described from the Ganges, and occurs throughout the East Indies and north on the China coast to Woosung.

\section{GOBIOIDID $Æ$}

This group comprises all those elongate, more or less eelshaped or ribbon-shaped gobies that lack a pouchlike blind sac on each side of the head above the opercle; the second dorsal and anal are long, low, united more or less with the caudal or ending at its base; the dorsals are united except in one genus, Trypauchenopsis Volst, and in many species the dorsals and anal are concealed under an envelope of thick, tough skin. The body may be cylindrical, but is more often laterally compressed, often strongly so, and may be naked or more or less covered with minute rudimentary cycloid scales; the head is more or less quadrangular to cylindrical, obtuse, with heavy, protruding lower jaw, the mouth large, oblique to nearly vertical; the sharp-pointed teeth may be in one, two, or several rows, those of the outer row more or less enlarged, curved, often fanglike; a pair of stout canines is present behind the symphysis of the lower jaw in some genera; except in the genus Paragobioides, the eyes are small to minute, laterodorsal to dorsal, covered with skin, distinct to invisible, sometimes represented by orbital fossæ; the pectorals are usually small and rounded, but may be elongate and pointed; the ventrals may be separate, but are usually completely united to form a disk, often large, rarely small. The gill openings are small to medium, vertical or nearly so, usually narrow, not extended forward, the isthmus broad.

Fishes of sandy beaches, estuaries, and rivers near salt water, from India to southern Japan and throughout the East Indies to Polynesia.

The assignment of the genera of this group is very unsatisfactory. S. L. Hora has published in the Records of the Indian Museum for 1924 a valuable and suggestive paper on the eelshaped gobioid fishes, placing those with pouchlike cavities in the subfamily Trypaucheninæ, the others in the subfamily Taenioninæ. He defines the genera for his first subfamily, but refuses to discuss the limits of the genera in the Taenioninæ.

Without a large amount of material from widely divergent localities and some study of the types, it is likewise impossible for me properly to limit the genera of the Gobioididæ. The genus Taenioides, to which I refer most of the Philippine species, 
is particularly ambiguous. In his Esquisse Bleeker evidently defined some of the genera without having examined the teeth, although he based his divisions primarily upon the dental characteristics. It seems to me that the genera of the Gobioididæ should be based upon the character of the teeth, the fins, and the eyes. Unfortunately, authors in general have given the teeth scant attention, anything from one to many rows being described as a "band of fine teeth" when they are not the outer row.

In the following key are given the genera that by reason of some outstanding character cannot be questioned, and also those that I have studied and defined for the purpose of this work; the omitted genera need to be revised by some one with access to type material.

Key to some genera of the family Gobioididse.

$a^{2}$. Dorsals separate

Trypauchenopsis.

$a^{2}$. Dorsal continuous.

$b^{1}$. Ventrals separate; eyes large

Paragobioides.

$b^{2}$. Ventrals united; eyes small to minute.

$c^{1}$. No true canines.

$d^{2}$. One row of teeth in each jaw.

Tyntlastes.

$d^{2}$. Two or more rows of teeth in each jaw, the outer row enlarged.

$e^{i}$. Two rows of teeth in upper jaw, two or more in lower jaw; small to minute scales present, at least at base of caudal; no barbels

Brachyamblyopus.

$\boldsymbol{e}^{2}$. More than two rows of teeth in each jaw; body naked; barbels present on chin

Taenioides.

$c^{2}$. A pair of stout canines behind symphysis of lower jaw.

$f^{1}$. Two rows of teeth in each jaw; pectoral long, pointed, equal to or longer than head; caudal very long, pointed; ventrals large, long, pointed; at least posterior half of body ribbonlike.

Sericagobioides.

The genus Trypauchenophrys Franz is unquestioned, but as I have been unable to obtain a copy or an abstract of his paper I cannot group it with the preceding.

\section{Genus 72. BRACHYAMBLYOPUS Bleeker}

Brachyamblyopus BLEEKER, Arch. Neerl. Sci. Nat. 9 (1874) 329.

The teeth in two to several rows in lower jaw, two rows above, the outer row in each jaw enlarged, long, pointed, inward-curved, fixed or depressible, without true canines and without postsymphysial canines in lower jaw. The body elongate, laterally compressed, the depth 7 to 10 times in length, the head com- 
pressed to subcircular, obtuse, the breadth and depth about equal, with convex dorsal profile, the tip of snout low, the lower jaw very heavy, prominent, without barbels, the mouth oblique. The eyes very small to minute, immersed, more or less visible, never conspicuous. The low dorsals and anal united with the elongate pointed caudal, but not covered with thick, tough skin, the rays visible. The body may be covered with small, half-immersed, sparsely scattered scales, larger posteriorly, or it may be smooth and naked, except for minute scales near base of caudal. Dorsal VI, I-28 to 32 ; anal I, 27 to 33 ; the pectorals very short, rounded, the ventrals small. The gill openings narrow, vertical, the isthmus wide; branchiostegals 5, according to Bleeker.

Species few, in. the East Indies.

165. BRACHYAMBLYOPUS OLIVACEUS kp. nov.

Plate 25, Fig. 3

Dorsal VI, I-30 to 32 ; anal I, 29 to 32 .

The body elongate, laterally compressed, the depth 7.3 to 8.3 times in length, the tail $\frac{1}{3}$ longer than head and trunk together; the large blunt head has a convex profile, downward-curved anteriorly and almost depressed, 5 to 5.5 times in the length, its depth and breadth approximately equal, 0.6 to $\frac{2}{3}$ its length; the low broad snout 3.6 to 4 times in head; the minute eyes distinctly visible, laterodorsal, the convex interorbital 0.6 to 0.8 of snout, 5 to 6 times in head; the lower jaw very large, heavy, and strongly projecting, the large oblique mouth at an approximate angle of $45^{\circ}$, the lips comparatively thin, without fleshy flaps at the corners; from ten to sixteen enlarged, erect, pointed teeth at outer edge of upper jaw, their tips inward-curved; behind them is a single row of small, slender, pointed teeth; in lower jaw is an outer row of ten to fourteen enlarged, long, curved, pointed, depressible teeth, inclined inward; behind them is a row of similar teeth, from half to less than half their size; no barbels, papillæ, pores, or ridges on head; the skin smooth, naked, with small, circular cycloid scales barely visible to the naked eye at base of caudal, and extending forward about onethird the distance to anus; the dorsals and anal continuous with caudal, not densely enveloped in skin; the caudal narrow, very elongate, pointed, easily broken, 3.6 to 4.5 times in length, much longer than head; the pectoral very broad, rounded, 2.15 to 2.75 times in head; the small, narrow ventrals 1.6 to 2.2 times in head, 8.7 to 10.2 times in length. 
The color in alcohol dull, dark olive brown, paler on head; the fins uniform pale yellowish.

Here described from seven specimens, 41 to 55 millimeters in length, collected at La Libertad, Oriental Negros, by a student from Silliman Institute. I have another specimen, 62 millimeters long, collected in the strait between Iloilo and Negros, by another Silliman Institute student.

This species is close to Amblyopus urolepis Bleeker, but he describes this as having several rows of teeth in each jaw and with conspicuous scales on the tail posteriorly. The scales on my specimen can be made out only with the aid of a lens, merely showing to the naked eye as a minute patch at the base of the caudal. The species might be made the type of a new genus.

Olivaceus, olive colored.

\section{Genus 73. TAENIOIDES Lacépède}

Taenioides LACÉPÈDE, Hist. Nat. Poiss. 2 (1798) 580; BLEEKER, Arch. Neerl. Sci. Nat. 9 (1874) 330.

The body elongated, nearly cylindrical and eel-shaped or more or less laterally compressed, naked; the dorsal fin very long, the anterior part of five slender spines, then a single spine in the middle of an interspace, followed by the second dorsal, I-40 to 52 rays; the anal also very long, I, 36 to 48 rays; the dorsals and anal may be continuous with caudal, separated by a notch only, or completely free from it, and may be covered by a thick, tough skin which entirely obscures the spines and rays, or the fins may be without a skin covering; the head cylindrical to oblong and nearly four-sided, usually flattened above; the mouth oblique to very oblique or almost vertical, the lower jaw and chin very prominent, bearing barbels; the tip of the tongue rounded; there is a short outer row of long, curved, stout teeth in each jaw; behind these is a long, rather narrow band of small or very small sharp teeth; there are no canines behind symphysis in lower jaw; the eyes on top of head, very small to minute, inconspicuous, in some species covered by skin, in some entirely concealed; the pectorals are small, short, rounded, without silky rays above; the ventrals completely united, not adnate to belly, usually broad and long; the gill openings narrow, the isthmus broad; branchiostegals 4 (5, according to Bleeker).

These little fishes with elongate body and bulldoglike lower jaw are often taken for eels by the uncritical, who are deceived by their serpentine appearance. They are found along sandy 
beaches, in estuaries, the lower reaches of fresh-water rivers, and in lakes, from the eastern coast of Hindustan through the Indo-Australian Archipelago and north to China and southern Japan.

\section{Key to the Philippine species of Taenioides.}

$a^{1}$. Dorsal and anal entirely separate from caudal; color leaden to blackish; caudal black, elongate, with threadlike tip

T. caeculus.

$a^{2}$. Dorsal and anal more or less connected with caudal; color pink to yellowish brown, never blackish.

$b^{1}$. A deep notch at junction of dorsal and anal with caudal; sides and top of head with many sensory ridges; caudal yellow.

T. cirratus.

$b^{2}$. Dorsal and anal continuous with caudal; no sensory ridges on head; caudal brown to blackish brown

T. gracilis.

\section{TAENIOIDES CAECULUS (Bloch and Schneider)}

Caepola caecula Bloch and Schneider, Syst. Ichth. (1801) 241, pl. 54.

Amblyopus caeculus GüNtheR, Cat. Fishes Brit, Mus. 3 (1861) 133. Gobioides caeculus DAX, Fishes of India (1878) 318, pl. 68, fig. 1.

Taenioides caeculus WEBER, Siboga Exped., Fische (1913) 486; RENDAHL, Arkiv Zoologi 16 (1924) 31.

Dorsal VI, 42; anal 38 in our specimens; dorsal VI, 40 to 44 ; anal 38 to 45 .

The body stout, the anterior half subcylindrical, the posterior half thin, laterally compressed, the depth at origin of dorsal 14 times in length; the tail 1.85 times as long as head and trunk together; the thick, blunt, subcylindrical head 6.6 times in length; its depth equals that of body; its breadth slightly exceeds its depth and is about 1.9 times in its own length; the wide snout horizontal above, blunt, its tip very broadly arched, 4 times in head; the small eyes. invisible, covered by thick skin, their position made out with difficulty, the interorbital space about 1.8 times in snout, 6.4 times in head; the mouth large, oblique, the posterior angle of maxillary reaching a perpendicular just before eyes; the lips thick, fleshy, expanded into broad pads at angles of mouth; there are twelve large, erect, inward-curved teeth in outer row above, ten below, about equal in size; some distance behind outer row above is a narrow band of two rows of small pointed teeth; the inner band in lower jaw much larger, of three complete, four partial rows, the teeth larger and coarser than those in inner band above; the chin very prominent, convex, with three pairs of short coarse barbels below symphysis, its sides very coarsely rugose with thick folds of skin, each 
bearing a row of sensory papillæ; the top of snout, ocular region, and sides of head covered with long ridges bearing sensory papillæ; beginning above base of pectoral and running back along middle of side to tail is a row of very short, vertical bars of sensory papillate pores; the dorsals and anal each densely enveloped in very thick, tough skin, and completely separated from caudal, which is narrow, with elongate-rounded tip, a little shorter than head, about 7.3 times in length; the small rounded pectorals about 3 times in head; the ventrals very large, broad, with a narrow, strong frenum, longer than caudal, 7 times in length.

The whole body blackish brown, the head more or less bluish gray, especially beneath; the caudal black, its upper and lower margins whitish; the other fins all whitish.

Here described from a fine specimen, 212 millimeters long, collected during stormy weather in October, 1924, at Dumaguete, Oriental Negros.

I place here two small specimens, 90 and 122 millimeters in length, from Villa, Iloilo Province, Panay. They are dull lead color, the wormlike body plump and rounded back to caudal fin, which is black, very narrow, elongate, with threadlike tip. I also determine as this species a specimen, 180 millimeters long, from Hoihow, Hainan, one from Amoy, 125 millimeters long, and one from Fu-chow, Fukien Province, China, length 130 millimeters, collected by Light. A small specimen, 67 millimeters long, taken in Pansipit River, just below Lake Taal, belongs here, as do also three dusky pinkish specimens from Pampanga River, 55, 105, and 110 millimeters long; the caudal is very elongate.

Six specimens, 45 to 75 millimeters long, from Ambulong, Lake Taal, were received after the above was written.

This species is very close in many respects to $T$. cirratus, but is usually to be recognized at a glance by the color and the differences in its fins. In very small specimens the eyes are distinctly visible. It occurs in both salt and fresh water, from the coast of Bengal to the Indo-Australian Archipelago and southern China. According to Day it varies much in color, but is mostly of a leaden hue; "it is exceedingly vicious and when captured snaps at everything near it; should its tail be touched it springs round and anything it seizes it holds on to in the most determined manner." 
167. TAENIOIDES CIRRATUS (Blyth)

Amblyopus cirratus BLYTH, Journ. As. Soc. Bengal 29 (1860) 147. Gobioides cirratus DAY, Fishes of India (1878) 318, pl. 69, fig. 4. Amblyopus brachygaster GÜNTHER, Cat. Fishes Brit. Mus. 3 (1861) 134.

Taenioides brachygaster JORDAN and RICHARDSON, Bull. Bur. Fisheries 27 (1908) 279.

Dorsal VI, I-42 to 46 ; anal I, 42 to 45 .

The depth of the stout, cylindrical, elongate body 15.6 to 16 times length; the tail 1.9 to 2 times as long as head and trunk together, its posterior third more or less laterally compressed; the stout, blunt head flattened above, oblong, 7.85 to 8.3 times in length, wider than body or its own depth, which equals or is 0.1 less than that of body; its depth 1.2 to 1.25 in its breadth, which is 1.65 to 1.75 times in its own length; the snout very broad, its tip convex, 3.5 times in head; the eyes very small, mere black dots beneath the skin, the interorbital space $\frac{2}{3}$ or a little less of the length of snout; the mouth strongly oblique, the posterior angle of maxillary extending about 0.75 the distance to a perpendicular from eye; the lips very much enlarged at angle of mouth, each with a broad, fleshy flap, the upper one especially with a fringe of sensory papillæ; there are six strong, erect, slightly inward-curved, prominent teeth forming the outer row in lower jaw, projecting over upper lip; in upper jaw is an outer row of ten to twelve nearly horizontal, downwardcurved teeth, a little smaller than those in outer row of lower jaw; the small inner teeth in each jaw in a long, narrow, lunate band of four rows, placed some distance behind the enlarged outer row; the chin prominent, vertical, with three pairs of barbels and usually a single one between the middle pair; the sides of chin, snout, cheeks, lower edge of preopercle, ocular region, opercles, and sides of nape back to gill opening covered with thick ridges of sensory papillæ; from upper end of gill opening to base of caudal is a median lateral row of prominent, short, transverse, vertical papillate pores; the dorsals and anal each enveloped in a thick, tough skin, and separated from caudal by a deep, well-marked notch; the short, broad, rounded pectorals 2.65 to a little less than 3 times in head and 22.3 to 23.3 times in length; the broadly lanceolate caudal 8.85 to 9.5 times in length, and always shorter than head; the broad, rounded ventrals 1.32 to 1.47 times in head, 11 to 11.5 times in length: the anal papilla truncate-cylindrical to subglobose. 
The color in alcohol yellowish brown with a pinkish red sheen; in life evidently pink; the sensory pores along the side surrounded by blue; the dorsals, anal, and caudal yellow; the pectorals and ventrals pinkish to yellowish; the anal papilla orange.

Here described from three specimens, 168 to 177 millimeters long, dug out of the sandy Pasay beach, Manila Bay.

A female specimen, 182 millimeters long, collected in the Manila market by Seale, July 20, 1907, is full of eggs. The Bureau of Science collection also contains a small specimen, 85 millimeters long, from Lake Naujan, Mindoro.

This species was recorded from Aparri, Luzon, by Jordan and Richardson. It was first described from the Hugli, at Calcutta, and is distributed through the East Indies.

\section{TAENIOIDES GRACILIS (Cuvier and Valenciennes)}

Plate 26, Fig. 1

Amblyopus gracilis CUVIER and Valenciennes, Hist. Nat. Poiss. 12 (1837) 125; GüNTHER, Cat. Fishes Brit. Mus. 3 (1861) 134.

Gobioides gracilis DAY, Fishes of India (1878) 378.

Dorsal VI, I-44 to 51 ; anal I, 41 to 47 ; 30 pores in a lateral series from posterior angle of nape to base of caudal.

The elongate, laterally compressed tail 2 to 2.2 times as long as head and trunk together, the trunk short, subcylindrical, its depth 14.7 to 18.6 times, the broad, flat, rather rectangular head 8.4 to 9.5 times in total length without caudal; the breadth of head a little more than its depth up to 0.3 more than its depth and 1.7 to 2.3 times in its own length; the snout very broad, horizontal, its tip gently rounded, 3.75 to 4 times in head; the tiny but perfectly distinct eyes on top of head, far apart, the interorbital space 4.3 to 5 times in head; the mouth very markedly oblique, the posterior angle of maxillary extending to lower margin of preopercle and about half distance to eyes; the lips thin, the lateral flaps rather narrow, not fleshy, their fringe of sensory papillæ very little developed; sixteen teeth in outer row above and ten in outer row below; the chin very prominent, strongly oblique, with two longitudinal rows of three pairs of small barbels and a median barbel between the middle pair; the dorsals and anal low, enveloped in very thick skin, continuous over both dorsals, and continuous with caudal, without a notch at their junction with the latter; the caudal small, pointed, 8 to 9 times in length; the small rounded pectoral 2.5 to 3.5 times in head 
and 27 to 34 times in length; the ventrals long, broad, pointed, 1.2 to 1.3 times in head, 10 to 12 times in length.

The color in alcohol yellowish brown, finely punctulated with rather sparsely scattered dots of darker brown; the caudal darker to blackish brown, the other fins pale yellowish.

Here described from seven specimens, 160 to 190 millimeters in length, purchased in the Manila market. They came from a bangos fish pond at Malabon. Sometimes they are caught in large numbers when the fish ponds are drained.

The Bureau of Science collection also contains a specimen, 212 millimeters long, in poor condition, obtained by Seale from the Manila market in 1907.

This species was originally described from Pondicherry, India, and is distributed throughout the East Indies. I have no doubt it occurs all through the Philippine Archipelago.

Genus 74. SERICAGOBIOIDES g. nov.

In both jaws there is an outer row of six or eight (ten?) widely spaced, large, fixed, curved teeth, set outside the lip so that the teeth and their roots are visible when the mouth is closed, the teeth interlocking and covering the opposite lip when the mouth is shut; behind outer row in each jaw is a much longer row of very short, stout, conical teeth extending almost to posterior angle of mouth; behind symphysis of lower jaw, inside inner row of teeth, is a pair of short, strong canines; the body elongate, ribbonlike, the dorsals and anal continuous with caudal, covered with a thin skin, the sixth dorsal spine separated from the five preceding and from second dorsal; the pectoral very long and pointed, equal to or exceeding head and longer than the large pointed ventrals, which are slightly shorter than head and partly adnate to belly; the long pointed caudal 1.5 to 2 times the oblong head; the tip of the thick tongue rounded; there are no barbels, sensory ridges, or papillæ on head; the eyes very small, laterodorsal, distinct; the body apparently naked anteriorly, with rudimentary scales embedded in skin on posterior half, but with a strong lens widely scattered scale pits can be made out along upper part forward to anterior end of trunk; the gill opening vertical, as wide as pectoral base, the isthmus broad, branchiostegals 5. Dorsal VI, I-39 to 49 ; anal I, 38 to 44 . Vertebræ $8+22$.

This genus is separated by its elongate pectorals, ventrals, and caudal, and by the presence of but two rows of teeth in each 
jaw, with a pair of symphysial canines in lower jaw. It is altogether probable that Amblyopus taenia Günther belongs here, as it has these fins elongate also and agrees in most other respects; the inner teeth are not described.

Sericus, of the Chinese.

169. SERICAGOBIOIDES LIGHTI sp. nov.

Plate 26, Fig. 2

Dorsal VI, I-39 to 44 ; anal I, 38 to 43.

The body very elongate, thin, ribbonlike, all the vertebræ visible, its depth 14 to 14.9 times in length, the tail 1.75 to 1.8 times head and trunk together; the angular bony head subquadrangular, 7.4 times in length, 1.7 times in trunk, its depth greater than its breadth and 0.1 greater than that of body; the top of head horizontal, the snout short, convex, with a median sharp hump, its tip broadly rounded, 3.4 times in head; the very small but distinctly visible eyes laterodorsal, each at the bottom of a broad shallow pit, the interorbital space nearly 1.4 times in snout, 4.7 to 4.8 times in head; the mouth very large, strongly oblique, the lips thickened posteriorly, the long, curved chin prominent, the posterior angle of maxillary extending well beyond a vertical from eye; the teeth as given for the genus; the head naked, the body apparently so, the caudal third thickly covered with minute scales invisible to the naked eye; these practically disappear on anterior half of body but a lens reveals the presence of scattered scale pits. as far forward as the region above basal part of pectoral ; the narrow, elongate, pointed caudal 4.3 to 4.5 times in length, 1.64 to 1.74 times head; the broad pectoral very long, pointed, equal to or 1.13 times head, 6.6 to 7.4 times in length; the ventrals large, long, pointed, with a strong frenum, attached to belly for over a third of the length, 1.13 to 1.07 times in head and 8 to 8.4 times in length.

The color in alcohol very pale brown or gray-brown, the opercles and predorsal region darker brown; the dorsals, anal, and caudal with violet-brown or blackish brown margins, the posterior half of caudal the same color; the other fins all pale.

Here described from two specimens, 112 and 126 millimeters long, collected at Amoy, China, by Prof. S. F. Light, for whom I take pleasure in naming the species. The Bureau of Science collection also contains eleven additional specimens from the same locality, 74 to 120 millimeters in length. These present no differences except that some have the body a little rounded 
and the dorsal and anal rays are fewer; the types have 42 to 44 rays in the second dorsal, 41 to 43 in the anal.

This species is close to Amblyopus taenia Günther, from which however it is very distinct.

\section{TRYPAUCHENIDAE}

This group includes those elongated, scaled, laterally compressed fishes with a blind pit or pouchlike cavity on each side, above the opercle.

The long body and short blunt head are both laterally compressed, the anterior profile steeply convex; the whole body covered with cycloid scales of moderate size or small, but always well developed and in one genus extending to eyes and on sides of head; the eyes lateral, distinct, but very small; the mouth rather small, oblique, the heavy lower jaw prominent, the chin
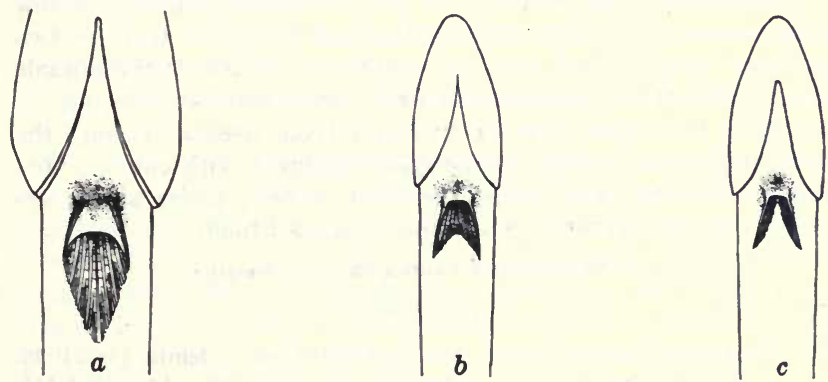

F16. 6. Ventral fins of Trypauchenide; a, Trypawchen vagina Bloch and Schneider, $X 1.5$; b, Ctenotrypakchen microcephalue (Bleeker), X 2; c, Trypauchenichthys typus (Bleeker), $\times 2$.

without barbels; the teeth in narrow bands, in one genus with canines in both jaws; the dorsals continuous, the dorsals and anal low, confluent with or narrowly separated from caudal; the small ventrals may be united, entire, forming a disk, or more or less notched, or united only at base; the gill openings narrow to moderate, vertical, the isthmus very broad; branchiostegals 4. Dorsal VI, I-40 to 60 ; anal I, 38 to 50 .

Four genera are recognized, of which two are thus far known from the Philippines. Common along sandy coasts and in muddy estuaries from India to Southern Japan. 


\section{Key to the genera of Trypauchenidx.}

$a^{1}$. Ventrals completely united, forming a funnel-shaped disk; teeth slender, in several rows, the outer ones enlarged. Trypauchen.

$a^{2}$. Ventrals with notched tip or separated to base.

$b^{1}$. Ventrals separated to base; teeth as in Trypauchen.

$b^{2}$. Ventrals united but notched posteriorly.

$c^{1}$. No canines.

Trypauchenichthys.

$c^{2}$. Canines present in both jaws. Ctenotry pauchen. Amblyotrypauchen.

Genus 75. TRYPAUCHEN Cuvier and Valenciennes

Trypauchen Cuvier and VAlenciennes, Hist. Nat. Poiss. 12 (1837) 115.

The entire fish is strongly compressed laterally, the body elongate, tapering from before backward, the head rather short but deep, with a very heavy, deep lower jaw which is more or less protruding; above opercles is a deep blind pit not communicating with gill cavity; the eyes lateral, minute, in shallow pits, covered with skin and more or less invisible; teeth in two or three rows in each jaw, the outer row enlarged; the dorsals continuous, the sixth spine of first dorsal separated by an interspace from the anterior five and from second dorsal; the anal and second dorsal many-rayed, confluent with caudal; ventrals united to form a disk; without spines; scales small, cycloid; the gill openings wide, the isthmus broad.

170. TRYPAUCHFN VAGINA Bloch and Schneider

Plate 26, Fig. 3

Trypauchen vagina BLoch and ScHNEIDER, Syst. Ichth. (1801) 73, No. 20 ; Cunier and Valenciennes, Hist. Nat. Poiss. 12 (1837) 115, pl. 351; GüNTHER, Cat. Fishes Brit. Mus. 3 (1861) 137; DAY, Fishes of India (1878) 320, pl. 68, fig. 2; Seale, Philip. Journ. Sci. § D 9 (1914) 77; RENDAHL, Arkiv Zoologi 16 (1924) 30.

Dorsal VI, I-40 to 49 ; anal, I, 40 to 48 ; there are 72 to 76 scales in a longitudinal series in my specimens, 80 to 85 according to Day.

The entire fish strongly compressed, the dorsal and ventral profiles tapering posteriorly from just behind head to base of caudal, the depth 9 to 9.2 in length; the head appressed dorsally, with a bony median ridge, short, deep, and heavy anteriorly, the depth 5 to 6.25 in length; the snout convex, short, 3.7 to 4 in head; the eyes invisible, covered with skin, their presence indicated by a dark spot in the bottom of the shallow orbital pit; the width of the high bony interorbital ridge about $\frac{2}{3}$ the 
length of snout; the mouth curved, somewhat oblique, the lower jaw deep, very large, the jaws subequal or the lower jaw strongly protruding and the upper jaw included, the posterior angle of maxillary beneath or scarcely reaching eye; the teeth of outer row in each jaw coarse, stout, conical, widely spaced, and more or less curved; behind them is a row of much smaller teeth or the lower jaw may have two rows anteriorly; the entire body covered with small cycloid scales, larger and somewhat elongate and overlapping posteriorly, smaller, four-sided, not imbricate but separated anteriorly, with their central part more or less depressed; the head naked but irregularly spotted with minute pits which may contain rudimentary scales, though I could detect none; the first dorsal very low, 6.5 times in head; the second dorsal low also but higher centrally and posteriorly, twice as high as first, 3.25 times in head; the anal is like second dorsal and equals it in height; the caudal more or less pointed, 4.5 to 6 times in length, always longer than head; the pectorals small, weak, 2.6 to 3 times in head; the narrow, pointed ventrals equal the pectoral in length.

The color in alcohol pinkish brown to gray or bluish brown, the head often paler, the fins yellowish or whitish.

Here described from eleven specimens, 69 to 162 millimeters long, from Amoy, China, collected by Light. I have also a fine specimen from Hoihow, Hainan Island, and three from Fu-chow, Fukien Province, China, also collected by Light. From Hongkong I have two poor specimens, each about 62 millimeters long, collected by Seale. From Calcutta I have a specimen, 127 millimeters long, collected and named by Sir Francis Day. While I do not doubt the occurrence of this fish in the Philippines, I have seen no specimens from the Islands.

This fish is abundant on the coasts of India and southern China and in the East Indies.

\section{Genus 76. TRYPAUCHENICHTHYS Bleeker}

Trypauchenichthys BleEker, Dert. Bijdr. Vischf. Borneo, Act. Soc. Sci. Indo-Neerl. 8 (1860) 63; HoRA, Rec. Ind. Mus. 26 (1924) 159.

The chief feature separating this genus from Trypauchen, which it otherwise closely resembles, is the form and structure of the ventral fins. In Trypauchenichthys the ventral fins are divided to the base and completely separated, and have but four soft rays each, the outermost being altered to a broad, flat spine, not shorter than the next two adjoining rays; the two 
inner rays are well developed in my specimen; according to Hora the two innermost are very small and rudimentary or the fourth ray may be absent; the body is elongate, compressed, as is the naked head; the minute eyes are more or less invisible, covered with skin; two rows of teeth in each jaw, the outer enlarged; the dorsals and anal are as in Trypauchen; the scales are small, cycloid, larger than in Trypauchen; the gill opening is of moderate width, very much wider than the pectoral base.

But a single species is known.

\section{TRYPAUCHENICHTHYS TYPUS Bleeker}

Trypauchenichthys typus BLEEKER, Dert. Bijdr. Vischf. Borneo, Act. Soc. Sci. Indo-Neerl. 8 (1860) 63; GüNTHER, Cat. Fishes Brit. Mus. 3 (1861) 138; JoRDAN and Richardson, Bull. Bur. Fisheries 27 (1908) 279.

Dorsal VI, I-51; anal I, 49; scales in a longitudinal series 56. According to Bleeker the dorsal is VI, 56 to 59 , anal I, 49 to 51 , the scales $\mathbf{5 0}$ to $\mathbf{5 5}$.

The entire fish is strongly compressed laterally, the dorsal and ventral profiles nearly horizontal, tapering gradually to caudal, the depth 7.11 times in length; the top of head compressed to a narrow bony ridge, the snout convex, the lower jaw heavy, protruding, larger than upper jaw and snout, the length of head 5.65 times in total length; the depth of head a little less than that of trunk, 0.75 its own length, and 0.5 more than its own breadth, which is twice in length of head; the snout low, short, blunt, 4 times in head; the eyes invisible, covered with skin at the bottom of the shallow pit in which they lie, separated by a high, narrow, interorbital ridge, its breadth $\frac{2}{3}$ the length of snout; the mouth oblique, the posterior angle of maxillary beneath eye; the teeth in two rows in each jaw, those of outer row curved inward and much larger than the small fine teeth of inner row; the head, predorsal region, and before ventrals naked; the rest of the body covered with small cycloid scales of nearly uniform size; the dorsals and anal low, the first dorsal lower than the second, the longest rays 2.77 times in depth and about 3.5 times in head; the anal equals second dorsal; the caudal narrow, pointed, 5.75 in length; the pectorals very small, weak, 3 times in head; the small ventrals completely separated, very narrow, pointed, 4 times in head.

The color in alcohol uniform dull brown, with a purplish tinge, the head grayish, the caudal golden brown. 
Here described from a good specimen, 69 millimeters long, collected by R. C. McGregor at Cagayancillo, one of the Cagayan Islands in the Sulu Sea. Jordan and Richardson had a specimen collected by Mr. McGregor at the same time and place.

This species has been collected at only two other places, as far as I know. Bleeker had two specimens, 113 and 127 millimeters long, from a salt-water river at Sungi-duri, Borneo. McGregor was the next to collect it, and Hora states (1924) that Dr. Annandale "recently obtained two fine examples of the same species in the Talé Sap, Siam."

\section{Genus 77. CTENOTRYPAUCHEN Steindachner}

Ctenotrypauchen SteINDACHNER, Sitzsungsber. Akad. Wiss. Wien 55 (1867) 530.

This species has been collected at only two other places, as separated by the structure of the ventral fins and the high, comblike keel, or sharp ridge, along the median line of the back part of head; the small ventrals are more or less notched, with four or five rays, and form a sort of funnel; the many-rayed second dorsal and anal are confluent with caudal; the minute eyes scarcely visible; two rows of teeth in each jaw.

A small genus, with one species each in China, Japan, and the East Indies.

172. CTENOTRYPAUCHEN MICROCEPHALUS (Bleeker)

Trypauchen microcephalus BLEEKER, Dert. Bijdr. Vischf. Borneo, Act. Soc. Sci. Indo-Neerl. 8 (1860) 62; Günther, Cat. Fishes Brit. Mus. 3 (1861) 137.

Dorsal VI, I-45 to 50 ; anal I, 43 to 44 ; scales in a longitudinal series, 65 ; ventral, 1 to 4 .

The body laterally compressed, its depth nearly 9 times in length; the large head more strongly compressed than the trunk, with a sharp ridge along median line above, 6.33 times in length, its depth greater than that of body, or its own breadth, the latter twice in its own length; the snout steeply inclined, 3.66 times in head; the eyes minute, covered with skin, the interorbital elevated, 2.2 times in snout; the skin of head deeply pitted, giving it a reticulated appearance; the mouth strongly oblique, the chin and lower jaw very prominent, projecting, the posterior angle of maxillary extending beyond eye; there 
are two rows of teeth in each jaw, those of outer row enlarged, widely spaced, those of inner row very much smaller and slender, all teeth more or less inward-curved; the head, predorsal region, belly, and sides above and below pectoral base naked; the scales on body deciduous, cycloid, those below first dorsal smaller than elsewhere; the dorsals and anal low, not continuous with caudal, the first dorsal very low, the others nearly uniform but the posterior part perhaps a little longer, the second dorsal 2.4 times in head, 1.6 times in depth, the anal still lower, 3 times in head, 2 times in depth; the caudal small, narrow, the end broken, about 10 times in length; the pectorals small, 3 times in head; the narrow ventrals notched for half their length, the tips divergent, about 3.5 times in head.

The color in alcohol uniform yellowish, the head grayish, the fins yellowish.

Here described from a specimen, 76 millimeters long, collected at La Libertad, Oriental Negros.

Hitherto known only from a single specimen, 120 millimeters long, collected from a salt-water river at Sungi-duri, Borneo, and described by Bleeker.

\section{ADDENDUM}

RHINOGOBIUS MACULIPINNIS (Fowler).

Drombus maculipinnis FowLer, Proc. Acad. Nat. Sci. Phila. 70 (1918) 69, fig. 27.

Dorsal VI, 1-9; anal I, 7; scales 23 in lateral series, plus 3 on caudal fin; in transverse series, $7 ; 6$ (?) before first dorsal.

Head 3 ; depth 3.6 ; head width 1.4 in its length; head depth at occiput 1.6 ; mandible $3 \frac{1}{6}$; first dorsal spine slightly less than head; eighth dorsal ray $1 \frac{2}{3}$; last anal ray 1.4 ; least depth of caudal peduncle 2.1 ; pectoral 1 ; ventral 1.4 ; snout 32 in head; eye 4.5 ; maxillary 3.5 ; interorbital about 2 in eye.

Head large, cheeks and lower sides greatly and evenly swollen backward; eye moderate, superior, largely directed upward; mouth small, mandible broad, protruding; teeth in rather broad villiform bands; head scaly, with numerous transverse cutaneous narrow areas on cheek, side of head, and snout; cutaneous flap nearly equal to pupil in length on each side of snout tip; caudal elongate, ending in median point; first dorsal spines elongate, flexible; pectoral large, reaching little beyond anal origin; ventral fins united for their basal halves, reaching anus. 
Color in alcohol dark chocolate brown, with bases of scales dusky to blackish and paler spots, producing a mottled appearance; fins all blackish or dusky brown, barred or spotted with whitish; cutaneous areas on head dark. Length 50 millimeters. Type, No. 47549, A. N. S. P., from Philippine Islands.

The above description is taken from Fowler, as I have seen nothing like this fish. Fowler created a new subgenus, Ulcigobius, based on the higher spinous dorsal, the larger scales, and the very conspicuous pores on the sides of the head. He says nothing in his specific description of the pores, and the figure shows none. He says "head scaly," but the figure has the opercles and cheeks naked. 



\section{INDEX}

[Names of new genera and species are printed in boldface; vernacular name are printed in italic.]

\section{$\mathbf{A}$}

Aboma, 202.

viganensis, 203.

Acanthogobius, 266. ommaturus, 266.

Acentrogobius acutipinnis, 204. acutipennis, Gobius, 204.

acutipinnis, Acentrogobius, 204. Aparrius, 204.

Gobius, 204.

Addendum, 342.

agilis, Hypseleotris, 38.

aglestes, Glossogobius, 157.

albo-oculata, Boroda, 58.

amabilis, Oxyurichthys, 250.

Amblychaeturichthys, 274.

hexanema, 274.

Amblygobius, 227.

bynoensis, 232 .

inornatus, 228.

insignis, 234.

linki, 231.

perpusillus, 229.

perpusillus buanensis, 230.

phalaena, 235.

sphinx, 237.

sphynx, 237.

Amblyopus brachygaster, 333 .

caeculus, 331.

cirratus, 333.

gracilis, 384.

amboinensis, Butis, 46 .

Eleotris, 46.

Amogu, 112.

Amoya, 225.

brevirostris, 226.

Aparrius, 204.

acutipinnis, 204.

moloanus, 207.

Apocryptes chinensis, 323 . serperaster, 262.

Apocryptichthys, 263.

sericus, 264.

Apocryptodon, 277.

montalbani, 277.

sealei, 278.

taylori, 279.

aporos, Eleotris, 65.

Ophiocara, 65.

argulus, Gobius, 249.

Oxyurichthus, 249.

Oxyurichthys, 249.

aspro, Platyptera, 22.

Rhyacichthys, 22.

Asterropterix, 27.

Asterropteryx, 27.

everetti, 28.

modestus, 41.

semipunctatus, 28.

atro-purpureum, Microsicydium, 296.

aucupatorius, Boleophthalmus, $\mathbf{3 2 5}$

Awaous, 210.

genivittatus, 211.

ocellaris, 218.

personatus, 216.

B

Bala, 161.

baliuroides, Gobius, 188.

Rhinogobius, 188.

Bal-la, 158.

Banasak, 316.

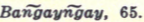

Baranog, 69.

barbarus, Gobius, 316.

Periophthalmus, $\cdot 316$.

barbatus, Triaenophorichthys, 281

Triaenopogon, 281.

Tridentiger, 281.

Bathygobius, 111.

bravae, 112.

fuscus, 113.

mearnsi, 116.

nox, 116.

Batog, 216.

Ba-tug, 161.

belobrancha, Belobranchus, 35 . Eleotris, 35.

Belobranchus, 35. belobrancha, 35 .

quoyi, 35.

taeniopterus, 35 .

Bia, 161.
ng bato, 158.
ng sapa, 189.
sunog, 47.
pakiu, 212.
puti, 161.

Biang bato, 216. 
Biang-Continued.

tuku, 124.

tulis, 212.

tulog, 157.

Biat, 245.

luzonica, 246.

luzonicus, 246.

bifasciatus, Tridentiger, 283.

bikolana, Vaimosa, 151.

biocellatus, Glossogobius, 156.

Gobius, 156.

bipartita, Hypseleotris, 39.

bitelatus, Gobius, 166 .

bivittata, Tamanka, 224.

Boleophthalmus, 322 .

aucupatorius, 325 .

chinensis, 323.

pectinirostris, 323.

viridis, 325.

Borod, 58.

Boroda, 58.

albo-oculata, 58.

expatria, 59.

Bostrichthys, 43.

sinensis, 43.

Bostrichus, 43.

Bostrychus, 43. sinensis, 43.

Boto-bot, 61.

boulengeri, Cingulogobius, 201. Pleurogobius, 201.

Brachyamblyopus, 328 . olivaceus, 329.

Brachyeleotris, cyanostigma, 28.

brachygaster, Amblyopus, 333.

Trenioides, 333.

bravae, Bathygobius, 112.

breviceps, Gobius, 113.

brevirostris, Amoya, 226.

Gobius, 226.

buanensis, Amblygobius perpusillus, 230.

bucculentus, Tukugobius, 121.

Bukto, 216.

Bunak, 61.

Bunaka, 60.

pinguis, 61.

Bunog, 161, 216.

Burok, 128.

Butis, 46.

amboinensis, 46 .

butis, 48 .

caperata, 53.

gymnopomus, 51.

koilomatodon, 53.

leucurus, 48.

prismaticus, 48.

serrif rons, 53.

butis, Butis, 48 .

Cheilodipterus, 48.

Eleotris, 48.

bynoensis, Amblygobius, 232.

Gobius, 232.

Odontogobius, 232. cacabet, Illana, 269.

caecula, Caepola, 331.

caeculus, Amblyopus, 331.

Gobioides, 331.

Trenioldes, 331.

Caepola caecula, 331.

calderae, Gobius, 182.

Rhinogobius, 182.

calliurus, Gnatholepis, 130.

caninus, Gobius, 186.

Rhinogobius, 186.

cantoris, Eleotris, 69.

caperata, Butis, 53.

Eleotris, 52.

caperatus, Eleotris, 52.

Caragobius, 286.

typhlops, 287.

carpenteri, Rhinogobius, 122.

Tukugobius, 122.

cauerensis, Gobius, 107.

cebuanus, Cryptocentrus, 240.

celebius, Glossogobius, 158.

Gobius, 158.

ceramensis, Gobiodon, 294.

Chaeturichtbys, 275.

hexanema, 274.

hexanemus, 274.

polynema, 270.

stigmatias, 276.

Cheilodipterus butis, 48 .

chinensis, Apocryptes, 323.

Boleophthalmus, 323.

Chlamydes, 118.

leytensis, 118.

Chonophorus, 210.

genivittatus, 211.

lachrymosus, 212.

melanocephalus, 216.

ocellaris, 218.

chrysospilus, Periophthalmus, 316 .

Cingulogobius, 201.

boulengeri, 201.

cirratus, Amblyopus, 333.

Gobioides, 333.

Taenioides, 333.

Cobitis pacifica, 30 .

Contents, 3.

crassus, Sicyopterus, 307.

Creisson, 139.

validus, 139.

criniger, Ctenogobius, 191.

Gobius, 191.

Rhinogobius, 191.

Cristatogobius, 170.

lophius, 170.

cristatus, Oxyurichthus, 251.

Cryptocentrus, 239.

cebuanus, 240.

filifer, 241.

fontanesii, 242.

fontanesii, Gobius, 242.

vagus, 243.

venustus, 244 . 
Ctenogobius criniger, 191.

Ctenotrypauchen, 341. microcephalus, 341.

Culius, 29. fuscus, 30 . melanosoma, 33.

cyanostigma, Brachyeleotris, 28.

Eleotriodes, 28.

Eleotris, 28.

cynocephalum, Sicydium, 306. cynocephalus, Sicyopterus, 306, 307. cyprinoides, Eleotris, 38, 41. Hypseleotris, 38.

Daing sahasa, 294.

davaoensis, Gnatholepis, 134.

decoratus, Rhinogobius, 181.

deltoides, Gnatholepis, 133.

Gobius, 133.

dispar, Gobius, 142.

Vaimosa, 142.

dispersus, Ptereleotris, 83.

Dolog, 161.

Dolong, 93.

Drombus, 176.

maculipinnis, 342.

palackyi, 178.

E

echinocephalus, Gobius, 172.

Paragobiodon, 172.

Eleotridæ, 25.

Eleotriodes cyanostigma, 28.

Eleotris, 29.

amboinensis, 46.

aporos, 65.

belobrancha, 35 .

butis, 48 .

cantoris, 69.

caperata, 52.

caperatus, 52.

cyanostigma, 28.

cyprinoides, $38,41$.

fusca, 30.

gymnopomus, 51.

hoedti, 65 .

humeralis, 48.

koilomatodon, 52.

laglaizei, 65 .

lineato-oculatus, 79 .

longipinnis, 76.

marmorata, 74 .

melanosoma, 33.

muralis, 76, 79 .

nigra, 30 .

obscura, 65.

ophiocephalus, 69 .

porocephala, 69 .

porocephaloides, 69 .

porocephalus, 69 .

semipunctata, 28.
Eleotris-Continued.

sinensis, 44.

strigata, 78 .

taenioptera, 35 .

Euctenogobius ophthalmonema, 257.

everetti, Asterropteryx, 28.

Eviota, 72.

gymnocephalus, 72.

sealel, 73.

expatria, Boroda, 59.

extraneus, Sicyopterus, 311.

Exyrias, 126.

puntangoides, 127.

\section{$\mathbf{F}$}

filifer, Cryptocentrus, 241.

Gobius, 241.

fimbriidens, Ranulina, 272.

fontanesii, Cryptocentrus, 242.

Gobius, 242.

Gobius (Cryptocentrus), 242.

Oxyurichtus, 242.

formosum, Microsicydium, 297.

freycineti, Periophthalmus, 320.

Fuliag, 309.

foliag, Sicyopterus, 309.

fulvus, Gobiodon, 292.

fusca, Eleotris, 30 .

Peocilia, 30.

fuscus, Bathygobius, 113.

Culius, 30.

Gobius, 113.

Mapo, 113.

fusiformis, Gobius, 158 .

Galera, 103.

\section{G}

produeta, 104.

gemmeus, Gnatholepis, 135.

genivittatus, Awaous, 211.

Chonophorus, 211.

Gobius, 211.

giurus, Glossogobius, 113, 161.

Gobius, 161.

obscuripinnis, Glossogobjus, 164.

Glossogobius, 156.

aglestes, 157.

biocellatus, 156 .

celebius, 158.

giurus, 113, 161.

giurus obscuripinnis, 164.

Gnatholepis, 126.

calliurus, 130 .

davaoensis, 134 .

deltoides, 133.

gemmeus, 135.

knighti, 137.

puntangoides, 127.

sternbergi, 98.

volcanus, 131.

Gobiichthys, 247.

papuensis, 253.

tentacularis, 257. 
Gobiida, 84.

Gobiodon, 291.

ceramensis, 294.

fulvus, 292.

hypselopterus, 293.

quinquestrigatus, 294.

Gobioidea, 19.

Gobioides caeculus, 831.

cirratus, 338.

gracilis, 384.

Gobioididæ, 327.

Gobiomorphus, 45. illotus, 45.

Gobiosoma, 289. insignum, 289. marmoratum, 291.

Gobius, 105.

acutipennis, 204. acutipinnis, 204. argulus, 249. baliuroides, 188. barbarus, 816. biocellatus, 156. bitelatus, 166. breviceps, 118. brevirostris, 226. bynoensis, 232. calderae, 182. caninus, 186. cauerensis, 107. celebius, 158. criniger, 191. deltoides, 138. dispar, 142. echinocephalus, 172. flifer, 241.

fontanesii, 242.

fuseus, 118.

fusiformis, 158. genivittatus, 211. giurus, 161. grammepomus, 216. grandinosus, 186. hasta, 267.

bexanems, 274. homocyanus, 118. interstinctus, 109. knuttell, 241.

lachrymosus, 212. litturatus, 216. melanocephalus, 216. melanosoms, 174. microlepis, 251. mystacinus, 208. nebulo-punctatus, 118. nebulosus, 191. neophytus, 195. notacanthus, 166. nox, 116. obscuripinnis, 164. ocellaris, 218. oligolepis, 110. ommaturus, 266. ophthalmonema, 257.
Gobius-Continued. ophthalmotaenia, 107. oplopomus, 166. ornatus, 108. padangensis,' 113. panayensis, 106. papuensis, 253. pavo, 158. pectinirostris, 823. periophthalmoides, 109. personatus, 216. phaiosoma, 158. phalaena, 285. polynema, 270. punetillatus, 113. puntang, 127. puntangoides, 127. quinquestrigatus, 294. sandvicensis, 113. scblosseri, 320. semidoliatus, 200. soporator, 118. spectabilis, 161. sphinx, 237. sphynx, 287. stenophthalmus, 282. sternbergi, 98. stigmatias, 276. strigatus, 78.

viganensis, 203.

viridi-punetatus, 179. viridis, 825.

xanthosoma, 175.

(Cryptocentrus) fontanesii, 242.

(Oxyurichthys) papuensis, 258. gracilis, Amblyopus, 334.

Gobloides, 334.

Taenioides, 834. grammepomus, Gobius, 216. grandinosus, Gobius, 186. gymnocephalus, Eviots, 72. gymnopomus, Butis, 51 .

Eleotris, 51.

\section{H}

hasta, Gobius, 267.

Synechogobius, 267.

Hazeus, 126.

hexanema, Amblychaeturichthys, 274.

Chaeturichthys, 274.

Gobius, 274.

hexanemus, Chaeturicbthys, 274.

koedti, Eleotris, 65.

Ophiocara, 65.

bomocyanus, Gobius, 118.

hongkongensis, Rhinogobius, 184.

humeralis, Eleotris, 48.

Hypseleotris, 37.

agilis, 38.

blpartita, 39.

cyprinoides, 88.

modestus, 41.

pangel, 42.

bypselopterus, Gobiodon, 298. 


\section{I}

Illana, 268.

cacabet, 269.

illotus, Gobiomorphus, 45.

Illustrations, 9.

inornatus, Amblygobius, 228.

insignis, Amblygobius, 234.

Inslgnum, Gobiosoma, 289.

interstinctus, Gobius, 109.

intonsa, Macgregorella, 100.

Introduction, 15.

ioturus, Tridentiger, 283.

Irin-irin, 142.

Itbaya, 288.

nuda, 288.

\section{J}

japonicus, Triaenopogon, 281.

\section{$\mathbf{K}$}

Kampa, 23.

Kamumbon, 128.

Kapalo, 161.

Kaple, 47.

knighti, Gnatholepis, 137.

knutteli, Gobius, 241.

koelreuteri, Periophthalmus, 316.

koilomatodon, Butis, 53.

Eleotris, 52.

Prionobutis, 52.

Kuchu, 122.

Kusung, 28.

Labanag, 65.

lachrymosus, Chonophorus, 212.

Gobius, 212.

lacrymosus, Sicyopterus, 303.

lacustris, Mirogobius, 93.

Laginlagen, 191.

laglaizei, Eleotris, 65.

leucurus, Butis, 48.

leytensis, Chlamydes, 118.

lighti, Sericagobioides, 336.

lineato-oculatus, Eleotris, 79.

linki, Amblygobius, 231.

litturatus, Gobius, 216.

Lomog, 41.

longipinnis, Eleotris, 76.

Valenciennea, 76.

Valenciennesia, 76 .

Lophiogobius, 272.

ocellicauda, 272.

lophius, Cristatogobius, 170.

lungi, Rhinogobius, 191.

luzonensis, Mistichthys, 95 .

luzonica, Biat, 246.

luzonicus, Biat, 246.

Macgregorella, 100.

intonsa, 100.

moroana, 102. macrognathos, Vaimosa, 145.

maculipinnis, Drombus, 342.

Rhinogobius, 342.

Mapo, 111.

fuscus, 113 .

mearnsi, 116.

Maringyan, 39.

marmorata, Eleotris, 74 .

Oxyeleotris, 74.

marmoratum, Gobiosoma, 291.

mearnsi, Bathygobius, 116.

Mapo, 116.

melanocephalus, Chonophorus, 216.

Gobius, 216.

melanosoma, Cullus, 33.

Eleotris, 33.

Gobius, .174.

Paragobiodon, 174.

melanosomus, Paragobiodon, 172, 174.

microcephalus, Ctenotrypauchen, 341 .

Trypauchen, $\mathbf{3 4 1 .}$

microlepis, Gobius, 251.

Oxyurichthys, 251.

Microsicydium, 295.

atro-purpureum, 296.

formosum, 297.

pulchellum, 299.

microstomia, Vaimoss, 146.

mindanensis, Parapocryptes (Paeneapocryptes), 262.

Mirogobius, 91.

lacustris, 93.

stellatus, 92.

Mistichthys, 95.

luzonensis, 95.

modestus, Asterropteryx, 41.

Hypseleotris, 41.

moloanus, Aparrius, 207.

montalbanl, Apocryptodon, 277.

moroana, Macgregorella, 102.

Mud skipper, 316.

multifasciatus, Rhinogobius, 190.

Mulug, 30, 157.

muralis, Eleotris, 76, 79.

Valenciennea, 79.

Valenciennesia, 79.

mystacina, Waitea, 208.

mystacinus, Gobius, 208.

\section{$\mathbf{N}$}

nebulo-punctatus, Gobius, 113.

nebulosus, Gobius, 191.

Rhinogobius, 191.

neophytus, Gobius, 195.

Rhinogobius, 195.

nigra, Eleotris, 30.

notacantbus, Gobius, 166.

Oplopomus, 166.

nex, Bathygobius, 116.

Gobius, 116.

nuda, Itbaya, 288. 


\section{o}

obscura, Eleotris, 55.

Odontobutis, 55.

obscuripinnis, Glossogobius giurus, 164. Gobius, 164.

obscurus, Odontobutis, 55 .

ccellaris, Awaous, 218.

Chonophorus, 218.

Gobius, 218.

ocellicauda, Lophiogobius, 27\%.

Philypnus, 43.

oculo-mirus, Oxyurichthys, 256.

ocyurus, Rhinogobius, 204.

Gdontokutis, 54.

obscura, 55.

obscurus, 55.

Odontogobius, 227.

bynoensis, 232.

oligolepis, Gobius, 110.

olivaceus, Brachyamblyopus, 329.

ommaturus, Acantbogobius, 266.

Gobius, 266.

Ophiocara, 65.

aporos, 65.

hoedti, 65 .

ophiocephalus, 69 .

porocephala, 69 .

porocephalus, 69 .

ophiocephalus, Eleotris, 69.

Ophiocara, 69.

ophthalmonema, Euctenogobius, 257.

Gobius, 257.

Oxyurichthys, 257.

ophthalmonemus, Pselaphius, 257.

ophthalmotaenia, Gobius, 107.

Oplopomus, 166.

notacanthus, 166.

oplopomus, 166.

pulcber, 166.

vergens, 168.

oplopomus, Gobius, 166.

Oplopomus, 166.

ornatus, Gobius, 108.

Oro-on, 164.

Oxyeleotris, 74 .

marmorata, 74.

Oxyurichthus, 247.

argulus, 249.

cristatus, 251.

papuensis, 253.

Oxyurichthys, 247.

amabilis, 250.

argulus, 249.

microlepis, 251.

oculo-mirus, 256.

ophthalmonema, 257.

papuensis, 253.

papuensis, Gobjus, 253.

tentacularis, 257.

viridis, 260 .

visayanus, 254 .

Oxyurichtus fontanesil, 242.

\section{P}

pacifica, Cobitis, 30 .

padangensis, Gobius, 113.

(Paeneapocryptes) mindanensis, Parapocryptes, 262.

Paku, 69.

Palace, 69.

palackyi, Drombus, 178.

Rhinogobius, 178.

Paliling, 303.

Palo, 56, 161.

Paló, 179.

Paloa, 56.

polylepis, 56.

Palowon, 65.

Palu, 69.

panayensis, Gobius, 106.

Sicsopterus, 313.

Pandaka, 196.

pusilla, 197.

pygmaea, 198.

pangel, Hypseleotris, 42.

Pañgel, 42.

papilio, Periophthalmus, 316 .

papuensis, Gobiichthys, 253.

Gobius, 253.

Gobius (Oxyurichthys), 253.

Oxyurichthus, 253.

Oxyurichthys, 253.

Parachaeturichtbys, 270. polynema, 270 . polynemus, 270 .

Paragobiodon, 172. echinocephalus, 172.

melanosoma, 174.

melanosomus, $172,174$.

xanthosoma, 175.

xanthosomus, 175.

Parapocryptes, 261.

serperaster, 262.

(Paeneapocryptes) mindanensis, 262.

parvei, Sicydium, 307.

Parviparma, 81.

straminea, 82.

Pasel, 48.

pavo, Gobius, 158.

pectinirostris, Boleophthalmus, 323 .

Gobius, 323.

Peocilia fusca, 30 .

Periophthalmidæ, 315 .

Periophthalmodon, 320 .

schlosseri, 320 .

periophthalmoides, Gobius, 109.

Periophthalmus, 316.

barbarus, 316 .

chrysospilus, 316 .

freycineti, 320 .

koelreuteri, 316 .

papilio, 316.

scholosseri, 320.

perpusillus, Amblygobius, 229.

buanensis, Amblygobius, 230.

Rhinogobius, 229. 
personatus, Awaous, 216.

Gobius, 216.

phaiosoma, Gobius, 158.

phalaena, Amblygobius, 235.

Gobius, 235.

phillppinus, Tukugobius, 124.

Philypnus ocellicanda, 43.

sinensis, 44.

piapensis, Vaimosa, 147.

Pilingan, 23.

pinguis, Bunaka, 61.

Platyptera, 22.

aspro, 22.

Pleurogobius boulengeri, 201.

polylepis, Paloa, 56.

polynema, Chaeturichthys, 270.

Gobius, 270.

Parachaeturichthys, 270.

polynemus, Parachaeturichthys, 270.

porocephala, Eleotris, 69.

Ophiocara, 69.

porocephaloides, Eleotris, 69.

porocephalus, Eleotris, 69.

Opbiocara, 69.

Prionobutis, 52.

koilomatodon, 52.

serrifrons, 53 .

prismaticus, Butis, 48.

producta, Galera, 104.

Pselaphias, 247.

Pselaphius ophthalmonemus, 257.

Ptereleotris, 83.

dispersus, 83.

pulchellum, Microsicydium, 299.

pulcher, Oplopomus, 166.

punctillatus, Gobius, 113.

puntang, Gobius, 127.

puntangoides Exyrias, 127.

Gnatbolepis, 127.

Gobius, 127.

pusilla, Pandaka, 197.

pygmaea, Pandaka, 198.

\section{Q}

quinquestrigatus, Gobjodon, 294.

Gobius, 294.

quoyi, Belobrancbus, 35 .

\section{$\mathbf{R}$}

Ranulina fimbriidens, 272.

Redigobius, 98. sternbergi, 98.

Rhinogobius, 176. baliuroides, 188.

calderae, 182.

caninus, 186.

carpenteri, 122.

criniger, 191.

decoratus, 181.

hongkongensis, 184 .

lungi, 191.

maculipinnis, 342.

multlfasciatus, 190.
Rhinogobius-Continued.

nebulosus, 191.

neophytus, 195.

ocyurus, 204.

palackyi, 178.

perpusillus, 229.

schultzel, 185.

suluensis, 193.

viridi-punctatus, 179.

Rhyacicbtbyidæ, 21.

Rhyacichtbys, 22.

aspro, 22.

rivalis, Vaimosa, 149.

\section{S}

sandvicensis, Gobius, 113.

sapanga, Vaimosa, 152.

Scartelaos, 324.

viridis, 325 .

schlosseri, Gobius, 320.

Periophthalmodon, 320.

Periophthalmus, 320.

schultzei, Rhinogobius, 185.

sealei, Apocryptodon, 278.

Eviota, 73.

semidoliatus, Gobius, 200.

Zonogobius, 200.

semipunctata, Eleotris, 28.

semipunctatus, Asterropteryx, 28.

Sericagobioides, 335 .

lighti, 336.

sericus, Apocryptichthys, 264.

serperaster, Apocryptes, 262.

Parapocryptes, 262.

serrifrons, Butis, 53.

Prionobutis, 53.

Sicydium, 300.

cynocephalum, 306.

parvei, 307.

Sicyopterus, 300.

crassus, 307.

cynocephalus, 306, 307 .

extraneus, 311.

fuliag, 309.

lacrymosus, 303.

panayensis, 313.

taeniurus, 311 .

siitensis, Tamanka, 220.

Simawar, 65.

Sinarapan, 95.

sinensis, Bostrichthys, 43.

Bostrychus, 43.

Eleotris, 44.

Philypnus, 44.

Sisigui, 139.

soporator, Gobius, 113.

spectabilis, Gobius, 161.

sphinx, Amblygobius, 237.

Gobius, 237.

sphynx, Amblygobius, 237.

Gobius, 237.

stellatus, Mirogobius, 92.

stenophthalmus, Gobius, 232. 
sternbergi, Gnatholepis, 98.

Gobius, 98.

Redigobius, 98.

stigmatias, Chaeturichthys, 276.

Gobius, 276.

straminea, Parviparma, 82.

strigata, Eleotris, 78.

Valenciennea, 78.

strigatus, Gobius, 78.

suluensis, Rhinogobius, 193.

Synechogobius, 267.

hasta, 267.

\section{$\mathbf{T}$}

Tabula, 158, 161.

Taenioides, 330.

brachygaster, 383.

caeculus, 331.

cirratus, 333.

gracilis, 334.

taenioptera, Eleotris, $\mathbf{3 5 .}$

taeniopterus, Belobranchus, 35 .

taeniurus, Sicyopterus, 311.

tagala, Tamanka, 222.

Talimosak, $\mathbf{3 1 6 .}$

Tamanka, 220.

bivittata, 224 .

siitensis, 220.

tagala, 222.

umbra, 223.

Tamanka, 220.

Tamasak, 316.

Tambasakan, 316.

Tamindak, $316 .$.

Taporak, 158.

Tapug, 175.

Tatok-layam, 200.

taylori, Apocryptodon, 279.

tentacularis, Gobiichthys, 257.

Oxyurichthys, 257.

tessellata, Vaimosa, 153.

Totot, 216.

Triaenophorichthys barbatus, 281. trigonocephalus, 285.

Triaenopogon, 280. barbatus, 281.

japonicus, 281.

Trldentiger, 283.

barbatus, 281.

bifasciatus, 283.

ioturus, 283.

trigonocephalus, 285.

trigonocephalus, Triaenophorichthys, 285.

Tridentiger, 285.

True gobies, 84.

Trypauchen, 338.

microcephalus, 341 .

vagina, 338.

Trypauchenichthys, 339. typus, 340.

Trypauchenidæ, 387.
Tuku, 120.

ng bia, 120.

Tukugobius, 119.

bucculentus, 121.

carpenteri, 122.

philippinus, 124.

typhlops, Caragobius, 287.

typus, Trypauchenichthys, $\mathbf{3 4 0}$.

\section{$\mathbf{U}$}

nmbra, Tamanka, 223.

\section{V}

vagina, Trypauchen, 338.

vagus, Cryptocentrus, 243.

Vaimosa, 141.

bikolana, 151.

dispar, 142.

macrognathos, 145.

microstomia, 146.

piapensis, 147.

rivalis, 149.

sapanga, 152.

tessellata, 153.

villa, 154.

Valenciennea, 75 .

longipinnis, 76 .

muralis, 79.

strigata, 78.

violifera, 80 .

Valenciennesia, 75 .

longipinnis, 76 .

muralis, 79.

validus, Creisson, 139.

venustus, Cryptocentrus, 244.

vergens, Oplopomus, 168.

viganensis, Aboma, 203.

Gobius, 203.

villa, Vaimosa, 154.

violifera, Valenciennea, 80 .

viridi-punctatus, Gobius, 179.

Rhinogobius, 179.

viridis, Boleophthalmus, 325:

Gobius, 325.

Oxyurichthys, 260.

Scartelaos, 325.

Virot, 33.

visayanus, Oxyurichthys, 254.

volcanus, Gnatholepis, 131.

Waitea, 208.

\section{W}

mystacina, 208.

\section{$\mathbf{X}$}

xanthosoma, Gobius, 175.

Paragoblodon, 175.

xanthosomus, Paragoblodon, 175

\section{$\mathbf{Z}$}

Zonogobius, 199.

semidoliatus, 200. 







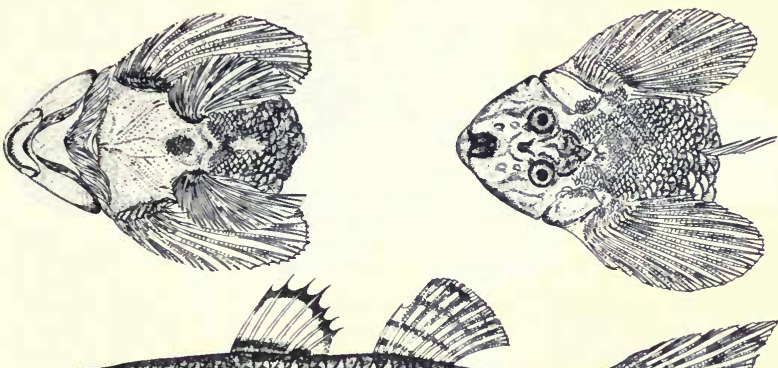

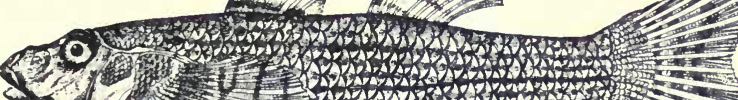

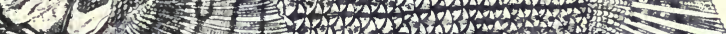

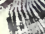

Th

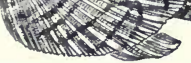

A. 


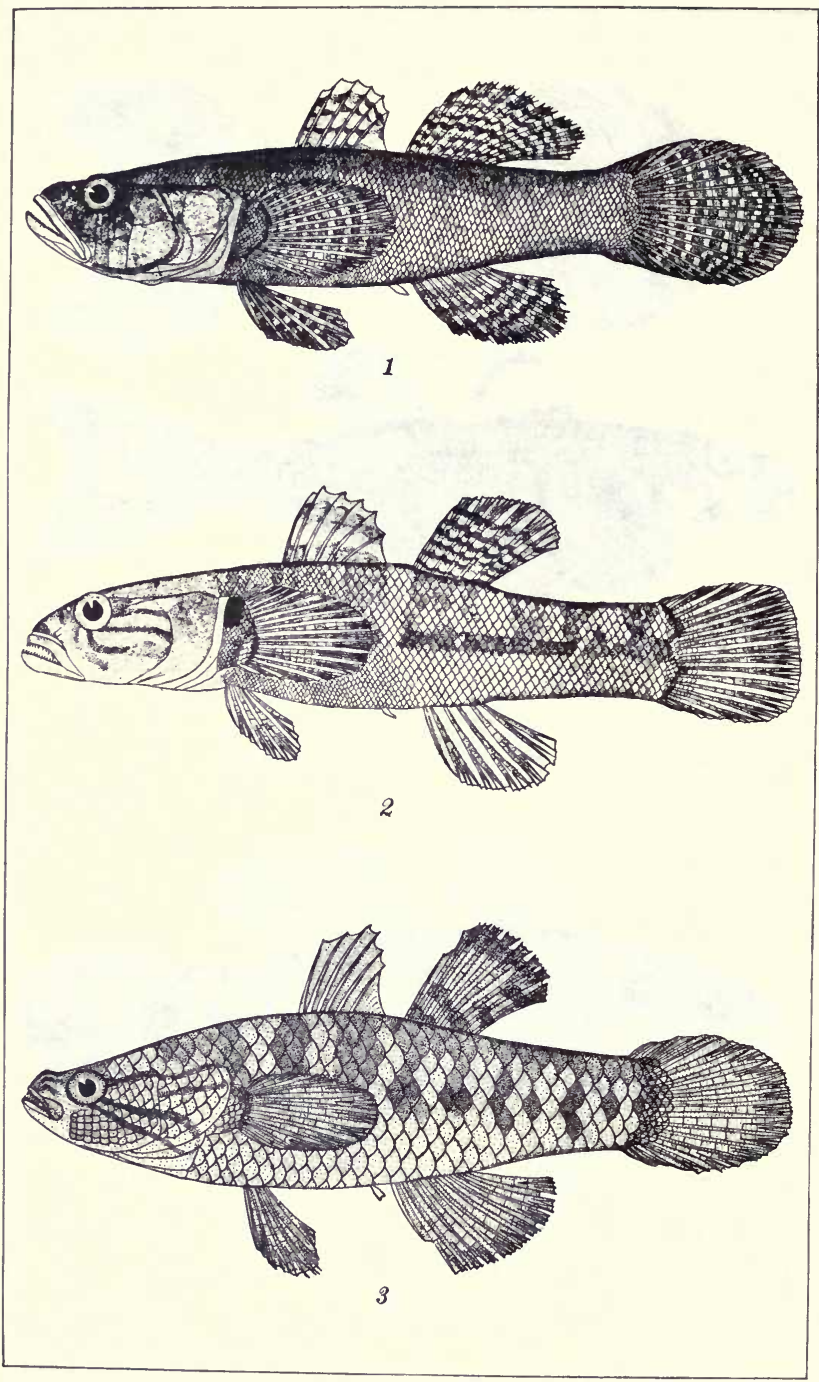

PLATE 2. 


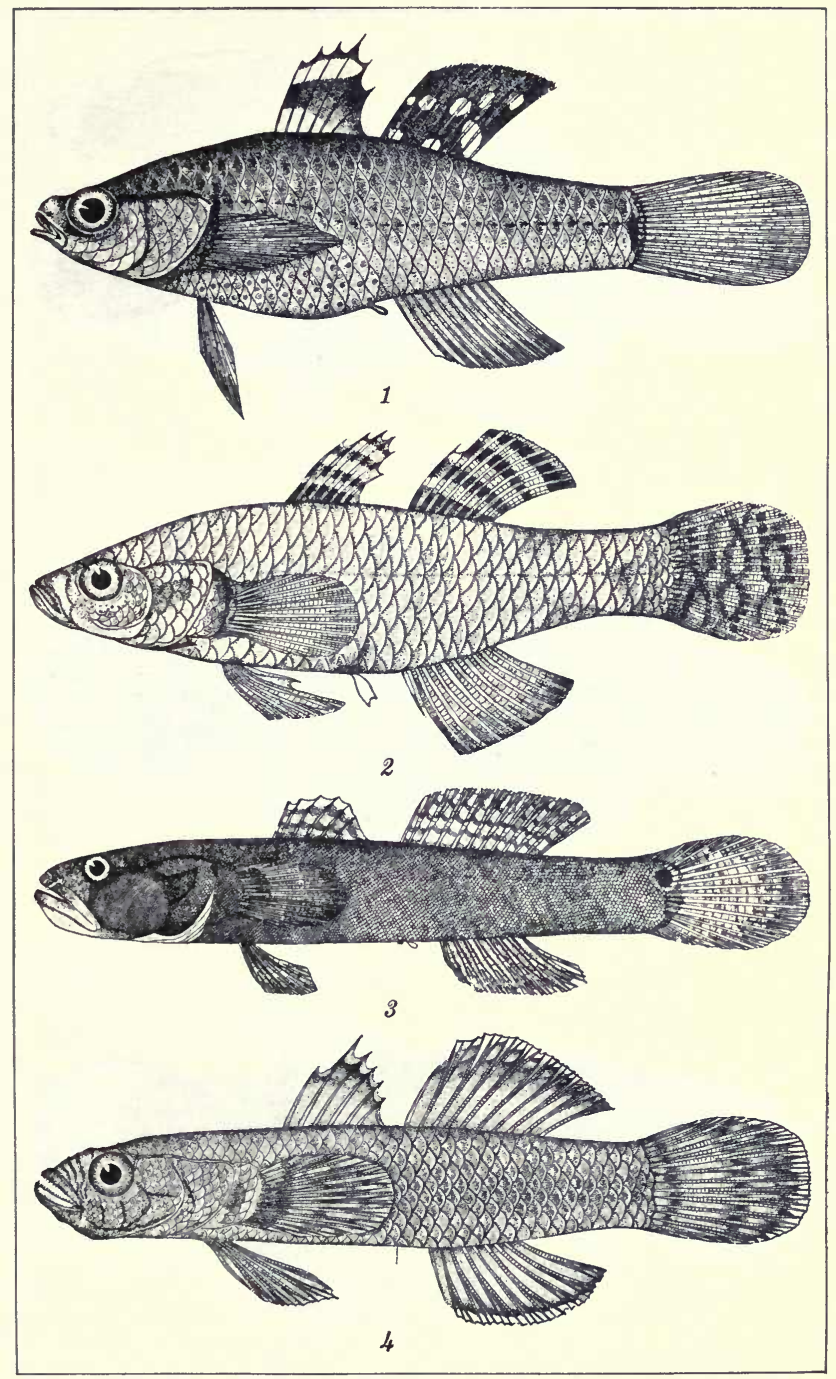

PLATE 3. 


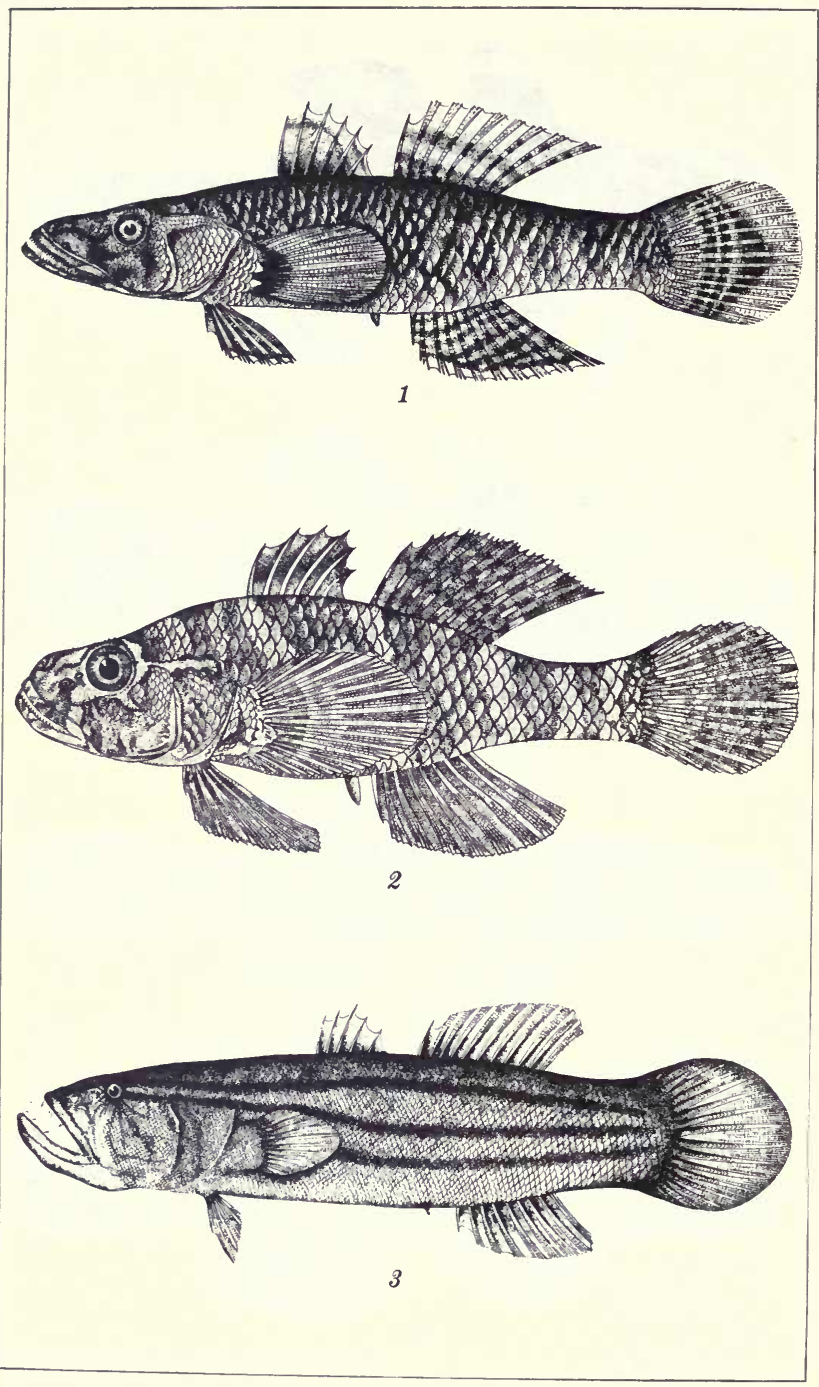

PLATE 4. 


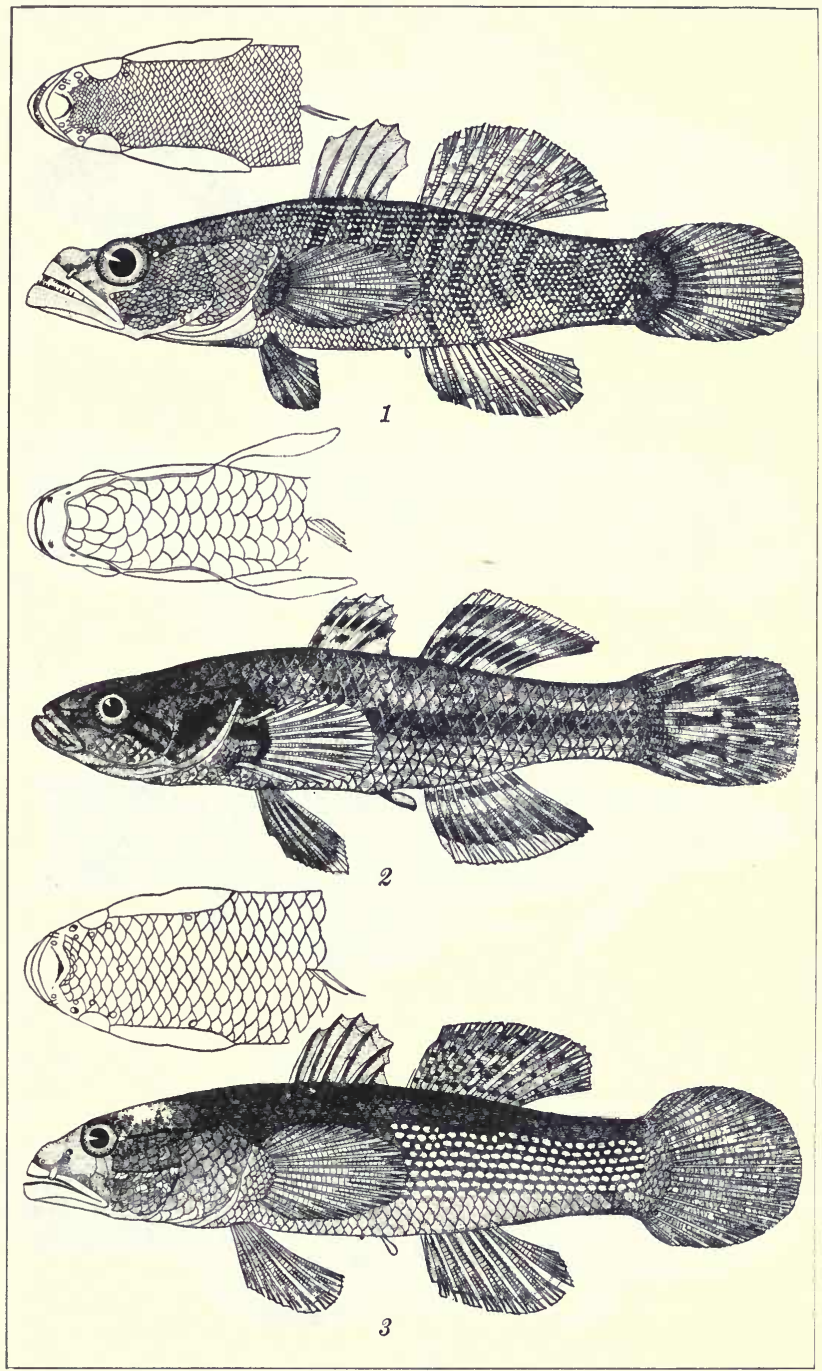

Plate 5. 


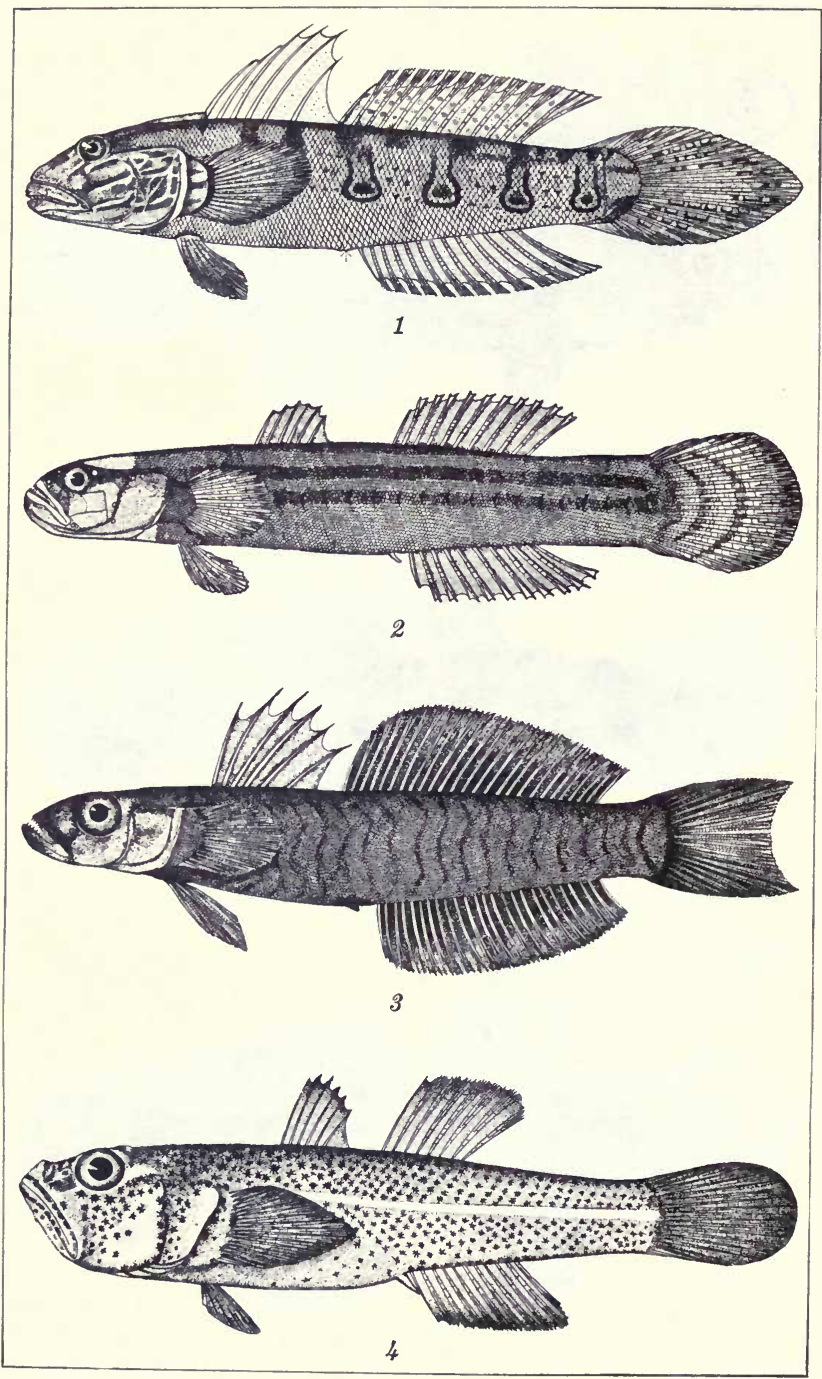

PLATE 6. 


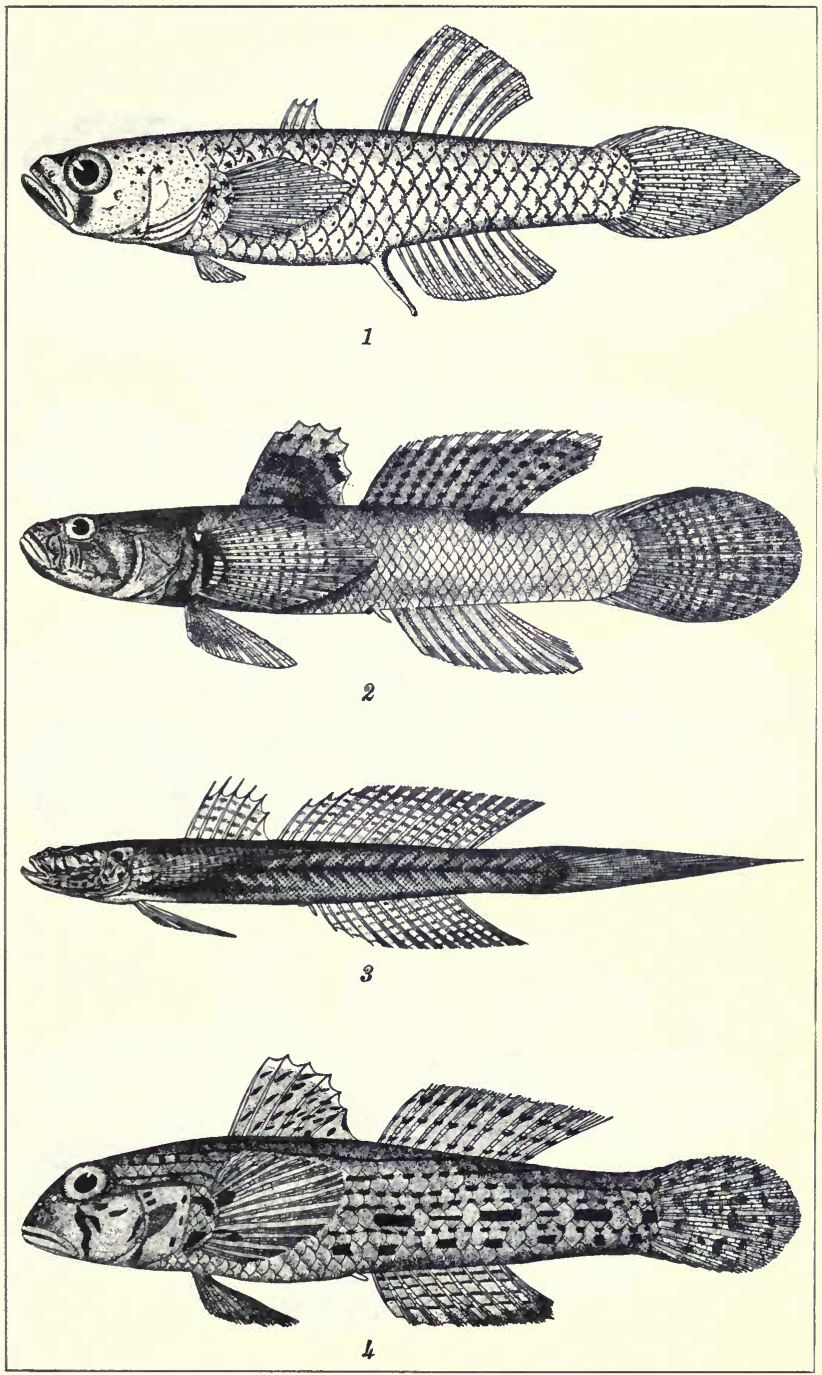

PLATE 7. 


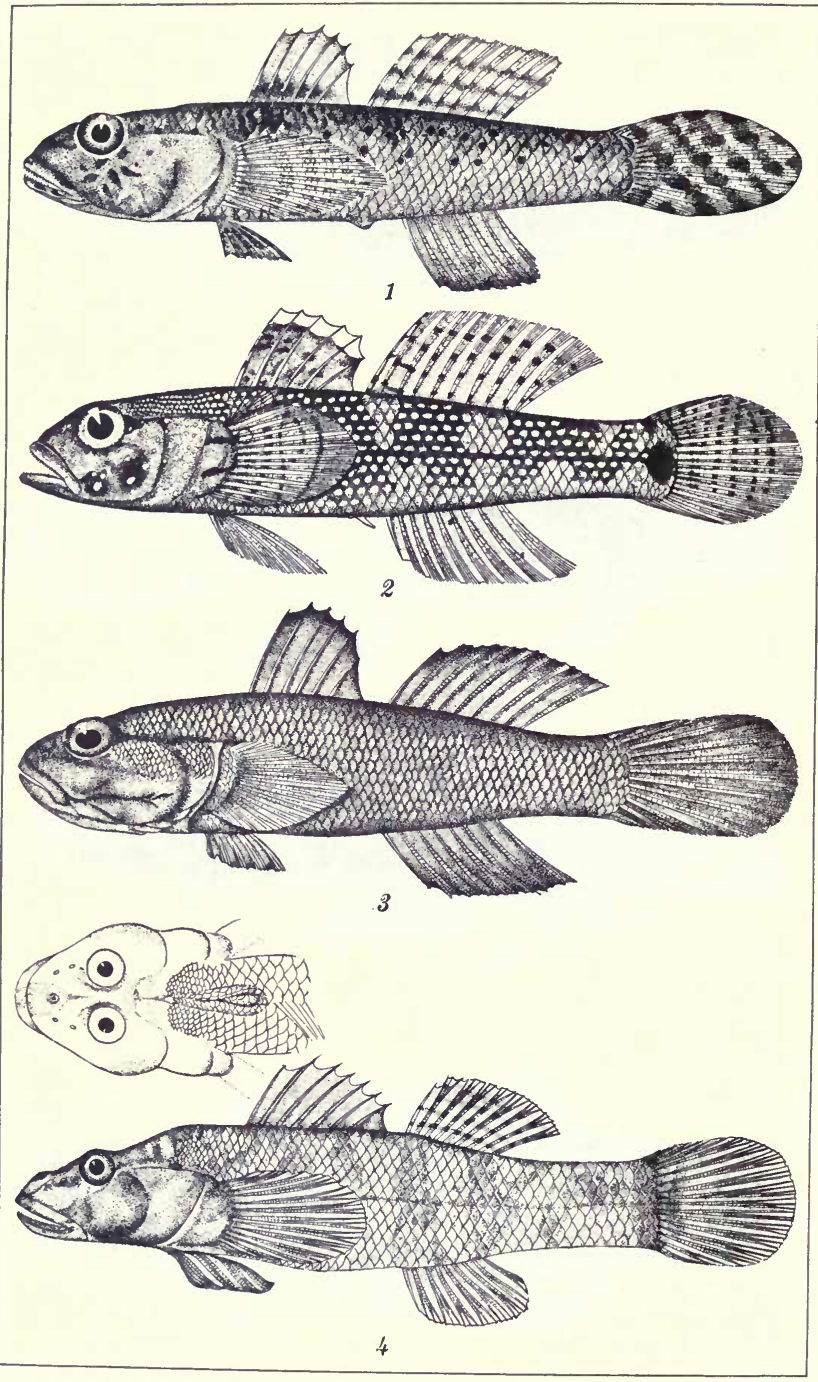

PLATE 8. 


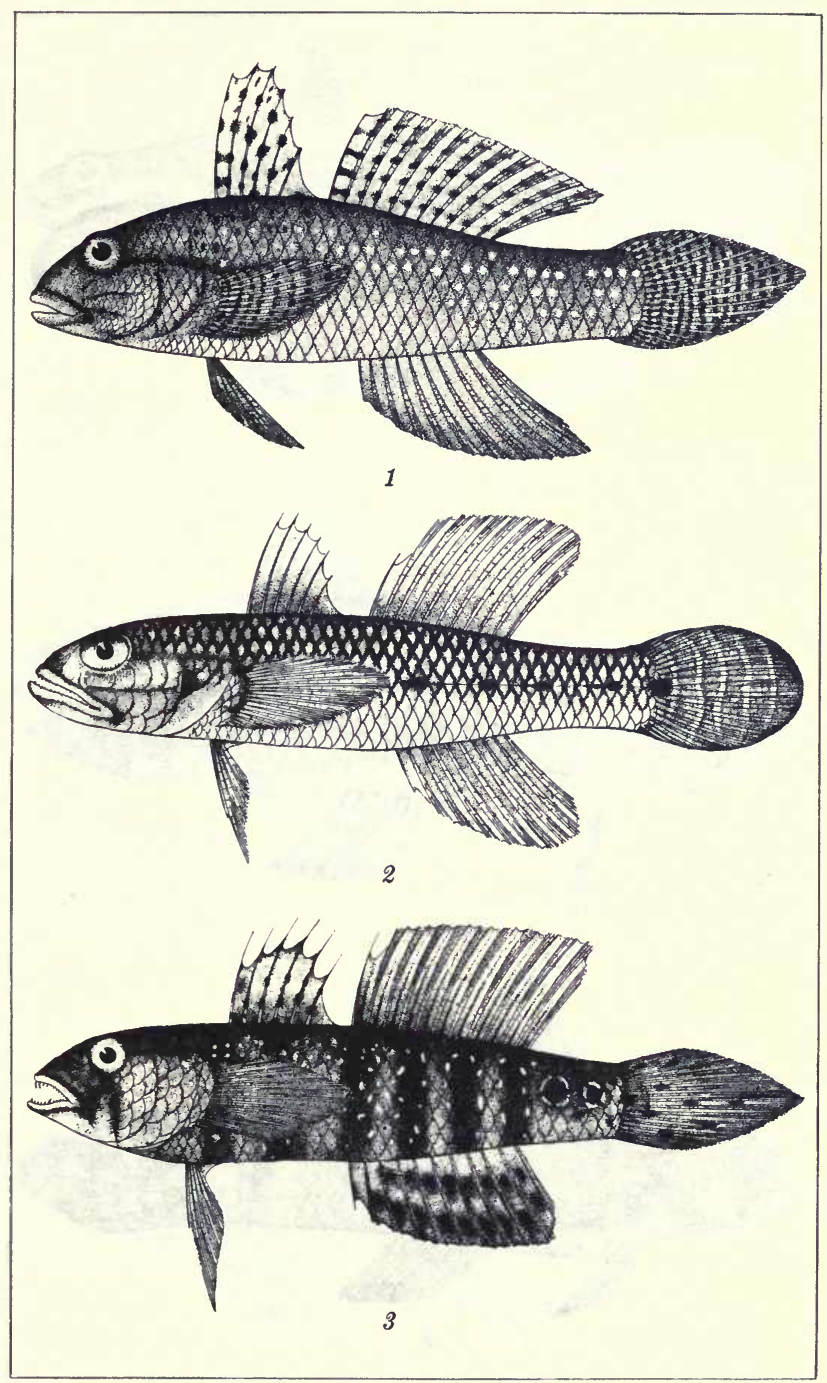

PLATE 9. 


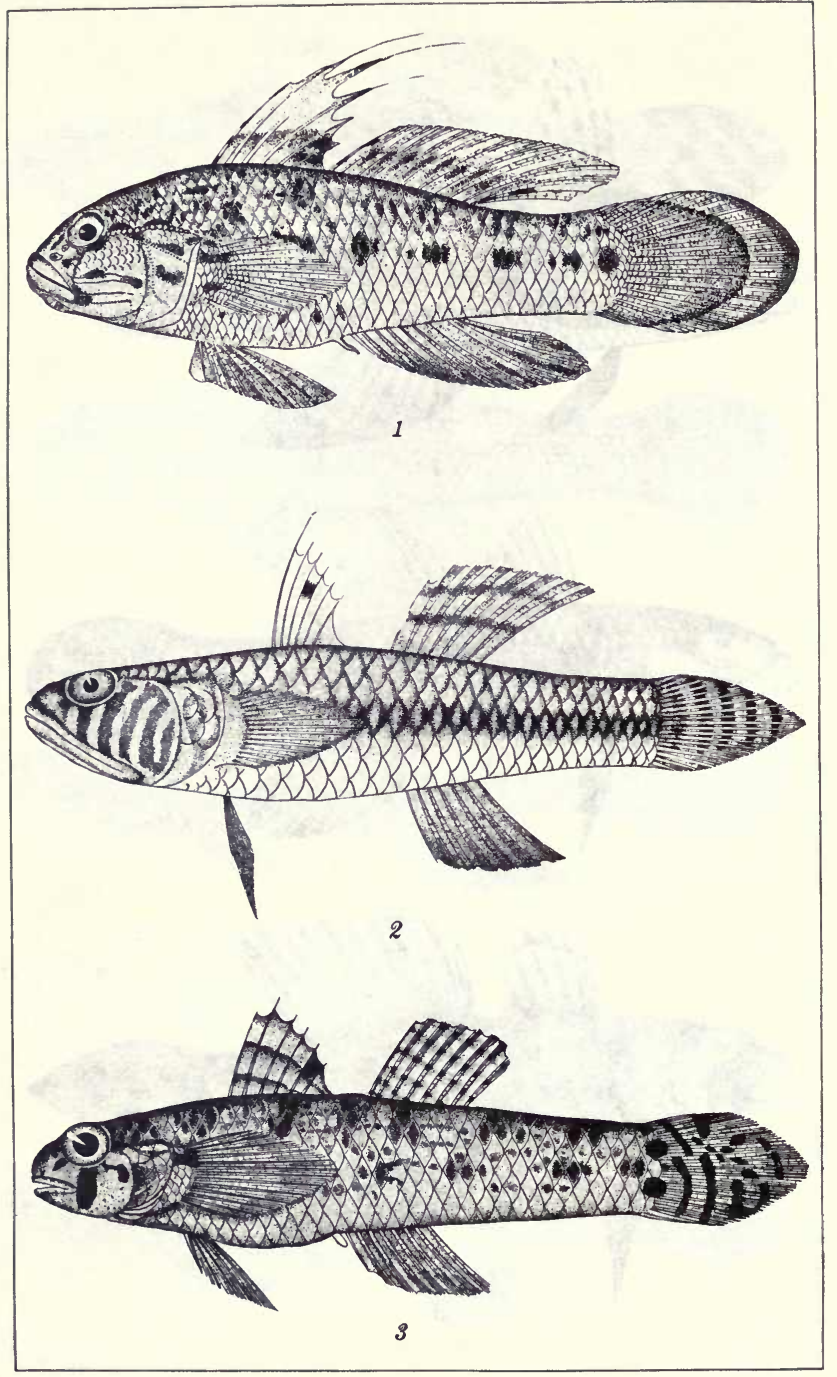

PLATE 10. 


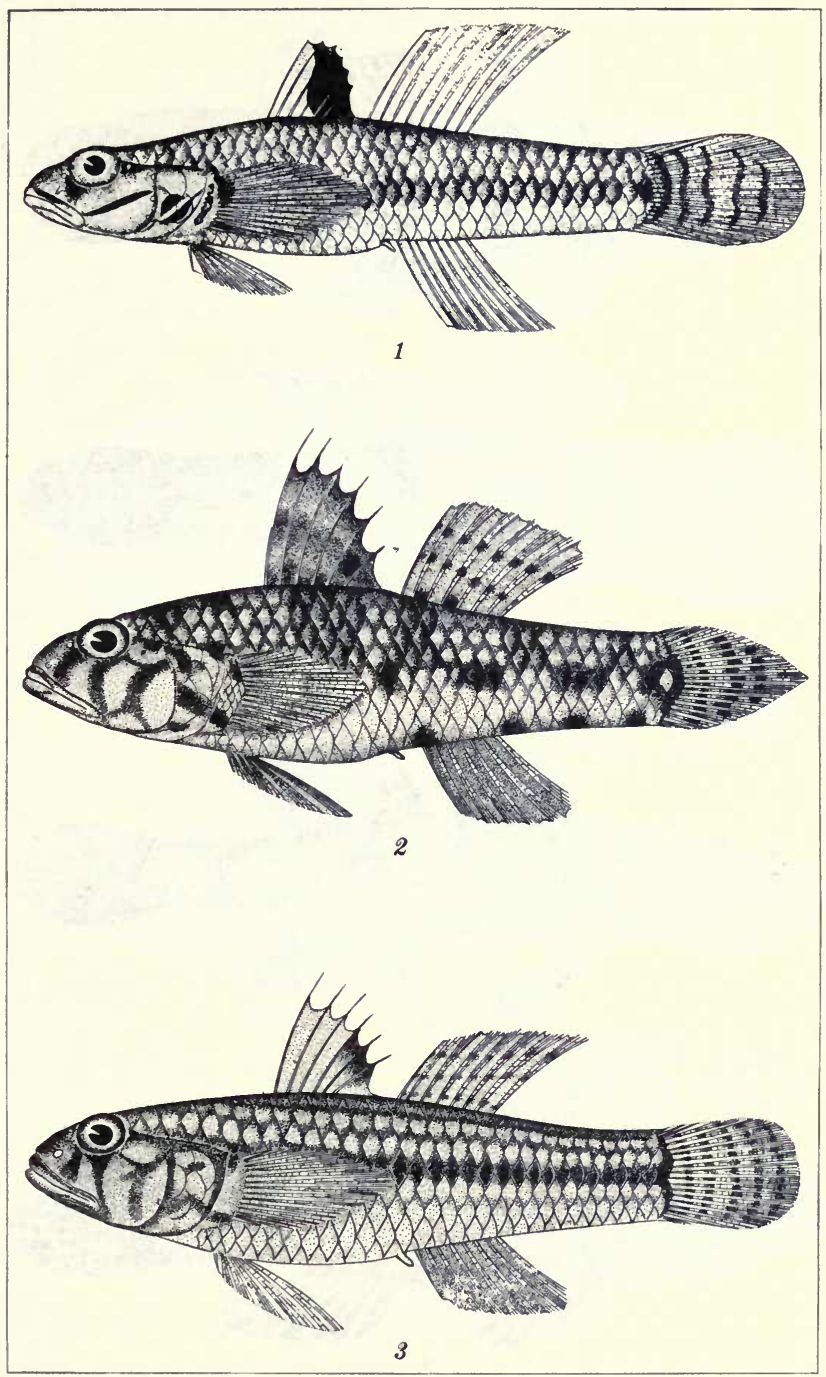

PLATE 11. 


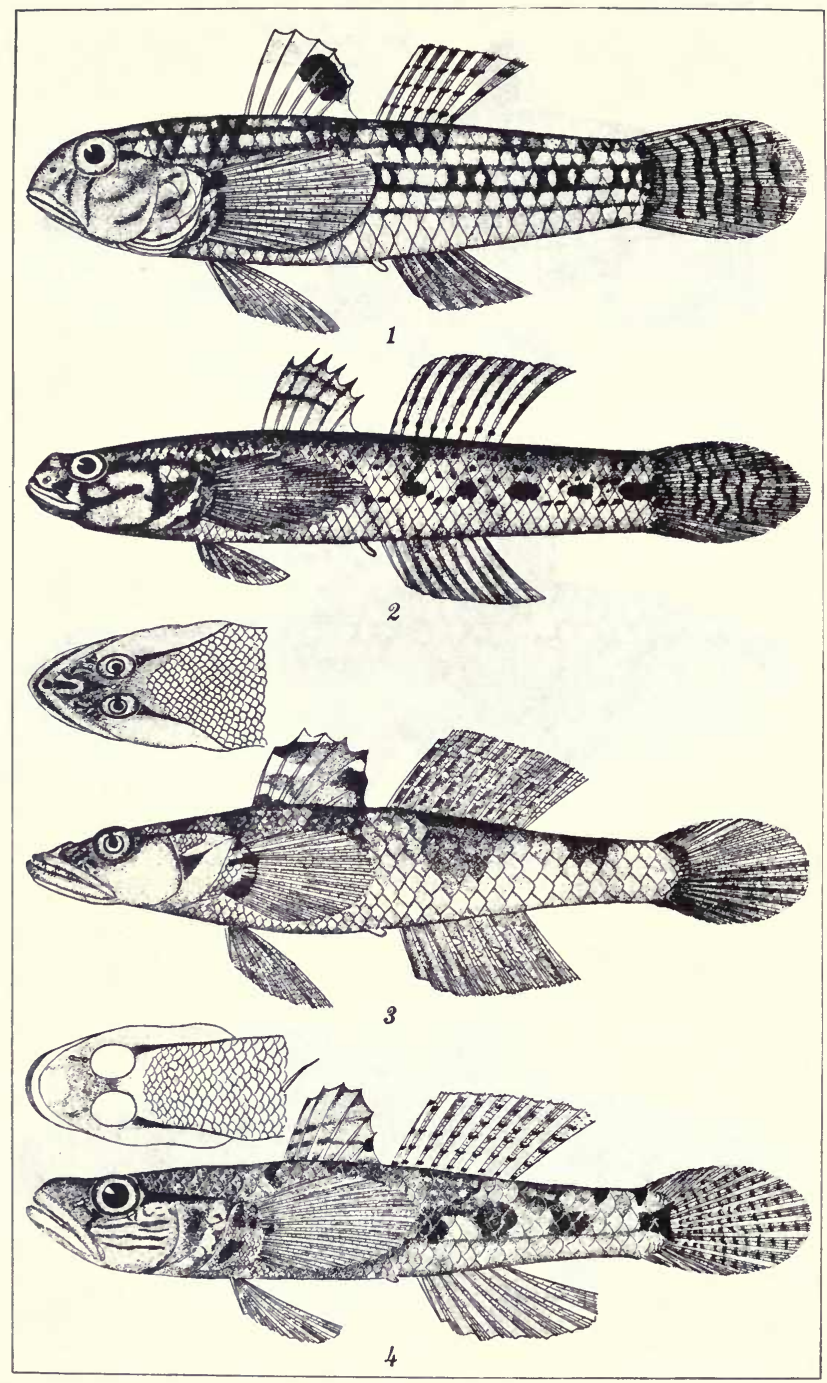

PLATE 12. 


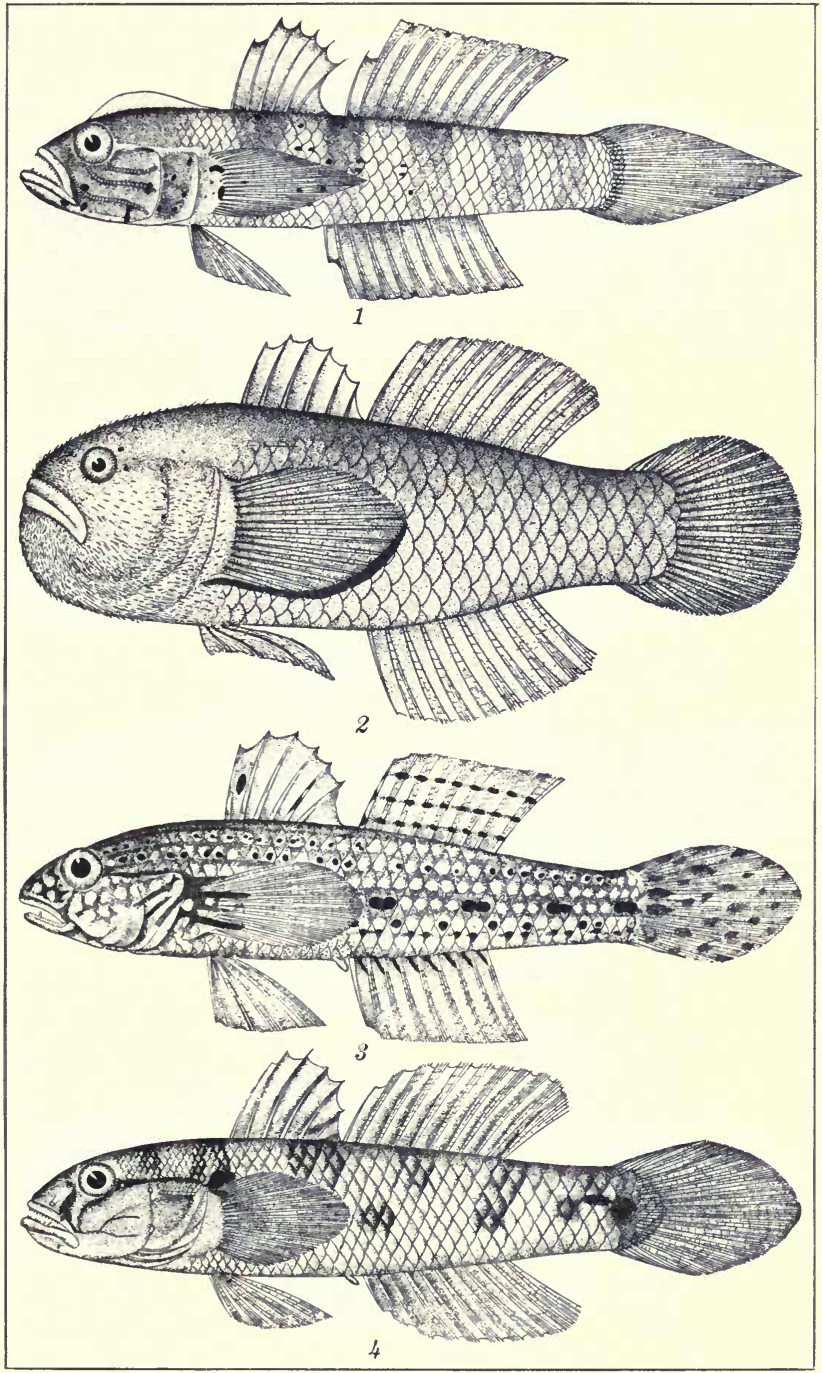

PLATE 13. 


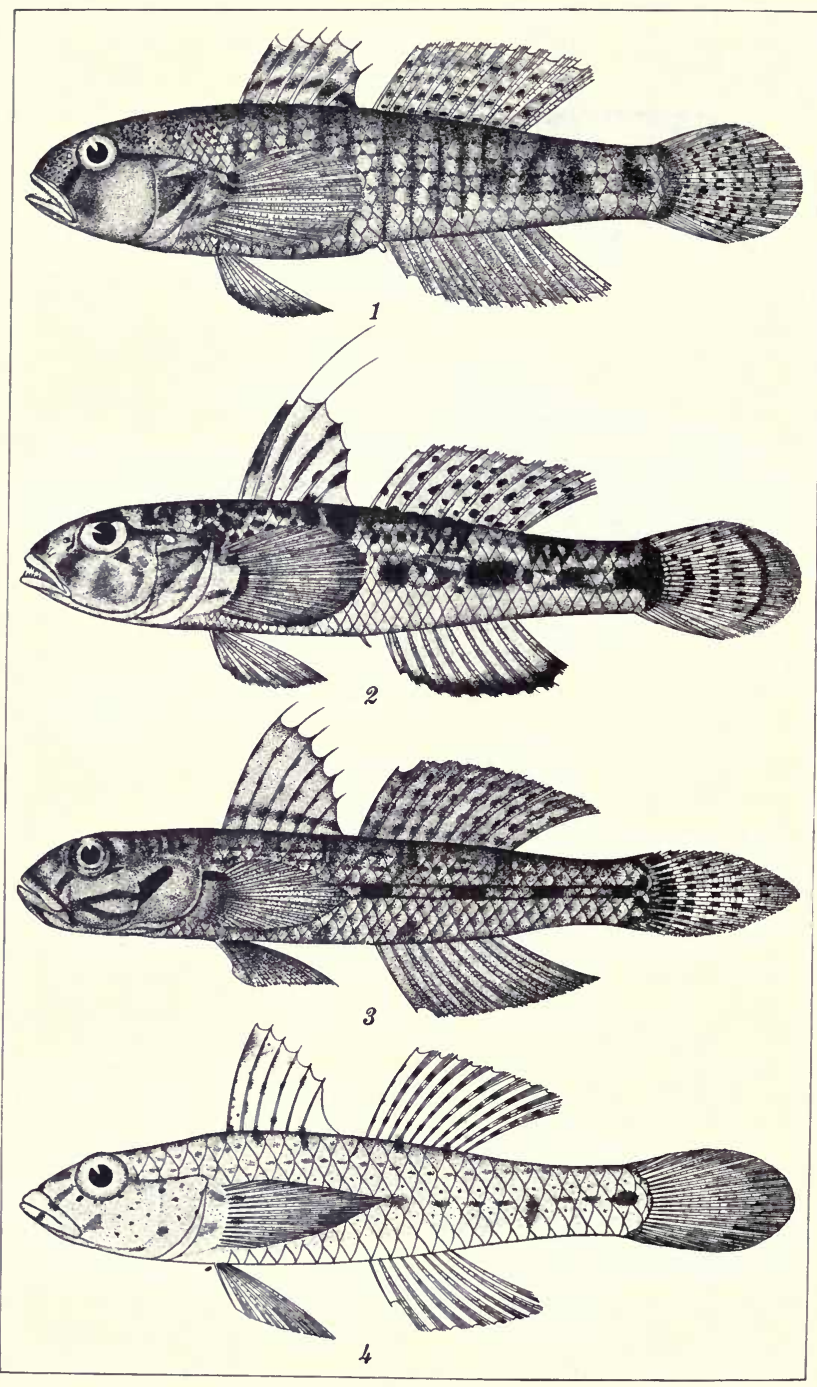

PLATE 14. 


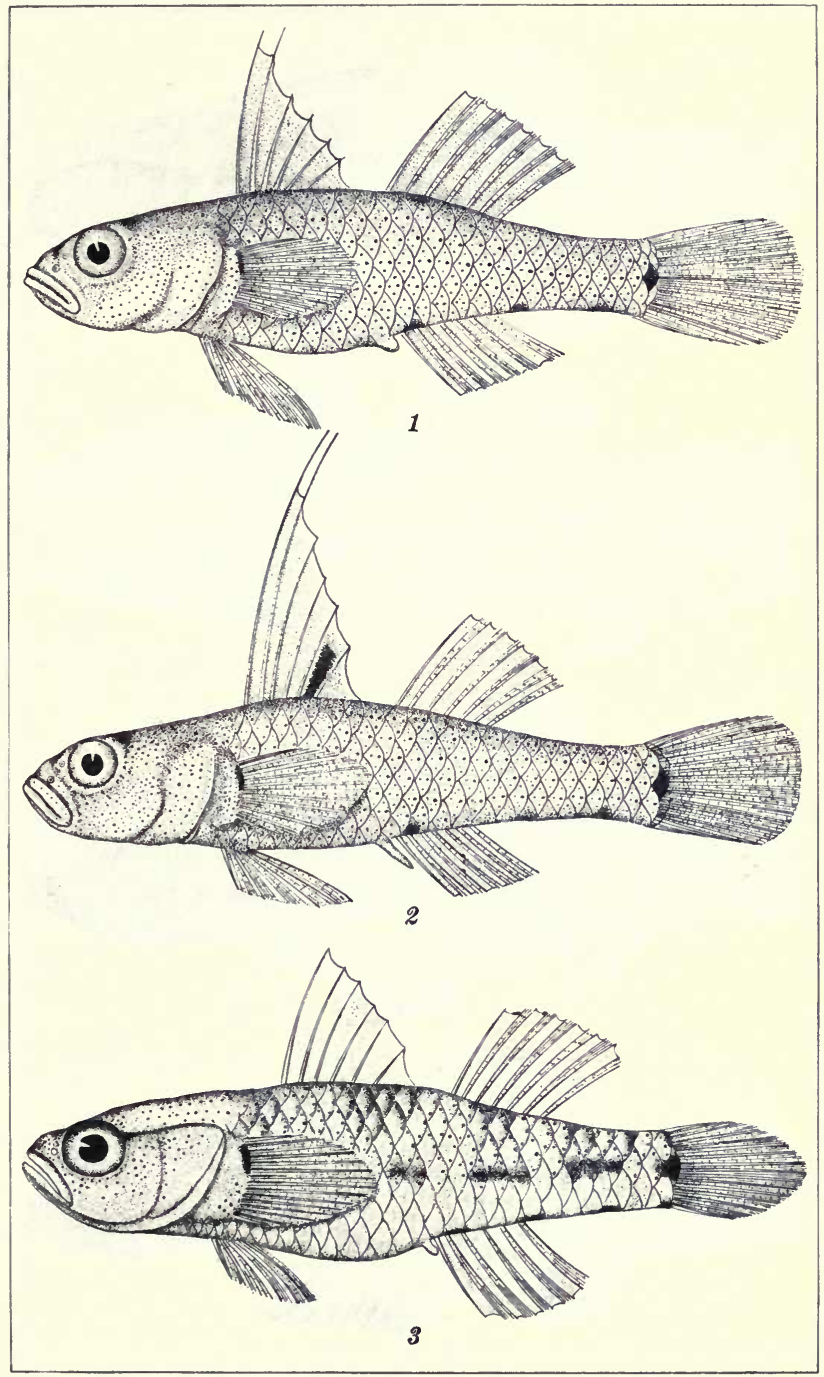

PLATE 15. 


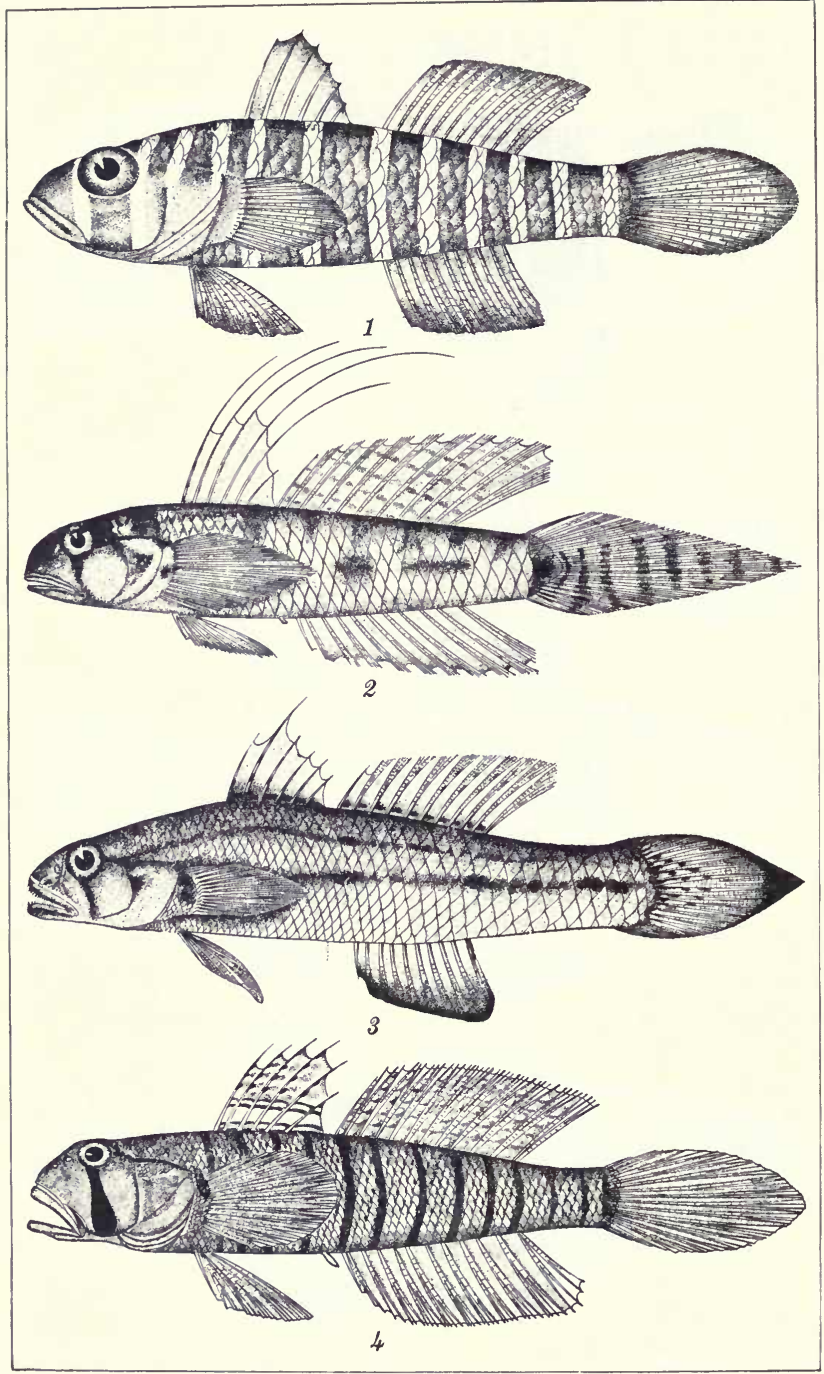

PLATE 16. 


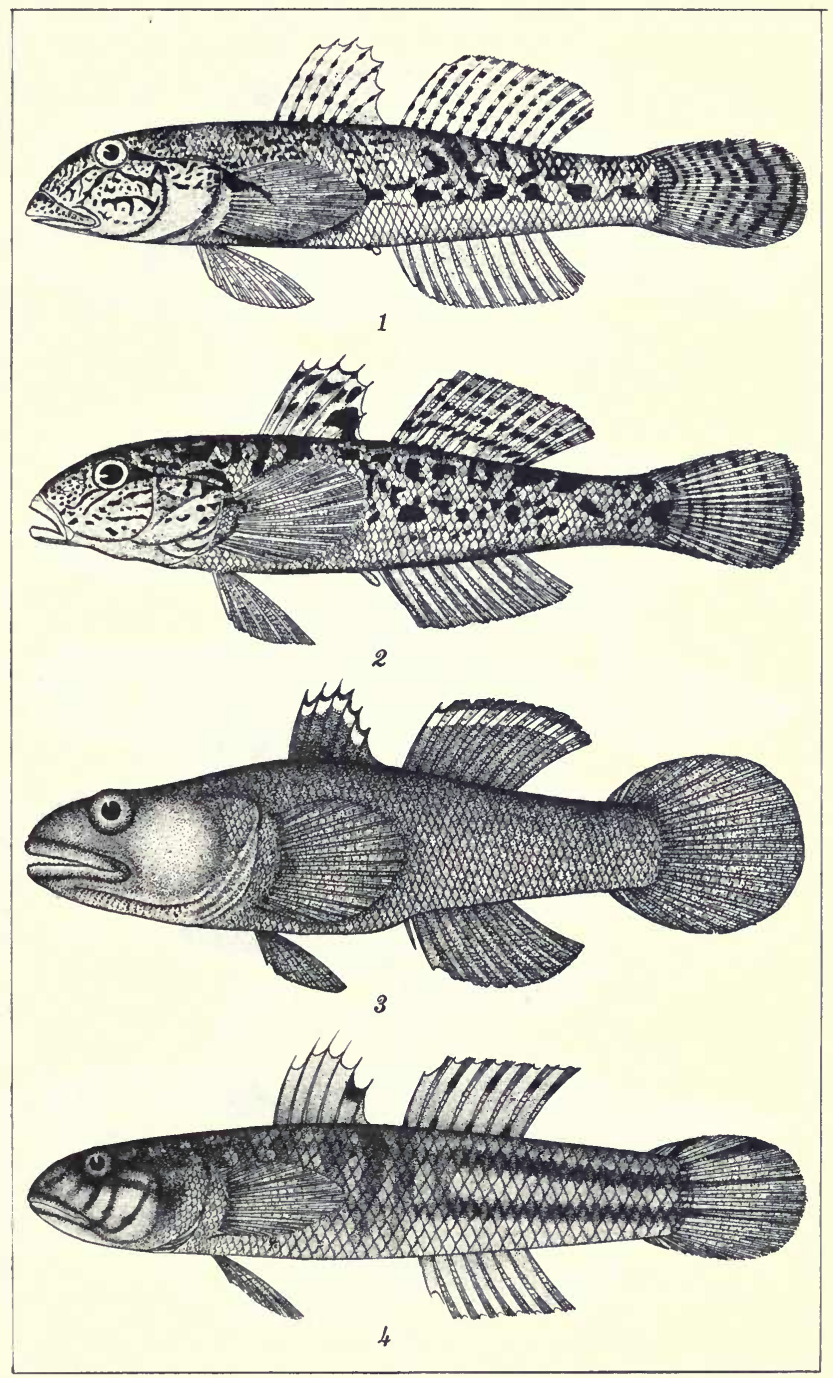




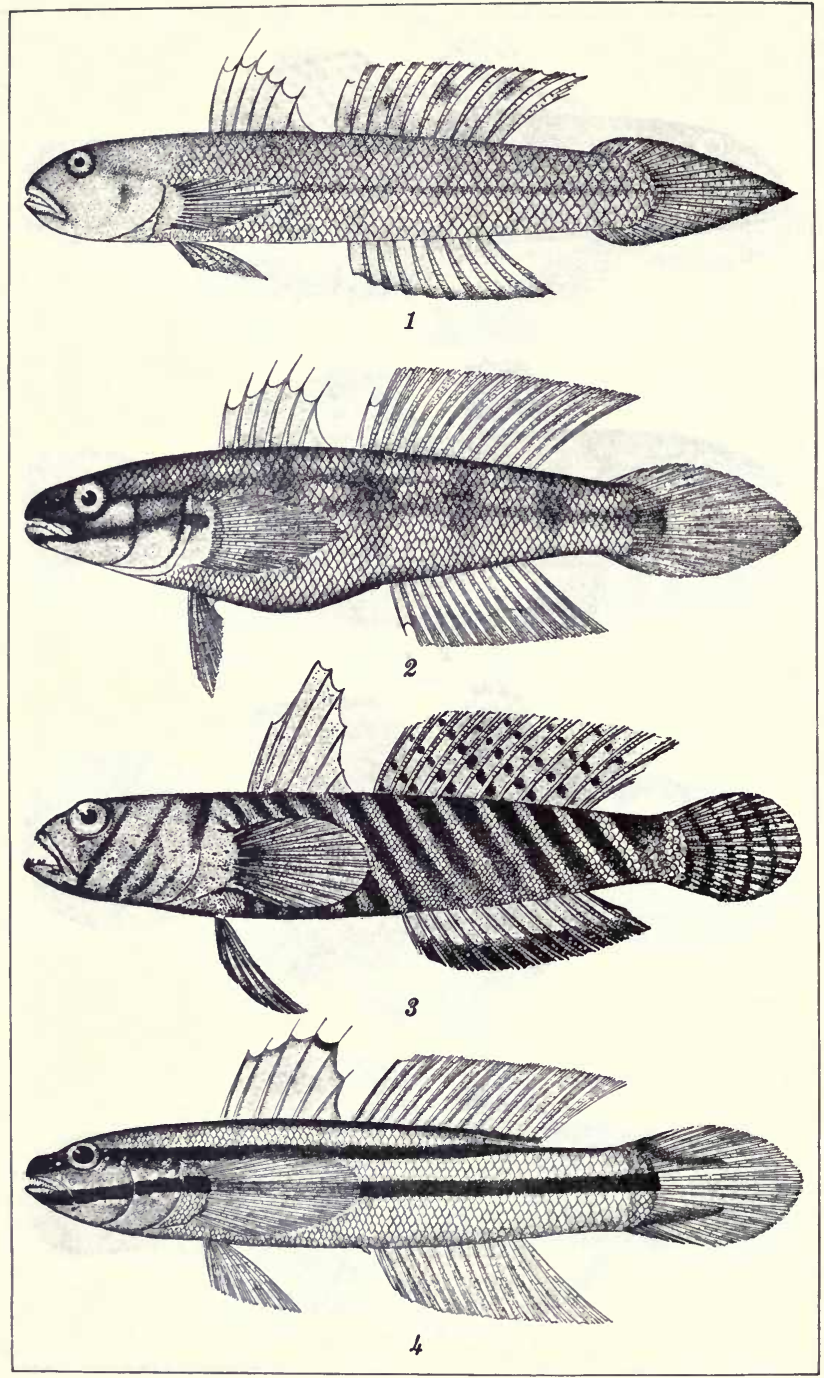

PLATE 18. 


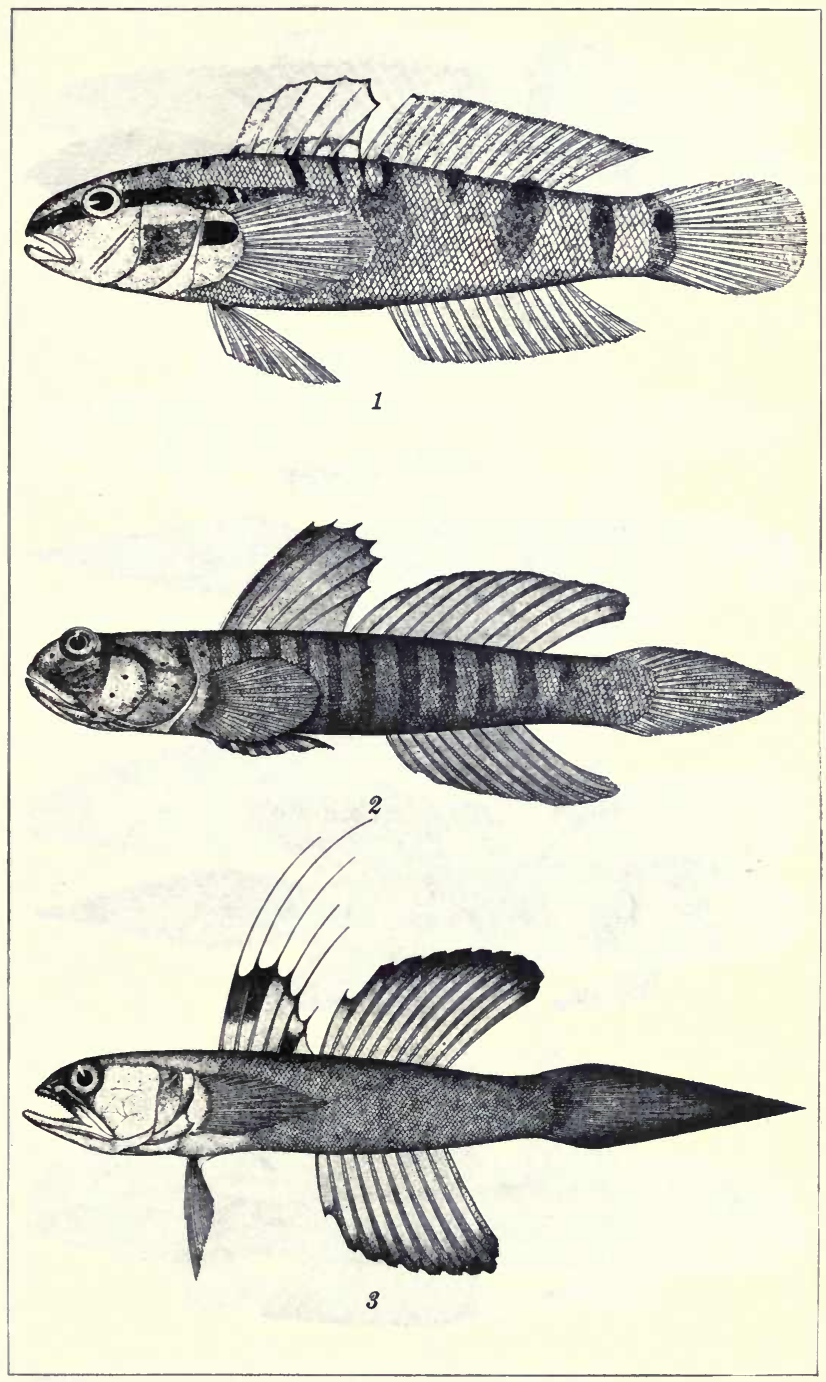

PLATE 19. 


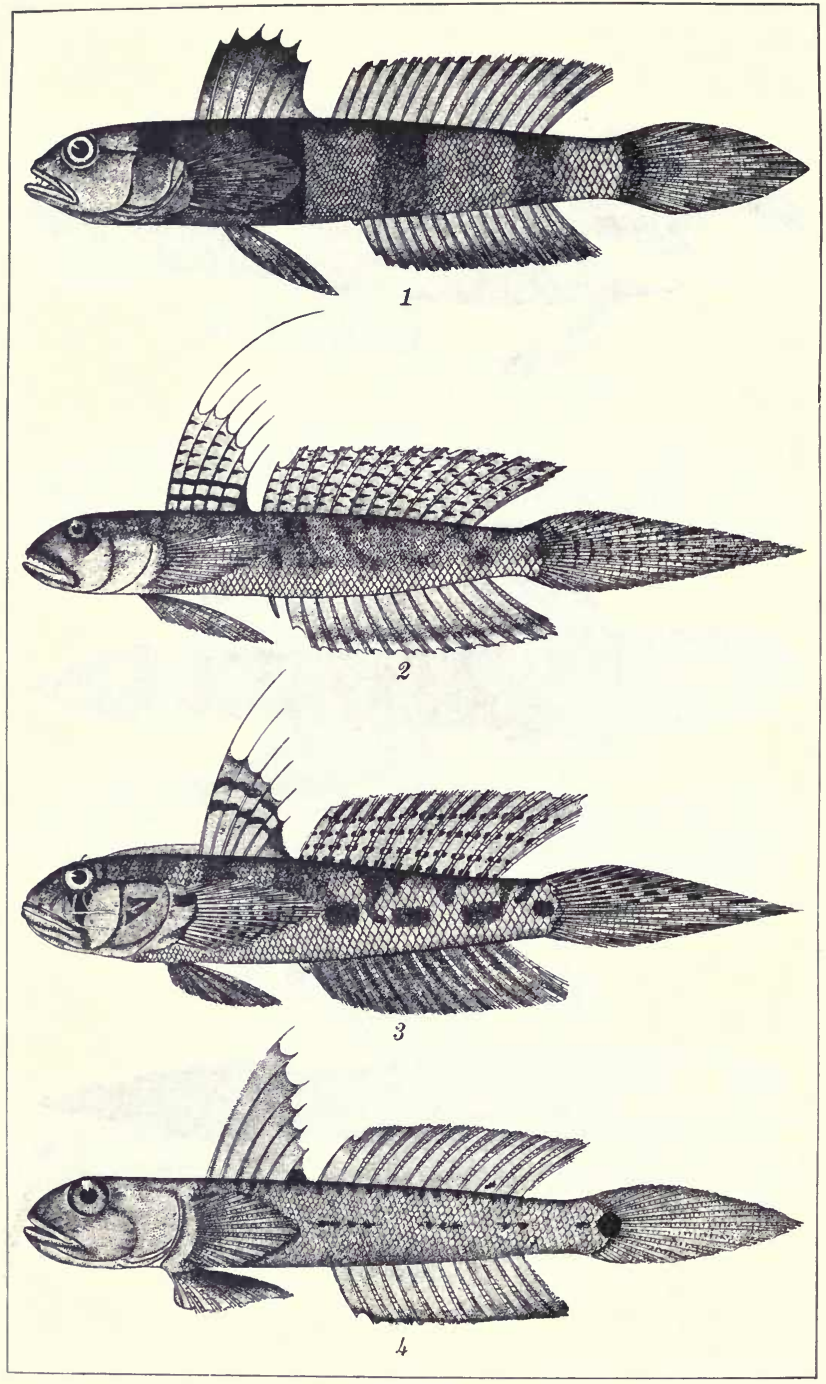

PLATE 20. 


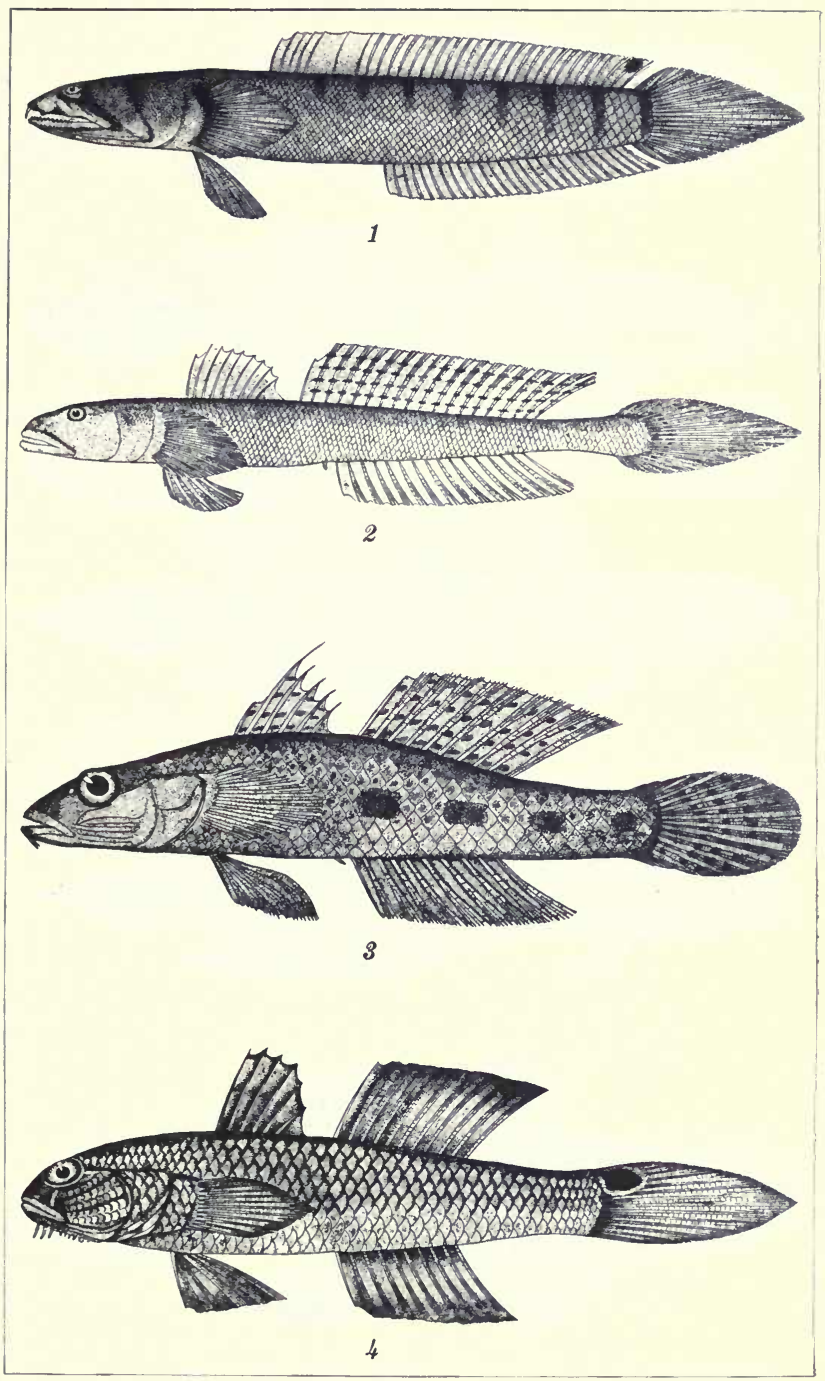

PLATE 21. 


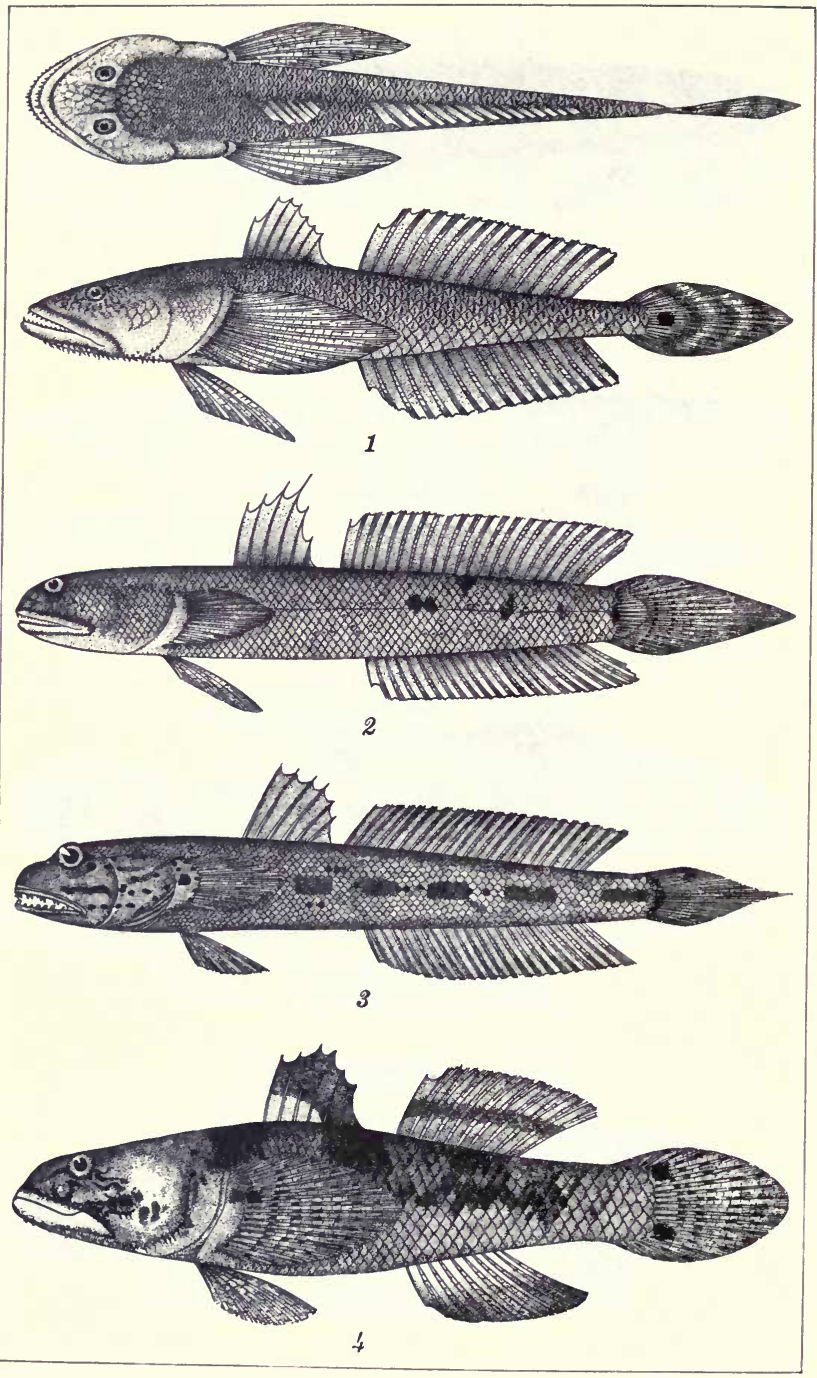

PLATE 22. 


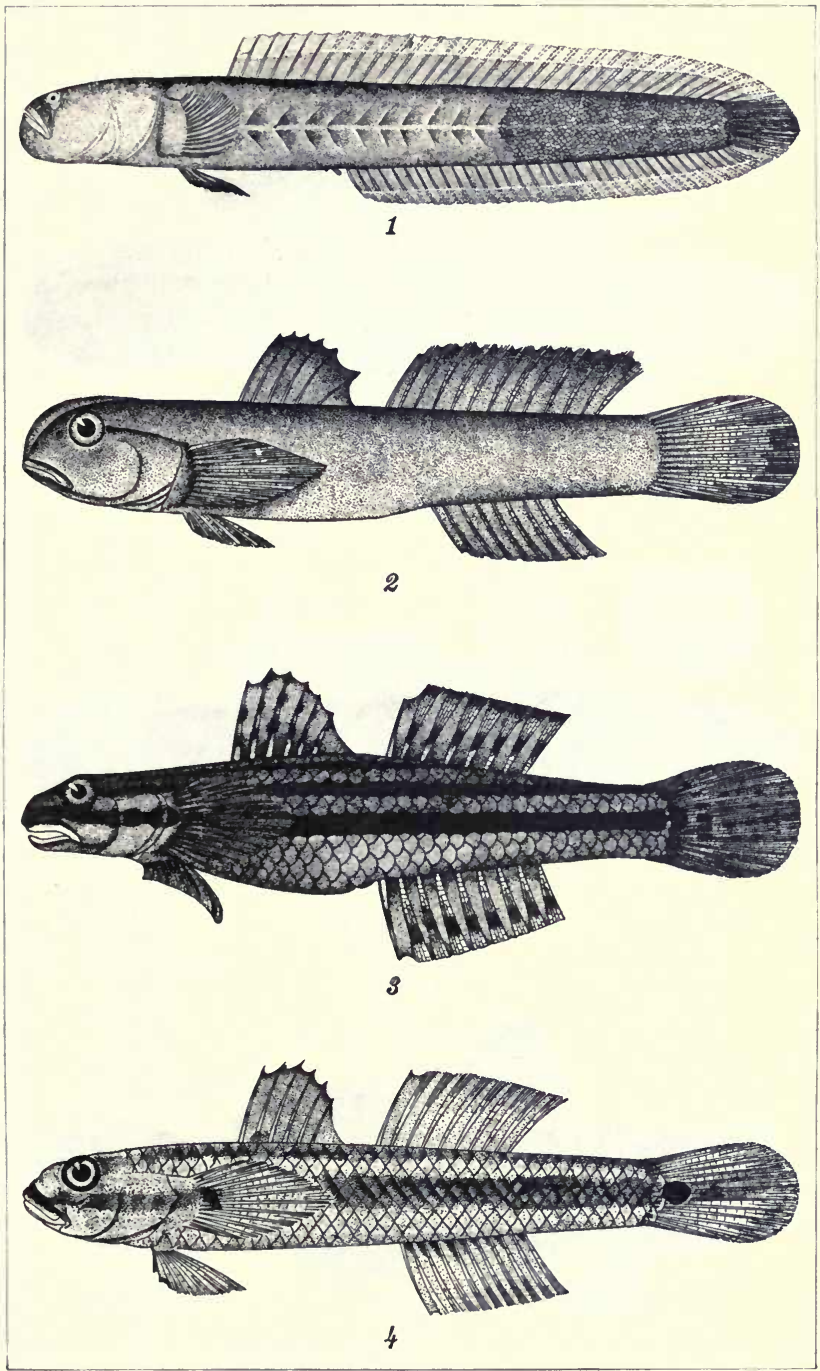

PLATE 23. 


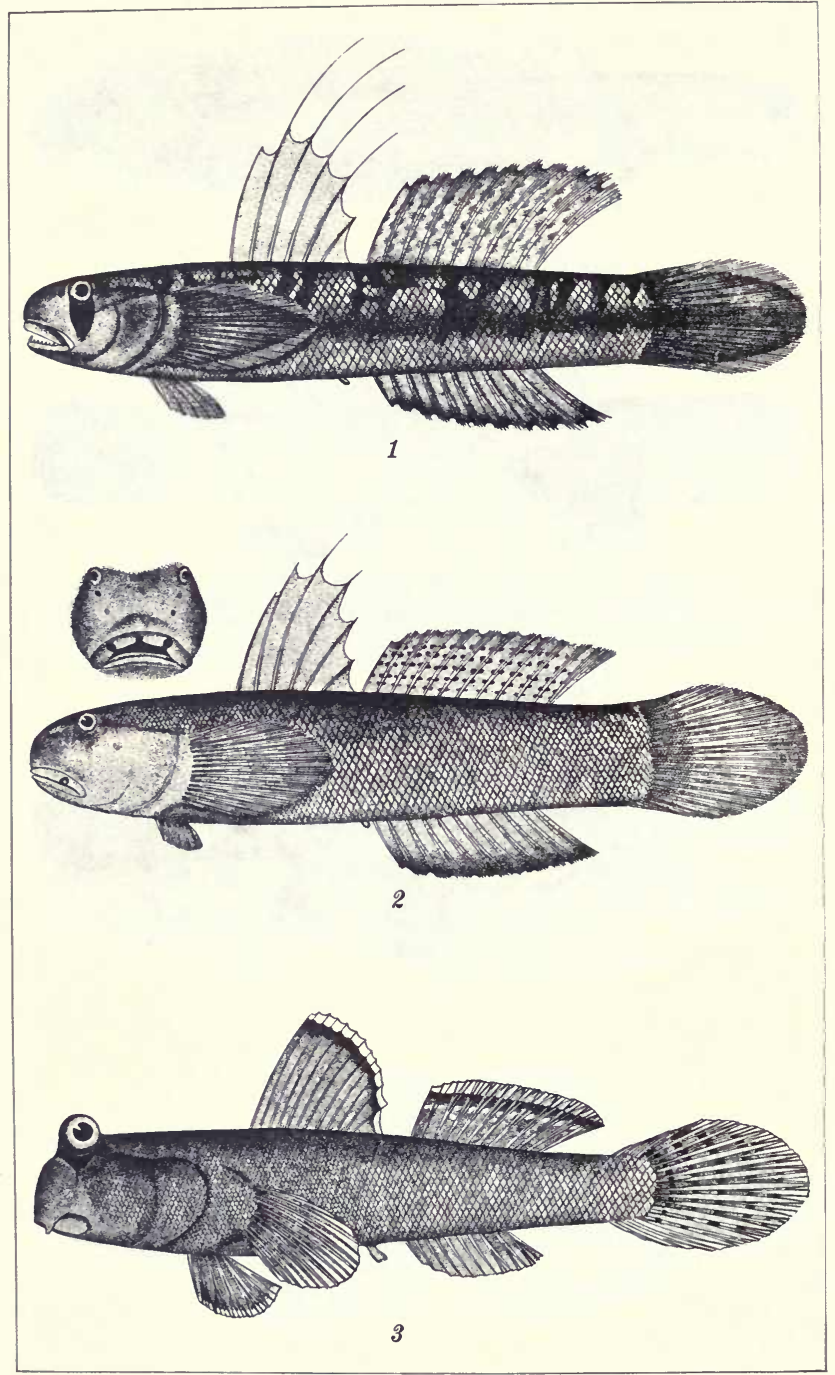

PLATE 24. 


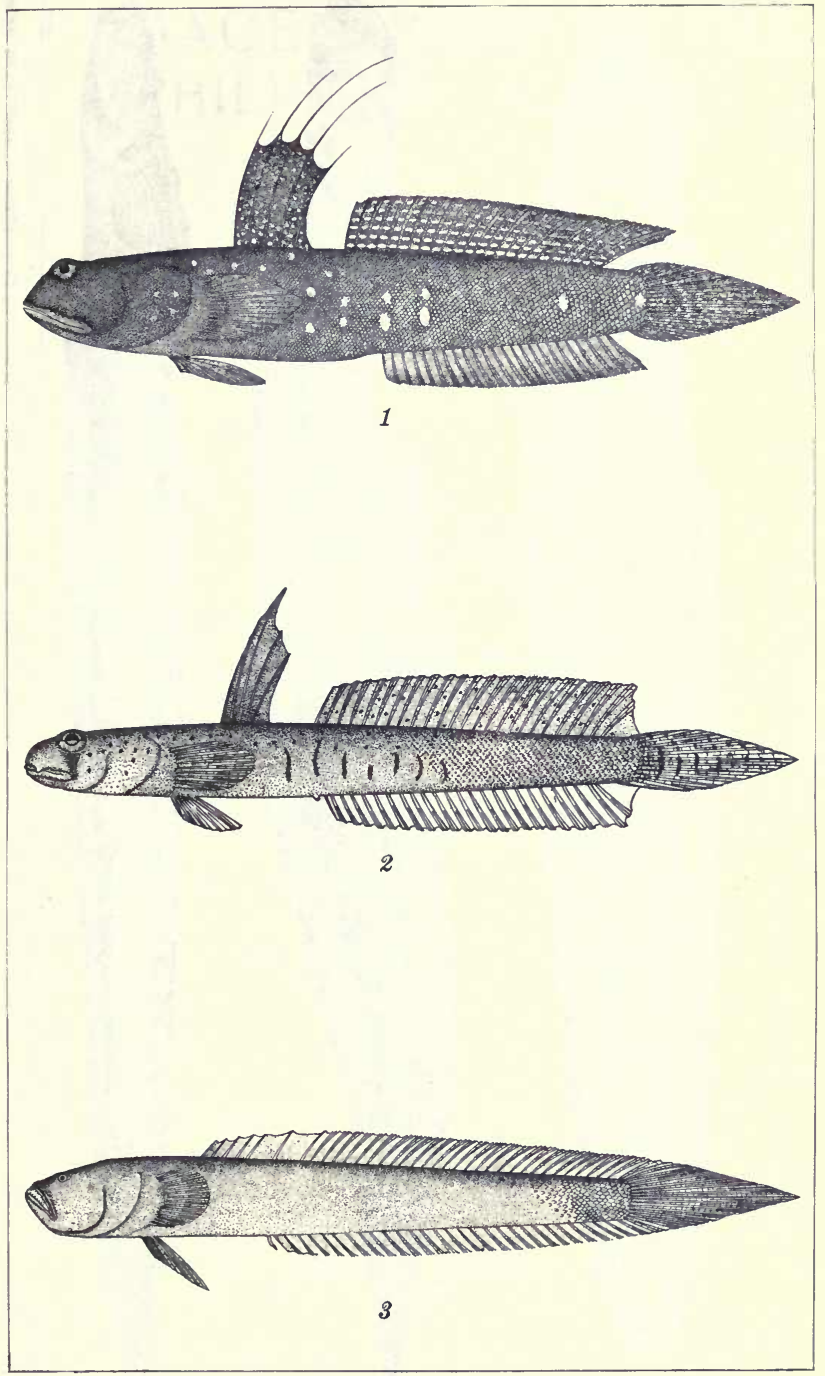

PLATE 25. 


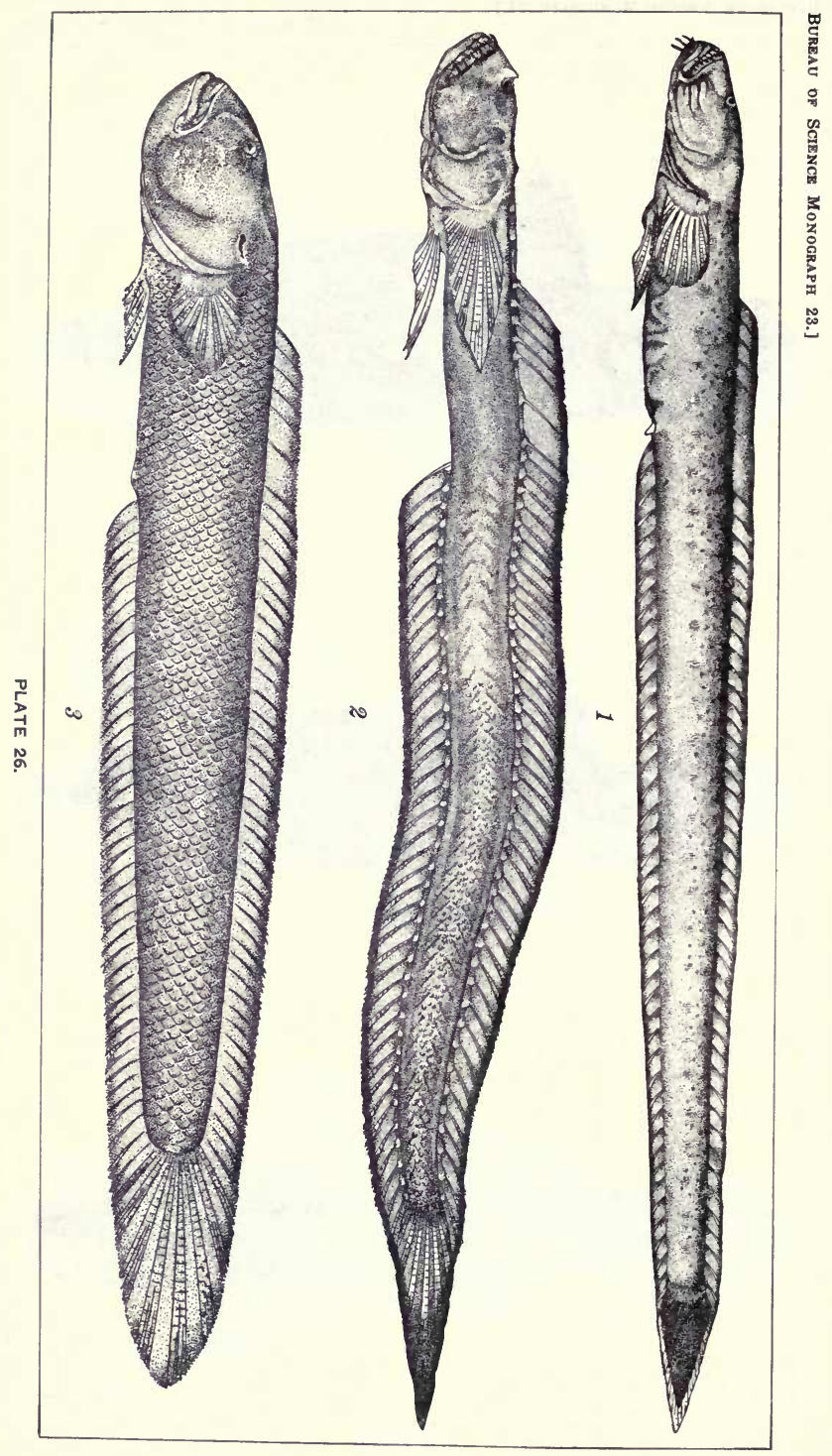




\title{
POMACENTRIDÆ OF THE PHILIPPINE ISLANDS
}

BY

\author{
HERACLIO R. MONTALBAN
}

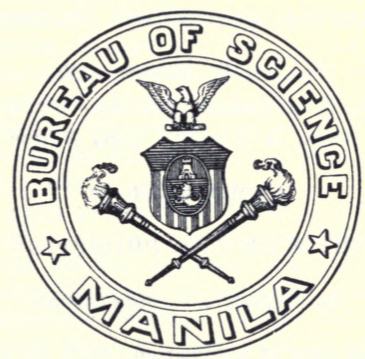

MANILA

BUREAU OF PRINTIN(; 


\section{MONOGRAPHS OF THE BUREAU OF SCIENCE}

MANILA, PHILIPPINE ISLANDS

William H. Brown, Editor

R. C. McGregor, Associate Editor

Anna B. Banyea, Copy Editor

Monograph 24

POMACENTRIDE OF THE PHILIPPINE ISLANDS

By Heraclio R. Montalban

(Actual date of publication, April 20, 1928.)

2 


\section{CONTENTS}

ILLUSTRATIONS

INTRODUCTION

FAMILY POMACENTRIDAE

DAMSEL FISHES

Genus Amphiprion Bloch and Schneider.

Amphiprion polymnus (Linnæus) ..................................................... 10

Amphiprion frenatus Brevoort...................................................... 12

Amphiprion percula (Lacépède) ...................................................... 14

Amphiprion bifasciatus (Bloch) ....................................................... 15

Amphiprion perideraion Bleeker....................................................... 16

Amphiprion akallopisos Bleeker......................................................... 17

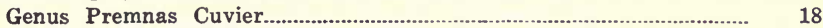

Premnas biaculeatus (Bloch) .......................................................... 18

Genus Dascyllus Cuvier........................................................................... 20

Dascyllus melanurus Bleeker............................................................ 20

Dascyllus aruanus (Linnæus) ........................................................... 21

Dascyllus trimaculatus (Rüppell) .................................................... 23

Dascyllus marginatus (Rüppell) ........................................................ 24

Dascyllus caudofasciatus sp. nov............................................... 26

Genus Acanthochromis Gill................................................................ 27

Acanthochromis polyacanthus Bleeker............................................ 27

Genus Chromis Cuvier..................................................................................... 28

Chromis xanthurus Bleeker......................................................... 29

Chromis xanthochir Bleeker.......................................................... 30

Chromis scotochilopterus Fowler.................................................... 31

Chromis ternatensis Bleeker.............................................................. 32

Chromis dimidiatus (Klunzinger) ...................................................... 33

Chromis caeruleus (Cuvier and Valenciennes)............................... 34

Genus Cheiloprion Weber.......................................................................... $\quad 35$

Cheiloprion labiatus (Day) …............................................................. 36

Genus Pomacentrus Lacépède .................................................................. $\quad 37$

Pomacentrus lividus (Forster) ...................................................... $\quad 39$

Pomacentrus albofasciatus Schlegel and Müller.......................... 40

Pomacentrus nigricans (Lacépède) .................................................. 41

Pomacentrus pavo (Bloch) ............................................................. 43

Pomacentrus violascens Bleeker..................................................... 44

Pomacentrus bankieri (Richardson) ............................................. 45

Pomacentrus taeniurus Bleeker........................................................ 46

Poimacentrus bifasciatus Bleeker....................................................... 47

Pomacentrus philippinus Evermann and Seale................................ 48

Pomacentrus tropicus Seale............................................................. 49

Pomacentrus moluccensis Bleeker................................................... $\quad 50$

Pomacentrus popei Evermann and Seale......................................... 51

Pomacentrus alexanderae Evermann and Seale............................. 51 
Genus Pomacentrus Lacépède-Continued.

Page.

Pomacentrus grammorhynchus Fowler........................................ $\quad 52$

Pomacentrus elongatus Seale............................................................... 54

Pomacentrus dorsalis Gill.................................................................... 55

Pomacentrus tripunctatus Cuvier and Valenciennes...................... $\quad 56$

Pomacentrus amboinensis Bleeker....................................................... 58

Pomacentrus simsiang Bleeker..................................................... 59

Pomacentrus chrysopoecilus Schlegel and Müller........................... 61

Pomacentrus notophthalmus Bleeker................................................ 62

Pomacentrus prosopotaenia Bleeker.................................................... 63

Pomacentrus trimaculatus Cuvier and Valenciennes........................ 64

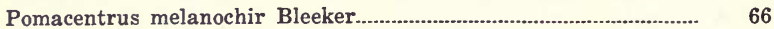

Pomacentrus fasciatus Cuvier and Valenciennes............................... 67

Pomacentrus breviceps (Bleeker) ........................................................ 68

Pomacentrus ovoides Cartier............................................................ 69

Pomacentrus albolineatus sp. nov.................................................... $\quad 70$

Pomacentrus opisthostigma Fowler............................................. 71

Pomacentrus tablasensis sp. nov................................................ 72

Genus Daya Bleeker........................................................................................ $\quad \mathbf{7 3}$

Daya jerdoni (Day) ........................................................................... 73

Genus Hemiglyphidodon Bleeker........................................................... $\quad 74$

Hemiglyphidodon plagiometopon (Bleeker) …................................ 75

Genus Abudefduf Forskål............................................................................ $\quad 76$

Abudefduf sordidus (Forskål) .................................................... 77

Abudefduf septemfasciatus (Cuvier and Valenciennes)................ $\quad 79$

Abudefduf bengalensis (Bloch) ...................................................... 80

Abudefduf saxatilis (Linnæus) ...................................................... 81

Abudefduf coelestinus (Cuvier and Valenciennes)......................... 83

Abudefduf curacao (Bloch) ............................................................. 85

Abudefduf aureus (Cuvier and Valenciennes)............................... 87

Abudefduf leucogaster (Bleeker) ........................................................ 88

Abudefduf coracinus Seale.................................................................. $\quad 89$

Abudefduf philippinus Fowler............................................................. 89

Abudefduf dickii (Lienard) ............................................................ 91

Abudefduf leucozona (Bleeker) ........................................................... 92

Abudefduf lacrymatus (Quoy and Gaimard) .................................... 93

Genus Chrysiptera Swainson.................................................................... 94

Chrysiptera melas (Cuvier and Valenciennes) ................................ 95

Chrysiptera xanthurus (Bleeker) ............................................... 96

Chrysiptera xanthonotus (Bleeker) ..................................................... 97

Chrysiptera oxyodon (Bleeker) ......................................................... 98

Chrysiptera uniocellatus (Quoy and Gaimard) ............................... 99

Chrysiptera parasema (Fowler) ....................................................... 100

Chrysiptera cyaneus (Quoy and Gaimard) ...................................... 101

Chrysiptera assimilis (Günther) ....................................................... 102

Chrysiptera turchesius (Jordan and Seale) ........................................... 103

Chrysiptera amabilis (De Vis) ........................................................... 104

Chrysiptera brownriggii (Bennett) ......................................................... 105

Chrysiptera rex (Snyder) ..................................................................... 110

Chrysiptera glauca (Cuvier and Valenciennes)................................ 111 


\title{
ILLUSTRATIONS
}

\author{
Plate 1
}

Fig. 1. Amphiprion polymnus (Linnæus). (Drawing by A. L. Caanlas.)

2. Chrysiptera amabilis (De Vis). (After Jordan and Seale.)

Plate 2

Fig. 1. Amphiprion frenatus Brevoort. (Drawing by A. L. Canlas.)

2. Amphiprion percula (Lacépède). (Drawing by A. L. Canlas.)

Plate 3

Fig. 1. Amphiprion bifasciatus (Bloch). (Drawing by M. L. Nievera.)

2. Pomacentrus philippinus Evermann and Seale. (Drawing by A. L. Canlas.)

Plate 4

Fig. 1. Amphiprion perideruion Bleeker. (Drawing by M. L. Nievera.)

2. Pomacentrus tropicus Seale. (Drawing by A. L. Canlas.)

\section{Plate 5}

FIG. 1. Hemiglyphidodon plagiometopon (Bleeker). (Drawing by A. L. Canlas.)

2. Dascyllus trimaculatus (Rüppell). (Drawing by A. L. Canlas.)

Plate 6

Fig. 1. Dascyllus caudofasciatus sp. nov. (Drawing by A. L. Canlas.)

2. Acanthochromis polyacanthus Bleeker. (Drawing by A. L. Canlas.)

Plate 7

FIg. 1. Abudefduf lacrymatus (Quoy and Gaimard.) (Drawing by A. L. Canlas.)

2. Chromis dimidiatus (Klunzinger). (Drawing by A. L. Canlas.)

\section{Plate 8}

FIG. 1. Abudefduf coelestinus (Cuvier and Valenciennes). (Drawing by J. L. Nievera.)

2. Chromis caeruleus (Cuvier and Valenciennes). (Drawing by J. L. Nievera.)

\section{Plate 9}

Fig. 1. Cheiloprion labiatus (Day). (Drawing by M. L. Nievera.)

2. Pomacentrus albofasciatus Schlegel and Müller. (Drawing by A. L. Canlas.) 
Plate 10

FIG. 1. Chrysiptera assimilis (Günther). (Drawing by A. L. Canlas.)

2. Pomacentrus pavo (Bloch). (Drawing by A. L. Canlas.)

\section{Plate 11}

FIG. 1. Pomacentrus chrysopoecilus Schlegel and Müller. (Drawing by A. L. Canlas.)

2. Pomacentrus popei Evermann and Seale. (Drawing by J. L. Nievera.)

\section{Plate 12}

Fig. 1. Pomacentrus melanochir Bleeker. (Drawing by P. Bravo.)

2. Pomacentrus trimaculatus Cuvier and Valenciennes. (Drawing by A. L. Canlas.)

\section{Plate 13}

Fig. 1. Pomacentrus breviceps (Bleeker). (Drawing by P. Bravo.)

2. Pomacentrus fasciatus Cuvier and Valenciennes. (Drawing by P. Bravo.)

\section{Plate 14}

Fig. 1. Pomacentrus albolineatus sp. nov. (Drawing by W. S. Atkinson.)

2. Pomacentrus tablasensis sp. nov. (Drawing by J. L. Nievera.)

Plate 15

Fig. 1. Daya jerdoni (Day). (Drawing by J. L. Nievera.)

2. Abudefduf sordidus (Forskål). (Drawing by J. L. Nievera.)

\section{Plate 16}

Fig. 1, Abudefduf septemfasciatus (Cuvier and Valenciennes.) (Drawing by J. L. Nievera.)

2. Abudefduf bengalensis (Bloch). (Drawing by J. L. Nievera.)

\section{Plate 17}

Fig. 1. Abudefduf curaçao (Bloch). (Drawing by J. L. Nievera.)

2. Abudefduf saxatilis (Linnæus). (Drawing by T. S. Espinosa.)

\section{Plate 18}

Fig. 1. Abudefduf coracinus Seale. (Drawing by P. Bravo.)

2. Abudefduf leucozona (Bleeker). (Drawing by P. Bravo.)

\section{Plate 19}

Fig. 1. Chrysiptera parasema (Fowler). (Drawing by A. L. Canlas.)

2. Chrysiptera melas (Cuvier and Valenciennes). (Drawing by J. L. Nievera.) 


\title{
POMACENTRIDÆ OF THE PHILIPPINE ISLANDS
}

\author{
By Heraclio R. MONTALbaN
}

\section{INTRODUCTION}

This paper deals with the Pomacentridæ, as represented in the waters of the Philippine Archipelago. It contains a systematic record of their characteristics, relationships, and present distribution, based largely upon the material collected under the authority of the Philippine Bureau of Science. It is the result of research performed at Stanford University, and continued in the Bureau of Science laboratory. Since my return to Government service many changes became necessary and they have been incorporated in the present paper based largely on new material, and on additional information concerning the habits and distribution of the fish. I have had the opportunity of examining in the Stanford University museum specimens from other regions for comparative study, and have availed myself of the privilege of using its working library. Almost all the illustrations were made in the Bureau of Science, and were drawn mostly from fresh and from living specimens.

The Philippine Archipelago is composed of over seven thousand islands lying wholly north of latitude $4^{\circ} 30^{\prime}$ north. The coast line is very irregular, presenting every conceivable variety of topography, and is more or less fringed with growing coral reefs which afford favorable haunts for fishes.

Of the approximately one hundred twenty known species of the family, seventy-eight are represented in Philippine waters. Three of them, believed to be new to science, are here described.

The Pomacentridæ, or damsel fishes, belong with those fishes which from their habits may be termed coral fishes. They are found in greatest abundance in company with other small fishes, such as chætodonts and Apogonichthyidæ, feeding chiefly upon very small marine animals and upon algæ. Many of them are brilliantly colored, the development and distribution of color being apparently dependent upon the agencies of climate and environment, and varying much with age in some species.

In spite of their bright coloration, many species of this family, because of their small size, escape from their enemies by hiding 
in coral and rock crevices. A coral head brought to the surface will often yield many specimens when broken into fragments.

The living specimens in the Bureau of Science aquarium have given me excellent opportunities to study their mode of life in captivity; they were taken in bobos, or small bamboo traps, at Calapan, Mindoro, which locality has furnished about twentyfive species. Many of the examples listed in this paper were collected by Dr. Albert W. Herre by the use of dynamite, or by means of the fish poison called tubli. Some of the material has been collected by me, when I have had the opportunity to observe the habits of the living fish in their natural surroundings.

The pomacentrids, although used as food, are not highly esteemed and are not caught in sufficiently large quantities to be of any economic importance. They are often caught in the muro-ami (a type of trap net recently introduced into the Islands by Japanese fishermen) along with chætodonts, hepatids, siganids, acanthurids, scaroids, labroids, balistids, and others found in the neighborhood of coral reefs. Not infrequently small quantities are obtained by the use of the dip net, the cast net, or the beach seine and, rarely, a few enter the fish corrals along with some of the important food fishes.

In this paper the scales in longitudinal series are counted to the base of the caudal fin, and the scale on the lateral line is not included in counting those in transverse series. The length of the body is measured from the tip of the snout to the base of the caudal rays. The diameter of the eye is given longitudinally in all cases.

I wish to express my indebtedness to Dr. David Starr Jordan for his reading of the original manuscript, and to Prof. John Otterbein Snyder, of Stanford University, and Dr. Albert W. Herre, chief of the division of fisheries, Philippine Bureau of Science, for assistance in various ways and for supervision over the preparation of this paper.

\section{POMACENTRIDAE}

\section{DAMSEL FISHES}

Local names: Aroro baybay, Ilocano; las-las, tibu, tibuk, or ulan-ulan, Tao Sug and Samal; baro-baro, pa-ata, paiata, palata, ulan-ulan, or puyong dagat, Visayan.

Body compressed, short or elongate, covered with ctenoid scales of varying size. Teeth in the jaws small and feeble, either conical or incisorlike; none present along the roof of mouth. Lateral line ceasing before the posterior end of dorsal fin. Spinous and rayed dorsal continuous, even or notched, 
both equally well developed; anal with two spines, the soft portion similar to the rayed dorsal; both dorsal and anal scaly at base, sometimes the spinous dorsal naked; ventral thoracic, with a single spine and five rays, the outer rays longest and more or less produced into filaments. Branchiostegals 5 to 7; gills $3 \frac{1}{2}$; pseudobranchiæ and air vessel present; pyloric appendages few. Vertebræ $12+14=26$.

Marine fishes chiefly from the tropical seas of the Indian and Pacific Oceans, with several representatives from the West Indies, and a few from Japan and the Mediterranean Sea.

Key to the Philippine genera of Pomacentridæ.

$a^{2}$. Scales small, 45 to 72 in lateral series.

$b^{2}$. Orbital ring serrated.

Amphiprion.

$b^{2}$. Orbital ring not serrated but armed with two very strong spines.

$a^{2}$. Scales large or moderate, not more than 30 in lateral series.

Premnas.

$c^{1}$. Teeth conical; caudal fin with two or more free spines on each margin of base.

$d^{2}$. Hind edge of preopercle serrated.

$e^{1}$. Teeth in a villiform band; dorsal spines 11 or $12 . . . . . .$. Dascyllus.

$e^{2}$. Teeth in a double series; dorsal spines 16 or 17 .... Acanthochromis.

$d^{3}$. Hind edge of preopercle entire.

$c^{2}$. Teeth compressed; base of caudal fin without any free spines.

$f^{2}$. One or more of the opercles serrated.

$g^{1}$. Preopercle only and, generally, the orbital ring serrated.

$h^{1}$. Lips thick, swollen, and completely reversed outward around mouth Cheiloprion.

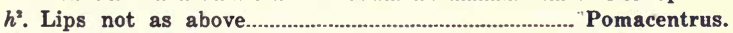

$g^{2}$. Opercles excepting the interopercle serrated; orbital ring entire.

$f$. None of the opercles serrated.

Daya.

$i^{2}$. Teeth in a single series.

$j^{2}$. Gill rakers very numerous, over 70 present on first arch.

Hemiglyphidodon.

$j^{2}$. Gill rakers few, about 28 or less present on first arch.

Abudefduf.

i. Teeth in a double series. Chrysiptera.

Genus AMPHIPRION Bloch and Schneider

Amphiprion BLOCH and SchNeIder, Syst. Ichth. (1801) 47, 200; ephippium.

Prochilus (Klein, Piscis Missus 5: 60, nonbinomial), BLEEKER, Nat. Verh. Holl. Maats. Wet. 2 (1877) 20; ephippium.

Body oblong, compressed, covered with small roughish scales, about 45 to 60 in a longitudinal series; lateral line ending under the posterior end of soft dorsal. All the opercles and the orbital ring serrated, the denticles on the opercular and sub- 
opercular bones very long. Teeth in a single series, small and conical. Dorsal fin continuous, even or notched, with 9 to 11 spines.

Brightly colored pomacentrids, occurring from the Red Sea and east coast of Africa through the seas of India to the Malay Archipelago and western parts of the Pacific.

Key to the Philippine species of Amphiprion.

$a^{2}$. Dorsal fin nearly even, not notched, the posterior spines not very much lower than the anterior rays.

$b^{2}$. Body with three distinct pearl white crossbands; caudal lunate.

A. polymnus.

$b^{2}$. Body with a single transverse band; caudal rounded in the young and subtruncate in the adult.

A. frenatus.

$a^{2}$. Dorsal fin deeply notched, the posterior spines very much shorter than the middle or some of the anterior ones.

$c^{2}$. Interorbital space naked.

$d^{1}$. Caudal markedly rounded; body with three permanent crossbands.

A. percula.

$d$. Caudal subtruncate; body with three vertical bands which vary relatively in size with age, the last one disappearing almost entirely

A. bifasciatus.

$c^{2}$. Interorbital space scaly.

$e^{i}$. A pearl white vertical band across the opercles.

A. perideraion.

$e^{3}$. No pearl white vertical band on the opercles

A. akallopisos.

AMPHIPRION POLYMNUS (Linnæus)

Plate 1, Fig. 1

Perca polymna Linnaeus, Syst. Nat. ed. 101 (1758) 291.

Amphiprion polymnus BLOCH and SCHNEIDER, Syst. Ichth. (1801) 203; Cuvier and Valenciennes, Hist. Nat. Poiss. 5 (1830) 297; Bleeker, Nat. Verh. Holl. Maats. Wet. 2 (1877) 28; JoRDAN and SNYDER, Proc. U. S. Nat. Mus. 24 (1902) 598; JoRdan and Seale, Proc. Daven. Acad. Sci. 10 (1905) 13, pl. 7; WEBER, Fische der Siboga Exped. (1913) 336.

Prochilus polymnus BlEEKER, Atlas Ichth. 9 (1878) pl. 400, figs. 7 and 8.

Amphiprion chrysopterus Cuvier and VAlenciennes, Hist. Nat. Poiss.

5 (1830) 301; GÜNTHER, Cat. Fishes 4 (1862) 8; JoRDAN and

Dickerson, Proc. U. S. Nat. Mus. 34 (1908) 611, fig. 4.

Amphiprion japonicus SCHLEGEL, Fauna Japonica (1846) 66.

Amphiprion chrysargurus RICHARDSON, Ichth. China (1846) 254.

Amphiprion boholensis CARTIER, Verh. Phys. Med. Ges. Würzburg (1873) 96.

Amphiprion ephippium GüNTHER, Fische der Südsee 2 (1876) 224, pl. 122, figs. D and C.

Amphiprion snyderi Ishikawa, Proc. Dept. Nat. Hist. Tokio Nat. Mus. 1 (1904) 11, pl. 5. 
Dorsal X, 15 to 17 ; anal II, 12 to 15 ; scales in lateral series 45 to 52 ; with tubules 33 to 42 ; between lateral line and origin of dorsal 8 or 9 ; between lateral line and vent 19 to 23 .

Body oblong, the dorsal and ventral outlines equally elevated, the latter more evenly arched, the deepest part of body at origin of dorsal fin 1.9 to 2.1 in length; head 3 to 3.3 ; depth of caudal peduncle 5.6 to 6.5. The evenly convex interorbital 2.7 to 3.1 in length of head; the circular eye 3.1 to 3.6 ; the rounded snout 2.8 to 3.2 , shorter than maxillary, which is contained 2.5 to 2.8 in head. Mouth very oblique, lower jaw slightly projecting, the maxillary ending posteriorly below front edge of orbit. Preorbital terminating in a strong spine, which is preceded by a shorter one; orbital serrated; opercle with radiating ridges which end in spines.

Head naked on snout, orbital ring, interorbital space, and posterior limb of preopercle; base of vertical fins covered by a low sheath of scales. Third and fourth dorsal spines highest; the last spine higher than the one preceding but lower than first dorsal ray. Caudal lunate; both pectoral and ventral fins extending to vent.

Alcoholic specimens either brownish or blackish, very much darker posteriorly and above toward the fins, with three milk white, black-edged transverse bands; the first from nape to interoperculum, touching hind edge of orbit; the second from the last two dorsal spines and the first two dorsal rays to origin of anal, not extending upward into margin of dorsal fin; the third on posterior half of caudal peduncle. Caudal, anal, ventral, and pectoral yellow, and in some cases the last three fins edged with black. In other specimens the anal is chocolate brown, narrowly edged with white.

Here described from thirty-three examples, varying from 19 to 89 millimeters in length. They were collected at the following places: Calapan, Mindoro; Tablas Island; Guindulman, Bohol; Dumaguete, Oriental Negros; Cagayan de Misamis and Zamboanga, Mindanao; and Bungau, Sibutu, Sitankai, and Tango Islands, Sulu Archipelago. Three females, each 79 millimeters in length, collected at Calapan in January, 1923, are about ready to spawn. The Bureau of Science collection has two examples, collected by Mr. Alvin Seale at Hongkong.

This species has been previously reported from the Philippines by Bleeker. Cartier's account of a specimen from Bohol reveals the identity of his species with Amphiprion polymnus. 
In the Bureau of Science aquarium are four living specimens which are colored as follows: Chocolate brown above and behind, gradually passing into orange yellow on the lower parts including the pectorals, anal, and ventrals; caudal fin and anterior portion of head lemon yellow; side of body traversed by three bright, dark-edged, pearl white bands, the last one of which covers caudal peduncle; dorsal fin chocolate brown, the rayed portion narrowly edged with white; anal fin tipped narrowly with brown.

A fresh specimen, collected by Morden Brown at Tablas Island, had the upper and posterior portions of the trunk deep chocolate brown, which passed into yellowish orange on the lower parts, and into reddish orange anteriorly and on head; spinous dorsal light chocolate brown, the rayed portion much darker and narrowly tipped with whitish; pectoral yellowish orange; ventral and anal orange red, the former with a narrow brown edge anteriorly and the latter on all of the outer portion; caudal fin yellow; three pearl white, black-edged bands traverse the side of body, the last one on the caudal peduncle.

This widely distributed species is known from Zanzibar and Mozambique on the east coast of Africa, through the Indian Ocean and Malay Archipelago, northward to the south of Japan and China, and southward to northern Australia.

\section{AMPHIPRION FRENATUS Brevoort}

Plate 2, Fig. 1

Amphiprion frenatus BREvoort, Exped. Japan (1856) 263, pl. 6, fig. 3; Gill, Proc. Acad. Nat. Sci. Phila. 11 (1859) 148; DAY, Fishes of India (1878) 378, pl. 80, fig. 2; Jordan and SNYder, Proc. U. S. Nat. Mus. 22 (1900) 752.

Amphiprion tricolor GüNTHER, Cat. Fishes 4 (1862) 8.

Prochilus polylepis BLEeKER, Nat. Verh. Holl. Maats. Wet. 2 (1877) 22; Atlas Ichth. 9 (1878) pl. 401, fig. 6.

Prochilus ephippium BLEEkER, Nat. Verh. Holl. Maats. Wet. 2 (1877) 23, in part; Atlas Ichth. 9 (1878) pl. 401, fig. 1.

Prochilus macrostoma BlEEKER, Nat. Verh. Holl. Maats. Wet. 2 (1877) 25; Atlas Ichth. 9 (1878) pl. 401, fig. 5.

Prochilus melanopus BlFekER, Nat. Verh. Holl. Maats. Wet. 2 (1877) 26; Atlas Ichth. 9 (1878) pl. 401, fig. 7.

Dorsal IX or X, 17 to 19 ; anal II, 14 to 16 ; scales in lateral series 47 to 49 ; with tubules 31 to 38 ; between lateral line and origin of dorsal 9 ; between lateral line and vent 17 to 21 .

Body oblong, its depth 1.7 to 1.9 in length; head 3 to 3.1 ; depth of caudal peduncle 5.6 to 5.9. The convex interorbital 2.9 to 3.2 in length of head; the small round eye 4 to 4.1 ; the snout 
and maxillary equal in length, each 2.8 to 2.9 in head. Mouth oblique, lower jaw slightly projecting, posterior end of maxillary not quite touching vertical through anterior edge of orbit. A single row of small, conical teeth present. Preorbital above hind end of maxillary wider than half diameter of eye. Orbital ring and vertical edge of preopercle strongly serrated, the anterior spine of the former larger but not much longer than the rest of the serrations. Opercle, subopercle, and interopercle with radiated ridges ending in spines.

Small scales covering head and body; interorbital, snout, orbital ring, and outer portion of opercle naked. Dorsal fin nearly even, the posterior spines having almost the same height; soft dorsal and anal pointed posteriorly and about equal in height; caudal slightly emarginate in the adult and rounded in the young.

Brownish black in àlcohol, lighter on chin and breast; a pearl white band edged with black descending over the opercles immediately behind eye; caudal, pectoral, ventral, and vertical fins yellowish.

The above account is based upon five specimens, ranging from 59 to 95 millimeters in length, two of which were collected at San Fernando, La Union, and the others at Calapan, Mindoro.

Two living specimens in the Bureau of Science aquarium, taken at Calapan, Mindoro, have the sides black which passes into bright orange red toward anterior portion of head, and toward breast, belly, vertical fins, and caudal; base and outer portion of ventral black, the rest of the fin orange red; anal spines black; pectoral bright orange red; the transverse band behind eye bright pearl white, edged in front and behind with black. A fresh specimen obtained at Tablas Island had the sides black, fading into deep carmine red on anterior portion of head and on breast, and toward the outward portions of dorsal, anal, and caudal fins; base of pectoral black, the remaining portion carmine red; ventral spine and rays black, the membranes reddish; a bright, pearl white, black-edged transverse band just behind eye.

All the examples I have examined are fairly large and have the pearl white transverse band on each side of head. Because of the presence of this band I have placed this species as distinct from Amphiprion ephippium. Although the specimens differ somewhat in the width of the vertical band and in the 
number of the dorsal spines, they probably all belong to the same species.

This species, which is new to the Philippines, occurs from Madagascar and the Andamans to the Malay Archipelago, northward to the Riu Kiu Archipelago and southward to Australia.

\section{AMPHIPRION PERCULA (Lacépède)}

Plate 2, Fig. 2

Lutjanus percula LACÉPÈde, Hist. Nat. Poiss. 4 (1803) 239, 248.

Amphiprion percula Cuvigr and Valenciennes, Hist. Nat. Poiss. 5

(1830) 298; GüNther, Cat. Fishes 4 (1862) 6; Fische der Südsee

2 (1876) 225, pl. 124, fig. A; DAX, Fishes of India (1878) 379, pl.

80, fig. 4; WEBER, Fische der Siboga Exped. (1913) 335.

Prochilus percula BlEEKER, Nat. Verh. Holl. Maats. Wet. 2 (1877)

33; Atlas Ichth. 9 (1878) pl. 400, fig. 2.

Anthias polymna var. BLoch, Ichth. 9 (1797).91, pl. 316, fig. 3.

Dorsal XI, 15 or 16 ; anal II, 12 to 14 ; scales in lateral series 50 to 60 ; with tubules 33 to 42 ; between lateral line and origin of dorsal 9; between lateral line and vent 23 to 28 .

Body oblong, moderately compressed, deepest below third and fourth dorsal spines, being 2 to 2.4 in length; head 3 to 3.2 ; depth of caudal peduncle 5.3 to 6.4. The narrow, almost flat interorbital 3.5 to 4 in length of head; the small circular eye 3.3 to 4.3 , situated high up on side of head; the rounded snout 2.7 to 3.1, its tip lower than the inferior margin of orbit; the maxillary 2.4 to 2.7, or slightly longer than snout. Mouth oblique, jaws even; teeth in a single row, their edges rather blunt. Greatest width of preorbital more than half the diameter of eye, its posterior edge serrated; suborbital and preopercle with radiating ridges which terminate in spines.

Top of head, snout, orbital ring, and outer margins of opercular bones naked. Dorsal spines moderately high, the third and fourth highest, while the posterior ones are very low. Dorsal fin deeply notched, its rayed portion and that of anal equal in height; caudal rounded; both pectoral and ventral fins rounded and extending to vent.

Color in alcohol ranges from light yellowish brown to dark brown, with three pearl white, black-margined crossbands; the first concave anteriorly across hind portion of head; the second angularly pointed in front from posterior dorsal spines to origin of anal fin; the third around caudal peduncle; spinous dorsal and ventrals edged with black; soft dorsal and other fins with black and white margins. 
The description given is from a large number of specimens, 22 to 59 millimeters long, taken at the following localities:

$\begin{array}{lr}\text { Calapan, Mindoro } & 88 \\ \text { Bantayan Island } & 7 \\ \text { Zamboanga and Basilan Island } & 13 \\ \text { Samal Island } & 10 \\ \text { Sitankai Island and Jolo, Sulu Archipelago } & 9\end{array}$

Of this list of examples thirteen are ripe females, 45 to 59 millimeters in length, collected in April, 1923; May, 1909; July, 1908; and December, 1925.

There are in the Ateneo de Manila museum one example from Capas, Balayan Bay, Batangas, and several from Surigao. The first Philippine record of this species is of one specimen, collected by Weber at Sanguisiapo, Sulu Archipelago.

This fish is well known for its small size and beautiful bright coloration, the three milk white transverse bands being very well marked. The ground color of the living specimens in the Bureau of Science aquarium varies from orange red to light carmine red, crossed by three bright, transverse, pearl white bands which are edged in front and behind with black; all the fins colored similarly to body; spinous dorsal and ventrals margined with jet black; the rayed dorsal and other fins with a white edge and a submarginal band of jet black.

A common reef-dwelling species, occurring from the seas of India and China, through the Indo-Australasian Archipelago, to Australia and Melanesia.

\section{AMPHIPRION BIFASCIATUS (Bloch)}

Plate 3, Fig. 1

Anthias bifasciatus BLOcH, Ichth. 9 (1797) pl. 316, fig. 2.

Amphiprion bifasciatus BLOCH and ScHNEIDER, Syst. Ichth. (1801)

204; Cunier and Valbenciennes, Hist. Nat. Poiss. 5 (1830) 294;

GüNTHER, Cat. Fishes 4 (1862) 3; DAY, Fishes of India (1878) 379, suppl., 800 .

Holocentrus bifasciatus BLOCH and ScHNEIDER, Syst. Ichth. (1801) 567.

Prochilus bifasciatus BLEEKER, Nat. Verh. Holl, Maats. Wet. 2 (1877) 31; Atlas Ichth. (1878) pl. 400, figs. 4, 5, and 6.

Lutjanus jourdin LACÉPÈDE, Hist. Nat. Poiss. 4 (1803) 191, 235.

Amphiprion laticlavius CUVIER and VALEnCIENnes, Hist. Nat. Poiss.

5 (1830) 296, pl. 132, fig. 1.

Amphiprion intermedius ScHLEGEL and Müller, Overz. Amphi. Verh.

Nat. Ges. Ned. Overz. Bezitt. (1839) 18.

Dorsal X, 14 or 15 ; anal II, 12 or 13 ; scales in lateral series 47 to 50 ; with tubules 37 to 41 ; between lateral line and origin of dorsal 8; between lateral line and vent 18 to 20 . 
Body oblong, deepest at about the origin of dorsal fin, being 2.2 to 2.3 in length; head 3.1 to 3.3 ; depth of caudal peduncle 5.6 to 6.5. The broad, strongly and evenly convex interorbital 2.8 to 3.1 in length of head; the circular eye 2.6 to 3.4 ; the short, rounded snout 2.9 to 3.3 , or shorter than maxillary which is contained 2.5 to 2.6 in head. Mouth very oblique, lower jaw slightly projecting, tip of snout a little lower than inferior margin of eye. Teeth conical and uniserial, those in front slightly curved. Preorbital terminating posteriorly in a short spine; suborbital with a rather indistinct denticulation; all the opercular bones serrated.

Snout, orbital ring, interorbital space, and edges of preopercle naked; rest of head covered with small scales. A deep notch between the spinous and the rayed dorsal; dorsal spines low and stout, the third the highest. Soft dorsal rounded; rayed anal slightly angular; caudal slightly convex; pectoral and ventral equal in length, the former ending before vent.

Chestnut brown in alcohol, with two or three milk white crossbands; the first descending from nape to subopercular bone, covering most of opercle and touching anteriorly hind margin of orbit; the second band descending from base of the last three dorsal spines and anterior dorsal rays to below the lateral line, and continued posteriorly through the upper portion of dorsal rays; the third band, if present, occupying upper half of caudal peduncle. A good series of specimens would show a decidedly marked shortening of the second band and a gradual disappearance of the third. Ground color of fresh specimens blackish brown, with yellowish wash in front, below, and on pectoral fin.

Of this species I have examined eight examples, 43 to 78 millimeters in length, from Bauang Sur, La Union; Atimonan, Tayabas; Calapan, Mindoro; and Estancia, Panay. A female specimen collected at Calapan in March, 1924, is 60 millimeters long and is nearly ready to spawn. There are two specimens from Cebu, Cebu, and one from Corregidor Island in the Ateneo de Manila museum.

This species is found from the Andamans, throughout the East Indies, to New Guinea.

\section{AMPHIPRION PERIDERAION Bleeker}

Plate 4, Fig. 1

Amphiprion perideraion BLEßKER. Nat. Tijd. Ned. Ind. 8 (1855) 437; GüNTHER, Cat. Fishes 4 (1862) 9.

Prochilus perideraion BLEFkER, Nat. Verh. Holl. Maats. Wet. 2 (1877)

37; Atlas Ichth. 9 (1878) pl. 400, fig. 1.

Amphiprion perideraeus GüNTHER, Fische der Südsee 2 (1876) 226. 
Dorsal X, 16; anal II, 12 to 14 ; scales in lateral series 45 to 47; with tubules 35 to 37 ; between lateral line and origin of dorsal 7 or 8 ; between lateral line and vent 20 to 22 .

Dorsal outline of head almost straight; body oblong, its depth 2.2 to 2.4 in length; head 3.2 to 3.3 ; depth of caudal peduncle 5.3 to 6.5. Interorbital space slightly convex, nearly as wide as length of snout, which is contained 3 to 3.3 in length of head; eye 3.3 to 3.6 in head. Mouth small, strongly oblique, the lower jaw slightly projecting; maxillary 2.5 to 3 in head, extending posteriorly to below anterior edge of orbit. Teeth conical, in a single series. Suborbital provided with a large, strong spine on anterior part, which is followed by a row of shorter ones; posterior limb of preopercle bluntly serrated. Subopercular, interopercular, and opercular bones with radiating ridges terminating in sharp spines.

Snout, orbital ring, and chin naked; dorsal fin with a low notch superiorly: fourth dorsal spine highest. Rayed dorsal and anal fins slightly angular; the other fins rounded; ventral shorter than pectoral and ending at anterior margin of anus.

Yellowish orange in alcohol, an indistinct light dot on the center of each scale; a pearl white longitudinal band running along the median of head and continued backward along base of dorsal fin to back of caudal peduncle; all the fins yellowish.

The six specimens above described were collected at Calapan, Mindoro, and range in length from 34 to 55 millimeters.

Three living specimens in the Bureau of Science aquarium, obtained at Calapan, Mindoro, are orange yellow, with a bright, pearl white line along the back from over the head, through base of dorsal fin to top of caudal peduncle, and with a vertical band of like color across the opercles. The light spot on each scale is hardly visible.

This species, which has not been previously listed from the Philippines, is found in the East Indies, Amboina, and the Palau Islands.

AMPHIPRION AKALLOPISOS Bleeker

Amphiprion akallopisos BLEEKER, Nat. Tijd. Ned. Ind. 4 (1853) 281.

Amphiprion akallopisus GüNTHER, Cat. Fishes 4 (1862) 10; DAY, Fishes of India (1878) 380.

Prochilus akallopisus BLEEKER, Nat. Verh. Holl. Maats. Wet. 2 (1877) 35; Atlas Ichth. 9 (1878) pl. 400, fig. 3.

Dorsal X, 16; anal II, 12; scales in lateral series 56 ; with tubules 34 ; between lateral line and origin of dorsal 7 ; between lateral line and vent 19. 
Body oblong, with the anterior dorsal profile nearly straight; depth 2.4 in length; head 3.5; depth of caudal peduncle 6.4. Interorbital space slightly convex, 3.3 in length of head, or about as wide as length of snout or diameter of eye. Maxillary extending posteriorly to below front edge of orbit, its length greater than the width of the interorbital space. Teeth in a single row, conical, with blunt tips. Suborbital with pointed spines; posterior edge of preopercle with few blunt serrations; the other opercular bones with radiating ridges which terminate in sharp spines.

Scales on top of head extending to above front edge of orbit; none on orbital ring and preopercular edges. Dorsal fin with a slight notch superiorly. Spinous dorsal rather low, the fourth spine highest.

Yellowish orange in alcohol, with a light center on each scale; a trace of the blue line present on middle of forehead, at base of dorsal fin, and on back of caudal peduncle.

Described from a single specimen, 45 millimeters in length, collected at Calapan, Mindoro.

This species, which is new to the Philippines, is known from the coasts of Priaman, Bouro, Ceram, and Amboina. It closely resembles Amphiprion perideraion Bleeker, and differs from it in the absence of the vertical pearl white band on the opercles.

\section{Genus PREMNAS Cuvier}

Premnas Cuvier, Regne Anim. ed. 1 (1817) 106; biaculeatus.

Body ovate, compressed. Each jaw with a series of small, conical teeth. All the opercles serrated; orbital ring with two strong spines. Scales small, about 66 to 72 in longitudinal series; lateral line ending below the posterior portion of soft dorsal. Dorsal fin continuous, notched, with 10 spines.

Only a single species is known of this genus.

PREMNAS BIACULEatus (Bloch)

Chaetodon biaculeatus BLocH, Ichth. 7 (1797) 7, pl. 219, fig. 2.

Premnas biaculeatus BleEkER, Nat. Tijd. Ned. Ind. 6 (1854) 105; Günther, Cat. Fishes 4 (1862) 10; BleEker, Nat. Verh. Holl. Maats. Wet. 2 (1877) 17; Atlas Ichth. 9 (1878) pl. 402, figs. 7 and 9; DAY, Fishes of India (1878) 380, pl. 80, fig. 5; WEBER, Fische der Siboga Exped. (1913) 334.

Premnas trifasciatus Cuvier and VAlenciennes, Hist. Nat. Poiss. 5 (1830) 304.

Premnas simicinctus Cuvier and Valenciennes, Hist. Nat. Poiss. 5 (1830) 307, pl. 133, fig. 1. 
Dorsal X, 16 to 18 ; anal II, 14 to 16 ; scales in lateral series 66 to 72 ; with tubules 46 to 54 ; between lateral line and origin of dorsal 12 to 14 ; between lateral line and vent 28 to 32 .

Body oblong; 1.9 to 2 in length; head 2.9 to 3 ; depth of caudal peduncle 4.9 to 5.4. Interorbital space wide, evenly arched, and contained 3.5 to 3.7 in length of head; diameter of the small round eye 4.9 to 5 ; snout, which is about as long as the maxillary, contained 2.8 to 3 in head. Tip of snout rounded, away below the horizontal passing through lower edge of orbit. Mouth slightly oblique, jaws about equal; posterior end of maxillary a little behind vertical through anterior margin of eye; a single row of conical teeth present. Preorbital ending in a strong spine, its greatest width almost equal to the eye's diameter; suborbital with a much longer spine; all the opercles serrated.

A naked area on interorbital space, snout, and chin; outer edges of preopercle, subopercle, and opercle unscaled. Second, third, and fourth dorsal spines highest, each being almost twice in head. Rayed dorsal and anal fins slightly angular; caudal, pectoral, and ventral fins rounded, the last-named two ending at base of anal spines.

In alcohol the color varies from dull yellow to chocolate brown, with three black-edged, white crossbands, which are wider superiorly; the first band, convex posteriorly, crossing over hind portion of head to subopercle; the second descending from the last three dorsal spines to origin of anal fin; the third around caudal peduncle; the last two bands slightly curved and angularly produced forward along middle part, this process being absent in some examples; all the bands named vary in length with age.

The Bureau of Science collection contains seven specimens, 35 to 108 millimeters long, from Calapan, Mindoro; Bantayan Island; Inabanga, Bohol; Surigao, Mindanao; and Bungau, Tango, and Sitankai Islands, Sulu Archipelago. The only previous record of this species from the Philippines is that of Günther.

In the Bureau of Science aquarium there is a fairly large living specimen, which is deep cherry red, traversed by three brilliant pearl white bands; pectoral is narrowly edged with whitish and has a narrow submarginal band of black; all the other fins are narrowly edged with black.

Easily recognized by the two strong sharp spines directed posteriorly from orbital ring and by the three well-defined, milk white, vertical bands. 
This species ranges from the seas of India throughout the East Indian Archipelago to New Guinea.

\section{Genus DASCYLLUS Cuvier}

Dascyllus CuviER, Regne Anim. ed. 2 (1829) 91, aruanus; also written Dascillus.

Tetradrachmum CANToR, Malayán Fishes (1850). 241, aruanus.

Body ovate or nearly orbicular. Teeth villiform, small and conical, in a narrow band, with an outer series of somewhat larger ones. Scales 26 or less in longitudinal series; lateral line ceasing below the soft dorsal fin. Preopercle and sometimes the orbital ring and opercular bone serrated. Dorsal fin not notched, with 12 or 13 spines; caudal fin with two or more free sharp spines on each margin of base.

This widely distributed genus occurs from the Red Sea and east coast of Africa through the seas of India and the Malay Archipelago to Polynesia and New Zealand.

\section{Key to the Philippine species of Dascyllus.}

$a^{2}$. Median dorsal spines longer than the rest; body with three distinct black crossbands.

$b^{2}$. First two bands vertical; caudal fin with a large black blotch.

D. melanurus.

$b^{2}$. First two bands oblique; caudal fin without a black blotch D. aruanus. $a^{3}$. Premedian dorsal spines longer than the others.

$c^{1}$. Body with milk white spot on each side

D. trimaculatus.

$c^{3}$. Body without any milk white spot.

$d^{2}$. Body with one or two broad crossbands.

$d^{2}$. Body not banded.

D. marginatus.

\section{DASCYLLUS MELANURUS Bleeker}

Dascyllus melanurus BlEEEKER, Nat. Tijd. Ned. Ind. 6 (1854) 109; GÜNTHER, Cat. Fishes 4 (1862) 12; Fische der Südsee 2 (1876) 23ti, pl. 124, fig. C; BLEEKER, Nat. Verh. Holl. Maats. Wet. 2 (1877) 149. Tetradrachmum melanurus BLEEKER, Atlas Ichth. (1878) pl. 409, fig. 1.

Dorsal XII, 11 to 13 ; anal II, 12 or 13 ; scales in lateral series 25 ; with tubules 16 or 17 ; between lateral line and origin of dorsal 3 ; between lateral line and vent 9 .

Body ovate, rather deep, 1.6 to 1.7 in length; head 2.6 to 3 ; depth of caudal peduncle 5.3 to 5.9. Interorbital space slightly and evenly arched, rather broad, 2.5 to 2.7 in length of head; eye rounded and large, 2.7 to 3 in head; snout blunt and short, 3.4 to 3.8 or shorter than maxillary which is contained 2.8 to 3.1 in head. Mouth very oblique, jaws equal, the posterior end of maxillary under or a little before front margin of eye. Teeth 
in a narrow band, villiform, those on outer set large and conspicuously pointed. Width of preorbital at angle of mouth less than half an eye diameter; suborbital narrow, finely serrated; posterior and inferior edges of preopercle denticulated.

Head everywhere covered with rough and thick ctenoid scales. Dorsal spines rather strong and elevated, decreasing in height posteriorly from the fourth. Soft dorsal pointed; soft anal rounded; caudal forked, with two prominent spines on each margin of base; both pectoral and ventral extending to anus.

Ground color of alcoholic specimens dull yellow, with three broad, black crossbands, the first running vertically from crown of head through eye to chin, leaving a yellowish area on anterior portion of head, the second band descending from the first four dorsal spines toward anterior half of ventrals, the third crossing body from the soft dorsal to the anal fin. Caudal yellowish at base and on upper and lower margins, the remainder black; pectoral blackish, with a dusky wash at base; ventrals black; posterior rays of vertical fins tipped with yellow.

Here described from thirty-six specimens, 13.5 to 48 millimeters long, from Puerto Galera and Calapan, Mindoro; Canigaran, Palawan; Samal Island and Cotabato, Mindanao; and Basbas and Sibutu Islands, Sulu Archipelago. A female example, 44 millimeters long, taken at Calapan in January, 1923, is in near-breeding condition; two others, 36 and 39.5 millimeters in length, obtained at Canigaran in November, 1925, are ripe females.

This species has been reported from Cagayancillo by Jordan and Richardson. It is known throughout the East Indies eastward to the Carolines and Melanesia.

\section{DASCYLLUS ARUANUS (Linneus)}

Chaetodon aruanus LINNAEU, Syst. Nat. ed. 1010 (1758) 464; BLосH, Ichth. 6 (1799) 45, pl. 198, fig. 2.

Lutjanus aruanus LAcÉPÈDE, Hist. Nat. Poiss. 4 (1803) 720.

Pomacentrus aruanus RÜPPELL, Fische des Rothen Meers (1828) 39. Dascyllus aruanus CUVIER and Valenciennes, Hist. Nat. Poiss. 5 (1830) 325; BLEBKER, Nat. Tijd. Ned. Ind. 6 (1854) 108; GüNTHER, Cat. Fishes 4 (1862) 12; Fische der Südsee 2. (1876) 235, pl. 124, fig. B; MeYer, Ann., Soc. España Hist. Nat. 14 (1885) 12; JoRDAN and Seale, Bull. U. S. Bur. Fisheries 25 (1906) 290; 26 (1907) 27; Fowler and BEAN, Proc. U. S. Nat. Mus. 62 (1922) 49.

Chaetodon araneus BENNETT, Fishes of Ceylon (1834) 17, pl. 17.

Tetradrachmum arcuatum CANToR, Cat. Malay. Fishes (1850) 241;

BLEmKR, Nat. Verh. Holl. Maats. Wet. 2. (1877) 147; Atlas Ichth. 9 (1878) pl. 409 , fig. 6 . 
Tetradrachmum aruanum DAY, Fishes of India (1878) 381, pl. 80, fig. 6; WEBER, Fische der Siboga Exped. (1913) 357.

Dorsal XII, 11 to 13 ; anal II, 11 or 12 ; scales in lateral series 25 or. 26 ; with tubules 15 to 18 ; between lateral line and origin of dorsal 3 or 4 ; between lateral line and vent 10 .

Body ovate and slightly elevated, dorsal outline deeper than the ventral; depth of body 1.6 to 1.8 in length; head 2.7 to 3.2 ; depth of caudal peduncle 5.5 to 6.1. The wide, slightly and evenly convex interorbital 2.5 to 2.9 in length of head; the large, rounded eye 2.5 to 3 ; the short, slightly rounded snout 3 to 3.7 or shorter than maxillary, which is contained 2.7 to 3.1 in head. Mouth strongly oblique, jaws equal, maxillary extending posteriorly to below anterior margin of orbit. Width of preorbital at hind end of maxillary less than half diameter of eye; suborbital, and the edges of the preopercular and opercular bones strongly denticulated.

Head covered everywhere with strong, rather thick ctenoid scales. Dorsal spines growing lower consecutively toward the last from the sixth, which is as high as the preceding one. Soft dorsal pointed; rayed anal rounded; pectoral extending to anal opening; ventral ending at origin of anal fin; caudal deeply forked, with two prominent and sharp spines on each of the upper and lower margins of base.

Body yellowish, with three black crossbands, the first running obliquely from origin of spinous dorsal through eye to chin and jaws, leaving a yellowish area in front of head, the second slightly curved, descending from base of fifth to the eighth dorsal spine through base of and under pectoral fin to ventrals, the third crossing vertically the vertical fins and the posterior portion of trunk; membranes of spinous dorsal blackish; pectorals, caudal, and tips of soft dorsal and anal fins yellow.

This easily recognizable fish is rather common in the Philippines, and numerous specimens, ranging from 11 to 53 millimeters long, were collected at the following places: Manila; Cavite, Cavite; Puerto Galera, Baco, and Calapan, Mindoro; Bantayan Island and Cebu, Cebu; Puerto Princesa and Canigaran, Palawan; Tagbilaran, Bohol; San Juan, Siquijor Island; Zamboanguita, Oriental Negros; Cagayan de Misamis, Zamboanga, Davao, and Samal Island, Mindanao; and Tandubas, Bungau, Bilatan, Sibutu, and Sitankai Islands, Sulu Archipelago. It apparently breeds throughout the year, since a number of the above examples, collected in nearly every month in the year, were found on examination to be ripe females. 
It has been recorded previously in the Philippines by Meyer from Cebu; by Jordan and Seale from Cavite; by Weber from Sanguisiapo, Sulu Archipelago; and by Fowler and Bean from Zamboanga.

A widely distributed species, ranging from the east coast of Africa through the seas of India, China, and the Indo-Malayan Archipelago to Polynesia and New Zealand. Day observes that it is numerous at the Andamans, Nicobars, and Burma, but much rarer in western than in eastern India.

\section{DASCYLLUS TRIMACULATUS (Rüppell)}

Plate 5, Fig. 2

Pomacentrus trimaculatus RüPPELL, Fische des Rothen Meers (1828) 39 , pl. 8, fig. 3 .

Dascyllus trimaculatus CuvieR and VALenciennes, Hist. Nat. Poiss. 5 (1830) 330; GÜNTHER, Cat. Fishes 4 (1862) 13; Fische der Südsee 2 (1876) 236; JoRdan and Seale, Bull. U. S. Bur. Fisheries 25 (1906) $290 ; 26$ (1907) 27

Tetradrachmum trimaculatum BLEEkER, Atlas Ichth. 9 (1878) pl. 409, fig. 6; DAY, Fishes of India, Suppl. (1888) 801.

Dorsal XII, 13 to 16 ; anal II, 13 or 14 ; scales in lateral series 26 ; with tubules 18 to 20 ; between lateral line and origin of dorsal 4 ; between lateral line and vent 11 .

Body very deep and much compressed, subcircular in form, dorsal profile a little more elevated than the ventral; deepest portion of body below anterior dorsal spines, 1.5 to 1.7 in length; head shorter than deep, 3.1 to 3.3; depth of caudal peduncle 5.3 to 6. Interorbital space strongly convex and steep, its width 2.5 to 3 in length of head; eye large and rounded, contained 2.5 to 3 ; the blunt snout 3.1 to 3.5 or slightly shorter than maxillary, which is contained 2.8 to 3.3 in head. Mouth very oblique, jaws equal, the maxillary ending posteriorly below front border of orbit; the conical teeth in a villiform band. Width of preorbital at angle of mouth a trifle greater than half the diameter of eye; the narrow orbital ring minutely serrated, as is the preopercle; posterior edge of opercle armed with a flat spine above and minute teeth below.

Head and body entirely covered with scales; base of vertical fins with a rather high sheath of scales. The strong dorsal spines decreasing in height posteriorly from the third. Soft dorsal angular and rayed anal rounded; caudal emarginate, with rounded lobes and two prominent free spines on each margin at base; pectoral ending above anus; ventral extending to base of anal spines. 
Ground color of alcoholic specimens blackish, with two large pearl white spots; one, which is indistinct or absent in older specimens, on top of head; the other, which disappears with age, on lateral line below the seventh, eighth, and ninth dorsal spines. Caudal, anal, and ventral fins blackish; spinous dorsal broadly margined with blackish; rayed dorsal and pectoral slightly brownish; each scale of body with a dark edge; lips also dark.

The above description is based upon thirty-one specimens, 17 to 101 millimeters in length, obtained at Monja Island, Corregidor; Calapan, Mindoro; Tablas Island; Puerto Princesa, Palawan; Cagayan de Misamis and Zamboanga, Mindanao; and Sibutu and Tambagaan Islands, Sulu Archipelago. Five examples taken in April, 1922, at Monja Island, which measure 35 to 101 millimeters in length, are nearly ready to spawn.

Ten living specimens at the Bureau of Science aquarium are dusky purplish, with a dark edge on each scale and brassy reflection below; there is a pearl white spot on top of head and another on lateral line on each side of body; soft dorsal and anal are blackish, while the spinous portions and the other fins are slightly lighter.

Previously reported in the Philippines from Manila by Jordan and Seale. A widely diffused species occurring from the Red Sea and east coast of Africa throughout the seas of India and the Indo-Australasian Archipelago to Polynesia.

\section{DasctLlug MaRginatus (Räppell)}

Pomacentrus marginatus RưPPDLL, Fische des Rothen Meers (1828) 38 , pl. 8, fig. 2.

Dascyllus marginatus CuvißR and VALBNCIENNEs, Hist. Nat. Poiss. 5 (1830) 329, pl. 133, fig. 2; GüNTHER, Cat. Fishes 4 (1862) 14.

Dascyllus xanthosoma BLşкजR, Nat. Tijd. Ned. Ind. 2 (1851) 247; GÜNTHER, Cat. Fishes 4 (1862) 14; Fische der Südsee 2 (1876) 237, pl. 124, fig. C.

Tetradrachmum marginatum DAY, Fishes of India (1878) 381, pl. 79, fig. 7.

Heliases reticulatus RICHARDSON, Ichth. China (1846) 254.

Dascyllus reticulatus CARTIER, Verh. Phys. Med. Ges. Würzburg (1873) 97.

Tetradrachmum reticulatum WEBER, Fische der Siboga Exped. (1913) 356.

Dorsal XII, 13 to 16 ; anal II, 12 to 15 ; scales in lateral series 25 or 26 ; with tubules 18 ; between lateral line and origin of dorsal 4 or 5 ; between lateral line and vent 11 . 
Body very deep and much compressed, nearly orbicular in outline; the deepest portion of body at anterior dorsal spines, 1.5 to 1.6 in length; head 3 to 3.3 ; depth of caudal peduncle 5.4 to 6.1 . The steep, evenly convex interorbital 2.4 to 2.9 in length of head; the large, circular eye 2.3 to 3.1 ; the short, blunt snout 2.8 to 3.4 , and nearly as long as or shorter than maxillary, which is contained 2.8 to 3.1 in head. Cleft of mouth almost vertical, jaws even, the maxillary ending posteriorly below or a little before front margin of eye; teeth subequal, the outer ones large, conical, and slightly curved. Orbital ring finely denticulated, its width at posterior end of maxillary less than half an eye diameter; inferior and posterior margins of preopercle serrated; opercle armed behind with a flat, blunt spine, below which are some fine teeth.

Head and body everywhere covered with closely set ctenoid scales; rayed dorsal and anal with a moderately high sheath of scales at base. Dorsal spines strong, decreasing gradually in height from the second to the last. Vertical fins about equal in height; caudal emarginate, with two prominent and free spines on each margin of base; pectoral falcate, about as long as head and extending to anus; ventral slightly longer than pectoral, its tip at base of anal spines.

Ground color in spirits dark violet brown with a dark border to each scale, and a blackish band passing from in front of and at base of the first three spines toward the ventrals, this band becoming less distinct in older specimens; another blackish crossband may be present between the rayed vertical fins. Front of eyes, lips, and chin black; caudal darker on upper and lower margins; spinous dorsal, anal, and ventrals black.

There are in the Bureau of Science collection thirty-five specimens, measuring from 19 to 85 millimeters long, which form the basis of this description. They were obtained at Puerto Galera and Calapan, Mindoro; Cabalian, Leyte; Cagayan de Misamis and Zamboanga, Mindanao; and Tambagaan, Bungau, and Sitankai Islands, Sulu Archipelago. Included among them are five ripe females, 25 to 62 millimeters long, taken at Calapan, Cabalian, and Cagayan de Misamis, in January, May, and September, respectively, thus indicating that they breed throughout the year.

Three living specimens in the Bureau of Science aquarium are purplish brown, with a silvery luster on the center of each scale; a blackish transverse bar behind head and a second one, rather 
indistinct, between the rayed dorsal and anal; dorsal fin entirely chocolate brown, as is the ventral; anal fin chocolate brown near base and lighter on outer portion; caudal colored similarly to body.

Cartier first recorded this species in the Philippines from Bohol as Dascyllus reticulatus, and Weber from Sanguisiapo, Sulu Archipelago, as Tetradrachmum reticulatum.

This fish, well distinguished from Dascyllus trimaculatus by the absence of the milk white spots, is rather common from the Red Sea and east coast of Africa through the Mauritius and the Andamans to south China and the Indo-Australasian Archipelago.

\section{DASCYLLUS CAUDOFASCIATUS sp. nov.}

Plate 6, Fig. 1

Dorsal XII, 11 to 13 ; anal II, 10 or 11 ; scales in a lateral series 27 ; with tubules 17 or 18 ; between lateral line and origin of dorsal 3 ; between lateral line and vent 10 .

Body ovate and compressed, with the profiles about equally elevated, its depth 2.1 to 2.2 in length; head 3.2 to 3.3 ; depth of caudal peduncle 6.2 to 6.4. Interorbital space evenly convex, its width equal to maxillary or an eye diameter, which is 2.7 to 2.8 in head; the short, bluntly rounded snout 3.4 to 4.3 in length of head and about twice the width of preorbital at posterior end of maxillary. Eye circular; mouth small, with even jaws and oblique gape; teeth conical, in a villiform band; posterior end of maxillary behind anterior edge of orbit. Orbital ring entire; only the vertical limb of peopercle serrated.

Scales on top of head extending almost to tip of snout; orbital ring and the rest of head completely covered with scales; vertical fins with a low basal sheath of scales; cheek with four rows of scales. Lateral line ending posteriorly below anterior half of the rayed dorsal. Dorsal spines decreasing in height posteriorly from fourth or fifth, which is a little lower than the second anal spine; rayed portions of dorsal and anal rounded; caudal fin forked, with the lobes equally produced and with two free spines on each margin of base; pectoral fin 3.7 to 4 in length of body and ending above anus; outer ray of ventral longest and reaching to base of anal spines.

In alcohol the ground color varying from brownish to blackish brown, slightly darker on top of head and back; ventrals and spinous dorsal blackish, the color of the latter extending to the tips of the anterior rays leaving the rest of the fin brownish; anterior two-thirds of anal hlackish and the remaining 
portion whitish; caudal whitish excepting the upper and lower borders which are broadly blackish; pectoral whitish.

Here described from thirteen specimens, 45 to 54 millimeters in length, collected by Dr. Albert W. Herre at Tambagaan, Bungau, and Sibutu Islands, all of Sulu Archipelago.

This species differs from the other members of this genus in having a blackish longitudinal band on each caudal lobe, and only the hind limb of the preopercle serrated.

\section{Genus ACANTHOCHROMIS Gill}

Acanthochromis GiLl, Proc. Acad. Nat. Sci. Phila. 15 (1863) 224; polyacanthus.

Body oblong, compressed, covered with finely ctenoid scales, about 28 to 31 in longitudinal series; lateral line terminating below base of anterior dorsal rays. Orbital ring and preopercle serrated. Teeth in a double series, conical, those in outer row larger. Dorsal fin continuous and even, with 16 or 17 spines.

This genus is separated from Chromis by the serrated orbitals and preopercle, and the greater number of dorsal spines; it differs from Dascyllus in the presence of a double series of teeth and of a greater number of dorsal spines also.

ACANTHOCHROMIS POLYACANTHUS Bleeker

Plate 6, Fig. 2

Dascyllus polyacanthus BLEEKER, Nat. Tijd. Ned. Ind. 9 (1855) 503; GüNTHER, Cat. Fishes 4 (1862) 15; WeBER, Fische der Siboga Exped. (1913) 357.

Acanthochromis polyacanthus BLFEKER, Nat. Verh. Holl. Maats. Wet. 2 (1877) 151; Atlas Ichth. 9 (1878) pl. 410, fig. 7.

Dorsal XVI or XVII, 14 or 15 ; anal II, 15 or 16 ; scales in lateral series 28 to 31 ; with tubules 19 to 23 ; between lateral line and origin of dorsal 6 or 7 ; between lateral line and vent 13 or 14.

The deep oblong body 1.8 to 1.9 in length, with the back and the abdomen about equally elevated; head 3.2 to 3.5 in length of body, its profiles nearly at right angles with each other; depth of caudal peduncle nearly twice in length of head or 6.6 to 7 in that of body. Interorbital space evenly and strongly arched, its width 2.5 to 2.8 in head and much wider than the length of the bluntly rounded snout, which is 3 to 3.9 in head; eye circular and moderate in size, its diameter 2.6 to 3.2 in head and slightly longer than maxillary which ends pos- 
teriorly behind anterior edge of orbit and is contained 2.8 to 3.4 in head. Mouth slightly oblique, jaws even, teeth conical and in a double series, those in the outer much larger than those in the inner. The lower edge of orbital ring distinctly serrated; width of preorbital at posterior end of maxillary less than half of eye diameter; both lower and vertical edges of preopercle serrated; opercle unarmed.

Scales finely ctenoid and moderate in size; portion of snout in front of nostrils, anterior half of preorbital, and the entire suborbital naked. Dorsal spines growing higher consecutively toward the last which is about as long as the ventral or the second anal spine; rayed portions of the vertical fins produced along the middle into a point; caudal fin deeply forked, with the upper lobe slightly the longer; pectoral fin longer than head, its tip above base of anterior anal rays; outer ray of ventral produced into a filament, which extends to base of anal spines.

Ground color in alcohol varying from brownish to blackish; body and fins with scattered black spots, which become rather indistinct in some individuals; all the fins colored similarly to body.

Here described from fifteen specimens, 58 to 89 millimeters in length, collected by Herre at Sibutu and Sitankai Islands, Sulu Archipelago.

This species, not hitherto known from the Philippines, occurs elsewhere on the coasts of Sangir, Batavia, and Amboina.

\section{Genus CHROMIS Cuvier}

Chromis Cuvier, Mem. Mus. Hist. Nat. (1815) 353; chromis.

Heliases Cuvier and Vaumnciennes, Hist. Nat. Poiss. 5 (1830) 495; insolatus; also written Heliastes.

Furcaria PoEY, Memorias Cuba 2 (1860) 194; puncta-multilineatus. Ayresia Cooper, Proc. Cal. Acad. Sci. (1863) 73; punctipinnis.

Body ovate or oblong, compressed. None of the opercles serrated. Teeth conical, in two or more series. Scales moderate in size, 27 or less in longitudinal series; lateral line ending under the posterior portion of soft dorsal; spinous dorsal scaly or naked; suborbital and lower jaw scaly, the former somewhat adnate to the cheek. Dorsal fin with 12 or 13 spines; each caudal lobe with two or more free sharp spines at base.

Although this genus is found in all tropical seas, it also extends northward to Japan and the Mediterranean, and southward to the coasts of Chile. 
Key to the Philippine species of Chromis.

$a^{1}$. Dorsal spines 13 .

$b^{2}$. Caudal peduncle bright yellow, this yellow area separated abruptly from the ground coloration; each caudal lobe without a longitudinal band

C. xanthurus.

$b^{2}$. Caudal peduncle not yellow; each lobe of caudal with a dark longitudinal band.

$c^{1}$. Longitudinal band on caudal fin broad and rather ill defined.

C. xanthochir.

$c^{2}$. Longitudinal band on caudal fin narrow and well marked.

C. scotochilopterus.

$a^{2}$. Dorsal spines 12 .

$d$. Spinous dorsal scaly; no bluish streak across preorbital.

$e^{2}$. Caudal fin with a blackish brown longitudinal stripe on each lobe.

C. ternatensis.

$e^{2}$. Caudal fin uniformly whitish

C. dimidiatus.

$d^{2}$. Spinous dorsal naked; a short bluish streak across preorbital.

CHROMIS XANTHURUS Bleeker

C. caeruleus.

Heliases xanthurus BleEkeR, Nat. Tijd. Ned. Ind. 6 (1854) 107; GüNThER, Cat. Fishes 4 (1862) 62.

Chromis xanthurus BLEEKER, Nat. Verh. Holl. Maats. Wet. 2 (1877) 159; Atlas Ichth. 9 (1878) pl. 405, fig. 5.

Dorsal XIII, 10 or 11; anal II, 10 or 11; scales in lateral series 27 ; with tubules 16 to 18 ; between lateral line and origin of dorsal 3; between lateral line and vent 9 .

Body ovate, upper and lower profiles equally curved and tapering behind toward end of tail ; deepest part of body at about the middle of ventral, 1.9 to 2 in length; head 3 to 3.4 ; depth of caudal peduncle 5.9 to 6.5. Interorbital space strongly convex, slightly bulging on top of head, rather broad, 2.7 to 2.9 in length of head; eye circular, large, contained 3.1 to 3.5 ; the short, blunt snout 3.5 to 3.8 in head; maxillary 2.9 to 3.1 , ending posteriorly to almost the front edge of pupil. Mouth very oblique, jaws about equal; front teeth of lower jaw strong and conical and a series of small ones behind them. Preorbital very narrow, its width at angle of mouth scarcely one-third the diameter of eye; suborbital adnate to cheek; opercle ending in a large flat spine.

All parts of head scaled. Fourth and last dorsal spines the highest. Soft dorsal and anal pointed along the middle, the former more or less produced into a filament; caudal deeply forked, armed superiorly and inferiorly at its. base with three sharp and prominent spines. 
Color in alcohol violet-brown, with a faint blackish spot on each scale; caudal peduncle and fin bright yellow, the line of demarcation between this color and that of body rather abrupt; dorsal, anal, and ventral fins dark violet-brown, and the posterior rays of the first two tipped with white; axil of pectoral dark; an irregular blackish blotch occupies the center of the middle caudal rays.

I have examined in the Bureau of Science collection fourteen specimens, 97 to 106 millimeters in length, obtained at the following localities: Monja Island, Corregidor; Hamilo, Batangas; Baco and Calapan, Mindoro; Sibuyan Island; New Washington, Capiz; and Bungau Island, Sulu Archipelago. The largest of these is a male, and the others are females in near-breeding condition, collected in March, 1926; April, 1922; July, 1925; and October, 1921.

This species, which is new to the Philippines, was originally described from Banda Neira by Bleeker. He recorded it also from Singapore, and Weber collected three specimens at Beo, Karakelang Island.

\section{CHROMIS XANTHOCHIR Bleeker}

Heliases xanthochir BlEEKER, Nat. Tijd. Ned. Ind. 2 (1851) 248; GüNTHER, Cat. Fishes 4 (1862) 62.

Chromis xanthochir BLEEKER, Nat. Verh Holl. Maats. Wet. 2 (1877) 158; Atlas Ichth. 9 (1878) pl. 402, fig. 5.

Dorsal XII, 11; anal II, 10 or 11 ; scales in lateral series 26 ; with tubules 15 to 18 ; between lateral line and origin of dorsal 3 ; between lateral line and vent 9 .

Dorsal and ventral profiles of the ovate body equally and evenly arched; greatest depth 2.2 to 2.5 in length; head 3.2 to 3.5 ; depth of caudal peduncle 6.6 to 7 . Diameter of the large, round eye about equal to the width of the strongly convex interorbital, 2.8 to 3.2 in length of head; the short, slightly pointed snout 3.4 to 4 , its tip on a line with center of pupil; maxillary 2.7 to 3 , extending posteriorly well behind anterior margin of orbit. Width of preorbital at angle of mouth less than half diameter of eye. Teeth in front strong and conical; one or more series of small ones behind. Suborbital adnate to cheek; opercle with a flat spine behind.

Head and body completely scaled. Dorsal spines rather slender, the middle ones highest. Soft dorsal and anal highest along the middle, the former more pointed; caudal deeply cleft, with 
the lobes produced and two accessory spines at base of each lobe free and sharp; both pectoral and ventral fins end at vent.

Greenish violet in alcohol, with silvery reflections which are more noticeable on lower portion of lateral surfaces; each scale with a dark edge; anterior dorsal and anal rays dusky, the posterior ones pale; dusky portion of caudal fin forming a broad, rather ill-defined longitudinal band on each lobe, middle rays pale; pectoral pale, ventral more or less washed with dusky; a blackish transverse band immediately behind preopercle and a yellowish violet spot at axil of pectoral.

Here described from ten specimens, 70.5 to 77 millimeters long, collected at Calapan, Mindoro; New Washington, Capiz; Bogo, Cebu; Placer, Surigao; and Sibutu Island, Sulu Archipelago. Six of these are females in a near-breeding state, collected in July, 1926, and September, 1925.

Apparently not common in the Philippines, this being the first record of the species here. It is known only from the East Indies.

CHROMIS SCOTOCHILOPTERUS Fowler

Chromis scotochilopterus Fowler, Proc. Acad. Nat. Sci. Phila. 70 (1918) 61, fig. 24.

Dorsal XIII, 11; anal II, 11; scales in lateral series 26; with tubules 18 ; between lateral line and origin of dorsal 4 ; between lateral line and vent 9 .

Body well compressed, contour ellipsoid; greatest depth at middle of belly, 2 in length; head 3.1 to 3.3 ; depth of caudal peduncle 6.3 to 6.8 . Interorbital space strongly convex, rather wide, its width greater than length of snout or diameter of eye; snout rounded, shorter than the diameter of the large circular eye, which is 3.2 to 3.3 in head. Cleft of mouth very oblique; maxillary equal to or slightly longer than width of interorbital space, its posterior end below anterior edge of orbit; teeth short and conical, in two rows.

Scales completely covering head, also present on the dorsal fin. Middle dorsal spines higher than the rest, but much lower than the strong second anal spine. Soft dorsal and anal about equal in height; caudal deeply cleft, with the lobes more or less produced; the three anteriormost accessory spines on each caudal lobe sharp and prominent; outer ray of ventral produced into a filament, which extends beyond anal opening. 
Ground color of fresh specimens uniformly dull violet brown, becoming slightly lighter on the lower parts. Spinous dorsal dark violet-brown, as were the anterior rays of the vertical fins, the rest yellowish; caudal with a well-defined upper and lower border of dark violet-brown, the rest of the fin yellowish; pectoral yellowish; ventrals lightly washed with violet-brown. A dark spot superiorly at base of pectoral. In alcohol the violetbrown color has become blackish brown and the yellowish color has disappeared.

Here described from thirteen specimens, 31 to 107 millimeters long, collected at Tagapula and Sayan Islands, Samar; Gigantangan Island, Leyte; New Washington, Capiz; and Tambagaan and Bungau Islands, Sulu Archipelago.

This species has been previously recorded by Fowler from specimens marked "Philippine Islands." Although it is closely. allied to Chromis xanthochir Bleeker, it differs in having a narrower and more strongly defined dark band on each caudal lobe.

CHROMIS TERNATENSIS Bleeker

Heliases ternatensis Bleeker, Nat. Tijd. Ned. Ind. 10 (1856) 377; GüNTHER, Cat. Fishes 4 (1862) 63.

Chromis ternatensis BLEEKER, Nat. Verh. Holl. Maats. Wet. 2 (1877) 161; Atlas Ichth. 9 (1878) pl. 403, fig. 4; WEBER, Fische der Siboga Exped. (1913) 359.

Chromis philippinus FowLER, Proc. Acad. Nat. Sci. Phila. 70 (1918) 63, fig. 25.

Dorsal XII, 10 or 11; anal II, 10 or 11; scales in lateral series 26 ; with tubules 16 ; between lateral line and origin of dorsal 3 ; between lateral line and vent 10 .

Body deep and much compressed, deepest at base of ventrals, upper profile more elevated than the lower; depth of body 1.9 to 2 in length; head 3.2 to 3.4 ; depth of caudal peduncle 6.7 to 6.9. Diameter of the large, round eye 2.8 to 2.9 in length of head and equal to the width of the strongly arched interorbital or the length of the maxillary; snout short, 3.5 to 3.6 in head. Mouth strongly oblique, jaws even; two series of conical teeth in each jaw. Suborbital adnate to cheek and extremely narrow.

Head and body completely scaled; spinous dorsal also covered with scales. Of the dorsal spines, the middle ones the highest. Rayed dorsal slightly rounded and soft anal angular; caudal deeply notched, with the lobes more or less produced into filaments and with three well-developed spines at base of each lobe; ventral shorter than pectoral, its tip at origin of anal fin. 
Fresh specimens brownish violet above, this color gradually fading into orange yellow below; the longitudinal stripe on each lobe of caudal brownish violet.

Ground color in alcohol brown, becoming darker on the back; each scale with a yellowish spot and dark edge; vertical fins violaceous; caudal with a dark blackish brown longitudinal stripe on each lobe. There is no bluish line in front of orbit.

The above account is of thirty-four specimens, 32 to 59 millimeters long, taken at Cabalian, Leyte; and at Tambagaan, Tawitawi, Sibutu, Bungau, and Siasi Islands, Sulu Archipelago. One of the examples, 37 millimeters in length, obtained in June, 1921 , at Siasi, is in near-spawning condition.

This species has been recorded previously from the Philippines by Fowler, as Chromis philippinus.

I can find but little difference between Chromis amboinensis and this species, and it is probable that the former is an adult stage of Chromis ternatensis. It was first described by Bleeker from three specimens collected in Ternate. It is known to occur also in Goram; Booroo; and Beo, Karakelang Island.

\section{CHROMIS DIMIDIATUS (Klunzinger)}

Plate 7, FIG. 2

Heliases dimidiatus KLUNZINGER, Fische des Rothen Meers 2 (1871) 529; GüNTHER, Fische der Südsee 2 (1876) 237, pl. 125, fig. E.

Dorsal XII, 12; anal II, 12; scales in lateral series 26; with tubules 17; between lateral line and origin of dorsal 3 ; between lateral line and vent 9 .

Depth of the ovoid body 2 in length; head 3.2, with the profiles evenly arched and equally elevated; depth of caudal peduncle 6.4 , or 7.2 in length. The broad, evenly arched interorbital 2.8 in head; the large, circular eye 2.3; the short, rounded snout 4.1, or shorter than maxillary which is contained 3.5 in length of head. Cleft of mouth oblique, jaws even, the maxillary terminating posteriorly behind front edge of the eye's orbit; teeth in double series, those in front strong and conical. Preorbital very narrow, its width above angle of mouth less than one-third the eye diameter; opercle unarmed behind.

Head and body completely scaly; vertical fins with a rather high sheath of scales. Middle dorsal spines highest, the last one higher than the second anal spine. Both rayed dorsal and anal rounded; caudal forked, with the lobes produced into filaments; pectoral fin longer than head, terminating above base 
of anal spine; outer ray of ventral produced into a filament, which extends to base of anterior anal rays.

Fresh specimen dark dusky brown; posterior half of the rayed dorsal, posterior third of soft anal, caudal peduncle, and caudal fin whitish, this coloration abruptly marked off from the ground color of body; ventrals and the rest of the vertical fins colored similarly to body; pectoral a little lighter and with a large black blotch at its base.

The coloration has not changed much in alcohol.

Here described from the only example present in the Bureau of Science, which measures 45 millimeters in length. It was collected by Herre at Bungau Island, Sulu Archipelago, and this is the first record of the species in the Philippines.

\section{CHROMIS CAERULEUS (Cuvier and Valenciennes)}

Plate 8, Fig. 2

Heliases caeruleus Cuvier and Valennciennes, Hist. Nat. Poiss. 5 (1830) 372; BLеEKeR, Nat. Tijd. Ned. Ind. 8 (1855) 455.

Chromis caeruleus JoRdan and Seale, Bull. U. S. Bur. Fisheries 25 (1906) 290, pl. 44, fig. 1.

Heliases frenatus CUVIER and VALENCIENnEs, Hist. Nat. Poiss. 5 (1830) 373.

Heliases lepisurus Cuvier and Valenciennes, Hist. Nat. Poiss. 5 (1830) 373.

Chromis lepisurus BlEEKER, Nat. Verh. Holl. Maats. Wet. 2 (1877) 164; Atlas Ichth. 9 (1878) pl. 403, fig. 7.

Glyphisodon bandanensis Blpsker, Nat. Tijd. Ned. Ind. 2 (1851) 248. Heliases lepidurus Günther, Cat. Fishes 4 (1862) 63; Fische der Südsee 2 (1876) 238, pl. 128, figs. C and D; DAY, Fishes of India (1878) 389 , pl. 82 , fig. 1.

Chromis lepidurus WEBER, Fische der Siboga Exped. (1913) 358.

Dorsal XII, 9 or 10; anal II, 9 to 11; scales in lateral series 25 ; with tubules 14 to 16 ; between lateral line and origin of dorsal 2; between lateral line and vent 9 .

Body ovate, profiles evenly curved from tip of snout to posterior portion of caudal peduncle, dorsal outline more strongly arched than ventral; depth of body 2 to 2.3 in length; head 2.9 to 3.3 ; depth of caudal peduncle 6.6 to 7.6. The strongly convex interorbital 2.7 to 3.3 in length of head; the circular eye 2.8 to 3.2 ; the slightly rounded snout 3.2 to 3.5 , its tip on a level with lower margin of orbit; maxillary 2.2 to 2.6, being longer than width of interorbital, its posterior end below anterior margin of eye or slightly behind it. Mouth large, very oblique, jaws equal; teeth in two rows in each jaw, small and conical. Orbital ring narrow and adnate to cheek. 
Head and body completely scaly; spinous dorsal naked. Dorsal spines decreasing in height posteriorly from the third, which is higher than the second anal. Soft dorsal and anal slightly rounded and of about the same height; caudal deeply cleft, with the lobes more or less produced and with the three anteriormost accessory spines on each margin of its base free and sharp. Pectoral and ventral fins of nearly the same length, the former extending to above anus and the latter with the outer ray produced into a filament which reaches to base of anal spines.

Ground color in life greenish, passing into silvery along belly; scales of head and sides with blue spots; caudal fin greenish and the other fins grayish; spinous dorsal having a narrow outer margin of blackish; pectoral with a blackish longitudinal stripe superiorly and a spot of similar color at its base and axil; iris golden.

Violet blue in alcohol with silvery luster all over, the ground color becoming lighter on the lower parts; each scale with a pale bluish spot; all the fins more or less washed with violet, spinous dorsal having a blackish outer edge; pectoral with a blackish axillary spot which extends over superiorly at base and with a blackish band along upper rays; caudal with upper and lower margins brownish; lips violet in front; a short bluish line in front of orbit.

Of this species I have examined in the Bureau of Science collection over one hundred specimens, the largest of which is 66 millimeters in length. It evidently breeds throughout the year, as several of them are ripe females, collected in different months. The specimens are from the following localities: Puerto Galera and Calapan, Mindoro; Bantayan Island; Cabalian, Leyte; Canigaran, Palawan; Surigao, Samal Island, and Zamboanga, Mindanao; and Tambagaan, Basbas, Bungau, Sibutu, and Sitankai Islands, Sulu Archipelago.

This species has been listed by Weber from Sanguisiapo, Sulu Archipelago, and is common from the Andamans, through the Indo-Australasian Archipelago, Micronesia, and the Carolines, to the South Seas.

\section{Genus CHEILOPRION Weber}

Cheiloprion WEBER, Fische der Siboga Exped. (1913) 342; labiatus.

Body ovate, compressed. Suborbital and the vertical margins of preopercle finely serrated. Teeth in two rows of uniform height, with slightly rounded tips. Lips thick and swollen, with outward radiating papillæ drawn together into visible furrows, 
completely reversed outward all around the mouth uncovering the teeth. Scales 26 in longitudinal series; lateral line ending under the hind portion of the rayed dorsal; dorsal spines 13, scaly, with rounded and lobed membranes; head completely scaled excepting the lips, orbital ring, and the space between the nostrils and tip of snout.

This genus is distinguished from Dichistodus of Bleeker in having the two rows of teeth in each jaw of equal length, and from both Dichistodus and Pomacentrus in the strangely developed lips. It is known only from the Nicobars, Andamans, Philippines, and Karakelang Island, one of the Moluccas. It probably occurs throughout the intervening territory but has been overlooked by collectors, as it lives in the interstices of coral.

There is but a single species representing this genus.

CHEILOPRION LABIATUS (Day)

Plate 9, Fig. 1

Pomacentrus labiatus DAY, Fishes of India (1878) 384, pl. 81, fig. 2, as Pomacentrus labiosus.

Cheiloprion labiatus WEBER, Fische der Siboga Exped. (1913) 342, fig. 73; Fowler, Proc. Acad. Nat. Sci. Phila. 70 (1918) 53.

Dorsal XIII, 13; anal II, 13; scales in lateral series 26; with tubules 18; between lateral line and origin of dorsal 4 ; between lateral line and vent 10 .

Body ovate, the outlines equally arched; depth 1.8 to 2 in length; head 2.6 to 2.8 ; depth of caudal peduncle 6.2 to 6.7. The wide, convex interorbital space 2.6 to 3 in length of head, wider than length of maxillary, which is greater than that of snout; the blunt snout 3.1 to 3.4 in head or about as long as diameter of eye; preorbital at angle of mouth less than half an eye diameter; maxillary extending posteriorly to a little before front edge of orbit. The extremely large and thick lips covered with outward radiating papillæ drawn together into distinct furrows, and completely turned back around mouth, thus exposing the teeth. Teeth in two rows of equal length in each jaw, minute, strongly compressed laterally, of uniform height, with slightly rounded tips. Suborbital bone and posterior margin of preopercle with fine denticulations.

Scales on top of head extending to nostrils, those at base of dorsal fin high; orbital ring naked. Middle and posterior dorsal spines about equal in height; soft dorsal pointed; rayed anal 
a little rounded; ventrals extending to origin of anal; caudal slightly forked, with the lower lobe a little shorter than upper. Blackish brown in alcohol, lighter on chest and opercular bones. Usually a bluish white spot is present on the center of each scale in the row above the lateral line, and some scattered bluish white spots on each side of head and on anterior portion of body below lateral line. All the fins have a deeper color than the body has.

Here described from eleven examples, 33 to 58 millimeters long, from Calapan, Mindoro; Canigaran, Palawan; and Sibutu Island, Sulu Archipelago. The only other record of this species from this country is that by Fowler, of two specimens labeled "Philippine Islands." It was originally described from the Andamans and Nicobars by Day, and later recorded from Beo, in Karakelang Island, by Weber. In his account of the fishes of the Siboga Expedition, Weber places the species under a separate genus, distinguished from any others by the enormously developed lips which are puffed out and covered with radiating papillæ.

\section{Genus POMACENTRUS Lacépède}

Pomacentrus LacéPÈDe, Hist. Nat. Poiss. 4 (1803) 508; pavo.

Pristotis RüPPELL, Neue Wirbelthiere, Fische (1838) 128; cyanostigma.

Pseudopomacentrus BLEEKER, Nat. Verh. Holl. Maats. Wet. 2 (1877) 40; littoralis.

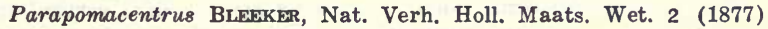
65; polynema.

Amblypomacentrus Blesker, Nat. Verh. Holl. Maats. Wet. 2 (1877) 68 ; breviceps.

Eupomacentrus BLEFKER, Nat. Verh. Holl. Maats. Wet. 2 (1877) 73; lividus.

Brachypomacentrus BLEEKER, Nat. Verh. Holl. Maats. Wet. 2 (1877) 73; albifasciatus.

Body compressed, oblong or ovate, with not more than 27 scales of moderate size in lateral series. Lateral line ending before posterior end of soft dorsal. Teeth in one or two series, compressed, entire or slightly emarginate. Dorsal fin continuous, even, with 12 to 14 spines. Only the vertical limb of the preopercle and generally the orbital bones serrated.

Species numerous; found about the coral reefs in the tropical seas of both hemispheres, but abundant in the Indian seas and in Polynesia.. 


\section{Key to the Philippine species of Pomacentrus.}

$a^{1}$. Dorsal spines 12.

$b^{1}$. Scales on top of head stopping above the nostrils

P. lividus.

$b^{2}$. Scales on top of head extending almost to tip of snout.

$c^{1}$. Body with a light crossband.

P. albofasciatus.

$c^{2}$. Body without a light crossband.

P. nigricans.

$a^{2}$. Dorsal spines 13.

$d^{2}$. Orbital ring smooth or indistinctly serrated.

$e^{1}$. Teeth truncate.

$f^{t}$. Orbital ring naked

P. pavo.

$f^{2}$. Orbital ring scaled.

$g^{2}$. Vertical limb of preopercle scaled.

$h^{2}$. Anal fin almost wholly dusky; dusky color on dorsal fin extending to fourth ray.

P. violascens.

$h^{2}$. Anal fin entirely yellowish; dusky color on dorsal fin extending to second ray.

P. bankieri.

$g^{2}$. Vertical limb of preopercle naked............................ P. taeniurus.

$e^{2}$. Teeth slightly rounded at tips...................................... P. bifasciatus.

$d^{2}$. Orbitals distinctly serrated.

$i^{1}$. Anterior denticulation of orbital enlarged and followed by a notch.

$j^{2}$. Scales on top of head extending to tip of snout; vertical fins with a rather high basal sheath of scales.

$k^{1}$. A large black spot at base of pectoral and another at axil of fin.

$k^{2}$. Base or axil of pectoral without any black spot.

P. philippinus.

$l$. Teeth in double series; a very small black spot superiorly at axil of pectoral and another above operculum.

$m^{1}$. Some bluish lines along forehead; bluish spots on opercles; caudal lobes slightly pointed

P. tropicus.

$m^{2}$. No bluish lines or spots on head; a light vertical streak on each scale; caudal lobes rounded........ P. moluccensis.

$l^{2}$. Teeth in a single series; no black spots anywhere on body.

P. popei.

$j^{2}$. Scales on top of head not extending to tip of snout but stopping in front of nostrils; a low sheath of scales occupying base of vertical fins.

$n^{1}$. Teeth in a single series.

$p^{1}$. Axil of pectoral entirely black.

P. alexanderae.

$p^{2}$. Axil of pectoral pale.

P. grammorhynchus.

$n^{2}$. Teeth in double series.

$q^{1}$. Body oblong, rather elongate

P. elongatus.

$q^{2}$. Body ovate, not elongate.

$r^{1}$. Caudal fin yellow, this coloration abruptly marked from the ground color. P. dorsalis.

$r^{2}$. Caudal fin yellow, this color gradually merging in the ground color.

$s^{1}$. A black spot on top of caudal peduncle.... P. tripunctatus.

$s^{2}$. No black spot on top of caudal peduncle.

$t^{1}$. Anus black

P. amboinensis.

$t^{2}$. Anus not black

P. simsiang. 
2. Orbital ring evenly serrated.

$u^{1}$. Inferior limb of preopercle scaly; scales on top of head extending to before front edge of eye.

$v^{2}$. Body with dark or white marks.

$w^{2}$. Body with white spot or band.

$x^{2}$. Body with a large white round spot along back but without any dorsal ocellus.

P. chrysopoecilus.

$x^{2}$. Body with a white transverse band and a dark ocellus.

$w^{2}$. Body with dark blotches.

P. notophthalmus.

$y^{2}$. Body with two wide dark blotches and a large blackish violet spot on axil of pectoral

P. prosopotaenia.

$y^{2}$. Body with three dark blotches but without any axillary spot on pectoral

P. trimaculatus.

$v^{2}$. Body without dark or white marks........................ P. melanochir.

$u^{\mathbf{1}}$. Inferior limb of preopercle naked; scales on top of head extending to above front rim of eye.

$z^{1}$. Body with yellow crossbands; teeth in double series, those on outer row neither contiguous nor truncate ..... P. fasciatus.

$z^{2}$. Body with dark crossbands; teeth in a single series, closely set and more or less truncate.

P. breviceps. P. ovoides.

$a^{2}$. Dorsal spines 14.

$a a^{1}$. Teeth with emarginate edges; body with a series of white transverse lines P. albolineatus.

$a a^{2}$. Teeth with rounded edges; body without a series of white transverse lines.

$b b^{1}$. Pectoral with a rather large black spot covering almost entirely its base; anal uniformly deep brown.

P. opisthostigma.

$b b^{2}$. Pectoral with a small black spot superiorly at its base and axil; posterior third of anal black and the remaining portion whitish or whitish violet.

P. tablasensis.

\section{POMACENTRUS LIVIDUS (Forster)}

Chaetodon lividus Forster, Des. Anim. Licht. (1844) 227.

Eupomacèntrus lividus BLEEKER, Nat. Verh. Holl. Maats. Wet. 2 (1877) 73; Atlas Ichth. 9 (1878) pl. 403, fig. 5.

Pomacentrus lividus GüNTHFR, Fische der Südsee 2 (1876) 228, pl. 124, fig. F; Jordan and Seate, Bull. U. S. Bur. Fisheries 25 (1906) 283; W

Pomacentrus cyanospilus MEYER, Ann., Soc. España Hist. Nat. 14 (1885) 34.

Dorsal XII, 15 or 16 ; anal II, 12 to 14 ; scales in lateral series 25 ; with tubules 16 to 18 ; between lateral line and origin of dorsal 3; between lateral line and vent 10 .

Body markedly oblong, dorsal profile deeper than ventral and more arched anteriorly than posteriorly; depth of body 2 to 2.1 in length; head 2.8 to 3 ; depth of caudal peduncle 5.7 to 7.3. The wide, evenly convex-interorbital 2.7 to 3.4 in length of 
head; diameter of the small, circular eye 3.3 to 4.3 or shorter than width of preorbital at angle of mouth in large specimens; the long, slightly pointed snout 2.5 to 3 , longer than maxillary, which is contained 3.1 to 3.6 in head. Cleft of mouth oblique, jaws even, tip of snout more inferior than lower margin of eye; teeth in two rows, those in outer row short and having slightly emarginate edges. Lower edge of suborbital and posterior edge of preopercle strongly serrated; opercle armed behind with two sharp spines.

Head naked on snout in front of nostrils and on edges of preopercle; base of vertical fins with a high sheath of scales. The last three dorsal spines almost equal in height. Middle rays of the vertical fins produced into a point; caudal emarginate, with the lobes broad and rounded; pectoral rounded, its tip within two scales from the point above anus; outer ray of ventral filamentous, ending behind at anus.

Brown or violet-black in alcohol, with scattered dots on head and a whitish spot on each scale of trunk, the spots on trunk forming more or less longitudinal series. In many of the examples a large dusky blotch is present at base and axil of the soft dorsal fin, and in the very young it is in the form of an ocellus edged anteriorly with bluish white. Pectoral yellowish, having a dark axillary spot which is absent in some specimens; all the other fins dusky.

Here described from forty-two examples, 20.5 to 97 millimeters long, collected at Puerto Galera and Calapan, Mindoro; Bulan, Sorsogon; Canigaran, Palawan; and South Ubian, Sibutu, and Sitankai Islands, Sulu Archipelago. This species has been previously recorded in the Philippines by Jordan and Seale from Negros Island.

In all the specimens examined the number of dorsal spines is twelve. I have examined also in the Bureau of Science collection some examples obtained by Seale at Guam, which are much lighter in coloration than those from the Philippines.

This species occurs from the Red Sea and east coast of Africa throughout the tropical Indo-Pacific seas to the islands of the South Seas.

POMACENTRUS ALBOFASCIATUS Schlegel and Muller

Plate 9, Fig. 2

Pomacentrus albofasciatus Schleger and MÜLLer, Overz. Amphi. Verh. Nat. Ges. Ned. Overz. Bezitt. (1839) 21; GüNthar, Cat. Fishes 4 (1862) 19; DAY, Fishes of India (1878) 384, pl. 80, fig. 9 ; JoRDAN 
and Seale, Bull. U. S. Bur. Fisheries 25 (1906) 282; JordaN and Richardson, Bull. U. S. Bur. Fisheries 27 (1908) 262.

Eupomacentrus albofasciatus BLERKER, Nat. Verh. Holl. Maats. Wet. 2 (1877) 75; Altas Ichth. 9 (1878) pl. 403, fig. 6.

Pomacentrus scolopsis GüNTHER, Cat. Fishes 4 (1862) 26; Fische der Südsee 2 (1876) 227, pl. 125, figs. A and B.

Dorsal XII, 16; anal II, 12; scales in lateral series 28; with tubules 20 ; between lateral line and origin of dorsal 3 ; between lateral line and vent 9.

Body ovate, upper profile from origin of dorsal to snout an even curve, depth 2.1 in length; head 3 ; depth of caudal peduncle 6.3. Interorbital space slightly convex, its width equal to length of snout, which is 3.1 in head or slightly longer than diameter of round eye; snout rounded, with its tip on a level with inferior margin of eye; mouth oblique; maxillary ending posteriorly below front margin of orbit; teeth in two rows, with slightly emarginate edges. Orbital ring at end of maxillary nearly half as wide as the length of eye diameter; preopercle finely serrated; opercle with a flat blunt spine behind.

There are no scales on the outer edges of preopercle; a rather high sheath of scales at base of vertical fins. Posterior half of dorsal spines of nearly the same height. Soft dorsal and anal highest along the middle, the former rounded and the latter angular; caudal forked; pectoral not quite reaching vent; ventral extending to base of anal spines, its outer ray produced.

In alcohol the color is olive brown, with a light brown streak at the edge of each scale. The broad light vertical band across middle of body between the posterior dorsal spines and the anterior anal fin is rather distinct; the blue lines on sides of head absent; a large, oblong, black spot occupying base of last dorsal rays, and another one present superiorly at base of pectoral. Ventrals and vertical fins blackish; outer portion of caudal pale.

The above account is that of two specimens, in the Stanford University museum, collected by R. C. McGregor at Calayan Island, Cagayan Province, as recorded by Jordan and Richardson.

This species is rather rare in the Philippines and is found from the Andamans throughout the Indo-Australasian Archipelago to Palau Islands and Samoa.

\section{POMACENTRUS NIGRICANS (Lacépède)}

Holocentrus nigricans LACÉPÈDE, Hist. Nat. Poiss. 4 (1803) 332, 367. Pomacentrus nigricans JORDAN and SEALE, Bull. U. S. Bur. Fisheries 
25 (1906) 281; JORdAN and Richardson, Bull. U. S. Bur. Fisheries 27 (1908) 262.

Pomacentrus scolopseus QuoY and GaImard, Voy. Uranie, Zool. 2 (1824) 398.

Dorsal XII, 17; anal II, 13; scales in lateral series 26; with tubules 21 ; between lateral line and origin of dorsal 3 ; between lateral line and vent 10.

Upper profile of head more strongly arched than the ventral; the deep compressed body 1.9 in length; head 3.2 ; depth of caudal peduncle 6.5. Interorbital space evenly convex, as wide as the length of snout, which is 3.1 in length of head; mouth small, almost horizontal ; maxillary 3.6 in head or as long as diameter of eye, its posterior end below front edge of orbit. Teeth in a double series, truncate. Width of preorbital at posterior end of maxillary nearly equal to half diameter of eye; suborbital and preopercle evenly and strongly denticulate; opercle ending in a flat spine.

Scales completely cover head and body, those on orbital ring and snout well embedded in the skin; a very high sheath of scales covers base of vertical fins. Dorsal spines evenly graduated posteriorly, the last one the highest. Rayed dorsal and anal tounded; caudal with the lobes rounded; pectoral short, not reaching vent; outer ray of ventral prolonged into a filament, which extends to base of anal spines.

Blackish brown in alcohol; a large black spot at base of last dorsal rays; a very distinct one superiorly at base of pectoral, extending into axil; a rather faint spot on most of the scales of body; an indistinct bluish streak on suborbital.

The above account is based upon a Samoan specimen, 98 millimeters long, which I examined at Stanford University Museum, there being no Philippine example available. Jordan and Richardson examined several specimens collected by McGregor at Calayan Island, Cagayan Province, and at Cagayancillo, Cagayan Islands.

This species appears to be close to Pomacentrus lividus, from which it is distinguished by a narrower preorbital and by the scaly orbital ring. It cannot be regarded as identical with Pomacentrus albofasciatus, because the latter has no scales on the inferior and posterior edges of preopercle. It is rather uncommon in the Philippines and is known to range from the Okinawa Islands throughout the Indo-Australasian Archipelago and the islands of the tropical Pacific to Polynesia. 


\section{POMACENTRUS PAVO (Bloch)}

Plate 10, Fig. 2

Chaetodon pavo BLoch, Ichth. 6 (1787) 44, pl. 198, fig. 1.

Pomacentrus pavo LACÉPÈDE, Hist. Nat. Poiss. 4 (1803) 508; RÜPPELL, Fische des Rothen Meers (1828) 37; Cuvier and Valenciennes, Hist. Nat. Poiss. 5 (1830) 310; GüNTHER, Cat. Fishes 4 (1862) 23; Fische der Südsee 2 (1876) 227, pl. 124, fig. E; BLEEKER, Nat. Verh. Holl. Maats. Wet. 2 (1877) 42; Atlas Ichth. 9 (1878) pl. 408, fig. 9; JoRdan and Seale, Bull. U. S. Bur. Fisheries 25 (1906) 279, pl. 40, fig. 1; Weber, Fische der Siboga Exped. (1913) 336. Pomacentrus pavo var. ? CARTIER, Verh. Phys. Med. Ges. Würzburg (1873) 99.

Dorsal XIII, 13 or 14 ; anal II, 13 to 15 ; scales in lateral series 26 ; with tubules 16 to 18 ; between lateral line and origin of dorsal 3 ; between lateral line and vent 9 .

Body elongate, dorsal and ventral contours similar, being low even curves from tip of snout to caudal peduncle; depth 2.5 to 2.8 in length; head 3.2 to 3.5 ; depth of caudal peduncle 6.7 to 7.5. The convex interorbital 3.3 to 3.8 in length of head; diameter of the large, round eye 2.7 to 3.3 or longer than snout, which is contained 3.8 to 4 in head; maxillary 3 to 3.3 in head, extending posteriorly a little behind front edge of orbit. Cleft of mouth almost horizontal, lower jaw slightly in advance of upper; teeth in two rows, compressed and truncated. Preorbital very narrow, its width at posterior end of maxillary about a third of eye diameter; suborbital indistinctly denticulate; preopercle finely toothed at its hind margin; opercle with two flat spines behind.

Scales on top of head extend forward to a little distance behind nostrils; orbital ring naked. Dorsal spines increasing in height posteriorly. Dorsal and anal fins angular and about equal in height. Caudal emarginate, with the lobes slightly pointed; pectoral and ventral equal in length, both extending to anal opening.

Deep blue in alcohol, yellowish on belly and fins; each scale with a brownish vertical streak; belly and base of vertical fins with bluish dots. A large black spot above operculum; a smaller one in axil of pectoral; two short dark bands in front of each eye, one across snout and the other on preorbital.

The foregoing account is taken from thirty examples, 17.5 to 52.5 millimeters long, collected at Calapan, Mindoro; Puerto Princesa, Palawan; Surigao and Cagayan de Misamis, Mindanao; and Sitankai Island, Sulu Archipelago. This fish un- 
doubtedly spawns the year round, since a number of the above examples, collected in different months, were found to be in near-breeding condition.

Living specimens in the Bureau of Science aquarium, taken at Calapan, are deep blue, this color passing into bright lemon yellow on the underparts and on anal, caudal peduncle, and fin; first spine and outer edge of anal bluish black; outer edge of caudal fin grayish; posterior dorsal rays yellow; ventral fin yellow, its spine bluish violet; a black spot at origin of lateral line and another superiorly at base of pectoral.

Pomacentrus pavo var.? Cartier is probably this species.

This very handsome little fish is abundant in the Indo-Australasian Archipelago, and ranges from the Red Sea and the east coast of Africa to Polynesia.

\section{POMACENTRUS VIOLASCENS Bleeker}

Pristotis violascens BlFEkER, Contr. Ichth. Sumb. Journ. Ind. Arch. 2 (1848) 637.

Pomacentrus violascens BleEkER, Nat. Tijd. Ned. Ind. 12 (1856) 222; GüNTHER, Cat. Fishes 4 (1862) 20; BlbekmR, Nat. Verh. Holl. Maats. Wet. 2 (1877) 46; Atlas Ichth. 9 (1878) pl. 408, fig. 6. Dascyllus xanthurus BLewker, Nat. Tijd. Ned, Ind. 4 (1853) 117.

Tetradrachmum xanthurus BLEEKER, Ned. Tijd. Dierk. 1 (1863) 250.

Dorsal XIII, 10 or 11 ; anal II, 10 or 11 ; scales in lateral series 26 ; with tubules 17 or 18 ; between lateral line and origin of dorsal 3 ; between lateral line and vent 9 .

Body oblong and slightly elongate, its profiles equally elevated; depth of body 2.3 to 2.4 in length; head 3.1 to 3.3 ; depth of caudal peduncle 6.1 to 6.2 . Interorbital space evenly arched, 3 to 3.2 in head; the large, round eye 3 to 3.6 ; snout shorter than maxillary, which is 2.8 to 3 in head. Mouth oblique, jaws even, tip of snout slightly higher than lower margin of orbit; teeth biserial, those in outer row truncate. Preorbital slightly notched in front; suborbital smooth; opercle with a large flat spine and two closely opposed small ones.

Head and body everywhere covered with scales. Dorsal spines increasing in height posteriorly. Middle rays of vertical fins and lobes of caudal more or less produced into filaments; pectoral fin extending to anus, and ventral at origin of anal fin.

Violet-brown in alcohol, with a bluish vertical streak on each scale; dorsal fin darker than ground color to fourth ray, the remaining portion yellow; anal entirely dusky or with the last rays yellowish; caudal peduncle yellow posteriorly, the fin simi- 
larly colored, with the upper and the lower edges partly or entirely dusky. A bluish spot in axil of pectoral and another one at origin of lateral line.

I have examined five specimens in the Bureau of Science collection, measuring 38 to $\mathbf{5 3 . 5}$ millimeters long, from Siaton, Oriental Negros, and Cagayan de Misamis, Mindanao. I have also examined an example from Siquijor, which is now in the museum of Stanford University. There is an example, 58 millimeters long, from Hongkong in the Bureau of Science collection.

This species is very close to Pomacentrus taeniurus, but is easily distinguished by the yellow area on the tail, by the illdefined dusky band on each caudal lobe, and by the scaly edges of the preopercle. It is apparently not very abundant in the Philippines, and is common only in the Indo-Australasian Archipelago from Sumatra to Ceram.

POMACENTRUS BANKIERI (Richardson)

Glyphisodon bankieri RICHARDSON, Ichth. China (1846) 253; GUNTHER, Cat. Fishes 4 (1862) 54.

Parapomacentrus bankieri BLFHKER, Nat. Verh. Holl. Maats. Wet. 2 (1877) 67; Atlas Ichth. 9 (1878) pl. 408, fig. 8.

Abudefduf bankieri EvermanN and Seale, Bull. U. S. Bur. Fisheries 26 (1907) 92.

Dorsal XIII, 10 or 11; anal II, 11; scales in lateral series 26; with tubules 15 to 18 ; between lateral line and origin of dorsal 3 ; between lateral line and vent 9 .

Body oblong, rather elongate, depth 2.4 to 2.7 in length; head 3.1 to 3.5 ; depth of caudal peduncle 6.1 to 6.7 . Interorbital space strongly convex, 3 to 3.2 in length of head; the large, round eye 2.8 to 3.4 ; the short, rounded snout 3.5 to 4.3 ; maxillary 2.6 to 3 . Mouth almost vertical, lower jaw slightly in advance of upper; a single series of distinctly notched teeth on each jaw. Preorbital very narrow; vertical edge of preopercle indistinctly serrated.

Head and body completely scaled. Dorsal spines slender, increasing in height toward behind. Soft dorsal and anal angular; caudal deeply forked, the longest rays of each lobe filamentous; outer ray of ventral fin produced into a filament, which extends to origin of anal fin.

Brownish violet in alcohol; head, back, and caudal peduncle with round bluish spots; each scale on the lower parts of body with a bluish vertical streak; dorsal fin dusky to the second ray, the remaining portion yellowish; caudal yellowish, with the upper and lower rays partly dusky; the other fins yellowish, a large 
blackish spot at origin of lateral line, a second one at axil of pectoral, and a third, small spot superiorly at base of pectoral.

Here described from eight specimens, 19 to 53.5 millimeters long, from Bacon, Sorsogon; Larena, Siquijor Island; and Cagayan de Misamis, Mindanao. The example from Bacon has already been recorded by Evermann and Seale.

Günther places this species under the genus Glyphisodon, but in the five examples cited above there is a weakly developed denticulation along the angle of the preopercle.

This species is evidently not common in the Philippines, though it occurs from the coast of China throughout the East Indies to New Guinea.

\section{POMACENTRUS TAENIURUS Bleeker}

Pomacentrus taeniurus BleEkER, Act. Soc. Sci. Ind. Neerl. 1 (1856) 51; GüNTher, Cat. Fishes 4 (1862) 22; var., Cartier, Verh. Phys. Med. Ges. Würzburg (1873) 100; BLEEKER, Nat. Verh. Holl. Maats. Wet. 2 (1877) 47; Atlas Ichth. 9 (1878) pl. 408, fig. 2; EvERMANN and Seale, Bull. U. S. Bur. Fisheries 26 (1907) 89.

Dorsal XIII, 10 or 11 ; anal II, 10 or 11 ; scales in lateral series 26; with tubules 16 to 18 ; between lateral line and origin of dorsal 3 or 4 ; between lateral line and vent 9 .

Body oblong, rather elongate; depth 2.4 to 2.7 in length; head 3.3 to 3.4 ; depth of caudal peduncle 6.3 to 6.9. The strongly convex interorbital 2.9 to 3.2 in length of head; the large circular eye 2.8 to 3.3 ; snout 3.4 to 3.9 , or shorter than maxillary, which is contained 2.7 to 3.1 in head. Mouth small and oblique; posterior end of maxillary below anterior border of eye; teeth in two rows, their edges truncate. Preorbital with a shallow notch anteriorly, its width at posterior end of maxillary less than half diameter of eye; lower edge of suborbital not serrated; the vertical limb of preopercle finely denticulated; opercle armed behind with two flat spines.

Head completely scaled excepting posterior limb of preopercle. Dorsal spines increasing in height toward behind. Middle rays of soft dorsal and posterior rays of soft anal filamentous; caudal deeply forked, the longest rays of each lobe filamentous. The short pectoral ends before anal opening, and the filamentous ray of ventral extends to base of anal spines.

Color in alcohol violet-brown, with a pearl-colored spot on each scale. A large dark spot above gill opening and a smaller one superiorly at base and axil of pectoral. Membranes of spinous dorsal narrowly edged with brown; pectoral and poste- 
rior portion of dorsal and anal yellowish; caudal with a distinct dark violet stripe on each lobe, the middle rays yellowish.

Here described from eighteen specimens, 29.5 to 67 millimeters long, from Buguey, Cagayan Province; Guinobatan, Masbate; Culion Island; Tacloban, Leyte; Bantayan Island; Malampaya Sound and Puerto Princesa, Palawan; and Tambagaan and Bungau Islands, Sulu Archipelago. The species has been previously recorded by Cartier from two specimens taken in Ubay, Bohol ; by Bleeker and by Evermann and Seale from specimens labeled "Philippine Islands." The lone specimen from Bantayan is now in the museum of Stanford University.

In the absence of scales on the vertical edge of preopercle and of the yellow color on the posterior portion of the tail, this species differs from Pomacentrus violascens Bleeker, which it resembles closely.

It is well distributed in the Indo-Australasian Archipelago. Elsewhere it is known from Faté and Tahiti.

\section{POMACENTRUS BIFASCIATUS Bleeker}

Pomacentrus bifasciatus BLEEKER, Nat. Tijd. Ned. Ind. 6 (1854) 330; Günther, Cat. Fishes 4 (1862) 18; Fische der Südsee 2 (1876) 226 ; DAY, Fishes of India (1878) 383.

Dichistodus bifasciatus BLEekm, Nat. Verh. Holl. Maats. Wet. 2 (1877) 88; Atlas Ichth. 9 (1878) pl. 401, fig. 3.

Dorsal XIII, 13; anal II, 13; scales in lateral series 25; with tubules 16 ; between lateral line and origin of dorsal 4 ; between lateral line and vent 10 .

Body oblong, 2 in length; head 3 ; depth of caudal peduncle 5.8. Interorbital space very slightly convex, its width 3 in length of head, or equal to length of maxillary; diameter of eye as long as snout, which is 3 in head. Jaws equal, the cleft of the small mouth oblique, maxillary extending posteriorly to below anterior edge of orbit; teeth biserial, compressed, with slightly rounded tips. Preorbital above angle of mouth less than half diameter of eye; edges of preorbital and suborbital smooth; preopercle denticulated behind.

No scales on snout, orbital ring, and vertical limb of preopercle. Middle dorsal spines higher than posterior ones. Soft portion of dorsal and anal slightly pointed; caudal a little emarginate, with the lobes rounded; tip of pectoral above anus, ventral reaching origin of anal fin.

Ground color yellowish brown, with two large black crossbands, one of which descends from front of spinous dorsal to 
opercles, and the other covers posterior dorsal spines and fades out below lateral line. Each side of head with traces of some bluish lines; all the fins yellowish.

Here described from a small specimen, 32 millimeters long, taken at Culion Island.

This is the first Philippine record of this species, which is known to occur elsewhere from the Andamans throughout the Indo-Australasian Archipelago to the Marshall Islands.

\section{POMACENTRUS PHILIPPINUS Evermann and Seale}

\section{Plate 3, Fig. 2}

Pomacentrus philippinus EvermanN and SeAms, Bull. U. S. Bur. Fisheries 26 (1907) 91, fig. 18.

Dorsal XIII, 13 or 14 ; anal II, 12 to 14 ; scales in lateral series 26 ; with tubules 17 or 18 ; between lateral line and origin of dorsal 3 or 4 ; between lateral line and vent 10 .

Body ovate, dorsal and ventral outlines similar and evenly arched, depth 2 to 2.1 in length; head 3.5 to 3.6 ; depth of caudal peduncle 6.3 to 6.8 . The width of the strongly arched interorbital 2.7 to 2.8 in length of head, slightly exceeding eye diameter, which is 2.9 to 3 in head; snout contained 3.3 to 4.3 in head; maxillary 3.2 to 3.3 , ending posteriorly below anterior margin of orbit or a little beyond it. Mouth oblique, jaws even, tip of snout on a level with lower margin of eye; each jaw with a series of very small teeth. Suborbital coarsely serrated, the anterior denticulation appearing to be enlarged; opercle with two flat spines behind, the upper one of which is scarcely noticeable.

Scales on top of head extending to tip of snout; orbitals and rest of head scaly, both dorsal and anal fins having a high sheath of scales at base. Dorsal spines increasing in height posteriorly. Soft vertical fins slightly rounded; caudal emarginate; both pectoral and ventral fins extending to vent.

Fresh specimens blackish violet, with a yellowish vertical streak on each scale; caudal fin yellow toward base and posterior rays of vertical fins similarly colored; a large black spot at outer and inner base of pectoral, and a large yellow area at axil.

An old alcoholic specimen purplish brown, with a light vertical streak on each scale; vertical fins blackish excepting the posterior rays, which are abruptly yellowish; ventrals also blackish, the rest of the fins dusky; pectoral with a large black spot entirely covering inner base, and a yellow area at axil. 
I described this species from a cotype, 50 millimeters long, from Bacon, Sorsogon, which is in the museum at Stanford University, and from five other specimens, 60 to 68 millimeters long, collected September, 1925, at Bogo, Cebu, one of which is a female about ready to spawn. The type specimen is in the United States National Museum.

\section{POMACENTRUS TROPICUS Seale}

Plate 4, Fig. 2

Pomacentrus tropicus Seale, Philip. Journ. Sci. § A 4 (1909) 517, pl. 12, fig. 1.

Dorsal XIII, 14; anal II, 14; scales in lateral series 25; with tubules 17; between lateral line and origin of dorsal 3; between lateral line and vent 9.

Body oblong, its greatest depth at origin of ventrals, 2 to 2.2 in length; head 3.1 to 3.3 ; depth of caudal peduncle 6.3 to 6.6. Interorbital space convex, contained from 2.6 to 2.8 in length of head; the diameter of the large, round eye 2.8 to 3.1 , or equal to length of maxillary; snout slightly pointed and a little shorter than maxillary, its tip a little below the horizontal line passing through lower margin of orbit. Mouth almost horizontal, jaws equal, maxillary terminating posteriorly below front edge of eye; teeth in a double series, with rounded tips. Suborbital ring and preopercle strongly serrated, the former with the anterior denticulation enlarged and followed by a cleft; opercle with two flat spines behind.

Scales on top of head extending to tip of snout; suborbital naked; base of vertical fins with a high sheath of scales. Dorsal spines increase in height posteriorly. Soft dorsal and anal slightly pointed; caudal slightly emarginate, with the lobes pointed; both pectoral and ventrals extending past vent, the latter with the outer ray filamentous.

Colors of fresh specimens are as follows: Top of head from tip of snout to base of spinous dorsal blackish; eye above edge of pupil also blackish, and rest of body bright orange yellow. Two short pearl white lines in front of each eye, another one on suborbital, and a few spots similarly colored on opercles. A black spot on shoulder, and a smaller one superiorly at base of pectoral; a pearl white line from each side of belly to anal fin. Outer edge of anterior anal rays and of spinous dorsal black; anus black. 
Almost uniform brownish yellow in alcohol, with whitish spots on opercles and cheeks, two short bluish lines in front of eyes, and an indistinct bluish stripe extending into anal rays from each side of belly; a black dot present above opercle, and a smaller one superiorly at axil of pectoral. All the fins yellowish; ventral, anal, and spinous dorsal tipped with dusky.

Here described from eight examples, 16 to 69 millimeters long, from Sialat Point, Catanduanes Island; Cebu, Cebu; and Tambagaan, Sibutu, and Sitankai Islands, Sulu Archipelago. The largest one, collected by Seale and Canonizado at Sitankai, is the type specimen, No. 4737, now in the Bureau of Science collection.

Contrary to Seale's account, this species has two rows of teeth.

\section{POMACENTRUS MOLUCCENSIS Bleeker}

Pomacentrus moluccensis BLEEKkR, Nat. Tijd. Ned. Ind. 4 (1853) 118; GÜNTHER, Cat. Fishes 4 (1862) 30; BLEEKER, Nat. Verh. Holl. Maats. Wet. 2 (1877) 56; Atlas Ichth. 9 (1878) pl. 402, fig. 3; EVERMANN and SEALE, Bull. U. S. Bur. Fisheries 26 (1907) 89; WEBER, Fische der Siboga Exped. (1913) 337.

Pomacentrus hebardi Fowler, Proc. Acad. Nat. Sci. Phila. 70 (1918) 46, fig. 18.

Dorsal XIII, 14; anal II, 13; scales in lateral series 25; with tubules 18 ; between lateral line and origin of dorsal 3 ; between lateral line and vent 10 .

Body ovate, its depth 2.1 in length; head 2.9; depth of caudal peduncle 6.7. The convex interorbital space 4 in head, as wide as diameter of eye or length of snout. Mouth oblique; jaws equal; the maxillary, which is shorter than eye, ends posteriorly below anterior edge of orbit; teeth in each jaw in two series, with the edges slightly rounded. Anteriormost tooth of suborbital enlarged and followed by a notch; opercle with two flat spines behind.

Only the orbital ring and posterior limb of preopercle naked; scales on top of head extending almost to tip of snout. Hind dorsal spines highest. Rayed dorsal more pointed than anal; lobes of the emarginate caudal fin rounded; pectoral and ventral extending beyond anal opening.

Yellowish brown in alcohol, with a light narrow vertical streak on most of the scales; a small brown spot above opercle and another one superiorly at base of pectoral; the light longitudinal line on anal fin has undoubtedly faded out.

Here described from a single specimen, 35 millimeters long, from Bantayan Island. This species has been recorded formerly 
from Bacon, Sorsogon, by Evermann and Seale; and an example from the "Philippine Islands" has been described by Fowler as Pomacentrus hebardi.

It is rather uncommon in the Indo-Australasian Archipelago, where it is known to occur.

\section{POMACENTRUS POPEI Evermann and Seale}

Plate 11, Fig. 2

Pomacentrus popei Evermann and Seale, Bull. U. S. Bur. Fisheries 26 (1907) 90, fig. 16.

Dorsal XIII, 14 or 15; anal II, 14 ; scales in lateral series 25 or 26; with tubules 18 ; between lateral line and origin of dorsal 3 ; between lateral line and vent 9 .

Body deep, 1.9 to 2 in length; head 3 to 3.1 ; depth of caudal peduncle 6.4 to 6.8 . Interorbital convex, 2.9 to 3 in head; snout 3.2 to 3.4 or about as long as maxillary, with the tip horizontally in front of lower margin of orbit; eye 2.6 to 3.2. Jaws equal in length, their posterior ends vertically below front edge of eye; teeth blunt and compressed, in a single series. Suborbital serrated, the first tooth enlarged and followed by a notch; opercle with a flat weak spine behind.

Preorbital and suborbital bones naked; scales on top of head extending to tip of snout; vertical fins with a high sheath of scales along base. Posterior dorsal spines highest, abnut as high as second anal spine. Soft dorsal more angular than soft anal; caudal emarginate, with the upper and lower lobes equal in length; pectoral and ventral reaching vent, the first ray of the latter more or less produced.

Uniformly yellowish in spirits, with a faint dusky margin on spinous dorsal and soft anal.

The Bureau of Science collection has two specimens, 37.5 and 48 millimeters long, which are here described. They are from Surigao and Cagayan de Misamis, Mindanao. The larger one, from the latter place, is a ripe female, collected in September, 1907.

This species was originally described by Evermann and Seale from the type specimen, No. 55903, from Bacon, Sorsogon, which is now in the United States National Museum. 
Dorsal XIII, 13 or 14; anal II, 13 or 14; scales in lateral series 26 ; with tubules 16 to 19 ; between lateral line and origin of dorsal 4 ; between lateral line and vent 10 .

Anterior profile rounded, body oblong, depth 1.9 to 2 in length; head 3 to 3.4 ; depth of caudal peduncle 6.4 to 6.7. Interorbital space strongly convex, 2.8 to 3 in length of head; snout and maxillary about equal in length, each slightly shorter than diameter of eye, which is 2.6 to 3.3 in head. Mouth small, slightly oblique; jaws equal; maxillary ending posteriorly below anterior margin of orbit; teeth in a single row in each jaw. Orbital ring above angle of mouth less than half diameter of eye, its outer edge denticulated, the first tooth enlarged and separated from the rest by a notch; opercle with a single spine at its hind margin.

Orbital ring naked; scales on top of head extending to nostrils. Dorsal spines increasing in height posteriorly, the last one as high as second anal spine. Soft dorsal and anal. angular, about equal in height; pectoral and ventral of the same length, both extending to origin of anal; caudal emarginate, the lobes pointed.

Ground color in alcohol blackish brown, lighter on the lower parts; pectoral fin whitish with a large black spot completely covering its base and axil ; the rest of the fins colored similarly as body; spinous dorsal with a black margin.

Of this species I have examined in the Bureau of Science collection fourteen specimens, 47 to 78 millimeters long, from Cabalian, Leyte; and Tambagaan, Bungau, Sibutu, and Sitankai Islands, Sulu Archipelago; also a cotype, 61 millimeters long, collected by C. J. Pierson at Bacon, Sorsogon. The smallest of the specimens, taken at Cabalian in May, 1921, is a female in near-breeding condition.

I have also examined another cotype of this species in the museum of Stanford University. Of the other cotypes there is one each at the Philadelphia Academy of National Sciences Museum, the United States National Museum, and the Indiana University Museum. The type, No. 55919, is in the United States National Museum.

\section{POMACENTRUS GRAMMORHYNCHUS Fowler}

Pomacentrus grammorhynchus FowLER, Proc. Acad. Nat. Sci. Phila. 70 (1918) 44, fig. 17.

Head 33; depth 15; D. XIII, 15, I; A. II, 15, I; P. II, 16, II; V. I, 5; tubes in upper arch of lateral line 18, and pores in straight section to caudal base $9 ; 3$ scales between spinous dorsal origin and lateral line, 
and 10 below 1.1. to spinous anal origin; 23 predorsal scales; head width 18 in its length; head depth about $1 \frac{1}{3}$; snout 3 ; maxillary 33 ; interorbital 23; first dorsal spine nearly 4; thirteenth dorsal spine 1t; eighth dorsal ray 18; second anal spine 2; sixth anal ray 18; least depth of caudal peduncle 17 ; ventral spine 1 .

Body robust, compressed, contour rather deeply ellipsoid, with greatest depth well over median region, predorsal slightly trenchant just before dorsal, otherwise edges convex, and profiles alike. Caudal peduncle compressed, length its least depth.

Head robust, moderately compressed, sides moderately convex, upper profile at first convex, then concave at occipital and predorsal bulging distinctly convexly. Snout convex over surface and in profile, length half its width. Eye rounded, little elevated, and hind pupil edge nearly midway in head length. Mouth broad, gape short, oblique, and jaws about even. Lips fleshy, rather narrow. Maxillary extends slightly beyond nostril, though not nearly to eye, and slips below preorbital. Teeth rather slender, somewhat compressed, pointed, crowded close to form an even cutting-edge in a single row. No teeth on mouth roof or on tongue. Inner buccal folds broad. Tongue thick, fleshy, apparently free in front. Nostril small pore about midway in snout length. Interorbital evenly convex. Preorbital broad, width about 13 in eye, ends behind in broad posteriorly directed spine. Lower suborbital and hind preopercle edges serrate, serræ on latter graduated longer below, and lower preopercle edge entire. Opercle with 2 blunt and inconspicuous spines, upper concealed by scales.

Gill-opening forward about opposite front eye edge. Rakers $6+13$, lanceolate, about half length of filaments and latter $1 \frac{1}{4}$ in eye. Pseudobranchiæ long as gill-filaments. Branchiostegal membrane short fold over short and constricted isthmus.

Scales finely ctenoid, largest over middle of side of trunk and become much smaller all about edges, in lengthwise rows parallel with upper arch of lateral line. All larger scales narrowly imbricated. All fin bases scaly. Short scale between ventral bases about length of spine. Suprascapula with 3 blunt points. Exposure of humeral scale little larger than pupil. Axillary ventral scale broad, pointed, $\frac{1}{4}$ length of spine. Cheek with 3 rows of scales. Suborbitals, preorbital, snout edge, lips and chin naked. Upper arch of 1.1. extends below front dorsal rays, concurrent with upper limit of squamation on dorsals. Tubes large, simple, and each extending well over scale exposure. Pores in straight section small, inconspicuous, simple or double irregularly, and not on caudal base.

Spinous dorsal origin about opposite that of pectoral, spines all more or less subequally high, edge of fin notched and slight cutaneous flap behind each spine tip. Soft dorsal inserted about last third in space between upper hind preopercle edge and caudal base, fin rounded with median rays longest. Anal inserted about midway between pectoral origin and caudal base, first spine about $\frac{3}{3}$ of second. Soft anal similar to soft dorsal. Caudal deeply emarginate, upper lobe much larger, $3 \mathbf{s}$ in combined head and trunk. Pectoral broad, about long as upper caudal lobe, reaches hind edge of vent and upper rays longest. Ventral inserted close behind peetoral base, reaches anal, and spine slightly over half length of fin.

Color in alcohol largely chocolate-brown above and posteriorly, head, breast and belly anteriorly paler or faded in appearance. Iris slaty. 
Dorsals and anals blackish-brown. Caudal pale brownish. Pectoral brownish, with large blackish-brown blotch, nearly large as eye on base mostly above. Ventral blackish-brown, rays and spine pale. Dusky line from snout tip to eye.

Length $115 \mathrm{~mm}$.

Type, No. 47,518, A. N. S. P.

Philippine Islands. Presented by the Commercial Museums of Philadelphia.

Allied with $P$. melanopterus Bleeker, but differs in the presence of the dark line from the eye to the snout.

An exact copy of Fowler's original description is reproduced above, there being no example of this species available for examination in the Bureau of Science collection.

POMACENTRUS ElONgatus Seale

Pomacentrus elongatus Seale, Philip. Journ. Sri. § A 4 (1909) 518, pl. 12, fig. 2.

Dorsal XIII, 13 or 14 ; anal II, 13 or 14; scales in lateral series 26 ; with tubules 18 ; between lateral line end origin of dorsal 4; between lateral line and vent 10 .

Body elongate, dorsal outline evenly curved from tip of snout to caudal peduncle, ventral outline similar to dorsal; depth 2.2 to 2.3 in length; head 3.3 to 3.5 ; depth of caudal peduncle 6.7 to 7 . Interorbital space convex, its width 3.1 to 3.3 in length of head; snout rounded, 3 to 3.1 in head or a little longer than maxillary, which is contained 3.3 in head; eye rather small, its diameter 3.8 in head. Mouth slightly oblique, jaws equal, posterior end of maxillary below anterior edge of orbit; two series of teeth in each jaw. Suborbital strongly denticulate, first tooth enlarged and followed by a wide shallow notch; opercle with two flat spines behind.

Scales on top of head extending to nostrils, leaving a naked space near tip of snout; orbital ring also naked; vertical fins with a rather high sheath of scales at base. Dorsal spines slender, becoming higher to the last; second anal spine higher than last dorsal. Soft vertical fins about equal in height, with their tips angular; caudal emarginate, with the lobes pointed; pectoral almost as long as head, its tip above vent; ventrals extending to origin of anal, its first ray filamentous.

Deep brown in alcohol, with a black spot above opercle, a bluish line above orbit, another one superiorly behind eye, a short one across preorbital, and several rather indistinct bluish spots on cheeks. Ventrals blackish, the other fins brownish. 
The above description is that of an example, 83 millimeters long, from Tanjay, Oriental Negros, and of a type, 59 millimeters long, collected at Limbones Cove at the entrance to Manila Bay.

\section{POMACENTRUS DORSALIS Gill}

Pomacentrus dorsalis GiL, Proc. Acad. Nat. Sci. Phila. (1859) 147; GÜNTher, Cat. Fishes 4 (1862) 29; SNYder, Proc. U. S. Nat. Mus. 42 (1912) 504.

Pomacentrus emarginatus CuviER and VALenciennes, Hist. Nat. Poiss. 5 (1830) 316; Lesson, Voy. Coquille, Zool. (1830) 189; Atlas Poissons (1826) pl. 28, fig. 1.

Pomacentrus chrysurus Cuvier and Valenciennes, Hist. Nat. Poiss. 5 (1830) 317; MEYER, Ann., Soc. España Hist. Nat. 14 (1885) 34. Pomacentrus trilineatus Blesker, Atlas Ichth. 9 (1878) pl. 406, fig. 2. Pomacentrus delurus Jordan and Seale, Proc. U. S. Nat. Mus. 28 (1905) 783.

Dorsal XIII, 14 or 15; anal II, 14 or 15; scales in lateral series 25 ; with tubules 17 or 18 ; between lateral line and origin of dorsal 3 or 4 ; between lateral line and vent 9 or 10 .

Body ovate, dorsal profile of head slightly more arched than ventral; depth of body 2 in length; head 2.8 to 3.1 ; depth of caudal peduncle 6.3 to 6.7. Interorbital space evenly convex, 3.3 to 4 in length of head; snout short, 3.4 to 3.7 , and shorter than either maxillary or diameter of eye, its tip on a level with lower margin of orbit; eye 2.6 to 3.5 in head; maxillary 2.9 to 3.5. Mouth small, jaws even, the posterior end of maxillary under or a little before front edge of eye; teeth biserial in each jaw. Orbital ring with the anterior denticulation enlarged and followed by a notch, its width at hind end of maxillary less than diameter of pupil; preopercle distinctly serrated.

A very narrow naked area near tip of snout; orbital ring and vertical limb of preopercle also naked. Dorsal spines increasing in height toward the last. Soft vertical fins slightly rounded; caudal emarginate; tip of pectoral a little before vent, ventrals extending beyond it.

Ground color varying from dusky green to yellowish brown in alcohol, with obscure light spots. In the young there is a large, blue-edged, black ocellus along the middle of the fourth to the eleventh dorsal ray A distinct black spot at origin of lateral line but none on top of caudal peduncle. The small dark spot at base of pectoral has faded in many of the specimens. There is a short bluish streak in front of eye, and a longer one immediately below orbit. Anal and ventrals blackish; dorsal 
fin colored similarly as body; caudal yellow toward base, this yellow area abruptly and sharply marked from the ground color.

Twenty-five examples, 42.5 to 53.5 millimeters long, have been examined, from Paraoir, Balaoan, La Union; Puerto Galera and Calapan, Mindoro; Culion Island, Canigaran, and Balabac Island, Palawan; Surigao, Mindanao; and Sibutu and Sitankai Islands, Sulu Archipelago. Two specimens from Negros have been described by Jordan and Seale as Pomacentrus delurus.

This species is known elsewhere from Amboina, and the seas of China and Japan.

\section{POMACENTRUS TRIPUNCTATUs Cuvier and Valeneiennes}

Pomacentrus tripunctatus CUvier and VALenciennes, Hist. Nat. Poiss. 5 (1830) 315; GüNTHER, Cat. Fishes 4 (1862) 33; JORDAN and SNYDER, Proc. U. S. Nat. Mus. 24 (1902) 604; EvERMaNn and Spale, Bull. U. S. Bur. Fisheries 26 (1907) 89; Valllant, Nouv. Arch. Mus. Hist. Nat. 5 (1893) 57.

Pomacentrus vanicolensis CuviER and VALenciennes, Hist. Nat. Poiss. 5 (1830) 316.

Pomacentrus littoralis CUvigr and VALenciannes, Hist. Nat. Poiss. 5 (1830) 318; Günther, Cat. Fishes 4 (1862) 32; EVERManN and SEalw, Bull. U. S. Bur. Fisheries 26 (1907) 89; Jordan and RichARDsoN, Bull. U. S. Bur. Fisheries 27 (1908) 263.

Pomacentrus trilineatus Cuvier and Valmenciennes, Hist. Nat. Poiss. 5 (1830) 321; Gunther, Cat. Fishes 4 (1862) 25; BleEkrR, Nat. Verh. Holl. Maats. Wet. 2 (1877) 61 (in part); Atlas Ichth. 9 (1878) pl. 406, fig. 6; DAY, Fishes of India (1878) 382; JORDAN and SNYDER, Proc. U. S. Nat. Mus. 23 (1901) 753; W EBER, Fische der Siboga Exped. (1913) 337; AHL, Blätter der Aquarien- und Terrararienkunde 36 (1925) with one text figure.

Pomacentrus brocellatus RüPPMn, Neue Wirbelthiere, Fische (1835) 127, pl. 31, fig. 3.

Pomacentrus katunko BLअFkझR, Nat. 'rijd. Ned. Ind. 3 (1862) 169. Pomacentrus punctatolineatus CARTIER, Verh. Phys. Med. Ges. Würzburg (1873) 98.

Pomacentrus dimidiatus BleskKr, Nat. Verh. Holl. Maats. Wet. 2 (1877) 63; Atlas Ichth. 9 (1878) pl. 406, fig. 8.

Dorsal XIII, 13 to 15 ; anal 13 to 16 ; scales in lateral series 25 ; with tubules 15 to 19 ; between lateral line and origin of dorsal 3 or 4 ; between lateral line and vent 10 .

Body generally ovate, the form, however, varying with age; depth contained 1.9 to 2.1 in length; head 2.9 to 3.4 ; depth of caudal peduncle 6 to 6.9. Interorbital strongly convex, slightly narrower than length of snout and contained from 3 to 4.2 in head; snout rather rounded in very large individuals and slightly pointed in smaller ones, its length varying from 2.6 to 3.7 in length of head or slightly greater than diameter of 
eye, which is contained 2.8 to 3.9 in head; mouth small, nearly horizontal; jaws even; maxillary ending posteriorly before front margin of orbit; teeth in two rows, with the tips slightly rounded. Orbital ring at angle of mouth slightly wider than half diameter of eye; anteriormost tooth of suborbital enlarged and followed by a notch; posterior edge of preopercle distinctly serrated.

Scales on head extend to nostrils, leaving a narrow naked space near tip of snout; no scales on orbital ring or on hind edge of preopercle. Dorsal spines evenly graduated toward the last, which is the highest. Pectoral shorter than ventral and not reaching vent; soft vertical fins slightly rounded; caudal distinctly emarginate.

Deep yellowish brown in alcohol, lighter behind and below; each scale in the young with one or more bluish dots, which become less distinct in the adult. Three black spots, one at origin of lateral line, another superiorly at base of pectoral, and the third on caudal peduncle, appear to be a distinctive character. In very large individuals the whitish spot immediately behind soft dorsal, which indicates the presence of the black spot on the tail, is absent. The ventral and vertical fins are usually darker, and the other fins lighter than the ground coloration. In the very young the bluish lines on top and sides of head are rather wide and are continued backward as a mass of spots toward a dark ocellus, which covers most of the posterior dorsal spines and anterior rays. In slightly older specimens the lines are narrower and some of the spots are absent, while the dorsal ocellus is reduced in size, sometimes occupying the anterior third of soft dorsal or covering the last one or more spines and a few anterior dorsal rays. In the next stages most of the blue spots are absent and there appears to be no connection between the ocellus and the lines. In a 45millimeter example this ocellus is absent and the lines on the head, which gradually disappear with age, are very narrow.

I have examined in the Bureau of Science collection ninetyeight specimens, 23 to 100 millimeters long, from the following localities: Balaoan, La Union; Atimonan, Tayabas; Taal Lake; Puerto Galera and Calapan, Mindoro; Bacon, Sorsogon; Culion Island and Malampaya Sound, Palawan; Estancia, Panay; Borongan, Samar; Bantayan Island and Cebu, Cebu; Tagbilaran, Bohol; Siquijor, Siquijor Island; Cagayan de Misamis, Samal Island, and Zamboanga, Mindanao; and Sitankai Island, Sulu Archipelago. Thirteen specimens, 45 to 55 millimeters, from 
Calapan, are ripe females; two, 55 and 61 millimeters, collected January, 1921, are ripe males; 3 from Puerto Galera, 54 to 57 millimeters, March to May, 1912, are ripe females. Four of the specimens from Malampaya Sound and Zamboanga, measuring from 67.5 to 100 millimeters in length, and taken in October, 1910 , and June, 1925, respectively, are females about ready to spawn. It is also interesting to note that a ripe female, $65 \mathrm{mil}-$ limeters long, was collected in February, 1922, at Lake Taal, which is a fresh-water lake.

This species has been recorded before in the Philippines from Bohol by Cartier; from Bacon by Evermann and Seale; from Cavite by Jordan and Seale and by Jordan and Richardson; and from Sanguisiapo, Sulu Archipelago, by Weber. The specimens constitute an interesting series and show every intermediate variety in form and color. The chief character, upon which this species is based, is the presence of three black spots; namely, one above the operculum, another on top of the tail, and a third on the anterior dorsal rays and partly on the posterior dorsal spines. Pomacentrus dimidiatus Bleeker, for example, represents a stage in this series in which the dorsal ocellus is small and confined to the last dorsal spine and the first two or three dorsal rays.

This species is very common in the Indo-Pacific regions from the Red Sea and the east coast of Africa to the South Sea islands.

\section{POMACENTRUS AMBOINENSIS Bleeker}

Pomacentrus amboinensis BLFEKBR, Versl. Akad. Amsterdam 2 (1868) 334; Nat. Verh. Holl. Maats. Wet. 2 (1877) 58; Atlas Ichth. 9 (1878) pl. 406, fig. 7; W EBER, Fische der Siboga Exped. (1913) 339.

Dorsal XIII, 14 or 15; anal II, 14 or 15; scales in lateral series 26 ; with tubules 17 to 19 ; between lateral line and origin of dorsal 4 ; between lateral line and vent 10 .

Body ovate and compressed, with upper and lower profiles about equally arched, depth 2.1 in length; head 3.2 to 3.3 in length of body; depth of caudal peduncle about twice in length of head or 6.5 to 6.7 in that of body. Interorbital space evenly convex, about as broad as length of maxillary, which is 3.1 to 3.3 in head; eye circular, superior, its diameter 2.9 to 3.2 in head; the short, bluntly rounded snout 3.2 to 3.5 in length of head; width of preorbital at posterior end of maxillary about a third of eye diameter. Mouth small and slightly oblique, jaws even; teeth in a double series, with slightly rounded edges; maxillary ending posteriorly below anterior edge of orbit; orbitals 
serrated, with first tooth enlarged and followed by a notch; posterior edge of preopercle distinctly serrated; opercle with a flat spine behind.

Scales on top of head extending to in front of nostrils; orbital ring and vertical limb of preopercle naked. Dorsal spines increasing in height toward the last, which is 1.7 in head; second anal spine as high as last dorsal ; the rayed portions of dorsal and anal fins slightly angular; caudal fin emarginate, with the upper lobe slightly the more produced; pectoral slightly shorter than head, its tip above anterior edge of anus; outer ray of ventral produced and reaching to behind anus.

Fresh specimens bright yellow in color, with pearl white spots scattered on each side of head and breast; a short pearl white line in front of each eye and a longer one just below it on suborbital; all the fins colored similarly to body; anal with two pearl white longitudinal lines; caudal and spinous portion of dorsal edged with blackish; a large black spot superiorly at base of pectoral and a smaller one at origin of lateral line; anus black.

Ground color yellowish brown in alcohol, the pearl white markings on head and breast becoming dull; the two white longitudinal lines on anal nearly faded out.

Here described from two specimens, 58 and 60 millimeters long, from Bantayan Island and from Sitankai Island, Sulu Archipelago.

This species, which is new to the Philippines, is known elsewhere only from Banda and Amboina.

\section{POMACENTRUS SIMSIANG Bleeker}

Pomacentrus simsiang BlEEkER, Nat. Tijd. Ned. Ind. 11 (1856) 90; GüNTHeR, Cat. Fishes 4 (1862) 22.

Pomacentrus bankanensis GÜNTHER, Cat. Fishes 4 (1862) 26.

Pomacentrus trilineatus BLEEKER, Atlas Ichth. 9 (1878) pl. 406, figs. $1,3,4$, and 5 .

Pomacentrus taeniometopon BLEEKre, Nat. Tijd. Ned. Ind. 3 (1852) 283; GüNTHER, Cat. Fishes 4 (1862) 25.

Pomacentrus burroughi Fowler, Proc. Acad. Nat. Sci. Phila. 70 (1918) 44, fig. 17.

Dorsal XIII, 13 to 15; anal II, 13 to 15; scales in lateral series 25 ; with tubules 15 to 19 ; between lateral line and origin of dorsal 3 ; between lateral line and vent 10 .

Body ovate, depth varying from 2 to 2.2 in. length; depth of caudal peduncle equal to or slightly less than length of head, which is 2.9 to 3.3 in that of body. Eye round, diameter ranging 
from 2.9 to 3.3 in head, larger in younger specimens, proportionately, than in older ones; interorbital space strongly convex, 3.2 to 3.7 in head; snout 3.1 to 4 , with its tip on a level with lower margin of orbit; mouth small, maxillary ending posteriorly below front edge of eye and contained 3 to 3.5 in head. Teeth in a double series, with the tips rounded; orbital ring with the anteriormost serration enlarged and separated from the rest by a notch; width of preorbital at angle of mouth narrow, being slightly less than half an eye diameter; preopercle with distinct serrations behind.

The narrow area between tip of snout and nostrils naked; orbital ring and vertical limb of preopercle also unscaled. Dorsal spines gradually increasing in height posteriorly, the last one being higher than the second anal spine. The soft vertical fins slightly rounded; caudal slighly emarginate; pectoral extending to above anus; ventrals reaching origin of anal fin.

Yellowish green to yellowish brown in alcohol; caudal yellowish toward base, this yellow area not abruptly set off from the ground color; head with some bluish longitudinal lines along forehead; upper parts of body and sides of head with spots of similar color. There is a black spot above opercle and a light center on most of the scales of body. With the exception of the opercular spot, the above color markings become indistinct with age. The lines on head are continued in the form of spots toward the dark blue-edged ocellus along the dorsal fin. In the very young this ocellus is merely a large irregular dark blotch surrounded by numerous, more or less connected, bluish white spots, and covers a large portion of the rayed dorsal. In older specimens the ocellus is smaller and more regular in form, with a distinct ring around it. In some examples the ocellus is on the middle rays, in others it is slightly more anterior or posterior. There is a black spot superiorly at base of pectoral but none on top of caudal peduncle. Some examples have one or more light longitudinal lines along anal fin.

I have examined in the Bureau of Science collection over a hundred specimens, 22 to 69 millimeters long, coming from the following localities: Hundred Islands, Pangasinan; Limbones Cove, Batangas; Puerto Galera, Mindoro; Bacon, Sorsogon; Guinobatan, Masbate; Borongan, Samar; Estancia, Panay ; Bantayan Island and Cebu, Cebu; Cabalian, Leyte; Tagbilaran, Bohol ; Canigaran, Puerto Princesa, and Balabac Island, Palawan; and Siasi and Sitankai Islands, Sulu Archipelago. Two specimens from Balabac Island, measuring 46 and 49 millimeters 
long, are ripe females; the larger specimen was collected in May, 1921, and the smaller one in September, 1925.

Fowler's Pomacentrus burroughi is evidently this species, which is separated from Pomacentrus tripunctatus Cuvier and Valenciennes by the absence of the black spot on the caudal peduncle.

This species is found throughout the East Indies, and ranges northward to the China Sea.

\section{POMACENTRUS CHRYSOPOECILUS Schlegel and Müller}

Plate 11, Fig. 1

Pomacentrus chrysopoecilus ScHLEGEL and MüLher, Overz. Amphi. Verh. Nat. Ges. Ned. Overz. Bezitt. (1839) 21, pl. 5, fig. 3; BцбљкҢR, Nat. Tijd. Ned. Ind. 3 (1852) 284; GüNTHER, Cat. Fishes 4 (1862) 20 ; MEYER, Ann., Soc. España Hist. Nat. 14 (1885) 34:

Dichistodus chrysopoecilus BLEEKER, Nat. Verh. Holl. Maats. Wet. 2 (1877) 84; Atlas Ichth. 9 (1878) pl. 406, fig. 9.

Pomacentrus pristigir JoRdAN and RICHARDSON, Bull. U. S. Bur. Fisheries 27 (1908) 263.

Dorsal XIII, 13 to 15; anal II, 13 or 14; scales in lateral series 26 ; with tubules 17 or 18 ; between lateral line and origin of dorsal 4 ; between lateral line and vent 10 .

Body oblong, rather thick and elongate; dorsal profile deeper than ventral, more arched anteriorly; greatest depth of body 2.1 to 2.3 in length; head short, 3.2 to 3.4 ; depth of caudal penducle 5.6 to 6.2. Snout long, slightly pointed, 2.5 to 2.9 in length of head, being longer than the width of the strongly arched interorbital, which is equal to or greater than length of maxillary; eye round, rather small, its diameter contained 3.6 to 4.5 in head, or shorter than maxillary. Mouth slightly oblique, its angle well in front of eye; tip of snout well below inferior margin of orbit; teeth compressed, slightly pointed, in a single series. Width of preorbital at posterior end of maxillary more than half diameter of eye; suborbital and preopercle strongly and evenly serrated; opercle with a single flat spine behind.

Scales on top of head advancing to front edge of orbit, leaving a naked space from there to tip of snout; the rest of head and body well covered with large ctenoid scales. Dorsal spines growing consecutively higher to the last, which is as high as second anal spine. Soft dorsal and anal rounded and about equal in height; caudal very slightly emarginate, the lower lobe shorter and more rounded than the upper; pectoral not quite reaching vent; ventral longer than pectoral, its tip at vent. 
Color in alcohol dark brown, with a large white spot on the back between lateral line and base of seventh and eighth dorsal spines. A large black spot above operculum; a bluish transverse streak on each scale; a white line on suborbital. Ventral and anal blackish.

The above account is based upon fifty-one examples, 33 to 125 millimeters in length, coming from the following localities: Puerto Galera, Mindoro; Canigaran, Palawan; Tagbilaran, Bohol; Clarendon Bay, Balabac Island; Samal Island and Zamboanga, Mindanao; and Sibutu and Sitankai Islands, Sulu Archipelago.

Previously known in the Philippines from an example collected by A. B. Meyer in Cebu, and from another one recorded from Cuyo by Jordan and Richardson as Pomacentrus pristigir. According to the authors, the Cuyo specimen had the following life colors : Body dull dark-green; fins dark brown; a line under each eye and a spot in front of eye; some spots on top of head of a rich violet color; opercles faintly washed with violet.

This well-marked species is known only from the East Indies.

POMACENTRUS NOTOPHTHALMUS Bleeker

Pomacentrus notophthalmus BLEEkER, Nat. Tijd. Ned. Ind. 4 (1853) 137; Act. Soc. Sci. Ind. Neerl. 1 (1856) 51; Günther, Cat. Fishes 4 (1862) 20; JoRdan and Seale, Bull. U. S. Bur. Fisheries 25 (1906) 280.

Dichistodus notophthalmus BLEEKER, Nat. Verh. Holl. Maats. Wet. 2 (1877) 82; Atlas Ichth. 9 (1878) pl. 401, fig. 4, and pl. 402, fig. 4.

Pomacentrus suluensis SEALE, Philip. Journ. Sci. § A 4 (1909) 519.

Dorsal XIII, 13 to 15 ; anal II, 13 or 14, scales in lateral series 26 ; with tubules 17 or 18 ; between lateral line and origin of dorsal 4 ; between lateral line and vent 10 .

Body ovate, dorsal outline slightly deeper than ventral; depth of body 2 in length; head 2.9 to 3 ; depth of caudal peduncle 5.7 to 6 . Interorbital convex, 3.3 to 3.7 in length of head, about as wide as length of snout, which is contained 3.3 to 3.4 in head; eye round and fairly large, its diameter about as long as maxillary, which is contained 3 to $3.1 \mathrm{in} \cdot$ head and ends posteriorly below anterior edge of orbit. Mouth oblique, jaws equal, tip of snout slightly pointed and on a level with inferior margin of eye; two rows of compressed and slightly pointed teeth in each jaw. Width of preorbital at angle of mouth almost equal to half the orbit's diameter; lower edge of orbital and vertical limb 
of preopercle strongly serrated; opercle armed behind with two flat spines.

Area between nostrils and tip of snout naked; orbital and posterior edge of preopercle also naked. The middle dorsal spines highest. Soft vertical fins slightly rounded; caudal emarginate, with the lobes rounded; pectoral ending above anal opening, ventral extending beyond it.

Brownish in alcohol, with a pearl-colored vertical band descending below the third, fourth, and fifth dorsal spines, and with a second pearl white crossband through the soft vertical fins in very young examples. A large blackish blotch on the ninth, tenth, and eleventh dorsal spines near base. Spinous dorsal narrowly edged with black; ventral and anal dusky; the other fins yellowish. A dark round spot superiorly on opercle; a short bluish white line in front of eye and another immediately under orbit; pearly white dots scattered on cheek; an indistinct light spot or streak on each scale.

Here described from eight specimens, 21 to 38.5 millimeters long, coming from Cuyo; Samal Island, Mindanao; and Sibutu and Sitankai Islands, Sulu Archipelago. A careful examination of Pomacentrus suluensis Seale shows that it is only the young of the present species, with the serration of the suborbital still undeveloped.

This species is found in small numbers in the Indo-Australasian Archipelago and in the islands of the South Seas. Jordan and Seale have recorded it from the islands of Woodlark, Faté, and New Hebrides.

POMACENTRUS PROSOPOTAENIA Bleeker

Pomacentrus prosopotaenia BLEEKER, Nat. Tijd. Ned. Ind. 3 (1852) 67; GüNTHER, Cat. Fishes 4 (1862) 23; Fowler and Bean, Proc. U. S. Nat. Mus. 62 (1922) 45.

Dichistodus prosopotaenia BLFEKER, Nat. Verh. Holl. Maats. Wet. 2 (1877) 80 ; Atlas Ichth. 9 (1878) pl. 407, fig. 8.

Pomacentrus n. sp. Cartier, Verh. Phys. Med. Ges. Würzburg (1873) 100.

Dorsal XIII, 13 or 14 ; anal II, 13 or 14 ; scales in lateral series 25 or 26 ; with tubules 16 to 18 ; between lateral line and origin of dorsal 4 ; between lateral line and vent 10 .

Body markedly oblong, upper profile of head steep and very slightly arched; depth 2 to 2.1 in length; head 3.3 to 3.4 ; depth of caudal peduncle 5.7 to 6.2 . Interorbital strongly convex, 3.1 to 3.4 in length of head; snout long, slightly pointed, 2.6 to 2.8 , 
its tip away below the horizontal line passing through lower edge of orbit; maxillary short, 3.2 to 3.3, ending in front of eye; eye small and round, 3.4 to 4.2. Cleft of mouth almost horizontal, jaws even; width of preorbital at angle of mouth greater than half diameter of eye; teeth biserial, compressed, with slightly rounded tips. Suborbital and hind edge of preopercle strongly serrated; opercle terminating in a large flat spine.

Scales on head extend to the bluish line between the orbits, the area below and in front of this line naked; orbitals and inferior limb of preopercle also naked. Dorsal spines increasing gradually in height to the last. Rayed dorsal and anal fins angular; caudal fin emarginate, with the lobes rounded; pectoral and ventral about equal in length, both ending at vent.

Ground color in alcohol yellowish olive, dusky below the soft dorsal and on anterior half of body. Each scale with a bluish vertical streak; head, anterior portion of trunk, and base of vertical fins irregularly dotted with blue. A bluish white line in front and between eyes; another from orbit, convergent at snout; a third one across suborbital; one or two more or less broken lines on cheek; a small black spot above opercle. Axil of pectoral entirely blackish violet; anal tipped with grayish and provided with a bluish longitudinal line near margin.

The above description is based upon an examination of six fairly large specimens, $\mathbf{7 5}$ to $\mathbf{1 1 8 . 5}$ millimeters long, obtained at Bantayan Island and at Sitankai Island, Sulu Archipelago. The only previous Philippine records of this species are from Zamboanga by Fowler and Bean, and from Cebu by Cartier as Pomacentrus n. sp.

This species appears close to Pomacentrus trimaculatus Cuvier and Valenciennes, agreeing with it in the general form of the body and in some details of color pattern, but differing from it in having a slightly deeper body and a large black spot at the axil of the pectoral. With the exception of the broad dark band on the anterior half of the body, the examples above described agree with Bleeker's figure.

The species is known from the coast of Singapore throughout the East Indies to New Guinea.

\section{POMACENTRUS TRIMAcUlatUS Cuvier and Valenciennes}

Plate 12, Fig. 2

Pomacentrus trimaculatus CuVIFR and VALanciennes, Hist. Nat. Poiss. 5 (1830) 320; ScHLeger and MüLlwr, Overz. Amphi. Verh. Nat. Ges. Ind. Overz. Bezitt. (1839) 20, pl. 4, fig. 2; Bцमझкв, Nat. Tijd. Ned. Ind. 4 (1853) 481; GÜNTHER, Cat. Fishes 4 (1862) 
19; Fische der Südsee 2 (1876) 227; DAY, Fishes of India (1878) 382, pl. 80, fig. 10; JORDAN and SEAle, Bull. U. S. Bur. Fisheries 25 (1906) 280; EvermanN and Seace, Bull. U. S. Bur. Fisheries 26 (1907) 89.

Dichistodus trimaculatus BLFEKвR, Nat. Verh. Holl. Maats. Wet. 2 (1877) 79; Atlas Ichth. 9 (1878) pl. 404, fig. 5.

Dorsal XIII, 13 or 14 ; anal II, 13 or 14 ; scales in lateral series 26 ; with tubules 15 to 18 ; between lateral line and origin of dorsal 4 ; between lateral line and vent 10 .

Body oblong, a little elongate, profiles similar; depth 2.1 to 2.3 in length; head 3.1 to 3.4 ; depth of caudal peduncle 5.5 to 6.1. Interorbital space strongly convex and moderately wide, being 3.2 to 3.8 in length of head or a little wider than the diameter of the small, round eye, which is contained 3.8 to 4.1 in head; snout long and slightly pointed, decidedly longer than either maxillary or diameter of orbit, being 2.5 to 2.9 in head, its tip below the horizontal line passing through inferior margin of eye. Mouth small, almost horizontal; maxillary 3.2 to 3.5 in head, ending posteriorly a trifle behind nostrils, teeth in a double series, compressed, with slightly rounded tips. Width of preorbital above posterior end of maxillary nearly equal to diameter of eye; suborbital and posterior edge of preopercle strongly and evenly serrated; opercle with a flat spine behind.

Snout in front of nostrils, orbital ring and vertical limb of preopercle bone naked. Dorsal spines evenly graduated to the last, which is as high as second anal spine. Rayed dorsal and anal slightly angular and of nearly the same height; ventral longer than pectoral, ending opposite vent.

Color in spirits yellowish, with three large blackish spots along back; one at origin of dorsal fin; the second below the seventh, eighth, ninth, and tenth spines; the third at the base of the last dorsal rays; the last two spots disappearing below lateral line. A light band on nape; two bluish lines across interorbital; another along suborbital, extending into more or less connected dots on preorbital; some scattered bluish spots on sides of head and on scales of vertical fins, and a narrow transverse streak of the same color on each scale of body. Anal with a longitudinal stripe along the middle, dorsal with two. A dark blotch surrounding vent and none on axil of pectoral.

The fourteen Bureau of Science specimens above described measure 41 to 120 millimeters in length, and were collected at Puerto Galera, Mindoro; Busuanga Island; Halsey Harbor, Cu$223796-5$ 
lion Island; Cebu, Cebu; Tagbilaran, Bohol ; Zamboanga, Mindanao; and South Ubian and Tango Islands, Sulu Archipelago. The species was first known in the Philippines from Bacon, Sorsogon, and from San Fabian, Pangasinan, as recorded by Evermann and Seale.

This species, easily recognized by the three large dark blotches on the upper parts of the body and by a large dark area around the vent, ranges from the Andamans eastward throughout the East Indies, New Guinea, and Micronesia, and northward to the coast of China.

\section{POMACENTRUS MELANOCHIR Bleeker}

Plate 12, Fig. 1

Pomacentrus melanochir BLEEKER, Nat. Verh. Holl. Maats. Wet. 2 (1877) 49; Atlas Ichth. 9 (1878) pl. 408, fig. 4.

Dorsal XIII, 10; anal II, 14; scales in lateral series 26 ; with tubules 17; between lateral line and origin of dorsal 4 ; between lateral line and vent 9.

Body ovate-oblong; slightly elongate; profiles about evenly arched; depth 2.5 in length; head 3.4 ; depth of caudal peduncle 6.6. Interorbital space strongly arched, wide, 3.4 in length of head; maxillary as long as eye diameter, each equal to width of interorbital; snout short and rounded, 4 in head. Cleft of mouth very oblique, lower jaw projecting, maxillary ending posteriorly in front of orbit; teeth in two rows, compressed and truncate. Suborbital and posterior edge of preopercle strongly denticulate, the width of the former behind angle of mouth about a third of eye diameter; opercle armed behind with two flat, sharp spines.

Scales on head extending to nostrils; orbitals and edges of preopercle naked; dorsal and anal fins with a low sheath of scales at base. Dorsal spines increasing in height posteriorly, the last one higher than the second anal spine. Soft dorsal and anal about equal in height, forming posteriorly acute angles; caudal deeply forked, with the lobes pointed; ventral slightly longer than pectoral, the latter extending to base of anal spines.

Color in alcohol brownish violet, with a light vertical streak on each scale; vertical fins and ventrals blackish; spinous dorsal with darker margin; pectoral and caudal fins yellowish, the former a little paler and with a large blackish blotch covering its base and axil. There is an indistinct dark spot at origin of lateral line. 
Described from a single specimen, 66 millimeters long, from Cabalian, Leyte, which is the first recorded from the Philippines. In the arrangement of scales on the head, in the general form of the body, and in color markings, this species is closely related to Pomacentrus coelestis Jordan and Starks, of Japan.

Known in the East Indies from Bali, Flores, Timor, Buro, and Amboina.

POMACENTRUS FASCIATUS Cuvier and Valenciennes

Plate 13, Fig. 2

Pomacentrus fasciatus Cuvier and Valenciennes, Hist. Nat. Poiss. 5 (1830) 320, pl. 134; Schlegel and Müller, Overz. Amphi. Verh. Nat. Ges. Ned. Overz. Bezitt. (1839) 20, pl. 4, fig. 1; GüNTHER, Cat. Fishes 4 (1862) 19; JoRdan and Richardson, Bull. U. S. Bur. Fisheries 27 (1908) 263.

Dichistodus fasciatus Gru, Proc. Acad. Nat. Sci. Phila. (1863) 214; BleEker, Nat. Verh. Holl. Maats. Wet. 2 (1877) 86; Atlas Ichth. 9 (1878) pl. 401, fig. 8.

Dorsal XIII, 13 or 14 ; anal II, 13; scales in lateral series 26; with tubules 17 to 19 ; between lateral line and origin of dorsal 4 ; between lateral line and vent 10 .

Upper and lower profiles of body similar, being regular curves trom tip of snout to tail; depth 2.1 to 2.2 in length; head 3.1 to 3.4 ; depth of caudal peduncle 5.6 to 6.4 . Interorbital space strongly arched, 3.1 to 3.4 in length of head; eye circular, rather small, its diameter 3.3 to 4.3 , or shorter than the blunt, rounded snout, which is 2.8 to 3.4 in head. Mouth small, slightly oblique; maxillary 2.9 to 3.4 in head, its posterior end a little before eyes; tip of snout lower than inferior margin of orbit; teeth rounded, noncontiguous, in two series in each jaw. Suborbital coarsely denticulated, the width of preorbital at end of maxillary greater than two-thirds eye diameter; opercle armed behind with two flat spines.

Top of head scaly to front rim of orbit, leaving snout entirely naked; orbitals and edges of preopercle also naked. Dorsal spines increasing in height toward behind. Soft dorsal and anal rounded, of nearly the same height; caudal very slightly emarginate; pectoral ending before anus and ventrals extending to origin of anal fin.

Dark brown in alcohol, becoming lighter toward the lower parts, with four yellow crossbands; one on the nuchal region, the second from front part of dorsal fin to behind axil of pectoral, the third across posterior dorsal spines, the fourth at axil of soft dorsal. A black spot above operculum; two parallel 
series of black specks along sides of body, originating from cpercle between lateral line and base of pectoral; in some specimens a third series also present just below lateral line; the three series of spots absent in very young individuals. Pectoral dusky at base and yellowish outward; all the other fins dusky ; most of the scales of body with a yellowish streak or spot. In some specimens there is a light longitudinal line on anal fin.

Described from twenty-three specimens, 21 to 111 millimeters in length, collected at the following localities: Paoay and Currimao, Ilocos Norte; Iba, Zambales; Polillo Island; Bantayan Island; Canigaran, Palawan; Balabac, Balabac Island; Canigao Island, Leyte; Zamboanga, Mindanao; and Tubigan, Jolo, Tawitawi, Bungau, Sibutu, and Saluag Islands, Sulu Archipelago. The example from Saluag Island, 111 millimeters in length, is a ripe female, collected in September, 1925.

I have examined several specimens at Stanford University Museum, from Bantayan, Canigao, and Bungau Islands. Günther listed an adult specimen from the "Philippine Islands;" Jordan and Richardson reported two specimens from Ticao Island; and Max Weber collected eleven from Sanguisiapo, Sulu Archipelago.

This fish, well marked by four yellow vertical bands on the head and body and by two or three longitudinal series of black spots on the sides, is evidently widespread in the Philippines. It occurs elsewhere in the East Indies from the coast of Singapore to the Moluccas.

POMACENTRUS BREVICEPS (Bleeker)

Plate 13, Fig. 1

Amblypomacentrus breviceps BLFEKER, Nat. Verh. Holl. Maats. Wet. 2 (1877) 69; Atlas Ichth. 9 (1878) pl. 404, fig. 7.

Glyphidodon breviceps GüNTHER, Cat. Fishes 4 (1862) 42.

Dorsal XIII, 10 or 11 ; anal II, 11 or 12 ; scales in lateral series 25; with tubules 15 to 17 ; between lateral line and origin of dorsal 3 ; between lateral line and vent 9 .

Body oblong and elongate, deepest at base of first three dorsal spines, being 2.2 to 2.6 in length; head 3 to 3.6 ; depth of caudal peduncle 6.1 to 7 . Interorbital narrow, slightly convex, 3.2 to 4.1 in length of head; eye fairly large, circular, 2.6 to 3 ; snout short and rounded, 3.5 to 4.9. Cleft of mouth almost vertical, lower jaw slightly projecting, maxillary terininating posteriorly behind anterior edge of eye and contained 2.8 to 3.4 in head; only one row of truncate and closely set teeth in each jaw. Preorbital 
narrow, less than half an eye diameter at its widest part; suborbital and vertical limb of preopercle very finely serrated.

Scales absent on snout, chin, suborbital, and edges of preopercle; a low sheath of scales covering base of vertical fins. Dorsal spines increase in height to the fourth, the rest about equal in height. Fifth and sixth dorsal rays filamentous, as are also the seventh and eighth anal rays; caudal lobes ending in filaments; the short pectoral fin ending before anal opening; outer ray of ventral fin extending to base of anal spines.

Yellowish brown in alcohol, with a silvery reflection on each scale and three broad brown crossbands; the first descending from crown of head through orbit and preopercle, the second broader than the light space before it, under origin of dorsal fin and the first six dorsal spines; the third below the last three dorsal spines and the rayed portion of dorsal; a large dusky blotch on base of caudal; soft dorsal and caudal with numerous light specks, which assume a bandlike arrangement.

Of this species there are twenty-six specimens in the Bureau of Science collection, 21 to $\mathbf{5 0 . 5}$ millimeters in length, from the following localities: Subic and Olongapo, Zambales; Nasugbu, Batangas; Concepcion, Busuanga Island; Estancia, Panay ; Bantayan Island and Cebu, Cebu; Cuyo and Puerto Princesa, Palawan; and Tagbilaran, Bohol. The above number includes fifteen ripe females, 28 to $\mathbf{5 0 . 5}$ millimeters long, collected January 13, 1924; May, 1907; and October 1, 1907. A number of specimens from Olongapo and Puerto Princesa are in the museum of Stanford University.

This species is recognizable by the three brcad dark crossbands on the body. A comparison of Philippine specimens with those from Sandakan, Borneo, reveals no specific differences.

This fish is known only from the Indo-Australasian Archipelago.

\section{POMACENTRUS OVOIDES Cartier}

Pomacentrus ovoides Cartibe, Verh. Phys. Med. Ges. Würzburg (1873) 98.

Dorsal XIII, 12; anal II, 13; lateral line 30 ; transverse $\frac{4 \text { or } 5}{9}$.

The height of the body is a little less than 2.5 in the length without caudal, the length of head slightly less than 4. The diameter of eye is greater than the length of snout.

The caudal is forked, the lobes are acute and produced into filaments. The vertical fins are brown, ventrals blackish; dorsal and anal bright at base, especially toward the posterior end, with indication of whitish dotlike spots. The preorbital is not toothed. Color of body brownish, clear 
on the belly, the scales with bright edges. Forehead blue, with bright blue spots on the opercles. A round black spot above the origin of pectoral.

The body has a regular ellipsoid form, while the profile of the head forms part of the oval outline of the body.

From Bohol and Cavite.

Two specimens, 10 and 9 centimeters long.

The above account is a translation of Cartier's original description. This species appears to be very closely related to Pomacentrus breviceps, from which it differs in the smoothness of its suborbital.

POMACENTRLS ALBOLINEATUS sp. nov.

Plate 14, Fig. 1

Dorsal XIV, 14; anal II, 15; scales in lateral series 26; with tubules 15 or 16 ; between lateral line and origin of dorsal 3 ; between lateral line and vent 11 .

Body oblong and deep, much compressed, anterior dorsal profile steep and very slightly arched; depth of body 1.9 in length; head 3.1; depth of caudal peduncle 6.7. Interorbital space almost flat, 2.7 in length of head or almost as wide as the diameter of the large round eye which is contained 2.6 in head; the short, bluntish snout 3.4 in head, its tip on a level with inferior margin of orbit; maxillary a little longer than snout and contained 3.2 in head, its posterior end slightly behind anterior edge of eye. Mouth small and oblique, jaws even; teeth in a single row, compressed, with the cutting edges emarginate. Preorbital narrow, its greatest width scarcely half an eye diameter : suborbital with indistinct serræ below; preopercle denticulated behind, serræ well developed near the angle; opercle armed at its hind margin with a flat spine.

Scales finely ctenoid, very thin and weak, rather loosely imbricated; those covering head extending to nostrils; none present on orbital ring or on vertical limb of preopercle; a low sheath of scales covering base of vertical fins; cheek with three longitudinal rows of scales, the lowest row on inferior limb of preopercle. Lateral line ending posteriorly below origin of soft dorsal. Dorsal spines increasing in height posteriorly, the last one about as high as second anal spine. Soft vertical fins slightly rounded; caudal emarginate; both pectoral and ventral extending to vent.

Ground color in alcohol light yellowish brown; scales on body with white transverse lines near base, these lines appearing to be continuous with the tranverse rows of scales; each scale at 
base of anal fin with a white spot; anal opening jet black; all the other fins yellowish; pectoral with a dusky axillary spot.

Known from only two specimens, one of which is in the collection of the Bureau of Science and the other at Stanford University Museum. They measure 37 millimeters each, and were collected by Dr. Albert W. Herre at Bungau Island, Sulu Archipelago, in 1921.

This species is distinct from the other members of this genus in having a series of white transverse lines across the body.

\section{POMACENTRUS OPISTHOSTIGMA Fowler}

Pomacentrus opisthostigma FowlerR, Proc. Acad. Nat. Sci. Phila. 70 (1918).

Dorsal XIV, 14; anal II, 15; scales in lateral series 26; with tubules 15 or 16; between lateral line and origin of dorsal 3 ; between lateral line and vent 10 .

Body ellipsoid and well compressed, with back and abdomen equally arched, greatest depth 1.9 to 2 in length; head 3 to 3.2 in length of body, with upper outline slightly more convex than lower; depth of caudal peduncle 2.1 to 2.3 in length of head or 6.6 to 6.9 in that of body. Interorbital space evenly convex and as wide as eye diameter, which is 2.9 to 3.2 in head; snout bluntly pointed and rather short, 3.2 to 3.4 in length of head and a little longer than maxillary which is contained 3.4 to 3.6 ; width of preorbital behind maxillary less than half eye diameter. Eye circular and a little elevated, its anterior edge above posterior end of maxillary. Mouth small and slightly oblique, jaws about even; the simple small teeth compressed and in a single series. Orbital ring distinctly serrated, first tooth enlarged and followed by a notch; only the hind limb of preopercle serrated; opercle armed with two flat spines behind.

Orbital ring, edges of preopercle and portion of snout in front of nostrils naked, and rest of head covered with scales. Dorsal spines evenly graduated to the last, which is the highest and 1.5 to 1.6 in head; second anal spine lower than last dorsal spine; soft dorsal and anal rounded; caudal fin a little emarginate; pectoral fin as long as head and reaching anus; outer ray of ventral produced into a filament which extends behind anal opening.

Color in alcohol brown, paler on belly and lower surface of head; each side of head with some scattered pearl white spots; two fine pearl white lines converging at snout, present on top of head, and a short one in front of each eye; dorsal fin deep 
brown, the spinous portion black-edged; anal fin deep brown; caudal, pectoral, and ventral fins brownish, a black spot at origin of lateral line and a rather large, wedge-shaped, black mark at base of pectoral; anus black.

The above description is of two examples, 40 and 51.5 millimeters in length, collected at Bungau Island, Sulu Archipelago.

This species has been previously recorded by Fowler, from three specimens labeled "Philippine Islands."

POMACENTRUS TABLASENSIS sp. nov.

Plate 14, Fig. 2

Dorsal XIV, 13; anal II, 15; scales in lateral series 26; with tubules 15 ; between lateral line and origin of dorsal 4 ; between lateral line and vent 10.

Body ellipsoid, compressed, slightly elongate, with both dorsal and anal profiles about equally elevated; depth of body 2.1 in length; head 3.2; caudal peduncle rather deep and strongly compressed, its least depth 1.8 in length of head or 6.3 in that of body. Interorbital space evenly convex, 3.2 in length of head or as wide as length of eye diameter or of maxillary; snout 3.3 in head, its tip on a level with lower margin of eye. Mouth small and a little oblique; teeth in a double series in each jaw, their cutting edges rounded. Orbital ring rather coarsely serrated; first tooth enlarged and separated from the others by a notch; posterior end of maxillary below anterior edge of orbit; least width of preorbital $\frac{1}{3}$ in length of snout; vertical limb of preopercle distinctly serrated; opercle armed with a flat spine behind.

Scales on each side of body moderately large, those on top of head extending to a little in front of nostrils, leaving a narrow naked space behind upper jaw; vertical fins with a low basal sheath of scales; orbital ring and vertical edge of preopercle unscaled; cheek with four longitudinal rows of scales. Lateral line ending posteriorly below origin of rayed dorsal. Middle dorsal spines of about equal height and slightly lower than the last spine, which is 1.7 in length of head and as high as second anal; both rayed dorsal and anal rounded; caudal emarginate, with rounded lobes, the upper one slightly the longer; the broad pectoral about as long as head, its posterior end above anus; ventral extending to base of anterior anal rays, its spine as long as second anal and its outer ray produced into a filament.

Ground color of a fresh specimen brownish violet, passing into whitish below, and into yellowish posteriorly below the 
rayed dorsal and on the caudal peduncle; dorsal fin brownish violet, with a blackish edge to the spinous portion; caudal slightly yellowish near base and brownish outwardly; posterior third of anal black, remaining portion whitish; pectoral slightly grayish with a small black spot superiorly at its base and axil; eye golden yellow, with a tinge of brownish violet above.

In alcohol the ground color is yellowish brown, fading into whitish below; dorsal fin yellowish brown; tail and base of caudal yellowish, rest of the fin grayish; anal black on its posterior third and whitish violet on the remaining portion; pectoral and ventral grayish, the former with a small black spot superiorly at its base and axil.

Here described from a single specimen, 95 millimeters long, collected by Mr. M. Brown, August 5, 1926, at Tablas, the largest island in Romblon Province.

\section{Genus DAYA Bleeker}

Daya Blfekrer, Nat. Verh. Holl. Maats. Wet. 2 (1877) 71; jerdoni.

Body oblong; elongate. Teeth in a single series, the middle ones short and large, almost flattened. Preopercle finely serrated as are the angle of opercle and the contiguous portion of subopercle; orbital ring entire. Scales of moderate size, about 30 or less in a longitudinal series; lateral line ceasing below soft dorsal fin. Dorsal fin continuous, not notched, with 13 spines.

I am obliged to separate this genus from Pomacentrus, from which it differs in the serration of the opercular and subopercular bones.

There is apparently but a single species, which is rare on the coast of India and in the seas of the Indo-Australasian Archipelago.

\section{DAYA JERDONI (Day)}

Plate 15, FIg. 1

Pomacentrus jerdoni DAY, Proc. Zool. Soc. (1873) 237; Fishes of India (1878) 383, pl. 80, fig. 7; EvgrmanN and SEALE, Bull. U. S. Bur. Fisheries 26 (1907) 89.

Daya jerdoni WEBER, Fische der Siboga Exped. (1913) 344.

Dorsal XIII, 12 or 13; anal II, 12 to 14; scales in lateral series 28 to 30 ; with tubules 19 to 21 ; between lateral line and origin of dorsal 6 ; between lateral line and vent 10 .

Dorsal and ventral outlines of the oblong, elongate body similar; depth 2.5 to 2.6 in length; head 2.9 to 3.6 ; depth of caudal peduncle 7.1 to 8 . Interorbital space with a low depression extending forward to tip of snout, its width contained 
3 to 3.7 in length of head; snout 3.5 to 3.7 in head, being shorter than the diameter of the large round eye which is contained 3.1. Mouth large, almost vertical ; jaws subequal; maxillary longer than width of interorbital or diameter of eye, its posterior end below front margin of orbit; teeth compressed, in a single series. Orbital ring entire, adnate to cheek; vertical limb of preopercle, angle of opercle, and the contiguous portion of subopercle serrated; opercle armed with two flat spines behind.

Scales on top of head extending to above anterior edge of pupil, leaving a naked space from there to tip of snout; preorbital and vertical edge of preopercle naked. Sixth and seventh dorsal spines highest. Soft vertical fins pointed posteriorly; caudal lobes produced, the upper one longer; pectoral as long as ventral and ending before vent.

Yellowish olive in alcohol, becoming lighter on the lower surface; seven series of white spots across gill opening; an unbroken line in front of eye, four more or less broken ones below it. Base of pectoral with a blotch superiorly, pectoral and ventral yellowish, the other fins dusky; dorsal and anal with light lines and spots; a row of light lines along the center of the scales on the sides.

Described from four specimens, 31 to 91 millimeters long, from Bulan, Sorsogon, and from Olongapo, Zambales. The two examples from Bulan are part of a number collected by C. J. Pierson, as recorded by Evermann and Seale, and those taken from the other locality in May, 1907, are females in near-spawning condition. A third specimen from Olongapo is now in the museum of Stanford University.

This species has been reported also from the Philippines by Max Weber, who obtained an example with a dredge in 13 meters of water at Tonquil Island, Sulu Archipelago. By the same method he collected on the Borneo Bank another specimen. No other record of the species has been reported elsewhere in the East Indies.

This species, distinct in having the angle of the opercle and the contiguous portion of the subopercle serrated, was originally described by Day from Madras, India.

\section{Genus HEMIGLYPHIDODON Bleeker}

Hemiglyphidodon Blarker, Nat. Verh. Holl. Maats. Wet. 2 (1877) 91; plagiometopon.

Ctenoglyphidodon Fowler, Proc. Acad. Nat. Sci. Phila. 70 (1918) 59 ; melanopselion. 
This genus is separated from Abudefduf by its very numerous and exceedingly long gill rakers, over 70 being present on the first arch, a character which I consider of generic value. It has a single series of flattened, more or less notched teeth, and entire opercular and orbital bones in common with Abudefduf.

Only one species is known and it is confined to the Indo-Australasian Archipelago.

\section{HEMIGLYPHIDODON PLAGIOMETOPON (Bleeker)}

Plate 5, Fig. 1

Glyphisodon plagiometopon BLEEkER, Nat. Tijd. Ned. Ind. 3 (1852) 67; GüNTHER, Cat. Fishes 4 (1862) 51; BleEkeR, Nat. Verh. Holl. Maats. Wet. 2 (1877) 103; Atlas Ichth. 9 (1878) pl. 410, fig. 4. Abudefduf melanopselion FowLer, Proc. Acad. Nat. Sci. Phila. 70 (1918) 59, fig. 23; Fowler and Bean, Proc. U. S. Nat. Mus. 62 (1922) 49.

Dorsal XIII, 12 or 13; anal II, 13 to 15 ; scales in lateral series 26 ; with tubules 15 to 18 ; between lateral line and origin of dorsal 4 or 5 ; between lateral line and vent 10 .

Body oblong and deep, anterior profile oblique, slightly arched; depth of body 1.9 to 2 in length; head 2.7 to 3.1 ; depth of caudal peduncle 6.3 to 6.9 . Interorbital space strongly convex, rather wide, being 2.7 to 3.2 in head or a little narrower than the length of the long, slightly pointed snout, which is contained 2.4 to 2.9 in head; cleft of small mouth oblique, jaws equal; maxillary 3.1 to 3.5 in head, its posterior end a little behind nostrils; eye rounded, its diameter 3.3 to 4.1 in head; teeth in a single series, with the tips truncate. Gill rakers very long and numerous, $35+45$ on first arch. Width of preorbital at angle of mouth about $\frac{2}{3}$ eye diameter; orbitals and preopercle with entire edges; opercle armed behind with a flat spine.

Head everywhere covered with scales excepting part of snout in front of nostrils, orbital ring, and posterior edge of preopercle; dorsal and anal fins with a low basal sheath of scales. Dorsal spines increasing in height to behind. Soft dorsal and anal slightly pointed; caudal obliquely truncated; pectoral extending to anus; ventrals reaching origin of anal fin, its two outer rays about equal in length.

Color in alcohol brown, with a bluish vertical streak on each scale of body; a bluish curved line on suborbital, some bluish dots on head and on base of vertical fins. All the fins dusky, the pectoral somewhat paler than the rest and having a blackish spot at base. 
The foregoing account was taken from eight examples, 87 to 122 millimeters long, coming from Bantayan Island; Samal Island and Zamboanga, Mindanao; and Bato Bato, Tawitawi, and Sitankai Islands, Sulu Archipelago. The two examples collected at Zamboanga in March, 1923, are females nearly ready to spawn.

Eight fresh examples, 29 to 55 millimeters long, obtained at a public market in Cebu, Cebu Province, are colored as follows: The ground color of large specimens yellow, with a shade of blackish violet on head and all the fins; the small examples blackish violet in front and above, bright orange yellow below and behind including the posterior dorsal rays, the caudal, and the ventrals and having a blackish violet spot at base of pectoral, and another at base of the last dorsal rays. Two pearl white lines radiating from eye toward upper jaw, the first one uniting with an opposite line at tip of snout and the other crossing preorbital; a third line of the same color present on orbital ring; one or more longitudinal series of pearl white spots on preopercle, and some scattered ones on the rest of the head and at base of vertical fins; each scale on lower half of sides with a pearl white vertical streak.

This species was first noted from the "Philippine Islands" by Fowler, and from Cebu by Fowler and Bean as Abudefduf melanopselion. Elsewhere it is found on the coasts of Singapore, Japan, and New Guinea.

\section{Genus ABUDEFDUF Forskål}

Abudefduf Forskill, Descr. Anim. (1775) 59; sordidus.

Glyphisodon LACEPऐ̀D, Hist. Nat. Poiss. 4 (1803) 542; moncharra; also spelled Glyphidodon.

Stegastes JenYNS, Voy. Beagle (1842) 63; imbricatus.

Euchistodus Gru, Proc. Acad. Nat. Sci. Phila. (1862) 145; declivifrons.

Amblyglyphidodon BLweKm, Nat. Verh. Holl. Maats. Wet. 2 (1877) 92 ; aureus.

Body short and deep, compressed, with about 28 scales or less in a longitudinal series. Lateral line interrupted before posterior end of soft dorsal. Teeth in a single series, entire or notched at tips. Gill rakers not very numerous, about 28 or less being present on the first arch. A single dorsal fin with 12 or 13 spines. None of the opercles serrated, orbital ring entire. 
This large genus, which is represented in the Philippines by thirteen species, is found in all tropical seas, extending northward to the latitude of Madeira in the Atlantic and of California in the Pacific, southward to the latitudes of New Zealand and South Australia.

Key to the Philippine species of Abudefduf.

$a^{1}$. Body ovate-oblong, with black crossbands.

$b^{1}$. Snout naked; the black crossbands wider than the interspaces.

$c^{2}$. Body with six black crossbands; a large black blotch on anterior dorsal spines and another on tail.

A. sordidus.

$c^{2}$. Body with seven black crossbands; no black blotch on either the spinous dorsal or the tail. A. septemfasciatus.

$b^{2}$. Snout scaled; the black crossbands not wider than the interspaces. $d^{3}$. Scales on top of head extending to nostrils.

$e^{1}$. Body with seven black crossbands

A. bengalensis.

$e^{2}$. Body with five black crossbands.

A. saxatilis.

$d^{2}$. Scales on top of head extending to tip of snout; body with five black crossbands; each lobe of caudal fin with a black longitudinal stripe

A. coelestinus.

$a^{3}$. Body subcircular, with or without black crossbands.

$f^{2}$. Body with three black crossbands

A. curaçao.

$f^{2}$. Body without black crossbands.

$g^{1}$. Soft dorsal and anal uniformly yellow.

A. aureus.

$g^{2}$. Anterior dorsal and anal rays blackish.

A. leucogaster.

$a^{2}$. Body markedly oblong, without any black crossbands.

$h^{1}$. Edges of teeth nearly pointed

A. coracinus.

$h^{2}$. Edges of teeth truncate or notched.

$i$. Dorsal spines 13

i. Dorsal spines 12 , rarely 13 .

A. philippinus.

$j^{1}$. Dorsal spines increasing in length posteriorly; a black vertical band between the soft vertical fins.

A. dickii.

$j^{2}$. Middle dorsal spines longest; no black vertical band between the soft vertical fins.

$k^{2}$. Spinous dorsal and back of tail with a large dark spot; body with a pearl white transverse band in the young..A. leucozona.

$k^{2}$. Spinous dorsal and back of tail without any dark spot; body without any pearl white band

A. lacrymatus.

\section{ABUDEFDUF SORDIDUS (Forskal)}

Plate 15, Fig. 2

Chaetodon sordidus ForSKÅL, Descr. Anim. (1775) 62, No. 87; BLocH and ScHNEHER, Syst. Ichth. (1801) 230.

Glyphisodon sordidus RüPPFL, Fische des Rothen Meers (1828) 34, pl. 8, fig. 1; Cuvier and Vatenciennes, Hist. Nat. Poiss. 5 (1830) 349; BLEmKR, Verh. Bat. Gen. 21 (1847) 16; GüNTHæR, Cat. Fishes 4 (1862) 41; Fische der Südsee 2 (1876) 231; BLझझквR, Nat. Verh. 
Holl. Maats. Wet. 2 (1877) 95; Atlas Ichth. 9 (1878) pl. 410, fig. 5; DAY, Fishes of India (1878) 385, pl. 83, fig. 1 .

Abudefduf sordidus Jordan and Seace, Bull. U. S. Bur. Fisheries. 25

(1906) 284 ; Jordan and Jordan, Mem. Carnegie Mus. 10 (1922) 68.

Dorsal XIII, 13 to 15; anal II, 12 to 15; scales in lateral series 26 ; with tubules 21 or 22 ; between lateral line and origin of dorsal 5 ; between lateral line and vent 14 .

Body deep and much compressed, with the dorsal outline deeper than ventral; greatest depth of body at origin of dorsal fin, 1.8 to 1.9 in length; head 2.6 to 3 ; depth of caudal peduncle 5.2 to 5.3. Interorbital space 3 to 3.4 in length of head and as wide as length of either snout or maxillary; the large, round eye 2.7 to 2.8 in head. Mouth almost horizontal; teeth very narrow and slender, uniserial in each jaw. Gill rakers $7+17$ on first arch. Orbital ring very narrow; posterior margin of opercle with two flat spines.

Scales on top of head advancing as far as front margin of orbit, leaving a naked space from there to tip of snout; no scales on orbital ring and edges of preopercle. Fourth to eighth dorsal spines highest, last dorsal spine higher than preceding one. Vertical fins obtusely rounded; caudal deeply forked; pectoral ending above anus; ventral extending to base of second anal spine, its first ray filamentous.

Color in alcohol yellowish brown, with six blackish, rather indistinct transverse bands which are much wider than the interspaces between them; the first band descending from origin of dorsal fin; the next three from the spinous dorsal; the fifth below anterior rays of dorsal fin; the last one across caudal peduncle, with its upper portion in the form of a large black spot. . A black spot. superiorly at base of pectoral and some minute dark spots scattered all over body. Anterior portion of spinous dorsal black; outer rays of ventral and of other fins dusky.

Of this well-marked species I have examined thirteen examples, 21 to 50 millimeters long, taken at Luna and Balaoan, La Union; Puerto Galera, Mindoro; Camiguin Island, Cagayan Province; and Bungau Island, Sulu Archipelago. The presence of a large black spot on the tail and of another on each anterior dorsal spine distinguishes the species from Abudefduf septemfasciatus.

This species ranges from the Red Sea and east coast of Africa eastward to Samoa and Hawaii and northward to China, Formosa, and Okinawa Islands. 
ABUDEFDUF SEPTEMFASCIATUS (Cavier and Valenciennes)

Plate 16, Fig. 1

Glyphisodon septemfasciatus CUVIER and VALENCIENNES, Hist. Nat. Poiss. 5 (1830) 346; GünTHeR, Cat. Fishes 4 (1862) 40; Fische der Südsee 2 (1876) 230; BlEEkER, Nat. Verh. Holl. Maats. Wet. 2 (1877) 97; Atlas Ichth. 9 (1878) pl. 409, fig. 5; pl. 81, fig. 7; DAY, Fishes of India (1878) 386, pl. 81, fig. 7.

Abudefduf septemfasciatus JoRDAN and SeALE, Bull. U. S. Bur. Fisheries 25 (1906) 285; EvermanN and Seale, Bull. U. S. Bur. Fisheries 26 (1907) 93; Srals and Bean, Proc. U. S. Nat. Mus: 33 (1908) 385; Weber, Fische der Siboga Exped. (1913) 247.

Dorsal XIII, 13; anal II, 12; scales in lateral series 27; with tubules 19 ; between lateral line and origin of dorsal 4 ; between lateral line and vent 11.

Body ovate-oblong, compressed, elevated, its depth 2 in length; head 2.8; depth of caudal peduncle 5.8. The convex interorbital 3.2 in length of head, as wide as length of snout; diameter of eye and maxillary equal in length, each contained 3.5 in head. Jaws even, cleft of mouth almost horizontal; teeth compressed in a single series, with the incisors emarginate. Gill rakers $8+15$ on first arch. Width of orbital ring above angle of mouth less than half diameter of eye.

Scales absent on orbitals, chin, and edges of preopercle; snout and anterior portion of interorbital space also naked. Fourth, fifth, and sixth dorsal spines highest, equal to second anal spine. Soft dorsal produced into a point; anal rounded; caudal unequally forked, the upper lobe longer; tip of pectoral above anus; ventral fin reaching origin of anal, its first ray filamentous.

Ground color in alcohol lemon yellow, with seven blackish crossbands which are wider than the interspaces between them; the first, rather indistinct, across head; the second across neck; the third, fourth, and fifth below spinous dorsal; the sixth from anterior dorsal rays to base of anal; the last one around caudal peduncle. Spinous dorsal with a dark margin; base of caudal with a conspicuous black spot superiorly.

The above account is that of an example, 58 millimeters long, collected at Paraoir, Balaoan, La Union. I have examined also four others, 28 to 82 millimeters in length, from Guam, which are in the Bureau of Science collection.

This species has been reported previously from the "Philippine Islands" by Günther; from Bulan, Sorsogon, by Evermann and Seale; and from Zamboanga, Mindanao, by Seale and Bean. Outside of the Philippines, it occurs throughout the Red Sea 
and the Indian Ocean, and from the islands of the Western Pacific to the Paumotus. It is rather widespread and common in the Indo-Australasian Archipelago.

\section{ABUDEFDUF BENGALENSIS (Bloch)}

Plate 16, Fig. 2

Chaetodon bengalensis BLocH, Ichth. 5 (1787) 82, pl, 213, fig. 2. Glyphisodon bengalensis Cuvigr and VALEncrennes, Hist. Nat. Poiss.

5 (1830) 342; BLFßKמR, Verh. Bat. Gen. 21 (1847) 11; GüNTHER, Cat. Fishes 4 (1862) 41; BLFEK (1877) 99; Atlas Ichth. 9 (1878) pl. 407, fig. 4; DAY, Fishes of India (1878) 387, pl. 83, fig. 3.

Abudefduf bengalensis W BBER, Fische der Siboga Exped. (1913) 344.

Dorsal XIII, 12 to 14; anal II, 12 or 13; scales in lateral series 27; with tubules 20 to 22 ; between lateral line and origin of dorsal 5; between lateral line and vent 12.

Body elevated, much compressed, deepest at about anterior portion of spinous dorsal, 1.6 to 1.8 in length; head 2.8 to 3.1, its upper profile very steep and almost straight; caudal peduncle strongly compressed, very short and deep, its depth contained 4.2 to 5.8 in length of body. Interorbital space broad, moderately convex, contained from 2.8 to 3.2 in length of head; the circular, fairly large eye 3.3 to 3.8 ; the blunt snout 2.9 to 3.4, its tip not quite on a level with lower margin of eye; maxillary 3.2 to 3.6 or a little shorter than snout. Mouth slightly oblique, jaws equal; teeth in a single row, having emarginate edges. Gill rakers on first arch 22 or 23 . Width of preorbital at posterior end of maxillary nearly equal to half diameter of orbit; opercle armed behind with two flat spines.

The naked area on head includes snout in front of nostrils, orbital ring, and edges of preopercle; a low scaly sheath at base of vertical fins. Fourth, fifth, and sixth dorsal spines highest. Soft dorsal and anal fins produced along the middle, forming acute angles; caudal fin forked, with rather broad lobes.

Body olive brown in alcohol, with seven blackish crossbands, which are a little narrower than the interspaces between them; the first, rather indistinct, across head; the second from the first two dorsal spines to axil of pectoral; the third from the fourth and fifth dorsal spines to belly; the fourth from the eighth and ninth spines to anus; the fifth from the last dorsal spines to the anterior anal rays; the sixth between the middle of soft dorsal and the posterior portion of rayed anal; the seventh in the form of a blotch on posterior half of caudal peduncle and on base of fin. A black margin on anal fin, that of the spinous 
dorsal continued on the anterior rays; a dark spot superiorly at base of pectoral.

Here described from sixteen examples, 30 to 114 millimeters long, collected at Taylon and Tanao Islands, Camarines Norte; San Miguel Bay, Camarines Sur; Halsey Harbor, Culion Island; Puerto Princesa, Palawan; Placer and Cagayan de Misamis, Mindanao; and Sitankai Island, Sulu Archipelago. The specimens mentioned above are identical with two examples from Hongkong, which are now in the Bureau of Science collection.

This species differs from Abudefduf septemfasciatus in having narrower bands and a dark blotch at the base of the caudal fin. It has not been recorded from the Philippines heretofore, is abundant in the Gulf of Bengal and on the coast of the Andamans, and is rarely known from the Malay Archipelago.

\section{ABUDEFDUF SAXATILIS (Linneus) \\ Plate 17, Fig. 2}

Chaetodon saxatilis LINNAEUS, Syst. Nat. ed. 10 (1758) 276.

Glyphisodon saxatilis RÜPPILL, Fische des Rothen Meers (1828) 35; GüNTHER, Fische der Südsee 2 (1876) 229, pl. 126, fig. A (not var. coelestina); JoRdan and SNYDkR, Proc. U. S. Nat. Mus. 24 (1902) 608; Jordan and EvirmanN, Proc.-U. S. Nat. Mus. 25 (1903) 352. Abudefduf saxatilis JoRdaN and SEALE, Bull. U. S. Bur. Fisheries 26 (1907) 28; JoRdAN and Richardson, Bull. U. S. Bur. Fisheries 27 (1908) 263.

Glyphisodon coelestinus GüNTHER, Cat. Fishes 4 (1862) 38 (not the variety); BLEEKkR, Nat. Verh. Holl. Maats. Wet. 2 (1877) 101; Atlas Ichth. 9 (1878) pl. 408, fig. 5; DAY, Fishes of India (1878) 386 , pl. 83, fig. 2, not of Cuvier and Valenciennes.

Dorsal XIII, 12 or 13 ; anal II, 12 or 13 ; scales in lateral series 27 , with tubules 20 to 23 ; between lateral line and origin of dorsal 5 or 6 ; between lateral line and vent 12 .

Body deep, much compressed, dorsal outline more elevated than ventral, which is pretty evenly curved from snout to caudal peduncle; depth of body 1.7 to 2 in length; head 3 to 3.3 ; depth of caudal peduncle 5.4 to 6.4 , or greater than its length. Interorbital space broad, strongly convex, 2.4 to 3 in length of head; eye circular, its diameter 3.1 to 3.8 ; the short, rounded snout nearly as long as maxillary, which is contained 3 to 3.5 in head. Mouth oblique, jaws equal, hind end of maxillary scarcely reaching the point below anterior margin of orbit; teeth in a single series, compressed, some of the incisors notched. Gill rakers on first arch 24 or 25 . Preorbital narrow, its width at angle of mouth less than half diameter of eye; opercle ending in a flat spine. 
Snout in front of nostrils, preorbital, and both inferior and posterior edges of preopercle naked. Middle dorsal spines of nearly uniform height, being as high as the last. Middle rays of soft dorsal and anal fins produced into a point; caudal deeply forked, with the lobes pointed and falcate; both pectoral and ventral extend to vent.

Color in alcohol brownish olive, with silvery reflection; body with five black transverse bands, which are as wide as the interspaces between them; the first descending from the front of spinous dorsal to axil of pectoral ; the second extending downward from the fifth, sixth, and seventh spines to about the middle of ventral fin; the third descending from the tenth, eleventh, and twelfth spines to base of anal spines; the fourth occupying the space between most of the base of rayed dorsal and the posterior third of soft anal; the fifth covering the middle portion of tail. Head dusky, darker on snout, chin, and interorbital space; vertical fins blackish excepting the edges of the rayed portions, which are pale; caudal dusky at base and on upper and lower margins, pale at tips of rays; ventral and pectoral with a little dusky color, the latter fin with a large black spot on upper half of its base.

The above description is based upon sixty-five individuals, 17 to 125 millimeters in length, collected at the following places:

$\begin{array}{lr}\text { Santo Domingo de Basco, Batan Island } & 1 \\ \text { Paoay, Ilocos Norte } & 1 \\ \text { Nalvo, Luna, La Union } & 21 \\ \text { Paraoir, Balaoan, La Union } & 3 \\ \text { Iba, Zambales } & 1 \\ \text { Monja Island, Corregidor (125 millimeters long, a ripe fe- } & 1 \\ \quad \text { male, collected April, 1922) } & 5 \\ \text { Calapan, Mindoro } & 2 \\ \text { Legaspi, Albay } & 3 \\ \text { Despujols, Tablas } & 2 \\ \text { Sayan Island, Samar (106 and 121 millimeters long, both } & \\ \quad \text { ripe females, collected February, 1925) } & 1 \\ \text { Tagapula İsland, Samar } & 1 \\ \text { Halsey Harbor, Culion } & 12 \\ \text { Cabalian, Leyte (119 millimeters long, a ripe female, col- } & \\ \quad \text { lected December, 1922) } & 1 \\ \text { Dumaguete and Siaton, Oriental Negros } & 6 \\ \text { Siquijor } & 3 \\ \text { Balabac } & \end{array}$

There are in the Bureau of Sciense several examnles, collected at Wakanoura, Japan, and Codd Island, Amoy, which agree in characters with the Philippine specimens. 
This species has been previously recorded in the Philippines by Jordan and Seale from Manila, and by Jordan and Richardson from the same locality and Calayan Island.

Ground color of living specimens in the Bureau of Science aquarium is lemon yellow, which is much brighter above; the fourth transverse band is between the bases of the middle soft dorsal and anal fins; top of head above eyes slightly blackish; a black spot at base of pectoral; upper and lower margins of caudal fin narrowly washed with blackish; membranes of spinous dorsal edged with blackish.

This species is easily distinguished from Abudefduf coelestinus (Cuvier and Valenciennes) by its deeper body; by the absence of black stripes on the caudal; by the naked area on the snout, orbitals, and limbs of preopercle; and by the more anterior position of the fifth band on the tail. The examples at hand differ from American individuals in the number and relative width of the crossbands. It is probable that the original description of this species by Linnæus was based upon an East Indian specimen, but the name has been applied to both the Asiatic and the American representatives.

It is apparently widely distributed in the Philippines, and is known to inhabit the entire Indo-Pacific region from the Red Sea and the east coast of Africa to the Austral and Hawaiian Islands northward to China, Formosa, and Japan.

\section{ABUDEFDUF COELESTINUS (Cuvier and Valenciennes)}

PlaAte 8, Fig. 1

Glyphisodon coelestinus CUvier and Valenciennes, Hist. Nat. Poiss. 5 (1830) 347, pl. 135; GüNTHER, Cat. Fishes 4 (1862) 38, var.; Peters, Mon. König. Akad. Wiss. Berlin (1868) 271; GüNther, Fische der Südsee 2 (1876) 229, pl. 126, fig. B; BlEEkER, Nat. Verh. Holl. Maats. Wet. 2 (1877) 101.

Abudefduf coelestinus JoRdan and SeAle, Bull. U. S. Bur. Fisheries 25 (1906) 285; SNYDer, Proc. U. S. Nat. Mus. 42 (1912) 505;

FOWLER and BEAN, Proc. U. S. Nat. Mus. 62 (1922) 48.

Dorsal XIII, 11 or 12 ; anal II, 12 or 13 ; scales in lateral series 28 ; with tubules 20 or 21 ; between lateral line and origin of dorsal 5 ; between lateral line and vent 12 .

Profiles evenly curved and equally elevated; body rather deep, 1.8 to 2 in length; head 2.1 to 3.4 ; caudal peduncle short, depth 5.6 to 6.2. Interorbital space strongly convex and rather broad, 2.7 to 3.3 in length of head, or slightly broader than length of maxillary, which is contained 2.9 to 3.4 in head; eye rounded, 3.1 to 3.9 in head; the short and rounded snout contained 3.1 
to 3.6. Mouth rather small, strongly oblique, jaws equal; tip of snout on a level with lower margin of orbit; maxillary extending posteriorly at anterior edge of eye or slightly before it; teeth in a single row, compressed and rather blunt. Gill rakers 8 or $9+17$ on first arch. Orbital ring very narrow, its width at angle of mouth less than half diameter of orbit; opercle with a flat spine at its hind margin.

Head and body completely scaly. Fifth, sixth, seventh, and thirteenth dorsal. spines highest. Rayed dorsal and anal similar, produced along median into a point; caudal deeply notched, lobes falcate and rather pointed; pectoral ending above vent; ventral fin extending to origin of anal fin.

Brownish violet in alcohol; body crossed by five blackish transverse bands, which are nearly as broad as the interspaces between them; the first one from nape to base and partly to axil of pectoral; second from base of fourth to seventh dorsal spines to middle of ventral fin; third from base of last four dorsal spines to origin of anal fin; fourth between middle of soft dorsal and posterior portion of anal; fifth on hind part of caudal peduncle. Head dusky, especially on interorbital space, chin, and lips; spinous dorsal dusky; the soft vertical fins similarly colored at base, the outer portion of rays pale; caudal with a blackish streak on each lobe; pectoral and ventral more or less dusky, the former fin with a large spot at axil and another one at base.

Here described from the following examples, varying from 14 to 120 millimeters in length:

Nalvo, Luna, La Union

San Miguel Bay, Camarines Sur (a ripe male and 2 ripe females, 104 to 107 millimeters long, collected December, 1918)

Calapan, Mindoro

Masbate

Halsey Harbor, Culion

Bogo, Cebu

Cabalian, Leyte

Canigaran, Puerto Princesa, Palawan

Placer, Surigao (one, a ripe female, 105 millimeters in length, collected September, 1907)

Cagayan de Misamis and Zamboanga, Mindanao

Tawitawi, Bungau, and Sibutu, Sulu Archipelago (29 to 177 millimeters long, one a ripe female, and the others' ripe males, all collected in August, 1924)

There is also in the Bureau of Science collection a specimen from Guam, measuring 29 millimeters long. 
The first Philippine record of this species is that of Peters from the southern coast of Luzon. It has been reported also by Fowler and Bean, from Cebu, Cebu.

Living specimens in the Bureau of Science aquarium are colored as follows: Ground color bluish, fading into yellowish white below; fourth black crossband descending from middle dorsal rays through middle portion of soft anal; remaining portion of rayed dorsal yellowish; spinous dorsal edged with black; transverse band on caudal peduncle united with the black longitudinal stripe on upper lobe of caudal fin; anal spines and anterior rays blackish as is also top of head; base of pectoral black.

According to Cuvier and Valenciennes the true Abudefduf coelestinus has a broad blackish band near the margin of each lobe of the caudal fin. Günther and Bleeker regard this as identical with one that has the caudal plain. An examination of the specimens at hand shows that some are females and some males, proving that this particular color pattern is not a sex character. A comparison has been made with Abudefduf saxatilis under which I place those with the caudal unstreaked, and Abudefduf coelestinus seems to differ in having a less deep body, in the presence of scales on all parts of the head, and in the more posterior position of the last vertical band.

Apparently common in the neighborhood of coral reefs in the Philippines. Elsewhere it occurs from the Red Sea eastward to Polynesia.

\section{ABUDEFDUF CURAÇAO (Bloch)}

Plate 17, Fig. 1

Chaetodon curaçao BLoch, Ichth. 5 (1787) 106, pl. 212, fig. 1.

Abudefduf curaçao EvermanN and Stale, Bull. U. S. Bur. Fisheries 26 (1907) 93; Fowler and Bean, Proc. U. S. Nat. Mus. 62 (1922) 48.

Glyphisodon curassao CUVIER and VALENCIENNES, Hist. Nat. Poiss. 5 (1830) 352.

Glyphisodon trifasciatus BLEEK WR, Verh. Bat. Gen. 21 (1847) 19; GÜNTHER, Cat. Fishes 4 (1862) 42; Fische der Sïdsee 2 (1876) 231; BLFњK KR, Nat. Verh. Holl. Maats. Wet. 2 (1877) 105; Atlas Ichth. 9 (1878) pl. 410, fig. 3.

Glyphisodon smaragdinus BREvooRT, Exped. Japan (1856) 264, pl. 6, fig. 3.

Dorsal XIII, 11 to 13 ; anal II, 12 to 14 ; scales in lateral series 25 ; with tubules 16 or 17 ; between lateral line and origin of dorsal 3 ; between lateral line and vent 10 . 
Body subcircular, greatly compressed, depth 1.6 to 1.7 in length; head 3 to 3.5 ; depth of caudal peduncle 5.8 to 6.3 . Interorbital wide, convex, and slightly bulging, 2.5 to 2.8 in length of head; eye large and circular, 2.5 to 3.1 ; snout short, pointed, 3 to 3.8 , shorter than maxillary, which is contained 2.7 to 3.1 in head and ends posteriorly behind front margin of orbit. Mouth oblique, jaws equal; teeth uniserial, those in front with sharp cutting edges, and those on sides more or less notched. Gill rakers about 27 on first arch. Preorbital with a shallow notch in front, its greatest width less than half diameter of eye; suborbital very narrow.

Head and body completely covered with scales. Middle dorsal spines highest, but lower than second anal spine. Soft dorsal angular, its height almost equal to length of head; anal rounded; caudal forked, with the lobes pointed; ventral fin much longer than pectoral, its outer ray produced into a long filament which reaches base of anterior anal rays.

Brownish olive in alcohol, with three black, rather ill-defined crossbands, wider above and formed by black spots on the cutaneous sheaths of the transparent scales; the first one below the anterior dorsal spines, the second one from the posterior dorsal spines to vent, and the third between the soft dorsal and anal. Spinous dorsal, anterior two-thirds of anal, and upper and lower margins of caudal blackish, the remainder of these fins yellowish; pectoral pale, ventrals a little dusky.

Here described from thirty-five specimens, 37 to 85 millimeters in length, obtained at the following places: Sialat Point, Catanduanes Island; Puerto Galera and Calapan, Mindoro; Bacon, Sorsogon; Bantayan Island and Bogo, Cebu; Cabalian, Leyte; and Tawitawi, Bungau, and Sibutu Islands, Sulu Archipelago. A single specimen, 71 millimeters long, collected at Sialat Point in September, 1925, and two others, each 75 millimeters in length, taken at Cabalian in December, 1922, are females about ready to spawn. The example from Bacon has been recorded before by Fvermann and Seale. Fowler and Bean also listed this species, from Zamboanga.

A living specimen at the Bureau of Science aquarium is yellowish with bluish black spots on some of the scales of head and trunk, forming ill-defined transverse bands which become lighter and narrower on the lower parts. The number and nature of these bands, together with the subcircular shape of the body, the slender dorsal spines, and the long strong second anal spine, make this species distinct from the others. 
It is known from the East Indies, and ranges eastward through New Guinea to Shortland Island and northward to the Riu Kiu Archipelago.

\section{ADUDFFDUF AUREUS (Cuvier and Valenciennes)}

Glyphisodon aureus Cuvier and VALENCIEnNes, Hist. Nat. Poiss. 5 (1830) 353; SCHLEGEL and MülleR, Over\%. Amphi. Verh. Nat. Ges. Ned. Overz. Bezitt. (1839) 22, pl. 5, fig. 1; CuVigr, Regne Anim. Ill. Poiss. (1840) pl. 33, fig. 1; BLFEKER, Labr. Cten. (1847) 21; GüNTHER, Cat. Fishes 4 (1862) 45; BLEEKER, Nat. Verh. Holl. Maats. Wet. 2 (1877) 109; Atlas Ichth. 9 (1878) pl. 405, fig. 4. Abudefduf aureus WEBER, Fische der Siboga Exped. (1913) 348.

Dorsal XIII, 12; anal II, 14; scales in lateral series 24 to 26 ; with tubules 15 to 18 ; between lateral line and origin of dorsal 4 ; between lateral line and vent 10 or 11 .

Body subcircular, strongly compressed, its depth contained 1.5 to 1.6 in length; head 2.9 to 3.2 ; depth of caudal peduncle 5.7 to 6.1 . Interorbital strongly convex, rather broad, 2.6 to 2.9 in length of head; eye large and circular, 2.5 to 3.2 ; snout short and blunt, 3 to 3.3 ; maxillary 3 to 3.4 . Teeth in a single series, those in front small and scarcely emarginate. Gill rakers on first arch 27. Preorbital with a distinct notch above maxillary, its width at angle of mouth less than half an eye diameter.

Scales extending forward to tip of snout, also covering orbital ring and preopercular limbs. Middle dorsal spines lower than the thirteenth. Soft portion of dorsal and anal fins produced into a point; caudal forked, having pointed lobes; pectoral fin reaching base of anal spines and ventral extending to base of anterior anal rays.

Uniformly yellowish brown in alcohol, without any blackish marking anywhere except on outer edge of membranes of spinous dorsal.

Here described from eleven specimens, 62 to 108 millimeters long, collected at Calapan, Mindoro; Gaspar Island, Marinduque; Tablas Island; Tagapula Island, Samar; New Washington, Capiz; and Cabalian, Leyte. An example, 104 millimeters long, obtained at Gaspar Island in March, 1925, and a slightly smaller one, taken at Cabalian in May, 1921, are females about ready to spawn.

This species is new to the Philippines and is known elsewhere in the Indo-Australasian Archipelago from Java, Celebes, Amboina, and Banda. 


\section{ABUDEFDUF LEUCOGASTER (Blekke)}

Glyphisodon leucogaster BLअझкघR, Verh. Bat. Gen. 21 (1847) 20; GüNTHFR, Cat. Fishes 4 (1862) 46; BLFrk Maats. Wet. 2 (1877) 108; Atlas Ichth. 9 (1878) pl. 407, fig. 6; DAY, Fishes of India (1878) 388, pl. 81. fig. 3.

Abudefduf leucogaster FowLer and Bran, Proc. U. S. Nat. Mus. 62 (1922) 48.

Dorsal XIII, 11 or 12; anal II, 12 to 14 ; scales in lateral series 24 to 26 ; with tubules 15 or 16 ; between lateral line and origin of dorsal 4; between lateral line and vent 9 or 10 .

Body strongly compressed, subcircular in outline, its depth 1.6 to 1.8 in length; head 2.8 to 3.2 ; depth of caudal peduncle 6 to 6.6. Interorbital space broad, its width 2.5 to 2.9 in length of head; eye rounded and rather large, 2.6 to 3.3; snout shorter than eye, 3.1 to 3.4 in head or nearly as long as maxillary which is contained 2.9 to 3.3 in head. 'Teeth compressed, in a single series, the incisors short and very small. Gill rakers on first arch 27 or 28 . Preorbital very narrow, having a shallow notch in front.

Head and body completely covered with scales. Middle dorsal spines as high as the last. Soft dorsal angular; the rayed anal rounded; caudal forked, with the lobes pointed; pectoral extending to origin of anal fin; ventral longer than pectoral, its first ray filamentous.

Yellowish brown in alcohol, with scattered blue dots in the young. Base and axil of pectoral with a prominent black spot superiorly; pusterior two-thirds of soft dorsal and hind third of rayed anal yellowish, the other portions of the fins blackish; upper and lower margins of caudal washed with blackish.

I have examined twenty-two specimens, 40 to 90 millimeters long, coming from Calapan, Mindoro; Cabalian, Leyte; and Jolo, Bungau, and Sibutu Islands, Sulu Archipelago. Two of the specimens from Cabalian, collected in May, 1920, are females about ready to spawn.

In the Bureau of Science aquarium there are three living specimens, which are dark brown merging into golden yellow" on belly and with a silvery center to each scale; caudal peduncle yellowish as is the fin with the exception of the middle rays which are whitish; posterior portion of rayed dorsal and anal yellowish; ventrals yellowish, pectoral whitish.

This species was first recorded in the Philippines from Zamboanga, Mindanao, by Fowler and Bean, and is known to occur from the Red Sea, east coast of Africa, and the Nicobars to the Indo-Australasian Archipelago. 


\section{ABUDEFDUF CORACINUS Seale}

Plate 18, Fig. 1

Abudefduf coracinus SeAle, Philip. Journ. Sci. § A 4 (1909) 521, pl. 13.

Dorsal XIII, 13; anal II, 13; scales in lateral series 26; with tubules 18; between lateral line and origin of dorsal 4 ; between lateral line and vent 11 .

Body markedly deep and compressed, its depth contained 1.9 to 2 in length; ventral outline of body deeper than dorsal; anterior dorsal profile from tip of snout to origin of dorsal very oblique and slightly convex; head 3.2 to 3.4 in length of body; depth of caudal peduncle 5.5 to 5.7 . Interorbital space strongly arched, wider than length of snout, 2.6 to 2.7 in head; eye round, small, its diameter 3 to 3.8 ; maxillary 2.9 to 3.3 in length of head and about as long as the rounded snout, which is horizontally in front of inferior border of orbit. Mouth small, oblique, jaws equal; maxillary not reaching anterior margin of eye; teeth in a single series, with rounded tips. Gill rakers on first arch 22. Preorbital above angle of mouth nearly half as wide as interorbital.

Body covered with large, weakly ctenoid scales. Snout naked below and in front of nostrils; orbital ring also naked. Dorsal spines increasing in height posteriorly, the last one 1.7 to 1.8 in length of head. Soft dorsal and anal rounded, their middle rays highest; caudal scarcely emarginate, with the lobes rounded; pectoral rounded, 1.8 to 2 in depth of body, its tip within two scales from vent; ventral extending to vent, with the outer ray produced.

According to Seale the color of this fish in life is uniform dark brown or blackish. Its color in alcohol is blackish brown; a blackish spot at axil of pectoral.

Here described from the type and three other specimens, measuring 58 to 99 millimeters long. The type was collected at Sitankai Island, and the others were collected at Sibutu Island, both in the Sulu Archipelago.

In the general form of the body and the relative size of the scales, this species is nearest to Abudefduf rhomaleus Snyder, but differs from it in having the orbital ring naked.

\section{ADUDEFDUF PHILIPPINUS Fowlar}

Abudefduf philippinus Fowher, Proc. Acad. Nat. Sci. Phila. 70 (1918)

54, fig. 21. 
Head 2t: depth 18; D. XIII, 11; A. II, 12; P. I, 14; V. I, 5; tubes in upper part of lateral line 17, and pores in straight section $7 ; 3$ scales above lateral line to spinous dorsal origin and about 8 scales below in vertical row to spinous anal origin; about 14 predorsal scales; head width 13 its length; head depth 1 ; snout $3 \frac{3}{\text {; }}$ eye $2 \frac{1}{3}$; maxillary $3 k$; interorbital 23; third dorsal spine 2; thirteenth dorsal spine 2l: fifth dorsal ray 18?; second anal spine 13 ; fifth anal ray $1 \frac{2}{7}$; least depth of caudal peduncle $2 \mathrm{~b}$; caudal $1 \mathrm{k}$; pectoral $1 \mathrm{~b}$; ventral $1_{\mathrm{T}} \frac{1}{\mathrm{r}}$

Body well compressed, contour orbicular, deepest midway in length, predorsal with slight median keel and other edges convexly rounded. Caudal peduncle compressed, length $1 \frac{1}{2}$ in its least depth.

Head moderate, well compressed, evenly constricted above and below, profiles similarly inclined. Snout convex over surface, very slightly so in profile, length 8 its width. Eye large, close to upper profile, and hind pupil edge nearly midway in head length. Mouth well inclined, gape moderate, and jaws about even. Maxillary extends back slightly beyond front eye edge, though not quite to that of pupil, upper edge entirely slips below preorbital. Row of moderate, even, rather crowded, compressed incisors in each jaw, end of each tooth truncate, and whole forms even cutting-edge. No teeth on tongue or mouth roof. Tongue depressed, pointed, free. Inner buccal folds broad. Lips fleshy, moderately wide. Nostril slightly behind middle in snout length. Interorbital convex. Preorbital width $3 \frac{3}{4}$ in eye. Hind preopercle edge slopes well forward, so that angle would fall nearly opposite center of eye, and like lower preorbital and suborbital edges, entire.

Gill-opening forward opposite front pupil edge. Rakers $7+16$, lanceolate, longest about long as gill-filaments or 3 in eye. Pseudobranchiæ slightly longer than gill-filaments. Isthmus narrowly constricted, trenchant, branchiostegal membrane moderately broad across.

Scales finely ctenoid, narrowly imbricated, in even lengthwise rows, smaller along body edges. Fins all scaly basally. Suprascapula thin, entire, small. Cheek with 4 rows of scales. Opercle with moderate scales, small on interorbital, and still smaller on upper part of snout. Moderate scales on suborbitals and preorbital. Chin, lips, and narrow strip on front of snout naked, though mandible scaly. Scaly ventral flaps damaged. Lateral line with upper branch curving up at first, and then largely concurrent with upper limit of general squamation on dorsal fins, and ends below soft dorsal origin. Tubes simple, large, extend nearly over first half in scale exposure. Pores in horizontal section inconspicuous, small, and one in middle of each scale exposure, not on caudal base.

Spinous dorsal inserted opposite pectoral origin, spines rapidly graduated up to third, then subequal, fin edge well notched. Soft dorsal origin nearly at last third between upper hind preopercle edge and caudal base, rays graduated up to sixth and seventh, which form sharp point behind. Spinous anal inserted well before soft dorsal, first spine about 3 in second, or fin origin nearly midway between ventral origin and caudal base. Soft anal like soft dorsal. Caudal (damaged) apparently little emarginate behind. Pectoral reaches anal. Ventral inserted below middle of pectoral base, nearly reaches soft anal origin, and spine nearly 3 fin length. Vent close before anal. 
Color in alcohol largely faded dull brownish generally, predorsal, head above and front of back with traces of darker mottlings. Fins all pale uniform brownish. Iris slaty.

Length $41 \mathrm{~mm}$. (caudal tip damaged).

Type, No. 47,531 , A. N. S. P.

Philippine Islands. Presented by the Commercial Museums of Philadelphia.

No. 47,532, paratype, same data. It shows: Head 2s; depth 18; D XIII, 11; A. II, 12; tubes in upper arch of 1.l. 17 and pores in straight portion 7 ; snout $3 \frac{7}{8}$ in head; eye 2 ; maxillary 3 ; interorbital 23 , length $36 \mathrm{~mm}$.

Apparently falls within the subgenus Amblyglyphidodon Bleeker, and without much in common with the four East Indian species Bleeker de scribes.

The above is Fowler's original description.

\section{ABUDEFDUF DICKII (Lienard)}

Glyphisodon dickii LIENARD, Dix. Rapp. Soc. Hist. Nat. Maurice (1839) 35; BLEEKER, Ned. Tijd. Dierk. 1 (1863) 274; GüNTHER, Fische der Südsee 2 (1876) 232, pl. 125, fig. C; BlEEkER, Nat. Verh. Holl. Maats. Wet. 2 (1877) 115; Atlas Ichth. 9 (1878) pl. 409, fig. 7 .

Abudefduf dicki Jordan and Seale, Bull. U. S. Bur. Fisheries 25 (1906) 285, pl. 41, fig. 2; JoRdAN and Richardson, Bull. U. S. Bur. Fisheries 27 (1908) 263.

Glyphisodon unifasciatus KNER and STEINDACHNER, Sitz. Akad. Wiss. Wien (1867) 375.

Dorsal XII, 17; anal II, 14; scales in lateral series 28; with tubules 21 ; between lateral line and origin of dorsal 3 ; between lateral line and vent 11 .

Dorsal profile deeper than ventral, upper outline of head very steep; greatest depth of body 2 in length; length of head 3.2 ; depth of caudal peduncle 5.8. Interorbital space rather wide, 2.8 in head; eve rounded, its diameter as long as maxillary, which is 3.7 in head: snout almost as long as width of interorbital, 2.8 in head, with its tip lower than inferior margin of orbit; teeth uniserial, with notched edges. Gill rakers about 23 on first arch. Greatest width of preorbital greater than half diameter of eye.

Head covered entirely with scales; base of vertical fins with a rather high sheath of scales. Dorsal spines increasing in height posteriorly; second anal spine equal in height to last dorsal. Soft dorsal and rayed anal produced along the middle, forming acute angles; caudal deeply forked, with the lobes rounded; pectoral ending before vent; first ray of ventral prolonged into a filament, which terminates at base of anal spines. 
Color in alcohol dark orange brown, with a blackish streak at edge of each scale; a black transverse band between anterior portion of soft dorsal and base of anal rays; behind this band the color is dull yellowish orange covering caudal peduncle and fin, and posterior dorsal and anal rays. Ventral blackish, pectoral yellowish orange.

Here described from a single specimen, 74 millimeters in length, which I examined in the museum of Stanford University. It was collected by R. C. McGregor at Cagayancillo, Cagayan Isla ids, as recorded by Jordan and Richardson.

This species, originally known from the Mauritius, occurs also in the East Indies where few representatives were taken. It is well known at Guam, Ponape, and Samoa.

\section{ABUDEFDUF LEUCOZONA (Bleeker)}

Plate 18, Fig. 2

Glyphisodon leucozona BL.झEKER, Nat. Tijd. Ned. Ind. 19 (1859) 338; GüNTHRR, Cat. Fishes 4 (1862) 49; Nat. Verh. Holl. Maats. Wet. 2 (1877) 112; Atlas Ichth. 9 (1878) pl. 407, fig. 2.

Abudefduf leucozona WBBER, Fische der Siboga Exped. (1913) 349.

Dorsal XII, 15; anal II, 12; scales in lateral series 25; with tubules 20 ; between lateral line and origin of dorsal 4 ; between lateral line and vent 10.

Body deep, 1.9 in length; dorsal outline more elevated than ventral; head 2.8; depth of caudal peduncle 6. Eye large and round, diameter 3.3 in length of head, or as long as the pointed snout; mouth small and almost horizontal; jaws equal; the maxillary, which ends posteriorly under anterior edge of orbit, 3.7 in head or equal to width of interorbital space; teeth in a single row, compressed, and notched. Gill rakers 19 on first arch. The orbital ring behind angle of mouth less than half diameter of eye.

Preorbital in front of eye and margins of preopercle naked, rest of head scaly; vertical fins with a high scaly sheath at base. 'I'he fifth, sixth, and seventh spines highest, being higher than second anal. Soft dorsal and anal about equal in height; caudal emarginate with the lobes rounded; pectoral ending above vent, its upper rays longest; first ray of ventral fin produced into a filament, which extends to base of anal spines.

Yellowish brown in alcohol, with a white vertical band descending from sixth, seventh, and eighth dorsal spines; a large dark ocellus edged with white at base of last three dorsal spines and above lateral line; another dark spot on back of tail imme- 
diately after dorsal fin; a small one superiorly at base of pectoral. Ventrals and tips of soft anal dusky, the fins yellowish.

The specimen above described is 32 millimeters in length and was obtained at Balabac Island, Palawan. In coloration this species resembles Chrysiptera brownriggii (Bennett), but is easily distinguished by its deeper body.

This is the first Philippine record of this species; it is rare in the rest of the Indo-Australasian Archipelago, from whence only it is known.

\section{ABUDEFDUF LACRYMATUS (Quoy and Gaimard)}

Plate 7, Fig. 1

Glyphisodon lacrymatus QUoY and GaIMARD, Voy. Uranie, Zool. 2 (1824) 388, pl. 62, fig. 7; CuVier and Valenciennes, Hist. Nat. Poiss. 5, (1830) 478; GüNTHER, Cat. Fishes 4 (1862) 49; Fische der Südsee 2 (1876) 232, pl. 125, fig. D; BLEEKGR, Nat. Verh. Holl. Maats. Wet. 2 (1877) 111; Atlas Ichth. 9 (1878) pl. 404, fig. 6. Abudefduf lacrymatus SEALe, Polyn. Ethnol. Nat. Hist. 1 (1901) 83; JoRdAN and Seale, Bull. U. S. Bur. Fisheries 25 (1906) 285.

Dorsal XII or XIII, 15 to 17 ; anal II, 12 or 13 ; scales in lateral series 25 ; with tubules 18 or 19 ; between lateral line and origin of dorsal 3 ; between lateral line and vent 10 .

Dorsal outline deeper and more arched than ventral; body short and deep, contained 1.8 to 1.9 in length; head 2.9 to 3.1 ; depth of caudal peduncle 6.1 to 6.6. Interorbital space 3 in head; eye circular, 3 to 3.3 ; mouth rather small, horizontal, lower jaw slightly included; snout 3.2 to 3.4 in head and about as long as maxillary, with the tip slightly pointed and not quite on a level with lower margin of orbit; teeth in a single series, compressed, with notched edges. Gill rakers on first arch 23. Width of preorbital above posterior end of maxillary greater than half diameter of eye; opercle provided with a flat spine behind.

Head and body completely scaled; base of vertical fins with a rather high sheath of scales. Posterior dorsal spines highest. Rayed dorsal and anal equal in height; caudal forked, with the lobes a little pointed, the upper one slightly the longer. Pectoral not reaching anal opening; ventral about as long as head, its first ray filamentous.

Fresh specimens deep brown with sapphire spots scattered over body and vertical fins; tail yellow; dorsal with a broad blackish margin; pectoral with a black spot at base.

Brownish in spirits, with small, scattered, bluish white spots; posterior dorsal rays, caudal peduncle, and fin yellowish; spinous 
dorsal dusky on outer portion; pectoral whitish, with a blackish spot across its base; anal and ventrals dusky.

The above account is from seven examples, 43 to 65 millimeters long, taken at Tagbilaran, Bohol; Canigaran, Palawan; and Tambagaan, South Ubian, Bungau, and Sitankai Islands, Sulu Archipelago. Two specimens from Guam, which I have examined, in the Bureau of Science collection, agree in every respect with the Philippine representatives.

This species has not been noted previously from the Philippines. It occurs in almost all parts of the Indo-Australasian Archipelago, whence it ranges eastward to Samoa.

\section{Genus CHRYSIPTERA Swainson}

Chrysiptera SwaInson, Nat. Hist. Fish. 2 (1839); azureus; not Chrysoptera Latreille (1885), a genus of Lepidoptera.

Paraglyphidodon BleEkrR, Nat. Verh. Holl. Maats. Wet. 2 (1877) 116; bonang.

Glyphidodontops BLEFKER, Nat. Verh. Holl. Maats. Wet. 2 (1877) 128; cyaneus $=$ azureus.

Body oblong or ovate, deep or elongate. Scales large or moderate in size, about 26 or less in longitudinal series; lateral line interrupted before the end of soft dorsal fin. Teeth in a double series, compressed, with entire edges. A single dorsal fin with 13 spines. Orbital ring and all the opercular bones entire.

Under Chrysiptera Bleeker recognizes two genera: Paraglyphidodon, with the body rather deep, teeth more or less rounded, and the snout scaly; and Glyphidodontops, with the body oblong or slightly elongate, the teeth more or less truncate, and the snout naked. It differs from Abudefduf in the presence of two rows of teeth.

Thirteen species of this genus are known to occur in the Philippines; it is widely distributed from the Red Sea and the east coast of Africa to Polynesia.

Key to the Philippine species of Chrysiptera.

$a^{2}$. Body markedly oblong and deep; snout scaly.

$b^{2}$. Orbital ring and vertical limb of preopercle scaly.

$c^{2}$. Body and fins uniformly blackish brown. C. melas.

$c^{2}$. Ventrals and anterior portion of anal black.

$d^{2}$. Spinous dorsal and some of the anterior dorsal rays edged with the blackish color; side of head with two dark vertical bands.

C. xanthura.

$d^{2}$. Dorsal fin and head without mark of any kind.... C. xanthonota. $b^{2}$. Orbital ring and vertical limb of preopercle naked........ C. oxyodon. 
$a^{2}$. Body ovate-oblong, more or less elongate; snout naked.

$e^{1}$. Suborbital naked.

$f^{2}$. Scales on top of head extending to above front rim of eye.

$g^{1}$. Middle dorsal spines shorter than or about as long as posterior ones C. uniocellata.

$g^{2}$. Middle dorsal spines longer than posterior ones.

$h^{1}$. Head with some dark streaks in front.

$i$. Each scale of body with a dark vertical streak.... C. parasema. i. Scales of body dotted.

$j^{2}$. Each scale indistinctly dotted with white C. cyanea.

$j$. Each scale with one or two black dots

$h^{2}$. Head without any dark lines in front

C. assimilis.

$f$. Scales on top of head extending to above nostrils.

$k^{1}$. Body with three yellow crossbands; dorsal fin without any ocelli.

C. amabilis.

$k^{2}$. Body with a single yellow crossband, present only in some individuals; dorsal fin with two dark ocelli in the young.

C. brownriggii.

$e^{2}$. Suborbital scaly.

$l$. A small black spot at origin of lateral line C. rex.

$l^{2}$. Body unmarked

C. glauca.

CHRYSIPTERA MELAS (Cuvier and Valenciennes)

Plate 19, Fig. 2

Glyphisodon melas CUvier and VAlenciennes, Hist. Nat. Poiss. 5 (1830) 353; Schlegers and MÜLlwR, Overz. Amphi. Verh. Nat. Ges. Ned. Overz. Bezitt. (1839) 23, pl. 5, fig. 2; GüNTHFR, Cat. Fishes 4 (1862) 45.

Paraglyphidodon melas BlezkER, Nat. Verh. Holl. Maats. Wet. 2 (1877) 123; Atlas Ichth. 9 (1878) pl. 404, fig. 4.

Chrysiptera melas JoRdAN and SNYDER, Proc. U. S. Nat. Mus. 24 (1902) 605.

Glyphisodon ater CUVIBR and VALENCIENnes, Hist. Nat. Poiss. 5 (1830) 473.

Glyphisodon violascens BreVoort, Exped. Japan (1856) 264.

Dorsal XIII, 13 or 14 ; anal II, 12 or 13; scales in lateral series 26 ; with tubules 16 or 17 ; between lateral line and origin of dorsal 4 ; between lateral line and vent 11 .

Body oblong, rather deep, contained 1.8 to 2 in length; the short head 3.1 to 3.5 ; caudal peduncle short, depth 5.8 to 6.4 . Interorbital strongly arched, 2.4 to 2.8 in length of head, slightly bulging on top of head; eye small, circular, 3.2 to 4.3 ; snout blunt, 2.8 to 3.1 in head or slightly longer than maxillary, which is contained 3 to 3.4 in head. Teeth in two series, very narrow, scarcely compressed. Width of preorbital at posterior end of maxillary a trifle greater than half diameter of orbit.

Head and body completely covered with large ctenoid scales. Dorsal spines low, very strong, becoming higher posteriorly. 
Soft dorsal and anal rounded, and of about the same height; pectoral not reaching vent; caudal slightly emarginate.

Uniformly blackish brown in alcohol, with very light greenish reflections.

Here described from thirteen specimens, 68 to 147 millimeters in length. They were collected at Sialat Point, Catanduanes Island; Puerto Galera and Calapan, Mindoro; Surigao, Samal Island, and Zamboanga, Mindanao; and Tambagaan, Bungau, and Sibutu Islands, Sulu Archipelago. In the Bureau of Science aquarium are eight living examples, which are deep rich violet throughout with no mark of any kind on the body.

This species, which is now recorded for the first time from the Philippines, ranges from the Red Sea through the East Indies to the New Hebrides.

\section{CHRYSIPTERA XANTHURA (Bleeker)}

Glyphisodon xanthurus BLFझKER, Nat. Tijd. Ned. Ind. 5 (1853) 345; GÜNTHER, Cat. Fishes 4 (1862) 47.

Paraglyphidodon xanthurus BLEEKER, Nat. Verh. Holl. Maats. Wet. 2 (1877) 122; Atlas Ichth. 9 (1878) pl. 405, fig. 3.

Abudefduf xanthurus Evgrmann and Seale, Bull. U. S. Bur. Fisheries 26 (1907) 92.

Dorsal XIII, 14; anal II, 13; scales in lateral series 25; with tubules 17 ; between lateral line and origin of dorsal 4 ; between lateral line and vent 10 .

Upper and lower outlines of head nearly straight and almost at right angles with each other; body deep and oblong, 1.9 in length; head 3.5; depth of caudal peduncle 6.3. Interorbital space broad, strongly convex, and 2.6 in length of head; snout rounded, as long as eye diameter, which is 3.5 in head. Jaws even, cleft of mouth slightly oblique; maxillary, which is a trifle shorter than snout, extends posteriorly a little before anterior margin of orbit; two rows of bluntish teeth present.

Head with scales everywhere except on symphysis of lower jaw. Posterior dorsal spines highest. Middle rays of soft dorsal and anal forming acute angles; caudal emarginate; pectoral as long as ventral, longest above and extending to above anus.

Brownish orange in alcohol, with a blackish violet edge on spinous dorsal and on anterior portion of soft vertical fins. Pectoral with a brown axillary spot superiorly. A bluish line extending from tip of snout to front of orbit; two dark vertical bands on each side of head, one below orbit and the other immediately behind preopercle. 
In the Bureau of Science collection is a single specimen, 72 millimeters long, which is described above. It is one of the eleven examples obtained at Bacon, Sorsogon, as reported by Evermann and Seale.

Outside of the Philippines, it is known from the coasts of Flores, Sangir, Amboina, and Ceram.

CHRYSIPTERA XANTHONOTA (Bleeker)

Glyphisodon xanthonotus BLwEkER, Nat. Tijd. Ned. Ind. 18 (1859) 357; GünthiR, Cat. Fishes 4 (1862) 48.

Paraglyphidodon xanthonotus BLBखK ER, Nat. Verh. Holl. Maats. Wet. 2 (1877) 126; Atlas Ichth. 9 (1878) pl. 404, fig. 3.

Dorsal XIII, 13; anal II, 13; scales in lateral series 24; with tubules 15; between lateral line and origin of dorsal 4; between lateral line and vent 11.

Body oblong, slightly elevated; profiles similar, equal in depth; depth of body 1.7 to 1.8 in length; head 2.9 to 3.2 ; depth of caudal peduncle 5.5 to 6 . The slightly convex interorbital 3 to 3.2 in length of head; the large eye 2.6 to 2.7, high up on head; snout 3.5 to 3.8 ; maxillary 3.3 to 3.5 , its posterior end below anterior margin of orbit. Mouth slightly oblique, jaws even; teeth very narrow and pointed, in two series. Suborbital ring less than half an eye diameter at its greatest width; opercle ending behind in a large flat spine.

Head and body covered everywhere with scales; base of dorsal and anal fins with a moderately high sheath of scales. Dorsal spines becoming higher toward the last. Soft vertical fins produced along the middle into a point; caudal emarginate, pectoral pointed superiorly, its tip above origin of anal; ventral extending to base of second anal spine, its outer ray filamentous.

In life the lower three-fourths of body, the posterior dorsal rays, and caudal are dark violet; upper part of head, back, and dorsal fin clear yellow; caudal fin has a yellow stripe on its upper and lower margins; the ventrals have a blackish violet spot between first and second rays; the anal has a large blackish violet blotch on outer portion of its anterior rays, the remaining portion varying from pale violet to clear yellow posteriorly.

Violet yellow in alcohol; anal blackish anteriorly, ventral similarly colored, with the tip whitish; upper and lower margins of caudal paler.

This species is easily identified by its deep body, and by the persistent deep blackish violet color on the ventral and anal fins. Known for the first time in the Philippines, from two 228796-7 
specimens, 30 and 48 millimeters long, obtained in Surigao and Zamboanga, Mindanao. Elsewhere reported only from Bawean Island, off the north coast of Java.

CHRYSIPTERA OXYODON (Bleeker)

Glyphisodon oxyodon BlEEkrR, Act. Soc. Sci. Ind. Neerl. 3 (1858) 14; GüNthirR, Cat. Fishes 4 (1862) 44.

Paraglyphidodon oxyodon BLEEKER, Nat. Verh. Holl. Maats. Wet. 2 (1877) 127; Atlas Ichth. 9 (1878) pl. 404, fig. 2.

Dorsal XIII, 13; anal II, 13; scales in lateral series 25 or 26; with tubules 16 or 17 ; between lateral line and origin of dorsal 4 ; between lateral line and vent 10 .

Body oblong and deep, 1.9 to 2 in length, with dorsal and ventral outlines equally elevated; head 2.8 to 3.1 . in length of body; depth of caudal peduncle 5.7 to 5.9. Interorbital space a little arched, contained 3 to 3.4 in length of head, or as wide as the diameter of the large, round eye or the length of maxillary; snout 3.4 in head, its tip slightly pointed and on a level with inferior margin of orbit. Teeth in two series, those on upper jaw slender, compressed, and pointed, some of those on lower lobate. Greatest width of preorbital half diameter of eye; opercle ending in a flat spine.

Scales entirely covering head, except from nostrils to tip of snout, orbitals, and limbs of preopercle; a moderately high basal sheath of scales on vertical fins. Dorsal spines evenly graduated toward the last, which is the highest. Soft dorsal and anal rounded and produced along the middle; caudal slightly emarginate, with the lobes rounded; pectoral terminating before vent; outer ray of ventral produced into a filament, which reaches origin of anal fin.

Color in alcohol brownish violet, with four bluish white oblique bands: The first from below origin of spinous dorsal to and around tip of snout; second from origin of soft dorsal to below lateral line; third from top of tail ending below base of dorsal rays; fourth running backward across opercles from chin. A fifth vertical band, pearl white in color, around body through belly and dorsal spines, appearing as a dull whitish blotch scarcely noticeable in some specimens; a brownish spot superiorly at base of pectoral.

The four specimens above described were taken at Sitankai Island, Sulu Archipelago. They range from 31 to 75 millimeters in length. This species is very striking on account of the arrangement of its bands and because of the nature of its 
teeth. It is one of the most beautiful pomacentrids seen among the coral reefs, which are its favorite haunts. With the exception of the milk-white vertical streak, the specimens referred to resemble Bleeker's figure.

There is no previous record of this species from the Philippines. Hitherto known only from the Celebes Sea.

\section{CHRYSIPTERA UNIOCELLATA (Quoy and Gaimard)}

Glyphisodon uniocellatus QuOY and GaImard, Voy. Uranie, Zool. 2 (1824) 393, pl. 64, fig. 4; Cuvier and Valenciennes, Hist. Nat. Poiss. 5 (1830) 360; Schlegel and Müller, Overz. Amphi. .Verh. Nat. Ges. Ned. Overz. Bezitt. (1839) 23; GüNTHER, Cat. Fishes 4 (1862) 52; Fische der Südsee 2 (1876) 234, pl. 128, fig. A (not of Bleeker).

Abudefduf uniocellatus Jordan and Seale, Bull. U. S. Bur. Fisheries 25 (1906) 288, pl. 43, fig. 2.

Dorsal XIII, 11 to 13 ; anal II, 11 to 13 ; scales in lateral series 25 ; with tubules 16 ; between lateral line and origin of dorsal 3; between lateral line and origin of anal 10 .

Body ovate, slightly elongate, with dorsal and ventral profiles similarly and evenly curved; depth 2.8 to 2.9 in length; head 3.1 to 3.2 ; depth of caudal peduncle 6 to 6.5 . Interorbital space slightly convex, 3.4 to 4.2 in head; eye large and round, diameter 2.8 to 2,9 , longer than snout which is 3.4 to 5 in head, or maxillary which is contained 2.8 to 4.5 in head. Mouth very small, almost horizontal, with the jaws equal; tip of snout nearly on a level with lower edge of pupil; maxillary extending posteriorly past below front margin of orbit; teeth very narrow, in a double series. Greatest width of preorbital about a third of eye diameter; opercle with two flat spines behind.

No scales on snout, orbitals, or limbs of preopercle. Middle and posterior dorsal spines nearly the same height. Soft vertical fins angular, produced along the median; caudal subtruncated, with rounded lobes; pectoral terminating above vent; outer ray of ventral produced into a filament, which extends to origin of anal fin.

Color of alcoholic specimens bluish, with one or two yellow spots on each scale; a dark band along middle of nape and of forehead; a wide one convergent at snout, passing through eye, to origin of lateral line; a third one across preorbital and upper jaw. A small round black spot occupies base of last three dorsal rays and the axil of the fin. Pectoral light violet, the outer portion of the other fins yellowish. 
Here described from six specimens, 19 to $\mathbf{3 5 . 5}$ millimeters long. collected at Despujols, Tablas Island; Tacloban, Leyte; Port Canoan, Siquijor Island; and Zamboanguita, Oriental Negros.

This species, not heretofore recorded from the Philippines, is known to occur in the Indo-Australasian Archipelago and in Polynesia, excluding Hawaii.

CHRYSIPTERA PARAgEMA (Fowler)

Plate 19, Fig. 1

Abudefduf parasema Fowher, Proc. Acad. Nat. Sci. Phila. 70 (1918) 56, fig. 22.

Dorsal XIII, 11; anal II, 12; scales in lateral series 26; with tubules 14 to 16 ; between lateral line and origin of dorsal 3 ; between lateral line and vent 10 .

Body ellipsoid and well compressed, its depth 2 to 2.1 in length; head 3 to 3.1 , moderately large, with dorsal and ventral profiles similar; depth of caudal peduncle 6.3 to 6.7. Interorbital space convex, 3 to $\mathbf{3 . 2}$ in length of head; eye large, rounded, its diameter 2.4 to 2.8 , or longer than snout, which is 3.3 to 3.4 in head; mouth small, slightly oblique, jaws about even; maxillary 3 to 3.4 in head, and reaching posteriorly to below front edge of eye; tip of snout on a level with lower margin of orbit; teeth in two series, those in front with truncate edges, those behind small, slender, and with rounded or slightly pointed tips. Preorbital slightly notched in front, its width at posterior end of maxillary about one-third eye diameter; opercle armed behind with a flat spine.

Scales on top of head extending to nostrils, leaving the space from there to tip of snout naked; both preorbital and suborbital naked; vertical limb of preopercle also unscaled. Middle dorsal spines highest. Soft vertical fins rounded and nearly the same height; caudal emarginate with the lobes slightly rounded, pectoral moderate, rather broad, reaching origin of anal fin; ventral extending to base of anal spines.

Fresh specimens violet blue, contrasting with the bright lemon yellow of the caudal peduncle and the anterior portion of fin; caudal fin dusky outwardly; the other fins dark brown, excepting pectoral which is pale; each side of head with three oblique, bluish white streaks and many spots; scales of body with vertical bluish white streaks and edged with dusky.

Ground color in alcohol brownish violet; caudal peduncle and anterior portion of fin yellowish; caudal fin dusky on its outer half; vertical fins dusky brown; pectoral pale; ventrals 
dusky; three oblique bluish white streaks on each side of head; each scale on head with a bluish white spot; scales on body with bluish white vertical streaks and edged with blackish; a dusky spot at base and axil of pectoral.

The above description is of three specimens, 29 to 36 millimeters in length, collected by Albert W. Herre at Tawitawi and Bungau Islands, Sulu Archipelago.

This species has been recorded from the "Philippine Islands" by Fowler.

\section{CHRYSIPTERA CYANEA (Quoy and Gaimard)}

Glyphisodon cyaneus QUOY and GaImard, Voy. Uranie, Zool. 2 (1824) 392, pl. 64, fig. 3.

Glyphidodontops cyaneus BLEEKER, Nat. Verh. Holl. Maats. Wet. 2 (1877) 130; Atlas Ichth. 9 (1878) pl. 409, fig. 2.

Abudefduf cyaneus EvErmanN and SEAls, Bull. U. S. Bur. Fisheries 26 (1907) 92.

Glyphisodon azureus Cuvirr and Valenciennes, Hist. Nat. Poiss. 5 (1830) 359; GüNTHBR, Cat. Fishes 4 (1862) 53.

Dorsal XIII, 12 or 13; anal II, 12; scales in lateral series 25; with tubules 17 or 18 ; between lateral line and origin of dorsal 3 ; between lateral line and vent 9 .

Body ovate-oblong, the profiles equally elevated, depth of body 2.2 to 2.3 in length; head 3.1 to 3.2 ; depth of caudal peduncle 6.5 to 6.8 . Interorbital space strongly arched, 3.1 to 3.8 in length of head; eye round and fairly large, diameter 2.8 to 3.3 , longer than snout which is contained 3.3 to 3.7 in head; maxillary long, 2.8 to 3 in head, extending posteriorly considerably behind vertical through anterior margin of orbit. Mouth slightly oblique, lower jaw a little included; teeth biserial in each jaw, with blunt tips. Width of preorbital at posterior end of maxillary about one-third diameter of eye; opercle with two flat spines at its hind edge.

Scales on top of head stopping at front rim of orbit; none on orbital ring or on edges of preopercle; a low sheath of scales at base of vertical fins. Middle dorsal spines highest. Soft dorsal and anal almost angular; pectoral shorter than anal and almost reaching vent.

Color in spirits brownish violet; the bluish color apparently has faded out; two short lines on head, one in front of eye meeting the other line on the opposite side at tip of snout, and the other across preorbital; all the fins yellowish.

Described from two examples, 32 and 34 millimeters long, which have been recorded from Bacon, Sorsogon, by Evermann and Seale, and from four others, 42 to 54 millimeters long, which 
were collected by E. H. Taylor at the southern coast of Cotabato Province.

Contrary to the account of Evermann and Seale, the specimens in the Bureau of Science collection and the one in the museum of Stanford University show very well two yellowish streaks on the anterior portion of the head and the dull yellow color on all the fins, thus removing any doubt as to their identity. All the specimens agree with the figure and description of Quoy and Gaimard.

This species is known only from the Indo-Australasian Archipelago and the Friendly Islands.

\section{CHRYSIPTERA ASSIMILIS (Günther)}

Plate 10, Fig. 1

Glyphisodon assimilis GÜNTHER, Cat. Fishes 4 (1862) 52; Peters, Mon. König. Akad. Wiss. Berlin (1868) 271, var.

Glyphisodon uniocellatus BLEEKER, Nat. Tijd. Ned. Ind. 4 (1853) 119; not of Quoy and Gaimard.

Glyphidodontops uniocellatus BLEEKkR, Atlas Ichth. 9 (1878) pl. 410, fig. 6.

Abudefduf sapphirus JoRdan and RICHaRdson, Bull. U. S. Bur. Fisheries 27 (1908) 264, fig. 10.

Dorsal XIII, 11 to 13 ; anal II, 12 or 13; scales in lateral series 26 ; with tubules 16 or 17 ; between lateral line and origin of dorsal 3 ; between lateral line and vent 10 .

Body rather elongate, with dorsal and ventral profiles similar; depth contained 2 to 2.3 in length; head 3.1 to 3.4 ; depth of caudal peduncle 6.1 to 6.6. Interorbital space convex, its width 3 to 3.6 in length of head; eye circular, contained 2.7 to 3.3 ; snout rather short, only 3.4 to 4 in head; maxillary 2.8 to 3.3, extending posteriorly beyond anterior margin of orbit. Mouth oblique, jaws equal; teeth in a double series, with rounded edges. Orbital ring very narrow, its width at posterior end of maxillary scarcely half diameter of eye; opercle with two flat spines behind.

No scales on snout, orbitals, or preopercular limbs. Middle dorsal spines higher than posterior ones. Rayed dorsal and anal rounded; caudal slightly emarginate, with the lobes rounded; pectoral terminating above vent; outer ray of anal prolonged and extending to origin of anal.

Color in alcohol varying from deep blue to yellowish brown, with one or two black dots on each scale, which have faded in some of the specimens; a blackish violet streak along middle of nape and forehead; another one from origin of lateral line, 
through eye to snout, meeting that of the other side; and a third one crossing preorbital and upper jaw. A horizontal series of specks of similar color across cheek. A round black spot, if present, occupies the base of the middle dorsal rays. In some examples, the outer portion of caudal and soft vertical fins is yellowish blue, and in others blackish.

The above account is based upon forty-six examples, varying from 16.5 to 46 millimeters in length. They were collected at the following localities: Nalvo, Luna, La Union; Calapan, Mindoro; Apo Reef, off the coast of Mindoro; Bantayan Island; Canigaran, Palawan; and Sibutu and Sitankai Islands, Sulu Archipelago. A single specimen, 32 millimeters long, taken at Canigaran in November, 1925 , is a ripe female.

This species has been previously recorded by Günther from one specimen marked "Philippine Islands," and by Jordan and Richardson from six examples collected by R. C. McGregor at Ticao Island, as Abudefduf sapphirus.

Living specimens in the Bureau of Science aquarium are deep sky blue, with two blackish violet streaks on each side of head and a longitudinal band of the same color on top of head; the fins lighter than the ground color. Vertical and caudal fins of those having a black spot at base of some of the dorsal rays edged with blackish; in some specimens all the fins uniformly bluish, without blackish markings of any kind; in others the vertical fins with blackish margins and the caudal uniformly bluish or partially edged with blackish.

Günther observes that there is considerable variation in the color pattern of the caudal fin, which is also exhibited in my examples and, in view of this fact, I cannot accept Abudefduf sapphirus as a distinct species. The dorsal spot in Chrysiptera assimilis is more anterior than in Glyphisodon uniocellatus Quoy and Gaimard.

This species is found in the Indo-Australasian Archipelago to the east of Borneo.

CHRYSIPTERA TURChESIUS (Jordan and Seale)

Abudefduf turchesius JORDAN and SEALE, Bull. U. S. Bur. Fisheries 26 (1907) 28, fig. 10; SNYDER, Proc. U. S. Nat. Mus, 42 (1912) 505.

Dorsal XIII, 11 or 12; anal II, 13; scales in a lateral' series 25 ; with tubules 15 to 17 ; between lateral line and origin of dorsal 3 ; between lateral line and vent 10 .

Body ovate-oblong, compressed, the depth 2.3 to 2.5 in length; head 3 to 3.3 ; depth of caudal peduncle 6.3 to 6.6. Width of 
the strongly arched interorbital 3.2 to 3.8 in head, or less than length of eye diameter, which is 2.8 to 4.5 in head; snout 3.5 to 3.7 in length of head, its tip on a level with inferior margin of orbit; maxillary 3.1 to 3.6 , its posterior end below front margin of orbit. Mouth slightly oblique, jaws even; teeth in two series, very closely appressed, their tips blunt. Preorbital at angle of mouth as wide as a third of eye diameter; opercle armed behind with two flat spines.

The space from front margin of eye to tip of snout unscaled; orbital ring and both inferior and vertical limbs of preopercle also naked. Middle dorsal spines a trifle higher than posterior ones. Rayed anal higher than soft anal, both fins rounded and produced along the middle; caudal obliquely truncate, with the upper lobe slightly longer; pectoral scarcely reaching vent; outer ray of ventral produced into a filament, which touches base of anal spines.

Deep blue in alcohol, lighter on the lower parts, each scale with a lighter margin; all the fins colored same as body, with the outer portion somewhat lighter.

I have examined in the Bureau of Science collection four specimens, 36 to $\mathbf{4 5 . 5}$ millimeters long, taken at Calapan, Mindoro. This species was originally described by Jordan and Seale from Cavite, Cavite.

Contrary to the diagnosis of the authors, this fish has two rows of teeth. J. O. Snyder recorded a number of examples from Okinawa Islands, where it is very common in the pools.

CHRYSIPTERA AMABILIS (De Vis)

Plate 1, Fig. 2

Glyphisodon amabilis DE VIS, Proc. Linn. Soc. N. S. W. (1883) 353. Abudefduf amabilis Jordan and Seale, Bull. U. S. Bur. Fisheries 25 (1906) 287, pl. 42, fig. 1; JORDAN and RichaRDSON, Bull. U. S. Bur. Fisheries 27 (1908) 264.

Glyphisodon brownriggii var. xanthozona GüNTHER, Fische der Südsee 2 (1876) 234, pl. 127, fig. D; not Glyphisodon xanthozona of Bleeker.

Dorsal XIII, 11 or 12; anal II, 12; scales in lateral series 26; with tubules 17 to 19 ; between lateral line and origin of dorsal 3 ; between lateral line and vent 8 .

Body ovate-oblong, its depth 2.4 to 2.5 in length; head 3.3 to 3.4, its profile convex above and slightly less beneath; depth of caudal peduncle 6.3 to 6.5. Interorbital space convex, rather narrow, 3.2 to 3.4 in head; diameter of eye 2.6 to 2.7, about as long as maxillary, which ends posteriorly below front edge 
of orbit; snout equal to width of interorbital space. Teeth in two rows with slightly rounded edges. Greatest width of orbital ring scarcely half diameter of eye; opercle with two flat spines behind.

No scales on the area between nostrils and tip of snout; none on orbitals, edges of preopercle, and chin. Middle dorsal spines as high as posterior ones. Soft anal slightly higher and more pointed than rayed dorsal; caudal slightly emarginate; ventral ending at vent.

Fresh specimens, dusky olive, with three.crossbands; the first one over the opercle yellowish orange, and two others above vent and across caudal peduncle lemon yellow. Ventrals and anal dusky; soft dorsal and caudal dusky at base and yellowish orange outward; spinous dorsal with a very narrow blackish margin; pectoral very slightly washed with yellow, with a dusky blotch at base; the opercular flap above the larger spine blackish.

Here described from four specimens, 32.5 to 45 millimeters long, collected at Paraoir, Balaoan, and Bauang Sur, La Union. I have examined in the museum of Stanford University three other examples of this species, collected by R. C. McGregor at Calayan Island, as recorded by Jordan and Richardson.

Günther regards this species as Glyphisodon brownriggii var. xanthozona, from which the species above described differs in the relative position of the second vertical band on the body. It differs also from xanthozona of Bleeker in having fewer crossbands and in the absence of a distinct dark blotch at the base of some of the dorsal rays.

This species is known throughout the tropical Pacific Islands.

\section{CHRY BIPTERA BROWNRIGGII (Bennett)}

Chaetodon brownriggii BENNETT, Fishes of Ceylon (1828) 8, pl. 8. Glyphisodon brownriggii Cuvier and VAlunciennes, Hist. Nat. Poiss. 5 (1830) 362; GÜNTHER, Fische der Südsee 2 (1876) 232, pl. 127, figs. B, C, E.

Abudefduf brownriggii JORDAN and RICHARDSON, Bull. U. S. Bur. Fisheries 27 (1908) 264; WEBBR, Fische der Siboga Exped. (1913) 352.

Abudefduf brownriggii var. zonatus WBBER, Fische der Siboga Exped. (1913) 353.

Glyphisodon unimaculatus CuVIER and VALENCIENNES, Hist. Nat. Poiss. 5 (1830) 358; SchLegre and MüLler, Overz. Amphi. Verh. Nat. Ges. Ned. Overz. Bezitt. (1839) 23, pl. 6, fig. 1; BleEkER, Nat. Tijd. Ned. Ind. 4 (1853) 284; GüNTHBR, Cat. Fishes 4 (1862) 51. Glyphidodontops unimaculatus BLFEK BR, Nat. Verh. Holl. Maats. Wet. 2 (1877) 140; Atlas Ichth. 9 (1878) pl. 407, fig. 5. 
Abudefduf unimaculatus JoRdan and Seale, Proc. U. S. Nat. Mus. 28 (1905) 784; Evermann and Seale, Bull. U. S. Bur. Fisheries 26 (1907) 93; JoRdaN and EvermanN, Bull. U. S. Bur. Fisheries 27 (1908) 263; Weber, Fische der Siboga Exped. (1913) 354.

Glyphisodon leucopomus CUVIER and VALENCIENNES, Hist. Nat. Poiss. 5 (1830) 359.

Glyphisodon antjerius CuVIER and VALENCIENNES, Hist. Nat. Poiss. 5 (1830) 360 ; BlEekgR, Nat. Tijd. Ned. Ind. 8 (1855) 454; GüNTHER, Cat. Fishes 4 (1862) 50; MeYer, Ann., Soc. España Hist. Nat. 14 (1885) 34.

Abudefduf antjerius Jordan and SEale, Bull. U. S. Bur. Fisheries 25 (1906) 287, pl. 42, fig. 2; EvermanN and Sfale, Bull. U. S. Bur. Fisheries 26 (1907) 93; JoRdan and Evermann, Bull. U. S. Bur. Fisheries 27 (1908) 264; SNYDkR, Proc. U.'S. Nat. Mus. 42 (1912) 419; Fowler, Proc. Acad. Nat. Sci. Phila. 70 (1918) 54.

Glyphisbdon biocellatus Cuvien and VArenCIEnnes, Hist. Nat. Poiss. 5 (1830) 361.

Glyphidodontops zonatus Cuvier and Valenciennes, Hist. Nat. Poiss. 5 (1830) 361; BLFikKR, Nat. Verh. Holl. Maats. Wet. 2 (1877) 138; Atlas Ichth. 9 (1878) pl. 407, fig. 3.

Abudefduf zonatus JORDAN and SFALE, Bull. U. S. Bur. Fisheries 25 (1906) 286; Evermann and Seale, Bull. U. S. Bur. Fisheries 26 (1907) 92; Jordan and Evarmann, Bull. U. S. Bur. Fisheries 27 (1908) 263.

Glyphisodon punctulatus Cuvier and VALENCIENNES, Hist. Nat. Poiss. 5 (1830) 362.

Glyphisodon xanthozona BLEEKER, Nat. Tijd. Ned. Ind. 4 (1853) 283; GüNTHER, Cat. Fishes 4 (1862) 43.

Glyphisodon rossii BLEEKER, Nat. Tijd. Ned. Ind. 7 (1854) 48.

Glyphisodon dispar GüNTHER, Cat. Fishes 4 (1862) 53.

Glyphisodon modestus GüNTHER, Cat. Fishes 4 (1862) 55.

Glyphisodon mutabilis CARTIER, Verh. Phys. Med. Ges. Würzburg (1873) 100.

Glyphisodon taeniomuptus CARTIER, Verh. Phys. Med. Ges. Würzburg (1873) 101.

Glyphisodon cingulatus var. near n. sp. ? CARTIER, Verh. Phys. Med. Ges. Würzburg (1873) 101.

Glyphidodontops modestus BLEEKER, Atlas Ichth. 9 (1878) pl. 403, fig. 9.

Dorsal XIII, 11 to 14 ; anal II, 11 to 13 ; scales in lateral series 25 ; with tubules 16 to 19 ; between lateral line and origin of dorsal 3 ; between lateral line and vent 9 .

Body ovate-oblong; upper profile of head slightly more arched than lower; depth of body 2 to 2.3 the length; head 3 to 3.4 or about twice the depth of caudal peduncle. Interorbital space convex and narrow, equal to or a trifle narrower than diameter of eye, which is 3 to 3.7 in length of head. Snout 3 to 3.6 in head, its tip not quite on a level with inferior edge of eye; maxillary contained 3 to 3.4, ending posteriorly a little before 
front margin of orbit; in large specimens snout and maxillary about equal in length, each slightly longer than eye, while in the young the eye is relatively much larger in proportion. Jaws even, forming an almost horizontal gape; teeth in two rows, rather slender, with rounded tips. Width of preorbital at hind end of maxillary about half diameter of eye; opercle with two flat spines behind.

Snout, orbital ring, and both vertical and inferior edges of preopercle naked; scales on top of head extending only to nostrils. Dorsal spines evenly graduated to the last, which is the highest. Soft portion of dorsal and anal rounded; caudal slightly emarginate with the lobes rounded; pectoral about as long as ventral and ending slightly before anus; outer ray of ventral more or less produced, extending to anal opening.

My total of one hundred twenty-eight examples of various sizes divides naturally into three excellent parallel color series. These show well the gradual variation of color markings due to age and their striking gradation in the different series. The young in all the series have bluish lines on the head, convergent at the snout, and all show that there are two distinct dark ocelli edged with blue, one under the last dorsal spines and the other at the base of the posterior rays. These color markings are absent in adult individuals. The lines on the head seem to disappear first, followed by the first dorsal ocellus. The ground color in alcohol of all the specimens varies from yellowish brown with purplish wash to dusky olive; a light or vertical streak on each scale; pectoral, caudal, and posterior rays of dorsal yellowish, the last two fins having a dark edge; ventrals and anal blackish. The yellowish crossband on body, absent in one series, appears to be persistent in all the stages of the other two, and these two series differ from each other in the presence in one of them of a light colored spot on top of the caudal peduncle immediately after the dorsal fin.

The color in alcohol of various specimens is as follows:

Twenty-eight specimens, 22 to 54 millimeters long, which I collected at the same time at Nalvo, Luna, La Union, represent an interesting series to show the gradual changes of color markings due to age. Ground color in alcohol greenish olive, each scale with a light vertical streak or spot; anal blackish, pectoral pale, soft dorsal slightly dusky, caudal yellowish toward the base and tipped with dusky. The second dorsal ocellus is persistent in all the stages, and the first one absent in individuals over 35 millimeters in length. The bluish lines on head are 
present in specimens up to 43 millimeters long. In the very young these lines are wide and long, being continued to the first dorsal ocellus, while in the older examples they are narrower and shorter. There is a short bluish line in front of eye and a much longer one on the suborbital of all the specimens. No yellowish vertical band is present on body.

Belonging also to the above series are fifty-seven examples, 20 to 57 millimeters long, coming from Currimao, Ilocos Norte; Luna and Paraoir, La Union; Nasugbu, Batangas; Puerto Galera and Calapan, Mindoro; Bacon, Sorsogon; Despujols, Tablas; Cabalian, Leyte; Canigaran, Palawan; Port Canoan and Lazi, Siquijor; Balabac Island; and Cotabato Province, Mindanao. They are brownish olive in alcohol, with a light vertical streak or spot on each scale. A short bluish line is present in front of eye, and a longer one on suborbital. There is persistent at the base of the last dorsal rays in all stages a black spot, which appears to be continued on the axil of the fin. Pectoral, caudal, and hind portion of rayed dorsal yellowish white, the last two fins with a blackish edge. Anal and ventrals blackish, caudal peduncle light posteriorly. In a specimen, 36 millimeters long, the second dorsal ocellus appears as a small spot, and the bluish lines on top of head are very fine. In smaller individuals there are two dorsal ocelli, and the bluish lines are usually present and well marked. These lines may also be present in some individuals up to 57 millimeters long.

The second series consists of twenty-three specimens, 25 to 68 millimeters long, coming from Currimao, Ilocos Norte; Nalvo, Luna, La Union; Polillo Island; Cebu, Cebu; San Juan, Siquijor Island; Canigao Island, Leyte; Balabac Island, Palawan; and Cotabato Province, Mindanao. They are dusky olive, with a rather indistinct light crossband on body and well-marked blue lines on top of head in very young specimens. Pectoral, caudal, and soft dorsal pale, the last two fins tipped with dusky. Individuals less than 47 millimeters in length have two dorsal ocelli, and one, 50 millimeters long, has the second ocellus at the base of the last dorsal rays. None in this series has a light spot at the axil of the dorsal fin. A specimen from San Juan, Siquijor Island, has the pectoral and caudal orange yellow.

Thirty examples, 23 to 84 millimeters long, from San Fernando, La Union; Bulan, Sorsogon; Canigaran and Balabac Island, Palawan; Samal Island, Mindanao; and Cagayan Sulu, Sitankai, and Saluag Islands, Sulu Archipelago, compose the third series. The ground color is yellowish brown in alcohol 
with a well-marked lemon yellow transverse band on body, a light spot or streak on each scale, and a yellow dot immediately behind the rayed dorsal. In examples up to 35 millimeters long the two black dorsal ocelli and the bluish lines on the head are present, the latter color marking being absent in the rest of the individuals. The two dorsal ocelli are to be found in specimens up to 46 millimeters in length. An example, measuring 50 millimeters long, has the second ocellus only, and larger ones do not have any of the dorsal ocelli.

Of the examples above described, forty-nine have spawned or are in near-breeding condition. They range from 35 to 85 millimeters in length, and were collected at the following localities:

Currimao, 1 ripe female.

Nalvo, 6 ripe females.

Paraoir, 1 ripe female.

Calapan, 8 ripe females, 2 ripe males, and 3 spent females.

Cebu, 1 ripe female.

Canigao Island, 2 ripe females and 1 ripe male.

Port Canoan, 1 ripe female.

Lazi, 1 ripe female.

Canigaran, 1 ripe female.

Balabac, 3 ripe females and 3 ripe males.

Samal Island, 4 ripe females.

Cotabato Province, 3 ripe females.

Sitankai Island, 4 ripe females.

Saluag Island, 1 ripe female and 3 spent females.

This fish breeds throughout the year, since the specimens referred to above were collected at all seasons.

Previously this species has been recorded in the Philippines from Cebu by Meyer; from Cebu and Bohol by Cartier; from Negros by Jordan and Seale; from Calayan and Cagayancillo by Jordan and Richardson; from Bacon by Evermann and Seale; from Sanguisiapo, Sulu Archipelago, by Weber; and from "Philippine Islands" by Fowler.

The Bureau of Science aquarium specimens are yellowish brown; slightly darker on posterior half of body, including caudal peduncle and anal fin. Ventrals blackish and the rest of the fins lemon yellow. There is a black spot at base of last dorsal rays.

It appears that this species undergoes considerable change in coloration, so that a great many species have been described. Some of my specimens, for example, which have the bluish lines on the head, the light vertical band on the body, and the two 
dark ocelli on the dorsal fin, show that the Abudefduf antjerius and Abudefduf zonatus of Jordan and Seale are identical. The original Chaetodon brownriggii Bennett is undoubtedly the young of the present species.

This widely distributed species is known to occur from the Red Sea and the east coast of Africa throughout the Indo-Australasian Archipelago to Polynesia.

\section{CHRYSIPTERA REX (Snyder)}

Abudefduf rex SNYDER, Proc. U. S. Nat. Mus. 36 (1909) 601, pl. 64, fig. 3.

Dorsal XIII, 13; anal II, 13; scales in lateral series 24; with tubules 15 and 16; between lateral line and origin of dorsal 3; between lateral line and vent 10 .

Body moderately elongate, dorsal and ventral contours similar; depth 2.1 to 2.2 in length; head 3.1 to 3.2 ; depth of caudal peduncle 6.2. Interorbital space convex, 3.3 to 3.9 in length of head; snout 4 ; mouth slightly oblique, with the jaws equal; maxillary, which is contained 3.4 to 3.8 in head, is equal to diameter of eye and ends posteriorly a little behind anterior edge of orbit; teeth in a double series, compressed, with pointed tips. Greatest width of preorbital less than half eye diameter.

Head completely scaled excepting portion of snout in front of nostrils. Dorsal spines increasing in height posteriorly, the last one about as high as second anal spine. Soft vertical fins angular; caudal notched; pectoral shorter than head; ventral much longer, its outer ray produced into a filament which extends to base of anterior anal rays.

Color in alcohol brownish, with a light dot at center of each scale. A narrow bluish line from front of orbit to snout, and appearing to unite with that on the other side; a short one across preorbital; a row of bluish dots more or less connected, directly below eye. Opercle and preopercle with some bluish spots, and origin of lateral line with a small black dot; all the fins yellowish white.

Here described from two specimens, 31 and 38 millimeters long, obtained at Sitankai Island, Sulu Archipelago. Contrary to Snyder's diagnosis, this species has two rows of teeth. The Philippine examples are identical with the Japanese representatives that I examined at Stanford University.

This species which has not been noted previously from the Philippines, was originally described by Snyder from specimens 
collected at Naha, Okinawa Islands, where it is well represented in the tide pools.

\section{CHRYSIPTERA GLAUCA (Cuvier and Valenciennes)}

Glyphisodon glaucus Cuvier and Valenciennes, Hist. Nat. Poiss. 5 (1830) 353; Jordan and Seale, Bull. U. S. Bur. Fisheries 25 (1906) 286; Evermann and Seale, Bull. U. S. Bur. Fisheries 26 (1907) 93; JoRdAN and RichaRdson, Bull. U. S. Bur. Fisheries 27 (1908) 264.

Dorsal XIII, 14; anal II, 15; scales in lateral series 25; with tubules 18; between lateral line and origin of dorsal 4 ; between lateral line and vent 9.

Body ovate-oblong, dorsal outline a low even curve from snout to caudal peduncle, ventral outline similar to dorsal; depth of body 2.1 in length; head 3.3 ; depth of caudal peduncle 6.5. Interorbital space strongly arched, its width 2.8 in length of head and nearly equal to the diameter of the large round eye, which is contained 2.6 in head; snout rounded and rather short, 4 in head, its tip above lower edge of orbit; maxillary slightly longer than snout and contained 3.2 in head, its posterior end on a vertical line with front margin of eye. Cleft of mouth very oblique; jaws even, teeth conical, in two rows in each jaw. Width of preorbital at posterior -end of maxillary about a third of orbit's diameter; opercle with a blunt, flat spine behind.

Head completely scaled; base of the rayed dorsal and anal with a low sheath of small scales. Middle dorsal spines higher than posterior ones. Soft dorsal and anal pointed and equal in height; caudal emarginate; pectoral and ventral fins nearly equal in length and both extending to vent.

Uniformly grayish brown in alcohol, with no spots or bands anywhere on head and body; all the fins yellowish.

One specimen that I examined in the Bureau of Science collection is 39.5 millimeters in length and was collected by C. J. Pierson at Bacon, Sorsogon, as recorded by Evermann and Seale. Three specimens have also been reported from Cagayancillo, Cagayan Islands, and from Ticao Island by Jordan and Richardson.

This species was originally described from Guam and is known from the East Indies northward to the Okinawa Islands. It has been recorded also from Samoa. 
7 


\section{INDEX}

[Names of new species are printed in boldface.]

Abadefduf, 76.

amabilis, 104.

antjerius, 106.

aureus, 87.

bankieri, 45 .

bengalensis, 80 .

brownriggii, 105.

brownriggii sonatus, 105.

coelestinus, 88.

coracinus, 89.

curaçao, 85.

cyaneas, 101.

dickt, 81.

dickii, 91.

lacrymatus, 93.

leucogaster, 88 .

leucozona, 92.

melsnopselion, 75 .

parasema, 100.

philippinus, 89.

rex, 110.

sapphirus, 102.

sexatilis, 81.

septemfasciatus, 79 .

sordidus, 77, 78.

turchesius, 103.

unimaculatus, 106.

aniocellatus, 99.

xanthurus, 96.

zonatus, 106.

Acanthochromis, 27

polyacanthus, 27.

akallopieos, Amphiprion, 17.

akallopisus, Amphiprion, 17.

Prochilus, 17.

albofasciatus, Eapomacentrus, 41.

Pomacentrus, 40.

albolineatus, Pomacentrus, 70.

alexanderse, Pomacentrus, 51.

amabllis, Abadefduf, 104.

Chrysipters, 104.

Glyphisodon, 104.

Amblyglyphidodon, 76.

Amblypomacentrus, 87. breviceps, 68 .

amboinensis, Pomacentrus, 58.

Amphiprion, 9.

akallopisos, 17.

akallopinus, 17.

bifasciatus, 15 .

boholensis, 10 .

chrysargarus, 10.
Amphiprion-Continued. chrysopterus, 10. ephippinm, 10.

frenatus, 12.

intermedius, 15.

japonicus, 10.

laticlavins, 15 .

pereula, 14.

perideraens, 16.

perideraion, 16.

polsmnus, 10.

snyderi, 10.

tricolor, 12.

Anthias bifasciatus, 15 .

polymna, 14.

antjerius, Abudefduf, 106.

Giyphisodon, 106.

arsneas, Chaetodon, 21.

arcuatum, Tetradrachmum, 21.

aruanum, Tetradrachmum, 22.

aruanus, Chaetodon, 21.

Dascyllus, 21.

Lntjanus, 21.

Pomacentrus, 21.

assimilis, Chrysiptera, 102.

Glypbisodon, 102.

ater, Glyphisodon, 95.

aureus, Abndefduf, 87.

Glyphisodon, 87.

Ayresia, 28.

azureus, Glyphisodon, 101.

$\mathbf{B}$

bandanensis, Gisphisodon, $\boldsymbol{\mu}$.

bankanensis, Pomsecentrus, 59.

bankieri, Abudefdus, 48.

Glyphisodon, 45.

Parapomacentrus, 45.

Pomacentrus, 45.

bengalensis, Abodefduf, 80 .

Chaetodon, 80.

Glyphisodon, 80.

binculeatus, Chaetodon, 18.

Premnas, 18.

bifaselatas, Amphiprion, 15.

Anthiae, 15.

Dichistodus, 47.

Holocentras, 15.

Pomacentrus, 47.

Prochlles, 15.

biocellatus, Glyphisodon, 106.

Pomacentros, 56. 
boholensis, Amphiprion, 10. Brachypomacentrus, 37 .

breviceps, Amblypomacentrus, 68.

Glyphidodon, 68.

Pomacentrus, 68.

brownriggii, Abndefduf, 105 .

Chaetodon, 105.

Chrysiptera, 105.

Glyphisodon, 105.

xanthozona, Glyphisodon,

zonatus, Abudefdue, 105.

burroughi, Pomacentrus, 59.

C

caeruleus, Chromis, 34 .

Heliases, 34 .

caudofasciatus, Dascyllus, 26.

Chaetodon araneus, 21.

aruanus, 21.

bengalensis, 80 .

biaculeatus, 18 .

brownriggii, 105.

curaçao, 85 .

lividus, 39.

pavo, 43.

saxatilis, 81.

sordidus, 77.

Cheiloprion, 35.

labiatus, 36 .

Chromis, 28.

caeraleus, 34.

dimidiatus, 33.

lepidurus, 34 .

lepisurus, 84.

philippinus, 82.

scotochilopterus, 31 .

ternatensis, 32.

xanthochir, 30.

xanthurus, 29.

chrysargurus, Amphiprion, 10.

Chrysiptera, 94.

amabilis, 104.

assimilis, 102.

brownriggii, 105.

cyanea, 101.

glauca, 111.

melas, 95.

oxyodon, 98.

parasema, 100.

rex, 110.

turchesius, 103.

uniocellata, 99.

xanthonota, 97.

xanthura, 96.

chrysopoecilus, Dichistodus, 61

Pomacentrus, 61.

Chrysoptera, 94.

chrysopterus, Amphiprion, 10.

chrysurus, Pomacentrus, 55.

cingulatus, Glyphisodon, 106.

coelestinus, Abudefduf, 83 .

Glyphisodon, 81, 83.
104.

Contents, 3.

coracinus, Abudefduf, 89.

Ctenoglyphidodon, 74 .

curaçao, Abudefduf, 85.

Chaetodon, 85.

curassao, Glyphisodon, 85.

cyanea, Chrysiptera, 101.

cyaneus, Abudefduf, 101.

Glyphidodontops, 101.

Glyphisodon, 101.

cyanospilus, Pomacentrus, 39.

\section{D}

Damsel fishes, 8.

Dascillus, 20.

Dascyllus, 20.

aruanus, 21.

caudofasciatus, 26.

- marginatus, 24.

melanurus, 20.

polyacanthus, 27.

reticulatus, 24 .

trimaculatus, 23.

xanthosoma, 24.

xanthurus, 44.

Daya, 73.

jerdoni, 73.

delurus, Pomacentrus, 55.

Dichistodus bifasciatus, 47. chrysopoecilus, 61 .

fasciatus, 67.

notophthalmus, 62.

prosopotaenia, 63 .

trimaculatus, 65 .

dicki, Abudefduf, 79.

dickii, Abndefduf, 91.

Glyphisodon, 91.

dimidiatus, Chromis, 33.

Heliases, 33.

Pomacentrus, 56.

dispar, Glyphisodon, 106.

dorsalis, Pomacentrus, 55.

\section{$\mathbf{E}$}

elongatus, Pomacentrus, 54. emarginatus, Pomacentrus, 55. ephippium, Amphiprion, 10.

Prochilus, 12.

Euchistodus, 76.

Eupomacentrus, 37.

albofasciatus, 41.

lividus, 89.

\section{$\mathbf{F}$}

fasciatus, Dichistodus, 67.

Pomacentrus, 67.

frenatus, Amphiprion, 12.

Heliases, 34.

Furcaria, 28. 


\section{G}

glauca, Chrysiptera, 111.

glancus, Glyphisodon, 111.

Glyphidodon, 76 .

breviceps, 68.

Glyphidodontops, 94.

cyaneus, 101.

modestus, 106.

unimaculatus, 105.

uniocellatus, 102.

zonatus, 106.

Glyphisodon 76.

amabilis, 104.

antjerius, 106.

assimilis, 102.

ater, 95.

aureus, 87.

azureus, 101.

bandanensis, 34 .

bankieri, 45.

bengalensis, 80 .

biocellatus, 106.

brownriggii, 106.

brownriggii zanthozona, 104.

cingulatus, 106.

coelestinus; 81, 83 .

curassao, 85.

cyaneus, 101.

dickii, 91.

dispar, 106.

glancus, 111.

lacrymatus, 98.

leucogaster, 88.

leucopomus, 106.

lencozona, 92.

melas, 95.

modestus, 106.

mutabilis, 106.

oxyodon, 98.

plagiometopon, 75 .

punctulatus, 106.

rossii, 106.

saxatilis, 81.

septemfasciatus, 79 .

smaragdinus, 86 .

sordidus, 77.

taenioruptus, 106.

trifasciatus, 85 .

nnifasciatus, 91 .

unimaculatus, 105.

uniocellatus, 99, 102.

violascens, 95.

xanthonotus, 97.

xanthozona, 106.

xanthurus, 96.

grammorhynchus, Pomacentrus, 62.

\section{$\mathbf{H}$}

hebardi, Pomacentrus, 50.

Heliases, 28.

caeruleus, 84.
Heliases-Continued. dimidiatus, 33.

frenatus, 34.

lepidurus, 34.

lepisurus, 34.

reticulatus, 24.

ternatensis, 32 .

xanthochir, 30.

xanthurus, 29.

Heliastes, 28.

Hemiglyphidodon, 74 . plagiometopon, 75 .

Holocentrus bifasciatus, 15. nigricans, 41.

Illustrations, 5 .

intermedius, Amphiprion, 15.

Introduction, 7 .

\section{J}

japonicus, Amphiprion, 10.

jerdoni, Daya, 78.

Pomacentrus, 73.

jourdin, Lutjanus, 15.

\section{$\mathbf{K}$}

katunko, Pomacentrus, 56.

\section{L}

labiatus, Cheiloprion, 36 . Pomacentrus, 36.

lsbiosns, Pomacentrus, 36.

lacrymatus, Abudefduf, 93.

Glyphisodon, 93.

laticlavius, Amphiprion, 15.

lepidurus, Chromis, 34.

Heliases, 34.

lepisurus, Chromis, 34.

Heliases, 34.

leucogaster, Abudefduf, 88.

Glyphisodon, 88.

leucopomus, Glyphisodon, 106.

leucozona, Abudefduf, 92.

Glyphisodon, 92.

littoralis, Pomacentrus, 66.

lividus, Chaetodon, 39.

Eupomacentrus, 39.

Pomacentrus, 39.

Lutjanus aruanus, 21.

jourdin, 16.

percula, 14.

M

macrostoma, Prochilus, 12.

marginatum, Tetradrachmum, 24.

marginatus, Dascyllus, 24.

Pomacentrus, 24.

melanochir, Pomacentrus, 66 .

melanopselion, Abudefduf, 75 .

melanopus, Prochilus, 12. 
melanurus, Dascyllus, 20.

Tetradrachmum, 20.

melas, Chrysiptera, 95.

Glyphisodon, 95.

Paraglyphidodon, 95.

modestus, Glyphidodontops, 106.

Glyphisodon, 106.

moluccensis, Pomacentrus, 50.

mutabilis, Glyphisodon, 106.

\section{$\mathbf{N}$}

nigricans, Holocentrus, 41.

Pomacentrus, 41.

notophthalmus, Dichistodus, 62.

Pomacentrus, 62.

\section{$\mathbf{O}$}

opisthostigms, Pomacentrus, 71. ovoides, Pomacentrus, 69. oxyodon, Chrysiptera, 98. Glyphisodon, 98.

Paraglyphidodon, 98.

\section{$\mathbf{P}$}

Paraglyphidodon, 94.

melas, 95.

oxyodon, 98.

xanthonotus, 97.

xanthurus, 96.

Parapomacentrus, 87.

bankleri, 45.

parasema, Abudefduf, 100.

Chrysiptera, 100.

pavo, Chaetodon, 48.

Pomscentrus, 48.

Perca polymna, 10.

percale, Amphiprion, 14.

Lutjanus, 14.

Prochilus, 14.

perideraeus, Amphlprion, 16.

perideraion, Amphiprion, 16.

Prochilus, 16.

philippinus, Abudefduf, 89.

Chromis, 82.

Pomacentrus, 48.

plagiometopon, Glyphisodon, 75.

Hemiglyphidodon, 75 .

polyacanthus, Acantbochromis, 27.

Dascylius, 27.

polylepis, Prochilus, 12.

polymna, Anthias, 14.

Perca, 10.

polymnus, Amphiprion, 10.

Prochilus, 10

Pomacentridse, 8.

Pomacentrus, 87.

albofasciatus, 40.

albolineatus, 70 .

alexanderae, 51.

amboinensis, 58.

araanus, 21.

bankanensis, 69.
Pomacentrus-Continued.

bankleri, 45.

bifasciatus, 47 .

biocellatus, 56 .

breviceps, 68 .

burroughi, 59 .

chrysopoecllus, 61.

chrysurus, 55.

cyanospilus, 39 .

delurus, 55.

dimldiatub, 56.

dorsalis, $\mathbf{5 5}$.

elongatus, 54 .

emarginatus, 55.

fasciatus, 67.

grammorhynchus, 52.

hebardi, 50.

jexdonl, 78.

katunko, 56.

labiatus, 86.

labiosus, 36.

littoralis, 56.

lividus, 89.

marginatus, 24.

melanochir, 66.

moluccensis, 50.

nigricans, 41.

notophthalmus, 62 .

opisthostigma, 71.

ovoides, 69.

pavo, 43.

philippinus, 48.

popel, 51.

pristigir, 61.

prosopotaenia, 68 .

punctatolinestus, 56

scolopseus, 42.

scolopsis, 41.

simsiang, 59.

suluensis, 62.

tablasensis, 72 .

taeniometopon, 59.

taeniurus, 46.

trilinestus, $55,56,59$.

trimaculatus, 28,64 .

tripunctatus, 56.

tropicus, 49.

vanicolensis, 56.

violascens, 44.

sp., 63.

popei, Pomacentrus, 51.

Premnas, 18.

biaculeatus, 18 .

simicinctus, 18.

trifasciatus, 18.

pristigir, Pomacentrus, 61.

Prístotis, 37.

violascens, 44.

Prochilus, 9.

akallopisus, 17.

bifasciatus, 15 .

ephippium, 12.

macrostoma, 12.

melanopus, 12. 
Prochilus-Continued.

percula, 14.

perideraion, 16.

polylepis, 12.

polymnus, 10.

prosopotsenia, Dichistodus, 63.

Pomacentrus, 63.

Pseudopomacentrus, 37.

punctatolineatus, Pomacentrus, 56.

punctulatus, Glyphisodon, 106.

\section{$\mathbf{R}$}

reticnlatum, Tetradrachmum, 24. reticuistus, Dascylius, 24.

Heliases, 24.

rex, Abndefduf, 110.

Chrysiptera, 110.

rossii, Glyphisodon, 106.

\section{$\mathbf{S}$}

sapphirus, Abudefduf, 102.

saxatilis, Abudefduf, 81.

Chaetodon, 81.

Glyphisodon, 81.

scolopsevs, Pomacentrus, 42.

scolopais, Pomacentrus, 41.

scotochilopterus, Chromis, 81.

aeptemfasciatus, Abudefduf, 79.

Glyphisodon, 79.

simicinctus, Premnas, 18.

simsiang, Pomacentrus, 59.

smaragdinus, Glyphisodon, 85 .

snyderi, Amphiprion, 10.

sordidus, Abudefduf, 77, 78.

Chaetodon, 77.

Glyphisodon, 77.

Stegastes, 76.

suluensis, Pomacentrus, 62.

\section{$\mathbf{T}$}

tablasensis, Pomacentrus, 72. taeniometopon, Pomacentrus, 59. taenioruptus, Glyphisodon, 106. taeniurus, Pomacentrus, 46. ternatensis, Chromis, 32. Heliases, 32.

Tetradrachmum, 20. arcuatum, 21. aruanum, 22. marginatum, 24. melanurus, 20. reticulatum, 24. trimaculatum, 28. xanthurus, 44. tricolor, Amphiprion, 12.

trifasciatus, Giyphisodon, 85 .

Premnas, 18.

trilineatus, Pomacentrus, 55, 56, 59.

trimaculatum, Tetradrachmum, 23.

trimaculatus, Dascyilus, 23.

Dichistodus, 65.

Pomacentrus, 28, 64.

tripunctatus, Pomscentrus, 56.

tropicus, Pomacentrus; 49. turchesius, Abudefdnf, 103.

Chrysiptera, 108.

\section{$\mathbf{U}$}

unifasciatus, Glyphisodon, 91. unimaculatus, Abudefdue, 106.

Glyphidodontops, 105.

Glyphisodon, 105.

uniocellata, Chrysiptera, 99.

uniocellatus, Abudefduf, 99.

Glyphidodontops, 102.

Glyphisodon, 99, 102.

\section{$\mathbf{v}$}

vanicolensis, Pomacentrus, 56.

violascens, Glyphisodon, 95.

Pomacentrus, 44.

Pristotis, 44.

\section{$\mathbf{x}$}

xanthochir, Chromis, 80.

Heliases, 80.

xanthonotus, Chryaiptera, 97.

Gisphisodon, 97.

Paragiyphidodon, 97.

xanthosoma, Daseyllus, 24.

xanthozona, Glyphisodon, 106.

Glyphisodon brownriggii, 104.

xanthura, Chrysiptera, 96.

xanthurus, Abudefduf, 96.

Chromis, 29.

Dascyllus, 44.

Glyphisodon, 96.

Heliases, 29.

Paraglyphidodon, 96.

Tetradrachmum, 14.

\section{$\mathbf{Z}$}

zonatus, Abudefduf, 106.

Abudefduf brownriggii, 105.

Glyphidodontops, 106. 





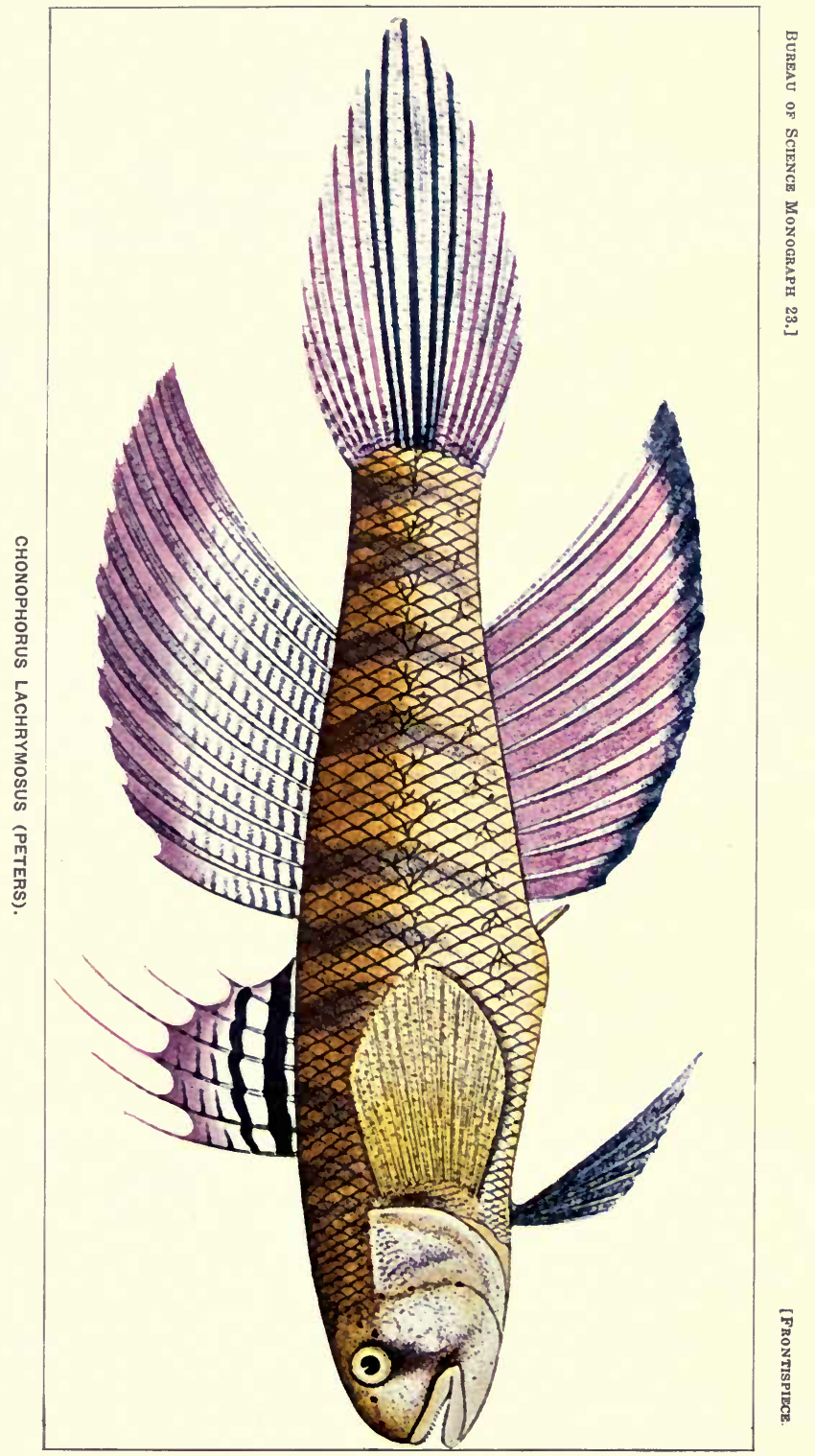




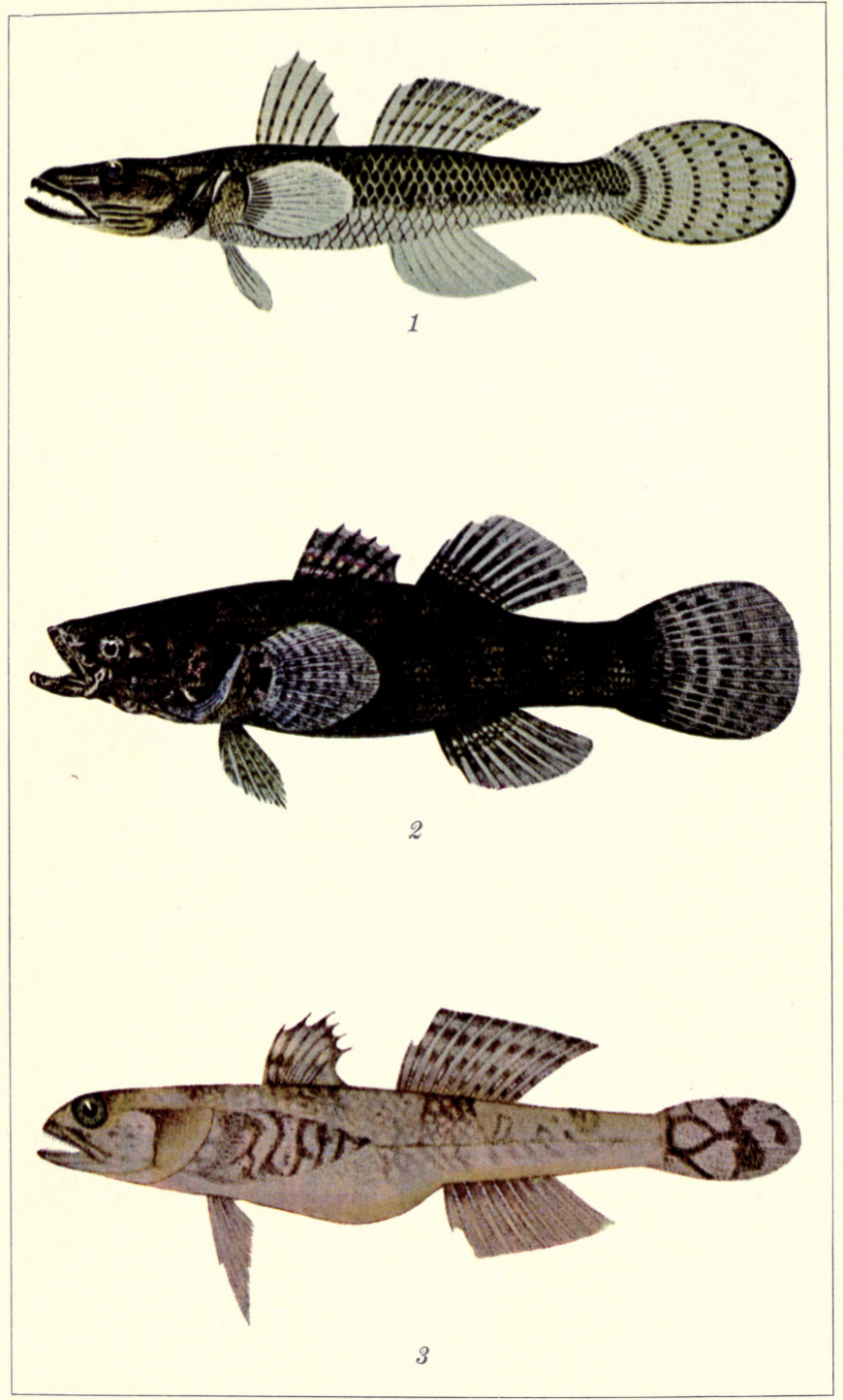


Bureau of Sctence Monograph 23.]

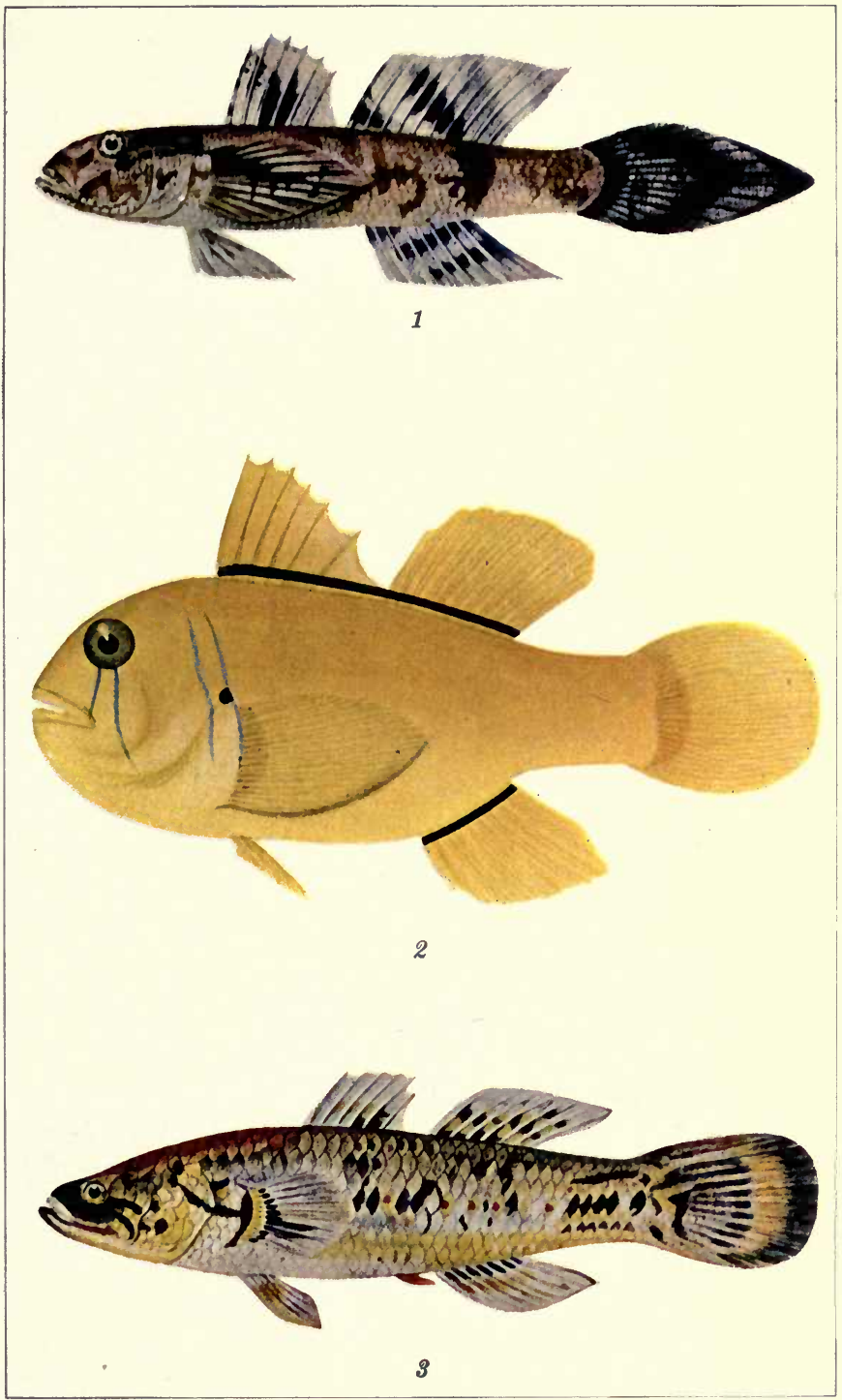

Plate 28. 

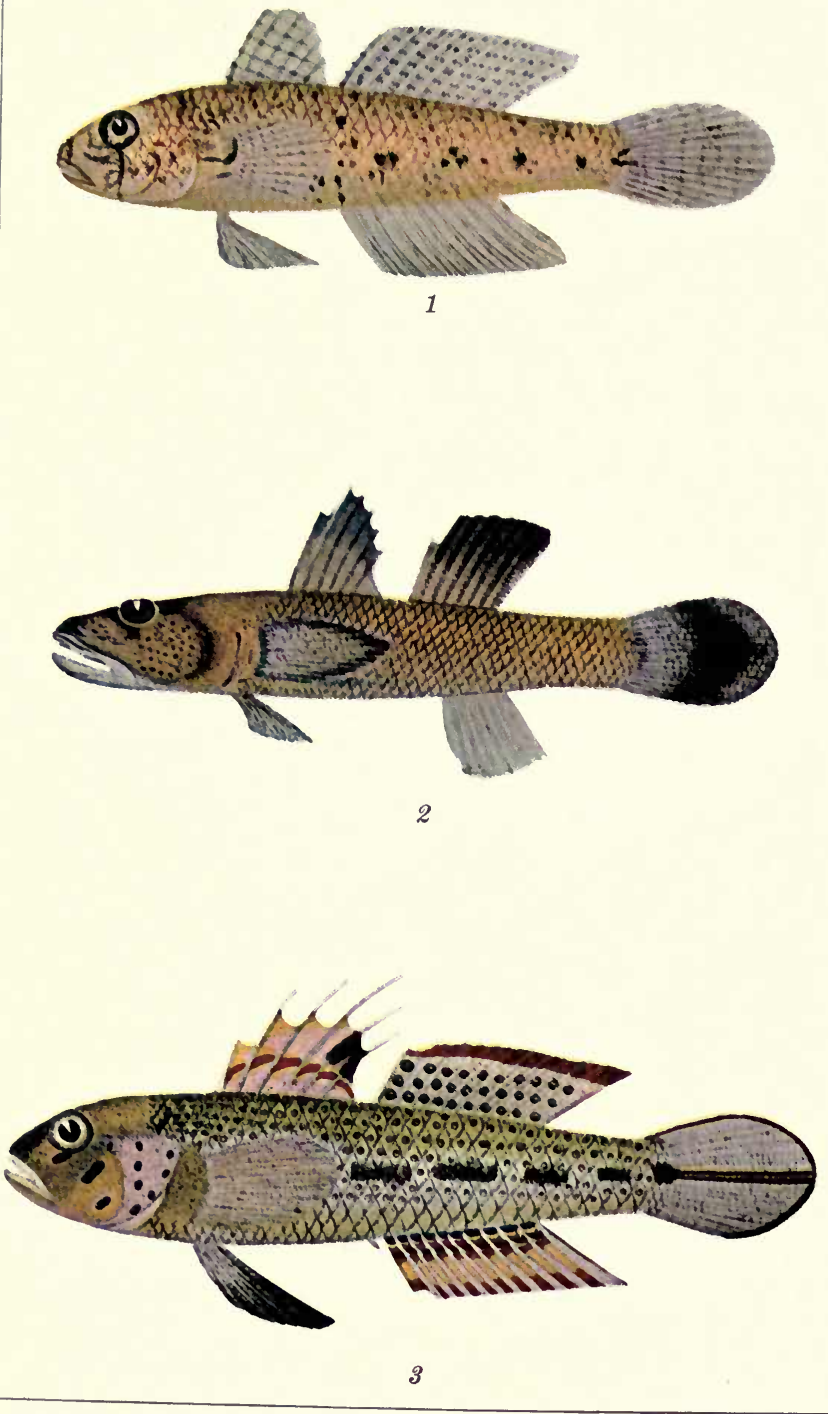

PLATE 29. 


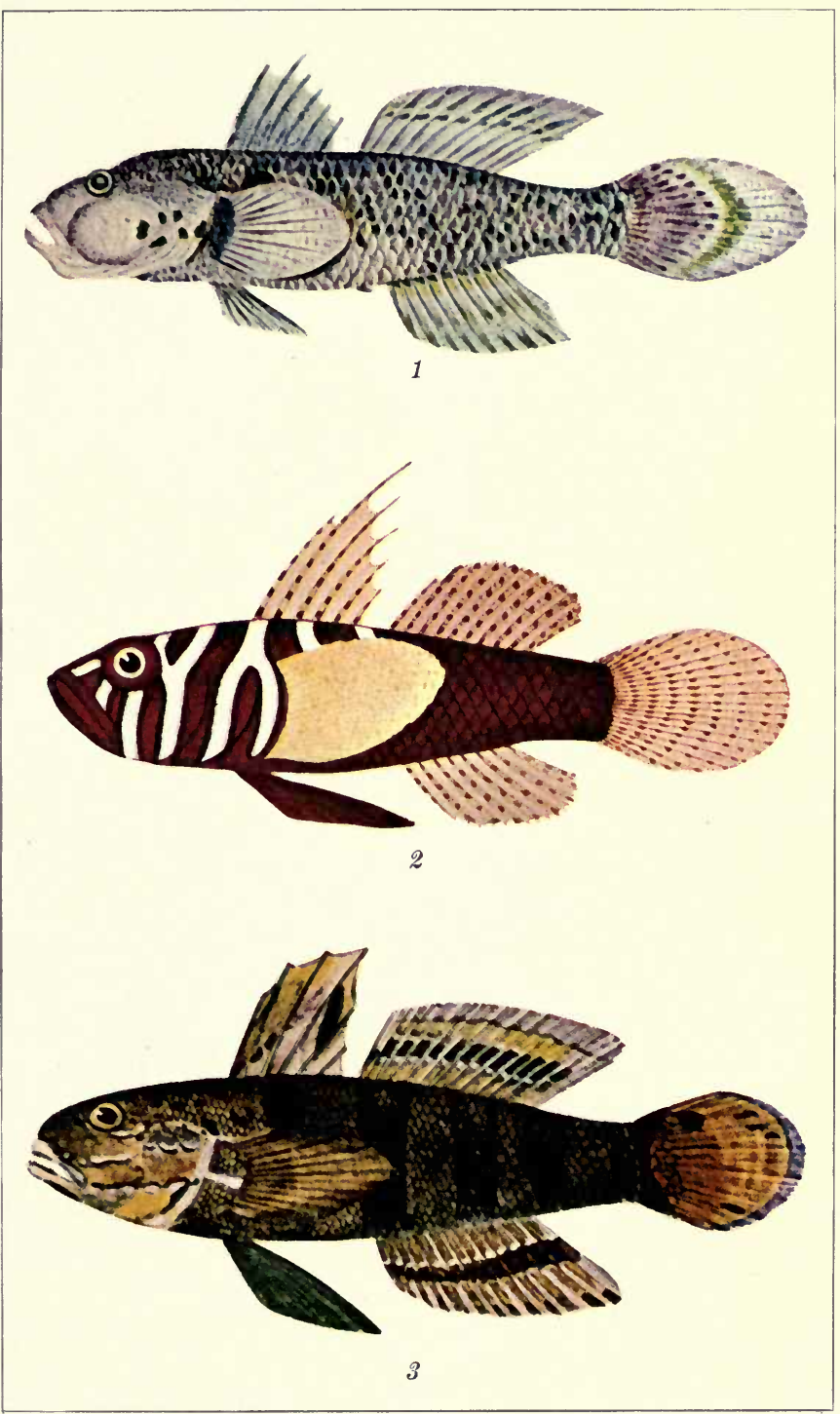

PLATE 30. 


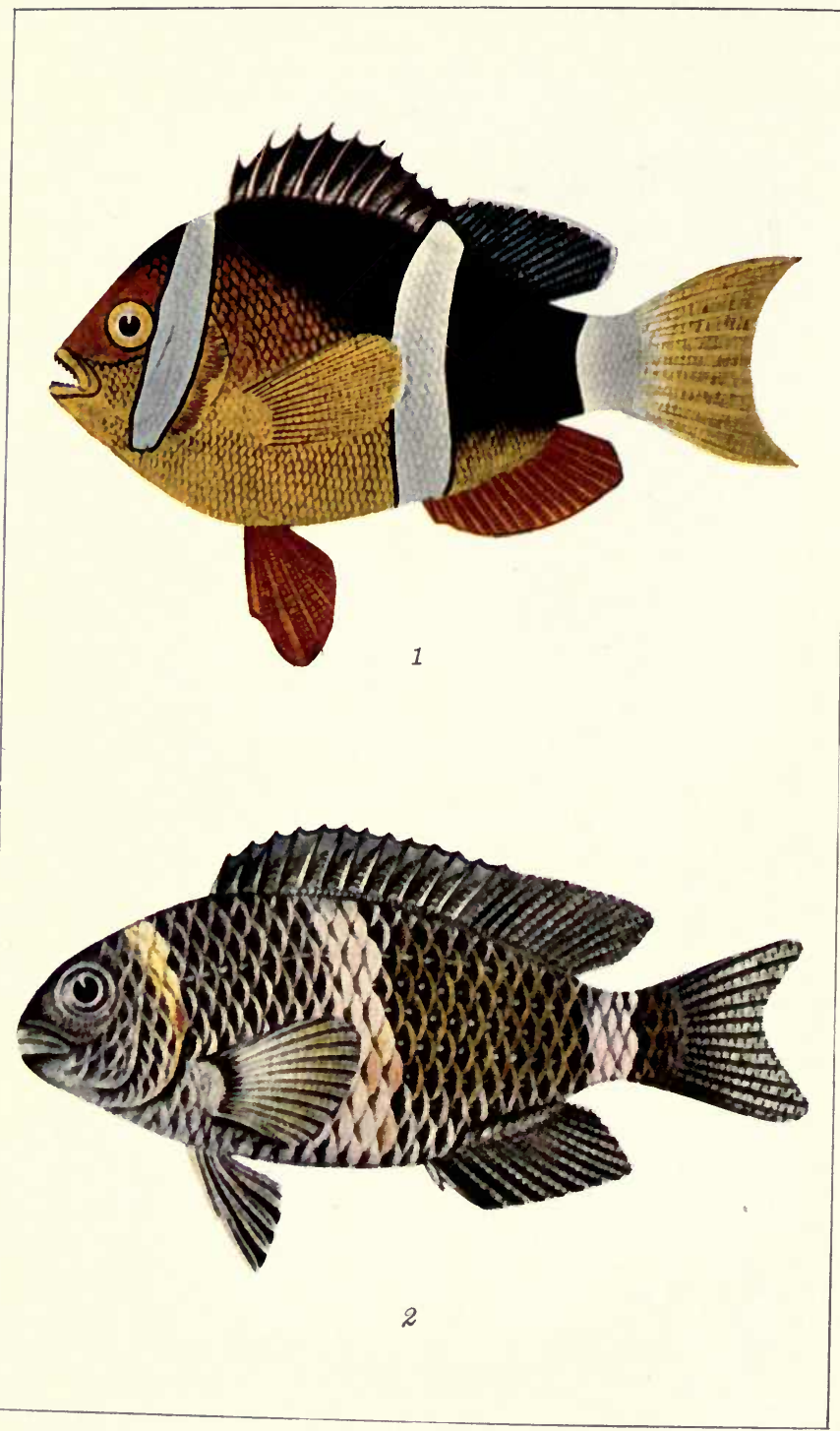




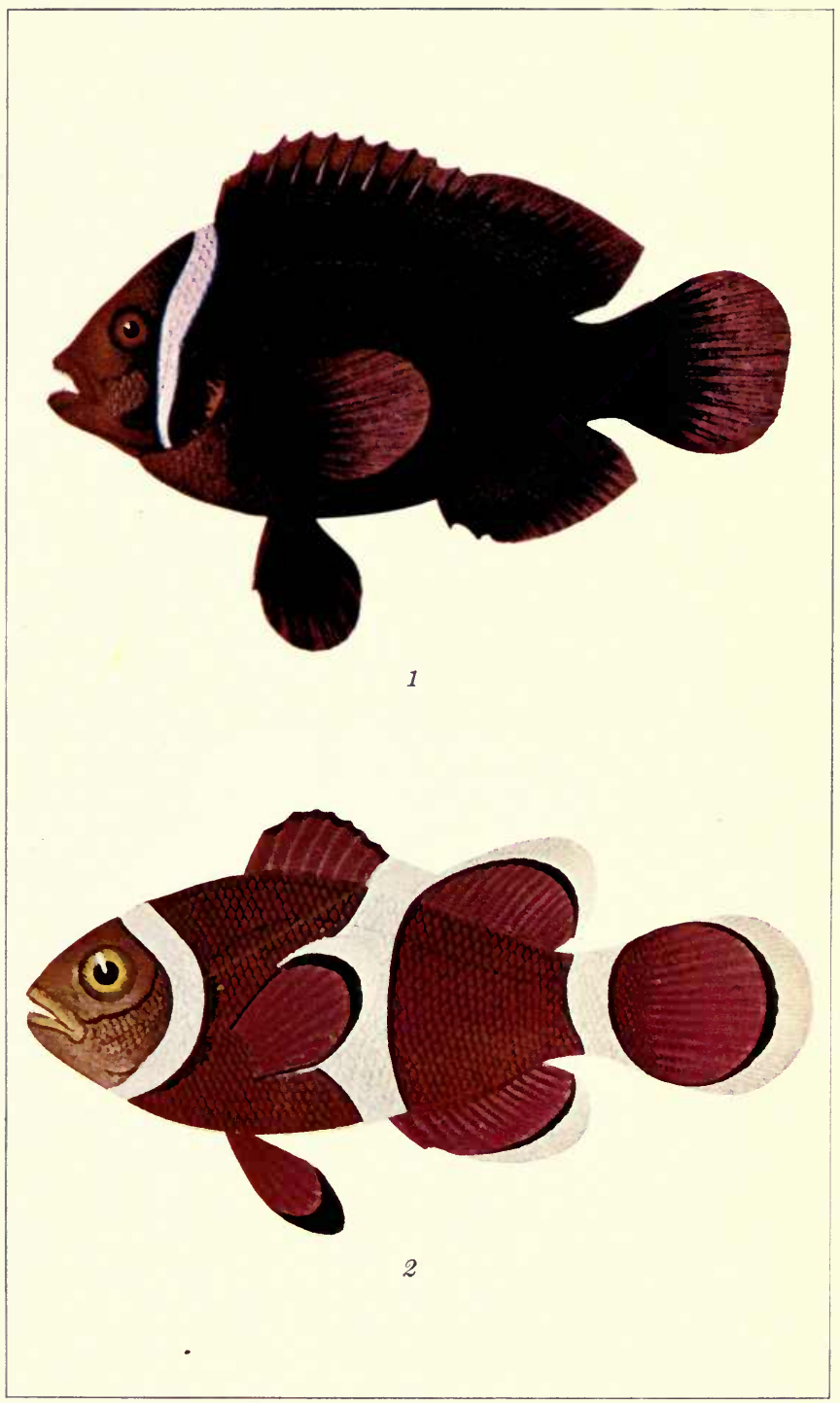

PLATE 2. 


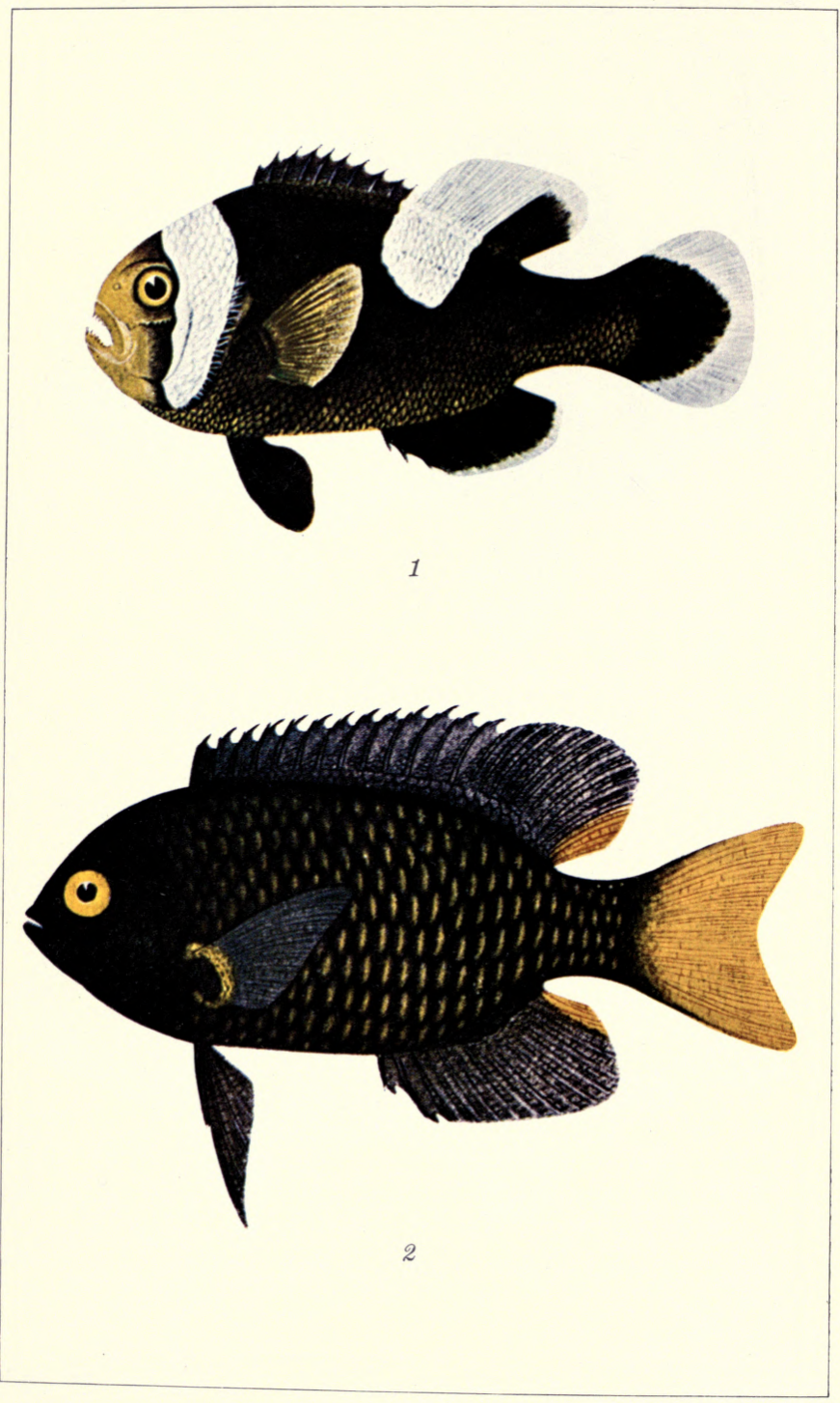




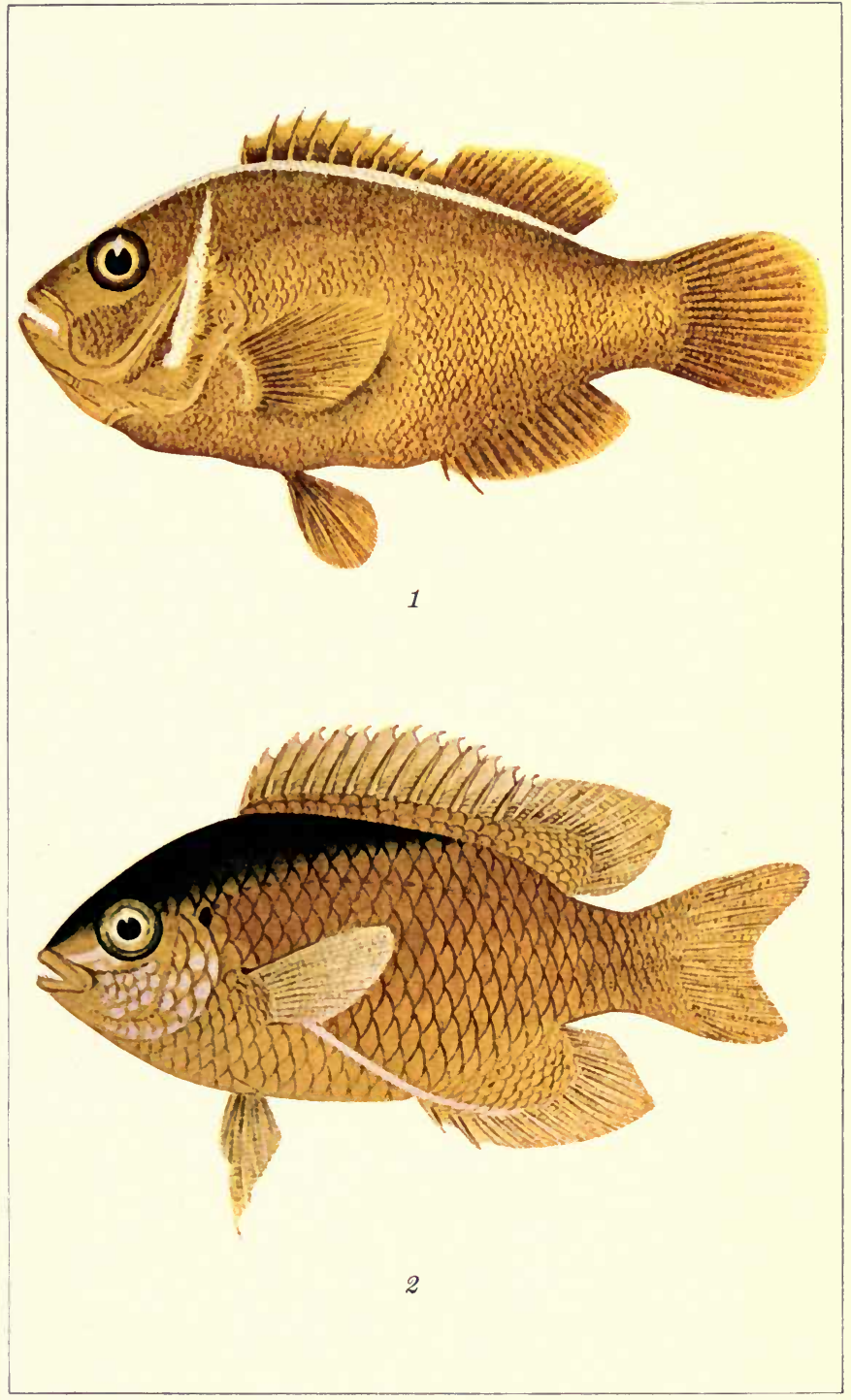




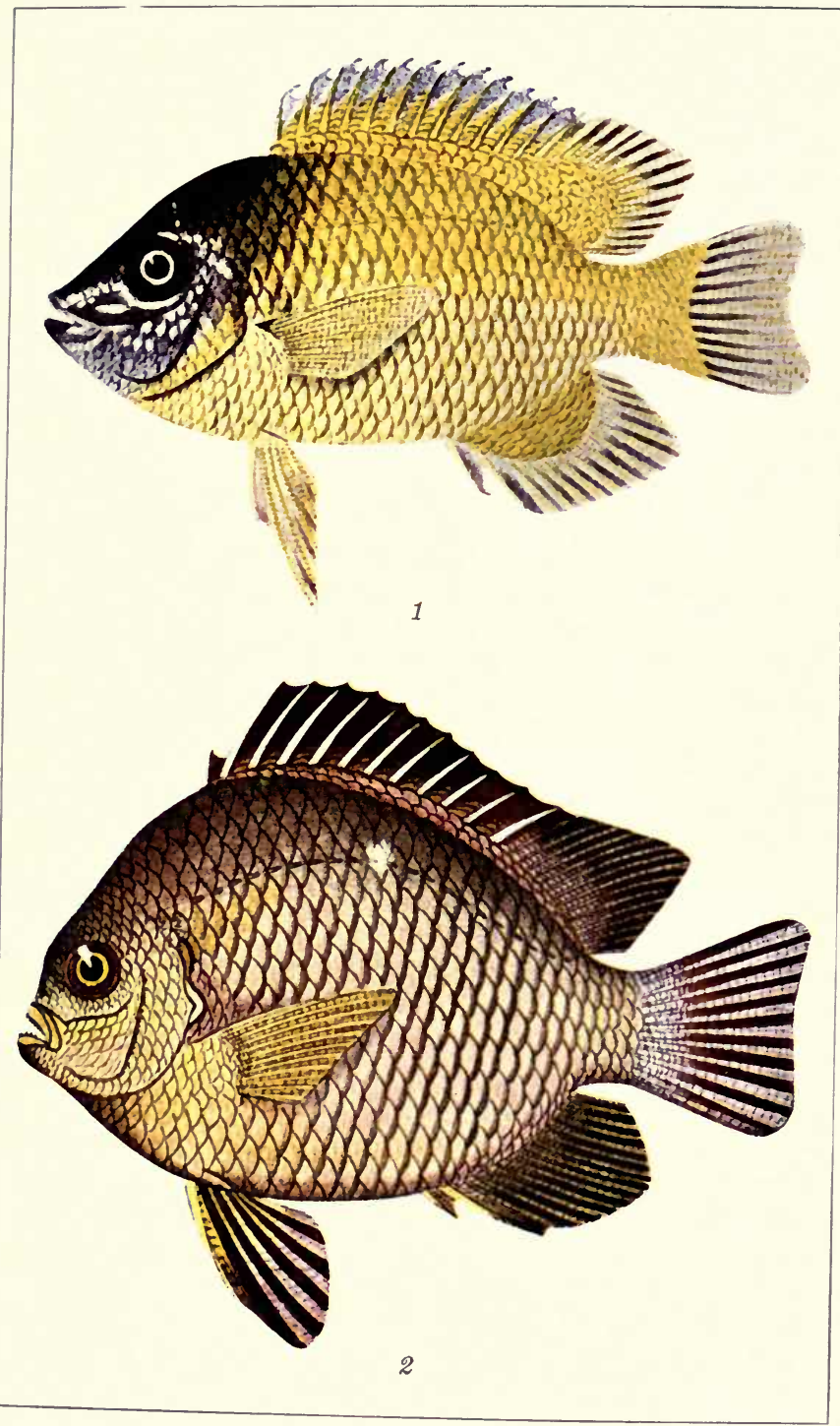




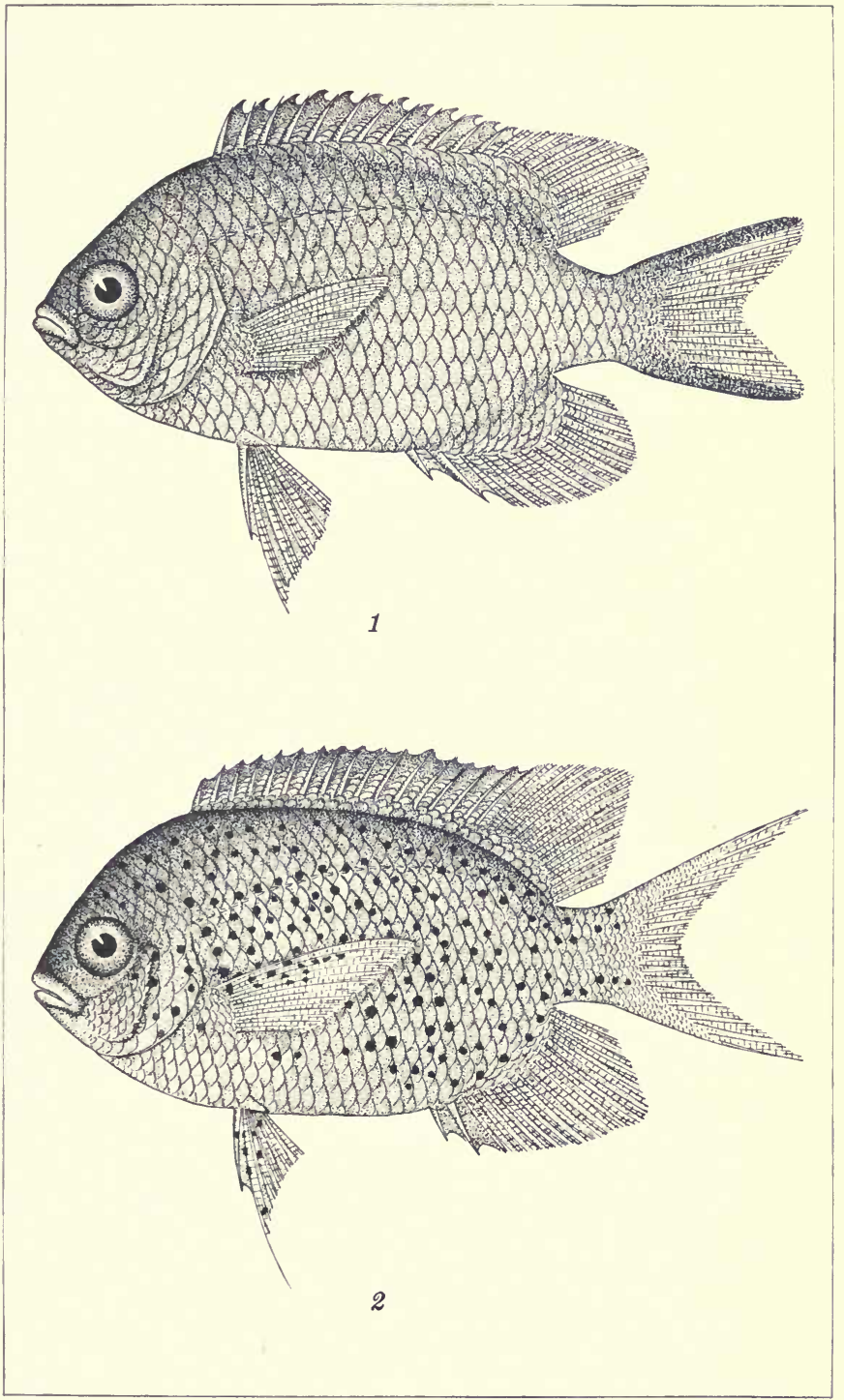

PLATE 6. 

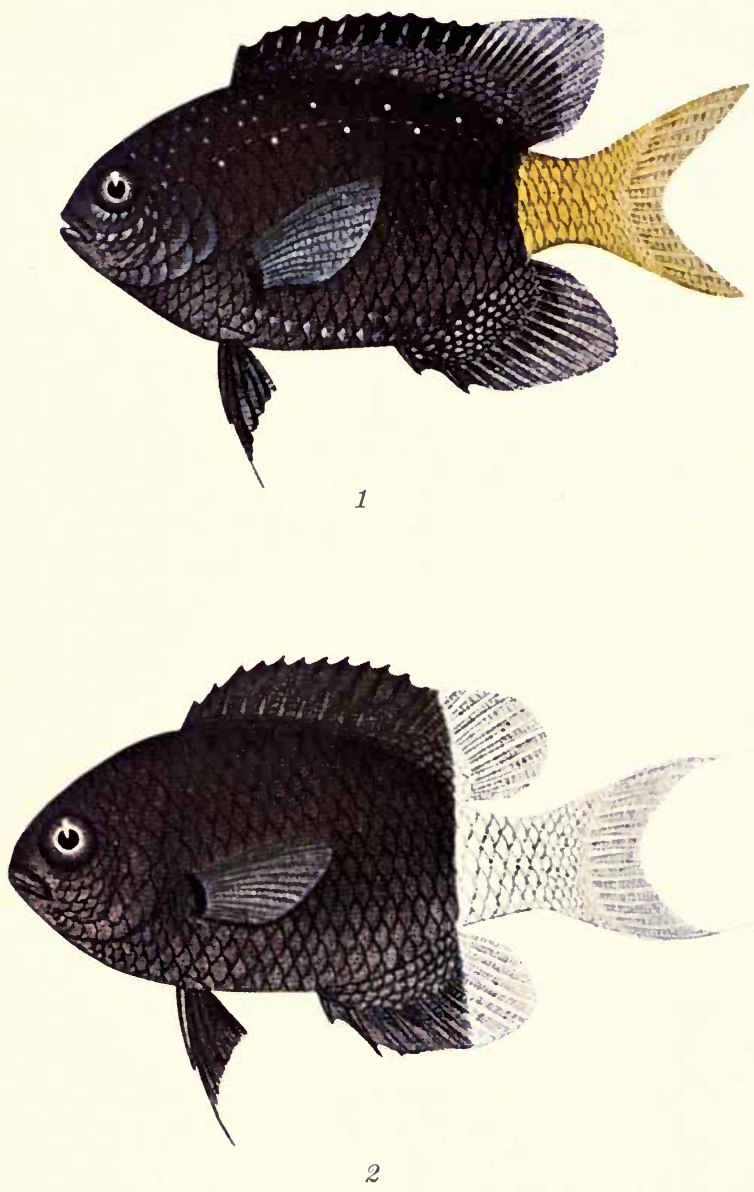

PLATE 7. 


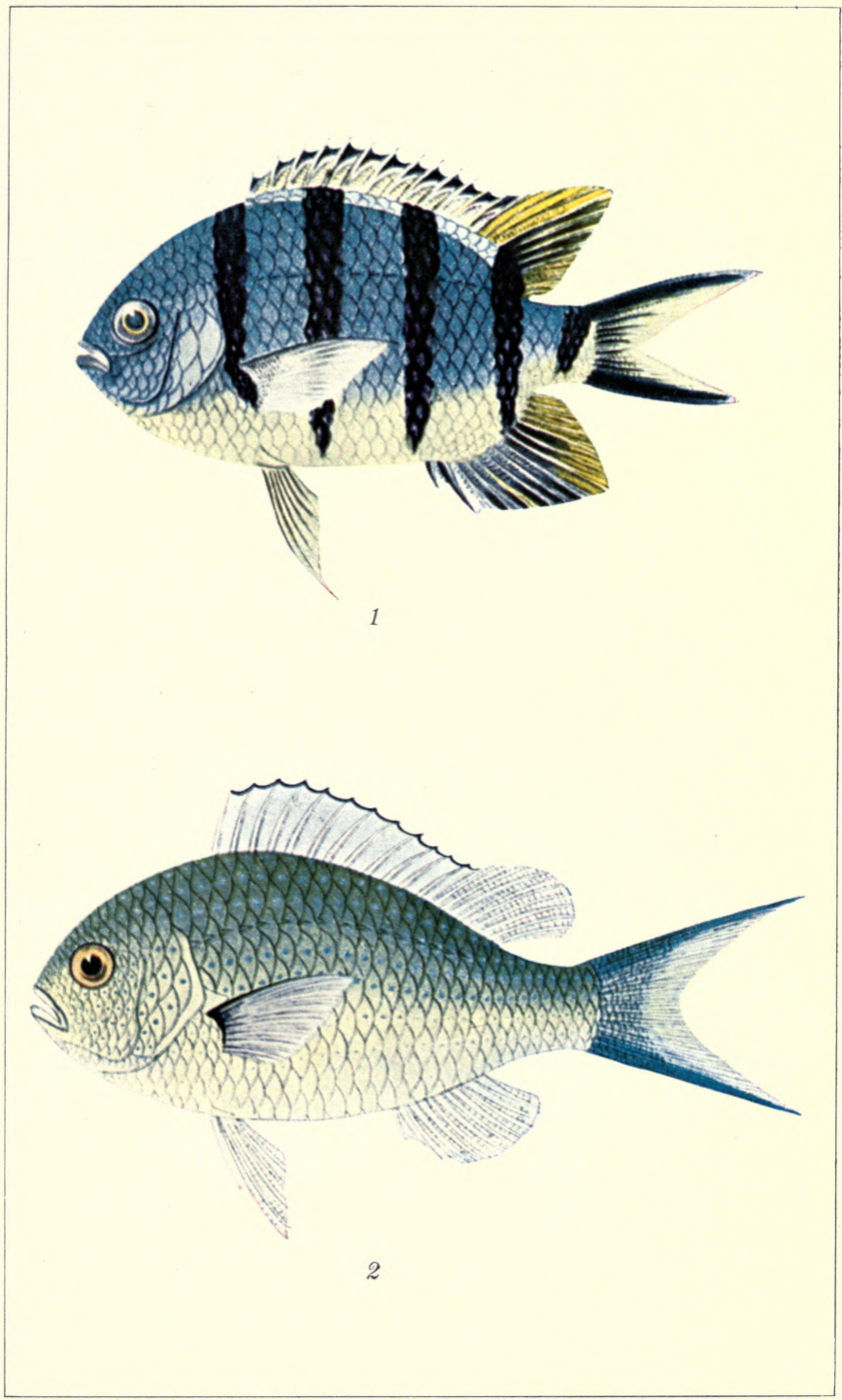

PLATE 8. 


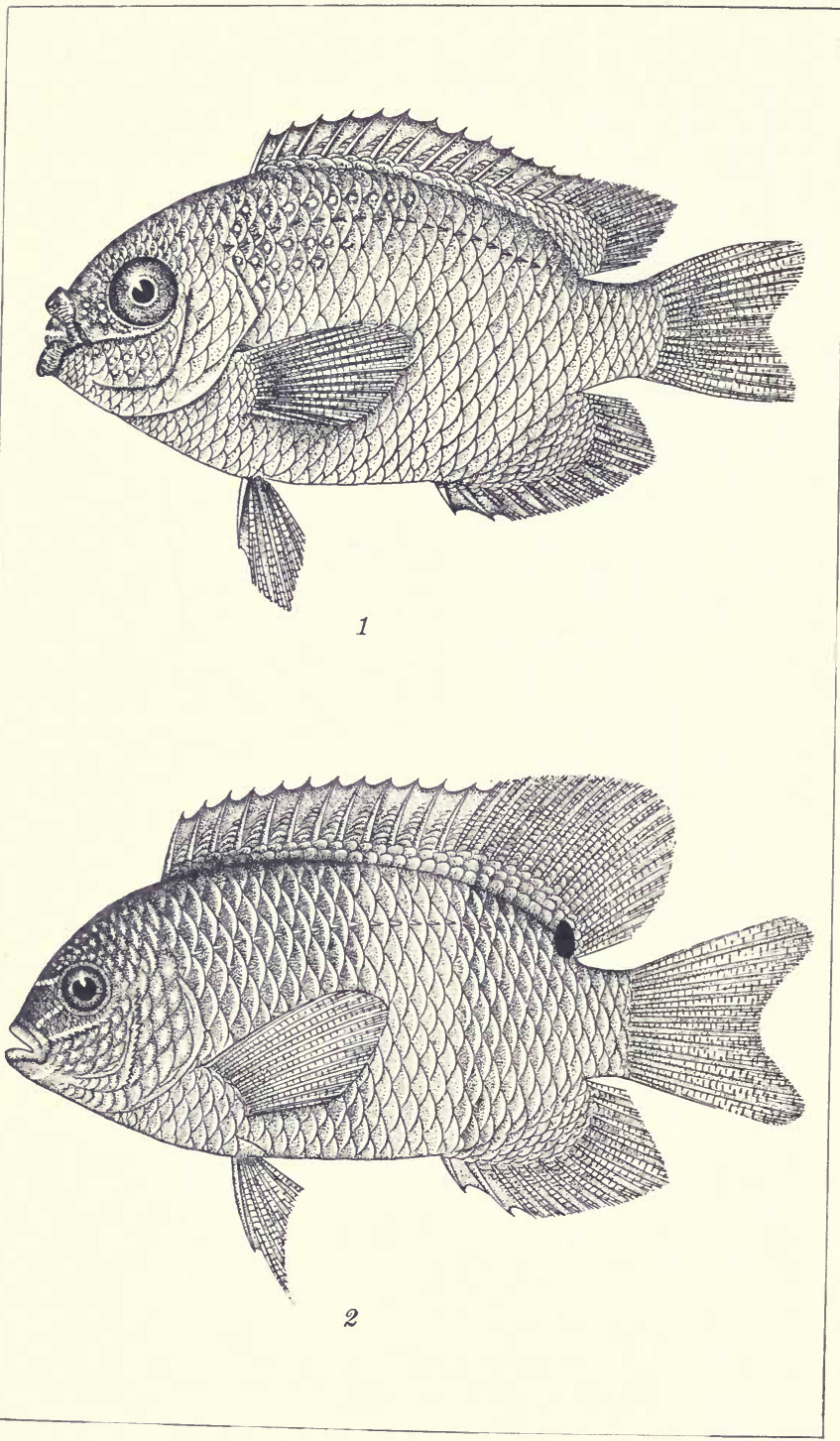

PLATE 9. 


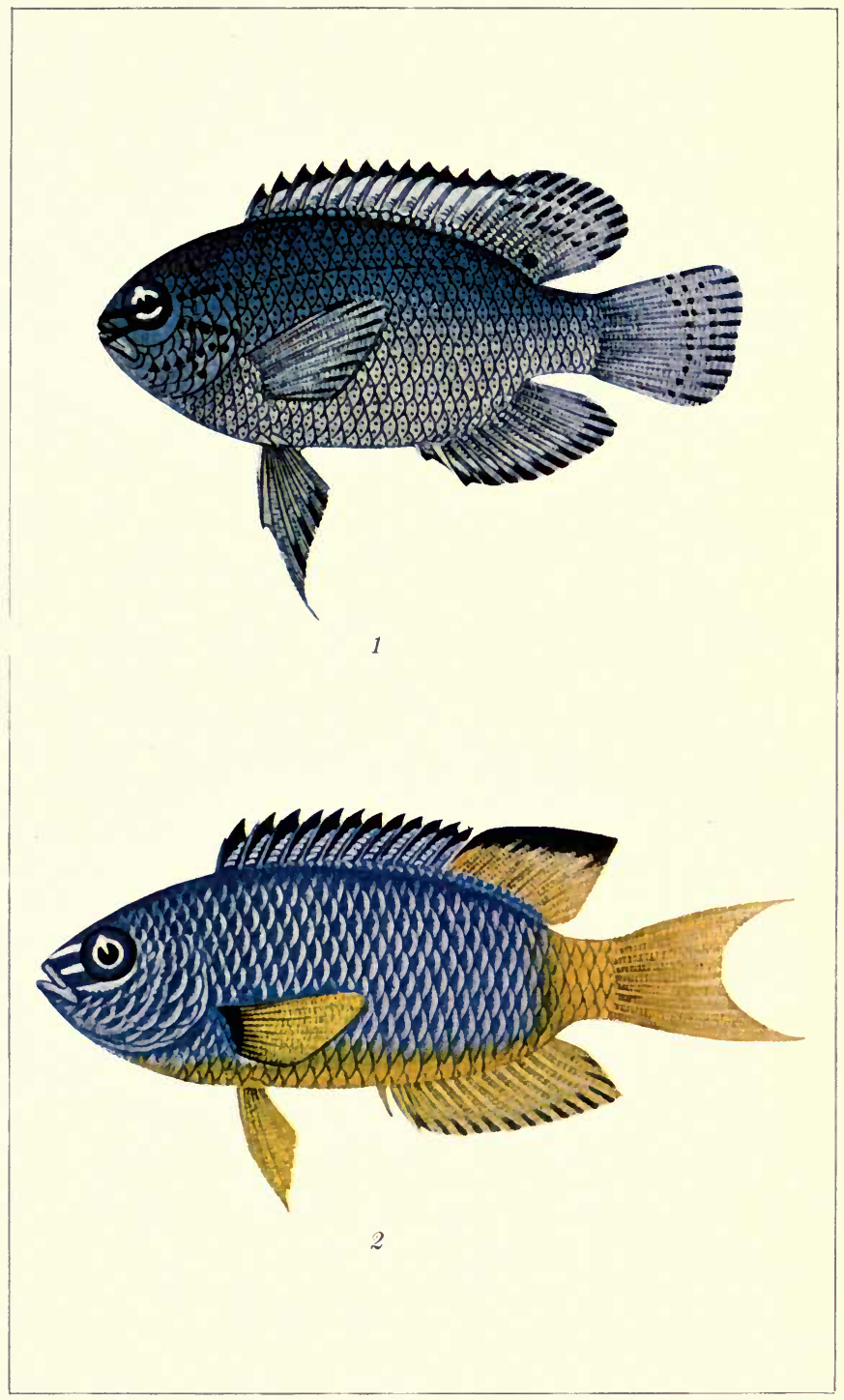

PLATE 10. 


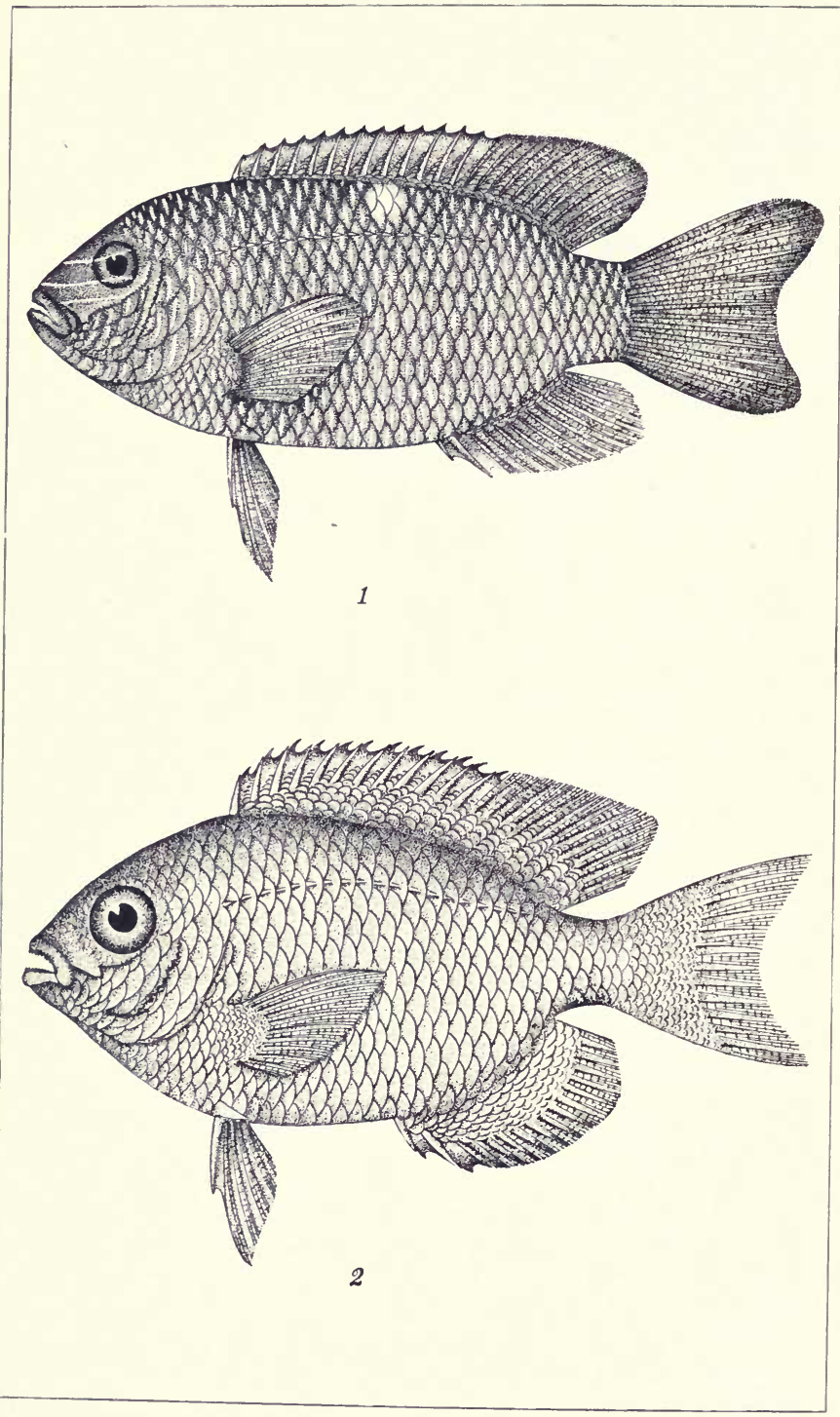




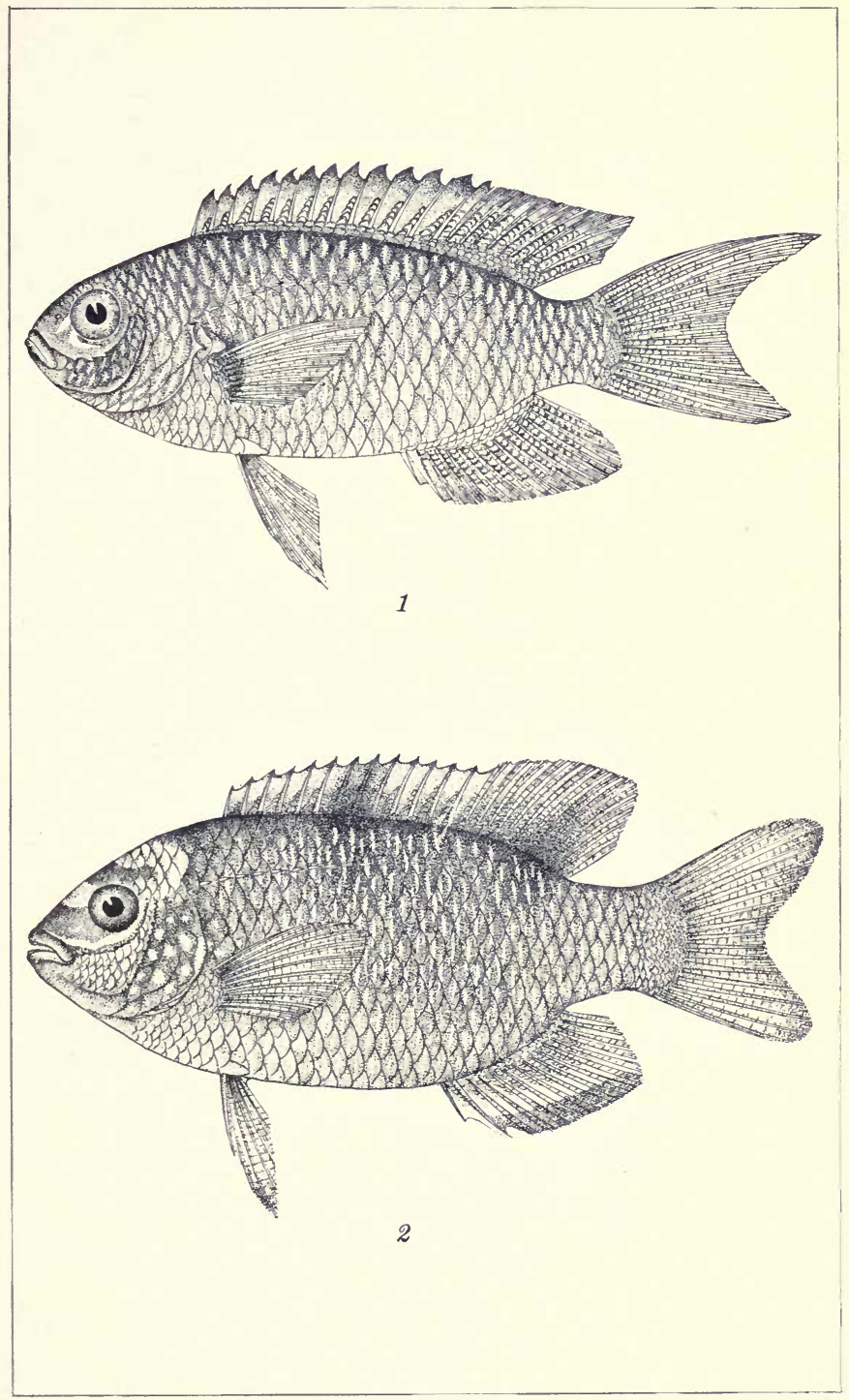

PLATE 12. 


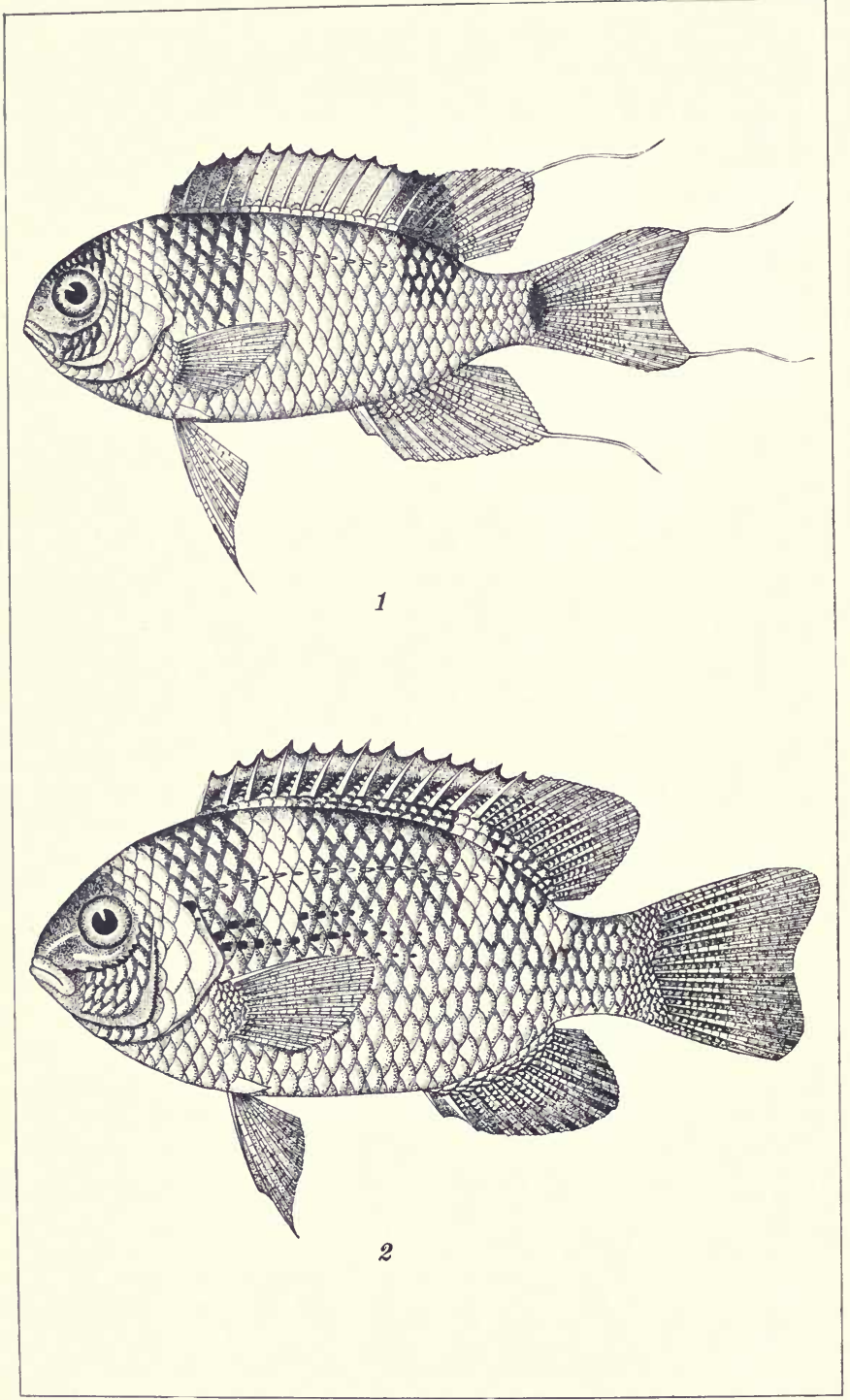

PLATE 13. 

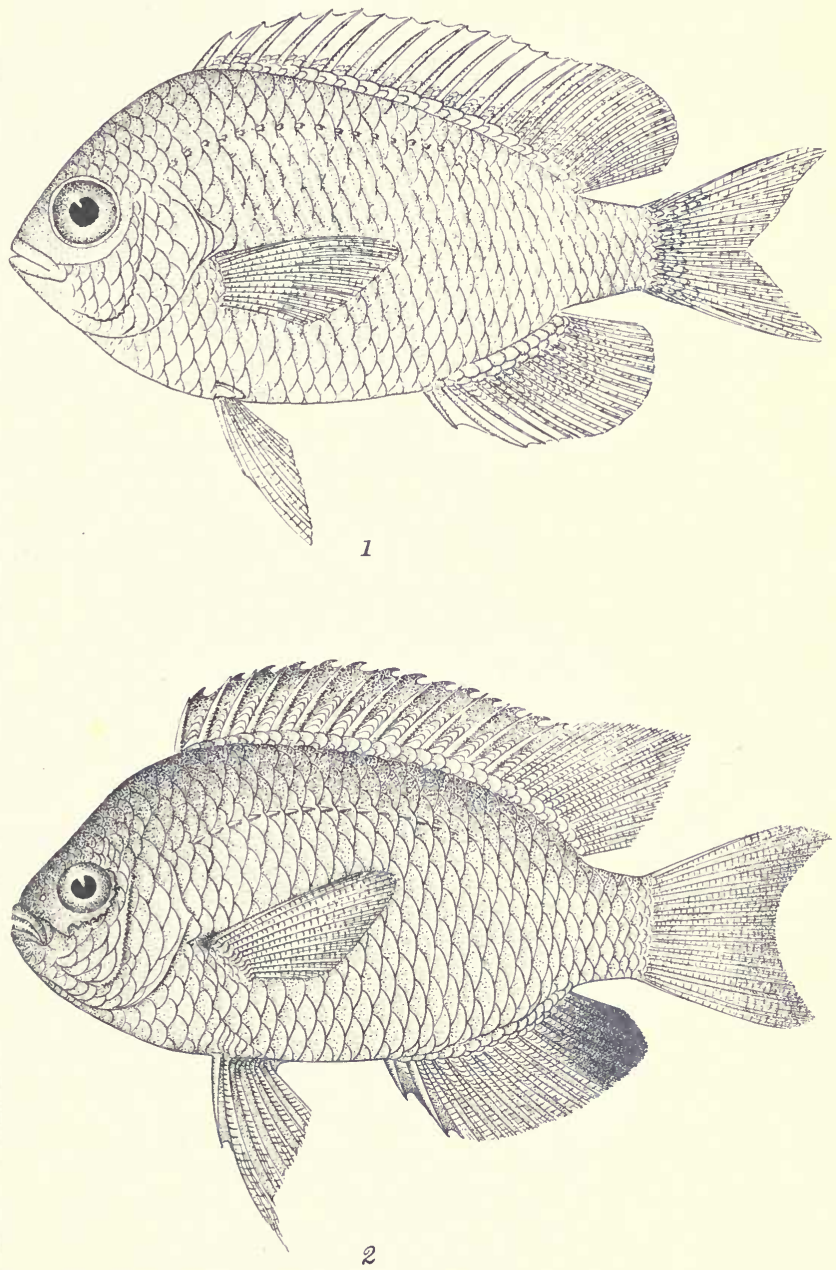

PLATE 14. 


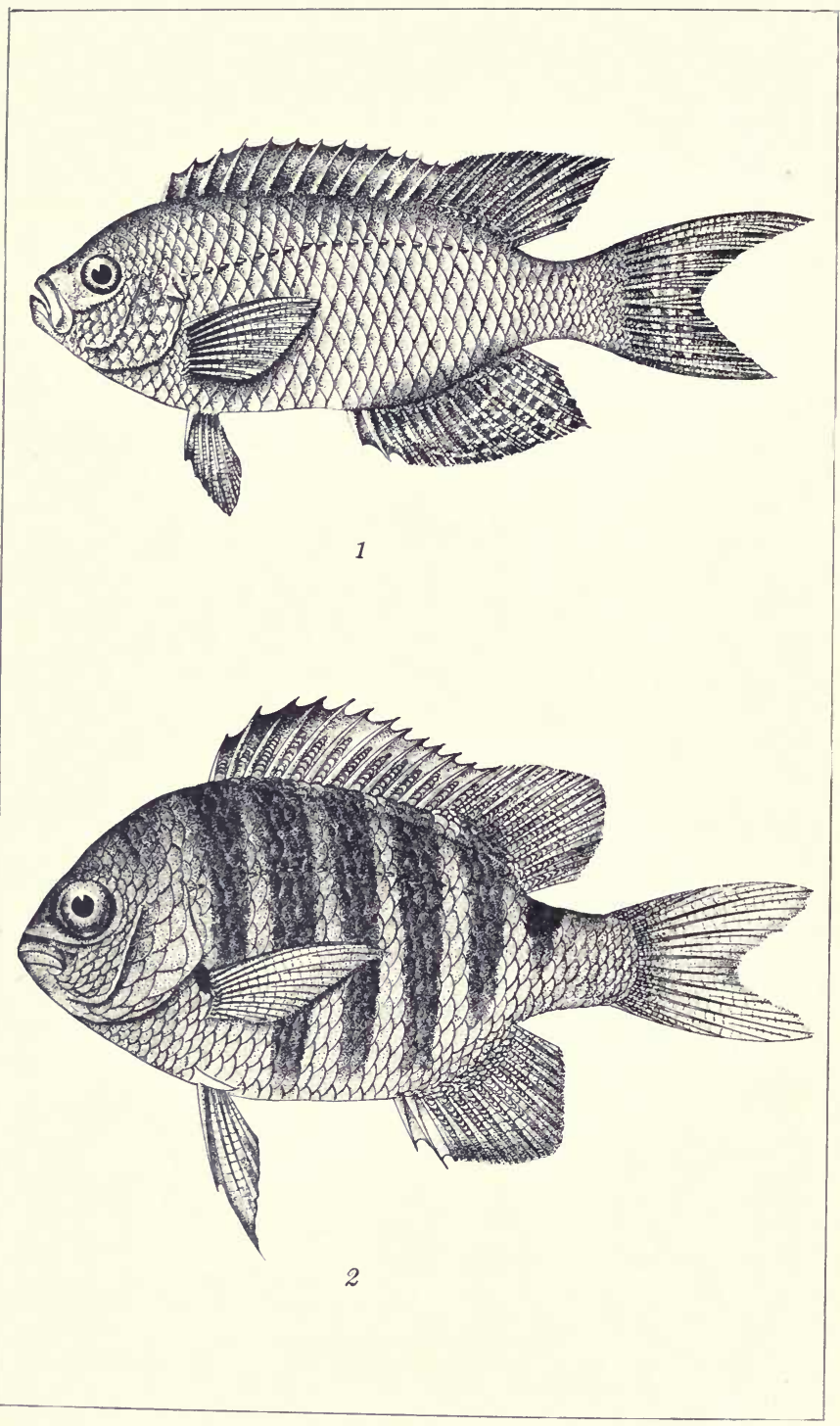

PLATE 15. 
Bureau of Science Monograph 24.]

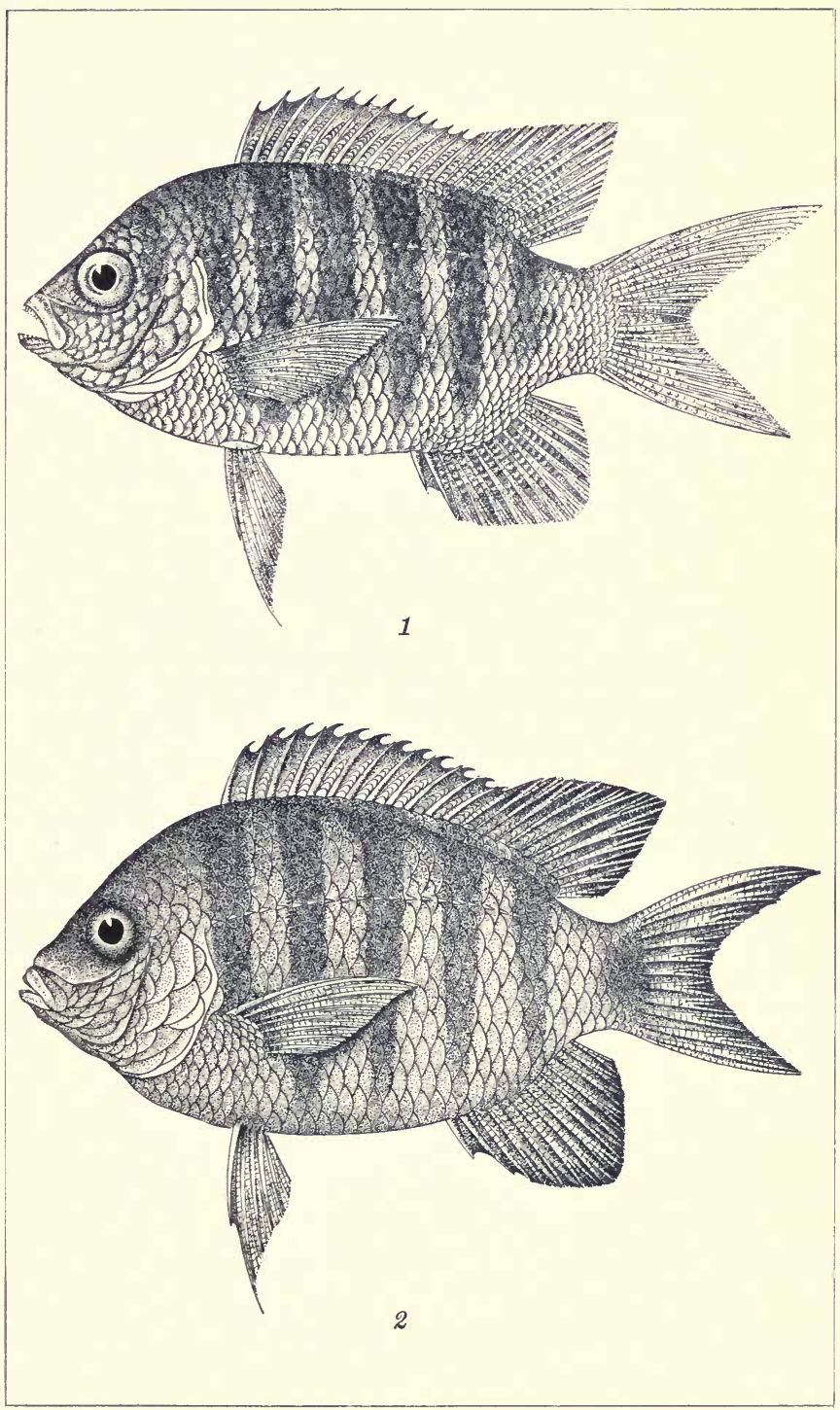

PLATE 16. 


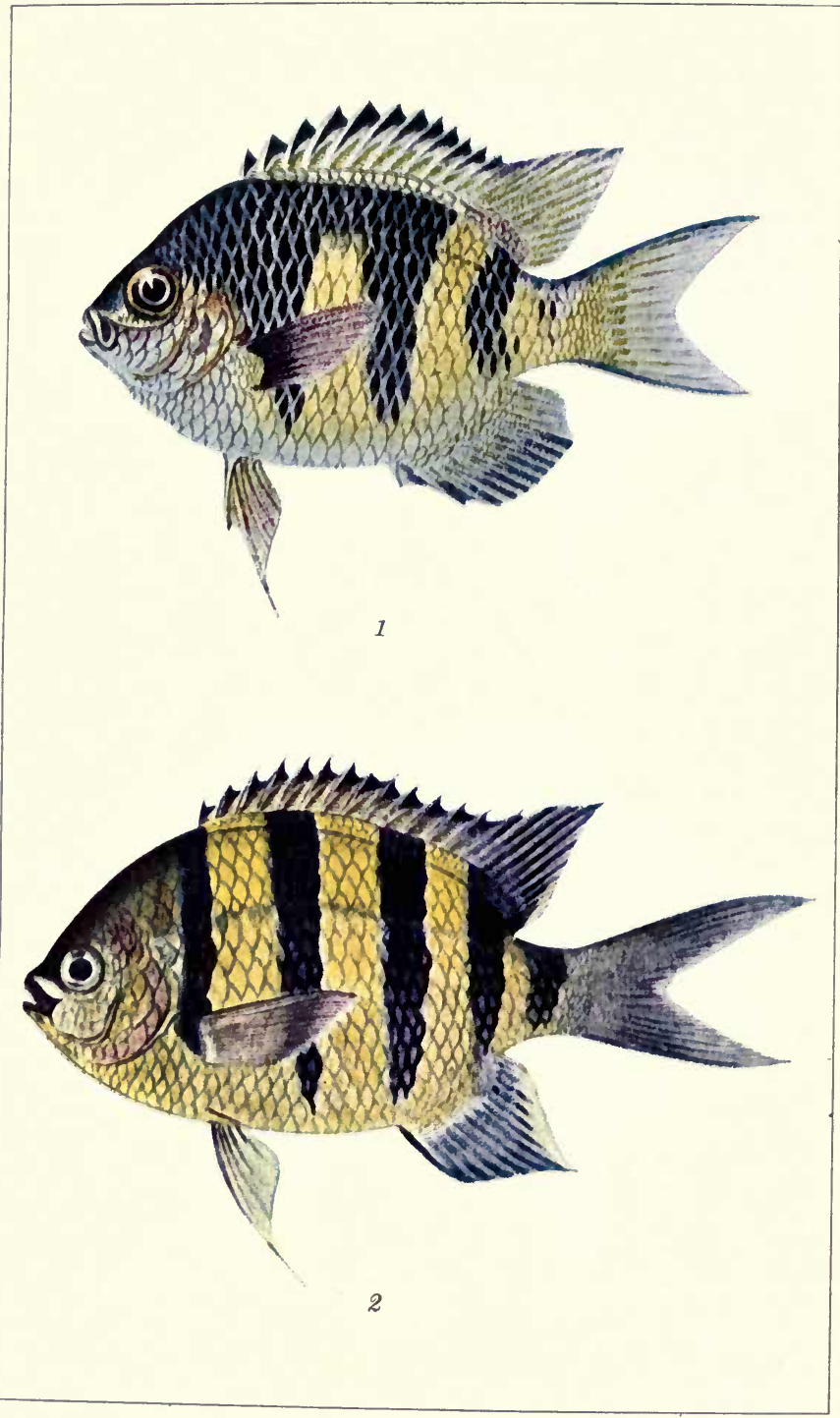




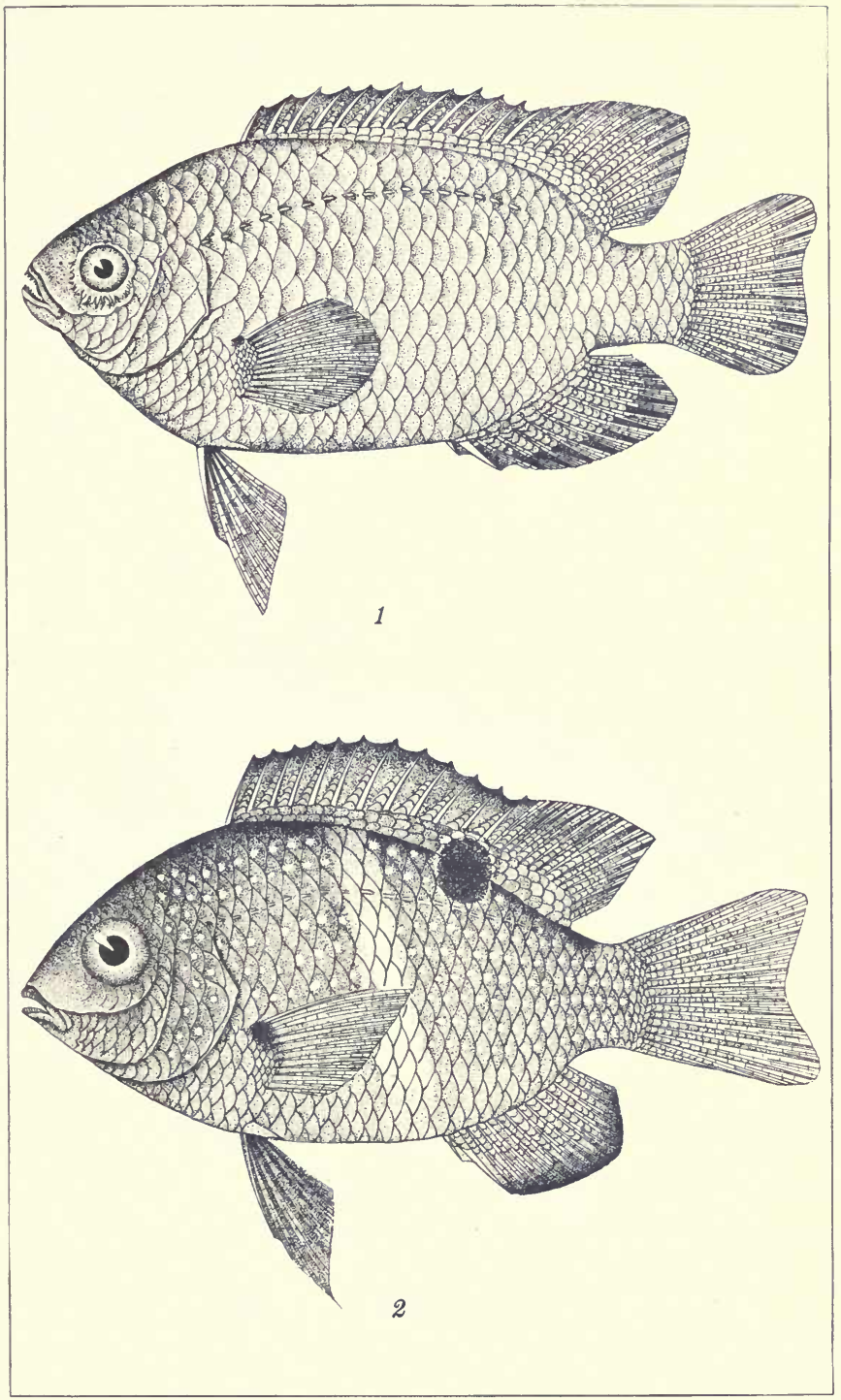

PLATE 18. 


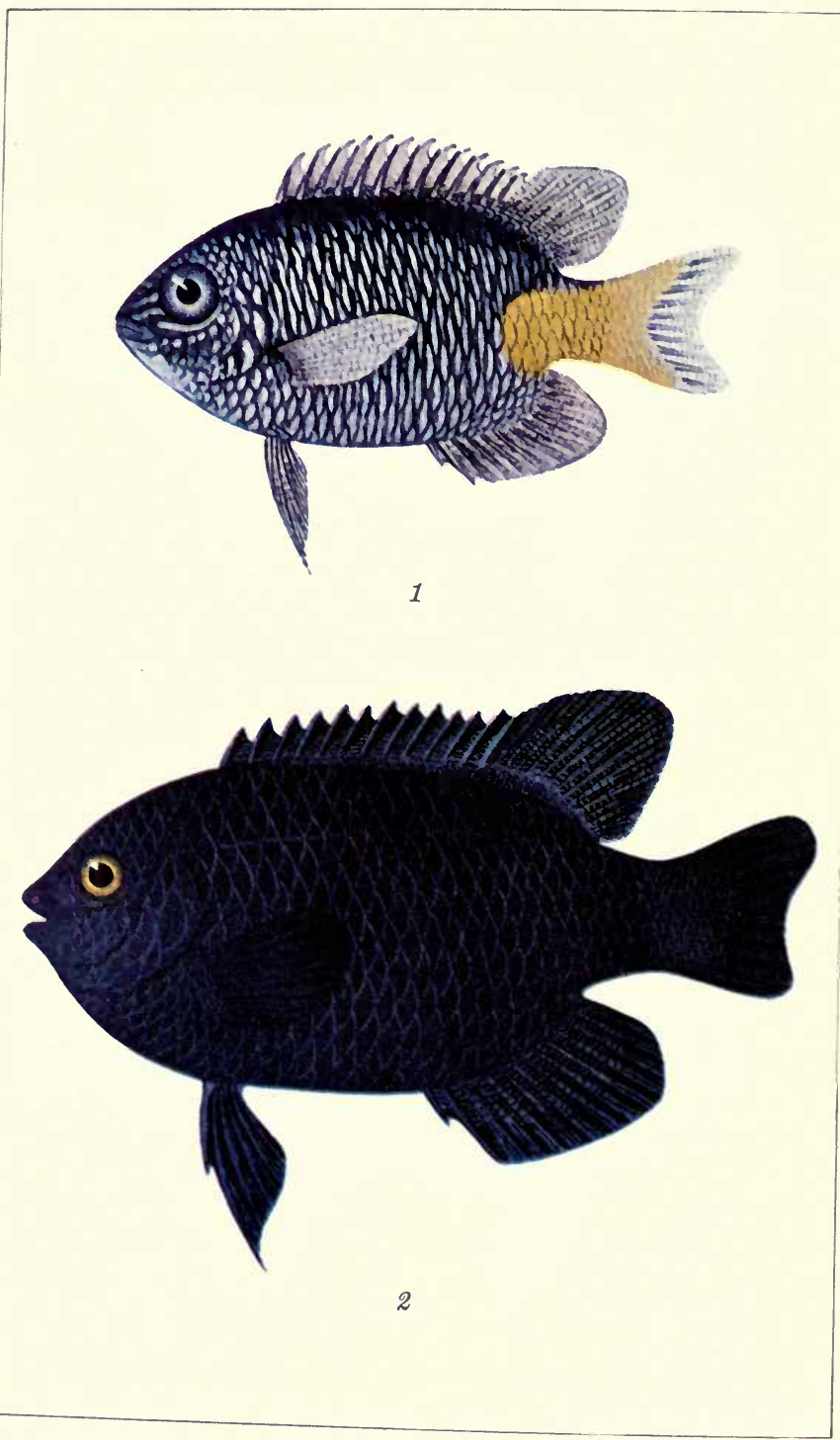





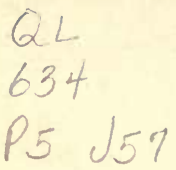

\section{THE LIBRARY \\ UNIVERSITY OF CALIFORNIA \\ Santa Barbara}

THIS BOOK IS DUE ON THE LAST DATE STAMPED BELOW. 


\section{IIVIN|W||||||||||||||||}

UC SOUTHERN REGIONAL LIBRARY FACILITY

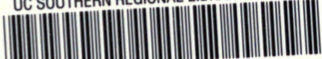

AA $001294394 \quad 0$ 
